\title{
Legitimiteit en onpartijdigheid bij vervolging : een vergelijking van de verhouding tussen het openbaar ministerie en de minister van Justitie in Frankrijk, Italië en Nederland
}

Citation for published version (APA):

van der Lee, P. P. (2003). Legitimiteit en onpartijdigheid bij vervolging : een vergelijking van de verhouding tussen het openbaar ministerie en de minister van Justitie in Frankrijk, Italië en Nederland. [Doctoral Thesis, Maastricht University]. Sdu Uitgevers. https://doi.org/10.26481/dis.20030417pl

Document status and date:

Published: 01/01/2003

DOI:

$10.26481 /$ dis.20030417pl

Document Version:

Publisher's PDF, also known as Version of record

Please check the document version of this publication:

- A submitted manuscript is the version of the article upon submission and before peer-review. There can be important differences between the submitted version and the official published version of record. People interested in the research are advised to contact the author for the final version of the publication, or visit the DOI to the publisher's website.

- The final author version and the galley proof are versions of the publication after peer review.

- The final published version features the final layout of the paper including the volume, issue and page numbers.

Link to publication

\footnotetext{
General rights rights.

- You may freely distribute the URL identifying the publication in the public portal. please follow below link for the End User Agreement:

www.umlib.nl/taverne-license

Take down policy

If you believe that this document breaches copyright please contact us at:

repository@maastrichtuniversity.nl

providing details and we will investigate your claim.
}

Copyright and moral rights for the publications made accessible in the public portal are retained by the authors and/or other copyright owners and it is a condition of accessing publications that users recognise and abide by the legal requirements associated with these

- Users may download and print one copy of any publication from the public portal for the purpose of private study or research.

- You may not further distribute the material or use it for any profit-making activity or commercial gain

If the publication is distributed under the terms of Article 25fa of the Dutch Copyright Act, indicated by the "Taverne" license above, 


\section{Legitimiteit en onpartijdigheid bij vervolging}


40,54 


\section{Legitimiteit en onpartijdigheid bij vervolging}

Een vergelijking van de verhouding tussen het openbaar ministerie en de minister van Justitie in Frankrijk, Italië en Nederland

\section{PROEFSCHRIFT}

ter verkrijging van de graad van doctor aan de Universiteit Maastricht, op gezag van de Rector Magnificus, Prof.dr. A.C. Nieuwenhuijzen Krusennan, volgens het besluit van het College van Decanen, in het openbaar te verdedigen op donderdag 17 april 2003 om 14.00 uur

door

PAULUS PETRUS VAN DER LEE 
Promotor:

Prof.mr. A W. Heringa

Co-promotor:

Mr. R.E. de Winter

Beoordelingscommissie:

Profmr. L.F.M. Verhey (voorzitter)

Prof.mr H.R.B.M. Kumineling (Universiteit Utrecht)

Prof.mr, G.P.M.F. Mols

Prof.mr. B.E.P. Myjer (Vrije Universiteit)

Prof.mr. F.A.M. Stroink

(c) 2003 Sdu Uitgevers BV, Den Haag

Omslagontwerp: Villa Y, Den Haag

Van deze studie is een handelsuitgave verschenen bij Sdu Uitgevers BV onder ISBN: 9054093684 


\section{Inhoud}

Lijst van afkortingen

xiin

\section{Hoofdstuk 1}

\section{Inleiding}

1. Inleiding

2. Inhoudelijke afbakening 2

2.1 Straf(proces)recht 2

$2.2 \mathrm{OM} \quad 3$

2.3 Minister en "de politiek"

2.4 Politicologie : 5

2.5 Rechtsfilosofie 5

2.6 Rechtshistorie 6

2.7 Internationaal recht $\quad 8$

3. Landenkeuze 9

4. Onderzoeksmethodologie 10

\section{Hoofdstuk 2}

\section{Verhouding tussen OM en minister van Justitie in Nederland}

1. Inleiding

2. Organisatie wan het $\mathrm{OM}$

2.1 OM en rechterlijke macht $\quad 12$

2.2 Interne organisatie 15

3. Bevoegdheden van het OM 18

3.1 Opsporing 19

3.2 Beslissing over de vervolging $\quad 19$

3.3 OM-beleid 21

3.4 Functie OM ter zitting 21 .

3.5 Rechtsmiddelen door het OM $\quad 22$

3.6 Rechterlijke controlle op het OM $\quad 22$

3.7 Conclusie 23

4. Minister en ministerie van Justitie 23

5. Rechtspositie van het OM 24

5.1 Benoeming 25

5.2 Overplaatsing, functiewijziging 26

$\begin{array}{ll}5.3 \text { Bezoldiging } & 26\end{array}$

5.4 Grondrechten $\quad 26$

5.5 Aansprakelijktheid 27

5.6 Disciplinaire straffen $\quad 28$

$\begin{array}{ll}5.7 & \text { Schorsing en ontslag }\end{array} 28$

5.8 Rechtspositionele rechtsbescherming 29

$\begin{array}{ll}5.9 \text { Conclusie } & 29\end{array}$ 
6. Functionele ministeriêle bevoegdheden 30

6.1 Bevoegdheden omtrent informatievoorziening 30

6.2 Aanwijzingsbevoegdheid $\quad 32$

6.2.1 Grondslag aanwijzingsbevoegdheid 32

6.2.2 Soorten aanwijzingen : 35

6.2.2.1 Aanwijzing om geen bevoegdheden uit te oefenen 36

6.2.2.2 Beleidsaanwijzingen 36

6.2.2.3 Aanwijzing in de opsporing 37

6.2.2.4 Aanwijzing tot vervolging 37

6.2.2.5 Aanwijzing tot niet-vervolging 38

6.2.2.6 Aanwijzing ten aanzien van het requisitoir 39

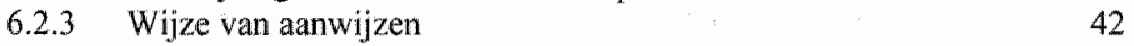

6.2.3.1 Procedure specifieke aanwijzingen 43

6.2.3.2 Procedure aanwijzing tot vervolging en ten aanzien van
het requisitoir

6.2.3.3 Procedure aanwijzing tot niet vervolgen 45

6.2.3.4 Spoedprocedure 46

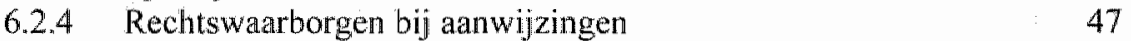

6.2.5 Plicht tot terughoudendheid 51

6.2.5.1 Terughoudendheid door rechtstreeks toegekende bevoegdheden 51

6.2.5.2 Terughoudendheid om het behoren tot de rechterlijke macht 52

6.2.5.3 Terughoudendheid als gewoonterecht 53

6.2.6 Conclusie 56

6.3 Petitie bij de minister $\quad 56$

6.4 Toezegging en mededeling omtrent de strafbaarheid 56

6.5 Vervolgingsbesluit bij ambtsmisdrijven politici $\quad 58$

6.6 Gezag over opsporingsorganen $\quad 58$

6.7 Bevoegdheden ten aanzien van budget en organisatie $\quad 59$

6.8 Informele invloed $\quad 60$

6.9 Conclusie 62

7. Verantwoording voor het $\mathrm{OM} \quad 62$

7.॥ Grondslag en reikwijdte verantwoordelijkheid 63

7.1.1 Verantwoordelijkheid door bevoegdheden 64

7.1 .2 Onbegrensde aanspreek baarheid,
rekening afleggen door bevoegdheden

$\begin{array}{ll}7.2 \text { Verantwoordingsproces } & 67\end{array}$

7.2.1 Sanctionering ministeriële verantwoordelijkheid 71

7.3 Verantwoording $\mathrm{OM}$ aan bet parlement $\quad 73$

$\begin{array}{ll}7.4 \text { Conclusie } & 73\end{array}$

8. Samenvatting en conclusie $\quad 74$

\section{Hoofdstuk 3 \\ Verhouding tussen OM en minister van Justitie in Frankrijk}

1. Inleiding 
2. Organisatie van het $O M$

2.1 OM en rechterlijke macht $\quad 75$

2.2 Interne organisatie $\quad 78$

3. Bevoegdheden van het $\mathrm{OM} \quad 81$

$\begin{array}{ll}3.1 \text { Opsporing } & 82\end{array}$

3.2 Beslissing over de vervolging $\quad 83$

3.3 'De derde weg' $\quad 84$

3.4 Vervolgingsstrategie 85

$\begin{array}{ll}3.5 \text { OM-beleid } & 87\end{array}$

3.6 Functie OM ter zitting $\quad 87$

3.7 Rechtsmiddelen door het OM $\quad 88$

3.8 Rechterlijke controle op het OM $\quad 88$

3.9 Conclusie $\quad 89$

4. Minister en ministerie van Justitie en President 90

5. Rechtspositie van het $O M$

5.1 Rekrutering en eerste benoeming. 92

5.2 Verdere benoeming en overplaatsing 92

5.3 Bezoldiging 95

5.4 Grondrechten 95

5.5 Aansprakelijkheid 96

5.6 Disciplinair regime 96

5.7 Schorsing en ontslag : : 97

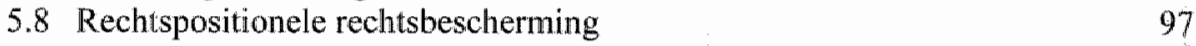

5.9 Conclusie 98

6. Functionele ministeriële bevoegdheden 98

6.1 Bevoegdheden omtrent informatievoorziening 98

6.2 Hiërarchisch beroep 101

6.3 Aanwijzingsbevoegdheid 101

$\begin{array}{ll}\text { 6.3.I Soorten aanwijzingen } & 101\end{array}$

$\begin{array}{lll}\text { 6.3.1.1 Circulaires } & 102\end{array}$

6.3.1.2 Specifieke aanwijzingen $\quad 103$

$\begin{array}{ll}\text { 6.3.1.3 Aanwijzing tot niet-vervolging } 104 & 106\end{array}$

$\begin{array}{ll}\text { 6.3.1.4 Overige aanwijzingen } & 106\end{array}$

$\begin{array}{ll}\text { 6.3.2 Aanwijzingsvorm } & 107\end{array}$

$\begin{array}{ll}\text { 6.3.3 Rechtswaarborgen bij aanwijzingen } & 107\end{array}$

6.3.4 Conclusie 110

6.4 Toestemming voor vervolging $\quad 110$

6.5 Gezag over opsporingsorganen 112

6.6 Bevoegdheden ten aanzien van budget en organisatie $\quad 113$

6.7 Informele invloed $\quad 114$

6.8 Conclusie 115

7. Verantwoording voor het $\mathrm{OM} \quad 115$

$\begin{array}{ll}7.1 \text { Grondslag en reikwijdte verantwoordelijkheid } & 115\end{array}$

$\begin{array}{ll}7.2 \text { Verantwoordingsproces } & 117\end{array}$

7.2.1 Sanctionering ministeriële verantwoordelijkheild $\quad 120$ 
7.2.2 Sanctioneringsproblematiek ministeriële verantwoordelijkheid 122

7.3 Verantwoording $\mathrm{OM}$ aan het parlement

\section{Hoofdstuk 4}

\section{Verhouding tussen OM en minister van Justitie in Italië}

1. Inleiding

2. Organisatie van het $\mathrm{OM}$

2.1 OM en rechterlijke macht

2.2 Interne organisatie

3. Bevoegdheden van het $\mathrm{OM}$

3.1 Legaliteitsbeginsel

3.2 Opsporing

3.3 Beslissing over de vervolging

3.4 'OM-beleid"

3.5 Vervolgingsstrategie

3.6 Functie OM ter zitting

3.7 Rechtsmiddelen door het $\mathrm{OM}$

3.8 Rechterlijke controle op het OM

3.9 Conclusie

4. Minister en ministerie van Justitie en President

5. Rechtspositie van het $O M$

5.1 Benoemingen

5.2 Overplaatsing en functiewijziging

5.3 Bezoldiging

5.4 Grondrechten

5.5 Aansprakelijkheid

5.6 Disciplinair regime

5.7 Schorsing en ontslag

5.8 Rechtspositionele rechtsbescherming $\quad 148$

5.9 Conclusie

6. Functionele ministerièle bevoegdheden

6.1 Bevoegdheden omtrent informatievoorziening 149

6.2 Bevoegdheden ten aanzien van de vervolging 151

6.2.1 Ministerieel verzoek 151

6.2.2 Toestemming door de minister en andere ambten 153

$\begin{array}{lll}6.2 .3 & \text { Toestemmingsprocedure } & 154\end{array}$

6.2.4 Vervolgingstoestemming voor de President 155

6.3 Gezag over opsporingsorganen 155

6.4 Bevoegdheden ten aanzien van budget en organisatie 156

6.5 Informele invloed 156

6.6 Conclusie 157

7. Verantwoording voor het $O M$ 
7.1 Grondslag en reikwijdte werantwoordelijkheid $\quad 158$

7.2 Verantwoordingsproces : 159

7.2.1 Sanctionering ministeriële verantwoordelijkheid 164

7.3 Verantwoording OM aan het parlement 165

$\begin{array}{ll}7.4 \text { Conclusie } & 166\end{array}$

8. Samenvatting en conclusie 167

\section{Hoofdstuk 5}

Vergelijking van onderschikking en autonomie

1. Inleiding 169

2. Vergelijking functionele ministeriële bevoegdheden 170

2.1 Bevoegdheden omtrent informatievoorziening 170

2.2 Aanwijzingsbevoegdheid. 171

2.3 Aanwijzingsprocedure $\quad 172$

2.4 Rechtswaarborgen bij aanwijzingen $\quad 173$

2.5 Overige bevoegdheden omtrent de vervolging 174

2.6 Informele invloed 175

2.7 Conclusie 175

3. Vergelijking rechtspositie van het $\mathrm{OM} \quad 175$

4. Conclusie rechtspositie en functionele positie 176

5. Factoren in de relatie tussen minister en het $\mathrm{OM} \quad 178$

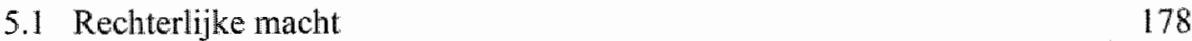

$\begin{array}{ll}5.2 \text { Organisatiestructuur } & 179\end{array}$

5.3 Minister en ministerie van Justitie 181

5.4 Bevoegdheden en discretie van het OM 182

$\begin{array}{ll}5.5 \text { Verantwoording voor het OM } & 187\end{array}$

6. Concluderende vergelijking 189

\section{Hoofdstuk 6 \\ Ratio en kritiek.}

1. Inleiding

2. Ratio ministeriële bevoegdheden ten aanzien van de rechtspositie van het OM 191

2.1 Informatieschaarste over ratio rechtspositie 191

2.2 Samenvallen functionele en rechtspositionele ratio 193

2.3 Conclusie 195

3. Ratio functionele relatie minister en OM 196

4. Legitimiteit: ratio voor onderschikking 197

4.1 Onathankelijkheid van de rechter als anomalie 199

4.2 Bestuursorgaan of regeringsvertegenwoordiger 200

4.3 Vervolging als een regeringsaangelegenheid 203

4.4 Pollitieke keuze of algemeen belang 205

4.5 Opportuniteitsbeginsel 206 
4.5.1 Ministeriële coördinatie door opportuniteitsbeginsel : $\quad 206$

4.5.2 Discretie door opportuniteitsbeginsel 207

$\begin{array}{ll}4.6 \text { Beleidsvrijheid } & 209\end{array}$

4.6.1 Discretie en initiatief $\quad \cdots, \quad 210$

$\begin{array}{ll}4.6 .2 \text { Beleidsvoering en individuele zaken } & 211\end{array}$

5. Legitimiteitsargumenten voor individuele aanwijzingen 214

$\begin{array}{ll}5.1 \text { Beleidscontrole } & 214\end{array}$

5.2 Anticipatie van wetgeving $\quad 216$

5.3 Buitenlandse betrekkingen $\quad 216$

5.4 Vervolgingsbeslissing als een politieke keuze, van algemeen belang $\quad 217$

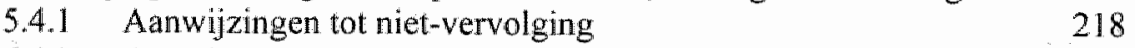

5.4.2 Aanwijzingen tot vervolging 220

6. Ministeriële rechtsbescherming, rechtmatigheidscontrole en rechtsontwikkeling 222

6.1 Rechtsbescherming en rechtmatigheidscontrole 222

6.1.1 Aanwijzing tot vervolging en niet-vervolging 223

6.1.2 Aanwijzing ten aanzien van het requisitoir 224

6.2 Proefproces en rechtsontwikkeling 225

6.2.1 Aanwijzing tot vervolging 225

6.2.2 Aanwijzing ten aanzien van het requisitoir 226

$\begin{array}{ll}\text { 7. Rechtsstatelijke ratio voor autonomie } & 227\end{array}$

$\begin{array}{ll}7.1 \text { Machtenscheiding } & 228\end{array}$

$\begin{array}{ll}7.2 \text { Rechterlijke taak } & 229\end{array}$

$\begin{array}{ll}7.3 \text { Rechtszekerheid } & 230\end{array}$

$\begin{array}{ll}7.4 & \text { Onpartijdige partij } \\ & 230\end{array}$

7.4. Partijdigheid door ministeriële invloed 232

$\begin{array}{ll}\text { 7.4.2 Onpartijdigheid als andere ambtenaren? } & 236\end{array}$

7.4.3 Functies van de onpartijdigheid van het $\mathrm{OM} 237$

7.4.4 Overdreven wantrouwen en voldoende waarborgen? 239

7.5 Autonomie OM als bescherming van de onafhankelijkheid van de rechter 241

8. Vergelijking ratio en kritiek $\quad 242$

9. Samenvatting en conclusie 243

\section{Hoofdstuk 7}

Hervormingen

1. Inleiding 247

2. Grondwettelijke belemmeringen $\quad 247$

3. Hervormingsvoorstellen in drie landen 248

3.1 Rechterlijke toetsing van aanwijzingen 250

3.2 Beperkte aanwijzingsbevoegdheid en ministerieel beklag 252

3.3 Autonome rechtspositie 253

3.4 Autonome rechtspositie met toetsing van aanwijzingen 254

3.5 Autonome rechtspositie met beperkte aanwijzingsbevoegdheid 255

3.5.1 Ministeriële zeggenschap 255

3.5.2 Zeggenschap door volksvertegenwoordigingen 258 
$\begin{array}{ll}3.6 & \text { Procureur-generaal "de la Nation" } \\ 3.7 & 260\end{array}$

$\begin{array}{ll}3.7 \text { Hervormingen in extremis } & 262\end{array}$

3.7.1 Vervolgingstaak aan minister van Justitie 263

$\begin{array}{ll}3.7 .2 & \text { Gekozen OM } 263\end{array}$

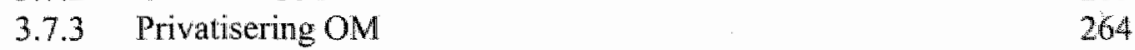

4. Europees Openbaar Ministerie 265

5. Vergelijking van voorstellen 268

6. Conclusie en eigen voorstellen $\quad 269$

6.1 Hervorming van de functionele relatie tussen OM en minister 269

6.2 Hervorming van de rechtspositie van het OM 271

6.3 Verantwoording voor het $\mathrm{OM} \quad 272$

$\begin{array}{ll}\text { Summary } & 273\end{array}$

$\begin{array}{ll}\text { Lijst van geraadpleegde literatuur } & 275\end{array}$

$\begin{array}{ll}\text { Zakenregister } & 299\end{array}$

$\begin{array}{ll}\text { Dankwoord } & 305\end{array}$

$\begin{array}{ll}\text { Curriculum vitae } & 307\end{array}$ 



\section{Lijst van afkortingen}

\begin{tabular}{|c|c|}
\hline AA & Ars Aequi \\
\hline Aa. Vv. & Autori Vari \\
\hline $\mathrm{AB}$ & Administratiefrechtelijke Beslissingen. \\
\hline Aecr & Aanwijzingen externe contacten rijksambtenaren \\
\hline $\mathrm{AN}$ & Assemblée Nationale \\
\hline $\mathrm{APC}$ & Archives de politique criminelle \\
\hline ARAR & Algemeen Rijksambtenarenreglement \\
\hline att. & $\begin{array}{l}\text { norme di attuazione, di coordinamento e transitorie del codice } \\
\text { di procedura penale }\end{array}$ \\
\hline Aw & Ambtenarenwet \\
\hline Awb & Algemene wet bestuursrecht \\
\hline BBRA & Bezoldigingsbeslunt Burgerlijke Rijksambtenaren 1984 \\
\hline Brra & Besluit rechtspositie rechterlijke ambtenaren \\
\hline $\mathrm{BW}$ & Burgerlijk Wetboek \\
\hline c.c. & codice civile \\
\hline c.p. & codice penale \\
\hline c.p.c. & codice dil procedura civille \\
\hline c.p.p. & codice di procedura penale \\
\hline Cass. pen. & Cassazione penale \\
\hline CdD, R.s. & Camera dei Deputati, Resoconto stenografico dell 'Assemblea \\
\hline CdD, R.s.C.g. & $\begin{array}{l}\text { Camera dei Deputati, Resoconto sommario } \\
\text { della Commissione giustizia }\end{array}$ \\
\hline $\mathrm{COJ}$ & Code de l'organisation judiciaire \\
\hline Const. & Constitution de la République \\
\hline Corte Cost. & Corte Costituzionale \\
\hline Cost. & Costituzione della Repubblica italiana \\
\hline CP & Code pénal \\
\hline CPP & Code de procédure pénale \\
\hline CRI & Compte rendue integral \\
\hline CRvB & Centrale Raad van Beroep \\
\hline CSM & $\begin{array}{l}\text { Conseil Supérieur de la Magistrature, Consiglio superiore } \\
\text { della magistratura }\end{array}$ \\
\hline cur. & a cura di \\
\hline $\mathrm{D}$ & Recueill Dalloz-Sirey \\
\hline d.l. & decreto legge \\
\hline d. $\lg$ & decreto legislativo \\
\hline d.m. & decreto ministeriale \\
\hline d.p.c.m. & decreto dell Presidente del Consiglio dei ministri \\
\hline d.P.R. & decreto dell Presidente della Repubblica \\
\hline $\mathrm{DACG}$ & Direction des Affaires criminelles et des Grâces \\
\hline $\mathrm{DD}$ & Delict en Delinkwent \\
\hline Dig. disc. pen. & Digesto delle Discipline Penalistiche \\
\hline Dig. disc. pub. & Digesto delle Discipline Pubblicistiche \\
\hline
\end{tabular}


Dir. pen. e proc. pen. Doc. Giust.

DP

Enc. dir.

Enc. giur.

EOM

EVRM

FIOD-ECD

Foro it.

Gaz. Pal.

Giur. cost.

Giust. pen.

Gw

Handelingen I

Handelingen II

HR

Ind. pen.

JCP

JHS

JO

Justices

Kamerstukken I

Kamerstukken II

1.

1.cost.

I.const.

l.org.

$\mathrm{NJ}$

NJB

NJCM

NIV

Nov. dig. it.

NPJ

NVVR

OM

ord.

ord.giud.

Pouvoirs

QR

Quad. cost.

Quad. giust.

Quest. giust
Diritto penale e procedura penale

Documenti Giustizia

Revue Droit Pénal

Enciclopedia del diritto

Enciclopedia giuridica Treceani

Europees Openbaar Ministerie

Europees verdrag tot bescherming van de rechten van de mens

en de fundamentele vrijheden

Fiscale Inlichtingen- en Opsporingsdienst

Economische Controledienst

Foro italiana

Gazette du Palais

Giurisprudenza costituzionale

Giustizia penale

Grondwet

Handelingen der Eerste Kamer der Staten-Generaal

Handelingen der Tweede Kamer der Staten-Generaal

Hoge Raad der Nederlanden

Indice penale

Jurisclasseur périodique

Jesus Hominum Salvator

Journal Officiel

Justices: revue générale de droit processuel

Kamerstukken der Eerste Kamer der Staten-Generaal

Kamerstukken der Tweede Kamer der Staten-Generaal

legge

legge costituzionale

loi constitionelle

loi organique

Nederlandse Jurisprudentie

Nederlands Juristenblad

Nederlands Juristen Comité voor de Mensenrechten

Nederlandse Juristen Vereniging

Novissimo digesto italiano

Nouveau Pouvoir judiciaire, Le

Nederlandse Vereniging voor de Rechtspraak

Openbaar Ministerie

ordonnance n. 58-1270 van 22 december 1958

ordinamento giudiziario

Pouvoirs: revue française d'études constitutionnelles et politiques

Questions et Réponses

Quaderni costituzionali

Quademi di giustizia

Questione giustizia 
r.d.

r.d.lgs.

RAN

$\mathrm{RC}$

RDP

RFDC

RIDP

Riv. dir. proc.

Riv, it. dir, proc. pen.

Riv. pen.

RMThemis

RPDP

RS

RSC

RvOEK

RVOMR

RvOTK

$\mathrm{S}$

SdR, R.s.C.g.

SdR, R.s.s.

$\mathrm{Sr}$

SR

Stb.

Stcrt.

Sv

TP

Trema

WAHV

Wet RO

Wmv

Wrra regio decreto

regio decreto legislativo

Règlement de l'Assemblée Nationale

Regolamento della Camera dei Deputati

Revue du droit public et de la science politique en France et à l"étranger

Revue française de droit constitutionnel

Revue international de droit pénal

Rivista di diritto processuale

Rivista italiana di diritto e procedura penale

Rivista penale

Rechtsgeleerd Magazijn Themis

Revue pénitentiaire et de droit pénal

Règlement du Sénat,

Regolamento dello Senato della Repubblica

Revue de science criminelle et de droit pénal comparé

Reglement van Orde van de Eerste Kamer

Reglement van Orde van de Ministerraad

Reglement van Orde van de Tweede Kamer

Recueil Sirey

Senato della Repubblica, Resoconto sommario

della Commissione giustizia

Senato della Repubblica, Resoconto sommario

e stenografico dell'Assemblea

Wetboek van Strafrecht

Sénat de la République

Staatsblad

Staatscourant

Wetboek van Strafvordering

Tijdschrift Privatisering

Tijdschrift voor de rechterlijke macht

Wet administratiefrechtelijke handhaving van verkeersovertredingen

Wet op de Rechterlijke Organisatie

Wet op de ministeriële verantwoordelijkheid

Wet rechtspositie rechterlijke ambtenaren 



\section{Hoofdstuk 1}

\section{Inleiding}

\section{Inleiding}

Het $O M$ is één van de meest dubbelzinnige instellingen van de centrale overheid. Enerzijds verdient het afstand, of autonomie, anderzijds eist de politiek gezag op over de vervolging. Het moet handelen in onpartijdigheid, maar niet ontsnappen aan demoeratische legitimatie. ${ }^{.}$Het kan deel zijn van de rechterlijke macht, maar ook een bestuursorgaan. Deze dubbelzinnigheid tekent de relatie van het $\mathrm{OM}$ met de minister.

Debat over de verhouding tussen OM en politiek is een vrij permanente aangelegenheid in het staats- en strafrecht. Daarin ontbreekt echter een systematische analyse van die verhouding en de ratio daarachter. De discussie over dit onderwerp is verder sterk nationaal gericht. Het onderhavige werk wil op deze punten een aanvulling betekenen. Naast een beschrijwing van de juridische rellatie tussen minister en $\mathrm{OM}$ in Nederland plaats ik een overeenkomstige beschouwing over Frankrijk en Italië. Een vergelijking wan deze stelsels verheldert de analyse van elk afzonderlijk. Vercler laat de rechtswergelijking het toe om enige conclusies van meer algemene aard te trekken. Deze exercitie vormt de basis voor het aangaan van het eigenlijke debat. Een afweging van de voors en tegens van een politiek autonoom of ondergeschikt OM kan dan tevens een vergelijkende opzet krijgen. De argumenten in Frankrijk en Italiẻ kunnen betrokken worden bij die in Nederland. Een concluderend oordeel over de wenselijkheid van een bepaalde verhouding tussen minister en OM laat zich ten slotte graag illustreren. Daartoe kunnen een analyse en vergelijking van relevante hervormingsvoorstellen bijdragen.

Uit het voorgaande laten zich vier hoofdvragen distilleren:

- Welke juridische verhouding bestaat in Nederland, Frankrijk en Italië tussen het OM en politieke ambten, waaronder met name de minister van Justitie?

- Welke verschillen en overeenkomsten bestaan in de mate van autononie of ondergeschiktheid in deze landen, en welke factoren zijn hierbij van belang?

- Wat voor gedachtegoed ligt achter deze stelsels en wat is de draagkracht van deze argumenten?

- Welke wijzigingen van de relatie tussen de minister en het OM zijn voorgesteld en in hoeverre zouden deze toepassing moeten vinden in Nederland?

De eerste vraag vindt een beantwoording in de hoofdstukken 2, 3 en 4. Deze vormen een analyse van het geldend recht in de afzonderlijke drie landen. Daarna volgt een vergelijking van deze systemen in hoofdstuk 5. Hoofdstuk 6 stelt de ratio achter deze stelsels aan bod. Een kritische beschouwing daarvan leidt tot een algemene conclusie. In hoofdstuk 7 neem ik enkele concrete hervormingen van de verhouding tussen het $\mathrm{OM}$ en de minister onder de loep. Daarbij trek ik conclusies over de wenselijkheid van invoering van dergelijke voorstellen in Nederland.

1 Over de begrippen onpartijdigheid, legitimiteit en legitimatie, zie hoofdstuk 6, 3. Ratio qunctionele relattie minister en $\mathrm{OM}$ 
In het onderstaande wil ik eerst bakens uitzetten binnen welke ik het onderzoek heb willen verrichten. Daarna geef ik enkele overwegingen die de keuze van de te vergelijken landen verdedigen. Ten slotte een enkel woord over de methode van onderzoek.

\section{Inhoudelijke afbakening}

Dit proefschrift is geschreven met een staatsrechtelijke microscoop en een strafrechtelijk vergrootglas. Daarmee doel ik niet zozeer op het grote aantal details, maar op de nadruk van het constitutionele gezichtspunt. Het onderwerp maakt deel uit van het recht der rechterlijke organisatie. Dit heeft met name staatsrechtelijke, maar ook strafrechtelijke (en privaatrechtelijke) aspecten. Anders dan in Frankrijk vormt dit rechtsgebied in Nederland en Italië geen afzonderlijke juridische discipline. Leerstoelen, afstudeerrichtingen en handboeken op het gebied van de rechterlijke organisatie bestaan in deze landen vrijwel niet. De onderhavige studie krijgt in Nederlandse termen dan ook het etiket 'interdisciplinair' opgeplakt. Deze algemene opmerking richt zich tot strafrechtgeleerden die dit proefschrift te staatsrechtelijk zouden kunnen achten, en staatsrechtbeoefenaars die menen dat er teveel strafprocesrecht aan bod komt. Om in Nederlandse categorieën te spreken is het de bedoeling de analyse van het relevante strafprocesrecht te beperken tot voor zover deze betrekking heeft op het betrokken staatsrecht.

Hieronder wil ik het onderzoeksobject nader preciseren in relatie tot het straf(proces)recht, de definitie van het $O M$ en de minister, de politicologie, de rechtsfilosofie, de rechtsgeschiedenis en het internationale recht.

\section{I Straf(proces)recht}

Vanuit clit uitgangspunt wil dit werk geen uitputtende beschrijving van de bevoegdheden van het OM zelf voorstellen, noch van het strafproces in de te beschrijven landen. [k neem verder enkel de uitoefening van strafrechtelijke bevoegdheden door het $O M$ in aanmerking. Bevoegdheden op het terrein van het privaatrecht of andere rechtsgebieden laat ik buiten beschouwing. De belangrijkste en politiek meest precaire taak van het OM betreft het strafrecht. De privatrechtelijke bevoegdheden worden minder gebruikt, afgezien van enkele specifieke onderdelen. Verder lijken deze bevoegdheden betrekking te hebben op onderling sterk verschillende rechtsverhoudingen in de drie landen. Een dergelijke variëteit leent zich moeilijk voor een inhoudelijke vergelijking. Met betrekking tot het strafrechtelijke handelen van het OM richt ik mij slechts op de bevoegdheden die de opsporing en de vervolging betreffen. De taken van het OM bij de executie geef ik geen expliciete aandacht. Deze taken zijn voor het onderhavige onderwerp minder van belang. De beslissingsruimte van de bevoegdheden bij de executie is niet omvangrijk. De uitvoering van de rechterlijke oordelen lat weinig beleidsvrijheid. ${ }^{2}$ De eventuele invloed van de minister hierop heeft nauwelijks tot enig debat aanvrijheid. 
leiding gegeven - deze discussie kan elders aangezwengeld worden. Eveninin onderwerp van analyse zijn de met strafrechtelijke opsporing en vervolging verwante handelingen als het opleggen van bestuurlijke boetes. Enkele van de hier volgende conclusies kunnen wel indirect van toepassing zijn voor de institutionele aspecten van de bestuurlijke boete. Dergelijke gevolgtrekkingen laat ik hier achterwege.

\section{$2.2 O M$}

Geen onderwerp van onderzoek is de procureur-generaal bij de Hoge Raad of het Hof van cassatie. In Nederland is deze sinds 1999 geen lid meer van het OM, maar in de andere landen is dit wel het geval. Met name de andersoortige taken van dit ambt doen deze buiten het onderwerp vallen.

Ik behandel verder enkel het $O M$ bij de gewone of strafrechtelijke rechterlijke colleges. Zo spreek ik hier niet over het in Frankrijk bestaande OM bij de administratieve gerechten, vertegenwoordigd door de zogenaamde regeringscommissarissen. (commissaires du gouvernement). Hun rol is om een conclusie te geven ten aanzien van de administratieve geschillen. $\mathrm{Zij}$ zijn ondanks hun benaming niet ondergeschikt aan een politiek orgaan. ${ }^{3}$ Ook geef ik geen speciale aandacht aan het $O M$ bij de militaire colleges en de jeugdrechters. ${ }^{4}$

\subsection{Minister en 'de politiek'}

In dit werk behandel ik onder meer de invloed van 'de politiek' op het OM. Onder deze noemer stel ik vooral de verhouding tussen OM en minister van Justitie aan de orde. Deze heeft in alledrie de landen een spilfunctie in relatie tot de overige overheidsambten - hoewel hij in Italië wel duidelijk minder centraal staat. De positionering van het OM met betrekking tot de overige ambten behoeft en krijgt daarom een minder uitvoerige beschrijving. Deze ambten zijn de regering en het parlement, en in Frankrijk en ltalië ook de President. Voor deze landen is de analyse van de rol van de Hoge Raad voor de Magistratuur verweven in de beschrijving van de relatie tussen minister en $O M$.

De samenhang tussen vervolging en wetgeving lat ik bijvoorbeeld achterwege. Het voeren van een zeer actief wetgevingsbeleid kan in beginsel het voeren van een vervolgingsbeleid grotendeels uitsluiten. De bestudering van wetgevingsactiviteit kan daarom relevant zijn voor een meer volkomen analyse van de politieke zeggenschap over het OM-beleid. Voor een inhoudelijke studie van de strafrechtelijke wetgeving is gezien de omvang daarvan hier geen ruimte gemaakt.

In de navolgende hoofdstukken besteed ik ruime aandacht aan de bevoegdheden van de minister ten aanzien wan het $\mathrm{OM}$ en diens handelen. Ik bezie welke taak de minister heeft ten aanzien van de rechtspositie van de rechterlijke ambtenaren van het OM. Daarnaast bespreek ik de functionele ministeriële bevoegdheden, zoals die on aanwijzingen tot vervolging te geven. Sommige zijdelings mogelijk relevante bevoegdheden

3 Arn. 1.112-2 e.x. Code des jurisdictions financières. Volff 1998, p. 100 e.v.

4 In Frankrijk: artt. 10 e.v. Code de justice militaire en artt. 4 e.v. ord. n. 58.1274 wan 22 december 1958 , art. 20 ord. n. 45-174 van 2 februari 1945 . 
laat ik hier echter buiten beschouwing. Aangezien ik de taak van het OM bij de executie buiten de bespreking laat, zal ik de ministeriële roll hierin evenzeer achterwege laten. Zoals gezegd is de relatie tussen OM en politiek op dit punt overigens niet controversieel.

Verder neent de minister van Justitie, in samenspraak met die van Buitenlandse zaken, besluiten aangaxnde internationale rechtshulp. Dergelige beslissingen kunnen de voortgang van de opsporing en vervolging bevorderen of belemmeren. Gezien de specificiteit van het betrokken onderwerp wil ik deze besluitvorming buiten beschouwing laten in dit meer algemene werk. Overigens worden veel verzoeken om rechtshulp, met name binnen de EU, rechtstreeks afgehandeld door de 'rechterlijke autoriteiten' (waaronder het $\mathrm{OM}$ ) onderling. De bijdrage van de ministers hierin wordt langzaamaan kleiner. ${ }^{5}$

Een andere bevoegdheid die ik onbesproken laat, is die om gratie te verlenen. Gratie verlicht of heft de gevolgen op van een rechterljk vonnis. Aangezien deze bevoegdheid. het vonnis betreft, en niet de vervolging, laat ik hem hier verder buiten beschouwing. ${ }^{6}$ Een gelijksoortig instituut, amnestie, wil ik eveneens slechts in deze inleiding noemen. Door middel van amnestie worden de gevolgen van een soort delict of een groep delicten opgeheven. Het ontneemt - anders dan gratie - het strafbare karakter aan gepleegde delicten. Wederom in tegenstelling tot gratie kan amnestie plaatsvinden voordat een vonnis is uitgesproken. Het kan mitsdien de instelling of de voortgang van vervolging direct belemmeren. Amnestie kan in alle betrokken landen echter alleen bij wet geschieden. Deze wetgevende aard van de bevoegdheid vormt voor mij reden om hier in de volgende hoofdstukken verder geen aandacht aan te schenken.

Dergelijke wetten komen in Nederland vrijwel niet meer voor. ${ }^{7}$ Frankrijk kent juist een uitgebreid gebruik van amnestiewetten. Volgens traditie neemt men bij elke presidentsverkiezing een wet atan die vooral voor kleinere vergrijpen amnestie verleent. Als referentiepunt verwijst deze wet dan ook naar de datum van het aantreden van de gekozen president. Daarnaast wordt evenwel ook buiten presidentiele verkiezingen om amnestie verleend. ${ }^{8}$ In Italië kwam amnestie in de afgelopen halve eeuw enkele tientallen keren

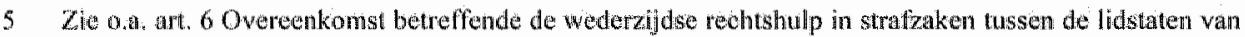
de Europose Unie.

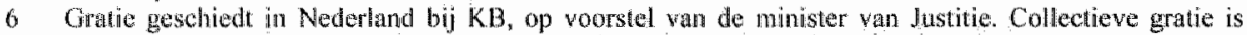
everizeer mogelijk, zic bijv, KB 17 juli 1975, Stb. 400. Art. 122 lid IGw Gratiewet.

In Fruktik en Italk wordt gratie verlend door de Puesident. Diens besluit wordt gecontrasigneerd door de minhter van Justitie. Voon Frankrijk: art, 17 Const; art: $133-7$; $133-8 \mathrm{CP}$. Voor ltaliè: art. 87 Cost.; art. 174 c.p.; art. 681 c.p.p.., art. 69-9 o.p.).

7 Voor het latst in 1949, Remmelink 1996, p. $882-883$. Ze art 122 lid 2 Gw. Tot 1983 bevatte de grondwet ook een thidrukkelijke bepalung over abolitive. Deze heeft dezelfde gevolgen als amuestie, naar beperkt zich tot een specilieke persoon (art. 77 oud).

8 Zie bijwoorbeld loi n. $81-736$ van 4 angustus 1981 (aantreden van Mitterand), n, $88-828$ van 20 juli 1988 (herverkiowing van Mitterand, refereert an 22 mei), n. 89.473 wan 10 juli 1989 (delicten bij de gebeurtenissen in Guadeloupe. Martinique en Corsica), n. $90-33$ van 10 januari 1990 (delicten rond the invoering van het nieuwe statuut wan Nonvelle-Caledonie), n. $90-55$ vath 15 januari 1990 (funancięn partjen), n. 95-884 van 3 augustus 1995 (antreden van Chirac). Met name de wet van 15 januari 1990 is sterk bekritiseerd. Vanuit de rechisprekende macht zijn er zells protestacties tegen geweest. De kritiek betreft de ammestie van Illeggle partijfinanciering, waarbij de politiek zich in feite een deel van zijn eigen schuld leek kwijt te schelden. Bouvier, Jacquin \& Vogelweith 1997, p. 21-24; Tureey 1997, p. 21; 
voor. Vanaf 1992 moet een ammestiewet echter met een meerderheid van tweederde van de leden van een kamer aangenomen worden. Sindsdien heeft geen amnestie meer plaatsgevonden."

\subsection{Politicologie}

Hoewel ik hier vooral een juridische beschouwing zal geven, heef het onderzoeksobject in twee betekenissen politieke connotaties. Enerzijds hebben de nationale politieke verhoudingen invloed op de positie van de minister, zeker in relatie tot het parlement. De aard van de politieke cultuur en het partijstelsel bepalen mede het functioneren van bevoegdheden en controlesystemen. Anderzijds raakt het onderwerp in Frankrijk en met name Italië nauw aan politieke gevoeligheden. In een context van strafrechtelijke vervolgingen van politici kunnen sommige voorstellen voor verandering van de positie van het $\mathrm{OM}$ bij voorbaat verdacht of dubbelzinnig geacht worden.

Het navolgende vormt evenwel geen volledige politicologische bespreking van de verhouding tussen de minister en het OM. Beschouwingen over de feitelijke machtsverhoudingen tussen OM en minister kunnen niet anders dan summier zij.j. Een onderzoek daarmaar zou op problemen van praktische uitvoerbaarheid stuiten. Zoals ik in de volgende hoofdstukken zal onderbouwen heeft een belangrijk deel van de werkelijke invloed van in ieder geval de Nederlandse en Franse ministers een informeel karakter. Documentatie van deze informele relatie is naar haar aard beperkt. Wel heb ik getracht precaire aspecten te vermelden en waar mogelijk praktijkvoorbeelden aan te halen.

\subsection{Rechtsfilosofie}

In deze verhandeling laat ik de algemene rechtstheorie en rechtslilosofie over het voorliggende onderwerp grotendeels buiten beschouwing. In de discussie halen auteurs begrippen als de 'rechtsstaat", 'machtenscheiding' en de 'democratie' wel geregeld naar boven. De algemene theorieën over deze beginselen wijden echter vaak wel woorden aan de rechter, of de rechterlike macht, maar niet aan het OM zelf. Voor zover deelnemers aan het debat over het OM een dergelijke uitgewerkte visie hebben, wordi deze echter maar zelden uitdrukkelijk gegeven. Het betreffende begrip wordt meestal en passant genoemd, waardoor geen inhoudelijke discussie of kritiek mogelijk is over de betekenis van deze concepten voor het $\mathrm{OM}^{10}$

Ilk wil hier geen 'eigen' toegesneden visie op de democratie en de rechtsstaat geven om vervolgens de vele redeneringen omtrent de relatie tussen OM en minister daaraan te

Chrestia 2000 , p. 760 .

9 Art. 79 Cost. Voor de grondwetswijziging: I.cost. 6 mart 1992, 11. 1 . Tot die datum geschiedde ammestie door de President na delegatie door de wel, bijw. bij: A.P.R. 12 april 1990, n. 75 an d.P.R. 20 januali 1992, n. 23. Daarnaast is een soort abstracte vorm van gratic mogelijk: indulto. Deze wondt bij wet verleend, en vermindert de opgelegde of nog op le leggen strat. Het strafbare karakter van het strafbare feat neent het niet weg. Tot 1.cost. 6 maart 1992, n. I geschiedde ook indulto door de President na delegatie doos de wet, bijv. d.P.R. 12 december 1990, n. 394.

10 Een uitzonderlijk uitgewerkte visie wormt het werk van "t Hart 1994. Hij bespreeki het OM uitwoerig gerelateerd aan de rechtsstaat. Democratische aspecten bijuen bij hem evenwel grotendeels buiten beschouwing. 
toetsen. Dat zou een omkering betekenen van de analyse zoals ik deze feitelijk heb verricht.

Daamaast bestaat geen debat over de vraag of landen als Nederland, Frankrijk en Italië well of niet een democratie of een rechtsstaat zijn. De discussie gaat veeleer over de invulling, de nadere uitwerking van deze waarden. De wraag is veeleer hoe de drie stelsels meer democratisch of rechtsstatelijk ingericht zouden kunnen worden.

Een algemene uitweiding $a$ priori over deze concepten laat ik dus achterwege. Wel poog ik te specificeren wat in de rol, de positie of het handelen van het $O M$ in de richting wijst van rechtsstatelijke eisen of democratische waarden. Vanuit deze insteek verbind ik het denken over autonomie voor het OM met de rechtsstaat, en de onderschikkingsgedachte met de democratie. Deze redenering zet ik in brede zin uit in hoofdstuk 6. De hoofdstukken daaraan voorafgaand zijn zoals gezegd voornamelijk beschrijvend en analyserend van aard. Deels vindt daar echter onvermijdelijk een zekere beoordeling van de stelsels plaats. Waar dat gebeurt, baseren mijn oordelen zich inhoudelijk op de argumentatie uit het zesde hoofdstuk. Om herhaling of oppervlakkigheid te vermijden verwijs ik naar dat hoofdstuk ${ }^{11}$ en geef ik op deze plaats geen inleidend normatief kader.

\subsection{Rechishistorie}

De beschrijving van de geschiedenis van het OM wordt door sommige auteurs begonnen vanaff de oude Egyptenaren. ${ }^{12}$ De problematiek wan de relatie tussen politiek en OM is veel jonger. Deze speelt pas na de ontwikkeling van institutionele machtenscheidingen en nadat het $\mathrm{OM}$ en de parlementaire democratie meer institutionele vormen hebben aangenomen. Die problematiek is aldus ongeveer anderhalve eeuw tot twee eeuwen oud. In het onderhavige onderzoek beperk ik mij evenwel tot de ontwikkelingen in de laatste decennia.

De verder teruggaande geschiedschrijving laat $i k$ om twee redenen achterwege. Ten eerste bestaan reeds uitvoerige werken op dit gebied, en zou een korte bijdrage mijnerzijds een herhaling van zetten betekenen. ${ }^{13}$ Een uitgebreide historische inleiding zou ten koste gaan van de leesbaarheid en uitvoerbaarheid van dit onderzoek. De tweede reden is inhoudelijk van aard. Ingaan op de oudere geschiedenis van het $O M$ is mijns inziens niet strikt nodig voor een analyse van het geldend recht en een standpuntbepaling omtrent de wenselijkheid daarvan. Het straf(proces)recht, het staatsrecht en het politieke stelsel hebben de latatste eeuwen namelijk vele, vergaande wijzigingen ondergaan. Het aantal strafbepalingen is sterk toegenomen, de handhaafbaarheid daarvan niet altijd evenzeer. Het karakter van strafbepalingen veranderde deels. Strafrecht is steeds vaker gebruikt als middel om de maatschappij te ordenen en te sturen. Het enkele handhaven van de wet is wat minder vanzelfsprekend geworden. De noodzaak van beleidsvoering door het OM werd meer en meer expliciet. Daarnaast kreeg het OM telkens nieuwe

II En in het bijzonder naar de algemene overwegingen van 3. Ratio functionele relatie minister en OM.

12 Morselli 1995, p. 476.

13.Zie voor de ontwikkeling in Nederland: Van Heijnsbergen 1929. Voor de periode van 1813 tot 1920: Pieterman 1990. Na WO II: Van de Bunt 1982; Vast 2000; 't Hart 2001, p. 7-25. Voor Frankrijk: Rassa" 1967; Carbasse 2000. Voor Italie: Vellani 1970; Morselli 1995. 
bevoegdheden, waarbij de mogelijkheden dwangmiddelen te gebruiken werden uitgebreid. De reikwijdte van de rechterlijke toetsing van het handelen van het OM groeide eveneens. Onder meer brachten verdragsbepalingen verscherpte controle mee. Tegelijkertijd steeg de criminaliteit sterk in verhouding tot de bevolking. Normschendingen veranderden van karakter door voortschrijdende georganiseerde criminaliteit en corruptie. Verder is de politiek zich meer direct gaan interesseren voor het handelen van het OM. Strafzaken hebben versterkte politieke aandacht gekregen. Het parlementair stelsel heeft zich eveneens nadrukkelijk ontwikkeld. De relatie tussen staatshoofd, regering en parlement is voortdurend van aard veranderd. Het parlement kreeg allengs meer invloed op de regering, maar vervolgens groeide de politieke dominantie van de laatste (in Frankrijk die van de President). Ten slotte onderging de rechterlijke macht enkele groeistuipen en statuswijzigingen. Zijn autonomie van de politiek kreeg geleidelijk verschillende gestaltes.

Door al deze veranderingen is een meer diepgaande historische beschrijving minder relevant voor een standpuntbepaling omtrent de huidige relatie tussen $O M$ en politiek. De toenmalige opvattingen over de noodzakelijkheid of wenselijkheid van een bepaald stelsel zijn moeilijk in te passen in het huidige debat. De mening dat het strafvorderlijke legaliteitsbeginsel praktisch volledige toepassing zou kunnen krijgen is bijvoorbeeld volkomen achterhaald. Voor enkel de analyse van het geldend recht is een beschrijving van de oudere geschiedenis evenmin strikt noodzakelijk. De huidige systematiek is goed uiteen te zetten zonder bijvoorbeeld de opvatting van de Nederlandse minister van Justitie Van Maanen in 1827 uitgebreid daarin te betrekken. De geschiedenis van het onderhavige onderwerp vertoont kortom zoveel discontinuitteit dat zij buiten het kader van het onderzoek kan vallen. ${ }^{14}$

De focus ligt hier op het heden en de tijd vanaf de jaren zestig van de vorige eeuw. In zowel Nederland en Frankrijk als in Italië leeft dan de discussie op over de verhouding tussen het OM en de politiek. De Nederlandse Juristen-Vereniging houdt daar in die tijd een uitvoerig debat over. Tegelijkertijd krijgt het opportuniteitsbeginsel dan belangrijke aandacht. De Franse Rassat publiceert in deze periode haar veel geciteerde standaardwerk over het OM. In Italië komen het conservatisme en conformisme in de hogere regionen van de rechterlijke macht aan de orde en wordt een debat gevoerd over de aard van het $\mathrm{OM}^{15}$

Vanaf de jaren zestig krijgt het onderwerp aandacht met afwisselende intensiteit. Vervolgens is midden jaren negentig het $\mathrm{OM}$ en diens relatie met politicke organen een kwestie van formaat. Het Nederlandse OM wordt gereorganiseerd en beleeft openlijke conflicten met de minister. In Frankrijk komen enkele affaires aan het licht en wordt hervorming van de relatie minister-OM een prestigeproject van president Chirac en premier Jospin. De Italiaanse operatie Schone Handen krijgt vrij baan en een openhar-

14 Enige korte, geschiedkundige kwesties komen as de orde in hoofdstuk 1, 6.2.1. Grondslag aunwijzingsbevoegdheid, hoofdstuk 6, 2.1. Informatieschaarste over ratio rechtspositie, 4.2. Bestursorgasan of regeringsvertegenwoordiger, 4.6.2. Discretie door opportuniteitsbeginsel.

15 In Nederland: Duisterwinkel 1968; Mostert 1968; Moons 1969. In Frankrijk: Rassant 1967. In Italia: Maranini 1962; Bartole 1964; Natura e funzione del p.m. 1967. 
tige discussie over prioriteitenstelling begint. De relatie tussen minister en $\mathrm{OM}$ behoudt ook daama nog actualiteit.

\subsection{Internationaal recht}

Internationale verdragen geven geen regels aangaande de constitutionele positie van het OM. Hoogstens is de uitoefening van sommige vervolgingsfuncties onderwerp van bindende internationale normering. Op het gebied van de relatie tussen $O M$ en politiek bestaan alleen regels van soft low. De laatste decennia is een veelheid van dergelijke normen totstandgekomen. De belangrijkste aanbevelingen komen van de Verenigde Naties, de Raad van Europa en de Europese Unie. ${ }^{16}$ Daarnaast lieten non-gouvernementele organisaties van zich horen, zoals de Internationale Juristen Commissie, de Internationale Vereniging van Strafrecht, de Europese Magistraten voor Democratie en Vrijheden en de Internationale Vereniging van Aanklagers. ${ }^{17}$ Al deze aanbevelingen wil ik op deze plaats niet afzonderlijk bestuderen. ${ }^{18}$ De vergelijking van de stelsels van een aantal landen is hier het voomaamste onderwerp. Wel zal ik ze, voor zover relevant, noemen in de uiteenzetting van hoofdstuk $6 .{ }^{19}$ Gezien de betogende aard van dat hoofdstuk, past het daarin melding te maken van het internationale normatieve gedachtegoed dat in de aanbevelingen tot uiting komt. De ontwikkeling van de internationale gedachtenvorming hieromtrent heeft zich echter niet al dermate gepreciseerd, dat deze ook als uitgangspunt van de huidige studie kan fungeren.

Daarnaast is Europeesrechtelijk gezien de ontwikkeling van een Europees Openbaar Ministerie (EOM) van bijzonder belang voor het onderhavige onderwerp. De realisatie van de plannen voor de instelling van een supranationale vervolgende instantie zou rechtstreekse gevolgen hebben voor het handelen van het nationale $\mathrm{OM}$ in de diverse landen. Dergelijke voorstellen zijn mede gebaseerd op argumenten voor en tegen de

16 Verenigde Naties: Guidelines on the Role of Prosecutors, aangenomen bij Resolution 45/166 van 18 december 1990. Compendium of UN Standards and Norms in Crime Prevention and Criminal Justice. Raad van Europa: "Conclusions et recommandations" in: La transformation de la Prokuratura en instance compatible avec les principes démocratiques de justice, (Conseil de l'Europe 1996), 162-163. Recommendation on the role of the public prosecution in the criminal justice system, Rec no. (00)19. Europese Unie: Conclusions Conference Rule of Law, Noordwijk 1997, ongepubliceerd.

17 Intemational Commission of Jurists: Draft Principles on the Independence of the Judiciary ( Syracuse principles"), CIJL Bulletin 1990, nz. 25-26, p. 59. International Association of Penal Law: Resolutions, Section II. The Relations Between the Organization of the Judiciary and Criminal Procedure, International Review of Penal Lisw 1990, p. 129. Magistrats Européens pour la Démocratie et les Libertés (MEDEL): Élénents d'un statut européen de la magistrature ("Verklaring van Palemo"), 1990; Declaration de principes sur le mintistere public, 1990. International Association of Prosecutors: Standards of Professional Responsibility and Statement of the Essential Duties and Rights of Prosecutors, The Hague: IAP 1999.

18 Zie over enkele aambevelingen: NJCM 1996, p. 985-986; Myjer 1999;; 2002; Falletti 2001. Verder verwijs ik mar een anstaande publicatie van mijn hand in de Maastricht Joumal onder de titel: International Norms on the Institutional Position of the Prosecutor: a Tendency towards Independence. Hierin besteed ik ook aandaclyt aan de institutionele positie van de aanklagers in her Internationaal Strafhof, het Yoegoslavie-tribunaal en het Rwanda-tribunaal. Deze laat ik hier verder buiten beschouwing.

19 Zie hooldstuk 6, 2.1. Informatieschanste over ratio rechtspositie, 4.6.2. Beleidswoering en individuele zaken, 5.4.1. Aanwijzingen tot niet-vervolging, 5.4.2. Aamwizzingen tot vervolging, 7.4. Onpartijdige partij en 9. Samenvatting en conclusie. 
nationale relatie tussen politicke organen en vervolgende ambten. Waar ik aandach besteed aan de hervormingswoorstellen in de drie landen zal ik daarom tevens twimte wijden aan de ideeên omtrent het EOM. ${ }^{20}$

\section{Landenkeuze}

De rechtsvergelijking richt ik in beginsel op Nederland, Frankrijk en Italië. Andere landen krijgen hier geen bijzondere aandacht. Frankrijk en Italië zijn gekozen, ondat zij in het algemeen goed vergelijkbaar zijn met Nederland. Zij hebben een gemeenschappelijke culturele en politieke achtergrond en een deels gelijksoortig rechtsstelsel. Het zijn alledrie westerse landen met vergelijkbare politieke stromingen, geworteld in een civil law traditie. Ze worden algemeen beschouwd als 'democratie' en 'rechtsstatat' en voldoen voor een groot deel aan gemeenschappelijke eisen zoals die door Europese en internationale normen gesteld worden. In Nederland wordt Frankrijk wel vaker gebruikt als object van rechtsvergelijking, Italië veel minder. De Italiaanse regeringsvorm vertoont evenwel vergaande gelijkenissen met de Nederlandse. Het Appenijnse schiereiland heeft verder een productieve juridische wetenschap die bijzonder open staat voor ideeën uit buitenlandse systemen. Dit rechtsvergelijkende onderzoek doelt daarom mede op het onder de aandacht brengen van een ten onrechte vrij onbekend rechtsstelsel. Onder de westerse landen zijn Frankrijk en Italië juist zo interessant voor dit onderwerp omdat daar een actuele discussie gaande is over de wenselijkheid van de verhouding tussen OM en politiek. In Frankrijk zijn voorstellen gedaan om tot een meer autonoom OM te komen, terwijl men in Italiẻ nadere controllemechanismen ten aanzien van het OM heeft overwogen. Deze feiten brengen met zich dat veel specifick onderzoeksmateriaal aanwezig is, hetgeen de rechtsvergelijking vergemakkelijkt.

Verder ligt de vergelijking voor de hand ondat de rechterlijke organisatie en het strafproces van Nederland en Italiè hun rechtshistorische wortels in het Napoleontische Frankrijk hebben liggen. Het Franse OM heeft in het verleden in belangrijke mate als model voor andere landen gefungeerd. Deze wortels brengen een gemeenschappelijk begrippenapparaat mee hetgeen van nut is voor de onderhavige beschrijwing.

Wat betreft mogelijke andere landen als onderzoeksobject wil ik het volgende opmerken. Het vaak voor rechtsvergelijking gebruikte Engelse systeem brengt voor de onderzoeker van het onderhavige onderwerp en aantal complicerende factoren mee. Ten eerste levert de common law traditie enkele vergelijkingsproblemen op. Het jonge OM en het strafproces aldaar hebben een rol die belangrijke functionele afwijkingen kent van die op het Europese continent. Daarnaast is problematisch dat Engeland geen echte minister van Justitie kent. De Lord Chancellor kan die naam niet dragen. Hij is meer een soort minister van wetgeving, en bowendien combineent hij rechterlijke functies, de rol van Speaker in the House of Lords en executieve taken. De Atrowney General heelt we in enkele opzichten gelijksoortige bevoegdheden als bijvoorbeeld de Nederlandse of Franse minister. Hij is echter wel lid van de regering, maar niet van het cabinet, de 
regering in enge zin. Naar gewoonterecht wordt hij geacht onafhankelijk van de regering te handelen.

De Verenigde Staten, een tweede land dat veelvuldig in aanmerking komt yoor rechtsvergelijking, kan slechts een beperkt inzicht geven in het onderhavige probleem. Naast het aspect van de common low traditie daar, brengt de presidentièle regeringsvorm met zich dat er geen ministeriële verantwoordelijkheid bestat ten opzichte van het parlement, zoals in de parlementaire regeringsvorm. De ministers zijn the president's men, en alleen van hem afhankelijk. Zij hebben daarmee een plaats in het staatsbestel die weinig aanknopingspunten heeft met in ieder geval de Nederlandse of Italiaanse. Een complicatie is daarnaast de federale structuur, waardoor er aanklagers en ministers van Justitie zijn op verschillende niveaus, met onderling weer verschillende relaties. Verder zijn veel openbare aanklagers in de Verenigde Staten direct gekozen, waardoor de discussie over hun positie vanaf een andere grondslag begint.

Het veel vergeleken Duitsland ten sllote, zou - afgezien van de federale vorm - weer veel beter voor vergelijking in aanmerking komen. De regeringsvorm, de rechtstraditie, de minister en het OM zijn in veel opzichten gelijksoortig. Om de haalbaarheid en de diepgang van het onderzoek te bevorderen is het echter geconcentreerd op drie landen.

\section{Onderzoeksmethodologie}

Het onderzoek is uitgevoerd aan de hand van wetgeving, de schaarse relevante jurisprudentie, parlementaire stukken en straf(proces)rechtelijke en staatsrechtelijke literatuur. Ten slotte heb ik interviews gehouden met enkele rechtsgeleerden, leden van het OM en departementsambtenaren. Het literatuuronderzoek werd op 1 september 2002 afgesloten. Met latere publicaties en gegevens kon slechts incidenteel rekening worden gehouden. 


\section{Hoofdstuk 2}

\section{Verhouding tussen OM en minister van Justitie in Nederland}

De vraag is, of strafverwolging een zwaard mag worden in de hand von het politisch of administratief Bestum. naar de inzigten van dat Bestur gezwaid of in de schede gehouden. J.R. Thorbecke, Bijdrage tot de herziening der Grondwet

\section{Inleiding}

Het zwaard van Vrouwe Justitia rust sinds de wijziging van de Wet RO eind jaren negentig met zoveel woorden in handen van de minister van Justitie. De daadkracht gegrond op zijn 'inzigten' blijft evenwel getemperd door de algemeen geëiste 'terug houdendheid'. Wat betekent dit precies voor de verhouding tussen minister en OM? Thorbecke vervolgt in zijn Bijdrage dat 'niets dan regterlijke ernst, niets dan regtwaardigheid" bij de vervolgingsbeslissing het leidend principe moet zijn. Maar capaciteitsoverwegingen en prioriteiten kunnen het (hedendaagse) OM evenmin ontgaan. Welke zeggenschap heeft de minister nu over het OM?

In dit hoofdstuk beschrijf ik de Nederlandse verhouding tussen de minister van Justitie en het OM. On te beginnen dient de positie van het OM onderzocht te worden. Alvorens een analyse van diens bevoegdheden te geven is het zaak het OM zelf te analyseren. Vervolgens kunnen de relevante bevoegdheden geplaatst worden in het geschetste beeld wan de organisatie van het $O M$. Een beschrijving van deze bevoegdheden moet noodzakelijkerwijs voorafgaan aan de bevoegdheden van de minister van Justitic ten aanzien van het OM. Voordat ik aan die ministeriële bevoegdheden begin zet ik kort de positie van de minister uiteen. Deze heeft bevoegdheden van tweeërlei soort: zowel ten aanzien van de rechtspositie als ten aanzien van het handelen van het OM. Eerst volgt een beschouwing over aspecten van de rechtspositie van de leden van het OM en de invloed wan de minister daarop. Daama geef ik een bespreking van de functionele bevoegdheden die de minister beeft ten aanzien van het OM. Vervolgens wordt de ministeriele verantwoordelijkheid bij de uitoefening van strafiechtelijke bevoegdheden van opsporing en vervolging beschreven. Het hoofdstuk eindigt met een korte conclusie over het Nederlandse systeem.

\section{Organisatie van het OM}

Voor het onderhavige onderzoek ligt het voor de hand eerst te beginnen met een analyse van het OM zelf. Voor een constitutionele plaatsbepaling van het OM beschrijf ik de positie binnen de rechterlifke macht en de verhouding tot de andere machten. Daarna bespreek ik de eigen organisatie van het OM. Zowel de verschillende ambten die er deel van uitmaken als de onderlinge relaties passeren de revue. 


\subsection{OM en rechterlijke macht}

Uit de grondwet kan afgeleid worden dat er andere leden van de rechterlijke macht zijn, dan alleen de leden 'met rechtspraak belast' (artt. 116 lid 2 en 117 lid 1). Uit het gebruik van deze zinsnede leidt men algemeen af dat de ledlen van het OM deel uitmaken van de rechterlijke macht' Geen enkele wettelijke regeling noent de ambtenaren van het OM echter met zoveel woorden 'leden van de rechterlijke macht'. De Wet RO en de Wrra gebruiken enkel het begrip 'rechterlijke ambtenaren'. Van 1999 tot 2002 werd in plaats daarvan cle term 'leden van de rechterlijke macht' expliciet genoemd in artikel 2 lid 2 Wet RO. ${ }^{2}$ De Wet organisatie en bestuur gerechten heeft dit begrip vervangen. De minister overwoog daarbij: "Het begrip "rechterlijke ambtenaren met rechtspraak belast" sluit aan bij de in de Grondwet gehanteerde terminologie voor leden van de rechterlijke macht. ${ }^{3}$ Gezien het bovenstaande is dit niet geheel juist. Ook rechterlijke ambtenaren die niet met rechtspraak zijn belast zijn leden van de rechterlijke macht.

'De rechterlijke macht' op zich heeft in de (grond)wetgeving één van twee betekenissen. Enerzijds doelt het op de leden - waaronder ambtenaren van het $\mathrm{OM}$ - die tot de rechterlijke macht behoren. Anderzijds gebruikt de wetgever het om te verwijzen naar de gerechten die tot de rechterlijke macht behoren. In de literatuur spreekt men dan wel van "de gewone rechterlijke macht". Het is in deze tweede betekenis dat het OM zelf niet tot de rechterlijke macht behoort. ${ }^{5}$ Uit de grondwet noch uit de wetgeving valt af te leiden dat het orgaancomplex OM zelf onderdeel is van de rechterlijke macht. Het OM is geen gerecht dat als zodanig is aangewezen als deel van de rechterlijke macht. Voor de gerechten bepaalt artikel 2 van de Wet RO dit echter wel uitdrukkelijk. Het is daarom minder exact om, zoals - velen doen ${ }^{6}$ - te menen dat het OM zélf tot de rechterlijke macht behoort.

De leden van het OM maken dus deel uit van de rechterlijke macht. Sommigen zien het OM als geheel echter uitdrukkelijk als een onderdeel van de 'uitvoerende macht' of de

1 Kamerstukken I, 1980/81, 16162, nr. 1006, p. 5; Remmelink 1991, p. 168; Osinga 1992, p. 58; Minister Sorgdrager, Kamerstukken II 1996/97, 25392, n. 3, p. 4. Ta.v. de oude grondwet bijw.: Corstens \& Tak 1974 , p. 30, Sommigen leiden hieruit al dat het OM zelf onderdeel is van de rechterlijke macht, bijwoorbeeld Stroink 1978, p. 158 . Zle noot 6.

Art. $116-(\ldots) 4$. De wet regelt thet toezicht door leden van de rechteriijke macht met rechtspraak belast uit te oefenein op de andbusvervuling doon zodanige leden en door de personen bedoeld in het vorige lid. Art. $117-1$. De leden wan de rechterlijke macht met rechtspraxk belast en de procureur-generaal bij de Hoge Rald worden bij koninklijk besluit voor het leven benoend. (...)

2 Onder de Wet RO van woón 1999 was dit niet met zoveel woorden het geval. Wel waren er al bepaalde verwijzingen, zie bijwoorbeeld art. 29 (het huidige art. I Wra, warin deze verwijzing is vervallen). Nog bestande verwijzingen zijn art. 42 en 50 Wra.

3 Kamerstukken II 1999/2000,27181, nr. 3, p. 41.

4 In deze zin bijroorbeld: art. $116 \mathrm{Gw}$; art. 2 Wet RO; art. 1:4 lid $2 \mathrm{Awb}$. Vgl. Kortmann 2001, p. 244245.

5 Zoals de volgende auteurs stellen, matar zonder te onderscheiden in de twee genoemde betekenissen: Cliteur 1996, p. 598; Corstens 1997, p. 223; Robben 2001, p. 93. Later schrijft Cliteur echter weer wêl "dat het OM tot de rechterlijke macht behoort". 1997, p. 93-94.

6 Jaarverslag OM 1974, Kamerstukken II 1975/76, 13600 V1, nr. 3, p. 15; Van Veen 1977, p. 264; Stroink 1978, p. 158; Buruma 1993, p. 267; Elzinga 1994, p. 53.4; Elzinga \& Koopman 1994, p. 229; De Doelder 1996, p. 120; Sorgdrager 1996, p. 6; Bovend Eert 1999, p. 7. 
"bestumrlijke macht". Geen van deze begrippen heeft in Nederland enige "juridische gevolgen. In de grondwet en andere regelgeving komen zij niet voor. Ook de litieratur gebruikt deze termen vrijwel niet bij de analyse van de Nederlandse regeringsvorm. Het is dus juridisch zinlloos om kwalificaties als "uitvoerende" of "bestuurlijke macht" op het OM te plakken. Opvallend tegenstrijdig is het ten slotte dat in sommige gevallen een zelfde tekst het OM na elkaar als uitvoerende en als rechterlike macht bestempelt. In hoeverre heeft het deel uitmaken van de rechterlijke macht nu rechtsgevolgen? De wet hanteett twee vormen voor het begrip 'rechterlijke macht'. Dit zijn de termen "leden van de rechterlijke macht" en "leden van de rechterlijke macht met rechtspraak belast". De wetgeving gebruikt de enkele term "rechterlijke macht' als zodanig net om de leden aan te duiden. De "leden wan de rechterlijke macht met rechtspraak belast" duidt op de ambtenaren met een rechtsprekende functie, zoals de raadsheren en rechters bij de rechtbanken. Deze term heeft in de grondwet en gewone wetten enige belangrijke gevolgen, zoals de benoeming voor het leven. De grondwet verbindt geen rechtsgevolgen aan het begrip 'leden van de rechterlijke macht' zonder de toevoeging 'met rechtspraak belast'. Gewone wetten en andere regelingen gebruiken het begrip zelden. Voor zover zij dat doen hebben die bepalingen maar weinig belang. Deze regels geven de leden van de rechterlijke macht nauwelijks een bijzondere positie in vergelijking met gewone ambtenaren." Een enkele wet noemt zelfs de "ambtenaren van het openbaar

7 Uitwoerende macht: Elzinga 1994, p. 535; Sorgdrager 1996, p. 6; Sorgdrager, Kamersukken II 1995/96, 24034, nr. 13, p. 7; Brouwer 1999, p. 51; Simonis \& Myjer 2001, p. 76; Bowend"Eert 1999, p. 7. Bestuurlijke macht: Borman 1981, p. 103. Elzinga, minister Sorgdrager, Brouwer en Simonis \& Myjer menen in een zelfde tekst tevens dat het $O M$ onderdeel is wan de rechterlijke macht, respectievelijk p. $534 ; 1996$, p. 6,1999 , p. 50 en 2001, p. 76 . Brouwer en Simonis \& Myjer stellen dat het OM "functioneel' deel is van de uitvoerende macht, maar 'formeel' deel van de rechterlijke.

8 Art. 56 wan de grondwet van 1972 stelde nog: 'De uitwoerende macht berust bij de Koning.' Deze bepaling stamde uit 1848 . De 'uütvoerende macht' betrof hier echter een lunctie, niet een organncomplex of staatsonderdeel.

9 Art. 4 lid 2 sub 1 onder $\mathbb{R}$ ROMR - I. De raad beraadslaagt en besluit over hat algemeen regeringsbeleïd en bevordert de eenheid wan dat beleid.

2. Te dien einde beraadslaagt en besluit de rad onder meer over: (...)

1. andere voordrachten woor koninklijke bes/uiten tot benouming van personen en ontslag wegens andere reden dan op verzoek van de betrokkenen, voor zover het niet betreft benoeming of ontslag:

1. van in Nederland werkzame leden van de rechterlijke macht, (...).

Art. $28 \mathrm{WwSr}-(\ldots) 2$. Ontzetting van leden van de rechterlijke macht die, hetzij voor hun leven, hetzij voor een bepaalde tijd, zijn angesteld, of van andere voor bun leven angestelde anvitenaren, geschiedt, ten opzichte van het ambt waartoe zij aldus zijn aangesteld, alleen in de gevallen en op de wijze bij de wet bepaald.

Art. 5396 W $\mathrm{S} S \mathrm{v}-1$. Anderen dan opsporingsambtenaren oefenen de bevoegdheden, in artikel $539 \%$ of in de tweede afdeling wan deze Titel toegekend, niet uit dan op aanwijzing van de officier van justilie, tenzij zodanige aanwijzingen niet kunmen worden afgewacht.

2. Leder die een bevoegdheid als bedoeld in het eerste lid heeft uitgeoefend, stell de officier wan justitie: onverwijld en op de snelst mogelijke wijze in kennis wan: (...)

5. Het bepaalde in de woorgaande leden geldt niet voor leden van de rechterlijke macht ten aanzien wan die verrichtingen waartoe zij als zodanig bevoegd z.jin.

Art. 6 Besluit ex artikel 859 Wetboek van Burgerlijke Rechtsvordering - (1.) De leden van de rechterlijke macht en de ledem wan de bureawx van consultatie zijn verplicht to geheimhouding van de luun door den inspecteur der directe belastingen of der registratie en domeinen werstrekte gegevens. (...) 
ministerie" naast de "leden van de rechterlijke macht", alsof de laatste categorie niet al de eerste zou overlappen. ${ }^{10}$

Veel auteurs concluderen dan ook terecht dat er nauwelijks rechtens relevante gevolgen zijn verbonden aan het feit dat de leden van het $\mathrm{OM}$ onderdeel zijn van de rechterlijke macht. Enkelen voegen toe dat 'het $O M$ ' (beter: de leden van het $O M$ ) hoogstens 'organisatorisch" of "formeel" deel zou uitmaken van de rechterlijke macht. Sommigen stellen echter incorrect dat dit geen rechtsgevolgen zou hebben."

Men geeft evenwel niet aan wat men precies bedoelt met een kwalificatie als "formeel". Dit soort toevoegingen komen mij als overbodig en zelfs suggestief voor. Zoals gezegd heeft het begrip "leden van de rechterlijke macht" juridisch weinig gevolgen. Zeggen dat het deel uitmaken van de rechterlijke macht voor de leden van het OM nauwelijks of slechts formele betekenis heeft, lijkt te suggereren dat dit anders is woor de rechters. Dit is niet het geval. Het maakt niet uit of die leden ambtenaren van het OM of van een rechtsprekend college zijn. Even weinig rechtsgevolgen zijn verbonden aan het feit dat rechters tot de rechterlijke macht behoren. Rechters vallen echter ook onder het begrip 'leden van de rechterlijke macht met rechtspraak belast', dat wèl enkele belangrijke consequenties meebrengt.

Eén enkel rechtsgevolg verdient aparte vermelding. Het deel uitmaken van de rechterlijke macht bepaalt de constitutionele positie van de leden van het $O M$, hetgeen van belang is bij een systematische interpretatie van het recht. Dit behoren tot de rechterlijke macht wordt met name gebruikt bij de interpretatie van de geoorloofdheid van het gebruik van ministeriële aanwijzingsbevoegdheden. Zo concludeert men op grond daarvan tot terughoudendheid voor de minister. Deze conclusie is te construeren als een rechtsgevolg - zij brengt een juridische plicht mee. In paragraaf 6 behandel ik deze beperking op de ministeriële aanwijzingsbevoegdheid nader.

Los daarvan zou het deel uitmaken van de rechterlijke macht een argument kunnen vormen om de wenselijkheid van autonomie voor het OM te bepleiten. Deze redenering komt in hoofdstuk 7 aan de orde. ${ }^{12}$

De Nederlandse grondwet heeft kortom weinig expliciete betekenis woor het OM. Impliciet erkent de hoogste wet wel dat het OM bestaat en dat de leden deel uitmaken van de rechterlijke macht. Dit biedt hun echter nauwelijks bijzondere rechten of plichten. Voor de relatie met andere overheidsambten betekent het weinig. Het behoren tot de

10 Art. 76 Wet op de beroepen in de individuele gezondheidszorg - (..) 2. De secretaris van het centrale vuchtcollege verstrekt desgevraagd aan de tuchtcolleges, de leden wan de rechterlijke macht en de ambo tenaren van het openbar ministerie inlichtingen ontrent onherroepelijke beslissingen. (...)

11 Niet juridisch relevant achten de kwalificatie: Stroink 1978, p. 158; Daalder 1991, p. 88; Osinga 1992 , p. 60; Chiteur 1996, p. 598. De kwalificatie is van weinig belang voor: Burnma 1993, p. 267. Over de 'formele positie' van het OM als deel van de RM: Elzinga 1994, p. 534; Elzinga \& Koopnana 1994, p. 229; Bovend'Eert 1999, p. 7; Simonis \& Myjer 2001, p. 76. Over het "organisatorisch" behoren tot de RM: Cliteu 1997, 93-94. Hei OM zou volgens enkelen eigenlijk niet tot de rechterlijke macht behoren. Om duidelijkheid te seheppen zouden de leden van het OM uit de rechterlijke macht moeten worden gezet. Brenninkmeijer 1995, p. 21.1. Anderen stellen dnt het OM zelf uit de rechterlijke macht zou moeten worden geplastst, RPF-fractie, Kamerstukken II 1997/98, 25392, nr. 6, p. 5.

12 Zie 6.2.5.2. Terughoudendheid om het behoren tot de rechterlijke macht, en hoofdstuk 7, 7.1. Machtenscheiding. 
rechterlike macht heeft hoogstens consequenties voor de interpretatie van de functionele ministeriele bevoegdheden.

\subsection{Interne organisatie}

Voor het bepalen van de verhouding tussen de minister van Justitie en het OM is het van groot belang de interne structurur van de laatste te kennen. De minister heeft namelijk niet bevoegdheden ten aanzien van alle ambten van het OM. Een belangrijke vraag is dan ook in hoeverre de organen waarop hij wel invloed heeft de andere delen van het OM kunnen aansturen. Een tweede relevante kwestie is de interne organisatievorm van de ambten van het OM. Daarbij is mede de al dan niet collegiale vorm van de organen van belang. Hieronder loop ik, na enkele algemene opmerkingen, eerst de verschillende parketten bij de rechterlijke colleges langs. Daarna behandel ik de relatie tussen parketten onderling. Ten slotte bezie ik de interne organisatie van elk parket.

Het OM is een ambt. Het is een instelling die met taken en bevoegdheden is bekleed. Eigenaardig aan het $\mathrm{OM}$ is dat dit ambt samengesteld is uit en samenvalt met een aantal ambten. Dit zijn het College van procureurs-generaal, de (plaatsvervangende) officieren van justitie en de (plaatsvervangende) advocaten-generaal. Deze ambten vormen samen het OM. Zij oefenen de bevoegdheden van het OM uit (art. 125 Wet RO). De wet kent bevoegdheden toe aan het OM of aan deze ambten zelf, ook zonder de term OM te gebruiken. Sommige wetsbepalingen noemen de officier van justitie en het $O M$ zelfs in ến zelfde zin. ${ }^{13}$

Bij het OM is sprake van deconcentratie. De betrokken ambten zijn bekleed met eigen bevoegdheden, mar staan onder bijzondere aanwijzingen van de minister van Justitie. ${ }^{14}$ Hoewel dit niet altijd het geval is bij deconcentratie wijst de wet zelf de ambtenaren aan die de betrokken bevoegdheden uitoefenen. Een ministerieel besluit hoeft de ambtenaren van het OM die het ambt uitoefenen niet aan te wijzen. Anders dan bij veel vormen van deconcentratie is het OM geen onderdeel van een ministerie. Het komt niet voor in de organisatieregeling van het ministerie van Justitie. De leden van het OM zijn

13 Bijwoorbeeld: Art. 27 Wer administratieftechtelike handhawing verkeersvoorschriften - (...) 7. Eon feder, behoudens degene an wie de administratieve sanetie is opgelegd, is verplicht desgevordend on verwijld aan de ofticier wan justitie, die met de inning van de adminstratieve sanctie is belast, de inlichtingen te verstrekken wetke naar het redelijk oordeel wan het openbaan ministerie moodzaketijk zijn ten behoeve van de toepassing van het eerste lid wan dit artikel. De antikelen 217 en 218 wan het Weboek wan Strafvordering zijn wan overeenkomstige toepassing.

Art 7 Wet bijzondere opnemingen in psychiatrische ziekenhuizen - (..) 2. Indien, in een geval als bedoeld in artikel 2 , wierde lid, de betrokkene, nadat de verklaring bedoeld in artikel 5 , eerste lid, ter kemis van het openbar ministerie is gekomen, is overgebracht natr eer ziekenhuis in een ander arrondissement, kan de oorspronkelijk bevoegde officier van justitie dan wel - na de vordering vin de officier van justitia - de oorspronkelijk bevoegde rachter besluiten de behandeling van de zaak voort te zetten. De rechter kan evenwel verwajzing wan de behandelling wan de vordering naar de rechter van dat andere arrondissement bevelen.

14 Corstens 1974, p. 51 ; Stroink 1978, p. 157; Lubberdink 1982, p. 62; litzinga 1994, p. 534; Elzirga \& Koopman 1994, p. 229-230. In deze defontie van deconeentratie gebruk ik dus - anders dain bijw. Stroink - niet de kwalificatic "departementsambtenaren" als een bepalende factor. 
geen ambtenaren van het ministerie. ${ }^{15}$ Het is verder niet verhelderend het $O M$ al dan niet een 'buitendienst' van het ministerie van Justitie te noemen. Dit is geen juridisch begrip. ${ }^{16}$ Deze kwalificatie lijkt overigens te suggereren dat het $O M$ een buitenstaand dienstonderdeel van het ministerie zou zijn. Zoals gezegd maakt het OM echter in geen opzicht deel uit van de ministeriële organisatie. Meestal stelt men echter dat het OM geen buitendienst is van het ministerie.

Het OM bestaat uit negentien arrondissementsparketten, vijf ressortsparketten, één landelijk parket en het parket-generaal. Bij dit laatste parket werken vijf procureursgeneraal, die samen het College van procureurs-generaal vormen. Eén van hen is bij koninklijk besluit aangewezen als voorzitter. Het College staat aan het hoofd van het OM. De leden van het OM zijn verplicht het College de inlichtingen te verstrekken die het nodig heeft. Het kan zowel algemene als bijzondere aanwijzingen geven aan de hoofden van de andere parketten. Het vergadert wekelijks over organisatorische en rechtspositionele aangelegenheden, maar ook over het vervolgingsbeleid en sommige specifieke strafzaken. Het College beslist bij meerderheid, maar praktiseert consensus. $^{17}$

De procureurs-generaal zijn tevens plaatsvervangend advocaat-generaal bij de ressortsparketten en plaatsvervangend officier van justitie bij de arrondissementsparketten en het landelijk parket. $\mathrm{Zij}$ kunnen net als andere plaatsvervangers opgeroepen worden door een parkethoofd voor het verrichten van werkzaamheden. Daarnaast kunnen zij worden aangewezen on een tak uit te oefenen bij een bepaald parket. Deze aanwijzing geschiedt op verzoek van de betrokkene bij koninklijk besluit en na advies van het College. Na oproep of aanwijzing kan de procureur-generaal zelf een functie van het parket uitoefenen. Hij kan rechtstreeks vervolging instellen, seponeren, transigeren of rekwireren. In beginsel heeft het hoofd van het betrokken parket dan dezelfde bevoegdheden over de procureur-generaal als over de overige (plaatsvervangende) ambtenaren bij het parket. ${ }^{18}$ Waarschijnlijk zal de feitelijke gezagsverhouding in dat geval evenwel

I5 Minister Sorgdrager, Kannerstakken UI 199697, 25392, nu, 3, p. 9; Organisatieregeling Ministerie wan Justitic 2000 regeling van 4 juli 2000 . Ten ontechte noemen Stroink 1978, p. 158 en Muller 1994, p. 81 de leden wan het OM tan onrechte wel ambtenaren van het ministerie van Justitie".

16 Stroink 1978, pi 158. Geen buittendienst van het ministerie wordt het OM genoemd door: Minister Van Agl, Handelingen II I975/76, p. 381, 4062; 1976/77, p. 1399; Oranje 1976, p. 24; De Doelder 1996a. Korthals Altes noende het OM wel een buitendienst, 1988, p. 371 .

17 Art 129 en 130 Wet RO; art. Besht reorganisatie openbaar ministerie en instelling landeljk parket; art. 8 Sv. art. 2-7 Reglemcat van Orde wan he College van procureurs-generabl; Commissie Kalsbeek, Kamerstuktein II 1998/99, 26269, nir. 5, p. 168 . Onden het oude art. 5 Wet RO concludeerden sommigen dat hisatheh hoger gephatsten geen onbeperkte aanwijzingsbevoegdheid hadden. Zo zouden zij geen aumwiging len anzien van het requisitoir hebben kunnen geven: Corstens 1974, p. 52-53; Corstents \& Tak 1982, p. 22; De Doelder 1996, p. 125.

18 Art 135 Wat RO; art. 5 en 6 Wrra. Anders dan 't Hart meent in zijn noot onder HR 14 maart 2000, NJ 2000,423 is voor het aanwijzen wan de procureur-general geen instemming van het parkethoofd nodig. Art 126 lid 1 Wet RO warop hij doelt heet enkel betrekking op mandatvertening door het een lid van het OM an nietwechterlijke ambenaren werkzam bij het parket. De mogelijkheid woor procureursm generan an als platsvervangend afficier van justitic op te treden is ingevoerd op initiatief van Tweede Kamerlid Dittrich. Kamerstukken II 1997/98, 25392, ni. 14. 
anders van aard zijn. In probleemsituaties zou het College eventueel met een aanwijzing aan het parkethoofd de knoop kumnen doorhakken.

Bij de ressortsparketten zijn de (plaatsvervangende) advocaten-generaal werkzaam. Zij staan onder leiding van een hoofdadvocaat-general met de titel hoofd van het ressortsparket. Advocaten-generaal zijn van rechtswege plaatsvervangend advocaat-generaal bij de ressortsparketten waar zij niet zijn aangesteld. De ressortsparketten nemen met name de vervolging op zich van zaken in hoger beroep en beklagzaken bij het gereehtshof. De (plaatsvervangende) officieren van justitie werken bij de arrondissementsparketten en het landelijk parket. Een hoofdofficier van justitie is hoofd van het parket. Van rechtswege zijn de officieren tevens plaatsvervangend officier bij de parketten waar zij niet werkzaam zijn. Arrondissementsparketten dragen zorg voor de vervolging in de zaken waarvoor de kantonrechter en de rechtbank competent zijn. De officieren bij het landelijk parket ten slotte hebben de vervolging van misdrijven van bovenlokale aard of waarbij een hoge mate van financiële en fiscale deskundigheid noodzakelijk is. ${ }^{19}$

Het Nederlandse OM bestond in 2001 uit ruim 500 leden. De rechtsprekende colleges kenden een bezetting van tweeëneenhalf duizend leden. ${ }^{201}$

De ressorts- en arrondissementsparketten en het landelijk parket staan in een nevengeschikte verhouding. Zij kunnen onderling geen aanwijzingen naar elkaar doen uitgaan. Wel bestaat een overleggroep, genaamd $\mathrm{OM}$ breed beraad. Hieraan nemen deel de leden van het College, de twintig hoofdofficieren van justitie van de arrondissementsparketten en het landelijk parket en de vijf hoofdadvocaten-generaal. Dit beraad heeft als functie de eenheid binnen het $\mathrm{OM}$ te bewaren. ${ }^{21}$

Intern in de verschillende parketten kan de leiding op zijn beurt algemene en bijzondere aanwijzingen geven aan de ambtenaren van haar parket. Het hoofd regelt verder de werkwijze en organisatie van het parket. Het parkethoofd kan desgewenst een strafzaak aan een ander lid van het parket toewijzen, of de zaak zelf behandelen. Indien een parketlid in strijd met aanwijzingen wan het hoofd handelt, zijn die handelingen niettemin rechtsgeldig. De leden wan het parket worden geacht het hoofd uit eigen beweging en op verzoek te informeren over beleid en individuele strafzaken. In de praktijk plegen parketleden en hoofd veeleer overleg dan dat de laatste bevelen geeft. Intern houdt men op alle niveaus regelmatig vergaderingen waarin organisatorische en beleidskwesties aan de orde komen. ${ }^{22}$

19 Voor de inrichting valu de parketten: art 136-138 Wel RO. Voor de competentie. art. 9-10 Sv; art. 6 Beslun reorganisatic openbarar ministerie en instelling landelijk parket. Nans de genoemde purketen is een zogenaamd Functioneel Openbar Minstenic (FOM) in oprichting. Dit parket zall zich ma name gaan richten op speciffeke sectoren van het strafrech als de handhaving van fratudebepalingen. Tot op heden is dit geen apart onderdeel van he: OM. Het bestat aldus nog uit. leden van bestande parkatten.

20 Bij de rechtsprekende colleges werkte in 20012611 fe's "rechisgeleerd ambtelijk personeel". Bij het OM 544 fie's. Kamerstuken 11 2001/02,28380, nr. 10, p. 135, Jarwerstag OM 2001.

21 Zie 0.a. Mister Korthals, Aanhangsel Handelingen II 1999/2000, n. | 136, p. 2251; "1 Hart 2001, p. 7475.

22 Art. 136 lid 2, 137 lid 2 en 138 lid 2, 139 lid 2 Wet RO. Een en ander blijkt uir gesprekken. Over da organisatie van het OM in het algemeen tavens: Van der Flier 1999, "t Hart 1999, p. 107-109; 2001, p. $52-75$ 
Het Nederlandse OM is een strak opgezet bedrij. De "directie", ${ }^{23}$ het College, kan de organisatie desgewenst tot en met individuele beslissingen toe aansturen. De bevoegdheden van parkethoofden spiegelen zich aan die van het College. Inlichtingenplichten en aanwijzingsbewogdheden sluiten naw op elkaar aan. Het OM wordt feitelijk everwwel voor grotendeels geregeerd bij consensus, warin inlichtingen en aanwijzingen in elkaar overgaan. Overleg voent de boventoon.

\section{Bevoegdheden wan het OM}

De beschrijving van de ambten van het OM kan nu gevolgd worden door een beschouwing van de bevoegdheden die deze uitoefenen. In het onderhavige onderzoek vormen zij het object van de relatie tussen OM en politieke organen. De autonomie of ondergeschiktheid die het OM in deze relatie ondervindt heeft en weerslag op de uitoefening van zijn bevoegdheden. Van belang is om in deze paragraaf vast te stellen wat het handelen is waar de invloed van de politiek betrekking op kan hebben. Een secundair aandachtspunt is de wijze waarop en de mate waarin rechterlijke controle op het handelen van het OM plaatswindt. Dit makt duidelijk in hoeverre een eventueel door de politiek beïnvloed handelen van het OM door de rechter gecontroleerd kan worden. Dit punt komt eveneens in paragraaf 6 aan de orde. ${ }^{24}$

"Het OM is belast met de strafrechtelijke handhaving van de rechtsorde en met andere bij de wet vastgestelde taken" (art. 124 Wet RO). Het OM heeft voor deze taken bepaalde strafrechtelijke bevoegdheden en daarnaast een aantal bevoegcheden in het burgerlijk recht en het bestuursrecht. ${ }^{25}$ Specifieke vermelding verdient het toezicht dat de officier van justitie houdt op de boeteoplegging door de politie in het kader van de Wet administratieve handhaving verkeersvoorschriften. Hij kan daartoe beleidsregels stellen. Tevens fungeert hij als administratief beroepsorgaan voor beroepen tegen deze boeteoplegging. ${ }^{26}$

Op het gebied van het strafrecht houdt het OM zich bezig met het bepalen en uitvoeren van het strafrechtelijke beleid, het geven van leiding aan de opsporing, het vervolgen van delicten en het doen uitvoeren van strafvonnissen. Het onderhavige onderzoek laat

23 'Hart en Vast noenew het College een soort "Rand van Bestum", respectievelijk 2000, p. 105 en 2001 . p. 95.

242 2e $6,2.4$. Rechiswarbongen bij aarwijzingen.

25 Het OM adviseert onirent graticwertening (ant. 4.5 Gratiewet). De rechtbank hoort het OM in bepalde civielrechtelijke zaken, bijvoorbeeld in cassatie, voon de bediging van makelars en adwocaten en voor de libilissementsverklaring (art. 324 RV: art. 63 a Weboek wan Koophandel; art. 3 lid I Advocallenwet: Hrit. 4 ea 10 fratlissementswe). Het OM heeft bevoegdheden ten aanzien wan akten wan geboorte en overlijden inet register wan de burgerlijke stand, her huwelijk de ondertoezichtstelling wan minderjarigen, curatele, onbinding van rechtspersonen, de matatenschap, ete. (art. 1:19b, 1:19h lid 4, 1:24 lid $1,1,53$ lid 1, 1:254 lid 2, art $1: 379,2 \% 19$ lid $2,4: 1173$ lid 1 BW) Verder heetl thet OM enkele bijzondere. meer bestumlijke bewoegdheden. Zo kan het OM bijvoorbeed vordeningen doen tot machtigug om psychiselh gestoonde in een psychiatrisch ziekentan is te doen opnemen (att. 2 lid 1, 32 lid 3 Wet bijzondere opneming in psychiatrisethe ziekenhuizen). Voor ex hier en daan wat verouderd overzicht: Corstens \& Tak 1982, p. 135 av.

Art 3 an 6 WAHV. 
de executie en de privaat- en bestuursrechtelijke taken buiten beschouwing. ${ }^{27}$ In het onderstaande geef ik een korte beschrijving van de strafrechtelijke bevoegdheden van het OM. Ik behandel ze opsommingsgewijs ten behoeve van een parallelle analyse in de rechtsvergelijking. ${ }^{28}$

\subsection{Opsporing}

De officier van justitie is belast met de opsporing en het toezicht daarop. De politie staat voor wat betreft de opsporing onder zijn gezag. Hij kan politieambtenaren, maar ook andere met opsporing belaste personen algemene en bijzondere aanwijzingen geven. ${ }^{29}$

De officier van justitie kan dwangmiddelen (doen) toepassen. Ten aanzien van bepaalde delicten kan hij verdachten aanhouden en naar een plaats voor verhoor geleiden. Hij kan een machtiging geven voor het binnentreden in woningen zonder toestemming van de bewoner. Bij ernstige bezwaren kan hij bepalen dat een verdachte aan zijn lichaam of kleding wordt onderzocht. De officier kan ten aanzien van bepaalde delicten bevelen dat de verdachte voor drie dagen in verzekering gesteld wordt, met de mogelijkheid van verlenging. Het $O M$ kan bevelen dat de verdachte aan maatregelen van identificatie onderworpen wordt. Het kan een DNA-onderzoek naar een onbekende verdachte doen instellen. Ten aanzien van bepaalde delicten kan de officier bij dringende noodzaak een doorzoeking doen ter inbeslagneming. Het OM kan verder besluiten tot het gebruik van bijzondere opsporingsbevoegdheden als infiltratie en pseudo-koop. Hiervoor gelden bijzondere procedureregels. ${ }^{30}$

In het zogenaamde driehoeksoverleg oefent het $\mathrm{OM}$ tevens invloed uit op het opsporingsbeleid. Hierin overlegt de hoofdofficier van justitie met de burgemeester en het hoofd van het regionale politiecorps over de taakuitoefening van de politie. Parallel daaraan overlegt het College van procureurs-generaal met de commissaris van de Koningin. Verder neemt de hoofdofficier deel aan het regionaal college dat zeggenschap heeft over het beheer en beleid van het regional politiecorps. ${ }^{31}$

\subsection{Beslissing over de wervolging}

Indien een strafbaar feit is opgespoord of anderszins bekend is geworden aan het $\mathrm{OM}$ kan de officier van justitie tot vervolging besluiten. In ruim vijftig procent van de zaken dagvaardt het $O M$ de werdachte. ${ }^{32}$ Indien de officier niet besluit tot vervolging kan hij (voorwaardelijk) seponeren of een transactie aanbieden.

Als de zaak bewijstechnisch haalbaar is heeft de officier van justitie de bevoegdheid de zaak voorwaardelijk te seponeren. Mogelijke voorwaarden zijn onder meer de eis dat

27 De tenuitwoerlegging wan rechterlijke beslissingen gebeurt op last van het OM bij het gerecht waarwan de beslissing afkormstig is (art. 553 ex. Sv). Zie hoofdstuk 1, 2.1. Strafliproces)recht.

28 Voor en meer gedetailleerde beschrijwing verwijs ik natr de relewante handboeken: 0.a. Osinga 1992; Van de Biggelaar 1994: Corsiens 2002; MinkenhofiReijntjes 2002; Melai c.s.

29 Art. 141, 148 Sv; art. 13 Politiewet 1993. Zie eveneens 6.6. Gezag over opsporingsorganen.

30 Art. $52 \mathrm{e}, \psi_{2}, 97.126 \mathrm{~g} \mathrm{c}, \mathrm{v}, 1.51 \mathrm{a}$ Sv, art. 3 Algemene Wet op het Binnentreden.

31 Art. 14, 20 en 27 Politiewet 1993.

32. Art. 167 en 242 Sv. OM 2002, p. 36-37. 
de verdachte zich binnen een proeftijd niet schuldig maakt aan een strafbaar feit of dat hij zich laat begeleiden door de reclassering. ${ }^{3.3}$

De officier van justitie kan de verdachte eveneens een transactie aanbieden als de zaak haalbaar is. Het OM stelt dan voorwarden als betaling van een geldsom, schadevergoeding of ontneming van het wederrechtelijk verkregen voordeel. Ook de politie kan de verdachte een (politie)transactie aanbieden. Het OM geeft de politie daartoe richtlinnen. Zowell bij het voorwaardelijk sepot als de transactie geldt, dat bij voldoening aan de voorwaarden het recht op strafvervolging vervalt. Samen vormen deze beslissingsvormen ongeveer een kwart van het aantal zaken dat het $\mathrm{OM}$ afdoet. ${ }^{34}$

Verder kan het $O M$ besluiten de verdachte een waarschuwing te geven. Dit kan schriftelijk of ten parkette geschieden. Voor het overige seponeert het OM de zaak in dat geval. ${ }^{35}$

De officier zal de zaak seponeren als zij technisch net haalbaar of de vervolging niet opportuun is. Tenzij nieuwe bezwaren bekend worden kan een verdachte niet alsnog vervolgd worden na een kennisgeving van het sepot. In tien tot twintig procent van de zaken seponeert het $\mathrm{OM}$ onvoorwaardelijk. ${ }^{36}$

In de bovenstaande gevallen besiuit het OM niet tot vervolging. Zoals hierna nader genoemd zal worden, kan een belanghebbende daartegen beklag aantekenen bij het gerechtshof. Het parket bij het hof heeft in een dergelijke procedure de taak dit college te adviseren omtrent de te nemen beslissing op het beklag. ${ }^{37}$

Wat betreft de vervolgingshandelingen kan de officier van justitie een vordering tot bewaring doen. Verwolgens kan hij de gevangenhouding vorderen van een verdachte in bewaring. De officier van justitie kan bij een ter kennis gekomen mogelijk strafbaar feit een vordering doen tot het instellen van een gerechtelijk vooronderzoek (gvo). De rechter-commissaris heeft daarin de leiding. ${ }^{38}$

Binnen het gerechtelijk vooronderzoek kan de officier van justitie van de rechtercommissaris een onderzoek ter beslagneming vorderen. Hij kan onder meer een onderzoek vorderen tot onderzoek van telecommunicatie of geautomatiseerde werken. De officier kan van de rechter-conmmissaris een machtiging vorderen voor een strafrechtelijk financieel onderzoek. Bij dringende noodzakelijkheid kan het OM vorderen dat het lichaam of de kleding van degenen ten aanzien van wie vermoed wordt dat zij sporen

Corstens 2002, p. 485-487; Van den Biggelaat 1994, p 48 e.v. Een uitdrukkelijke regeling bestat enkel voor voorwaardelijk sepot na voorlopige hechtenis of een gvo, art. 244 lid 3 en 245 lid $3 \mathrm{~Sv}$.

34 Art. 74 Sr. Osinga 1992, p. 113; Van den Biggellaar 1994, p. 67 e.v.; Corstens 2002, p. 773 e.w. Voor de poltitietransactic art. $74 \mathrm{c}$ Sr lid 4. Daarnaast kan de politie de verdachte voorstellen dat hij deelneemt an een HALT-project, ter vookkoming van doorzending van het proceswerbaal an de officier wan justitite. Do oflicier geefl de betreffende aanwijzingen om dit te regelen (art. 77e lid $3 \mathrm{Sr}$ ). OM 2002 , p. $36-37$.

35. Van den Biggellatr $1994, \mathrm{p} .56$.

36 Ant 167, 242 e.v. Sv. Van den Biggelaar 1994 p. 11 e.v.; Corstens 2002, p. 487. Het politiesepot heeft geen wettelijke grondstag, maar werd gesanctioneend in het Broodjeswinkel-arrest, HR 31 januari 1950 , N. 1950,668 m.nt. Pompet. OM 2002, p. 36-37.

37 Art. 12 a lid $2 \mathrm{Sw}$. Zie verder 3.6. Recherlijke controle op het $\mathrm{OM}$.

38 Voor de bowaring: art. $63 \mathrm{~Sv}$. Gievangenhouding: art. $65 \mathrm{~Sv}$. Gvo: art. $149 \mathrm{~Sv}$. 
van thet strafbaar feit dragen worden onderzocht. Het kan een DNA-onderzoek vorderen. De officier kan een bevel vorderen tot overbrenging van de verdachte voor klinische observatie. Hij kan getuigen en deskundigen doen horen. Ten slotte kan de officier van justitie het gerechtelijk vooronderzoek doen sluiten, door de rechtercommissaris mede te delen dat hij van verdere vervolging afziet. ${ }^{39}$

De officier van justitie kan, als de zaak haalbaar is, beslissen de verdachte (verder) te vervolgen, of toch daarvan af te zien, ondat vervolging in het woorliggende geval inopportuun is. Doet hij dit laatste niet dan zal hij de verdachte dagvaarden. Zolang het onderzoek op de terechtzitting nog niet is aangevangen kan hij de dagvaarding intrekken. De officier kan beslissen de verdachte voor bepaalde strafbare feiten niet te dagvaarden, maar deze feiten ad informandum te voegen. ${ }^{40}$

\section{$3.3 \quad$ OM-beleid}

Het College bepaalt de hoofdlijnen van het landelijke beleid van het OM door het opstellen van een jaarplan en het geven van algemene aanwijzingen. In het jaarplan legt het OM de jaarlijkse vervolgingsprioriteiten vast. De minister overlegt met het College over de te kiezen prioriteiten en het jaarplan. ${ }^{41}$ Posterioriteiten zijn tot nog toe evenwel een onbekend fenomeen. ${ }^{42}$ Verder geeft het College beleidsregels met betrekking tot te volgen werkwijzen ten aanzien van bepaalde delicten of bepaalde fasen in het strafproces. Voorbeelden zijn de Richtlijn voor strafvordering sociale zekerheidsfraude en de Aanwijzing opsporingsbevoegdheden. ${ }^{43}$

Op lokaal niveau bepalen rechtbankparketten binnen het kader van het jaarplan het plaatselijke vervolgingsbeleid. Parketten stellen daartoe een parketplan op. Hierin verwerkt het parket landelijke en lokale prioriteiten en werkwijzen. Sinds de jaren negentig toetst de rechter het handelen van het OM uitdrukkelijk aan diens beleid. ${ }^{44}$

\subsection{Functie OM ter zitting}

Ter zitting draagt de officier van justitie de zaak voor. Hij stelt daartoe de tenlastelegging op en legt een dossier over aan de rechter. Het OM kan ter zitting de aanvulling of wijziging van de tenlastelegging vorderen. In het onderzoek ter zitting kan de officier van justitie het woord voeren en vorderen dat de rechtbank van haar bevoegdheden gebruik maakt. De offier moet gehoord worden over vorderingen van de verdachte. Ten

39 Art 104 e.v., 125i, $1251,126,192$ e.w., $210,227,237 \mathrm{~Sv}$

40 Art. 258, 266 Sv. De voeging ad informandum is niet in de wet geregeld, mata anvarar door de Hoge Rand in het arrest HR 13 februari 1979. NJ 1979, 269 m.nt. ThWV W, Corstens 2002, p. 685-687.

41 Art 8.10 Reglement varn Orde van het College van procureurs-genteral. Over de ministeriele rol met

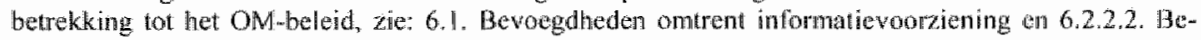
leidsaanwijzingen.

42 Wel noemt het OM recentelijk posterioriteiten als een moodzalk, OM 2002\%, n. 18

43 Sinds 1999 makt het OM een duidelijk onderscheid tussen aanwijzingen, richtlingen, instructics en handleidingen. Vgl. Instructio Beleidsregels Openbaar Ministeris.

44 HR 19 juni 1990, NJ 1991,109, m.nt. ThWvV en MS. 
slotte houdt hij zijn requisitoir en legt dit schriftelijk over aan de rechter. Het OM spreekt zich daarbij uit over een eventueel op te leggen straf. ${ }^{43}$

\subsection{Rechtsmiddelen door het OM}

Tegen uitspraken van de rechter in eerste aanleg kan de officier van justitie in hoger beroep komen De rol en de bevoegdheden van het OM in beroepszaken zijn vergelijkbaar met die in eerste aanleg. Het parket bij het gerecht dat een uitspraak heeft gedaan kan daartegen nog beroep in cassatie instellen. Dit is enkel mogelijk als geen ander gewoon rechtsmiddel open staat of heeft opengestaan. Cassatie kan verzuim van vormen of rechtsschending betreffen. Het parket dat hoger beroep of beroep in cassatie heeft ingesteld kan het zelf weer intrekken. Bij sommige gevallen van hoger beroep kan de advocaat-generaal het beroep van de officier van justitie intrekken. ${ }^{46}$

Om herziening van rechterlijke uitspraken kan het OM niet vragen. Overigens is het OM evenmin bevoegd verzet te doen. ${ }^{47}$

\subsection{Rechterlije controle op het OM}

De beslissingen van het OM over de vervolging kunnen onderwerp wormen van controle door de rechter via de bezwalarschrift- en beklagprocedure.

Een verdachte kan bij de rechtbank een bezwaarschrift indienen tegen verdere vervolging of de dagvaarding. De rechter verricht dan een summiere toetsing waarin feitelijke verweren slechts marginaal worden beoordeeld. Van de rechtbank wordt niet geëist dat zij ook zelfstandig naar andere bezwaren zoekt. Indien de rechter het bezwaar gegrond oordeelt stelt hij de verdachte buiten vervolging. ${ }^{48}$

Wanneer het OM niet (verder) vervolgt kan een rechtstreeks belanghebbende (rechts-) persoon beklag doen bij het gerechtshof. Het hof onderzoekt de zaak summier op de mogelijkheid van vervolging. Wanneer het hof de zaak haalbaar oordeelt, moet het bezien of de vervolging opportuun is. Het hof kan weigeren de vervolging te bevelen op gronden aan het algemeen belang ontleend. Een dergelijke beslissing is uitzonderlijk. Als het hof het beklag toewijst beveelt zij de vervolging. In een later stadium kan het $O M$ alsnog afzien van vervolgen, wanneer het hof daarmee instemt. ${ }^{49}$

45 Art. 284, $311-3135 \mathrm{~s}$

46 Voor het hoger beroep: art. 404 e.v.. 415 Sv. Voor het beroep in cassatie: art. 427 e.w. Sv. Voor het intrekent art. 453 e.v. Sw.

47 Voor de hertening; ant. 457 ev. Sv. Corstents 2002, p. 750 e.v. Voor het werzet: art. 399 Sv.

48 Art. 250 en 262 Sv. Corstens 2002, p. $496 \mathrm{a}$.

49. Art. 12 e.v. Sw, 246 lid $3 \mathrm{~Sv}$. Corstens $2002, \mathrm{p} .500$ a. Owerigens kan de minister wan Justitie geen beklag indienten tegen nietwervolging. Zie 6.2.2.4. Aanwijzing tot wervolging. Minister Korthals, Kanerstukken II $2001 / 02,28093$, p. 3.4. De minister theft specifieke bevoegdheden die beklag overbodig maken en mirshiten. Hij $\mathrm{kari}$ zich (eventueel wooralgaand aan een beslissing) laten infomeren en een anwijzing tot vervolging geven. Zie 6 . Functionele ministeriele bevogdheden. Of de minister van deze bevoegdheden gebruik makt is een andere zakk, die niteraard voor zijn rekening komt. 


\subsection{Conclusie}

Een veelheid aan strafrechtelijke keuzemogelijkheden presenteert zich aan het $O M$.

Naast vervolging staan vergaande afdoeningsprocedures open, zonder dat daaraan een rechterlijk fiat gegeven hoeft te worden. Over de opsporing heeft het OM daarnaast een dominerende zeggenschap. Belangrijke dwangmiddelen staan de parketten in deze fase ter beschikking. De handelingssfeer van het $\mathrm{OM}$ is wel doorweven met algemene aanwijzingen afkomstig van het College. Verder hebben belanghebbenden de optie, om een rechterlijk oordeel te vragen over een niet vervolgen door het $O M$.

\section{Minister en ministerie van Justitie}

De minister van Justitie is geen ambt van het $\mathrm{OM}^{50} \mathrm{Hij}$ oefent geen taken of bevoegdheden van het $O M$ uit. Het ministersambt is bekleed met onder meer bevoegdheden over het $\mathrm{OM}$ en het ministerie van Justitie.

De minister van Justitie is lid van de regering en de ministerraad. De minister-president is de voorzitter van de raad. De minister-president ziet toe op de samenhang van het regeringsbeleid, waaronder het vervolgingsbeleid. ${ }^{51}$ Kabinetten vormen echter pertinent coalities van gevarieerd pluimage. Zij komen voort uit een pluralistisch parlement dat geen bepalende 'links-rechts' polariteit kent. Overleg, compromis en consensus bepaw len kabinetsbeslissingen.

De beleidssamenhang wordt bevorderd in onderraden en ministeriële commissies van de ministerraad. Voor het werkterrein van het OM zijn met name de raden en commissies voor justitiële aangelegenheden van belang. Zij hebben onder meer tot taak om beleid en wetgeving voor te bereiden op het terrein van de rechtshandhaving en rechtspleging. De minister-president zit deze onderraden en commissies voor. Leden zijn verder onder meer de ministers van Justitie en van Binnenlandse Zaken. ${ }^{52}$ De ministerraad beraadslaagt over onderdelen van het vervolgingsbeleid. In bijzondere gevallen vergadert de raad ook over individuele strafzaken. ${ }^{53}$

50 Hij komt niet voor in de opsomming van art. 125 Wet RO. Vgl. verder reeds Van Veen 1977, p. 264; Rapport relatie OM-zittende magistratuur $19811, p, 115$.

51 Art. 2 en 16 RrOMR.

52 Voor onderraden: art. 17-24 RvOMR. Ministeriele commissies: art. 25 RvOMR. Onder het kabinet Kok II en het kabinet Balkenende waren de relevante onderraden de de Raad voor het Grote Stedenbeleid (RGSB) en mei name de Raad woor Justitie, Bestuur en Veiligheid (RJBV). De RGSB en RJBV zijn ingesteld op 2 oktober 1998 . Sinds I 1 september 1992 bestaat de Ministeriële Commissie fratudebestrijding, sinds 1998 omgedoopt in Ministeriele Commissie Bestrijding Fraude en Financied-taconomische Criminaliteit. Onder Kok I bestond de Ministeriële commissie voor wetgevingsbeleid en rechththandhaving. Over de noodzaak tot overleg van de minister van Justitie met andere ministers reeds: Stroink $1978, p .166-167$.

53 Bij de Bloemenhowe- en Lockheed-zaak bijwoorbeeld vergaderde de ministerrad uitwoerig over de te volgen handelswijze. Kamerstukken II 1975/76, 13964, nr. 1, p. 2. Zte ook 6.2.2.5. Aanwijzing tot nietw vervolging. Over de Slawenburg-zaak in 1983 beraadslaagde de minister van Justitie samen mel die van Financiën en de minister-president. Brants \& Brants. 1991, p. 229. 
De ambtenaren van het ministerie staan onder leiding van de minister (art. 44 lid 1 Gw). Deze kan hen specifjeke en algemene aanwijzingen geven. De minisier stelt zelf de organisatie van het ministerie vast. ${ }^{54}$ Het ministerie is verdeeld in dienstonderdelen onder leiding van de secretaris-generaal, zoals de directie Voorlichting, en vier directoraten-generaal. Deze staan onder leiding van een directeur-generaal. Onder de directoraten-generaal vallen verschillende directies en diensten met aan het hoofd directeuren. Enkele onderdelen van het ministerie hebben in het bijzonder met het OM te maken. De directie Rechtspleging van het directoraat-generaal Wetgeving, Rechtspleging en Rechtsbijstand draag zorg voor de voorbereiding van ministeriële beslissingen omtrent de rechtspositie van leden van het $\mathrm{OM}$ en andere magistraten. De directeur-generaal van het directoraat-generaal Rechtshandhaving is beheersverantwoordelijke voor het OM. Onder dit directoraat-generaal vallen daarnaast de directie Handhaving en het bureau Operationele Zaken: De directie Handhaving ontwikkelt het vervolgingsbeleid "met inachtneming van de verantwoordelijkheden van het Openbaar Ministerie". Het bureau Operationele Zaken onderhoudt het contact met het OM over 'politiek gevoelige' taken, zoals het gebruik van bijzondere opsporingsmethoden. ${ }^{55}$ De secretarisgeneraal of een directeur-generaal onderhouden namens de minister het contact met het $\mathrm{OM}^{56}$

\section{Rechtspositie van het $\mathrm{OM}$}

Nu het OM en diens handelen beschreven zijn kunnen de politieke mogelijkheden om op dat handelen invloed uit te oefenen onder de aandacht komen. Daartoe bekijk ik hier de bevoegdheden die de minister heeft ten aanzien van de rechtspositie van de leden van het OM. In paragraaf 6 bezie ik dan de ministeriële bevoegdheden ten aanzien van het strafrechtelijke handelen zelf van het $\mathrm{OM}$. Het onderzoek naar de rechtspositie geschiedt vanuit de hypothese dat rechtspositionele bevoegdheden van de politiek gevolgen kunnen hebben voor de wijze van handelen van het OM. Via het gebruik van bevoegdheden ten aanzien van de rechtspositie zou de politiek het gebruik van de strafrechtelijke bevoegdheden van het OM indirect kunnen beünvloeden.

Hieronder geef ik eerst enkele algemene opmerkingen over de wetgeving die de rechtspositie regelt. Daarna beschrijf ik de benoeming, het carrièreverloop binnen het $O M$ en de mogelijkheid van overplaatsing. Verder behandel ik de bezoldiging, de grondrechten, de aansprakelijkheid, de disciplinaire procedure, de regels voor schorsing en ontslag en de rechtsbescherming.

Op de positie van de leden van het $O M$ is een aantal bijzondere bepalingen van toepassing. Naast de Wet RO geldt voor hen de Wet rechtspositie rechterlijke ambtenaren (Wra) en het daaraan verbonden Besluit rechtspositie rechterlijke ambtenaren (Brra). Deze regelingen gelden ook voor het rechtsprekende deel van de rechterlijke macht.

54 Art. 2 hid I Coodinatiebs luit inrichting organisatic en tormatie rijks sdienst.

55 Organtsitieregeling Ministerie var Just tie 2000 , regeling van 4 juli 2000 . 1.h.b. art. 39 .

56 Kamerstuklken II 1996/97, 25392, nr. 3, p. 9. Ower de contacten cussen minister en OM zie 6.1. Bevoegdtheden onment informatievootziening. 
Verder is een deel van de Ambtenarenwet (Aw) op hen van toepassing en zijn delen van het Algemeen Rijksambtenarenreglement (ARAR) op hen van overeenkomstige toepassing verklaard. ${ }^{57}$

\subsection{Benoeming}

Aan de benoeming van leden van het $O M$ gaat een specilieke opleiding vooraf, tezamen met toekomstige rechters. Daarnaast kunnen personen met jarenlange juridische ervaring in aanmerking komen voor benoeming. ${ }^{58}$

Alle leden van het OM worden benoemd bij koninklijk besluit, behalve plaatsvervangende officieren van justitie. Deze benoemt de minister van Justitie zelf. De ministerraad beraadslaagt enkel over de hoogste functies. ${ }^{59}$ Aan de benoeming gaat een procedure vooraf waarin de minister aanbevelingen ontvangt en eventueel betrokkenen hoort. Voor de officieren van justitie selecteert het parkethoofd sollicitanten en doet een aanbeveling aan het College. Dit dient het advies marginaal te toetsen en het door te zenden aan de minister. Deze toetst de aanbeveling wederom marginaal en doet een voordracht voor een koninklijk besluit. Voor de plaatsvervangende officieren van justitie geldt een zelfde procedure, die evenwel eindigt met een ministerieel besluit.

Voor de hogere functies selecteert het College kandidaten en verzoekt dan het betreffende parkethoofd om advies. Verwolgens maakt het College een aanbevelingslijst op. Hierna houdt het ministerie namens de minister selectiegesprekken met de kandidaten. De aanbeveling van het College geldt hierbij als 'uitgangspunt'. Wanneer het een functie betreft als hoofdofficier of hoofdadvocaat-generaal vergadert de ministerraad hierover. Daarna volgt de voordracht bij de Koning.

De minister beslist in alle vrijheid over de procedure bij de benoeming van leden van het College. Wel adviseert dit eerst over de te volgen procedure. De minister moet vervolgens in de procedure in ieder geval de NVvR en het College over de benoeming zelf horen voordat hij de voordracht doet. Vervolgens beraadslaagt de ministerraad over de voordracht voor een koninklijk besluit.

Al deze adviesprocedures zijn overigens niet wettelijk vereist voor ambtenaren van het $\mathrm{OM}$ - in tegenstelling tot de leden van de rechterlijke colleges. Hieromtrent bestaan enkel beleidsregels. ${ }^{60}$ Overigens lijkt het in de geschiedenis van de Nederlandse rechterlijke macht geen gebruik geweest te zijn om politieke benoemingen te doen. Wel

le art. 2 lid 2 Aw art 39 Brra

58 Deze zogeheten Ralio-opleiding ös gebaseerd op art. 145 . Wet RO. Vgl. Simons 1996, 19. 74 e.v.

59 Art. la en $1 f$ Wrra; art. 4 lid 2 sub 1 onder 1 R vOMR. Wan de zittende magistratur worden alle leden voor het leven benoend bij koninklijk besluit (art. 117 lid $1 \mathrm{G}$ ). Andere ambtenaren worden alloen bij koninklijk besluit benoemd in functies met de hoogste salarisschalen, en an alle overige gevallen door de betreffende minister (art. $7 \mathrm{Aw}$ ). In vergeliking met deze schalen krijgen bijna alle gewone ofticieren van justitje een lagere bezoldiging. Leden wan het OM worden dus over het algemeen met een zwarder besluit benoemd dan gewone ambtenaren.

60 Zie Leidraad benoeningsprocedue Openbaar Minisierie, 14 augusitus 1996; art, 13 Reglemenil van Orde van het College van procureurs-generaal. Vgl. Simons 1996, p. 142. Voor rechters is een aanbeveling wel vereist (antl. le Wra). Vgl. (over de toenmalige bepalingen in de oucle Wet RO) Simons 1996, p. 139-142; De Werd 1994, p. 46-48. Over de exd die leden wan thet OM afheggen bij hun installering, zie hoofdstuk 6,7.4.2. Onpartijdigheid als andere ambtenaren? 
komt het voor dat de minister een kandidaat kiest die lager op de aanbevelingslijst van het College staat.

\subsection{Overplaatsing, functiewijziging}

De minister kan leden van het $O M$ een andere functie bij her $O M$ opdragen. Uit de praktijk is het opmerkelijke geval bekend van de overplaatsing van procureur-generaal Steenhuis in $1998{ }^{62}$ Daarnaast kumen leden verplicht worden tijdelijk 'andere werkzaamheden' te verrichten dan die zij gewoonlijk verrichten. Zij kunnen echter niet zoals gewone ambtenaren - verplicht worden een andere 'passende functie' te aanvaarden, "wanneer het belang van de dienst zulks vordert'. Een dergelijke plicht is niet overgenomen in de Wrra, omdat dat volgens de betreffende Memorie van Toelichting voor rechterlijke ambtenaren 'niet passend' (!) werd geacht. ${ }^{63}$

Voor het verkrijgen van een functie bij een rechterlijk college bestaan geen beletselen of bijzondere voorwaarden. Eveneens kunnen rechtsprekende leden van de rechterlijke macht de overstap maken naar het $O M$.

\section{$5.3 \quad$ Bezoldiging}

De hoogte van de bezoldiging van leden van het $\mathrm{OM}$ is verbonden aan de beklede functie. De bedragen voor leden van het $O M$ en rechters zijn vergelijkbaar met de bezoldigingen in de hoogste schalen die voor gewone ambtenaren gelden. De bezoldiging stijgt automatisch en jaarlijks, tot een maximum verbonden aan de functie. De hoogte van de bedragen is bepaald bij wet, in de bijlage bij de Wrra. ${ }^{64}$

\subsection{Grondrechten}

Voor een ambtenaar van het OM geldt dat hij zich dient te onthouden van uitoefening van het recht van vrije meningsuiting, het recht tot vereniging, tot vergadering en betoging indien hierdoor de 'goede vervulling van zijn taak of het goede functioneren van

61 Minister Sorgdrager, Handelingen 11 1997/98, p. 4841. Eén en ander blijk uin gesprekken.

62 Art. 42 Woi RO. De overplatsing was bén van de maatregeten als reactie op de schijn van bellangen-

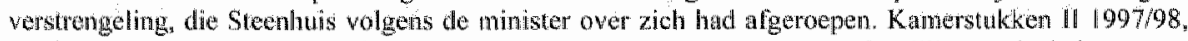
25852, nr. 12. Voor overplatsing van de rechtsprekende leden wan de rechterlijke mach is hun overeenstemming nodig (at. 9 Wet RO).

63 Art. 41 Writ. Zaak Steenhuis: Kamerstukken II 1994/95, 24220, ni. 3, p. 20. Voor gewone amblenaren gelden de bepalingen van arti. $57-58$ ARAR.

64 Art 7 Wrra. Een gewone ambtenan knjgt jaarliks een stapsgewijze verhoging van de bezoldiging "indien hij nas bet ootdeel wan het bevoegd gezag in voldoende mate fimmotoneert" (art. 7 BBRA). "Indien hij has hot oordeel van het bevoegd gezag meer dan in voldoende mate functioneert dan wel indien dawtoe nar het worded wan het bevoegd gezag op andere gronden aanleiding bestaat' kan hij ook een hoger bedrag krijgen dan het nasthogere bedrag. Zells als hij het maximumsalaris van de voor hem geldende salarisschns heeft bereikt, kan het bedrag worden werhoogd, "indien bij nam het oordeel wan het bevoegd gezag uitstekend functioneert" (art. 8 BBRA). En als de ambtenaar "natar het oordeel wal he bevoegd gezag niet in voldoende mate functioneert, blijf salarisverhoging achterwege" (art. 7 lid 3 BBRA). Het bevoegde gezag is voor gewone ambtenaren de minister waan zij onder ressorteren (art. 24 lid 1 sub b BBRA). Voor hun salarièring zijn deze ambtenaren klaarblijkelijk in sterkere mate a hankelijk van het oordeel van de betreflerde minister, dan de leden van het $O M$. 
de rechterlijke nacht niet in redelijkheid zou zijn verzekerd" (art 43 Wrra). De beperking op het recht tot vereniging is niet van toepassing op het lidmaatschap van een politieke groepering of vakvereniging. Leden van het OM kunnen probleemloos lid zijn van een politieke partij. ${ }^{65}$

De Aanwijzingen externe contacten rijksambtenaten bepalen voor ambtenamen hoe zij met hun vrijheid van meningsuiting horen om te gaan en in hoeverre zij contacten met kamerleden en derden kunnen hebben. ${ }^{6}$ Deze ministeriële regeling zow ook woor leden van het OM gelden volgens de toelichting bij Aanwijzing 2. Daar worden zij specifiek genoemd als ambtenaren die onder het "gezagsbereik" van een minister of staatssecretaris vallen. Wat het OM betreft berusten deze Aanwijzingen echter niet op een juiste wettelijke bepaling. Artikel 127 Wet RO bepaalt dat alleen de minister van Justitie het OM aanwijzingen kan geven. Deze Aanwijzingen zijn echter door de minister president vastgesteld. Dat dit gebeurd is in overeenstemming met het gevoelen van de ministerraad", zoals de aanhef meldt voegt daar niets aan toe. De Aanwijzingen zijn in dit opzicht een staatsrechtelijk monstrum. De minister-president gaat ervan uit dat de leden van het $O M$ gewone rijksambtenaren zijn, in plaats van rechterlijke. De Aanwijzingen gelden kortom niet voor de leden van het OM. Hoogstens kunnen zij een leidraad vormen bij het bezien of een meningsuiting niet in strijd komt met de goede vervulling van de taak van het OM.

Rechterlijke ambtenaren hebben slechts een enkele specifiek op hen gerichte vakbond waar zij lid van kunnen zijn. Dit is de Nederlandse Vereniging voor Rechtspraak (NVvR), waar een grote meerderheid lid van is. Vertegenwoordigers van de NVVR vormen de Sectorcommissie rechterlijke macht. Binnen deze Sectorcommissie voeren ambtenaren wan het OM overleg met de minister over hun rechtspositie en het personeelsbeleid. Dit overleg geldt ook voor de andere rechterlijke ambtenaren en raio's. Bij geschillen in dit overleg, of ten behoeve van advies is er een Advies- en Arbitragecommissie. Deze commissie bestaat uit door zowel de minister als de Sectorcommissie aangewezen leden. ${ }^{67}$

\subsection{Aansprakelijkheid}

De Staat is aansprakelijk voor schade ontstaan uit onrechtmatige daden door de leden van de rechterlijke mach. De onrechtmatige daad kan onder meer ontstaan door een vorm van rechtsdwaling, ongeacht of het betrokken lid van hel OM schuld had aan die verkeerde witleg.

Dit lid draagt zelf slechts aansprakelijkheid voor zover het zelf een persoonlijk verwijt gemaakt kan worden. De Hoge Raad stelt hieraan hoge eisen. Indien het OM-lid een onjuiste rechtsopvatting huldigde, draagt hij slechts schuld wanneer deze opvatting ge-

65 Een owereerkomstige regeling geldt voor gewotbe ambtenaren (art. 125 a Aw). Voor de rechsprekende leden wan we rechterligke macht gelden geen specifieke beperkingen.

66 Stcrt. 1998, 104 .

67 Voor de Sectorcommissie rechterlijke macht: art. 48 e.w. Wra, art. 2 e.v. Brra. Soortgelijk overleg vind woor andere ambtenaren plats tussen de minister en de Sectorcommissie overleg rijkspersonew (art. 105 e. . ARAR). Deze commissie bestati unit wertegenwoondigers wan centrales van amblenaremenenigingent. 
heel onaannemelijk was: Tot nog toe werd nimmer een lid van het OM persoonlijk aansprakelijk gehouden. ${ }^{68}$

\subsection{Disciplinaire straffen}

Voor leden van het OM geldt ongeveer het disciplinaire regime voor gewone ambtenaren. Hiervoor geldt dat de straffen worden opgelegd door het ambt dat de ambtenaren aanstelt. Voor de meeste leden van het $O M$ is dat de Kroon. Enkel voor de plaatsvervangende officieren van justitie legt de minister zelf de straf op. Een officiẻle procedure woor het opleggen van de straf ontbreekt geheel. De straffen die opgelegd kunnen worden varièren van berisping tot ontslag. Een voorstel tot ontslag van OM-leden in de hoogste functies wordt officieel beraadslaagd in de ministerraad. ${ }^{6.9}$

Voor rechters geldt een eigen disciplinair regime. De Wrra bepaalt dat de president van het rechterlijke college hen in bepaalde gevallen een waarschuwing kan geven, terwijl de Hoge Raad hen als straf kan ontslaan. Daartoe dient de procureur-generaal bij de Hoge Raad bij dat college een vordering in te stellen. Dit beslist vervolgens op de eis en legt eventueel de straf van ontslag op. ${ }^{70}$

Het gebeurt zelden dat de minister ambtenaren van het OM officieel berispt. Het is verder mogelijk dat de minister op informele wijze enkel zijn 'ongenoegen' over een handelswijze uitspreekt. Disciplinaire zaken die stof hebben doen opwaaien zijn die van officier van justitie Drenth in 1996, en van procureur-generaal Steenhuis in 1998. ${ }^{71}$

\subsection{Schorsing en ontslag}

Ambtenaren van het OM kunnen op dezelfde gronden door de minister geschorst worden als andere ambtenaren. Dit kan indien tegen de ambtenaar strafrechtelijke vervolging ter zake van een misdrijf is ingesteld of als onvoorwaardelijk ontslag dreigt. Tevens is schorsing mogelijk indien "het belang van de dienst zulks vordert".

Rechters kunnen alleen door de Hoge Raad geschorst worden. Dit moet in ieder geval geschieden indien zij in voorlopige hechtenis zitten, zij een vrijheidsstraf of maatregel hebben gekregen wegens een misdrijf bij een nog niet onherroepelijk geworden rechterlijke uitspraak, of in geval van curatele, faillissement, surséance van betaling of lijfsdwang. ${ }^{73}$

Ar. 6:162 lid 3 BW. HR 11, oktober 1991, NI 1993, 165, m.nt. CJHB (Van Hilten).

A.t. 80 . $\%$. ARAR jo ant. 39 lid I Brta; at. 4 lid 2 sub I R WOMR.

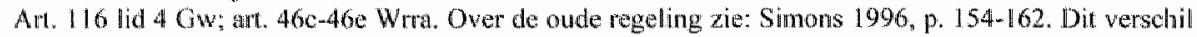
tussen OMl en rechters is wan veel grotere betekenis dan de benoeming voor het leven, meent Enschede $1980.1 \% .90$

71 Drenth: CRvB 10 julli 1997. NJB 1997, nE, 31. Zie verder 6.2.2.6. woofdstuk 6, 6.1.2, beide getiteld: Aanvijzing ten anzien van het requisitoir. Steenhuis: zte verder 5.2 . Overplatsing, functiewiziging. Zio over het beroep paragraat 5.8 .

2. Art. 39 lid I Brra jo art. 90 e.y. ARAR; art. 91 lid 1 sub c ARAR. Deze bepalingen gelidem tevens woor gercechtsauditeurs en raio's.

Art. $461-46 \mathrm{~g}$ Wrra. 
Leden van het OM kunnen ontslagen worden op de in artikel 36 Brta opgesonde gronden. Deze komen wrijwel overeen met de voor gewone ambtenaren geldende gronden van artikel 98 ARAR. Afgezien van ontslag bij wijze van straf of wegens incompatibiliteiten betreft het gevallen van gebreken in benoembaarheidsvereisten of onjuiste of onvolledige inlichtingen bij de indiensttreding of keuring. Daarnaast is ontslag mogelijk indien een vrijheidsstraf wegens misdrijf onherroepelijk is geworden, bij curatele, bij lijfsdwang, bij onbekwaamheid of ongeschiktheid voor het ambt en bij het bereiken van de pensioengerechtigde leeftijd. Op grond van ongeschiktheid tot het verrichten van de arbeid wegens ziekte kunnen ambtenaren onder bepaalde voorwaarden ook worden ontslagen. Ontslag geschiedt bij koninklijk besluit of, voor plaatsvervangende leden van het $\mathrm{OM}$, bij ministerieel besluit. ${ }^{74}$

Belangrijk is dat een lid van het OM ook op 'andere gronden' ontslagen kan worden. Daarbij verleent de minister of de regering aan het lid een uitkering, naast de verlening van wachtgeld. In enkele gevallen zijn leden van het $O M$ op belangrijke posities op deze wijze door de minister ontslagen. Markante gevallen vormden in het verleden het ontslag van procureur-generaal Van Randwijck in 1995 en dat van de voorzitter van het College van procureurs-generaal Docters van Leeuwen in $1998^{75}$

\subsection{Rechrspositionele rechtsbescherming}

Tegen besluiten over rechtspositionele kwesties kunnen leden van het OM en rechters na bezwaar direct beroep instellen bij de Centrale Raad van Beroep (art. 47 Wrra). Zij stellen dus niet eerst beroep in bij de rechtbank. ${ }^{76}$ Dit is te verklaren uit de te betrachten distantie, die tussen de rechtbanken en de betrokken leden van de rechterlijke macht te gering zou zijn. ${ }^{77}$

Gevallen waarin de betrokken ambtenaar beroep instelt tegen de oplegging van een disciplinaire straf zijn uiterst zeldzaam. ${ }^{78}$

\section{$5.9 \quad$ Conclusie}

De positie van het OM kent nauwelijks juridische garanties tegen politieke beïnvloeding. Hun bezoldiging is in ieder geval niet direct afhankelijk van een ministerieel oordeel over hun functioneren. Hun positie toont verder weinig overeenkomsten met die van de zittende magistratuur. Met name de disciplinaire procedure, de schorsing en ontslag vormen onderdelen die het OM-lid zwakke bescherming geven. De minister kan via deze aspecten een grote invloed op ambtenaren van het $O M$ hebben. Daanaasu

74. Rechtsprekende leden van de rechterlijke macht kunnen doom de Hoge Raad ontslagen worden wagens ongeschiknheid, incompatibilitenten, verlies van het Neclerlanderschap, onherroepelijke veroordening met wrijheidsbeneming wor een misdrij, ontaerroepelijke cutratele, fallissement, strseance wam betalumg. gojzeling en in bepalde gewallen wegens ziekte. Arh. 46h-46n W/ra.

75 Art 99 ARAR jo at 39 Bra. Van Randwijck, zue: Kamerstukken 1l 1995/96, 24470, nr. I. Docters van Leeuwen: Kamerstukken II 1997/98, 25897, nr. 1.

76 Andere ambtenaren kunnen na bezwadr berowp instellen bij de rechbank, en vervolgens pas hoger beroep bil de Centrale Raact (art. 8.1 Awb en 18 Beroepswet).

77 Simons 1996, p. 162.

78 Zie de zak Drenth in 5.6. Disciplinaire straffen. 
zijn zij voor benoeming vooral afthankelijk wan de opstelling van de regering. Op dit punt lijkt evenwel de gewoonte te bestaan om politieke benoemingen te vermijden.

\section{Functionele ministeriële bevoegdheden}

Naast zeggenschap over de rechtspositie van het OM heeft de minister bevoegdheden ten aanzien van het strafrechtelijke handelen zelf. Anders dan de rechtspositionele bevoegdheden hebben de onderhavige bevoegdheden direct betrekking op het handelen in de strafvordering, het inhoudelijk functioneren door het OM. Ter onderscheiding noem ik ze daarom functionele bevoegdheden.

Allereerst bespreek ik de mogelijkheden voor de minister om zich te laten informeren door en te overleggen met het $\mathrm{OM}$. Hiterna volgt een uitvoerige behandeling van de ministeriele aanwijzingsbevoegdheden. Aansluitend noem ik de gevolgen van een petitie bij de minister. Verder behandel ik de ministeriële toezegging en de mededeling omtrent de strafbaarheid van een feit. Ten slotte schenk ik kort aandacht aan bevoegdheden bij ambtsmisdrijven begaan door politici, enkele bevoegdheden ten aanzien van opsporingsorganen en organisatorisch-budgettaire invloeden.

\subsection{Bevoegdheden omtrent informatievoorziening}

Contacten tussen de regering en het OM dienen alleen via de minister van Justitie te lopen. Andere ministers dienen geen rechtstreeks contact te zoeken met het OM. Al het verkeer tussen minister en OM dient via het College te lopen. Minister en departementsambtenaren dienen geen direct contact te hebben met officieren van justitie. ${ }^{79}$ In de wet of in een andere regeling wordt dit evenwel niet uitgesloten. De Memorie van Toelichting bij het wetsvoorstel voor de Wet RO van 1999 meldt zelfs dat de inlichtingenplicht van 'ieder lid van het OM' ten opzichte van de minister 'vanzelfsprekend' is. ${ }^{80}$ Rechtens is dit geenszins het geval. Immers, "de leden van het openbaar ministerie verstrekken het College de inlichtingen die het College nodig heeft (cursief PPvdL)." (art. 129 Wet RO). Verder zou uit een inlichtingenplicht ten opzichte van de minister de onjuiste conclusie getrokken kunnen worden, dat alle leden ook met de minister zouden kunnen of zelfs moeten overleggen. Dit zou geheel in strijd zijn met de wettelijke systenatiek van de relatie minister-OM. ${ }^{81}$

79 Minister Sorgdrager, Handelingen II 1997/98, p. 4824-4825.

80 "Vanzelfprekend ligt in de wehouding ussen de Minister en het OM besloten dat ieder lid van het OM een inlichtingenphicht ten opzichte van de Minister heeft, zodat de Minister zich voor het verkrijgen van inlichtingen ook kan wenden tot een individueeh lid van het $O M$, maar in normale gevallen vornt het College voor de (M)inister binnen het OM het eerste aanspreekpunt.' Kamerstukken II 1996/97, 25392, ni. 3. p. 47 .

81 Een samenhangende kwestie is dat de betreftende Memorie wan Toelichting het ten onrechte voor mogelijk houdt dai de minister specifieke aanwijzingen aán een parkethoofd zou kunnen geven, in plats van aan het College. Zie $6,2,3.1$. Procedure specifieke anwijzingen. 
In de praktijk heeft de minister ook wel rechtstreeks overleg gehad met andere leden van het $\mathrm{OM}^{82}$ Ook nu komen contacten tussen de departementstop met lokale parketten voor. Ambtenaren van verschillende departementen overleggen bijvoorbeeld met officieren van justitie in regiegroepen over de aanpak van onder meer strafzaken. ${ }^{83}$

Het College is verplicht de minister van Justitie de inlichtingen te verschaffen 'die deze nodig heeft' (art. 129 Wet RO). Dit gebeurt op verschillende wijzen. Zo geeft het OM sinds 1970 een eigen jaarverslag uit dat het aan de minister zendt, en via hem aan het parlement. Maandelijks vindt daarnaast een overlegvergadering plaats van de minister met het College. Ook vindt er ad hoc overleg plaats. Dit laatste geschiedt veelal tussen de minister of de secretaris-generaal en de voorzitter van het College. ${ }^{84}$

Verder overlegt het College met de minister over beleidsprioriteiten. De parketten en het College stellen binnen deze informele kaderstelling het beleid op in een concept jaarplan. Ten slotte legt het OM de minister het jaarplan voor ter "goedkeuring'. Formeel gezien vraagt het $\mathrm{OM}$ de minister bij deze gelegenheid enkel om zijn visie. De ministeriële goedkeuring heeft geen rechtsgevolgen voor het OM-beleid. Voor het teweegbrengen daarvan dient de minister een aanwijzing te geven. Dit kan hij doen wanneer hij niet instemt met het beleidsvoornemen. Voordat het zover komt overlegt de minister echter met het College, teneinde dit van wijzigingen te overtuigen. Behalve het jaarplan legt het College de minister alle algemene College-aanwijzingen voor, wanneer deze de uitoefening van strafrechtelijke bevoegdheden betreffen. ${ }^{85}$

Naast algemene beleidszaken krijgt de minister specifieke gevallen onder ogen. Ten aanzien van het gebruik van bepaalde bijzondere opsporingsbevoegdheden eist de wet dat het College een voorgenomen beslissing aan de minister voorlegt. Dit betreft hei aangaan van een overeenkomst voor burgerinfiltratie en het bevel tot het doorlaten van schadelijke of gevaarlijke voorwerpen die vatbaar zijn voor inbeslagname. ${ }^{86}$ Behalve wettelijke bepalingen eisen ook sommige beleidsregels dat het College zaken aan de minister voorlegt voordat een vervolgingsbeslissing genomen wordt. Dit geldt onder meer in geval het OM overweegt te vervolgen na euthanasie of een besluit wil nemen in een strafzaak omtrent ministeriële ambtenaren. Verder meldt het $O M$ wanneer het vervolgingsbeslissingen neemt ten aanzien van rijksoverheidsorganen en politieke ambtsdragers. Tevens raadpleegt het College de minister bij bepaalde gevoelige, hoge transacties en overeenkomsten met criminelen. Ten slotte bepaalt het reglement van het

82 In het verleden vond vaak direct contact plaats iussen een olfeicer van justitic en het ministerie. Bijworbeeld in de Bloemenhowe-zaak: Handelingen 11 1975/76, p. 4227-4228. Datamatast hadden andere ministers well eens directe contacten met het OM. Fen apaif woorbeeld vormde het overleg tussen minister van Justitie Sorgdrager en haar collega van Binnenlandse Zaken Dijkstal met de burgemeester en hoofdofficier van justitie wan Groningen in 1998, Van Liempl \& Van Westing 2000, p. 57.

83 Handelingen II 1997/98, p. 4825; 't Hart 2001 , p. 93.

84 Kamerstukken II 199697, 25392, nr. 3, p. 7-8; Commissie Kalsbeck, Kamerstukken II 1998999, 26269, nr. 5. p. 169. Voorbeelden wan overleg in Kamersitukken II 1994/95, 22999, nr. 25. p. 1; Kamerstuken II 1997/98, 25852, nr. 11, p. 1; Kamerstukken II 1999/20000, 26800 VI, nr. 2, p. 35.

85 Art. 8-10 Reglement van Orde wan het College van procureurs-generaal. Kamerstukken $\| 1997 / 98$, 24034 , nr. 24 , p. 4 ; nr. 28, p. 20 - 22 .

86 Art. $140 \mathrm{a} \mathrm{Sv}$; art. 11 hid 2 Reglement van Orde van het College van procureurs-generall. De strafvorderlijke regeling is ingevoegd bij amendement van leden wan de Tweede Kamer, Kamerstukken II 1998 ; 89,25403 , nr. 16 . Handelingen II 1998999 , p. 1550.1553. 
College dat het de minister op de hoogte moet stellen "van voorvallen en van strafzaken die de hoofdlijnen van het beleid met betrekking tot de strafrechtelijke rechtshandhaving raken of die van bijzondere betekenis zijn voor de rechtshandhaving'. In de toelichting noemt het College het beleid rond de Eurotop in 1997 als een woorbeeld dat onder deze algemene omschrijwing valt. ${ }^{87}$

In al deze gevallen warin het College een voorgenomen beslissing aan de minister voorlegt, heeft het oordeel wan de minister geen rechtsgevolgen voor de betrokken zakk. Wanneer de minister zich niet met het voornemen verenigt zal hij een aanwijzing moeten geveri om rechtens zijn eigen oordeel te doen prevaleren. De facto komt dit laatste niet voor. Wel vinden in ieder geval maandelijks consultaties over specifieke zaken plaats.

Er bestaan geen juridische uitzonderingen op de plicht de minister te informeren. Het $O M$ is daar ook toe gehouden als geheimhouding van de gegevens in het belang is van de opsporing of de vervolging van strafbare feiten. Bepalingen in de Wet openbaarheid van bestuur die onder meer deze belangen behartigen kunnen alleen aan burgers tegengeworpen worden (art. 10 WOB).

\subsection{Aanwijingsbevoegdheid}

De minister is bevoegd het OM aanwijzingen te geven. Hieronder bespreek ik eerst de grondslag en betekenis wan deze bevoegdheid. Daarna volgt een beschouwing van de mogelijkheden en moeilijkheden de bevaegdheid te gebruiken bij de uitoefening van bepaalde soorten strafrechtelijke bevoegdheden door het OM. De procedure van aanwijzen komt dan ter sprake. Vervolgens bespreek ik mogelijke rechtswaarborgen die op aanwijzingen van toepassing kwmen zijn. Ik besluit met een analyse van de terughoudendheid die van de minister geëist wordt bij het geven van aanwijzingen.

\subsubsection{Grondslag aanwijzingsbevoegdheid}

In het Nederlandse rechtsstelsel heeft de minister van Justitie op grond van de Wer RO aen aanwijzingsbevoegdheid ten aanzien van het OM. Tot de wijziging van deze wet in

87 Art 131 lid 5 Wet RO; ant. II lid I Reglement vath Orde van het College wan procureurs-generaal; art. 1.3.4 en 2.11.4 Amwijzing opsporingsbevogdheden. Omtrent euthanasie zic: art. I Aanwijzing vervolgingsbestissing inzake leverasbeeindiging op verzok; Kamerstukken II 199697, 23877, nu. 13, p. 5. Omtrowt departementalic onderzokent art. 7 Cinculaine taken en inzetcriteria rijksrecherche. Omtrent overtheidsonganen zis: art. 4 Aanwizing voor de opsporing en vervolging wan overheder. Omtrent transnetlezken: ur. 5 Aanwijzing hoge transaties en transacties in bijzondere zaken. Omtrent owereenkomsten met delinquenten: ant. 5 Richtign afspraken met criminelen. Il het werleden moest de minister zelts toestemming of goedketwing werlenen voot wervolging in strakaken betreffende abortusklinieken. Een woorbeeld: HR 18 maan 1975, NJ 1975, 247, m.nt. ThWvV. Voorbeelden wan politieke ambtsdragers als verdachte in: Aanhangsel handelingen 11 $1995 / 96$, nor. 1324 en 1623.

88 Kamestukken I1 1996/97,25392, n. 3, p. 49; Over de frequentie van da consultatie van de minister ten aanzien van bijzondere opsporingsmethoden Commissie Kalsbeek, Kanmerstukken Il 199899, 26269, nr. 5, p. 187, 'Ongeweer én à̉ twee keer per mand'. Minister Hirsch Ballin was hiervan an het verteden 'nauwelijks tot niet op de hoogte". Commissie Van Traa, Kamerstukken Il 1995/96, 24072, nr. 11, p. 445. Zie verder 6.8. In formele ünvloed. 
1999 was de ministeriele aanwijzingsbewoegdheid gebaseerd op artikel 5. Dat jaar kreeg deze bepaling een nieuwe formulering en nummering (art. 127). ${ }^{\text {of }}$ De neuwe tekst brengt preciseringen, maar lijkt qua reikwijdte whjwel niet van de vorige af te wijken. Met de wijziging beoogde ook de minister blijkens de Memorie van 'Toelichting geen inhoudelijke wijziging, alleen een verduidelijking. Hier is verder niet op ingegaan door kamerleden. ${ }^{91}$ Heronder kan ik dan ook, bij de bespreking van de huidige bepaling, verantwoord gebruikmaken van de standpunten over het voormalige artikel. Waar van belang zal ik wijzen op enkele verschillen.

De wetsbepaling is niet de vanzelfsprekende grondslag voot de aanwijzingsbevoegdheid. Verscheidene auteurs hebben de opvatting verdedigd dat de bevoegdheid impliw ciet aanwezig was of dat deze voortvloeide uit de ministerièle verantwoordelijkheid. Deze standpunten komen achtereenvolgens aan bod.

In de Toelichting bij het wetsvoorstel voor de Wet RO van 1999 schreef de minister over het oude artikel 5: 'De bepaling is niet geredigeend in de vorm van cen bevoegdheid om aan het OM bevelen te geven, doch als een verplichting deze op tre volgen. De bevelsbevoegdheid wordt in artikel 5 voorondersteld.' De D66-fractie in de Tweede Kamer volgde de argumentatie van de minister. Zij meende eveneens 'dat artikel 5 de ondergeschiktheidsrelatie reeds veronderstelt en dat deze relatie uit de aard van het OM voortvloeit. ${ }^{92}$ Deze meningen zijn staatsrechtelijk gezien opvallend. Blijkbaar zou de minister zonder specifieke attributiebepaling al de bevoegdheid hebben om aanwijzingen te geven. Het legaliteitsbeginsel eist juist dat een wettelijke bepaling een bevoegdheid toekent. De "aard van het $O M$ ' creeert uiteraard geen aanwijzingsbevoegdheid! Deze opvattingen zijn dus in strijd met het legaliteitsbeginsel.

Zij zijn evenzeer in strijd met hetgeen uit de rechtshistorie blijkt. De Wet RO kwam in 1827 tot stand. Sindsdien is artikel 5 niet meer gewijzigd tot an 1999. De woordvoerders bij de toenmalige behandeling van de wet gingen er niet van uit dat de minister al een bepaalde zeggenschap zou hebben zonder artikel 5 aan te nemen. Toenmalige voorstanders van de bevoegdheid stelden wel regelmatig dat het OM onder de bevelen van de minister zou horen te staan, of dat dit "altijd" al 20 geweest was. Dit waren dan slechts argumenten op grond waarvan artikel 5 juist in de Wet $\mathrm{RO}$ zou moeten worden opgenomen. Tegenstanders van de aanwijzingsbevoegdheid vonden dit artikel negatieve gevolgen hebben. Zij keerden zich tegen de bepaling, opdat deze niet aangenomen zou worden. Als zij wan mening waren geweest dat de minister zonder artikel 5

89 Art. 5 Wet RO 1827 - De anbtenaren bij het openbat ministerie zijn werplicht de bevelen na te komen, welke hum in hun ambtsbetrekking door de deartoe bevoegde mach, vanwege do koning. zullen worden gegeven".

90 Art 127 Wet RO - 'Onze Minister var Justitie kan algemene en bijzondere anwijzingen geven betreffende de uhoefening van de taken en bevoegdtieden wan het openbaar ministerie' In de Vierde tranehe van de Awb komt eveneens een bepaling voor die de anwijzingsbevoegdheid tegelt vian een bestumsargan dat verantwoordelikheid dragt voor een persoon of college waaran eigen bevoegdhoden ajo toegedeeld, artikel 10.1.3.1.

91 Kamerstukken I 1996/97, 25392, nr. 3, p. 22.

92 De minister: Kanerstuken II 199697,25392, n. 3, p. 21. De D66-fractie: Kamersilkken II 1997908, 25392, ar, 6, p. 20. Zie ook de minister in een eerdere brief: Kamerstukken II 1995/96, 24034, nr. 13 , p. $4-5$. 
toch al wel bevelen had kunnen geven, zou hun betoog weinig zin hebben gehad. Het artikel riep juist een uitgebreid debat op, waaruit blijkt dat voor- en tegenstanders niet al een soort ondergeschiktheidsrelatie veronderstelden. ${ }^{93}$ De Memorie van Toelichting laat de toenmalige parlementaire behandeling van de Wet RO overigens buiten beschouwing.

Wel was de redactie van het oude artikel 5 zodanig dat deze de bevelsbevoegdheid in racilkundige zin vooronderstelde. De gebruikte woorden "zijn verplicht de bevelen na te komen' gingen volgens hun letterlijke betekenis uit van een bevoegdheid tot het geven van aanwijzingen. Dit gegeven kan evenwel niet de juridische betekenis hebben dat de minister die bevoegdheid al had, los van die woorden. De bepaling was slechts in passieve zin geredigeerd; zij was geschreven ten aanzien van het OM, niet ten aanzien van de minister. Het artikel stond tussen een aantal andere bepalingen die het $\mathrm{OM}$ betroffen. De wet had onder meer tot onderwerp juist de positie van het OM te regelen. Het lag dan voor de hand een passieve redactie te hanteren, gericht op de plichten van het OM. Het nieuwe artikel 127 is darentegen in actieve zin geredigeerd, gericht op de minister. Over een verplichting tot nakoming wordt niet eens gesproken. Uiteraard volgt die plicht uit de aanwijzingsbevoegdheid van de minister. De huidige formulering van de bevoegdheid zou geen onjuiste conclusies meer teweeg mogen brengen omtrent een vooronderstelling van ondergeschiktheid. ${ }^{94}$

Sommigen menen dus ten onrechte dat de hiërarchische relatie tussen minister en $\mathrm{OM}$ verondersteld zou zijn. Een andere, deels samenhangende mening stelt dat de ministeriële bevoegdheden voortkomen uit diens verantwoordelijkheid voor het $\mathrm{OM}$. Volgens een aantal auteurs zou uit de verantwoordelijkheid of de verantwoordingsplicht van de minister rechtstreeks zijn gezag voortvloeien over ambtenaren, zoals leden van het $\mathrm{OM}$. Indien de minister verantwoordelijk is dan moet hij ook over de bevoegdheden beschikken waarmee hij zijn verantwoordelijkheid waar kan maken, is de redenering. Op grond van zijn verantwoordelijkheid zou hij dan bevoegd zijn een aanwijzing te geven. $^{95}$

Minister Sorgdrager ging in eerste intantie ook uitdrukkelijk uit van deze opvatting. 'Waar geldt dat een minister in beginsel verantwoordelijk is voor elke gedraging van ambtenaren of (andere bestuursorganen) op het niveau van de rijksoverheid op zijn beleidstertein, vloeit daaruit noodzakelijk de volledige bevoegdheid ten aanzien van - dat wil zeggen: de volledige zeggenschap over - die ambtenaren en die bestuursorganen." ${ }^{96}$

93 Bijlage Handelingen II $1819 / 1820$, nr. XXV-2, p. 602 tot mr. XXV-6, p. 623. Bijlage Handelingen Il 182627 , nr. XIll-2, p. 312 10i nr. XIII-4A, p. 482. Wet RO 1827, Stb. nr. 20, p. 664-667. Bijlage Handelingen II 1828/29, nr. XVIII-2A, p. 712 tot wr. XVIIl-5, p.771. Handelingen II 1828.29, p. 284-724. Bijlage Handelingen II 1834/35, nr. LX, p. 292-3:4, De wet trad in werking per 1 oktober 1838, Stb. nr. 12.

94. Dittrich stelde bij de behandeling in de Tweede Kamer en amendement voor om na de ministeriele bevoegdheid bevelen te kunnem geven een hepaling als het oude artikel 5 Wet RO toe te voegen. Minister Sorgdrager wond bij het moderniseren vam de wet deze bepaling onnodig, Handelingen 11 1997/98. p. 4824 .

95 De Wildt 1968, p. 64; Clateur, 1996, p. 600; Van Angeren 1996, p. 368 en 371 ; Broukver 1999, p. 53.

96 Kamerstukken 11 1995/96, 24034, nk. 13. p. 2; Sorgdrager 1996, p. 6. 
Op een later moment - in de Memorie van Toelichting bij het wetsvoorstel voor de Wet RO van 1999 - drukt de minister zich iets genuanceerder uit:

"Het beginsel dat aan iedere uitoefening van overheidsbevoegdheden ook een verantwoordingsplicht moet zijn gekoppeld, wordt op Rijksniveau ingevuld door de verantwoordingsplicht te concentreren bij de minister en de volksvertegenwoordiging de bevoegdheid te geven die verantwoordelijkheid te mobiliseren. Aldus vormt de minister - in de woorden van de commissie-Scheltema - het scharnierpunt voor de democratische controle op de overheidsorganisatie. Dit laatste impliceert een hiertarchische verhouding tussen de minister en degenen die als ambtenaar bij de rijksoverheid werkzaam zijn, tenzij uit de wet anders blijkt." (cursief PPvdL)

Ten slotte is een belangrijk element van de ministeriële verantwoordelijkheid dat er geen verantwoordingsplicht is zonder bevoegdheid. ${ }^{97}$

Weer lijkt de minister hier te suggereren dat de ministeriële verantwoordelijkheid althans de concentratie daarvan bij de minister - een ministeriële aanwijzingsbevoegdheid meebrengt. ${ }^{98}$

Deze implicatie is onjuist. ${ }^{99}$ Uit het feit alleen dat de minister een verantwoordingsplicht heeft, vloeit niet voort dat hij dáárom juridisch bevoegd zou zijn tot het geven van bevelen. Het kan hoogstens wenselijk of efficiënt worden gevonden dat in een parlementair stelsel de verantwoordelijke minister bepaalde bevoegdheden heeft. Met bevoegdheden tot informatieverkrijging of beïnvloeding van het te verantwoorden handelen zou een minister wellicht beter verantwoording kunnen afleggen. Deze bevoegdheden dienen echter gegeven te worden door wettelijke bepalingen. Verantwoordelijkheid impliceert geen hiërarchie, maar andersom, zoals ook voortvloeit uit het door de minister genoemde "beginsel".

\subsubsection{Soorten aanwijzingen}

Een eerste stap is te bezien op welke bevoegdheden de ministeriële aanwijzingen betrekking kunnen hebben. Over de reikwijdte van de aanwijzingen bestaat niet altijd overeenstemming in de literatuur en de parlementaire stukken. Veel schrijvers stellen dat de minister het $O M$ voor al zijn handelingen en in elke fase van de strafrechtketen een aanwijzing zou kunnen geven. ${ }^{101}$ Enkele schrijvers die hierna aan bod komen menen daarentegen dat ten aanzien van bepaalde aspecten de minister niet bevoegd zou

97 Kamerstukken II 199697, 25392, nr. 3, p. 20, Kamerstukken II 1996/97, 25392, B, p. 2-3. Zo ook Koekknek, Handetingen II 1997/98, p. 4789. De minister baseert zich woor het scharnicrpuntconcept op het rapport wan de commissie Schellema, 1993, p. 8. De implicatie van de hierarchische verhouding is echter een gedachte uit de Memorie van Toelichting zell.

98 Zoals hierboven in deze paragraf vermeld, wees de analyse wan de oude Wet RO in de Memorie wan Toelichting al in dezelfde richting 'De bevelsbevoegdheid wordt in artikel 5 voorondersteld.', vgl noot 92 .

99 De Doelder 1996a, p. 295; De Winter 1997, p. 1270, Kormanm 1996, p. 243-244; Verthey 2001, p. J81.

100 Zie verder 7.1. Grondslag en reikwijdte verantwoordelijkheid.

101 O.a. Dusterwinkel 1965, p. 8; Mostert 1968, p. 311; Lubberdink 1982, p. 63; Van Maarseveen 1983, p. 181. 
zign een aanwijzing te geven. Dit stel ik aan de orde bij de nu volgende bespreking van de te onderscheiden soorten aanwijzingen.

\subsubsection{Aanwijzing om geen bevoegdheden uit te oefenen}

Corstens meent dat de minister niet de bevoegdheid heeft "een lid van het openbaar ministerie bij wijze van sanctie geheel of voor een wezenlijk deel in de uitoefening van diens bevoegdheden te beknotten. ${ }^{102}$ Volgens Duisterwinkel daarentegen heeft de minister wel de bevoegdheid een aanwijzing te geven dat een ambtenaar van het $O M$ voorshands geen bevoegdheden mag uitoefenen. De officier die dan bijvoorbeeld toch vervolging instelt zal dan wel ontvankelijk verklaard worden. Hij zou echter disciplinair gestraft kunnen worden voor zijn handeling. ${ }^{103}$

Beide opvattingen zijn te bekritiseren. Uit niets blijkt dat de minister een dergelijk besluit niet zou kumnen nemen. De beslissing zou verder niets afdoen aan het bestaan van de bevoegdheden van het lid van het OM. Daarnaast kan men niets aanvangen met het onbepaalde begrip "wezenlijk deel'. Wat is het "wezen" van de bevoegdheden van het OM? Een dergelijk ministerieel besluit dient echter niet in de vorm van een aanwijzing te geschieden. De minister moet het lid van het OM eenvoudigweg schorsen. De minister dient dan aannemelijk te maken dat het 'belang van de dienst' een schorsing vordert. Zou de minister daarentegen de aanwijzingsvorm kunnen gebruiken, dan zou hij aan dit inhoudelijke criterium voorbij kunnen gaan. ${ }^{104}$

\subsubsection{Beleidsaanwijzingen}

Het OM zelf voert een beleid. Dit is niet het beleid van de minister van Justitie, zoals dat geldt voor het ministerie van Justitie. Wel is de minister bevoegd beleidsaanwijzingen te geven aan het $\mathrm{OM}{ }^{105}$ Het kan gaan om een aanwijzing die het vervolgingsbeleid voor een sector of voor een bepaalde bevoegdheid vaststelt. De minister zou ook aanwijzingen kunnen geven om een landelijke richtlijn met een bepaalde inhoud aan te nemen, of om een bepaalde richtlijn anders te formuleren.

De minister mag uiteraard geen aanwijzingen geven ter bevordering van een beleid dat het OM zelf ook niet mag voeren. Het beleid mag vanzelfsprekend niet in strijd zijn met het recht. Daarnaast kent het vaststellen van vervolgingsbeleid een specifieke begrenzing. Het is niet mogelijk om stelselmatig in het geheel niet te vervolgen. Deze beperking geldt ook de minister. Hij zou de wettelijke bepaling zijn kracht ontnemen indien hij het $\mathrm{OM}$ zou bevelen de vervolging daarvan volkomen achterwege te laten. Hij zou zich wel kumnen richten op het initiëren van een wetswijziging ten aanzien van

102 Corstens 2002, p. 104. Vgl. Corstens 1974, p. 52.

103 Duisterwinkel 1975, p. 197. Analoog m.b.t. opsporingsambtenaren CRvB 22 december 1938, NJ 1939, 53.

104 Zie 5.7. Schorsing en ontslag.

105 Ook onder het oude art. 5 Wet RO werd de minister algemeen bevoegd gehouden om algemene aanwijzingen te geven aan het OM. Zie bijw: Van Veen 1977, p. 262; Ficq 1991, p. 164; Sehalken 1991, p. 181; Viering \& Kummeling 1996, p. 594; NVwR 1996, p. 320. Alleen Den Doelder en Boek waren van mening dat de minister alleen maar algemene aanwijzingen kan geven, respectievelijk 1996, p. 122 en 1997, p. 136. 
het onderwerp. Daamaast zou de minister wel tijdelijke posterioriteiten kumen voorschrijven: ${ }^{106}$

In de praktijk geeft de minister zeer zelden beleidsaanwijzingen. Hij wordt echter nauw betrokken bij de jaarlijkse planningscyclus van het OM. In overleg stelt hij zo met het College prioriteiten vast. Posterioriteiten komen daar echter in feite niet aan de orde. ${ }^{10}$

\subsubsection{Aanwijzing in de opsporing}

De minister is bevoegd om, in geval het OM naar aanleiding van een delict geen opsporing instelt, een aanwijzing tot opsporing te geven. Omgekeerd zou de opsporing van een delict tot staan gebracht kunmen worden door een negatieve aanwijzing. Daarnaast zou het object van het onderzoek beperkt kunnen worden door een aanwijzing. ${ }^{108}$ Voor dergelijke negatieve aanwijzingen geldt evenwel hetgeen ik overweeg met betrekking tot aanwijzingen tot niet-vervolging. Andere varianten zijn een aanwijzing die de opsporing op andere verdachten richt; een aanwijzing om de opsporing te richten op andere (soorten) delicten die zouden zijn begaan door een zelfde verdachte; het gebruik doen maken van bepaalde dwangmiddelen, of thet gebruik daarvan verbieden of opheffen; een aanwijzing tot het geven van een bevel aan de politie.

De bevoegdheid aanwijzingen in de opsporing te geven werd in het verleden wrijwel niet in twijfel getrokken. De minister heeft zich dan ook bij enkele gelegenheden in opsporingszaken gemengd. Bij de herziening van de Wet $\mathrm{RO}$ is deze bevoegdheid nog eens uitdrukkelijk bevestigd.

\subsubsection{Aanwijzing tot vervolging}

Indien een strafbaar feit is opgespoord of anderszins bekend is geworden aan het OM, kan het besluiten niet te vervolgen. De minister zou vervolgens kunnen besluiten een aanwijzing tot vervolging te geven. De minister kan bijvoorbeeld een aanwijzing geven tot vordering van een gerechtelijk vooronderzoek of dagvaarding. ${ }^{10}$ In de praktijk komen dergelijke aanwijzingen wel eens voor. ${ }^{111}$

106 Oranje 1974 , p. 11. Vgl, Corstens 2002, p. 483.

107 Zie ook 3.3. OM-beleid en 6.1. Bevoegdheden omnent informatiovoorziening.

108 Minister Sorgdager noemde deze laatste mogelijkheid expliciet, Handelingen 11 199798, p. 4828.

109 De formulering van art. 128 lid 1 zelf noemt ook de opsporing". Ten manzien wan art. 5 Wet RO neeth de alleen De Doelder dat en minister niet of 'warschijblijk' geen bevelen mag geven over het hantewen van opsponingsbevoegdheden, $1995, \mathrm{p}$. 60; sterker: $1996, \mathrm{p} .122$. ln de jaren tachig van de negenthende eeww liet minister van Justitie Modderman de leider van de Social-Democratisehe Bond Domela Nieuwenhus schaduwen. Verburg 1994 , p. 446 . In 1974 en 1976 gaf de minister "het groene licht" voor respectiewelijk het vorderen en het verrichten vary en huiszoeking ter inbeslagneming in we aak Bloemenhove, Handelingen II 1974/75, p, 1025-1026; 1975/76, p. 4227-4228; Kanmersukken II 1975/ 76, 13964, nr. 1, p. 2. In 1985 in de zaak Kok, warin een arrestant in zijn cel overleed, wond het OM geen grond om een strafrechtelijk onderzock te openen. Op instigatie van minister wan Justitic Kothals Altes werden er varwolgens meer verhoren gehouden on werd het onderzoek voortgezet. Handelingen II $1985 / 86$, p. $1875-1893,1919$.

110 Onder het oude ant. 5 Wet RO is deze bevegdheid wrijwel nooit in wijfel getrokken. Bevestigend biju: Renumelink 1991, p. 171.

111 In 1815 overlegde procureurs-generaal en de minister van Justitie over de eventuele verwolging van de Gentse bisschop Maurice, hertog De Broglie. Om politieke redenen vond minister Van Manen het in 
Mogelijk is dat een belanghebbende in een bepaald geval reeds beklag heeft ingesteld bij het hof ex artikel $12 \mathrm{~Sv}$. Als het hof geen reden tot strafvervolging aanwezig heeft geacht, zou de minister desalniettemin de vervolging kunnen bevelen. De officier zou dan het bevel van de minister moeten nakomen. ${ }^{12}$ De afwijzende beslissing van het hof op het beklag houdt namelijk geen verbod om te vervolgen in. ${ }^{113}$

Op deze plaats wijs ik er verder op dat in een ingestelde vervolgingsprocedure de minister desgewenst kan bevelen dat het $O M$ van bepaalde procesbevoegdheden gebruikt maakt. Ten slotte moet hier de mogelijkheid vermeld worden om na de rechterlijke uitspraak een anwijzing te geven die het $O M$ hoger beroep of beroep in cassatie in doet stellen. ${ }^{114}$

\subsubsection{Aanwijzing tot niet-vervolging}

De minister is bevoegd een aanwijzing te geven tot niet of niet verder (opsporen of) vervolgen. Ook indien een zaak technisch haalbaar is, kan de minister een aanwijzing geven om te seponeren, omdlat hij vervolging in het voorliggende geval inopportuun vindt. De minister zou de officier ook kunnen bevelen de verdachte voor bepaalde strafbare feiten niet te dagvaarden, maar deze feiten ad informandum te voegen. Hij kan de officier van justitie bevelen gebruik te maken van diens bevoegdheid voorwaardelijk te seponeren. Verder kan de bewindspersoon een aanwijzing geven om een verdachte in plaats daarvan een transactie aan te bieden. Een aanwijzing is denkbaar tot het doen van een andere transactie, met andere voorwaarden (zoals een hoger of lager bedrag, een taakstraf, etc.). Indien een verdachte al is gedagvaard kan de minister een bevel geven de dagvaarding in te trekken, zolang het onderzoek op de terechtzitting nog niet is aangevangen. De minister is ten slotte bevoegd een aanwijzing te geven om geen hoger beroep in te stellen, of on een ingesteld beroep in te trekken. ${ }^{115}$ Een op-

eerste instantie beter de zaak te laten rusten. Vervolgens besloot de Koning op zijn woorstel in 1816 om de vervolging te bevelen. Overigens speelde deze zaak nog voor de totstandkoming van de Wet RO. Verburg 1994, p. 147-150. In 1886 drong de minister van Justitie persoonlijk op vervolging an van Domela Nieuwerhhuis. Deze werd vervolgd en veroordeeld voor majesteitsschennis wegens een antimonarchistisch artikel, Stolwijk 1992. p. 36* Sorgdrager 1999. p. 183. In 1987 gaf minister Korthals Alles en schriftelijke anmwijzing tor vervolging van een overtreder van het zogenaamde graasverbod na de Tsjemobyl-ramp, Sorgdrager 1999, p. 183 . Voor de stralzaka, zie HR 28 februari 1999 , NJ 1990, 28 , m.nt. ALM.

112 Van Dullemen 1958, p. 16. Overigens is geen beklag moge ijk als de verdachte buiten vervollging is gesteld (art. 250 lid 4 Sv), of als een beschikking dat de zaak tegen hem is geeindigd aan hem is betekend (art. $36 \mathrm{~Sv}$ ). Na een kennisgeving van niet verdere vervolging (art. $238 \mathrm{~Sv}$ ) is beklag mog mogelijk tot drie manden nadat de belanghebbende net de kennisgeving bekend is geworden (art. $|2| S_{v}$ ).

113 Corstens 1974, p. 105; 1999, p. 510.

114 thier zij vermeld dat de minister van Justitie geen beklag kan indienen tegen niet-vervolging. Minister Korthals; Kamerstukken III 200】/02, 28093, p. 344. De minister heeft specifieke bewoegdheden die beklag overbodig maken en uitsluiten. Hij kan zich (eventueel vooratgaand aan een beslissing) laten informeren en cen anwijzing tot vervolging geven. Het bestaan van deze bevoegdheder laat concluderen dat de syslematiek van de wetgeving een ministerieel beklag uitsluit. Of de minister van deze bevoegdheden gebruik maakt is een andere zask, die uiteraard voor zuin rekening komt.

115 Onder het oude art. 5 Wet RO concludeerden velen all tot deze bewoegdheid: Hazewinkel-Suringa 1953 . p. 151; Van der Bufg in zijn noot onder HR 17 december 1985, AB 1986, 264; Remmelink 1968, p. 170; 1991, p. 171. Hij wees al op het sinds 1967 geldende art. 9 Uitleveringswet: 
- merkeljke zaak waarin de regering zelf afwijzend besloot over de vervolging was de Lockheed-affaire. Overigens resulteerde dit voor zover bekend niet in een formele aanwijzing. Het $O M$ heeft zich ook niet bezig gehouden met de zaak. ${ }^{116}$

\subsubsection{Aanwijzing ten aanzien van bet requisitoir}

Wanneer bij een strafzaak het onderzoek ter zitting is begonnen kan de mimister een aanwijzing geven hoe de officier van justitie in het proces dient te handelen. Hij kan bijvoorbeeld een aanwijzing geven de tenlastelegging ter zitting aan te vullen of te wijzigen. De minister zou de officier kunnen bevelen een bepaald requisitoir te houden, met een bepaalde conclusie, stratmaat en strafmodaliteit.

Een aanwijzing kan een combinatie vormen van een aanwijzing tot vervolging en een aanwijzing ten aanzien van het requisitoir. Ten aanzien van een zaak waarin het $\mathrm{OM}$ geen vervolging heeft ingesteld kan de minister de aanwijzing geven 'te vervolgen' en daarmee tevens bedoelen dat het $O M$ in het requisitoir de veroordeling eist. Dit lijkt het geval geweest te zijn in de zogenaamde zaak-Drenth. Een dergelijke aanwijzing kan verschil van mening opleveren over de inhoud van de aanwijzing. Beter ware het wanneer de minister beide wensen afzonderlijk zou formuleren. Voor een duidelijk begrip zou het beter zijn als de minister in een dergelijk geval tevens de aanwijzing geeft

1. Uitlevering van de opgexiste persoon wordt niet toegestaan voor een feil terzake waarvam: a. ten thije van de beslissing op het verzoek tot uitlevering en strafverwolging in Nederland tegen hem gatinde is (...) 2. Het bepalde in het vorige lid, annefen onder a, lijdt untzondering in gevallen wanrin Onze Minister bij zijn beslissing tot inwilligung van het verzoek tot uitlevering tevens opdrach geef ds vervolging te staken.' (curs. PPvdL).

Tegen het bestan van een dergelijke bevoegdheid sprak De Doelder zich uit, 1996, p. 123. Eerder meende hij dat dit wel een bevoegdheid van de minister was, 1995, p. 60. Over het doen intrekken van een beroep: Oranje 1976, p. 16. Voor een woorbeld zie noot 243 onder 7.2. Verantwoondingspraces.

116 In de Lockhed-affaire in 1976 stelde de fegering en speciale commisside Donner in om strafbare luten te onderzoeken waar een "hoge regeringsunctionaris", wellicht Prins Bernhard, bij betrok tho zot zijh

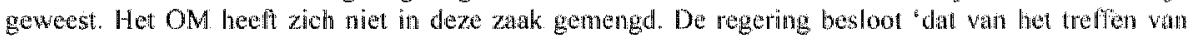
justitiele maatregelen dient to worden algezien." Kamerstukken II 1975/76, 13787 ; Handelingen II $1975 / 76, p .5115-5117$. Volgens Van Marseven was de handetswijze wan de regering negaliel to beoordelen. Door de publiciteit die het handelen van de regering ten gevolge had. zou Privis Bionahad meer geschaad zindan in wen normale procedure het geval zou zijn geweest. Daatnast zou de gang van zaken het vertiouwen in de rechtsorde geschokt hebben, dar een uilzondering op dë reguliere procedure gemaakt is aangezien er een 'hoge regeringsfunctionaris' bij betrokken zou zijn. Van Marscveen 1976, p. 377. Voor kritiek op de aanwijzing tot niet-vervolging, zic o.a. hoofdstuk 7, 7.4.1. Partijdigheid

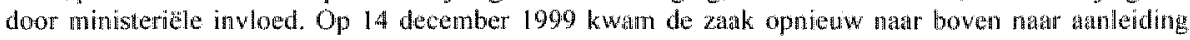
var verklaringen in een televisie-Litzending. Hieruil zou bljken dat de prins wel geld van Lockheed zou hebben angenomen. Eet mand later werden delen gepubliceerd wan exn kopie van de motulen van de ministeratadsvergadering warin omtrent het rapport van de commissie Donner werd besloten. Hicruit zou blijken dat onder andere de minister wan Jugtitie van mening was dat er gronden waren om een strafrechtelijke vervolging te starten. De meeste ministers, inclusiel de minister van dustätie zalf, wilkel echter afizen wan vervolging, ondat die onwenselijke gevolgen zou hebben woor de positie van de koningm. NRC Handelsblad 14 december 1999; 15 januari 2000. Aanhangsel Handelingen 11 1999. 2000 , nir. 467, p. 1059 ; nr. 596, p. 1323. Mirnister Korthals kon zich eer anwijzing tot niet-venvolging naukeljijss voorstellen. Handelingen 1199899, p. 1787. 
"de veroordeling te eisen". Dan is duidelijk dat de minister zowel het instellen van de vervolging als het worderen van de veroordeling wenst.

De aanwijzing ten aanzien van het requisitoir is het meest omstreden geweest: Over het feit dat een officier van justifie zich in beginsel aan rekwireenichtijnen moet houden. bestat al lang algemene overeenstemming. Het OM kan in een specifieke strafzaak, eventueel om op de zitting gebleken bijzonderheden, afwijken van richtlijnen. Minder eensgezincheid bestond er over de vraag, of de minister in een concrete zaak een requisitoir kan voorschrijven, en zo ja, of de officier daamaast een eigen mening kan geven. Bij de herziening van de Wet $\mathrm{RO}$ is hieromtrent wederom niets wettelijk vastgelegd. Nog altijd meldt de wet geen nadere eisen over de aanwijzingen ten aanzien van het requisitoir. Dit is opvallend gezien de mate van discussie die deze aanwijzing heeft opgeleverd. Een interpretatie van de betekenis van de wet voor de vrijheid van het requisitoir blijkt slechts uit de wetsgeschiedenis. Aangezien dit onduidelijkheid kan scheppen wil ik hier aandacht besteden aan de opvattingen die onder de oude Wet RO hieromtrent leefden. Deze weergave zal tevens verduidelijken dat de interpretatie van de wet op dit punt sterk gewijzigd is.

Onder de oude wet meenden sommige auteurs dat het OM geen vrijheid van requisitoir had. Hoogstens had het OM mogen afwijken van een aanwijzing wanneer er nieuwe elementen ter sprake komen die de minister niet in overweging kón nemen. ${ }^{118}$

De meeste schrijvers waren evenwel van mening, dat de minister de officier van justitie niet een bepaald requisitoir mocht voorschrijven. Het requisitoir zou mede bepaald moeten worden door hetgeen naar voren komt bij het onderzoek ter terechtzitting, hetgeen geen ruimte zou laten voor ministeriële interventie. ${ }^{119}$ Enkelen stelden expliciet

117 Voor de zaak Drenth: CRvB 10 juli 1997, JB 1997, 199; TwA 1997, 141; NJB 1997, p. 1287. Aanhangsel Handelingen II 1995/96, ni. 286. Kamerstukken 11 1994/95, 23877, nr. 2. De minister berichtie an de procureur-genenal: "Ik verzoek u damon te bevorderen dat de vervolging wordt voortgezet: Do procureur"gencrall vermeldde aan offeier van justite Drenth: "De minister is van oordeel dat de verwolging moet worden woorgezet. I loes dit zodang dat een vervolging moet worden angesparnen. "Nadtat de offeier had vervolgd, en primair niet-ontvankelikverklaring wan het oM had gedst, werd hij bertspt wegens plichtverzum. Volgens de Centrale Raad wan Beroep was de vordering niet te verengen met de strekking van de opdracht die de officier van justitie kreeg. Echter, in overeeristemming met de popheht had de officier vervolging ingesteld. Dat hij verwolgens niet-ontwankelijkheidverklaring eiste deed daar niet aan af. De rechter is immers vrij in zijn beslissing op een dergelijke eis. Zile ook hoofdstuk 6, 6.1.2. Aanwijzing ken anzien van het requisitoir.

$\$ 18$ Onder het oude art. 5 Wet RO al. Van Dullemen 1958, p. 15; Mostert 1968, p. 310 . Van Dullemen meende uitdrukketijk dat de minister zelfs het eisen wan een bepaalde straf kan gelasten. Viering a Kummeling 1996, p. 594. Het OM zou in hum visid alleen nogen afwijken van een aamwijzing wanneer er nueuwe elementen ter sprake komen die de minister niet overweging kon nemen. Citeur 1997a $p$. 1.26-127. In 1999 meld de A.G Korkinius die ontslag genomen heeft, dat het haar niet gemakkelijk gemalat (werd) harar kribsche oordeel in wijheid te ventileren tegenover het Gerechtshof", "In de Hakkelaazaak was het standpunt van de eerste lijn al gefiatteerd door de top en zelfs - zij het naderhand door de minister, werd mij min of meer prangend voorgehouden". Van een formele aanwijzing van de minister likkt hier geen sprake geweest, Opportum $1999, \mathrm{p} .10$.

119 Corstens 1974, p. 52-53; Van Veen 1977, p. 265; 1979, p. 114; Herstel 1978, p. 73; Corstens \& Tak 1982, p. 22; Singer-Dekker 1982, p. 129; Remmelink 1991, p. 170; Elzinga 1994, p. 535. 
dat de minister geen concrete strafeis of strafmodaliteit mag voorsolnrijwen. ${ }^{120}$ Een en ancler zou blijken uit de 'eigen wetteligke opdracht' krachtens welke het OM zijn werkzaamheden verricht, en uit de eed die leden van het OM afleggen. Enkelen meenden zelfs dat er sprake was van een "staatsrechtelijke gewoonte of conventie" dat de minister ter terechtzitting geen invloed uitoefent. ${ }^{12}$ Ook enkele ministers hebben in het verleden gezegd dat het "niet juist" (Polak) zou zijn als zij controle uit zouden oefenen op hetgeen het OM gaat rekwireren, of dat het niet hun taak zou zijn (Van Agt). ${ }^{122}$

Volgens sommigen zou de minister wel een aanwijzing kunnen geven, maar zou het OM eventueel wel een afwijkende mening of bezwaren tegen de regering mogen uiten. ${ }^{123}$ Volgens Schalken zou de officier alleen van een aanwijzing mogen afwijken "wanneer dat op grond van particuliere en zittingsgebonden factoren onvermirdbaar" is (cursief Sch)". Dat zou hij niet mogen wanneer de reden waarom hij tot een bepaalde beslissing komt "niet exclusief samen(hangt) met de inhoudelijke beoordeling van die specilieke strafzaak': 124

Bij de totstandkoming van de Wet RO van 1999 gaf minister Sorgdrager een uitgebreide precisering. $\mathrm{Zij}$ vond dat de officier van justitie wel zou mogen afwijken van de aanwijzing bij ter zitting nieuw opgekomen omstandigheden. Echter, de officier zou wel gehouden zijn om 'als de aard van een door' de minister gegeven opdracht daartoe aanleiding geeft' alsnog de minister te consulteren. Hij zou daartoe schorsing kunnen vragen. ${ }^{25}$ Het zou dan moeten gaan om nieuwe elementen die de minister niet zou hebben overwogen in zijn aanwijzing. Aangezien aanwijzingen zelf al bijzonder zeldzaam zijn, zal het feit dàt de minister er éen geeft de 'aard van de opdracht' al sterk beïnloeden. Het OM zal al snel moeten concluderen dat het bij een nieuw element de minister moet consulteren. Wanneer deze aanwijzingsbevoegdheid zo functioneert blifft wrijwel niets over van een requisitoirvrijheid. ${ }^{126}$

120 Van Veen 1974, p. 526; Schalken 1996, p. 93. Van Veen will wel een uitzondering maken voor "sterk regelend strafrecht, zoals delen van het e(c)onomisch- en werkeersstralivecht".

121 Over de wettelijke opdracht en de eed: 't Hart 1976, p. 31; Rapport relatie OM-zillende magistratuur 1981. p. 116. Over de staatsrechtelijke gewoonte: Rapport reatie OM-zittende magistratuur, idem; Elzinga 1994, p. 535; Boek 1997 , p. 136.

122 Minister Polak. Handelingen II 1968/69. p. 3515: Minister Van Agd, Aanhangsel Handelingen II 1972/73, nr. 282, p. 565: 'De Minister van Justie kan het niet lot zijn taak rekenen een oondeel te gewen over of te interveniëren met betrekking toi het requisitoir in een individuete stratzaak. "Hierover: Oranje 1976, p. 19: Singer-Dekker 1982, p. 127: Corstens \& Tak 1982, p. 22.

123 Mostert 1968, p. 311 ; Duisterwinkel 1965, p. 6-7; Duisterwinkel 1968, p. 204; Van Veen 1974, p. 525. Remmelink was van mening dat de minister he OM well kan woorschrijven een bepaald requisitoir te houden, mat dat het $O M$ daaraan niett gebonden is, omdat het hier "functionele atulonomie" heeft. Echter, als de persoonlijke opvatting van de officier dwars tegen de amwiijzing van de minusler in zou gaan, zou de officier zich moeten laten vervangen. Het gezag van het recht zou ondermijnd worden als het OM "met dubbele tong" zou gaan spreken. Remmelink 1968, p. 1172 . Volgens Osingi $z 0 u$ in Nederland het adagium gelden van 'la plume est serve, la parole est libre'. Osinga $\$ 992$, p. 76 . Onder het huidige recht in tedter geval ten onrechte, zie hiema.

124 Schalken 1996, p. 93.

125 Kamerstukken II 1995/96, 24034, nr. 13, p. 6.

126 Volgens Corstens 1999 , p. 101 zou een dergelijke handelswijze de positie wan het OM ter zitting 'ondermijnen'. 
Over de eigen visie van de officier van justitie stelde de minister het volgende. Als tijdens het strafproces een aanwijzing is gegeven zal de officier van justitie er vervolgens mee in overeenstemming moeten handelen en deze ter terechtzitting loyaal moeten verdedigen. Het staat hem wel "vrij om aandacht te vragen voor die overwegingen omtrent het recht die de rechter naar objectieve maatstaven mede in het oordeel over de voorliggende casus zou moeten betrekken?. De officier zal de verschillende aspecten kunnen belichten die bij de afweging voorafgaande aan de beslissing tot vervolging een rol hebben gespeeld. Hij wordt geacht de rechter op een onpartijdige wijze te voorzien van de informatie en argumenten benodigd voor de beslissing. ${ }^{127}$

De minister heeft echter uitdrukkelijk aangegeven dat het OM niet tegelijkertijd twee versehillende opvattingen aan de rechter moet voorleggen. ${ }^{128}$ Het is dus niet de bedoeling dat de officier alle argumenten weergeeft, daarna de conclusie uit de aanwijzing en vervolgens een andere uitkomst suggereert die hij zelf voorstaat. Wanneer een aanwijzing op tafel ligt mag de eigen conclusie van de officier niet expliciet blijken. In Nederland geldt dus niet onverkort thet Franse adagium "la plume est serve, la parole est libre".

\subsubsection{Wijze van aanwijzen}

Met uitsluiting van andere ministers kan alleen de minister van Justitie aanwijzingen geven aan het OM. Het is dus uitgesloten dat bijvoorbeeld de minister-president het OM aanwijzingen geeft. ${ }^{130} \mathrm{De}$ minister kan zowel algemene aanwijzingen geven als bijzondere aanwijzingen in een specifieke strafzaak. Voor de laatste soort bestaan procedureregels.

De minister kan een algemene aanwijzing geven voor het gebruik van bepaalde strafrechtelijke bevoegdheden. Een algemene aanwijzing is niet aan enige vorm ge-

127 Kamerstukken II 1996/97, 25392, nr. 3, p. 27. De tekst is op aandringen van hel OM zelf in deze Memorie van Toelichting opgenomen, Simonis \& Myjer 2001, p. 77. De formulering is woordelijk overgenonen in art. 3 sub 5 sub $A$ Gedragseode OM: "De officier tal ter terchtzitting een gegeven manwijzing loyat verdedigen. Wel stat hat hem vrij on aandacht te vragen voor die overwagingen omtrent hat recht die de rechter naar objectieve maatstaven mede in het oordeel over de voorloggende casus $20 u$ moten betrekken.'

128 Kamerstukken II 1997/98, 25392, nr. 7, p. 28; Corstens 1999, p. 100-101; 't Han 2001. p. 43. Opvallend is dat Corstens in zijn handboek nog steeds meent dat het OM zich kan beroepen op zijn vrijheid van requisitoir. 1999, p. 105,578-579. Ook het handboek vam Minkenhoffreijntjes 2002, p. 49 meent ten onrechte dat in de Menorie van Toelichting gelezen kan worden dat leden van het OM "hun eigen siandpunt" aan de rechter kenbaar kunnen maken.

129 Ower hei adagium: hoofdstuk $3,6.3 .3$. Rechtswatarborgen bij aanwijzingen. Over de vergelijking met Frankrijk verder: hoofdstuk 5, 2.2. Aanwijzingsbevoegdheid. Vgl. De Doelder 2002a, p. 5.

130 Handelingen II. 1997/98, p. 4824-4825. Ook onder het oude art. 5 Wet RO bestond er overeenstemming over het feit dat het de minister van Justitie was die de bevoegdheid had aranwijzingen te geven. De tekst sprak, voor zover van belang, over bevelen gegeven "door de daartoe bevoegde macht, vanwege de Koning: Zie bijwoorbeeld Suywer 1976, p. 168 ; Stroink 1978, p. 166. Slechts Hoefer was van mening dat in werkelijklheid de regering bevoegd was, en dat de ministeriele competentie slechts op een taakverdeling beruste, Hoefer 1976, p. 1022. In de huidige wet is uitdrukkelijk (alleen) de minister bevoegd verklaard. De exclusieve bevoegdheid van de minister van Justitie betekkent dat de Aanwijzingen exteme contacten rijksambtenaren - andiers dar de bijbehorende toelichting suggereert - niet geldend ten aanzien van het OM. Zie 5.4 Grondrechten. 
bonden. Een schriftelijke vorm, een motivering of een advies van het College zijn niet vereist. De minister kan het OM schriftelijke aanwijzingen geven door gebruik van circulaires of brieven. Een aanwijzing over het beleid kan eveneens tijdens een gelegenheid van overleg gegeven worden, in een vergadering van procureurs-generaal waar de minister bij aanwezig is. De beknopte aard van de notulen van de collegevergadering zou weinig openbaarheid geven an deze wijze van aanwijzen. Het is niet wettelijk vastgelegd dat de algemene aanwijzingen op enige wijze openbaar gemaakt moeten worden. In de praktijk zijn ministeriële beleidsaanwijzingen samen met het beleid van het $\mathrm{OM}$ wel grotendeels gepubliceerd in de Staatscourant. ${ }^{131}$

\subsubsection{Procedure specifieke aanwijzingen}

Voor de aanwijzingen in individuele strafzaken gelden wel procedureregels. De minister is verplicht het College eerst zijn voorgenomen aanwijzing schriftelijk mee te delen. Het College van procureurs-generaal moet daarna een advies uitbrengen alvorens de minister de aanwijzing geeft. De minister kan het College een termijn stellen waarbinnen deze het advies moet geven. De voorgenomen aanwijzing, het advies en de aanwijzing zelf moeten schriftelij $\mathrm{k}^{132}$ en gemotiveerd $\mathrm{zijn}$.

Het advies zal altijd negatief van aard zijn. Immers, is het College het eens met de minister, dan zal deze geen aanwijzing hoeven geven. Een aanwijzing zal in alle gevallen het resultaat zijn van mislukt overleg tussen minister en College. ${ }^{133}$

Door het advies van het College wordt het "strafvorderlijk perspectiel" van de zaak nog eens belicht en zal de minister aanleiding kunnen hebben zijn beslissing te heroverwegen. ${ }^{134}$ De minister kan echter vrij afwijken van het advies, zolang hij het maar motiveert. Bovendien vraagt de minister slechts de mening van het onderdeel van het OM dat zich enkel bezighoudt met de leiding en het algemene beleid. De collegeleden zijn niet aan een gerecht verbonden en houden zich (normaliter) niet met de behandeling van rechtszaken bezig. Wel zijn zij plaatsvervangend advocaat-generaal en plaatsvervangend officier van justitie 'om voeling te houden met de praktijk. ${ }^{135}$ Hun optreden in specifieke strafzaken zal echter zeldzaam zijn, alls het al voor zal komen. ${ }^{\text {ith }}$ $\mathrm{Zij}$ kunnen zich gaan verwijderen van de aan het praktische handelen van het $\mathrm{OM}$ verbonden 'magistratelijke" cultuur. De aard van de taak van het College bevordert zo geen 'professioneel-inhoudelijke' attitude bij het geven van een advies bij een aanwijzing. Al met al lijkt het College dichter bij de minister te staan dan bij de strafvorderlijke praktijk. ${ }^{1, j 7}$

131 Wat betreft de ongepubliceerde richthingen werd wel gesproken werd wan her "gelheim van hel plein" (nast het 'geheim van Soestdijk'). Suyver 1976, p. 164; Singer-Dekker 1982, p. 131.

132 Zie verder 6.2.3.4. Spoedprocedure.

133 Over dil overleg: 6.8 . Informele invloed.

1.34 Kamerstukken II 1996997, 25392, nr. 3, p. 44.

135 Kamerstukken II 1996/97,25392, nr, 3, p. 51. Over de plaatsvervanging 2ie 2.1. Interme organisatie.

136 Vgl. minister Sorgdrager, Handelingen II $1997 / 98, \mathrm{p} .4820$.

137 Dit werd voorheen in ieder geval ook binnen het OM zo gevoeld, meld Selwalken 1991, p. 186. Ook 1 Hart wijst op "het gewar van verveemding", 2001, p. 9.5 . 
De wet laat open de vraag of de minister de specifieke aanwijzing aan het College moet geven, of aan het desbetreffende parkethoofd. De Memorie van Toelichting bij het voorstel van de Wet RO van 1999 geeft de minister uitdrakkelijk de keuze. ${ }^{138}$ Een dergelijke interpretatie strookt niet met de systematiek van de wet en leidt verder tot minder reclitsbescherming.

In de wet is de rode lijn in de relatie minister-OM immers die tussen minister en College. Het College geeft de minister inlichtingen. Het College legt specifieke beslissingen en beleidsplannen voor aan de minister. De minister overlegt met het College. Het lagere $\mathrm{OM}$ verschaft het College de benodigde inlichtingen. ${ }^{139}$ Een systematische interpretatie van de wet leidt daarom - anders dan een historische - tot de conclusie, dat de minister zijn aanwijzingen aan het College dient te richten. Daarbij komt dat een andere opvatting betekent dat één van de hierna te bespreken 'rechtswaarborgen' zou vervallen. Als een specifieke aanwijzing niet eerst door thet College in ontvangst genomen zou worden, zou de nuttige bufferfunctie van het hoogste orgaan binnen het OM uitgeschakeld worden. ${ }^{140}$

\subsubsection{Procedure aanwijzing tot vervolging en ten aanzien van het requisitoir}

Wat betreft de procedure van het geven van specifieke aanwijzingen moet de aanwijzing tot niet-vervolging enerzijds onderscheiden worden van de aanwijzing tot vervolging en de aanwijzing ten aanzien van het requisitoir anderzijds.

Voor de laatste twee geldt dat de voorgenomen aanwijzing, het advies en de aanwijzing zelf in het procesdossier van de betreffende strafzaak worden gevoegd. Voeging van de aanwijzing bij de processtukken blijft achterwege voor zover naar het oordeel van de minister het belang van de staat zich daartegen verzet. Dan wordt wel het feit dát een aanwijzing gegeven is vermeld. Echter, de minister zal alleen aanwijzingen geven in 'zeer uitzonderlijke situaties'. Vaak zal dan juist het belang van de staat in het geding zijn. Verder kunnen sommige aanwijzingen zelfs alleen maar effectief zijn wanneer de inhoud ervan niet in het dossier vermeld wordt. Dit is met name het geval bij een aanwijzing om bepaalde gegevens niet of niet volledig in het dossier of het requisitoir op te nemen. ${ }^{141}$ De inhoud van de aanwijzing zal dus vaak onbekend blijven voor de verdachte.

De mogelijkheid dat de aanwijzing niet in het strafdossier voorkont zinde de Raad van State niet. Deze meende terecht dat "procesdeelnemers in het licht van artikel 6 van het Europees Verdrag tot bescherming van de rechten van de mens en de fundamentele vrijheden (EVRM) ervan op de hoogte moeten zijn dat sprake is van een politieke factor die op enige wijze invloed heeft of heeft gehad op het instellen van de vervol-

138 Kamerstukken II 1996/97, 25392, nr. 3, p. 43. Vgl. Minkenhof/Reijntjes 2002, p. 48.

139 Zie over deze zaken 6.1. Bevoegdheden omtrent informatievoorziening.

140 7ie 6.2.4. Rechtswarborgen bij annijzingen.

141 Over 'zeer uitzonderlijke situaties': Kamerstukken II $1996 / 97,25392$, nr. 3, p. 46. Kalsbeek-Jasperse stelt uitdrukkelijk dat bij een uitzonderlijke situatie valk het belang van de staat in het geding zall zijn, Handelingen II 1997/98, p. 5569 . 't Hart 1999, p. 116 stelt zelfs dat bij zaken van opsporing en verwolging het belang van de statat altijd in het geding is. Over de aarnwijzing bepaalde gegevens niet of niet volledig in het requisitoir te melden, zie "t Hart, idem. 
ging of op de inhoud van het requisitoir. Feit van de aanwizing en iwhoud downom zouden bekend moeten worden genaakt." (curs. PPwdL) ${ }^{12}$

Een beroep op het belang van de staat hoeft echter geen definitieve geheimliouding tegenover de rechter te betekenen. De rechter zou de officier wan justitie kunnen bevelen de aanwijzing zelf alsnog by het dossier te voegen. Als uiterste sanctie op dit bevel zou de rechter het OM anders zelfs niet-ontvankelijk kunnen verklaren. ${ }^{143}$

Ten slotte mellt de minister van Justitie jaarlijks bij de begroting of hij gebruik heef gemaakt van zijn bevoegdheid bijzondere aanwijzingen te geven. Minister Sorgdrager zei dit toe in 1998. Na het inwerkingtreden van de nieuwe Wet RO heet minister Korthals eenmaal bij de begroting voor 2000 gerapporteerd over de aanwijzingsbevoegdheid. Tevens meldde hij bij de financiele verantwoording over het jaar 2000 of hij dat jaar gebruik had gemaakt van de bevoegdheid. Dit was steeds niet het geval. Opmerkelijk is dat bij de begrotingen voor 2001, 2002 en 2003 reeds de melding van eventuele bijzondere aanwijzingen ontbreekt. Hier wreekt zich het feit dat dit ministeriele informeren niet wettelijk verplicht is, matr enkel gebeurde op grond van een oude ministeriele toezegging. 144

\subsubsection{Procedure aanwijzing tot niet vervolgen}

Hiervoor betrof het steeds de aanwijzingen tot vervolging en die ten aanzien van het requisitoir. Bij de begroting zou de minister tevens aanwijzingen tot niet-vervolging kunnen melden, maar voor dit type geldt daamaast een aparte regeling.

Een dergelijke aanwijzing moet de minister per geval en zo spoedig mogelijk bekend maken aan de kamers. Het feit dát de aanwijzing is gegeven makt de minister in ieder gewal op eigen initiatief bekend aan de kamers. De stukken die op de aanwijzing be trekking hebben hoeft de minister slechts te verstrekken voor zover dat niet in strijd is met het belang van de staat. Zoals bleek in de vorige subparagraaf, zou het staatsbelang al gauw in het geding kunnen zijn. Op verzoek van een kamer is dan wel vertrouwelijke kennisgeving mogelijk. ${ }^{145}$

In het geval een aanwijzing tot niet-vervolging is gegeven kan de inhoud van de aanwijzing eveneens aan de rechter bekend raken. Bij het uitblijven wan de vervolging zou een belanghebbende een klachtprocedure conform artikel $12 \mathrm{~Sv}$ kunnen beginnen. Een

142. Kamerstukem 11 1996797, 25392, B, p. 6-7. Tow de Raad zijn advies gaf bepalde hel wetswooratel mog net dat in ieder geval het feit dat er en athwijzing gegeven is in hot dossier opgenomen wordt. Nawn aamleiding van het advics is deze bepaling opgenomet.

143 Kamerstukken II $1997 / 98,25392$, ni. 7, p. 40 .

144 Voor de begroting. Kamerstuken II 1999/2000, 26800 V1, ni. 2, p. 33-43 er 130.147. Voor de finan-

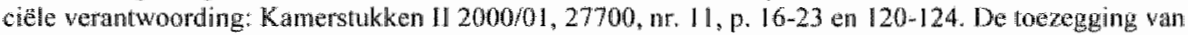
Sorgdrager: Handelingen It 199798 , p. 4826. Tweede Kamerlid Koekkoek stelde destijds nog een amendenent woor dat de Tweede Kamer periodiek, per kalenderjar geinformeerd zou worden, Kamerstukken II 1997/98, 25392, nrs. 19 en 24. Het anendernent werd later ingetrokken ondat we weing steun woor was, Handelingen II $1997 / 98$, p. 5568 .

145 Deze regeling is op aandrang van de Tweede Kamer in een zesde lid toegevoegd. Kamerstukken II 1997\%8, 25392, nr. 7, p. 25. Over de vertrouwelijke kennisgeving. Kamerstukken II 1997/98, 25392,

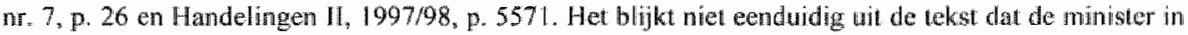
ieder geval het feit bekend moet maken dát hij een aanwijzing heeft gegeven. Minister Sorgrdrager bevestigde deze uilleg uitdrukkelijk. Handelingen II1997/98, p. 5572 . 
gegeven aanwijzing tot niet vervolgen dient nu eveneens gevoegd te worden bij de stukken in het sepotdossier dat de rechter onder ogen krijgt. ${ }^{146}$ Dit gebeurt weer niet wanneer het belang van de staat zich wolgens de minister daartegen verzet. Het kan voorkomen dat dit het geval is en de rechter - onbekend met de inhoud van de aanwijzing - niettemin voornemens is de vervolging we bevelen. Het OM zou in dat geval om arnhouding van dle beslissing kurnen vragen, teneinde de inhoud van een geheime aanwijzing aan de rechter bekend te maken. Door bekendmaking aan de rechter zou het OM deze kunnen overreden on niet de vervolging te bevelen. De rechter zou het bevel tot vervolging dan alsnog kunnen weigeren "op gronden aan het algemeen belang ontleend". "H7 Het is mogelijk dat de klager ondertussen onbekend blijft met de inhoud wan de aanwijzing. Artikel $12 \mathbb{f ~ S v}$ geeft de voorzitter van het gerechtshof immers de mogelijkheid om kennisneming van bepaalde stukken die op de zaak betrekking hebben uit te sluiten op ' $z$ waarwichtige' gronden aan het algemeen belang ontleend.

Deze mogelijkheden van rechterlijke controle op een niet openbaar genaakte aanwijzing tot niet-vervolging bestaan echter niet wanneer er geen belanghebbende is, of wanneer deze geen beklag will doen.

\subsubsection{Spoedprocedure}

Bijzonder problematisch zijn sommige annwijzingen in spoedgevallen. ${ }^{148}$ Dat geldt vooral voor de aanwijzingen ten aanzien van het requisitoir. Het zou kunnen voorkomen dat een zaak eindigt voordat de anwijzing op schrift is gesteld. Dan is er geen sprake meer van opname van de stukken in het procesdossier. De actoren in het strafproces weten dan pas achteraf dat de officier ter zitting op aanwijzing van de minister handelde. Geen wettelijke regeling verplicht de officier in dat geval tijdens het proces te melden dat hij een aanwijzing heeft gekregen. In sommige gevallen zou een dergelijke mededeling juist tegen het doel van de aanwijzing in kunmen werken. ${ }^{149}$

Deze mogelijkheid van een onbekende aanwijzing kan gaan knagen aan het vertrouwen dat de procesdleelnemers in de officier van justitie stellen. Zij gaan ervan uit dat hij hen ompartijdig en volledig voorlicht. Het vertrouwen kan geschaad worden dat een eventule politieke invloed op het proces bekend zal zijn op het moment dat de officier van justitie handelt. Deze gang van zaken kan in strijd zijn met artikel 6 EVRM. Met de Raad wan State moet men aannemen dat dit artikel impliceert dat procesdeelnemers op de hoogte moeten zijin van een dergelijke aanwijzing. ${ }^{150}$ Minister Sorgdrager stelde enkel dat "de eisen van behoorlijke procesorde meebrengen dat het OM hiervan aanstonds melding makt". 151 Een dergelijke eis zou echter in artikel 128 opgenomen moeten worden. De overige deelnemers aan het strafproces hebben op dit punt immers al een zwakke controlepositie. Eenvoudiger en systematischer is het evenwel om een

146 Katnerstuktken II 1996/97, 25392, mar. 3, p. 46 .

147 Art. i.2 lid 2 Sv. Kamerstukken II 1997/98, 25392, nur. 7, p. 39-40.

148 Ditrich, Handelingen 111997198, p. $4806-4807$.

149 Wel kan het OM-lid ter zitting aandacht vagen yoor ovenvegingen omtrent het recht. Hierover zie 6.2.2.6. Aanwijzing ten atuzien van het requisitoir.

150 Zie 6.2.3.2. Procedtre anwijzing tot vervolging en ten andien wan het requisitoir.

151 Kamerstukken II $\llbracket 99697.25392$, nr. 3, P. 47. 
aanwijzing ten aanzien van het requisitoir in mondelinge vorm uit te sluiten. Dit zou de actoren ter zitting rechtszekerheid geven en bijdragen aan de vertrouwenspositie van het $O M^{152}$

De aanwijzing tot niet-vervolging in geval van spoed lijkt minder problemen op te leveren. Volgt het $O M$ de aanwijzing op en seponeert het, dan kan een belanghebbende hiertegen beklag instellen. In deze procedure kan het feit dat de aanwijzing is gegeven en de inhoud ervan achteraf nog bekend worden. Tevens zullen de kamers geïnformeerd moeten worden over de gegeven aanwijzing. Op aandrang van de kamers of op bevel van de rechter in de klachtprocedure kan dan alsnog vervolging plaatsvinden. De desbetreffende problematiek verschilt niet van een aanwijzing tot niet-vervolging zonder spoed.

Bij een spoedaanwijzing tot wervolging ten slotte, bestaan evenmin specifieke aandachtspunten, als de aanwijzing ten tijde van de zaaksbehandeling tenminste op schrift gesteld is. Indien de verdachte bezwaar maakt tegen de vervolging, zal de aanwijzing voor de behandeling van het bezwaarschrift in het dossier gevoegd moeten worden.

Of de minister een spoedaanwijzing achteraf op schrift stelt is echter nog maar de vraag. Een sanctie is hier niet aan verbonden. Wat zal de minister bewegen on de aanwijzing op schrift te stellen? Het opvolgen van een mondelinge aanwijzing is teitelijk niet te onderscheiden van een beslissing van het OM na overleg met de minister. Zelfs de beide actoren zelf zullen het verschil niet altijd kunnen zien. Het moet wel om een bijzonder geval gaan wil het OM een mondelinge aanwijzing uitvoeren waar deze het niet mee eens is, eventueel onder de toezegging dat de minister deze later op schrift stelt. Waarom zou het OM nog aandringen op schriftelijke bevestiging als de minister deze nalaat? De beslissing is de jure toch na overleg met de minister door het OM zelf genomen. Is de zaak van dien aard dat het OM achteraf openlijk eist om een schriftelijke bevestiging door de minister, dan kan deze zich op het standpunt stellen dat er geen sprake was van formele aanwijzing.

\subsubsection{Rechtswaarborgen bij aanwijzingen}

Bij de bovengenoemde aanwijzingen bestaan enkele juridische warborgen mei verschillende effectiviteit. Ten eerste zijn er de algemene middellen die verdachten en belanghebbenden kunnen gebruiken tegen het handelen van het $\mathrm{OM}$ of het uitblijven daarvan. Ik noemde reeds de instrumenten van het bezwaarschrift van de verdachte tegen de vervolging en het beklag van de rechtstreeks belanghebbende tegen de nietvervolging. In deze procedures kan de rechter een toetsing verrichten van de beslissingen van het $\mathrm{OM}$ die het gevolg zijn van een aanwijzing.

Ten tweede bestaan nadere mechanismen die de gevolgen van aanwijzingen zouden kunnen beperken. Hieronder bespreek ik de toetsing aan het recht door het OM, gezien in verband met de disciplinaire toetsing en de ontslagname door een lid van het $O M$. Verder noem ik het toezicht door de procureur-generaal bij de Hoge Raad, de optie van

152 In het Franse stelsel bestaan evenmin wettelijke uitzonderingen op het vereiste van schriftelijkheid, Zile hoofdstuk 3, 6.3.1. Aanwijzingsvorm. Zie ook - verdergaand: hoofdstuk 7, 6.1. Hervorning van de functionele relatie tussen $\mathrm{OM}$ en minister. 
artikel $112 \mathrm{Gw}$ en een eventueel Awb-beroep. Daarna komen enkele specifieke waarborgen aan bod met betrekking tot respectievelijk de aanwijzing tot vervolging en tot niet-vervolging.

Het OM kan en moet elke aanwijzing toetsen aan het recht. Onder de oude Wet RO meenden sommigen al dat de officier van justitie na toetsing van de aanwijzing aan het recht een van de aanwijzing (deels) afwijkende beslissing kon nemen. Hij zou dan niet gehoorzamen aan de aanwijzing. ${ }^{153}$ De Wet RO meldt hier niets over, evenmin als de oude wet. Rechtens lijkt echter niets aan de toetsingsmogelijkheid in de weg te staan. Zij kan evenwel bepaalde gevolgen meebrengen.

Het toetsen kan als volgt werken. In eerste instantie verricht het College een toetsing aan het recht. Zoals gezegd adviseert dit orgaan de minister over zijn voorgenomen aanwijzing. Wanneer de minister een negatief geadwiseerde aanwijzing doorzet kan het College deze uitvoeren, of eventueel naast zich neerleggen. Wanneer het College de aanwijzing na een megatief advies uitvoert, kan het lagere OM nogmaals een toetsing van de aanwijzing verrichten. Indien dit OM de aanwijzing alsnog naast zich neerlegt, handelt het behalve tegen de wens van de minister, ook tegen het bevel van het College in. Het lagere $O M$ kan dan rechtspositionele tegenmatregelen verwachten. De minister zou hem een disciplinaire sanctie op kunnen leggen. Het betrokken lid kan ook direct op de aanwijzing reageren met ontslagname. Deze opties werk ik hieronder nader uit. Zoals gezegd kan de minister een OM-lid, dat een aanwijzing toetst aan het recht, en die niet uitvoert, disciplinair sanctioneren. De officier kan tegen een disciplinaire maatregel bezwaar maken en vervolgens beroep instellen bij de Centrale Raad van Beroep. Deze rechter kan bij de beoordeling van de rechtmatigheid van de maatregel indirect de aanwijzing toetsen. De rechter zou kunnen vaststellen of de aanwijzing geoorloofd was. ${ }^{154}$ Schuering vond zelfs dat de raad zou moeten onderzoeken 'of de minister zich inderdaad op staatsbelang kon beroepen' om de aanwijzing te kunnen geven. ${ }^{155}$ Niets verplicht de Raad daartoe. Voor zover de rechter zich aan deze toetsing zou wagen, zou deze slechts uiterst marginaal kunnen zijn. Een werkelijke toetsing aan het belang van de staat komt niet aan de orde. Het gaat hier verder slechts orn een indirecte toetsing, die achteral' en buiten de strafzaak on behandeld zal worden. Deze rechterlijke toetsing zal geen gevolgen hebben voor de strafzaak waarop de anwijzing betrekking heeft. Voor die zaak vormt deze procedure geen waarborg, wel voor de appellant. Daarnaast is de Centrale Raad in de eerste plaats een administratiefrechtelijke rechter, met een bijbehorende competentie. Daarom is deze rechter niet de meest aangewezen waarborg voor toetsing aan strafrechtelijke regelgeving en beginselen. ${ }^{156}$

Men kan tevens een waarborg zien in de mogelijkheid dat een officier van justitie ontslag kan nemen. $\mathrm{Na}$ een negatief uitvallende toetsing van een aanwijzing aan het

153 Van Dullemen 1958, p. 15; A-G Remmelink in HR 22 mei 1979, NN 1979, 301, m.nt. GEM (Menten I1); De Doelder 1996a, p. 295; NVvR 1996, p. 321.

154 Kanerstukken II 1996/97, 25392, nr. 3, p. 28; Koekkoek. Handelingen II 1997/98, p. 5567; Corstens 2002, p. 105.

155 Sohuering 1968 , p. 69.

156 Zie de struftechlelijk miet zo sterke redenering in de bekritiseerde zaak Drenth, bij (hoofdstuk 2) 6.2.2.6. en hoofdst $3 k$ 6, 6.1.2., beide getiteld: Aanwijzing ten aanzien van het requisitoir. 
recht zou het OM-lid als reactie zijn ontslag kunnen indienen. De Tweede Kamer zou de minister in zulk een opzienbarend geval wellicht ter verantwoording roepen. ${ }^{157} \mathrm{De}$ OM-leden zouden eigenlijk een soort klokkenluidersfunctie verwullen voor de Tweede Kamer. Zij zouden dan bereid moeten zijn on daartoe hun functie op te geven. Zij zouden het risico moeten lopen om enkel als querelant gezien te worden, hotgeen hun carrière zou kunnen schaden. Hier lijkt een groot vertrouwen gesteld te worden in de persoonlijke kwaliteiten van de ambtenaren, die enkel het "algemeen belang" voor ogen zouden moeten hebben. Een dergelijke waarborg vergt (wellicht te) weel van de bij het OM werkzame personen. In ieder geval vormt de ontslagname geen sterke juridische garantie tegen onregelmatige aanwijzingen.

Hierbij roep ik in herinnering dat de leden van het College van rechtswege plaatsvervangend officier van justitie en plaatsvervangend advocaat-generaal zijn bij alle parketten. Indien het College meent dat een aanwijzing van de minister uitgevoerd moet worden, dan kan het daar desmoods zelf voor zorgen. Een collegelid verzoekt dan de minister om aangewezen te worden een taak uit te oefenen bij het betrokken parket. Na advies van het College wijst een koninklijk besluit het collegelid vervolgens aan. Als plaatsvervangend lid van het parket zou hij zo de benodigde strafrechtelijke handelingen kunnen verrichten. 158

In het bovenstaande ging ik uit van het geval dat het College, ondanks het negatieve advies, de ministeriële aanwijzing uit will voeren. Daarnaast zou het College zelf de aanwijzing naast zich neer kunnen leggen. Welke rol zouden de behandelde waarborgen van de disciplinaire procedure en de ontslagname dan kunnen spelen? In theorie zouden zij op analoge wijze gelden voor de collegeleden zelf. In de praktijk zou echter sprake moeten zijn van een institutionele crisis van ongekende onvang. Het is moeilijk denkbaar dat de minister alle collegeleden disciplinair straft, of dat zij gezamenlijk hun ontslag indienen. Men kan zich nog voorstellen dat een enkel collegelid - met name de voorzitter - disciplinair gestraft wordt, of ontslag neemt. Het is mogelijk dat dit lid zich als enige tegen de aamwijzing heeft verzet, of een vooraanstaande rol had in het "verzet" tegen de minister.

De procureur-general bij de Hoge Raad houdt eveneens toezicht op de uitoefening van de taak van het OM. Hij kan daartoe stukken en inlichtingen verkrijgen van het College. Wanneer het OM in zijn taak "de wettelijke voorschriften niet naar behoren handhaaft of uitvoert' kan hij de minister daaromtrent inlichten (art. 122 Wet RO). De toelichting bij dit artikel spreekt hier over een 'niet onbelangrijk te achten signaleringsfunctie uit een oogpunt van handhaving van het recht'.

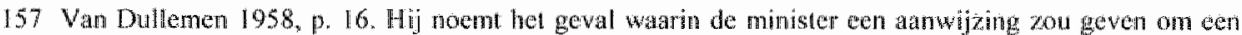

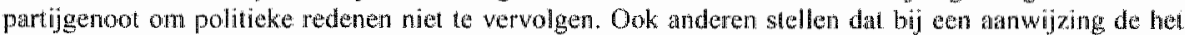
OM-lid in elk geval ontslag kan memen: Van Veen 1979, p. I15: Koekkoek Handelingcu II 1997/98, p. 4820 .

1587 ie 2.2 . Interne organisatie. In aen dergellik geval zal de weg van art. 6 Wra bewandeld moetent worden. Art. 5 kan geen topassing vinden, aangexien het parkethood niet wan zins zal zign cen Collegelid op te roepen.

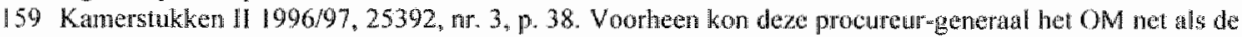
minister bevelen gewert. Art. 53 Reglement I (vervallen). 
well geen nut te hiebben als controle op onregelmatige ministeriêle aanwijzingen. De procureur-generaal bij de Hoge Raad dient zijn "signalering" namelijk aan de minister zelf te richten. Het zal slechts een correctie kormen op het handelen van de minister voor zover hem dat uitkomt. Het toezicht van de procureur-generaal bij de Hoge Raad zou als waarborg tegen misbruik van de aanwijzingsbevoegdheid dus niets toevoegen. Verder zou artikel 112 van de Grondwet een vangnet kunnen zijn voor elk rechtsgeschil in Nederland. Rechterlijke controle op een aanwijzing via dit artikel zou volgens Koekkoek niet uitgesloten zijn. ${ }^{160} \mathrm{Ik}$ zie evenwel niet in hoe de burgerlijke rechter betrokken zou kunnen worden. Hoogstens zou de rechter benaderd kunnen worden op de grond dat de minister een onrechtmatige daad gepleegd zou hebben jegens het OM of een tid van het OM. Het OM zelf heeft echter geen eigen rechtspersoonlijkheid. De minister en het OM maken beide deel uit van de rechtspersoonlijkheid van de Staat. Een individuele officier van justitie zal verder niet persoonlijk geschaad worden door een ministeriële beslissing, buiten de gevallen die al onder de bevoegdheid van de Centrale Raad vallen. Het $O M$ of een officier van justitie kan daarom niet met vrucht een beroep doen op de burgerlijke rechter. Belanghebbenden of verdachten die zich door de aanwijzing benadeeld achten zouden niet ontvankelijk verklaard worden. Aangezien de strafrechter uitsluitsel zou geven over de strafzaak waar de aanwijzing op betrekking zou hebben, zou zijn privaatrechtelijke collega zich hier afzijdig houden.

Zou daarnaast controle kunnen plaatsvinden op grond van de Awb? Deze wet is op grond van artikel 1:6 niet van toepassing op de uitoefening van de aanwijzingsbevoegdheid. Deze heeft namelijk betrekking op de opsporing en vervolging van strafbare feiten. Deze strekking blijkt ook uit de parlementaire geschiedenis. ${ }^{161}$ Een beroep op de bestuursrechter tegen de aanwijzing zelf is dus uitgesloten.

Bij een aanwijzing tot vervolging zou naast de tot nu toe besproken instrumenten nog een specifieke waarborg bestaan. Minister Sorgdrager beweerde dat bij een aanwijzing tot vervolging de strafrechter mede een oordeel zal kunnen vellen over de rechtmatigheid van de aanwijzing in het kader van zijn toetsing. ${ }^{162}$ Dit is echter onjuist. De strafrechter gaat in het proces de rechtsvragen na op basis van de tenlastelegging. Daarbij toetst hij wel het handelen van het OM aan het recht. Hoogstens kan de rechter een oordeel geven over het handelen van het $\mathrm{OM}$ dat de aanwijzing gehoorzaand heeft. Men kan beweren dat de aanwijzing daardoor indirect getoetst wordt. Toetsing van de aanwijzing zelf zal echter hoogstens in een obiter dictum ter sprake komen. ${ }^{163}$

Ten slotte is geopperd dat bij een aanwijzing tot niet-vervolging een bijzondere garantie aanwezig zou zijn. Naast de genoemde optie van een klacht door een belanghebbende burger is nog een bijzonder gebruik van de klacht voorstelbaar. Koekkoek heeft de wat bizarre gedachte opgeworpen dat een lid van het $O M$ als rechtstreeks belanghebbende wellicht zou kunnen klagen op grond van artikel $12 \mathrm{~Sv} \cdot{ }^{164}$ Het zou dan blijk-

160 Koekkoek, Handelingen $111997 / 98$, p. 5568.

161 Kamerstukken II 1988/89, 21221, nr. 3, p. 43; Kamerstukken II 1996/97, 25392, nr. 3, p. 28.

162 Kamersukken 11199697,25392 nr. 3, p. 29.

$163 \mathrm{Zie}$ ook hoofdstuk 6,6.1.2. Aanwijzing ten aanzien van het requisitoir.

164 Koekkoek, Handelingen $111997 / 98$, p. 5567. 
baar moeten gaan om een geval waarin het $\mathrm{OM}$ een aanwijzing tot niet vervolgen nakomt, en vervolgens zelf beklag instelt bij het hof tegen deze beslissing.

Bij de vraag of het OM of de officier van justitie rechtstreeks belanghebbende is zou het hof echter negatief oordelen. $Z$ ij worden immers door het achterwege blijven van de vervolging niet getroffen in een belang dat hen bepaaldelijk angaat. ${ }^{16}$ Welk belang zou geconstrueerd kunnen worden? De beslissing tot niet-vervolging heeft zelfs geen persoonlijke rechtspositionele consequenties voor de betrokken officier. Hij heeft de aanwijzing namelijk gewoon opgevolgd en dus zijn ambtelijke plicht vervuld. De officier kan strafvorderlijke argumenten hebben die pleiten voor vervolging, maar dit makk hem nog niet tot rechtstreeks belanghebbende. Het OM kan kortom geen beklag instellen tegen zijn eigen bestissing. Het gerechtshof zou de officier niet ontvankelijk verklaren.

\subsubsection{Plicht tot terughoudendheid}

De minister heeft onmiskenbaar een bevoegdheid aanwijzingen te geven. In boeverre is hij evenwel vrij om naar bevinden deze bevoegdheid uit te oefenen? Men stelt bij veel gelegenheden dat de minister daar 'terughoudend' mee moet ongaan, met name met aanwijzingen in individuele zaken. In de literatuur gaan velen ervan uit dat de minister het "eigen gelaat' van het OM zal moeten respecteren. Het OM moet in bepaalde zin "zelfstandigheid' bezitten. De minister \eidt het OM 'met de fluwelen handschoen" "166" Welke grond bestaat om deze plicht tot terughoudendheid aan te nemen? Twee argumenten komen met name in de literatuur aan de orde: enerzijds de wettelijke attributie van de strafrechtelijke bevoegdheden aan de leden van het $\mathrm{OM}$, anderzijds het feit dat zij behoren tot de rechterlijke macht. Verder hebben alle minister zich in normatieve zin over de terughoudendheid uitgelaten sinds in de jaren zeventig het onderwerp op de politieke agenda kwam. Hoe denken de achtereenvolgende ministers over de terughoudendheid? De laatste vraag is ten slotte of hier sprake is van staatsrechtelijk gewoonterecht. Wat voor betekenis en gevolgen zou een dergelijk recht hebben? Achterenvolgens komen deze kwesties hier aan de orde.

\subsubsection{Terughoudendheid door rechistreeks toegekende bevoegdheden}

Men woert redenen aan voor terughoudend gebruik van de ministeriele aanwijzingsbevoegdheid. Eén daarvan is de rechtstreekse toekenning van strafrechtelijke opsporingsen vervolgingsbevoegdheden aan de leden van het $O M$.

Velen zien het $O M$ in een bijzondere positie gezien het feit; dat het zijn bevoegdheden aan de wet ontleent. De wetgever zou met die atributie hebben proberen te bereiken dat het OM enige zelfstandigheid zou hebben. De minister zou gezien die attributie tot zelfbeperking en afstand zijn gehouden bij het geven van aanwijzingen. Een veelvuldig

165 Wgl. de formulering van HR 7 maart 1972, N.I 1973, 35, m.nt. A.L. Melai.

166 Over het 'eigen gelat': Mostert 1968, p. 311-312. Zelfstandigheid: Jawrwerslag OM 1974. Kamerstukken II 1975/76, 13600 VI, nr. 3, p. 15. 'Fluwelen handschoen': Oranje 1976, p. 13; '1 Hart 1976, p. 25. Oranje meent dat Duisterwinkel deze tem gebnukik. In de teksten wan de lakatste blikn dit miet. 
gebruik van de aanwijzingsbevoegdheid zou van de bevoegdheidstoekenning aan het OM een lege huls maken. Dit zou op gespannen voet staan met de wettelijke competentieverdeling. ${ }^{167}$

Minister Van Agt meende dat het feit dat het OM zijn taak en verantwoordelijkheid rechtstreeks aan de wet ontleent betekent 'dat de Minister een zekere terughoudendheid moet betrachten omtrent de wijze waarop zij han wettelijke taak vervullen' (cursief PPvdL). Ook algemene beleidsaanwijzingen ten aanzien van het requisitoir zou hij slechts 'met schroom en voorzichtigheid' kunnen geven. ${ }^{168}$ Minister Sorgdrager vond slechts dat de rechtstreekse toekenning 'een van de redenen is om terughoudend te zijn met ministeriële aanwijzingen. ${ }^{, 169}$

Met anderen ben ik evenwel van mening dat de attributie van bevoegdheden aan het $\mathrm{OM}$ op zich geen juridische gevolgen in de richting van autonomie jegens een aanwijzingsbevoegde minister geeft. De toekenning impliceert slechts dat de minister die bevoegdheden niel zelf kan uitoefenen. De attributie doorbreekt de normale hiërarchische verhoudingen niet. Het rechtstreeks toekennen van bevoegdheden aan het $O M$ heeft geen gevolg voor het gebruik van de aanwijzingsbevoegdheid. ${ }^{170}$ Ook minister Sorgdrager schreef met zoveel woorden dat de attributie aan het $\mathrm{OM}$ 'juridisch (...) niet relevant' is voor de zeggenschap van de minister ten aanzien van het $O M^{171}$

\subsubsection{Terughoudendheid om het behoren tot de rechterlijke macht}

Velen zijn verder wel van mening dat het $\mathrm{OM}$ een 'bijzondere plaats' in ons staatsbestel inneemt, ondat het deel uitmaakt van de rechterlijke macht, ${ }^{172}$ waardoor het in bepaalde zin 'zelfstandigheid' of een 'autonome positie' zou moeten bezitten. ${ }^{173}$ De grondwetsbepalingen die er naar verwijzen worden wel gezien als 'een bevestiging van

167 Enschede 1968, p. 79; latwerslag OM 1974, Kamerstukken II 1975/76, 13600 VI, nr. 3, p. 15; Corstens \& Tak 1982, p. 26: Cremers 1983, p. 51; Corstens 1988, p. 226; 1999, p. 103; Buruma 1993, p. 164; De Doelder 19964, p. 296; Viering \& Kummeling 1996, p. 594; D66-fractie, Kamerstukken 11 1997/98, $25392, \mathrm{nr}, 6, \mathrm{p}, 20$. In het algemeen over het niet bestatu van een shikte ondergeschiktheidswerhoudine bij deconcentratie, Stroink $1978, \mathrm{p}, 143$.

168 Handelingen 11 1975/76, p. 761,4062,4228; 197677, p. 1379. Hei betrof toen de Bloemenhove-zaak. In de Menten-affire, ook in 1976, liet de mimister de Tweede Kamer zich wel utgebreid in een individaele zank begeven.

169 Kamerstukken II 1997/98, 25392, n. 7, p. 22. Ze verwijst daarvoor natar de Memorie van Toelichting. Datrin scheef za echter enkel dat het niet zonder betekenis is dat "de wetgever destijds" de zelfstandige bevoegdheid on al dam nietwervolging in te stellen aan de officier wan justitie attribueerde. Het zou onderstrepen dat de officien van justitie niat "nanens" de minister handelt man wel onder diens verantwoordehikheid. Er zou gen sprake zijh van een mandaatorganisatie. Kamerstukken II 1996/97, 25392,

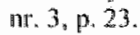

170 Oranje 1976, p. 24; Corstens \& Tak 1982, p. 16; Picq 199:, p. I63; Stolwijk 1992, p. 38; Cliteur 1997. p. 92, Corsters 2002, p. 102 . Ficq zirt wel in het behoren van het OM tot de rechterlike macht macht de bevestiging van een rechsstaditie die het OM een mate van onathankelijkheid laat.

171 Minister Sorgdrager Kanterstukken II 1995/96, 24034, nr. 13, p. 5. Wel meldde zij bij deze gelegenheid dat uit de toekenning wan de bevoegdheden an het OM blijkt dat het de "wens wan de wetgever" is om "een zekere distantie tot stand te brengen hussen het bevoegde organ en de werantwoordelijke minister".

172 Cremers 1983, p. $\$ 1$

173 Jatuerslag ON1 1974, Kamerstukken Ill 1975/76, 13600 VI, nr. 3, p, 15; NVVR 1996, p. 321. 
de rechtstraditie die het openbaar ministerie een zeker mate van onathankelikhaid laat'. ${ }^{74}$ Sommigen zien mede in de kwalificatie van het OM als deel van de rechterlijke macht het bestaan van "een zekere rechtsplicht" on terughoudendheid te betrachten met het geven van aanwijzingen. ${ }^{175}$

Minister Korthalls Altes verbond aan het deel uitmaken van de rechterlijke macht door (de leden van) het OM dat het "in een zekere mate van onafhankelijkheid en zelfstandigheid' inhoud moest geven aan de 'tmagistratelijke" aspecten wan zijn taak. "76 Minister Hirsch Ballin meende dat de minister 'zonder twiffel' terughoudendheid "past' bij de behandeling van een individuele strafzaak. "Als orgean vain de uivoerende macht" zou de minister geen "rechtstreekse confrontatie met de onafhankelijke rechter" behoren aan te gaan. ${ }^{177}$ Minister Sorgdrager meende dat het deel uitmaken van de rechterlijke macht meebrengt "dat het OM - hoewel het de bevelen van de minister moet opvolgen - toch een zekere distantie heeft ten opzichte van de minister. 178

Zoals eerder gezegd leidt het deel witmaken van de rechterlijke macht in het algemeen tot weinig rechtsgevolgen. ${ }^{179}$ Het behoren tot deze macht biedt evenwel een interpretatiekader, aan de hand waarvan geconcludeerd moet worden tot een plicht tot terughoudendheid. Het gegeven dat de leden van het OM rechterlijke ambtenaren zijn, kan rechtens niet los gezien worden van hun functionele relatie met de minister.

De vraag die ik hier behandel is of de kwalificatie van het behoren tot de rechterlijke macht een positiefrechtelijke plicht meebrengt. Een andere vraag is of men een mate van autonomie van het OM wenselijk acht, beargumeerd met het beginsel van de machtenscheiding. Deze kwestie behandel ik in hoofdstuk $6 .{ }^{180}$

\subsubsection{Terughoudendheid als gewoonterecht}

De vraag is nu wat voor rechtskarakter an de plicht tot terughoudendheid toegekend kan worden. Minister Sorgdrager beweende dat 'de wet de nodige aanknopingspunten bevat voor de vaststelling dat de minister van Justitie zijn bevoegdheden ten aanzien van het OM met terughoudendheid dient te hanteren' (cursief PPvdL), ${ }^{181}$ Waar die aanknopingspunten precies uit bestaan bleek daatbij niet. Tijdens de behandeling van de Wet RO van 1999 stelde ze dat 'als vaststaand beleid geldt dat met name bij indivi-

174 Fücq 1991 , p. 164.

175 D66-fractie, Kamerstukken II 199798,25392, nr. 6, p. 20.

176 Kamerstukken ll 1989/90, 21300 VI, n. 2, p. 44; Korthals Altes 1988, p. 372.

177 Karnerstukken II 1992/93, 22800 VI, nr. 2, p. 7.

178 Sorgelrager 1996 , p. 6. Buj de totsiltndkoming wan de Wet fo wan 1999 scheef Sorgdrager allewn expliciet dat het onderdeel uitmaken van de rechterlijke macht een basis zou geven voor "de vertrou" wensrelatic tussen OMA en rectutep". Kamerstukken II 1996/97, nr. 3, p. 9 en 21; ti. 7, p. 3-4. Mij lijkt de

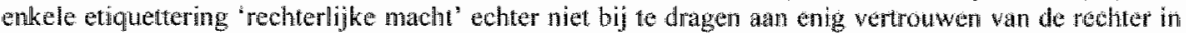
het OM. Als dat etket geen gevolgen heefi voor de relatie tussen OM en minister lijkt mij niet dot het de rechter "vertrouwen" in het OM zou kumen geven. Ower de stelling dat de vertrouwensrelatid tussem rechter en OM cen mate van waghoudendheid van de minister eist, zie hoofdstuk 6,7,4,3. Funclies van de onpartijdigheid wan het OM. Ook zou de kwalificatie rechterlike machiets zeggen ower de onpartij dige roll wan het OM, Kamerstukken II 1995/96, 24034, nr. 13, p. 7-8.

179 Zie 2.1. OM en rechterlijke macht.

180 Zic 7.1. Machtenscheiding.

181 Kamerstukken II $1996 / 97,24034$, ar. 16, p. I. 
duele opsporings en vervolgingsbeshissingen terughoudendheid wordt betracht 1.82 Waar dat in "vast" zou liggen maakte de minister niet duidelijk. Het is niet vastgelegd in een richtlijn van de minister of een andere regeling. De minister lijkt tevens de indruk te wekken alsof dat "beleid" van terughoudendheid niet (snel) gewijzigd zal of kan worden.

De kamer besprak tijdens de behandeling van de Wet RO van 1999 een amendement dat bepalde: "Met betrekking tot het geven van bijzondere aanwijzingen betracht Onze Minister grote terughoudendheid.' Enerzijds vond men dat die norm "zeer rekbaar" zou zijn, of inhoudelijk 'in feite geen enkele normering' zou geven. Anderzijds zou in de geschiedenis en in de praktijk altijd duidelijk geweest zijn 'dat er sprake moet zijn van grote terughoudendheid." ${ }^{\prime \prime 8}$ Blikbar was een geschreven regel niet nodig ondat een algemeen aarvaarde ongeschreven regel bestaat.

Kunnen wij hier nu spreken van een staatsrechtelijk gewoonterecht? Sommigen menen zelfs expliciet dat zich op dit punt een rechtstraditie; een 'gewoonteregel' of "staatsrechtelijk gewoonterecht' heeft gevormd. ${ }^{184}$ Anderen gaan er van uit dat het enkel een belleidsvraag is of de minister van zijn bevoegdheden ten aanzien van het OM (veel of geen) gebruik dient te maken." 85

Zowel de literatuur, de voorgaande ministers, als de minister en de kamerleden bij de behandeling van de Wet RO waren van oordeel dat er terughoudendheid 'behoort" te zijn. De minister 'moet' terughoudend zijn met het gebruik van zijn aanwijzingsbevoegdheid. Daamaast bestaat een praktijk waarin de minister zelden ingreep in individuele zaken. De minister stelde zich terughoudend op met directe sturing van het OM. ${ }^{186}$ Het is een gewoonte voor de minister om terughoudend te zijn met aanwijzingen. In de Nederlandse rechtsorde bestaat wat dit betreft dus een regelmatig terugkerend gedrag (consuetudo) en de overtuiging dat het gedrag rechtens is vereist (opinio imis).

Men kan nog twisten over de vraag of de ministeriële terughoudendheid "noodzakelijk (is) voor het in stand houden van de staat als besluitvaardige handelingseenheid." is7 Anders gezegd kan men zich afvragen of die terughoudendheid 'noodzakelijk is voor de bestendigheid van het staatsbestuur' of de 'coherentic van het rechtsstelsel' (opinio necessitatis). ${ }^{\text {"s }}$ Sommige staatsrechtgeleerden stellen deze aanvullende eis om gewoonterecht an te nemen. De genoemde noodzakelijkheid valt wel te verdedigen. De terughoudendheid draagt bij tot een onpartijdige vervolging en daarmee het vertrouwen

182 Kitmerstukken 11 1996/97, 25392, nr. 3, p. 26 .

183 Dittrich, Kamerstukken II 1997/98, 25392, ni. 12. Handelingen II 1997/98, p. 48044806. Minister Sorgutrager, p. 4823 .

184 Rechstraditic: Ficq 1991, p. 164. Gewoonteregel: Corstens \& Tak 1982, p. 23; Muller 1994, p. 81. Statisrechtelijk gewoonterechl: De Doclder 1992, p. 913. Boek 1997. p. 136 spreekt van een "in de prakijk gegroeide statsrechelijke regel".

185 Fiplicie 20 bijw.: Komtmann 1994, p. 750.

186 Bijv. Bosch 1992, p. 20; Enquêtecommissie Opsporingsmethoden 1996, p. 397 e.v.

187 Wan der Pot/Donnkr/Prakke e.a. 2001, p. 170.

188 Kormm 2001, p. 31. 
van de burger en de rechter in het $\mathrm{OM}^{1{ }^{189}}$ Als de minister zich niet terughoudend op zou stellen, zou daar geen of minder plaats voor zijn. Burgers zouden het optreden van het $\mathrm{OM}$ gaan wantrouwen. Het zou een andere opstelling van de rechter meebrengen en de verhoudingen binnen de rechterlijke macht schaden. Het zou de relatie tussen de regering en de rechterlijke macht bemoeilijken. Verder zou de legitimiteit van de minister zwaar op de proef gesteld worden. Een voortdurend gebruik van de aanwijzingsbevoegdheid zou een geintensiveerde controle van het parlement oproepen. De kamers zouden zich (nog) meer gaan mengen in strafzaken. Deze zaken zouden voortdurend onderwerp van politiek debat worden. Dit zou wrijving opleveren tussen de rechterlijke macht en het parlement. Veel van deze gevolgen deden zich al in enige mate voor, al dan niet in samenhang. Een minder terughoudende opstelling van de minister zou ze evenwel versterken. Zonder tot de beschrijving van rampscenario's over te gaan kan ik dus stellen dat de terughoudendheid noodzakelijk is voor de "bestendigheid van het staatsbestuur". Op grond hiervan kan ik concluderen dat er sprake is van een staatsrechtelijke gewoonteregel dat de minister zich met zijn aanwijzingsbevoegdheid terughoudend opstelt tegenover het $\mathrm{OM}$.

Welke waarborg kan dit gewoonterecht nu vormen? De minister bepaalt eigenlijk zelf hoe zijn verhouding met het $O M$ zal zijn, en hoe terughoudend hij daarin is. ${ }^{190}$ Het is ook niet zeker wat voor gebruik toekonstige ministers van de aanwijzingsbevoegdheid zullen maken. Bij de totstandkoming van de Wet RO in 1827 leek de toenmalige minister het tegendeel van terughoudendheid voor te staan. "Het openbaar ministerie beslist. niets', begon minister Van Maanen zijn betoog over het onderwerp. ${ }^{196}$ Minister Hirsch Ballin schreef nog dat de 'verantwoordingsrelatie' van het OM ten opzichte van de minister intensiever zou worden. ${ }^{192}$ Minister Korthals verklaarde evenwel dat hij zeer terughoudend zou zijn met aanwijzingen in individuele zaken. ${ }^{193}$ Een minister zou van de huidige vorm van terughoudendheid af kunnen stappen, misschien onder druk van de publieke opinie of kamerleden. De mate van terughoudendheid wordt bepaald door politieke redenen, en is sterk aan verandering onderhevig, naar gelang de verhoudin=gen. Het Nederlandse stelsel biedt ruimte aan politieke 'alfaires' met stralzaken. ${ }^{194}$ Het is daarom niet voldoende te stellen dat er "geen aanwijzingen zijn dat dit in de toekomst het geval zal zijn'. ${ }^{195}$

189 Met de verdediging van de noodzakelijkheid beland ik op het betogenede terrein van hoofdstuk 6 . Ovar de onpartijdigheid en bet vertrowwen in het $\mathrm{OM}$, zie aldaal 7.4. Onpartijdige partij.

190 Zoals procureur-generaal Sorgdrager zelf al stellde, 1989, p. 75; Stolwijk 1992, p. 39; Sichalken 1999, p. 860 .

191 Handelingen III $1826 / 27$, mr. XIII, p. 364.

192 Hirsch-Ballin 1991, p. 199; wgl ook Siolwijk 1992, p. 37.

193 Lindio 1998 , p. 1720.

194 De Doelder 1995, p. 63-64; 1996, p. 297. Zie verder mijn betoog in hooldstuk 6, 7.4.1. Puntijdigheid door ministeriële invloed.

195 Zoals Elzinga 1996a, p. 1662. Zie werder hoofdstuk 6,7.4.4. Overdreven wantrouwen en voldoende waarborgen? 


\subsubsection{Conclusie}

Potentieel kan de minister veel invloed uitoefenen via zijn aanwijzingsbevoegdheid. Deze heeft betrekking op alle vormen van handelen van het OM. Zelfs een aanwijzing om niet te vervolgen of een aanwijzing ten aanzien yan het requisitoir is niet uitgesloten. De aanwijzingsbevoegdheid voor individuele gevallen kent wel uitgebreide procedurevoorschriften voor met name de aanwijzing tot niet-vervolging. Daarnaast wordt de minister geacht terughoudendheid te betrachten bij het gebruik van zijn bevoegdheden. Met dit al geeft de minister in praktijk echter nauwelijks specifieke aanwijzingen.

\subsection{Petine bij de minister}

Burgers kunnen tegen de strafrechtelijke beslissingen van het $\mathrm{OM}$ 'beklag' instellen bij de minister. ${ }^{196}$ Het gaat hier niet om administratief beroep in de zin van de Awb. De mogelijkheid om beklag te doen is niet vastgelegd in een wettelijk voorschrift. Het beklag betreft enkel een vorm van het algemene petitierecht van burgers. Het staat hen daarbij vrij de minister te vragen om een aanwijzing te geven. ${ }^{197}$ De minister is niet rechtens verplicht te beslissen op het beklag. Indien de minister op het beklag een beslissing met rechtsgevolgen wil nemen, dient hij een specifieke bevoegdheid te gebruiken, zoals een aanwijzing.

\subsection{Toezegging en mededeling omtrent de strafbaarheid}

De minister heeft de mogelijkheid om aan personen een toezegging te doen dat zij niet zullen worden vervolgd. Een daaraan verwante optie is om een mededeling te doen omtrent de strafbaarheid van bepaalde feiten.

De ministeriële toezegging kan een directe invloed hebben op de uitkomst van een strafproces. Het is mogelijk dat de minister zowel een toezegging doet aan de betrokkene, als een aanwijzing geeft aan het OM om niet te vervolgen. De zaak komt dan in beginsel niet voor de rechter, tenzij een bereidwillige rechtstreeks belanghebbende beklag doet bij het hof ex artikel $12 \mathrm{~Sv}$. Een andere situatie is denkbaar, waarin de minister een toezegging doet, maar het $\mathrm{OM}$ de betrokken persoon desalniettemin vervolgt.

In beide gevallen kan de aangezochte rechter concluderen dat de toezegging bij de verdachte het gerechtvaardigde vertrouwen heeft kunnen wekken dat hij niet zou worden vervolgd. Wanneer het $\mathrm{OM}$ dan toch vervolgt, kan de rechter besluiten dat het $\mathrm{OM}$ niet ontvankelijk is. Wanneer het OM niet vervolgt, en beklag bij het hof wordt gedlaan, kan dit besluiten dat het beklag om dezelfde reden verworpen dient te worden. Vervolging kan nog slechts plaatsvinden wanneer 'zwaarder wegende belangen' dat eisen. Dit is bijvoorbeeld het geval wanneer de toezegging uitsluitend tot stand zou zijn geko-

196 Wittop Koning 1972 , p. 283 ; Corstens 1974 , p. $49-50$.

197 Hier is overigens geen sprake wan een 'klacht' in de zin van art. $9: 1$ Awb. Een klachtschrift tegen de beslissingen van het OM dient do klager bij het OM zelf te deponeren. Overigens zal deze niet waak in behandeling genomen moeten worden gezien ant. 9:8 lid I sub if. Voor het petitierecht: art. $5 \mathrm{GW}$. 
men als gevolg van een misvatting omtrent het recht. De rechter zal niet gaww oordelen dat zwarder wegende belangen aanwezig zijn als de minister enkel op grond van redenen van opportuniteit tot de toezegging besluit. De rechter zal geneigd zijn tot een marginale toetsing. De toezegging kan overigens niet effectief door andere bewindslieden gedaan worden. Zij zal niet het bedoelde effect teweegbrengen wamneer zij afkomstig is van een andere minister dan die van. Justitie. Ook moet het gaan om een 'uitdrukkelijke en onvoorwaardelijke toezegging". 198

Een enigszins vergelijkbare interventie is een mededeling van de minister omtrent de strafbaarheid wan bepaalde feiten. De minister kan een persoon zijn interpretatie mededelen dat het verrichten van bepaalde handelingen niet strafbaar is. Als de betrokkene deze feiten vervolgens begaat, kan het voorkomen dat het OM tot vervolging besluit: De rechter kan dan een oordeel geven over de gevolgen die de ministeriële mededeling meebrengt. Het is ook mogelijk dat de minister zowel een dergelijke mededeling doet als een aanwijzing geeft tot niet vervolgen. Het hof kan vervolgens gevraagd worden te beslissen op een beklag van een belanghebbende.

De rechter kan in deze situaties oordelen dat de verdachte in redelijkheid mocht vertrouwen op de mededeling van de minister. Bij vervolging dient de verdachte dan te worden ontslagen van rechtsvervolging. Een eventueel beklag ex artikel $12 \mathrm{~Sv}$ kan eveneens op die grond verworpen worden. ${ }^{109}$

De toezegging en de mededeling omtrent de strafbaarheid zijn enigszins te vergelijken met de aanwijzing tot niet vervolgen. Alledrie deze ministeriele handelingen kunnen plaatsvinden vóór de strafvervolging en kunnen een verdachte uiteindelijk behoeden voor een rechterlijke veroordeling. De aanwijzing is echter gericht aan het $O M$, terwijl de toezegging of mededeling aan de (potentiële) verdachte gedaan wordt. Moons lijkt wel te stellen dat de toezegging uitsluitend door een aanwijzing geëffectueerd zou kunnen worden. ${ }^{200}$ In een dergelijke opvatting zouden de toezegging en de aanwijzing in elkaar geschoven worden. Natuurlijk kan de minister na het toezeggen zelf een aanwijzing tot niet vervolgen geven. Echter, de toezegging kan zonder dit laatste al effect sorteren bij de rechter. Ook als geen aanwijzing volgt zou deze kunnen oordelen dat de betrokkene gerechtvaardigd vertrouwen kon stellen in het woord van de minister. Dit vertrouwen wordt immers enkel gebaseerd op de toezegging. Uit de bovengenoemde jurisprundentie volgt niet dat de betrokken burger kennis genomen moet hebben van een aanwijzing tot niet-vervolging om te kunnen spreken van een uitdrukkelijke toezegging. De minister hoeft dus geen aanwijzing tot niet vervolgen te hebben gegeven om een effectieve toezegging te kunnen doen.

198 HR 29 mei 1978, Nj 1978, 358, m.nt. ThWvV (Monten I); HR 22 mei 1979, N1 1979, 301, m,nt. GEM (Menter II); HR 17 december 1985, NJ 1986,591, m.ni. ThW (DSM). Voor een toezeging door enkel het OM zelf: HR 15 februari 1994, N.1994, 322, m. nt. AHJ. Kritisch: Van Veen 1979, p. 116. 117 ; Meijers 1988, p. 146-147.

199 HR 19 oktober" 1993, NJ 1994, 216, rn.nt. 'illt.

200 Mondelinge commentaar van de president van de loge Raad Mooms, volgens de weergave van Mulder in zijn nowt onder HR 22 mei 1979. NJ 1979, 301 (Menton II). 
Een specifieke procedure bestaat niet voor de toezegging, noch voor de mededeling omtrent de strafbaarheid. Over geen van beide hoeft de minister de kamers van het parlement te informeren. Dit is een manco in vergelijking met de aanwijzing tot nietvervolging. Zoals gezegd kan de minister met deze bevoegdheden namelijk een soortgelijk gevolg teweegbrengen als met een aanwijzing. Wel kan een rechter oordelen over de waarde van een toezegging of mededeling. Als de minister evenwel enkel op grond van politieke opportuniteit tot de toezegging komt, zal de rechter die grond al snel accepteren. Hoogstens zal de openbaarheid van een dergelijke zaak vervolgens de aandacht en de kritiek van de publieke opinie en het parlement eisen. Deze mogelijkheid werkt preventief tegen het misbruik van toezeggingen.

Echter, wanneer de minister een toezegging heeft gedaan, heeft het OM nog nauwelijks ruimte om over te gaan tot vervolging. Het zal rekening moeten houden met het feit dat de rechter tot niet-ontvankelijkheid zal kunnen beslissen. Het is aannemelijk dat het OM dan besluit niet te vervolgen. De openbaarheid van de rechterlijke beoordeling blijft dan achterwege, tenzij een belanghebbende beklag instelt bij het hof: In zaken waar geen belanghebbende is, kan de toezegging dan ongehinderd zijn effect krijgen. Voor de praktijk lijken de besproken bevoegdheden weinig betekenis te hebben. De minister doet voor zover bekend zelden of nooit een dergelijke mededeling of toezegging. Hij richt zich veeleer op overleg met het $\mathrm{OM}$.

\subsection{Vervolgingsbesluit bij ambtsmisdrijven politici}

Een bijzondere procedure gaat vooraf aan de vervolging van ministers, staatssecretarissen en kamerleden voor ambtsmisdrijven. Hiervoor moet de Tweede Kamer namelijk op voorstel van vijf leden een aanklacht in overweging nemen. Indien de Kamer vervolgens besluit dat vervolging moet plaatsvinden, belast hij de procureur-generaal bij de Hoge Raad hiermee. Wanneer de Tweede Kamer aldus de vervolging heeft bevolen, heeft de regering uiteraard geen bevoegdheid de procureur-generaal te bevelen de vervolging te staken.

De regering heeft eveneens de bevoegdheid bij koninklijk besluit de vervolging van de opgesomde politici te bevelen. Voor het overige gelden dezelfde procedurele regels. Tot nog toe besloot noch de Kamer noch de regering ooit tot de vervolging van een politicus. $^{201}$

\subsection{Gezag over opsporingsorganen}

Naast het $\mathrm{OM}$ hebben verscheidene andere organen vergelijkbare strafrechtelijke bevoegdheden. Sommige van deze bevoegdheden zijn van bepalende invloed op de doorgang van strafprocessen. De meeste betrokken organen staan onder zeggenschap van een minister. Deze minister kan via deze organen invloed uitoefenen op strafrechtelijke procedures.

201 Zie de Wet münisterisle verantwoordelijkheid (Wmv); art. $119 \mathrm{Gw}$; art. $482 \mathrm{~Sv}$; art. 76 Wet RO. Over deze procedure: Broeksteeg, Sikkema \& Warmelink 2000. 
De belangrijkste rol spelen hier de politie, de Rijksrecherche en de Koninklijke Marechaussee. Deze nemen het grootste deel van de opsporing voor hun rekening. De regionale politiekorpsen vallen onder de burgemeester-korpsbeheerder en de minister van Binnenlandse Zaken. De recherche ressorteert onder de minister van Justitie en de marechaussee onder die van Defensie. Andere organen van belang zijn de bijzondere opsporingsdiensten als de Fiscale Inlichtingen- en Opsporingsdienst en de Economische Controledienst (FIOD-ECD) van het ministerie van Financiën. ${ }^{202}$

Enkele bestuursorganen hebben de bevoegdheid een selectie te maken van te vervolgen zaken of zelfs een transactie te doen. Door te voldoen aan woorwaarden waaronder een betaling van een geldsom vervalt vervolgens het recht tot strafvordering. Het bestuur kan zelf besluiten welke zaken het ter vervolging overdraagt aan het $\mathrm{OM}^{203}$

Alle bovengenoemde ambten hebben bevoegdheden die het instellen of de reikwijdte van een opsporingsonderzoek kunnen bevorderen of beperken. Zoals gezegd kan de officier van justitie bevelen geven aan personen die met de opsporing zijn belast. Daarnaast staan deze ambtenaren evenwel hiërarchisch onder een minister (en/of de burgemeester). Deze heeft in ieder geval zeggenschap over de organisatie en funanciën van de betreffende organen. Tevens heeft hij rechtspositionele bevoegdheden ten aanzien van de ambtenaren van deze organen. Via deze wegen hebben politieke ambten verdere, indirecte invloed op de opsporing en de vervolging .

\subsection{Bevoegdheden ten aanzien van budget en organisatie}

De financiën van het OM zijn, net als die van de gerechten, een onderdeel van de begroting van het ministerie van Justitie. De verdeling van de middelen over de parketten geschiedt tevens door de minister. De parketten delen deze budgetten niet met de rechterlijke colleges. De financiële ruimte die de minister het OM hier laat is van invloed op de capaciteit van het M. $^{204}$

De minister neemt verder besluiten ten aanzien van de organisatie van het $\mathrm{OM}$. Hij bepaalt de personeelsaantallen van de rechterlijke ambtenaren. Deze worden immers op zijn voorstel benoemd. In mandaat van de minister heeft het OM eigen voorzieningen en beheer en betrekt deels diensten van van de stafdienst van de rechterlijke colleges. ${ }^{205}$

202 Verder zijn te nomen de Inspectie voor de Gezondheidszorgen de Keuringsdienst vaty Wam wail het ministerie wan Volksgezondheid, Welzin en Sport en de Inspectie Milieullygiene wan het ministeria van Volkshuiswesting, Rumtelijke Ondening en Milieuhygiene en de Algemene Inspentedienst (ADI) van

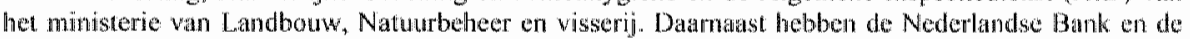

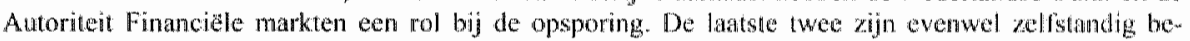
stumsorganen. Ministers hebben daarom echter weanig zeggensehap over deze organen.

203 Voor ransactio door de belastingdienst: art. 76 en 80 AWR. Voor die selectie door de Regionale toetsingscommissies voor leverubeeindiging op verzoek en lnulp bij zelfoding. tart. 8 ev. Wet hoetsing levels sbecindiging op verzoek en luulp bij zelldading.

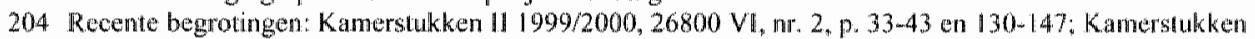
II $2000 / 01,27400 \mathrm{VI}, \mathrm{nr} .2, \mathrm{p}, 49-60$ en p. $\| 54-171$; Kamerstukken II $2000 / 02,28000$ VI, nI. 2, p. 5867. Begrotingswetten wan het ministerie van Justitic: wet van 19 februari 2000,50 , 99; wet wan 1 februari $2001,8 t b .65$, wet van 14 maart $2002,8 b .154$.

205 Besluit reorganisatie openbaar ministerie en instelling landeljk parket, wan 11 mei $1999,516.197$. Orgarisatieregeling beheer gerechten en landelike diensten en Organisatieregeling dicnstonderdelow OM, regelingen van 15 december 1997; Aanvillend besluit biji de Organisatieregeling dicustonderdelen 


\subsection{Informele iwvloed}

Terwij de minister allerlei functionele bevoegdheden heeft tem aanzien van het $O M$, kan hij tevens op andere, niet gereguleerde wijze invloed uitoefenen. Hij zou het OM tot en bepaald handelen kunnen aanzetten zonder een aanwijzing te geven. De procedurebepalingen voor aanwijzingen zouden zo omzelld kunnen worden. De onderhandse beinvloeding kan ertoe bijdragen dat het OM een zaak niet laat uitlopen op een beoordeling van de toezegging ter zitting.

Minister Sorgdrager meende dat (n)iet elke handeling waarmee de minister zijn oordeel kenbaar maakt of zjn invloed aanwend, moet worden aangemerkt als een aanwijzing'. Zo zal 'goed overleg' in de meeste gevallen ertoe leiden dat een aanwijzing niet nodig is. Dit overleg zal in de meeste gevallen tot een vorm van overeenstemming. leiden. In hoeverre de minister achter de schermen aanspoort tot een bepaald besluit, blifft in het verborgene. ${ }^{206}$

Een aspect van informele beînwloeding vormen daarnaast de mededelingen van aan ministers ondergeschikte departementsambtenaren. Hun adviezen en invloed zin uiteraard niet kenbaar. Deze bespreken zaken met leden van het OM. In gesprek kunnen departementsambtenaren duidelijk maken dat het ministerie een bepaalde beslissing al of niet wenselijk acht. Zo zouden ministeries druk kunnen uitoefenen op een officier van justitie. 207

Deze informele invloed van de minister op het OM heeft gevolgen voor het functioneren van de aanwijzingsbevoegdheid. Minister Sorgdrager impliceert dit in feite ook. Door de informele invloed - het overleg - beperkt de minister de noodzaak on een aanwijzing te geven.

Zoals gezegd bestaat op de eis van de schriftelijke vorm van de aanwijzing geen sanctie. Wanneer de minister een mondelinge aawwijzing geeft, wordt het College geacht on een schriftelijke bevestiging te vragen. Volgt die niet, dan hoeft het College de aanwijzing niet op te volgen, zo is de theorie. Vraagt het College echter om een schriftelijke aanwijzing, dan kan de minister dit als een vertrouwensbreuk ondervinden. De minister kan tot de conclusie komen dat hij geen vertrouwen meer heeft in het functioneren van het College. In dat geval ligt het voor de hand dat al dan niet gedwongen ontslagen van collegeleden volgen. Een mondeling gegeven aanwijzing zou $z 0$ in het verbotgene blijven. 208

OM: regeling van 27 hebumat 2001 .

206 Minister Sorgdrager: Kamerstukken II $1.996 / 97,25392$, m. 3, p. 42 en ("goed overleg') p. 24 . Vgl. Handelingen II 1997/98, p. 4825; Schalken 1991, p. 189.190; De Doelder 1992, p. 916; 1995, p. 62; Kookkoek, Handelingen II 1997/98, p. 4790. Hirsch Ballin meende dat gebruiknaking var de anwijzingsbevoegdheid "owerbodig" was aangezien het OM de minister op de juste ogenblikken "raadpleegt" Kannerstukken II 1992/93,22800 VI, m. 2, p. 8. Van Agt onderstreepte de wenselijkheid van zoveel mogelijk overleg", Handelingen 11 1975/76, p. 4062. Het belang wan de informele inwoed wordt mede ondersireept in de uitsprak: "Een bevel geven is in Nederland dé manier om te zorgen, dat iets niet gebeunt: " Docters wan Leewwen in TVP 1996, 6, p. 4.

207 Handelingen II 1997/98, p. 4825.

208 Vgl, voor spoedaanwijzingen: 6.2 .3 .4 . Spoedprocedure. 
De procedurele regeling omtrent de anwijzingsbevoegdheid van de minister is bedoeld om te voorkomen dat "op een ongeoorloofde manier druk wordt uitgeoefend op het OM: ${ }^{209}$ Drie punten van kritiek zijn te signaleren.

Ten eerste brengt het bestaan van de aanwijzingsbevoegdheid zelf al een indirecte ministeriële invloed mee. De bevoegdheid vormt inmers de stok achter de deur van het overleg. Het OM zou ervoor kunnen gaan kiezen de opvattingen wan de minister te volgen in de wetenschap dat de minister uiteindelijk toch het laatste woord heeft.

Op dit punt is het ten tweede van belang te onderstrepen dat de rechtspositie van de leden van het OM op informelle wijze de functionele relatie met de minister kan beïnloeden. ${ }^{210}$ Leden van het $\mathrm{OM}$ zullen rekening houden met hun carriereperspectieven, die mede bepaald worden door de mening die het ministerie over hun houding heef. Dit kan meebrengen dat in een informeel overleg de leden van het OM eieren voor hun geld kiezen en thun voornemen wijzigen. Een lid van het OM zou geneigd kumnen zijn een 'wenk' op te volgen, 'ook al zou hij met deze 'wenk' niet erg gelukkig zijn' 2.1

Men kan tegenwerpen dat een OM-lid dat in een dergelijk geval zijn rug niet recht houdt "geen knip voor de neus waard" is. Het OM zou zich juist moeten emanciperen en aansturen op een officiële aanwijzing. ${ }^{212}$ Marr het lijkt mij de vrang of het departement zo zal denken over de 'waarde' van een weigerend OM. Feit blijft dat de leden van het OM zich rechtspositioneel in een afhankelijke positie van de minister bevinden. Men kan enkel hopen op een "rechte rug" van de leden van het OM.

De vraag is of de leden van het college evenzeer rechtspositioneel afhankelijk van de minister zijn. De minister meende: "Het college bestaat uit mensen van een hoog niveau en dan mag je er van uitgaan dat ze op een normale manier met de minister communiceren en dat die zich ook niet onder druk laten zetten". ${ }^{213}$ Deze personen worden echter wel bij koninklijk besluit benoemd, op voondracht van de minister van Justitie. Dat ze van een 'hoog niveau' zijn hangt daardoor in ieder geval sterk af van de minister zelf. de regeling legt in ieder geval een hypotheek op de personen die de ambten van de minister en het College vervullen. Het goede functioneren van het systeem is in deze wel in hoge mate afhankelijk van hun persoonlijke kwaliteiten. ${ }^{214}$ Voorheen stonden de procureurs-generaal bekend als "gezegend met een witzonderlijk soepele en elastische ruggegraad: 215

209 Handelingen II 1997/98, p. 4825. Vgl. Kanerstukken II 1996/97, 25392, nr. 3, p. 26. In de lateratuar spreek men well van een verbetering op het punk van de transparantic in de verhouding tussen minister en OM. Van der Flier 1999, p. 743.

210 Hierover ook: hoofdstuk 5, 4. Conclusie redispositie en functionele positie en hooldstuk 6,2.2. Samenwallen functionele en rechtspositionele tritio.

211 Duisterwinkel 1968, p. 223, 232; Dittrich, Handelingen II, 1997/98, p. 4806; Pitsta, Handelingen ${ }_{*}$ 199899 , p. 1179.

212 Corstens 1.997, p. 224; Kalsbeek-Jasperse, Handelingen II 1997198, p. 4802.

213 Handelingen II 199798, p. 4825. Over de "rechl te houden" rug van het College: Corstens 2002, p. 104; $1999 \mathrm{a}, \mathrm{p} .100$

214 "t Hart 1999, p. 118,2001, p. 94; Schalken 1999, p. 861. De zaak tond het ontsigg van Docters van Leeuwen noemen de auteurs niet bepaald een atamoediging tol emaneipatie ten opzichte van de minister. Zie over de zaak 5.7 . Schorsing en ontslag.

215 "t Hart 1994, p. 15. 
De aard van de rechtspositie van het $O M$ draagt dus bij tot vormen van informele inwoed. Ten derde kan de culturur wan het OM dergelijke invloed vergemakkelijken. In het algemeen is het voor 'de goede relatiesfeer en verstandhouding' eenvoudigweg "niet opportuun om zaken op het scherpst van de snede uit te vechten" ${ }^{216}$ Daarbij komt dat een zekere ambtenarencultuur binnen het OM kan bijdragen tot een verminderde noodzaak voor aanwijzingen. Door de zaak te laten uitlopen op een ministeriële aanwijzing treedt de kwestie waarover OM en minister verschil in opvatting zouden hebben naar buiten. De vraag is of de leden van het OM dit niet zullen willen voorkomen. Een dergelijke houding past in het algemeen bij de ambtenarencultuur. De minister wordt in zekere zin geblameerd door het $\mathrm{OM}$ als een formele aanwijzing gegeven moet worden. De minister lijkt de zaak dan niet meer "in de hand te hebben', of het OM lijkt 'het politiek primaat' in twijfel te trekken. Voor zover daar naar buiten toe iets van bleek, leek deze cultuur voorheen niet zeer dominant binnen het $\mathrm{OM}$. Bij de reorganisatie van het OM eind jaren negentig werd echter regelmatig gehamerd op de noodzaak de cultuur binnen thet $O M$ te veranderen. De organisatie moest onder andere meer als een eenheid gaan werken. De band met de minister lijkt daarop sterk te zijn aangehaald. ${ }^{217}$ In een organisatiecultuur die zich richt op het belang van de minister heeft de laatste geen behoefte om aanwijzingen te geven.

\subsection{Conclusie}

De minister heeft in potentie een uitstekende informatiepositie. Niet alleen heeft hij de bevoegdheid alle informatie van het OM te vragen, het OM moet hem ook op eigen initiatief informeren. Voor sommige specifieke situaties is het informeren zelfs apart voorgeschreven. De minister en het College plegen weelvuldig overleg met elkaar. De bewindspersoon heeft mede hierdoor ruime gelegenheid voor informele beïnvloeding van het OM. Daarnaast heeft hij een aanwijzingsbevoegdheid met een inhoudelijk onbegrensde reikwijdte. Hij kan derden toezeggingen doen over een strafrechtelijk handelen en mededelingen omtrent de strafbaarheid van feiten. Van deze specifiek interveniërende bevoegdheden makt hij echter weinig gebruik. Verder heeft hij zijn hand aan de geldkraan. Ten slotte heeft hij met zijn medebewindslieden een kaderstellende rol ten aanzien van de opsporingsdiensten die samenwerken met het $O M$. De Nederlandse minister heeft kortom desgewenst een goed zicht op het strafrechtelijke handelen en heeft de beschikking over veel sturingsmiddelen jegens het OM.

\section{Verantwoording voor het $\mathrm{OM}$}

De minister heeft belangrijke bevoegdheden ten aanzien van het $\mathrm{OM}$. Tegelijkertijd is hij verantwoordelijk voor het handelen van het $O M$. Het gebruik van de term "ministeriële verantwoordelijkheid" leidt bij kwesties over strafrechtelijke opsporing en vervolging geregeld tot woordenwisselingen. Dit kan mede samenhangen met het feit dat 
de discussie over de onderhavige kwestie is gevoerd vanut verschillende wetenschappelijke disciplines. Verder kunnen ministers van Justitie die zich in het debat mengen niet gezien worden als belangeloze deelnemers. Hun standpunt heeft tevens politieke consequenties.

Het hierna volgende is een poging tot een nieuwe analyse. De bepalende vraag is die van de grondslag of de reikwijdte van de verantwoordellikheid. Op grond van welk criterium is de minister verantwoordelijk in zaken die het OM betreffen? Waar is de minister precies voor verantwoordelijk? Na deze vragen bespreek ik de loop van het verantwoordingsproces en aspecten van de praktijk van verantwoording voor vervolgingszaken. Ik besluit net enkele opmerkingen over directe contacten tussen OM en parlement.

\section{I Grondslag en reikwifite verantwordelikheid}

In de Nederlandse doctrine legt men drie afzonderlijke criteria aan om te bepalen op grond waarvan ministeriele verantwoordelijkheid voor het OM bestaat. De oorsprong van deze verantwoordelijkheid zou kunnen liggen in het behoren van thet OM tot de uitvoerende macht, in de ondergeschiktheid van het OM aan de minister of in het bestaan van de aanwijzingsbevoegdheid.

Onder meer minister Sorgdrager was (in eerste instantie) van mening dat de minister politiek verantwoordelijk is voor het OM ondat dit deel uit zou maken van de uitvoerende macht: Uitdrukkelijk stelde zij dat de aanwijzingsbevoegdheid van het oude artikel 5 Wet RO slechts de ministeriële verantwoordelijkheid zou concretiseren. ${ }^{218}$

Het gebrek aan juridische betekenis van de kwalificatie van 'uitvoerende macht' in het Nederlandse stelsel beargumenteerde ik reeds eerder in dit hoofdstuk. ${ }^{219}$ Daamaast ontstaan door het hanteren van deze grondslag voor de ministeriele verantwoordelijkheid systematische problemen. Zou een dergelijke grondslag meebrengen dat de minister niet verantwoordelijk is voor het beheer van de rechterlijke colleges? Vallen zellstandige bestuursorganen wel onder de uitvoerende macht? Deze definitieproblemen maken het begrip ongeschikt om te gelden als verantwoordelijkheidsgrondslag. Ten slotte komt een dergelijke opvatting verder niet voor in de parlementaire praktijk of staatsrechtelijke literatuur.

Een tweede criterium is dat wan de onderschikking van het OM aan de minister. Verantwoordelijkheid op deze grondslag noemt Warmelink wel "hierarchische verantwoordelijkheid'. Voor het vaststellen van deze verantwoordelijkheid is het niet van belang of de wet middellen toekent on de beslissingen van de ambtenaren te beinvloeden. Essentieel is of de wet de minister dergelijke midclelen ontzegt. De crux zit hem in de wijze waarop bepaald wordt dat de leden van het OM 'ondergeschikt" zijn aan de

218 Sorgdrager 1996, p. 6. Zo ook Van Angeren 1996 , p. 368. De latste meent dat de regering vertimtwoordelijk is voor 'het besturr' van de centrale overheid, afgezet tegen de wegeving en de rectutsprata. Sorgdrager heef zich eveneens van het weede criterium bediend, zie thiema.

219 Zie 2.1. OM en rechterlijke macht. 
minister. Voor het OM is dit volgens Warmelink "in het bijzonder af te leiden uit artikel 5 Wet RO'. In de huidige wet hebben de artikelen 127 en 128 Wet RO die bepaling overgenomen. De 'ondergeschiktheid' wordt hier onderscheiden van de situatie waarin de minister 'enkel' een aanwijzingsbevoegdheid heef. ${ }^{220}$ Dit onderscheid is evenwel in het algemeen onhoudbaar en in het bijzonder achterhaald door de nieuwe Wet RO.

Het is niet duidelijk wat nu het precieze verschil is tussen de ondergeschiktheid van het $O M$ en het feit dat de minister een aanwijzingsbevoegdheid heeft tegenover het OM: Beide begrippen bedoelen dat de minister algemene en specifieke aanwijzingen kan geven aan het OM. Ondergeschiktheid bestaat niet zonder bevoegdheden van een bovengeschikte ten aanzien van een ondergeschikte. Juist de aanwijzingsbevoegdheden vormen de ondergeschiktheid. Ministeriële verantwoordelijkheid om ondergeschiktheid is dus uiteindelijk gegrond op ministeriële bevoegdheden.

In de vroegere formulering zou men misschien nog een grondslag voor een ondergeschiktheid van het OM kunnen lezen. Voorheen waren de ambtenaren van het OM 'verplicht de bevelen na te komen, welke hun in hun ambtsbetrekking door de daartoe bevoegde macht, vanwege de Koning, zullen worden gegeven' (art. 5 oud). Volgens de huidige tekst kan de minister 'algemene en bijzondere aanwijzingen geven betreffende de uitoefening van de taken en bevoegdheden van het openbalar ministerie' (art. 127). ${ }^{221}$

\subsubsection{Verantwoordelijkheid door bevoegdheden}

Het belangrijkste criterium om verantwoordelijkheid vast te stellen is die van de bevoegdheid. Binnen deze denkrichting bestaan twee mogelijke stromingen. Eén opvatting luidt dat de minister verantwoordelijk is voor het gebruik van zijn eigen bevoegdheden. Een andere mening acht de minister verantwoordelijk voor het handelen of de uitoefening van de bevoegdheden van het $\mathrm{OM}$.

Daarbij komt dat verantwoordelijkheid algemeen gezien wordt in de betekenis van verantwoording. Dat de minister verantwoordelijk is beduidt dat de minister aangesproken kan worden en rekenschap moet afleggen. ${ }^{222}$ Schrijvers melden veelal niet expliciet wat de reikwijdte van de verantwoording is. Elzinga vindt uitdrukkelijk en in algemene zin dat een minister slechts ter verantwoording kan worden geroepen voor zover hij verantwoordelijk is. ${ }^{22.3}$ Dit lijkt impliciet ook de mening te zijn van hen die vinden dat verantwoordelijkheid (mede) de betekenis heeft van aanspreekbaarheid.

Over de reikwijdte van de verantwoordelijkheid Jeert de meest gedeelde theorie dat de minister in het algemeen verantwoordelijk is voor het (niet) uitoefenen van zijn eigen

220 Warmelink 1994, p. 113; 1998, p. 1342-1343.

221 Warmelink legt ook bijzondere nadruk op de wijze van formulering van artikel 5. Warmelink 1998, p. 1343 , moot 14. Sommige vroegere auteurs menen wel dat artikel 5 aen 'ondergeschiktheidsrelatie' instelt. Zij betrekken dit gegeven echter niet op de ministeriële verantwoordelijkheid. Stellinga: "dat het $O M(\ldots)$ 'niet onafhankelijk is, doeth hiërarchisch staat onder de Koning' zou volgen uit artikel 5 Wet RO. 1953, p. 418. Van Dullemen schreef dat in artikel 5 was neergelegd 'het principe der volkomen ondergeschiktheid aan en athankelijkheid van de leden van het OM aan het uitvoerend gezag". 1958, p. $7-8$.

222 Commissie Scheltema 1993, p. 8; Warmelink 1994, p. 105; Elzinga 1994, p. 536.

223 Elzinga 1990, p. 99; 1994c, p. 38, 42; 
bewoegdheden. ${ }^{224}$ Wat betreft het $\mathrm{OM}$ stelt menigeen dan ook dat de verantwoordelijkheid van de minister niet verder strekt dan zijn aanwijzingsbevoegdheid. ${ }^{225}$ Veel auteurs stellen daarbij uitdrukkelijk dat de minister niet verantwoordelijk is voor de uitoefening van bevoegdheden door of het handelen zelf van het $\mathrm{OM} .{ }^{226}$

Degenen die menen dat de minister slechts verantwoordelijk is voor zijn bevoegdheden, zijn dan blijkbaar tevens van mening dat de minister slechts verantwoording aflegt voor het (niet) gebruiken van zijn bevoegdheden. Wat betreft het OM stellen enkelen dan ook uitdrukkelijk dat de minister geen verantwoording aflegt voor het handelen van het $\mathrm{OM}$, maar enkel voor het gebruik van de aanwijzingsbevoegdheid. ${ }^{227}$

Een tweede theorie stelt echter dat de minister van Justitie verantwoordelijk is voor 'alles wat het (OM) verricht', "voor (diens) activiteiten of achterwege blijven daarvan", 'voor het doen en laten' van het OM of 'voor de uitoefening van (diens) bevoegdheden'. ${ }^{228}$ De minister zou dan ter verantwoording geroepen kunnen worden voor het handelen zelf van het $\mathrm{OM}$.

Een enkele keer bundelen de twee theorieën zich in tegenstrijdigheid. Deze volgt wanneer tegelijkertijd gesteld wordt dat de minister èn verantwoordelijk is voor zover hij bevoegd is èn verantwoording draagt voor het handelen zelf van het $O M{ }^{229}$

De tweevoudige theorievorming en de tegenstrijdigheid kunnen verklaard worden doordat de toepassing van de theorieèn op het $O M$ hetzelfde resultat geeft. Men zou kumnen stellen dat ten aanzien van het $\mathrm{OM}$ het geen verschil maakt of de minister verantwoordelijk is voor zijn bevoegdheden of voor het handelen van het OM. De minister zou immers via zijn bevoegdheden het handelen van het $\mathrm{OM}$ in alle opzichten kunnen sturen. Het object van zijn verantwoordelijkheid is in beide stellingen hetzelfde.

Deze overeenkomst is tewens zichtbaar in het verloop van het verantwoordingsproces. Bestaat een effectief verschil tussen de twee typen van verantwoording? Het lijkt alsof de verantwoording voor het (niet) gebruiken van de aanwijzingsbevoegdheid beperkter zou zijn dan het aanspreken van de minister voor het handelen van het OM. Dit is niet het geval. Het parlement zal in beide visies de minister in gelijke mate om inlichtingen kunnen vragen. De minister zal in beide vormen van verantwoordelijkheild feitelijke informatie moeten geven die gevraagd wordt. Hij kan daarbij de gronden waarop het OM een besluit heeft genomen uiteenzetten. In beide visies zal de minister zijn eigen mening en eigen handelen uitleggen en motiveren.

224 Belinfante 1980, p. 14-15; Stroink 1978, p. 140-141; Commissie Scheltema 1993, p. 9; Warmelink 1994, p. 104; Elzinga 1994c, p. 38; Kortmann 2001, p. 309.

225 Stroink 1978, p. 163,168 ; Kamerstukken II $1995 / 96,24034$, nr. 13, p. 2.

226 Corstens 1974, p. 54; 1988a, p. 301; Singer-Dekker 1982, p. 128; Corstens \& Tak 1982, p. 23; Schalken 1991, p. 191; De Douelder 1992, p. 921 ; Tuurenhout 1992, p. 37; Kortmann 2001, p. 310. Vgl. de term 'materieel verantwoordelijk' van Korthals Altes, 1988, p. 372.

227 Enschedé 1968, p. 79; Cremers 1983, p. 51 .

228 Alles wat het verricht: Mostert 1968, p. 311. Voor (diens) activiteiten of achterwege blijven daarvan: Jaarverslag OM 1974, Kamerstukken If 1975/76, 13600 VI, nr. 3, p. 15. Voor het doen en latem: Compmissie Van Traa, Kamerstukken II $11995 / 96,24072$, nr. 11, p. 474. Voor de uitoefening wan (ditris) bevoegdheden: Düsterwinkel 1965, p. 8.

229 Elzinga 1994, p. 535.536. Elzinga is juist degene die uitdrukkelijk en in algentene zin meent dat de minister slechts werantwoording kan worden geroepen voor zover hij verantwoordelijk is. 
De vraag is met name of er een verschil bestaat ten aanzien van het verdedigen van, het voor rekening nemen wan het handelen van het OM. Laten wij nu even aannemen dat de minister ('enkel') verantwoordelijk is voor het gebruik van zijn aanwijzingsbevoegdheid. Van de minister wordt dan verwacht dat hij uitlegt waarom hij al dan niet gebruik heeft gemaakt van deze bevoegdheid. De minister kan dit echter niet duidelijk maken zonder in te gaam op het handelen van het OM. Hij zal daaromtrent een opwatting moeten geven en deze tegenover het parlement moeten verdedigen. Een verdediging van het gebruik van zijn aanwijzingsbevoegdheid brengt een verdediging mee wan het handelen zelf van het $O M$.

Het onderscheid tussen de twee theorieën van verantwoordelijkheid ontbreekt dus ten aanzien van het OM. Een verschil zou alleen blijken wanneer men gebruik zou maken van een hypothetische redenering. Deze zou als volgt luiden: zou de minister niet een dergelijke ruime bevoegdheid gehad hebben, dan zou hij volgens de eerste theorie maar in beperktere mate verantwoording af hebben kunnen en hoeven leggen. De dubbelzinnigheid van deze hypothese wil ik in de volgende paragraaf bespreken.

\subsubsection{Onbegrensde aanspreekbaarheid, rekening afleggen door bevoegdheden}

Beter is het een onderscheid te maken tussen twee onderdelen van de verantwoordingsplicht. De verantwoording omvat dan enerzijds de aanspreekbaarheid van de minister, en anderzijds het verdedigen, voor zijn rekening nemen door de minister. Alleen voor de laatste vorm van verantwoording zijn de specifieke ministeriële bevoegdheden de grondslag.

Voor de aanspreekbaarheid (van de minister voor het OM) kan men stelien dat die vrijwel onbegrensd is. De minister kan worden aangesproken door het parlement voor zover het onderwerp binnen zijn competentieveld ligt. Het maakt voor de aanspreekbaarheid niet uit of de minister bevoegd is. De minister mag een vraag dan ook niet afdoen door te stellen dat hij ter zake geen bevoegdheid bezit. ${ }^{230}$ De kamers kunnen wat het handelen van het $\mathrm{OM}$ betreft al hun bevoegdheden aanwenden ter verkrijging van informatie en ter controle van de minister en het OM. Zij kunnen de minister vragen stellen, een interpellatie doen, een enquête houden, enzovoort. Deze bevoegdheden van het parlement en haar leden worden niet beperkt door het feit dat de minister al dan niet een bevoegdheid over het onderwerp heeft. Zij kumnen de minister eveneens aanspreken voor het handelen van het $\mathrm{OM}$ geheel los van een aanwijzingsbevoegdheid. Ook al heeft de minister geen bevoegdheid ten aanzien van het verantwoordingsobject, hij kan niettemin ter verantwoording worden geroepen. De minister is gehouden het parlement in te lichten, te informeren en te antwoorden. Wanneer hem zijn mening wordt gevraagd dient hij die te geven.

$230 \mathrm{Vgl}$. Van Marseveen 1977, p. 214; Kortmann 1996, p. 244; Den Boer 1999, p. 7-8. Den Boer was echter wel van mening dat de minister alleen verantwoordelijk is woor zover hij bevoegd is p. 5. De auteur stelt dat de reikwijdte van de ministeriële antwoordplicht "niet per definitie" samenvalt met de reikwijdte van de ministeriële verantwoordelijkheid. Blijkbaar moet de aanspreekbaarheid (soms?) onderscheiden worden van de verantwoordelijkheid. Beter is het evenwel om zowel de aanspreekbaarheid als het voor rekening nemen te zien als onderdeel van de verantwoordelijkheid. 
Een andere vraag is of de minister iets moet verdedigen en voor zijn rekening moet nemen. Uiteraard moet de minister altijd zijn eigen handelen verdedigen en voor zijn rekening nemen. De vraag is wanneer hij het handelen van anderen moet verdedigen. Slechts voor dit aspect van verantwoordelijkheid geldt dat de minister verantwoording af kan leggen voor zover hij bepaalde bevoegdheden heeft. Daarbij gelden de volgende preciseringen.

Wanneer de minister vindt dat het handelen van het $O M$ in een zaak past in het bestaande recht en beleid kan hij dat handelen verdedigen. Dit geldt ook als hij denkt dat een door het OM besloten afwijking van het beleid in een zaak gerechtvaardigd is. Een dergelijke vorm van verdedigen heeft geen grond in of bijzonder verband met specifieke bevoegdheden die de minister heeft.

Mogelijk is dat de zaak past in het recht en het beleid, maar dat de minister het toch niet eens is met het handelen waarover het parlement verantwoording vraagt. Alsdan kan hij het initiatief nemen het recht of het beleid, waarbinnen het ongewenste handelen past, te wijzigen. Hij kan de intrekking van een strafbepaling bepleiten, ${ }^{231}$ of het creëren van een nieuwe bepaling. Hij kan nieuw beleid uitvaardigen. Voor het verdedigen van deze situatie is het niet strikt noodzakelijk dat de minister verderstrekkende bevoegdheden heeft. Een aanwijzingsbevoegdheid ten aanzien van specifieke zaken is voor deze gevallen in beginsel overbodig. ${ }^{232}$

Verder is denkbaar dat het handelen van het $O M$ in een zaak volgens de minister niet overeenstemt met het recht of geen terechte uitzondering vormt op het beleid. Neemt het OM het besluit om te vervolgen, strijdig met recht of beleid dan zal het daaropvolgende rechterlijke oordeel dit vast kunnen stellen. De minister kan desgevraagd verwijzen naar de rechterlijke uitspraak. Voor een dergelijke ministeriële verantwoording is een bevoegdheid om aanwijzingen tot niet vervolgen te geven onnodig. Vervolgt het OM niet, in strijd met de ministeriële interpretatie van het recht of het beleid, dan kan de minister beleid en regelgeving ontwikkelen opdat een dergelijk handelen in de toekomst niet of minder zal voorkomen. Om dat specifieke geval voor zijn rekening te kunnen nemen,moet de minister echter wel bijzondere bevoegdheden hebben. Daartoe dient bijvoorbeeld de bevoegdheid om aanwijzingen tot vervolging te geven of om disciplinaire initiatieven nemen. Zou de minister in dergelijke situaties niet de betreffende bevoegdheid hebben, dan zou het zinloos zijn als hij het handelen van het $O M$ voor zijn rekening zou nemen. Hij zou de mogelijkheid niet hebben zijn opvattingen geldend te maken, eventueel in strijd met die van het $O M$.

\subsection{Verantwoordingsproces}

$\mathrm{Na}$ een beschrijving van hetgeen de verantwoordelijkheid van de minister bepaalt, volgt nu de kwestie hoe de activering van de verantwoordelijkheid functioneert. Daar-

231 Commissie Openbar Ministerie 1994, p. 86.

232 Als het OM verkolgt overeenkomstig het recht en het beleid, maar in strijd mel de opvating van de minuster kan deze laguste een aanwijzingbevoegdheid on niet te vervolgen wenselijk winden. Verwolgt het OM juist niet, in overeenstemming met recht en beleid, matu tegen minsteriele wens in, dan zou de minister wel nut zien in een anwijzingsbevoegdheid om te verwolgen. Voor de minsterite verantwoording zijn deze bewoegdheden echter niet nodig. 
bij kijk ik eerst naar de verantwoording die de minister zelfstandig al aflegt aan de kanjers. Daarna loop ik de inlichtingen- en debatinstrumenten van het parlement na. Aansluitend beschouw ik de sanctioneringsfase.

Bij enkele gelegenheden informeert de minister de kamers op eigen initiatief Jaarlijks geeft de minister bij de begroting een uiteenzetting over het beleid van het OM. Hij noemt daarbij een aantal ontwikkelingen of veranderingen in de stroom delicten en de aanpak daarvan. ${ }^{234}$ Een zelfde worm van verantwoording vindt plaats tijdens de jaarlijksse financielle verantwoording aan de kamers. De inhoud hiervan verschillt niet sterk van die bij de begrotingstoelichting. ${ }^{235}$ Naast deze algemene verantwoording richten de minister of de regering zich tot de kamer in beleidsnotities over onderdelen van het vervolgingsbeleid. De minister bespreekt met name zaken als de fraudebestrijding, de handhaving van milieuwetgeving, het drugsbeleid en euthanasie. ${ }^{236}$

Verantwoording geinitieerd door kamerleden geschiedt onder meer door het stellen van schriftelijke en mondelinge vragen. Verder zijn parlementaire onderzoeken en enquêtes mogelijk. Deze instrumenten komen hierna kort aan bod. Overigens bestaan ook wel informele contacten tussen de minister en kamerleden. ${ }^{237}$

Elke parlementarier kan de minister vragen stellen over onder meer het handelen van het OM (art. $68 \mathrm{Gw}$ ). Schriftelijk kunnen kamerleden via de kamervoorzitter vragen stellen aan de minister. Voor mondelinge vragen houdt de Tweede Kamer elke dinsdag een vragenuur. Vooraf geven de sprekers aan de voorzitter het onderwerp waarover zij zich wensen te informeren. Een derde optie is dat een lid de kamer vraagt om verlof voor het stellen van vragen over een niet geagendeerd onderwerp. Voor deze zogenaamde interpellatie informeert de vragensteller de voorzitter over de te stellen vragen, ${ }^{238}$

233 Voor de drie fasen van thet verantwoordingsproees, zie Elzinga 1989, p. 70 a. w; 1990, p. 98; 1994c, p. 42 .

234. Minster Sorgdrager heeft toegezegd dat de ministar buj de begroting meldt of hij gebruik heeft gematakt van zijn bevoegdheid bijondere anwizingen te geven. In de praktijk meld hij dit nit neer. Zie 6.2.32. Procedure anwijzing tot verwolging en ten anzien wan het requisitoir.

235 Voor de begroting zie: 6.8. Bevoegdheden ten anzien van budget en onganisatie. Voor de financiele verantwoording recentelujk: Kamarstukken II $1999 / 2000,2712 \%$, $\mathrm{nr}, \quad 11$, p. $18-23$ en 100-110; Kamerstukken II 2000i01,27700, nr. 11, p. 16-23 en 120-124; Kanerstukken II 2001/02, 28380, nr. 10, p. 18-27, 62-63, I 40 e.v.

236 Misbnik en oneigenlipk gebrubk op het gebied wan belastingen, sociale zekerheid en subsidies, Kamerstuken Il. 1984/85-2001/02, 17050, ars, 1-224. Georganiseerde criminaluteit in Nederland, Kanterstukken II 1992/93-1997/98,22838, ar. 1-18. Handhaving milieuwetgeving, Kamerstukken II $1994,95-2201 / 02,22343$, nt. 1-59. Vervolgingsbeleid inzake euthanasiz, Kamerstukken Ill en I $1994 / 95$. 1998/99, 23877, nrs, 1-28. Reorganisatie Wha het openbaar ministerie, Kamerstukken II 1994/95-1999/ 2000, 24034, nis. -32. Drugbeleid, Kamerstukken II 1994/95-2001/02, 24077, nrs. I-95. Late zwangerschapsondertorekng, Kamerstukken 11 1974/75, 13161, mr. 1, 1998/99-2002/01, 26717, nt. 1-2. Crimina-

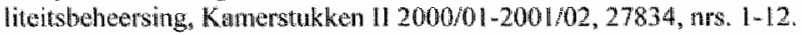

237 Informele contaeten: by w. tussen minister Sorgdragen fractiewoorzitters voorafgaand aan het debat over de zak Lancee in 1997, Van Lienpt \& Van Westing 2000, p. 47.

238 Omtrent de vragenrechlen; art $133-139$ RWOTK; art, 139-140 RVOEK. De Doelder stelt dat als uitgangspunt geldt 'dat over individuele zaken door de Kamer geen kragen behoren te worden gesteld', De Doelder 1996, P. 123. Minister Van Agt wond dat de Kamer, of commissies van de Kamer, zich (niet) 
De kamer kan de minister vragen stellen nadat het OM een handeling heeft verricht. Daarnaast kan de kamer de minister desgewenst vooraf ter verantwoording roepen. ${ }^{239}$ Wanneer een zaak bekend is bij de kamer en in een beginstadium is, kan zij de minister bijwoorbeeld vragen naar de stappen die het OM of de minister nog zullen nemen.

De Tweede Kamer stelt naar verhouding veel meer vragen dan de Eerste. Het parlement stelt redelijk wat vragen over de strafvervolging. ${ }^{240}$ De controle van de kamers is sterk gericht op concrete strafzaken, individuele kwesties of detailonderwerpen. Daar worden relatief veel vragen over gesteld. ${ }^{241}$ Met betrekking tot concrete zaken vragen kamerleden de minister vrijwel steeds on nader onderzoek of om wel te doen vervolgen. ${ }^{242}$ Het komt zelden voor dat de kamer de minister vraagt om het OM niet of remmend te laten handelen. ${ }^{243}$ Vragen met betrekking tot het requisitoir zijn eveneens zeldzaam. ${ }^{244}$ De kamer betracht geen merkbare terughoudendheid met het stellen van vragen over individuele strafzaken. ${ }^{245}$

De minister is verplicht kamervragen te beantwoorden, voor zover dat niet in strijd is met het belang van de staat (art. $68 \mathrm{Gw}$ ). Vragen die de uitoefening van de strafrechtelijke bevoegdheden betreffen nemen geen juridische uitzonderingspositie in. De minister kan ervoor kiezen bepaalde informatie ter vertrouwelijke kennisneming aan de kamers te laten toekomen. Belangen van het opsporingsonderzoek en de privacy van verdachte kunnen zo beschermo blijwen. ${ }^{246}$

behoren te begewen in een toetsing vooraf van de vragg, of ambtenaren van het openbar ministerie in een concrete zaak al of niet gebruik behoren te maken van wettelijke bevoegdheden wasrover zij ontegenzeggelijk beschikken". Handelingen I\| $1975 / 76$, p. 4228. Dit is onjuist in zoverre dat in deze geen juridische beperkingen bestaan. Van Agt meende later dat njet wan een staatsrechtelijke gewoonte gesproken kon worden met betrekking tot de praktijk "dat de kamer zich niet dan in zeer bijzondere gevallen begeeft in individuele zaken". Handelingen $11,1975 / 76, p .5229$. Nicolai verdedigde in een krantenartikel dat de parlementaire kamers zich niet zouden mogen 'bemoeien' met het opsporings- en vervolgingswerk van het $O M$ in individuele lopende zaken. Well zouden ze de minister ter verantwoording kunnen roepen over beleidsmatige zaken. NRC Handelsblad 20 april $200 \mathrm{l}, \mathrm{p} .7$.

239 Stroink 1978, p. 162. Anders, met betrekking tot het requisitoir (ongemotiveerd): Elzinga 1994, p. 535.

240 Corstens 1974, p. 55; Oranje 1976, p. 15. Bestudering van de huidige kanervragen lant zien dat dit nog steeds het geval is.

241 Zie reeds Remmelink 1968, p. 171; Otamje 1976, p. 29; De Beanufort 1983, p. 160; Van Marseveen 1983, p. 180.

242 Oranje 1976, p. 15. Een beroend woorbeeld is de zaak Menien. Een recent woorbeeld van belang is de Bouwfraude-zak. In een interpellatie vroegen kamerleden om een stralfechlelijk onderzoek wen vervolging in een zaak warbij een transactie was gesloten. Handelingen II 2001/02, p. 1622-1735, 20892133; Kamerstukken II 2001/02, 28093, nr. I e.w.

243 Orarje 1976, p. 16. Oranje noent een voorbeeld uit 1973, wasrin kamerleden de minister vroegen ol hij bereid was te bevorderen dat een appël tegen een vonnis van eef rechtbank werd ingetrokken. De minister had "geen aanleiding gevonden om gebruik ta maken de bevoegdheid, omschreven in artikel 5 wan de Wet op de rechterlijke organisatie". De Gaay Fortman meent zelfs dat er sprake is van "een grens die in het gehele parlementaire optreden in incidentele affaires in acht plesgt te worden genomen: geen pogingen doen zaken te onttrekken aan een rechterlijk wordwel.' 1981, p. 125.

244 Oranje 1976, p. 19. Een voorbeeld: Aanhangsel Handelingen II 1998\%9, nr. 525. Het kamerlid vraagt hoe een vordering van het $O M$ zich werhoudt met bet rechtsstelsel. De minister legt uit waarom de wordering gedian is, en waarom deze niet in strijd is met het stelsel. Zie ook 6.2.2.6. Aanwijzing ton aanzien van het requisitoir.

245 De Doelder 1996, p. 122.

246 Een voorbeeld van een transactievoorstel, wertrouwelijk ter inzage gegeven aan de kamer is dat in de 
De antwoorden van de minister op kamervragen omtrent kwesties van vervolging zijn voorzichtig geformuleerd: ${ }^{247}$ In zijn antwoord geeft de minister een feitelijke uiteenzetting van de zaak die de vraag betreft. Hij geeft aan welke beslissingen het OM heeft genomen. De minister voegt meestal toe dat hij de genomen beslissing verantwoord acht. ${ }^{248}$ Bij gelegenheid keurt de minister hetgeen de leden van het $\mathrm{OM}$ hebben gedaan af, maar ineemt er tegelijkertijd afstand van, of neemt het in ieder geval niet voor zijn rekening. ${ }^{249}$ Wanneer de minister de leden van het $\mathrm{OM}$ in dergelijke gevallen openlijk bekritiseert zet dit de werking van de ministeriële verantwoordelijkheid onder druk. Een dergelijk handelen schaadt de verhoudingen tussen minister en ambtenaren. Als de minister het bandelen van het $O M$ publiekelijk enkel afkeurt, moet hij het ook voor zijn rekening nemen, en daaruit eventueel consequenties voor zichzelf trekken.

De minister is zoals gezegd gehouden kamervragen te beantwoorden. Een andere kwestie is of de minister moet ingaan op verzoeken uit het parlement om van zijn bevoegdheden gebruik te maken. Hij is niet verplicht om te voldoen aan een verzoek om een bevoegdheid te gebruiken. ${ }^{250}$ Als hij niet voldoet aan het verzoek kan hij daarvoor zowel politieke en juridische redenen geven. Hij kan een verzoek afwijzen met de argumentatie dat hij het niet wenselijk vindt om in te grijpen. De minister onderbouwt zijn beslissing dan met politieke argumenten. Indien een kamer hem vraagt een handeling te (doen) verrichten waartoe hij de bevoegdheid niet heeft, zal hij de kamerleden duidelijk moeten maken dat daar juridische redenen aan in de weg staan. ${ }^{251}$

Naast het stellen van vragen door individuele parlementariërs informeert de kamer zich via haar commissies omtrent het handelen van het OM en de minister van Justitie. Binnen de vaste kamercommissies kunnen zij de minister daaromtrent vragen stellen, maar ook bijvoorbeeld hoorzittingen houden. De kamers kunnen ook tijdelijke commissies instellen voor een aangelegenheid gerelateerd aan de vervolging of het $\mathrm{OM}^{252}$

Ten slotte kan de kamer besluiten tot het houden van een parlementaire enquête. Het onderzoeksobject van de commissie is niet wettelijk beperkt en wordt bepaald door het parlement. De enquêtecommissie heeft de bevoegdheid stukken op te vragen, getuigen te laten verschijnen en onder eed te verhoren. Niet voldoen aan de vorderingen van de commissie betekent een strafbaar feit. Wel kunnen getuigen zich op een verschonings-

bouwfraude zank: Kamerstukken II 2001/02, 28093, wr. 17.

247 Zie reeds Corstens 1974, p. 55.

248 Oranje 1976, p. 15; Cremers 1983, p. 51 .

249 Vootbeelden zijn de houding van Van Agt in de zaak Menten in 1976: 'Ik sta voor wat mijn medewerkens hebben gednan, wie zij ook zijn. (...) Bovendien kan ik alleen stawn woor het optreden van ambtenaren wier gedrag ik goedkeut." Handelingen $11.1976 / 77$, p. 1378. Van Maarseveen 1977, p. $212 \mathrm{er}$ 214. De uitlatingen van Kok ('niet geheel volwassen gedrag' en 'redelijk kinderachrig') en Sorgdrager (' $1 \mathrm{k}$ neem them wel het een en ander kwalijk...lk heb echt een heel sterk verwijt aan do voorzitter'), beiden in in da zaak Doeters van Leetuwen in 1998, Van Liempt \& Van Westing 2000, p. 135-136, 157158; Handelingen 11, 1997/98, p. 3667.

250 De Winter 1997, p. 1273; Corsiens 1999, p. 98.

251 De Doelder 1988 a, p. 375 . Hij kan echer niet stellen dat hij dan niet politiek verantwoordelijk is, zoals De Doelder daana beweert.

252 Omtrent de commissies: art. 15 e.w. RvOTK. Bijvoorbeeld de Tijdelijke commissie evaluatie opsporingsmethoden (Commissie Kalsbeek, rapport Opsporing in uitwoering, Kamerstukken II 1998/99, 26 269 , nrs. 4-5). 
recht of een geheimhoudingsplicht beroepen. Desgewenst kan de commissie de minister van Justitie, voormalige bewindslieden en leden van het OM horen. De commissie kan tewens gebruikmaken van documenten uit strafzaken, zoals processen-verbaal. Enquêtes komen weinig voor, de laatste vijftig jaar nog geen tiental, de meeste echter wel in de laatste decennia. Wel hadden sommige onderzoeken (mede) betrekking op strafbare feiten of het handelen van het $O \mathrm{M}^{253}$

Een (eventueel jaarlijks) systematisch beraad over het algemeen vervolgingsbeleid tussen minister en kamers bestaat niet. Het parlementaire debat heeft zelden betrekking op principiele beleidsombuigingen in het vervolgingsbeleid. Er bestaat weinig parlementaire controle over de algemene beleidslijnen van de vervolging. ${ }^{254}$ Het jaarverslag van het OM wordt niet besproken zoals bijvoorbeeld de jaarlijks terugkerende behandeling van het verslag van de ombudsman. Hoogstens wordt er nog terloops aan het verslag van het $\mathrm{OM}$ gerefereerd in de dialoog tussen regering en parlement. ${ }^{255}$ Hoewel het algemene vervolgingsbeleid zelden in de kamer ter sprake komt, is op een aantal specifieke terreinen van het vervolgingsbeleid wel sprake van parlementaire controle. $\mathrm{Zo}$ is er veel aandacht voor het beleid ontrent zaken als euthanasie en drugserimina liteit. $^{256}$

\subsubsection{Sanctionering ministeriële verantwoordelijkheid}

In de sanctiefase staat het parlement een aantal correctiemiddelen ter beschikking om te reageren op de verantwoording van de minister. Een kamer kan een motie aannemen, de Justitiebegroting wijzigen en op eventuele andere manieren haar kritiek laten blijken. In enkele gevallen is het handelen van het OM onderwerp van een motie. Daarin

253 Zie Wet op de Partennentaire Enquête. Het belangrijkste voorbeeld was de Enquêtecommissie Opsporingsmethoden, waarbij leden van het $O M$ en zowel züttende als voormalige ministers van Justitie gehoord werden (Commissie Van Traa, rapport Inzage opsporing, Kamerstukken 111 1995/96, 24072, nr. 11). Zie onk de recente Bouwfraude-enquểte, ingesteld na Kamershukken II 2001/02, 28093, nr. 11. In de Bijlaner-enquête gebruikte de commissie geanonimiseerde processen-werbaal. Kamerstukken II 199899, 26242, nr. 3, De Enquêtecommissie Opsporingsmethoden makkle afspraken voor bronbescherming, Kamerstukken II 1994/95, 24072, nt. 3.

254 Oranje 1976, p. 29; De Gaay Forman 1981, p. 120; De Beaufori 1983, p. 160; Van Maarseveen 1983, p. 180.

255 Het janrwerslag wordt ook niet meer als kimmerstuk gedrukt. Tot het wer\$lag ower 1986 was dit nog het geval. De penvoerder van de vergadering wan procureurs-generall was in het verteden wel eens anthwezig bij de bespreking van luet verslag. Kosto 1986, p. 202. Hoogstens wordt het jarrverslag van het OM een enkele keer genoemd. Bijvoorbeeld: Behardeling van de begroting van het Ministerie vall Justitie woor het jaar 1994, Handelingen II $1995 / 96$, p. 1804; woor het jaan 1999, Handelingen If 1998\%9, p. 1243, 1311. Algemene politieke besehouwingen inzake thet in 1996 te woeren beleid, Kamerstukken I 1995/96, p. 191 . Beleidsdebat inzake Justitie, Handelingen I 1995/96, p. 1715.

256 Behandeling wan stukken m.b.t. vervolgingsheleid inzake euthanasie, Handelingen II 1994/95, p. 3078 e.x. Algemene politieke beschouwingen inzake het in 1996 te voeren beleid, Handelingen 1 1995/96, p. 172. Beleidsdebat inzake Justitie, Handelingen I 1995/96, p. 1702 e.v. Debat nell de regering over bei rapport Enquêtecommissie Opsporingsmethoden, Handelingen II $1995 / 96$, p. 5264 e. ., 5345 e.v., 5423 e.v. 5461 e.v. Behandeling begroting Justitie voor 1997, Handetingen $111996 / 97$, p. 2348. Behandeling brief ministers van Justitie en VW/S ower het vervolgingsbeleid inzake euthanasie, Handelingen I 1997/ $98, \mathrm{p} .1460 \mathrm{e} . \mathrm{v}$. Behandeling begroting ministerie van Justilice voor 2000 , Handelingen If $1999-2000$, p. 1254. Behandeling notitie Vervolgingsbeleid euhanasie, Handelingen $120000 \mathrm{I}, \mathrm{p} .1211 \mathrm{e.}$. Zie woor relevante kamerstukken noot 236. 
vraagt de kamer de minister dan veelal te bewerkstelligen dat het OM overgaat tot een door een meerderheid gewenste handelswijze. ${ }^{257}$ Als uiterste sanctie kan een kamer de vertrouwensregel toepassen. Deze sanctieniddelen kan de kamer gebruiken onafhankelijk van de vrag of de minister in kwestie een relevante bevoegdheid had. Het gebruik van de motie van wantrowwen kan geheel los staan van de wijze van verantwoording van de minister. De vertrouwensregel is aldus gebaseerd op een volkomen subjectief criterium. $^{258}$ In enkele gevallen werd een motie wan wantrouwen ingediend omtrent het handelen van de minister tegenover het OM. In geen enkel geval is een dergelijke motie tegen en minister van Justitie aangenomen. ${ }^{259}$ Aangezien er veel politieke belangen spelen is het 'op een gegeven ogenblik de moeite niet waard, politiek gezien, om een overigens geaccepteerd minister lastig te vallen of te laten verdwijnen voor het individuele geval". 260

De minister kan daarnast zelf besluiten om op te stappen als hem blijkt dat de kamer geen vertrouwen in hem heeft. Tot nu toe hebben twee (voomalige) ministers van Justitie hun functic om deze reden neergelegd naar aanleiding van een kwestie die mede het functioneren van het OM betrof. ${ }^{261}$ Veel ministers in de afgelopen halve eeuw hebben hun volledige temijn uitgezeten. Meerdere keren stapten ministers van Justitie op tezamen met partijgenoten of thet hele kabinet om politieke redenen die niets met de strafvervolging van doen hadden. Enkele ministers hebben wel uitdrukkelijk hun ont-

257 In de Bloemenhove-zaak stelden kamerleden wel een motie voor dat de minister all zou zien van vervolging. Tevens werd gevaagd dat de vordering tot het verlenen van verlof om huiszoeking ter inbeslagneming ingetrokken zou worden. Kamerstukken II 1974/75, 13161, nr. 4-5, 1975/76, 13922, nr. 1-3; Oranje 1976, p. 16-17. Minister Van Agt sprak ten anzien van de aangenomen motie ni. 3 wan een "staatsrechtelijk ontoelaabare interventie van de Tweede Kamer (...) met de wijze warrop het openbaar ministerie in en individuefe stralzakk wel of niet zou procederen. " Kamersiukken III 1975/76, 13964, nr. 1, p. 2. Niet valt in te zien waarom daarvan sprake was. Kamernoties zijn niet aan inhoudelijke normen onclerworpen. Vgl. Hoefer 1976, p. 1021.

In de Bouwfraude-zak nam de Tweede Kamen moties an on de minister beklag un te laten stellen tegen de transactiebeslissing van het $O M_{\text {, }}$ on het transactiebeleid aan te passen, en om in een verwante wak een strafrechlelijk onderzoek in te stellen. Kamerstukken $11200102,28093, n \%, 1,5,6,14,15$; 28216, nr. 3. Dit leddde onder andere to de Aanwijzing hoge thansacties en transacties in bijzondere aken var het Collage.

258 Commissic Scheltema 1993, p. 12,13, Elzinga 1994b, p. 45, Kortmann 2001, p. 294-295.

259 Motie Marijnissen met betrekking tother ontslag van procureur-genemal Randwijck in 1995 , Kamersmkken II 1995/96, 24470, nt: 5. Motie Marjunissen met betrekking tot de verwikkelingen rond de nevenfunctie van procureur-generan Stecnhuis in 1998, Kame"stukken ll 1997/98, 25852, mir. 3; Motie Rosenmöler en Poppe met betrekking tor de ransactie in de fraudezak bij de Schphothmel in 2001 , Kamerstukken II 2001/02, 28093, nt" 16 .

260 Duisterwinkel 1968 a, p. 109.

261 In 1994 verzocht Minister Hirsch Ballin de Koringin hem ontslag te werlener madat een motie Dijkstal Was aumgenomen door de Tweede Kamer. Het betrof owerigens geen motie van wantrouwen die de münister to aftreden werphichte. De mote was gericht tegen de vorming en ansturing van de interregionale rechercheteams door de ministers wan Binenlandse zaken en Justitie die "ernstig tekort geschoten" Waren in de samenwerking. Ook minister van Binnenlandse zaken Van Thijn trad daarop al. Handelingen II $1993 / 94$, p. 5273,5280 . Kamerstukken II 1993/94, 23593, ar. 14 en 15. Minister Korthalls trad in 2002 af naar anleiding van de bouwfraude-enquête. Hij werd bekritiseerd ondat hij de kamer onjuist geunformeer zou hebben over en transactie warr het College hem had over ingelicht. Overigens was Korthals op het moment van aftredien minister wan Defensie, ma in het kabinet daarvóor de functie wan minister van Justitie bekleed te hebben. 
slag overwogen in verband met het functioneren van het OM (Van Agt in 1976, Sorgdrager in 1998). 2.2

\subsection{Verantwoording OMan het parlement}

Ten slotte vindt een zekere vorm van verantwoording van het handelen van het OM plaats door directe contacten met de kamer of de publieke opinie. In het verleden kwam het In ieder geval voor dat individuele kamerleden informatie inwonnen bij een parket. zonder tussenkomst van de ministers. ${ }^{263}$ Daamaast heeft de vaste commissie voor Justitie van de Tweede Kamer de procureurs-generaal eens in een besloten vergadering ontvangen. ${ }^{264}$ Verder kan een kamer zoals gezegd een enquêtecommissie instellen die desgewenst leden van het OM direct kan ondervragen. Andersom gebeurde het een enkele keer dat het OM een brief direct aan de Tweede Kamer zond. ${ }^{265}$ Ook bestonden zekere informele contacten tussen onder meer procureurs-generaal en kamerleden. ${ }^{266}$

\subsection{Conclusie}

De minister is zonder beperkingen aanspreekbaar voor alle vormen van handelen van het OM. Gezien het bestaan van specifieke bevoegdheden - zoals de aanwijzing tot vervolging - moet hij dit handelen ook verdedigen en voor zijor rekening nemen. De minister verantwoordt het handelen geregeld op eigen initiatief. Daarnaast moet hij veel kamervragen hierover beantwoorden. Deze vragen bestrijken het gehele gamma van handelen van het OM. Een regelmatig debat over het samenhangende, algemene vervolgingsbeleid vindt niet plaats. Bepaalde onderdelen krijgen wel specifieke aandacht. Sanctionering van de ministeriele verantwoordelijkheid voor het OM heeft nooit het uiterste karakter van een motie van wantrouwen gehad. Enkele keren stapte een minister van Justitie in dit verband wel op eigen initiatief op. Daarnaast vullen vormen van directe verantwoording aan het parlement de ministeriële verantwoording enigszins aan.

262 In 1976 overwoog Van Agt zijn ontslag gezien de pastelling in de Bloemenhove-zaak. Kamersikken II $1975 / 76,13964$, nr. 1, p. 4. Sorgdrager yroeg zich tijdens de kwestie Docters van Leawen in 1998 af of zij niet moest aftreden, gezien de omstreden nevenfunctie van procureuf-generaal Steenhuis. Van Liempt \& Van Westing 2000, p. 154-155.

263 "t Hart 1999, p. 114-115. In 1976 zocht en ontwing Roethof informatie bij de officier van justitie in de zaak Bloemenhove, Handelingen II 1975/76, p. 4226; Een recent woorbeeld: NRC Handelsblad 22 december 1999 , p. 2.

264 Jurgens. 1994, p. $271-272$.

265 De zogendamd Domburgbrief uit 1996. Vgl. Van Liempt en Var Westing 2000 , p. 33.

266 Van Liernpt en Van Westing 2000, p. $35,78,145$. Overigens vond een enkele keer een vorm van verantwoording wan of controle op hel vervolgingsbeleid plats door de Algemene Rekenkamer. Zie: Opsporing en vervolging van fraude, rapport van de Algemene Rekenkamer, Kamerstukken II 2000/, 27555 , nr. 2. Het rapport werd op eigen initiatief geschreven raar aanleiding van het uitbrengen een kabinetsnotitie over fraudebestrijding. 


\section{Samenvatting en conclusie}

In Nederlland zijn OM en minister gesprekspartners, zij het in ongelijkwaardigheid. Het $\mathrm{OM}$ is volkomen ondergeschikt in rechtspositie en functionele relaties. De organisatie is evenwell niet nauw politiek geaffilieerd aan de minister, die zich terughoudend moet opstellen. De bewindspersoon heeft wel de middelen om zich goed te doen informeren en betrokken te zijn via overleg. Hij staat verder onder voortdurende parlementaire aandacht.

De leden van het Nederlandse OM maken deel uit van de rechterlijke macht. Deze kwalificatie brengt nauwelijks effectieve gevolgen met zich.

Het $O M$ is hiërarchisch en eenvormig georganiseerd. Leidinggevenden hebben allesbestrijkende bevoegdheden. Het hoogste orgaan, het College kan in alle aspecten het laatste woord hebben. Individuele leden van het OM hebben intern geen enkele gewaarborgde handelingsvrijheid. In de praktijk is de organisatie wel sterk gekarakteriseerd door overleg op en tussen alle niveaus.

Het OM heeft op strafrechtelijk gebied een waaier aan bevoegdheden. Het stuurt stevig in de opsporing, past dwangmiddelen toe en kan op vele manieren zaken afdoen zonder rechterlijke tussenkomst. Belanghebbenden kunnen zich tegen (het gebrek aan) initiatieven van het $O M$ wel weren bij de rechter.

De minister is onderdeel van een coalitie. Deze besluit door consensus mede over zaken aangaande het vervolgingsbeleid. De minister wordt ondersteund door een ministerie dat een politiek neutraal apparaat is, dienend aan de minister.

De rechtspositie van leden van het $\mathrm{OM}$ is formeel zwaar gedomineerd door regeringsinvloed. Benoemingen, disciplinaire en ontslagprocedures zijn afhankelijk van de overwegingen van de minister en het kabinet. Feitelijk lijkt van politisering van het $\mathrm{OM}$ echter geen sprake. Wel wordt bij gelegenheid een opmerkelijk gebruik gemaakt van met name disciplinaire sancties en ontslagbevoegdheden.

De minister heeft een allesomvattende functionele greep op het $\mathrm{OM}$. Hij kan zich op de hoogte stellen van landelijk en lokaal beleid en specifieke strafzaken. Zijn bevoegdheden kunnen al het handelen van het OM raken. De minister wordt evenwel geacht terughoudend te zijn met het gebruik daarvan. Hij oefent feitelijk ook vrijwel geen formele bevoegdheden uit, maar pleegt well regelmatig overleg met het College.

Het ministeriële contact met de kamers is eveneens uitvoerig. Het parlement wordt tot op details van strafzaken ingelicht, maar debatteert ook mee over het vervolgingsbeleid ten aanzien van afzonderlijke delicten. De kamers uiten zich evenwel niet over de samenhang van prioriteiten in het gehele beleid. Over afzonderlijke relevante aangelegenheden kan de verantwoordelijkheid wel sanctionerende gevolgen hebben voor de minister.

Het Nederlandse OM kenmerkt zich door juridische ondergeschiktheid. Het heeft echter een sterke structuur en is in feite rechtspositioneel en functioneel autonoom. Tegenover zich heeft het een machtige, maar terughoudende minister die zich intensief verhoudt met het parlement. Overleg vormt het bindmiddel tussen OM en minister. 


\title{
Hoofdstuk 3
}

\section{Verhouding tussen OM en minister van Justitie in Frankrijk}

\author{
Dans un pays, wh Etat er un Ministere public \\ penvent suffre au bonheur des citoyens, \\ Carbonnier, Droit civil, 1962,1, p. 281.
}

\section{Inleiding}

Niet alleen het bonheur van de burgers, ook dat van politici kan gediend zijn met het OM. Het hiërarchisch gestructureerde Franse OM vormde in de ogen van sommige politici een nuttig instrument om het eigen malheur te voorkomen. Het wegmoffelen van strafzaken blijkt echter slechts wanneer het mislukt. Zoals wanneer een minister tevergeefs een helikopter aanstuurt achter een parkethoofd dat vakantie houdt in de Himalaya. Een dergelijke actie kan van belang zijn om te garanderen dat zijn parket conform de procedures handelt. Daarnaast had die bij kunnen dragen tot het geluk van een vervolgde partijgenoot van de minister."

Een dergelijke affaire wekte niet alleen de hoon op van het Franse parlement, maar prikkelt ook de interesse voor het functioneren van de Franse relatie tussen de minister van Justitie en het OM. De volgende vragen werpen zich op: Hoe steekt de organisatie van het OM in elkaar? Welke bevoegdheden oefent het uit? Wat is de positie van de minister van Justitie en de President? Welke rechtspositie hebben de leden van het OM? Wat voor bevoegdheden heeft de minister ten aanzien van het handelen van het OM? Op welke wijze legt hij verantwoording af in het parlement voor de vervolging? Deze kwesties komen achtereenvolgens aan bod.

\section{Organisatie van het OM}

Welke plaats heeft het OM binnen de overheid? Uit wellke onderdelen bestaat het? Analoog aan de analyse van het Nederlandse OM bekijk ik eerst de verhouding van het Franse OM met de rechterlijke macht en de interne opbouw van het OM.

\subsection{OM en rechierlike mach}

Het bestaan van thet OM is vastgelegd in de Franse grondwet in artikel 65. Deze tekst duidt de leden ervan aan met de term magistrats du parquet. ${ }^{2}$ De grondwet zegt evenwel niets over de functies die het parket zou moeten hebben. Wel blijkt iets over de rechtspositionele status uit de grondwet. Deze status wordt in samenhang met de leden van de rechterlijke colleges beschreven. Leden van het $\mathrm{OM}$ en rechters zijn allen

1 Zie over deze zaak 6.3.1.3. Aanwijzing tot niet-vervolging.

2 Art. 65. - "Le Conseil Supérieur de la Magistrature est présidé par le Président de la République. Le Ministre de la Justice en est le vice-président de droit. II peut suppléer le Président de la Républiqule.

Le Conseil Supérieur de la Magistrature comprend deux formations, l'une compétente à l'égard des magistrats du siège, l'autre à l'égard des magistrats du parquet...' 
onderdeel van de rechterlijke macht. In het Frans wordt hiervoor met name het grondwettelijke begrip autorité judiciaire (art. 64 en 66 Const.) gebruikt, maar ook wel de term corps judiciaire.

De laatste kwalificatie komt uit de ordonnantie op het statuut van de magistratuur (hierna 'ord.', art. 1). ${ }^{3}$ Corps judiciaire slaat op de ambtenaren die deell uitmaken van de rechterlijke macht. Het heeft alleen betrekking op de rechtspositie van de leden. De 'magistraten van het parket' delen die voor een groot deel met de andere leden van de rechterlijke macht. Het begrip corps judiciaire onderscheidt de rechtspositie van leden van het OM aldus van die van andere ambtenaren. Het verwijst niet direct naar de staatsrechtelijke verhouding van thet OM met andere overheidsorganen.

Dat doet de term autorité judiciaire wel. De grondwetgever noemt de autorité alleen (art. 66), maar geeft er geen definitie van. De jurisprudentie van de Conseil constitutionnel geeft hierover wel uitsluitsel. In twee uitspraken interpreteert de Conseil het begrip zó dat het eveneens het OM omvat. De grondwet garandeert mitsdien de eenheid van de rechterlijke macht. Het OM behoort zo uitdrukkelijk niet tot de administration. Deze laatste stelt de grondwet ter beschikking van de regering (art. 20). ${ }^{4}$

Deze eenheid betreft vooral de rechtspositie van de leden van de rechterlijke macht. In functionele zin heeft de kwallficatie maar beperkte betekenis. Zij brengt niet mee dat het $O M$ mede een rechterlijke functie uitoefent, of functionele onafhankelijkheid geniet. Wel is artikel 64 Const. in deze van belang. Dit bepaalt: 'De President van de Republiek staat garant voor de onafhankelijkheid van de rechterlijke macht.' Aangezien nu het OM deel is van de rechterlijke macht, deelt het ook in deze 'onafhankelijkheid'. Die wordt voor het OM evenwel geheel anders ingevuld dan voor de rechters. Zoals in paragraaf 6 aan bod zal komen heeft de minister van Justitie een aanwijzingsbevoegdheid tegenover het OM. Deze bevoegdheid nu is niet in strijd met de constitutionele eis van onafhankelijkheid van de rechterlijke macht. Op die aanwijzingsbevoegdheid bestaan namelijk enkele beperkingen. Deze ziet men als voldoening aan de grondwettelijke "onafhankelijkheid" van het OM als onderdeel van de autorité judiciaire. De genoemde beperkingen laten het OM echter geenszins functioneel geheel onafhankelijk. De eerste beperking is namelijk het eenvoudige gegeven dat de minister niet zelf de vervolging kan uitoefenen. Een tweede is de vrijheid van het mondeling requisitoir. Voor het overige kan de minister het $\mathrm{OM}$ in principe sturen door het geven van aanwijzingen. ${ }^{5}$

De grondwet heeft zo vrij weinig betekenis voor de functionele positie van het parkett. De lhoogste wet stat wel in de weg aan institutionele wijzigingen die een verdergaande onderschikking inhouden. Zo zou de formele toebedeling van de bevoegdheden van thet OM aan de minister van Justitie in strijd zijn met de grondwet.

3 De ongmise wet betreft ord $58-1270$ wan 22 december 1958 , meermads gewijzigd.

4 Conseil constitutionnel 5 en $\| 1$ augustus 1993. Zie Volff 1998, p. 24-25; Casorla 1999, p. 34 e. \%.

5 Malibert 1994, p. 20: Delnus-Marty 1994, p. 153. Nader over deze beperkingen zie: 6.3.3. Rechtswasborgen bij aanwijzingen. Enkel Mathias is wan mening dat deze onafhankelijkheid meebrengt dat de ministar geen aanwijing tot niet-vervolging zou nogen gewen. Zie 6.3.1.3. Aanwijzing tot nietvervolging 
De grondwetsartikelen hebben verder enkel enige gevolgen voor de rechtspositje van het OM. Deze gevolgen dankt het aan het bestaan van de Hoge Raad voor de Magistratuar (Conseil Superieur de la Magistrature. CSM). In paragraf 5 zal blijken dat de grondwet de raad vraagt om adviezen te geven in de disciplinaire procedure en over de meeste benoemingen binnen het OM. Deze adviezen zijn juridisch echter niet bindend. Harde rechtspositionele waarborgen geeft de grondwet het OM niet.

De CSM zelf bestaat uit twee secties, éen voor de zittende en één voor de staande magistratuur. Een plenair college bestaat formeel niet. Elke sectie heeft twaalf beden. In beide secties zijn dat de President en de minister van Justitie. Daamaast zit in elke sectie een lid benoemd door de President, twee leden benoemd door de beide kamervoorzitters en een lid van de Raad van State. Ten slotte maken zes door hun collega"s gekozen magistraten deel wit van een sectie. In de sectie voor het OM zijn dat vijf leden van de staande en één van de zittende magistratuur. Leden van de rechterlijke macht kunnen aldus niet overstemd worden door buitenstaanders in de CSM. Wal vormt de raad een verbindingsschakel tussen de autorite judiciaire en andere centrale overheidsambten."

De relatie tussen de rechterlijke macht en de andere machten is evenwel problematisch in Frankrijk. De doctrine ziet in de Franse séparation de pouvoirs geen gelijkwaardige plaats weggelegd voor de rechterlijke macht. Deze conclusie wordt gestaafd door het grondwettelijke begrip autionte judiciaire. De grondwet gebruikt niet een voor de hand liggende term als powvoir judiciaire. In andere wetgeving komt die evenmin voot. De rechterlijke macht staat dan ook niet helemaal op een 'gelijk' niveau als de powvir exécutif en de pouvoir législatif. De 'lagere' plaats van de autorité in het constitutionele bestel is gegrondvest op parlementair-democtatische overwegingen. De rechterlijke macht wordt namelijk niet door verkiezing gelegitimeerd, zoals voor de andere machten geldt. De autorité judiciaire is aldus 'slechts" een openbare dienst ("service public"), volgens sommigen zelfs een administration. ' Overigens heeft dit onderscheid tussen "autorité en "pouvoir" geen directe juridische gevolgen. Het is wel een uitdrukking van de rechtscultuur achter het systeem. Het werkt met name door in de formulering van de ratio van het Franse stelsell, waarover in hoofdstuk 6.

Opvallend is evenwel dat de tekst van de grondwet de regering en het parlement nergens respectievelijk pouwoir exécutif en pouvoir législatif noemt. De grondwêt maakt geen terminologisch onderscheid tussen pouvoirs en autorité. Dé pouvoir exécutif en législatif komen wel voor in de preambule van de Déclaration des droits de l'homme et du citoyen van 1789. Deze noemt de rechterlijke macht echter helemaal niet. De drie begrippen bestaan slechts maast elkaar in de wet van 3 juni 1958, die de re-

6. De rad heefit een hervorming ondergaan bij l.const. n. $93-952$ van 27 juli 1993 en l.org. n. $94-100$ wan 5 februar 1994. Voorheen had de CSM elle leden, en waren zij behalve de President zell an de mimister allen benoemd door de President. Deze raad had zelfs geen adviesbevoegdheder ten abmion vali de rechspositio van het OM. Zij had enkel een functie woor de rechtsprekende leden van de ruchterlijke macht. Voor verdergaande thervormingen: hoofdstuk 7, m.n. 3.5.1. Ministeriele zegeenswhap. Perrot 1998, 40 e.w. Wheent e.a. 1999 , p. 122 e.v.; Albers Voemans 1999, p. 46 e.w.

7 Beteille, Commission de réflexion sur la Justice, Annexes 1997, p. 59; Zoller 1999, p. 340 en 349; Vincent e.t. 1999, p. 90-91. Contra: Matagrin 1996, p. 114. Wolgens hen dient simpelweg geen onderscheid gemaakt te worden tussen de "pouvoirs" en de "atutorite". 
gering van De Gaulle de bevoegdheid gaf een nieuwe grondwet voor te stellen. De wet geeft hoofdlijnen aar waarop de daaropvolgende grondwet gebaseerd zou moeten zijn. De tekst van deze wet noemt als enige zowvel de pouvoir exécutif en de pouvoir législatif als de autorité judieiaire. Andere, geldende wetten noemen de autorite judiciaire nog wel afzonderlijk.

Samengevat zijn het bestaan van het Franse OM en zijn eenheid met de rechterlijke colleges grondwettelijk gewaarborgd. De relevantie hiervan is betrekkelijk. De grondwet biedt vrijwel geen functionele garanties voor het OM. Op het rechtspositionele vlak hebben de grondwettelijke taken van de CSM wel enige betekenis. Als onderdeel van de rechterlijke macht heeft het OM echter een 'ongelijkwaardige' positie ten opzichte van de andere staatsmachten.

\subsection{Interne organisatie}

Het OM wordt in Frankrijk nooit gedefinieerd als zou het op enige manier deel uitmaken van het ministerie van Justitie. Het OM staat organisatorisch volkomen los van het departement. Evenmin karakteriseert men het $\mathrm{OM}$ als een vorm van déconcentration. Dit begrip wordt enkel gebruikt ten aanzien van instellingen die deel uitmaken van de administration. In de vorige paragraaf bleek reeds dat het $\mathrm{OM}$ daar niet geacht wordt deel van uit te maken.

De organisatie van het OM loopt grotendeels, maar nier helemaal gelijk met die van de rechterlijke colleges. ${ }^{8} \mathrm{Er}$ is een parket bij elk van de 181 hoofdrechtbanken (tribunatx de grande instance). De procureur van de Republiek heeft hier de leiding over de substituten, de eventuele adjunct-procureurs van de Republiek en eerste substituten. Bij sommige parketten is er ook een eerste adjunct-procureur. Dit parket oefent strafrechtelijke functies uit bij de correctionele rechtbank (tribunal correcrionnel), die onderdeel is van elke hoofdrechtbank. De tribunal correctionnel is competent voor misdaden, behalve de allerzwaarste (alleen délits). Bij de hoofdrechtbank zelf dienen overigens alleen civiele zaken. ${ }^{9}$ Verder nemen de parketten bij de rechtbanken de vervolging op zich wan zaken voor de politierechter (tribunal de police). Deze behandelt alleen overtredingen (contraventions). Veelal zijn het hier politieambtenaren die de vervolging uitoefenen, onder leiding van het parket bij de rechtbank. ${ }^{10}$ Zaken bij de kinderrechtbank (iribunal pour enfonts) worden behandeld door het parket bij de rechtbank in wiens ressort de kinderrechtbank zetelt. ${ }^{11}$

Boven de lagere parketten staat een parket-generaal bij de 35 hoven van beroep (cours d'appel). Aan het hoofd van deze parketten staat een procureur-generaal. Zijn onder-

8 Ze maken integraat deel uit van de gerechten waar zij thun functie uitoefenen. Ze zijn dan ook deel van de personele bezetting en het budget wan het gerecht. Volff 1998, p. 26. Overigens noemt de wet alleen voor het Hol wan cassatie de leden van het parket als onderdeel wan het hof (art. L121-1 COI).

9 Art. L311-14, 15 COI art. 39, $24 \| \mathrm{CPP}$.

10 Art. L623-1 - 623-2 COJ: art. 39, 44, 45 en $48 \mathrm{CPP}$. De politierechter zetelt meestal bij elke gewone rechtbank, waarvan er 473 zijn

11 Art. L.521-1-522-6 COJ; art. $8-9$ ord. n. $45-174$ van 2 februari 1945. 
geschikten zijn advocaten-generaal en substituten-generaal. Bij sommige hoven van beroep fungeren ook een eerste advocaat-generaal en een eerste substitunt-generaal. De parketten-general hebben de verwolging van zaken in hoger beroep als hoofdtaak." Tevens behandelen zij de zaken die dienen voor de hoven van assisen (cours of "assises). Daar komen de zware miscladen voor de rechter (crimes). De parketten bij de hoven nemen overigens enkel de vervolging van deze zaken op zich. De rechtbankparketten beslissen over het instellen van de wervolging. ${ }^{13}$

Ten slotte is het parket-generaal bij het Hof van cassatie (Cotr de cassation) onderdeel van het OM. De procureur-generaal wordt aldaar ondersteund door advocaten-generaal, substituten-generaal en een eerste advocaat-generaal. De procureur-generaal bij het Hof van cassatie heeft geen bevoegdheden over de andere parketten. Hij verzorgt de vervolging bij het Hoge Hof van Justitie (Hawte Cour de justice) en het Hof van Justitie van de Republiek (Cour de justice de la République). Deze hoven zijn competent ten aanzien van respectievelijk hoogverraad gepleegd door de President en delicten gepleegd in de uitoefening van de functie van ministers. ${ }^{14}$

In total bestond de rechterlijke macht in 2001 uit ruim zesduizend magistraten. Ongeveer een kwart daarvan was lid van het $\mathrm{OM}{ }^{15}$

De verhouding tussen hogere en lagere parketten is grotendeels hiërarchisch van aard. De procureur-generaal bij het hof van beroep heeft in beginsel de leiding over de parketten van het OM in het betreffende ressort. Hij kan de respectievelijke hoofden aanwijzingen geven. Dit kumnen algemene beleidsregels zijn, maar ook aanwijzingen tot vervolging of ten aanzien wan het schriftelijke requisitoir. Aanwijzingen tot viet-vervolging kan hij niet geven. Evenmin heeft hij zeggenschap ten aamzien van het mondelinge requisitoir. Zijn leidinggevende positie brengt ook niet mee dat de procureur-generaal een bevoegdheid kan uitoefenen in de plaats van een lager parket. Hij kan ook geen voorafgaande instemming eisen voordat lagere parketten een bepaalde actie ondernemen. ${ }^{16}$

De hoofden wan de parketten bij de rechtbanken dienen hun procureur-generaal op de hoogte te houden van relevante zaken. Bij belangrijke zaken melden zij deze zo snel

12 Art L121-1,1.213-4 COJ; ant. 34 CPP.

13 Art. L621-1 COJ; ant 231-267, 288, 289, 295-305, 371 CPP. Het hot van assisen is in alk hol valu beroep gesitued. Overigens kom het woo dat de rechbankparkethen deze tak behatigen, wanner de

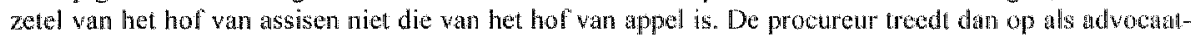
generaal (art. 39 lid 2 CPP). De rechterlije indeling van de nechterlijke colleges en bijhehorende parketten is geregeld bij art. R212-1, R311-7, R321-31, R621-1 COJ en annexe tabellen n. 1 ch 5 en alt. R41CPP.

14 Art. 67 - 68-3 Const. Zie over thet Cour de justice de la République ook 6.4. Toestemming voor vervolging en 7.2. "Verantwoordingsproces. Ower de procureur-generall bij het Hol van cassatio: Clat"bonnier 1991, p. 316 e.w.; Maynier \& Casolla 1993, p. $541 \mathrm{e.v}$.

156846 magistraten werkten bij de gewone rechterljke mach (exchsief administratieve rechlors). Minustere de la lustice 2002, p. 11; htp://www justice.gowv.fr/chifres/chiffres.htm. Gegevens over bet precieze aantal leden wan thet OM wat hieronder valt geeft het ministerie niet ill zjn jaarlijkse begroting.

16 Art. 5 ord; art. 37 CPP. VolfT 1998, p. 36, Lemesle \& Pansier 1998, p. 44. Volgens Rassat zou de procureur-generaal theoretisch everhee direct and de substituten eet anwijzing geven. Praktisch heefl dit geen betekenis. Rassat $1967, \mathbb{1}$. 116. 
mogelijk. Daarnaast zijn ze wettelijk verplicht maandelijks een verslag te geven van de behandelde zaken. In deze vorm vindt die regel evenwel vrijwel geen toepassing meer, aangezien de parkethoofden hun procureurs-generaal stelselmatig informeren over individuele dossiers. ${ }^{17}$ Ten slotte heeft de procureur-generaal een algemene toezichtstaak ten aanzien van lagere parketten. Samen met de eerste president van het hof ziet hij toe op het functioneren van de parketten en rechterlijke colleges van het ressort. $\mathrm{Zij}$ hebben daarbij de gezamenlijke taak deze ambten te inspecteren. ${ }^{18}$

Binnen het Franse OM bestaat een aantal overlegcircuits. Sinds enkele jaren bestaat verder een praktijk waarbif procureurs-generaal regelmatig de لeden van het OM van hun ressort bijeenroepen om het strafrechtelijk beleid te harmoniseren. Deze vergaderingen hebben een informele status. Hoogstens kunnen de resulterende conclusies achteraf nog vorm krijgen in een aanwijzing van de procureur-generaal. Daarnaast bezoeken procureurs-generaal elk jaar de parketten van de hoofdrechtbanken. ${ }^{19}$ De lokale parketten komen in principe alleen bijeen in de genoemde vergaderingen onder het voorzitterschap van hun gezamenlijke procureur-generaal. De procureurs-general zelf zien elkaar sinds eind jaren negentig geregeld in de Confërence nationale des procureurs généraux. Zij komen bijeen om te spreken over meer concrete problemen van vervolging en strafrechtelijke politiek. Deze conferentie heeft evenmin een juridjsche vorm of bevoegdheden ten aanzien van ambten van het OM. Wel heeft de instelling permanent een voorzitter en eigen secretariaat. De Conferentie komt niet op regelmatige tijden bijeen, maar ongeveer vier, vijf keer per jaar. De vormgeving van de Conferentie lijkt nog in ontwikkeling. De grote omvang van de 35 leden tellende vergadering maakt het tot nog toe een weinig effectieve instantie. Los van de nationale conferentie vergaderen de procureurs-generaal van een bepaalde regio ook jaarlijks een aantal malen. Het gaat dan om ongeveer vijf ambtsdragers die het beleid en de problematiek van het betrokken gebied bespreken. Deze vergaderingen zijn eveneens officieus. ${ }^{20}$

De interne organisatie van elk parket en parket-generaal is sterk hiërarchisch. Zoals gezegd staan de procureur-generaal en de procureur van de Republiek aan het hoofd van hun respectievelijke parketten. Zij hebben de leiding over de andere leden, die hun ondergeschikten zijn en hun aanwijzingen moeten opvolgen. Het parkethoofd heeft verder de taak de werkzaamheden van zijn substituten te verdelen. Daarbij houdt hij rekening met dé onderdelen van het parket - parketdiensten - en de kamers van het betrokken rechterlijk college. ${ }^{21}$ Indien een parketlid een strafrechtelijke bevoegdheid uitoefent tegen de wens in van het parkethoofd is de handeling wel rechtsgeldig. Het hoofd kan

17 Maliber 1994, p. 24. De makndelijkse verstaglegging is geregeld in att. 35 lid 2 CPP. De plicht voor lagcre parketien on de procureur-generaal ook daarbutem op de hoogte to stellen van lopende zalken is niet geregeld. Do doctrinc neemt aan dat dexe plicht voortwloeit uit de tussen dexe organen bestande hitrarchische relatie. Volti 1998, p. 37; Pradel 2000, $\%$. 127. Alleen Rassat is van mening datt de parketm ten wat gohouden zijn on an de procumer rapportage om, 1996, p. 106.

18 Art. R2 $13-29 \mathrm{COJ}$

19 Conmission de rétlexion sur la Justice 1997, p. 25 en $31, \mathrm{Volff} 1998, \mathrm{p} .45$.

20 Conference nationale des procureurs générax, Commission de réfexion sur la Justice, Annexes 1997 , 1). 400. Overigens komen ook de presidenten wan de hoven op gezette tijden bijeen. Feen en ander bljk wit gesprekken met OM-ledert.

21 Art 34 en 44 CPP; art R132-1-R132-2, R213-21-R213-23, R311-34 e.r. COJ. 
deze handeling vervolgens niet vernietigen of annuleren. Tegen de wens van het hoofd in handelen kan wel disciplinaire gevolgen hebben. ${ }^{22}$ Anders dan de procureur-generaal kan het parkethoofd zich desgewenst in de plaats stellen van zijn ondergeschikten om een procesrechtelijke bevoegdheid uit te oefenen. Tevens kan hij een substituut van een zaak afhalen om deze aan een ander toe te vertrouwen. ${ }^{23}$ Ondergeschikten moeten verslag en verantwoording afleggen aan het hoofd, met name omtrent belangrijke zaken. ${ }^{24}$ Intern houdt men verder ad hoc of periodiek parketvergaderingen. Deze hebben geen officieel karakter. ${ }^{25}$

De interne organisatie van het Franse $O M$ is aldus sterk piramidaal. De mate van hiërarchie neemt toe naar gelang men lager in de organisatie afdaalt. Hogere parketten hebben belangrijke bevoegdheden ten aanzien van lagere parketten. Intern in de parketten is het parkethoofd bevoegd vrijwel al het handelen te bepalen. De piramidale opbouw geldt echter slechts vanaf elke procureur-generaal naar beneden in de organisatie. Een formele top boven de parketten bij de hoven ontbreekt, en ook de conferentie van procureurs-generaal heeft (nog) weinig invloed. Feitelijk staan de procureurs-generaal elk voor zich alleen in hun relatie met externe organen, zoals de minister van Justitie.

\section{Bevoegdheden van het $\mathrm{OM}$}

Wat doet het Franse OM? Welke strafvorderlijke mogelijkheden heeft het? Overeenkomstig het hoofdstuk over het Nederlandse stelsell bespreek ik nu de bevoegdheden van het Franse OM in de opsporing en de vervolging. Daarbij schenk ik aandacht aan de rechterlijke controle op dit handelen.

Naast enkele extra- of parajudiciële en civielrechtelijke taken heeft het $O M$ zijn belangrijkste taak op het strafrechtelijke terrein ${ }^{26}$ Daar heeft het de leiding over de opsporing en de diensten die daarin actief zijn. Het is het belangrijkste overheidsorgaan dat de vervolging kan beginnen en uitoefenen. Wel kan het slachtoffer van een delict de vervolging in gang zetten, en in enkele gevallen de administratie. ${ }^{27}$

22 Lemesle \& Pansiar 1998, p. 43-44, Angibaud 1999, 33-34. Zie verder 5 6 Disciplinair regime.

23 Rassat 1993, p. 229; 1996, p. 100; Volf 1998, p. 36; Lemesle \& Pansier 1998, p. 44. In thwotie geldi (ook) voor de substituten van de procureur dat zij wrijheid van spreken hebben tegenoveir de rechter. De procureur kar hen echter belenten om voor de rechter te versehijnen door ofl dit zelr te doen, bl de zak ower le dragen asm andere substiuut. Zie herover 6.3.3. Rechswamborgen bij anwijzingen.

24 Volff 1998, p. 37; Pradel 2000, p. 127.

25 Volff $1998, p .41$. Officiel zouden in het parquet assemblés generales getouden worden. Deze worden als omslachtig en disfunctioneel gezien. De conelusies varn deze laarte zijn overugens pun adviserend van aard. De assemblée générale kan adviezen uitbrengen over de wökverdeling de organisalie en de werkornstandigheden R76 l-25-761-26 COJ.

26 Pudel 2000, pu 130 . De extrajudiciele taken betreffen o.a. toezich op dewrwarders, notarissen. grifhers, toezich op pententiaire en psychatrische inrichtingen, elc., Perrot 1998, p. 410; Voltf 1998, p. 77 e.v. llemesle \&: Pansier 1998, p. 96-97; Vincert e.a. 1999, p. 571-572. Het OM hedf civicle taken 1.6.w. bijwoorbeeld de burgerlike staat, bescheming van kinderen, geestelijk gehandicapnen, aril. 144-145. 375-3, 375-5, 421-425 Code de procedure civile. Volff 1998, p. 72 e.v.; Lemesle \& Pansier 1998, p. 109 c.x.; Angiband 1999, p. 74 e.w.

27 Zie 6.5. Gezag over opsporingsorganen. Voor het slachtoffer, 2ie 3.8. Rechterlijke controle op het OM. 


\section{Hoonostuk 3}

Voer de werwolging geldt in Frankrijk het opportuniteitsbeginsel. Het OM is in principe vrij om te beslissen on miet te vervolgen, ook om opportuniteitsredenen. "Le procureur de la Republique reçoit les plaintes et les dénonciations et apprécie la suite à leur donner (art 40 II CPP). Naast de keuze tussen sepot of verwolging staan het parket altematieve strafrechtelike mogelijkheden ter beschikking. Wanneer de procureur besluit te verwolgen rekwireert hij vervolgens ter zitting. Na de uitspraak kan hij hoger beroep en cassatie instellen. Ten slotte heeft het parket een witvoerende en controlerende takk bij de executie. ${ }^{20}$ Afgezien van deze laatste komen de zojuist genoemde fasen en opties hieronder éen voor én aan de orde.

\subsection{Opsporing}

Elk parket krijgt jaarlijks vele duizenden aangiften van burgers. Daarnaast zijn alle overheidsorganen en ambtenaren in de uitoefening van bun functie gehouden om het OM in te lichten als zij kennis krijgen van een strafbaar feit. In het bijzonder dienen de politiefunctionarissen berichten hierwan door te geven aan het parket. ${ }^{30 i}$ Het lokale parket heeft de leiding over de opsporing en het handelen van de politie daarin. De procureur kan opsporingsambtenaren algemene of bijzondere instructies geven. Tevens kan hij kiezen aan welke dienst hij een onderzoek toevertrouwt. ${ }^{31}$

De procureur-generaal houdt het toezicht over de betreffende politiediensten in zijn ressort. Daartoe heeft hij enkele functionele en rechtspositionele bevoegdheden ten aanzien van politieambtenaren. Hij kan hun bevoegdheidsverklaring (habilitation) schorsen of intrekken. Agenten zijn daardoor niet langer gerechtigd hun functie uit te oefenem. Verder beoordeelt hij hen elk jaar op voorstel van het lokale parkethoofd en houdt hun persoonlijke dossier bij. De beoordeling door de procureur-generaal weegt mee bij een beslissing tot bevordering van politieambtenaren. Ten slotte kan hij een disciplinaire procedure tegen hen beginnen.

Het OM heeft een zekere directe controle op de feiteli ke behandeling van zaken door de politie. Politiediensten melden delicten systematisch en direct aan het parket, veelal telefonisch (rraitement en rempss rée). ${ }^{33}$ Daarnaast heeft het OM gedeeltelijke zeggenschap over de samenhang van de prioriteiten van de politie. Dit laatste is een gevolg

28 Orerigens is het opporturnteitsbeginset in Frankrijk niet mitukkelijk vastgelegd. Artikel $40 \mathrm{CPP}$ regelt de beslissing van het $\mathrm{OM}$, man zegt niet op wolke gronden een beslut on niet te vervolgen gebaseerd kan wordem. Fr stat niet letterlik dat het OM alleen on technische of ook on opportunteitsnedenen kan seponeren, Rassat 1967, r. 313; Mathias 1999, p. 76. De rest van de doctrine leest wel het opportunireitabeginsel un arijel 40. Bijv. Pradel 1991, p. 15;2000, p.470.471.

29 Voor de execulie: arti 707 .v. CPP Hirtin heef het OM in praktijk echer ook een enigszins dis cretiona bre rol. Door de gegevens wan de rechterlijke uitsprak niet door te geven kan het parket er voor zorgen dat deze fentelijk niet uigevoerd wordt. Dit komt woor war gevangenissen te druk bezet zijn. Tevens kan uitstel wan executie gegeven worden. Volf 1998, p. 68; Angibaud 1999, p. 73. De executie komt hier verder thiet an bod.

30 Over de vendere nol van bestursorganen bij verwolgingsbeslissingen zie 6.5 . Gezag over opsporingsorgancuth.

Voor de vorscherdene inlichtingsplichten zie artt. $19,27,29,40,54$ en $67 \mathrm{CPP}$.

31 Art. 12, 41.42,75; ant. D 1-5 CPP

32 Ant $13,16-16-3,19-1,38,75,224-225,230$ en R $13-16$ CPP

33 Lemerile \& Pansier 1998, p. 62-63; Angibaud 1999 , p.50 e.v.; Pradel 2000, p. $485-486$. 
van zijn rol bij de totstandkoming van de departementale veilgheidsplannen. Het hoofd van het rechtbankparket in de hoofdstad van elk departement makt deel wit van de Departementsraad woor de preventie van de criminaliteit (Conseil départemental de prévention de la délinquance). Het parkethoofd is hiervan vice-voorzitter, terwijl de prefect de voorzitter is. Met leden van rechterlijke colleges en lokale ambisdragers vergaderen zij over een scala aan initiatieven ter voorkoming van de criminaliteit. $\mathrm{De}$ procureur stelt in overleg met de prefect een veiligheidsplan op, dat ter instructie van de opsporingsdiensten in het departement dient. Verder neemt het OM deel aan de gemeentelijke Conseil communal de prévention de la délinquance. ${ }^{34}$ Onder voorzitterschap van de burgemeester overlegt de lokale procureur hier met gemeentelijke diensten en vereniging.

Tijdens de opsporing heeft het parket - en onder diens gezag de politie - een aantal onderzoeksbevoegdheden. De procureur kan plaatsen bezichtigen, huiszoekingen doen en zaken in beslag nemen, maar enkel met de toestemming van de persoon bij wie dii plaatsvindt. Hij kan personen met de sterke arm mee laten brengen om hen te horen of hen een identiteitscontrole doen ondergaan. Hij kan bedrijfscontroles of technische onderzoeken laten plaatsvinden. Verdachten kan hij voor 48 uur laten vasthouden (garde à vue). Dit alles is mogelijk zonder dat een beslissing van een rechter nodig is. In geval van heterdaad heeft het OM - net als bepaalde politieambtenaren - rumere bevoegdheden. Zo kan de procureur huiszoekingen doen, stukken en zaken in beslag nemen, ter plaatse technisch onderzoek laten verrichten, personen horen, en lichamelijk onderzoek laten verrichten. De toestemming van betrokken burgers of een mechter is dan niet nodig. ${ }^{35}$

\subsection{Beslissing over de vernolging}

Het OM kan bij een opgespoord feit beslissen te vervolgen, te seponeren of een alternatieve strafrechtelijke actie ondernemen. Niet besluiten is in principe niet mogelijk. De procureur heeft de plicht een beslissing te nemen. Jaarlijks behandelen de parketten ruim wiereneenhalf miljoen zaken ${ }^{36}$ Hier behandel ik eerst het sepot, vervolgens de alternatieve acties. De wijze van vervolging komt daarna aan bod.

In totaal wordt ruim tachtig procent van de zaken geseponeerd. Dit aantal omvat echter ook de sepots om technische redenen. In tweederde van de zaken kan de verdachte namelijk niet achterhaald worden. In nog geen tien procent van de gevallen gaat het om redenen van opportuniteit. ${ }^{37}$ Indien het OM niet vervolgt wijst het een specificke grond

34 Falleti, Commission de renexion sur la fustice, Annexes 1997, p. 88; Leneste \& Pansier 1998, P. $58-$ 60. Pradel 2000, p. 134-136. De prefect staat an het hoofd van het departement, als wertegenwoordiger wan de regering. Décret n. 92-343 wan 1 april 1992; interministeriele cinculäres van 9 septenber 1993 eni 2 jathuari 1997.

35 Voor de onderzoeksbevoegdheden: ant. 75-78-6 CPP. Woor de bevoegdheden in geval wan heterdand: art! $53-74 \mathrm{CPP}$.

36 Malibert 1994, p. 28. Ministère de la Justice 2002, p. 1101. De hierna nog te bellandelen hoetes (antendes forfatares) dienen daar nog bij te worden opgeteld woor een total van meer dan vijtien miljoen behandelde zaken.

37 Ministere de la Justice 2002, p. 99-101. 
aan waarop het seponeert. Deze gronden betreffen met name de persoon van de verdachte, de ernst van de feiten en de gevolgen van het delict. Het slachtoffer en de aangever dienen van een sepot op de hoogte gesteld worden. Een motivering is slechts werplicht woor een aratal bijzondere delicten tegen minderjarigen. ${ }^{38}$

De procureur kan op eigen initiatief terugkomen op zijn besluit. De beslissing tot sepot blijt een woorlopige totdat het delict is verjaard: Een bijzondere motivering voor het alsnog vervolgen is niet noodzakelijk. ${ }^{39}$

\section{3" 'De derde weg'}

Van relatief recente datum zijn de meeste wettelijke mogelijkheden om een andere strafrechtelijke reactie te geven dan vervolging of een enkel sepot. Deze serie mogelijkheden noemt men gezamenlijk 'de derde weg' (la troisième voie). Het betreft de bemiddeling, de waarschuwing, de verschillende vormen van voorwaardelijk sepot en de zogenaamde strafrechtelijke compositie.

Indien het delict een slachtoffer heeft kan de procureur een poging doen tot bemiddeling (médiation). Hij brengt daartoe de verdachte en het slachtoffer bijeen ten overstaan van een derde. Indien het bemiddelingsproces slaagt besluit het OM tot sepot. Hiermee is het recht tot strafvordering overigens niet vervallen. ${ }^{40}$

Verder kan het parket de verdachte een waarschuwing geven. De procureur wijst hem dan op zijn plicht on de wet te respecteren en deelt hem mee dat een volgende overtreding een wervolging met zich zal brengen. Dit alternatief voor vervolging wordt het vaakst gebruikt. ${ }^{41}$

Bovendien heeft het OM een viertal mogelijkheden van voorwaardelijk sepot. Daarbij bericht de procureur de verdachte dat het OM seponeert als hij aan een voorwaarde voldoet. Het parket kan de verdachte ten eerste verzoeken om de schade die het delict veroorzaakte te vergoeden. Ten tweede kan het vragen om het regulariseren wan een situatie in overeenstenming met de wet. In deze gevallen stelt het OM een termijn waarbinnen aan het verzoek voldaan moet zijn. Een derde mogelijkheid is om de verdachte nar een sociale of medische installing te zenden. Indien de verdachte medewerking verleent, seponeert men de zaak. Wanneer het feit specifiek het illegaal gebruik. van drugs betreft heeft het parket ten vierde de mogelijkheid om de beslissing over de vervolging te laten afhangen van de uitkomst van het ondergaan van een afkicktherapie (injonction therrapentique). De meest gebruikte voorwaarde is die van schadevergoeding aan het slachtoffer. ${ }^{42}$

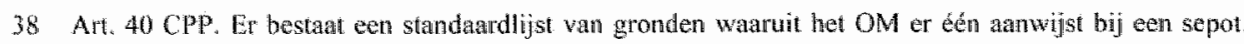
Angiband geefteen vrij uitgebreide weergave, 1999 , p. 55-59.

39 Vineent e.a. 1999 , p. 565; Guinchard \& Butsson 2000, p. 497; Pradal 2000, p. 472. Zie ook 7.2. Verantkoordingsproces.

40 Ant 41-1 CPP Pradel 2000, p. 474-475.

41 Art, 41-1 CPP. Guinchand \& Buisson 2000, p. 500. Deze optie bestond in de praktijk al vóor de regeling in 1999. Volf 1998, p. 65; Lemesle \& Pansier 1998, p. 69; Angibaud 1999, p. 67.

42 Voor de eerste drie vormen vary voorwaardelijk sepot: art. 41-1 CPP. Voor de vierde versie: ant. I. 628. 1 Code de la smoté publique. Pradel 11991, p. 19; Guinchard \& Buissom 2000, p. 500. 
De bovenstaande opties van bemiddeling, waarschuwing of voorwaardelijk sepot kunnen gebruikt worden voor alle soorten delicten. Zware misdrijven (crimes) zijn hier niet expliciet uitgesloten. In de praktijk gebruikt het OM 'de derde weg' evenwel niet voor deze misdrijven. Daarvoor zijn de genoemde opties te reparatoir van aard. ${ }^{43}$

Een meer punitief karakter heeft de 'strafrechtelijke compositie' (composition pénale). De procureur kan deze voorstellen bij een limitatief opgesomde lijst van delicten. Hij doet dit voorstel aan de verdachte die uitdrukkelijk moet instemmen. Deze moet meerderjarig zijn en het feit erkennen. Het voorstel kan inhouden de betaling van een bedrag aan de staat, het afstand doen van voorwerpen die in het delict betrokken waren, de inlevering van het rijbewijs of de jachtvergunning voor een periode of het verrichten van onbetaalde arbeid. Het parket verzoekt na instemming door de verdachte de voorzitter van de rechtbank om bekrachtiging van de 'compositie'. De voorzitter kan daartoe de verdachte en getuigen horen. Als hij de overeenkomst bekrachtigt en de verdachte deze uitvoert, vervalt het recht op strafvordering. Tegen de bekrachtiging kan geen beroep aangetekend worden. ${ }^{44}$

\subsection{Vervolgingsstrategie}

Wanneer het $O M$ niet seponeert of 'de derde weg' bewandelt gaat het tot vervolging over. ${ }^{45}$ De vervolging kan direct beginnen met een dagvaarding. Het parket kan ook besluiten eerst een vordering te doen tot opening van een gerechtelijk onderzoek. Deze laatste optie bespreek ik als eerst.

Als een zaak een lichte misdaad of een overtreding betreft (andere délits en contraventions) kán het parket beslissen om een gerechtelijk onderzoek (information judiciaire) te vragen. In geval van zwaardere misdaden (crimes en bepaalde dellits) echter, is het OM verplicht een gerechtelijk onderzoek te vorderen. De uitvoering ervan geschiedt door de onderzoeksrechter (inge d'instruction). Het OM heeft daarbij een kaderbepalende rol. Het onderzoek geschiedt op grond van de feiten die de procureur weergeeft in zijn openingsverzoek (réquisitoire introductif). Indien de onderzoeksrechter geheel nieuwe delicten tegenkomt in zijn onderzoek, kan hij deze daar niet eigenmachitg in betrekken. Het parket kan wel vorderen dat het onderzoek daartoe wordt uitgebreid, of kan een nieuw onderzoek vorderen. Het OM kan elke vordering doen die hem nuttig voorkomt. Het kan op elke moment verzoeken dat de onderzoeksrechter hem informeert over de stand van zaken. De onderzoeksrechter doet onderzoekshandelingen op vordering van het $\mathrm{OM}$ of op eigen initiatief, waarbij hij het $\mathrm{OM}$ hoort. ${ }^{46}$

43 Guinchard \& Buisson 2000, p. 501. Dit blijkt ook uit gesprekken met OM-leden. Over de indeling in crimes, délits en contraventions, art. 111-1,111-2

44 Artt. 41-2 - 41-4 CPP.

45 Ten aanzien van bepaalde delicten is voordat to vervolging overgegaan kan worden cen klacht nodig van het slachtoffer of een klacht of conform advies van een bestuursorgatan. Daarnast is voor de vervolging wan bepaalde personen een vorm van toestemming (outorisation) nodig. Klachtdelicten zijn bijvoorbeeld bepaalde schendingen wan het prive-lewen (art. 226-len 226-2 jo 226-6 CP). Voor de bevoegdheden van administratieve organen en de toestemming zie 6.5 . Gezag over opsporingsorganen en 6.4. Toestemming woor vervolging.

Artt. $79-84$ CPP. 
De mogelijkheden die een gerechtelijk onderzoek biedt zijn veel rumer dan de bevoegdheden die het OM normaliter heeft. Huiszoeking en inbeslagname van zaken kunnen gedaan worden zonder toestemming van degene bj wie dit platsvindt: De onderzoeksrechter kan conmunicatiemidelen doen onderscheppen en onderzoek aan lichaam en kleding bevelen. Hij kan personen met de sterke arm mee laten brengen on hen ook onder eed te verhoren. Hij kan personen voor 24 uur vast laten houden. Zonodig kumen verdachten onder "rechterlijke controle" (contrôle judiciaire) geplaatst. worden. Deze controle kan bestaan uit een variatie aan verboden. Voorbeelden zijn verboden om zich niet buiten of binnen een bepaald gebied te begeven, om bepaalde personen niet te ontmoeten of om zich te onthouden van bepaalde activiteiten. De onderzoeksrechter kan de rechter voor de vrijheden en de detentie (juge des libertés et de (a détention) verzoeken de verdachte in voorlopige hechtenis te memen. Afhankelijk van de zwaarte van het delict kan deze variëren van vier maanden tot vier jaren. ${ }^{47}$

Uiteindelijk neemt de procureur een réquisitoire défmitif, waarop de onderzoeksrechter het onderzoek sluit. Het is deze laatste die daarbij beslist of de zaak technisch te vervolgen is. Het parket kan slechts requireren maar heeft geen beslissingsbevoegdheden meer over de vervolging. De onderzoeksrechter kan niet op grond van opportuniteit seponeren. Als hij de zaak haabaar acht volgt verwijzing naar de terechtzitting. In nog geen tien procent van de zaken wordt een gerechtelijk wooronderzoek feitelijk gebruikt. ${ }^{48}$

Afgezien van het gerechtelijk onderzoek, kan het parket de vervolging beginnen door een dagvaarding. Deze kan op verschillende wijze vorm gegeven worden.

Het OM kan besluiten de verdachte direct te dagvaarden (citation directe). Dit gebeurt door tussenkomst wan een deurwaarder. De verdachte komt dan na enkele weken of maanden voor de rechter. Men spreekt van een convocation en justice als de betekening niet door een deurwaarder, maar eenvoudigweg door een politieambtenaar, griffier of directeur van huis van bewaring (maison d'arrêt) geschiedt, wederom op instructie van een parketlid. De citation directe en de convocation en justice vormen elk een derde van de gebruikte procedures. ${ }^{49}$

Een volgende optie voor het parket is om zelf, per proces-verbaal aan de verdachte een datum te melden waarop deze voor de nechtbank moet verschijnen (rendez-vous judiciaire of convocarion par proces-verban). Deze datum mag niet eerder dan tien dagen en niet later dan twee maanden daarna liggen. In één procent van de zaken kiest het OM voor deze procedure. In plaats daarvan is het voor de procureur eenvoudiger om voor de convocation en justice te kiezen. ${ }^{50}$

Verder kan het OM de verdachte ook enkel een bericht geven dat de zaak voor de rechtbank komt. Wanneer de verdachte dan (vrijwillig) verschijnt, spreekt men van

47 Artt. 92-174-1 CPP.

48 Art. 175-190 CPP. Lemesle \& Pansier 1998, p. 81; Angiband 1999, p. 65. In Frankrijk vindt overigens: een jarendang debat plats over de aventuele afschaffing van de onderzocksrechter. Daarvór o.a. Commissie Delmas-Marty 1990, p. 125: Volff 1998, p. 99.

49 Voor de citation directe. art. 44,79 en 550 e.v. CPP. Voor de convocation en justice: art. $390-1$ CPP. Lemesle \& Pansier 1998, p. 71 en 73; Angibaud 1999, p. 64; Guinchard \& Buisson 2000, p. 523 e. y.

50 Artt. 393 a.k. CPP. Lemesle \& Pansier 1998, p. 72-73; Angibaud 1999, p. 66; Guinchard \& Buisson 2000, p. $5211-522$ 
comparution volontaire: In praktijk wordt deze vorm alleen nog gebruikt wanneer het OM heeft nagelaten een delict toe te voegen aan de dagvaarding of het proces-verbaal waarmee de verdachte al is opgeroepen. ${ }^{51}$

Ten slotte heeft de procureur de mogelijkheid om te besluiten tot een onmiddellijke verschijning voor de rechtbank, de comparution immédiate. De verdachte komt dan in principe dezelfde dag voor de rechter. Als dit niet mogelijk blijkt, kan het parket de rechtbankpresident verzoeken de verdachte in bechtenis te nemen. Hij verschijnt dan uiterlijk de tweede daaropvolgende werkdag voor de rechtbank. Deze procedure kan slechts gebruikt worden voor strafbare feiten waarop maximaal zeven jaar staat. Deze procedure wordt in nog geen tien procent van de zaken gebruikt. ${ }^{52}$

Nadat de vervolging aldus is aangevangen heeft het OM niet de mogelijkheid om de vervolging te staken. Het kan de zaak niet zonder rechterlijke uitspraak ten einde brengen. $^{53}$

\subsection{OM-beleid}

Het hoofd van het parket en de procureur-generaal definiëren bepaalde beleidsregels waarmee de parketleden in hun beslissingen rekening dienen te houden. De bevoegdheid daartoe is niet uitdrukkelijk in de wet vastgelegd. Die regelt expliciet alleen de bevoegdheden ten aanzien van individuele zaken en stelt dat leden van het OM onder leiding en controle van hun biërarchische superieuren staan (art. 37 en 44 CPP; art. 5 ord.).

In het bepalen van de beleidsregels hebben de organen van het $\mathrm{OM}$ een belangrijke marge van autonomie. Het beleid kan voorschriften inhouden voor een bepaalde handelwijze ten aanzien van een bepaald delict. Daarnaast kunnen superieuren prioriteiten geven. In de praktijk voeren weinig parketten een strafrechtelijke politiek met een samenhangend geheel van vooraf opgestelde prioriteiten. ${ }^{54}$

\subsection{Functie OM ter zitting}

Tijdens de terechtzitting is de leiding van het proces in handen van het rechterlijk college. Het OM moet well gehoord worden over elke beslissing die de rechter wil nemen. De procureur heeft de bevoegdheid om vragen te stellen aan personen die voor het rechterlijk college verschijnen. Op ieder moment kan het parket vorderingen doen, waarop de rechter gehouden is te antwoorden. Het heeft de mogelijkheid getuigen en deskundigen op te roepen en nader onderzoek te vorderen. Uiteindelijk neemt de procureur zijn requisitoir, waarin hij een bepaalde uitspraak vordert. Dit requisitoir wordt

51 Art. 389 CPP. Guinchard \& Buisson 2000, p. 527.

52 Art. 395 e.v. CPP. Lemesle \& Pansier 1998, p. 72; Angibaud 1999, p. 54; Givinchard \& Buisson 2000, p. $512 \mathrm{e} \times$

53 Malibert 1994, p. 29; Angiband 1999, p.54; Stefani, Levasseur \& Bouloc 2000, p. 140.

54 Volf 1998, p. 43; Lemesle \& Pansier 1998, p. 57-58; Angibad 1999, p. 57. Over de praktik: Pradel 1990, p. 302; Accomando 1997a, p. 93. Over de beleidsamwijzingen van de minister, 2ia 6.3.1.1. Circulaires. 
schriftelijk owerlegd, vergezeld van een mondeling requisitoir ter zitting. De vordering en argumentatie van het OM zijn van grote invloed op de beslissing van het college.

\section{Rechtsmiddelen doow het $\mathrm{OM}$}

Tegen beslissingen van de onderzoeksrechter of de rechter yoor de vrijheden en de detentic kan het OM beroep instellen bij de chambre d'instruction van het hof van beroep. Tegen de einduitspraak kan de procureur in beroep gaan bij het hof zelf. Gaat het lagere parket niet in berocp, dan kan de procureur-generaal dat alsnog doen. Beroep kan ook ingesteld worden als de rechter overeenkomsitg het requisitoir van het lagere parket uitspraak heeft gedaan. Na het beroep kan het OM in cassatie gaan. Het OM kan niet om revisie van een rechterlijke uitspraak vragen. Wel kan dit door de veroordeelde, enkele anderen en door minister van Justitie zelf gevraagd worden. ${ }^{56}$

\subsection{Rechrerlije controle op het OM}

Een magistraat van het OM kan niet, zoals een rechter, gewrakt worden. In het proces is de procureur partij en vertegenwoordigt hij het hele parket. Wel hebben parketleden de plicht om twijfel over hun onpartijdigheid te vermijden. Zo worden zij geacht niet te beslissen omtrent de vervolging van personen met wie zij een bijzonder vriendschappelijke of wijandelijke relatie hebben. Deze plicht kan disciplinair gesanctioneerd worden. 57

Het Franse OM zelf kan niet voor de burgerlijke rechter aansprakelijk gesteld worden voor schade als gevolg van het uitoefenen van de vervolging. De staat kan hierop evenwel onder strikte voorwaarden aangesproken worden. Zoals in de eerste paragraaf gezegd zijn de ambten van het OM geen administratieve instellingen. Daarom is tegen hun handelen geen beroep mogelijk op de bestuursrechter. ${ }^{58}$

$E r$ is evenmin rechterlijk beroep mogelijk tegen de beslissing tot sepot zelf ${ }^{59}$ Wel kan een slachtoffer de vervolging doen beginnen in geval van sepot of het uitblijven van een beslissing. In geval van een crime of een délit kan hij daartoe een klacht indienen met burgerlijke partijstelling bij de onderzoeksrechter. ${ }^{60}$ Naast het slachtoffer kunnen onder voorwaarden verenigingen in bepaalde zaken een klacht indienen. De onderzoeksrechter beslist omtrent de gegrondheid van de klacht, na het OM gehoord te heb-

55 Artt. $312-3113,346,458,460$ CP P. Lemesle \& Pansier 1998, p. 88.

56. Voor beroep tegen de eindiutsprak: art. 497, 546, Voor cassatie: 567 CPP. Voor beroep op de chambre d'instruction: art 185 CPP. Voor revisie: art. 623 CPP. Malibert 1994, p. 12 en 31 ., Stefani, Levassenr \& Bowloc 2000. p. 140. V6or loi n. $2000-1354$ van 30 december 2000 heette de cluanbre d'instruction mog chambre d"accusation. Overgens kan de procureut-generaal buj hat Hof van cassatie op eigen initiathe " of op anwijzing van de minister cassatic instellen in het belang der wat (art. 620-621 CPP).

57 Voor walking: art 669 lid 2 CPP. Malibert 1994, p. 16; Pradel 2000, p. 125; Josserand 1998, p. 425; Volf 1998, p. 53.54; Angibaud 1999, p. 34 e.x. Voor een witwerking van de onpartijdigheidplicht Advies CSM 21 december 1994, in: CSM 1998, p. 22; Angiband 1999, p. 119. Over de disciplinaire procedure zie 56. Disciplinatir regime.

58 Over het beroep op de burgerlikk recht zie verder 5.5. Aansprakelijkheid.

59 .losserand 1998, p. 423 .

60 Overigens heeft de verdachte geen mogelikheid te verzoeken om vervolgd te worden. Pradel 2000, 1. 484. 
ben. Indien hij de klacht - eventueel na nader onderzoek - afwijst, kan de belanghebbende beroep instellen tegen deze beslissing. Luidt deze echter dat de klacht gegrond is, dan verwijst de onderzoeksrechter de zaak naar de rechtbank. De onderzoeksrechter heeft niet de mogelijkheid op grond van opportuniteitsoverwegingen de klacht af te wijzen. De uitoefening van de vervolging zelf is verder altijd in handen van het $O M$. Het gebruik van deze klachtvorm is in de jaren negentig aanmerkelijk toegenomen. ${ }^{61}$

Wanneer het OM niet vervolgt in geval van een delit of een contravention heeft de belanghebbende een andere mogelijkheid. Hij kan dan een geïdentificeerde verdachte direct dagvaarden voor de rechter. Het gebruik van deze optie heeft slechts zin als er geen enkele twijfel bestaat over de dader. Het OM neemt in een dergelijke zaak ter zitting wel een requisitoir, maar hoeft verder geen initiatieven te ondernemen. ${ }^{62}$

Belanghebbenden zoals het slachtoffer kunnen 'hiërarchisch beroep' (recours hiérarchique) instellen tegen een beslissing omtrent de vervolging. Dit beroep kan zowel gericht zijn aan hoofd van het parket als de betreffende procureur-generaal. Hieromtrent is echter niets formeel geregeld. Het staat burgers vrij om een hiërarchische meerdere te vragen van diens bevoegdheden gebruik te maken. Indien deze meent dat de ondergeschikte een onjuiste beslissing genomen heeft kan hij gebruik maken van zijn aanwijzingsbevoegdheid. Het parkethoofd zelf heeft zoals gezegd ook de mogelijkheid zich desnoods in de plaats te stellen van de substituut die de zaak behandelt. Tegen een beslissing tot vervolging is een beroep zinloos. De procedure is dan in gang gezet, en de superieur heeft niet de mogelijkheid deze stop te zetten. In de praktijk komen dit soort hiërarchische beroepen vrij weinig voor. in veruit de meeste gevallen verwerpt de superieur het beroep. Vaker en steeds meer wordt er gebruik gemaakt van de mogelijkheid om een klacht in te dienen bij de onderzoeksrechter. ${ }^{63}$

De verdachte heeft de volgende rechtsmiddelen. Hij kan zich verweren voor de onderzoeksrechter en de rechter voor de vrijheden en de detentie en eventuee] beroep instellen tegen hun beslissingen. Wordt hij direct gedagvaard, dan bestaat geen mogelijkheid van voorafgaand beroep of bezwaar. Pas na de terechtzitting staan voor hem dan de gewone beroepsmogelijkheden open. ${ }^{64}$

\subsection{Conchusie}

De Franse procureurs hebben een scala aan strafrechtelijke mogelijkheden, maar zijn voor een aantal belangrijke dwangmiddelen afhankelijk van de onderzoeksrechter. Deze kan in de voorfase een vergaande taak hebben. Daarnaast kunnen belanghebbenden een grote rol spelen om de vervolging in gang te zetten. Voor het overige staan de opsporingsdiensten sterk onder de leiding van het $\mathrm{OM}$. Ook heeft het parket een behoorlijke keuze tussen strafrechtelijke alternatieven voor vervolging. Hieronder zijn een aantal opties waar geen rechter aan te pas komt.

61 Art. 85-91 CPP. Angiloaud 1999, p. 62. Zie verder over de klacht (plaince): Guinclaral \& Buisson 2000; p. 535 e.v.; Stefani. Lewasseur \&ouloc 2000, p. 183 av.

62 Art. 392,533 CPP. Guinchard \& Buisson 2000, p. 548-549.

63 Volf 1998, p. 64, 95, Angubaud 1999, p. 62. Eén en ander blijkt wilt gesprekken met OM-lleden. Over het beroep op de mimister zie 6.2. Hierarchisch beroep.

64 Voor het bercep tegen de juge d'instruction en de juge pour les libertés el la detention: art. $181 \mathrm{CPP}$. 


\section{Minister en ministerie van Justitie en President}

De politieke organen die bevoegdheden bezitten ten aanzien van het nu besproken OM zijn de minister van Justitie en de President. Met name de eerste heeft belangrijke bevoegdheden ten aanzien van zowel de rechtspositie als het handelen van het OM. De President heeft maar weinig juridische middelen in relatie tot het $O M$, en enkel wat betreft de rechtspositie. Zijn politieke rol kan evenwel van belang zijn. Wat is de positie van deze ambten?

De President wordt direct gekozen door het electoraat. Hij benoemt zelf de ministerpresident, en de andere ministers op voorstel van de premier. De presidentiële positie varieert al naar gelang de President en de op de Assemblée steunende regering van dezelfde politieke kleur zijn of niet: Wanneer dit niet het geval is spreekt men van cohabitatie (cohabitation). Ten tijde van cohabitatie steunt de premier op de volksvertegenwoordiging van de Assemblée. De persoonskeuze van de kamer heeft de President dan te accepteren. Buiten cohabitatie prevaleert evenwel zijn politieke autoriteit over de minister-president. ${ }^{65}$

De minister van Justitie is lid van de Ministerraad. De President zit de raad voor. Bij cohabitatie heeft de minister-president de inhoudelijke, politieke leiding over de regering en de raad: Hij coördineert het handelen van ministers. Zijn invloed op hun beleid kan groot zijn. Buiten cohabitatie heeft hij een zwakkere positie tegenover de positie van de President, die dan wint aan belang. In dat geval geeft deze politieke leiding aan de premier en de ministers. Verscheidene ministers onderhouden dan ook directe contacten met de President. ${ }^{6.5}$

De minister-president zorgt voor de coördinatie van het handelen van de ministers in de regering. Daarbij spelen onderraden een rol. Op justitieel gebied bestaat sinds 1997 een interministerieel comité, genaamd de Binnenlandse veiligheidsraad (Conseil de sécurité intérieure). Deze staat onder leiding van de minister-president. De ministers van Justitie, Binuenlandse zaken, Defensie en de minister inzake douaneaangelegenheden zijn permanent lid van deze interministerielle raad. Andere leden van de regering kumnen tevens deelnemen. De raad heeft geen eigen bevoegdheden. Hij neemt politieke beslissingen die mede het strafrechtelijke beleid kunnen raken. Op grond van beslissingen in deze raad geeft de minister van Justitie vervolgens in voorkomende gevallen circulaires uit. $^{67}$

De minister van Justitie is naast de minister-president de enige minister die genoemd word in de grondwet (art. 65). Hij is daarin aangewezen als vice-voorzitter van de

65 Art. 6-9.9Const.

66 Art. 21 Const. Gicquell 1999, p. 573-577; Favoreu e.a. 2000, p. 655-660.

67 Décret n. 97-1052 van 18 november 1997; Décret n. 2002-890 van 15 mei 2002. Een sprekend voorbeeld van een dergelijke circulaire is die van 6 november 1998 'relative à la délinquance des mineurs: mise en oeuve des décisions adoptểes par le Conseil de sécurité inhérieure.' 
CSM. De President is voorzitter van de raad en benoemt nog een lid ervan. Zijn functie in deze is meer dan symbolisch. ${ }^{68}$

De minister van Justitie staat niet als zodanig aan het hoofd van het OM, en maakt er geen onderdeel van uit. ${ }^{69}$ Wel staat hij aan het hoodd van het ministerie van Justitie, dat in zijn naam handelt. Het ministerie kent een aantal diensten en directies met respectievelijke onderverdelingen, maar is sterk gecentraliseerd. Voor de relatie van het ministerie met organen van het $O M$ zijin de volgende onderdelen van belang. De belangrijkste directie is die voor strafrechtelijke zaken en gratie (DACG). Deze onderhoudt functionele contacten met het OM. De directie houdt zich bezig met het OM-beleid en volgt een aantal individuele strafzaken. De uitoefening van bevoegdheden ten aanzien van het handelen van het OM wordt hier voorbereid. De Directie rechterlijke diensten verzorgt de ambtelijke ondersteuning voor het gebruik van ministeriële bevoegdheden aangaande de rechtspositie van het OM. Daartoe onderhoudt deze directie een relatie met de CSM. Ten slotte maakt de Algemene inspectie voor de rechterlijke diensten deel uit van het ministerie. Het belangrijkste onderdeel van het ministerie is het ministeriële cabinet. De leden ervan zijn geen gewone ambtenaren, maa: politieke vertrouwelingen die meestal komen en gaan met de persoon van de minister. Het kabinet adviseert de minister niet alleen, maar coördineert ook het handelen van de directies. Soms nemen leden ervan politieke beslissingen in naam van de minister. Sommige strafzaken die DACG van dichtbij volgt staan mede onder observatie van het kabinet. ${ }^{76}$ Een groot aantal posten en met name de leidinggevende posities binnen het ministerie zijn bezet door magistraten. Een verandering in de politieke kleur van de regering heeft evenwel vrijwel altijd tot gevolg dat de minister anderen op deze posten benoemt. Deze ministeriele magistraten behoren vaak tot een vakbond die ideologisch niet ver van de regerende meerderheid af staat. ${ }^{71}$

\section{Rechtspositie van het $\mathrm{OM}$}

Hiervoor bracht ik de staatsrechtelijke positie van de minister, de President en vooral het $O M$ in kaart. Vervolgens schetste ik de strafrechtelijke bevoegdheden van het $O M$. Welke invloed hebben minister en President nu op de uitoefening van deze bevoegdheden? De minister heeft functionele bevoegdheden, zoals een aanwijzingsbevoegdheid. Hier bekijk ik echter eerst de rechtspositionele bevoegdheden ten aanzien van het $\mathrm{OM}$. Daarbij volg ik dezelfde indeling als in het vorige hoofdstuk. Na algemene opmerkingen loop ik de belangrijkste afzonderlijke onderdelen wan de rechtspositie van het OM na.

68 Ower de CSM zie 2.1. OM en rechterlijke macht en 5. Rechispositie wan hei OM.

69 Volff $1998,0.47$.

70 Enguelegueté 1998, p. 283. Een en ander blikk uit gesprekken met OM-leden. In heth voorsiel van de Commission de réflexion sur la Just: ze zou de ministeriele inspectie conform advies van de CSM be noend moeten worden, Commission de réflexion sur la Justice 1997, p. 49.

71 Over magistraten op ministeriele posten: art. 5-8 décret n. 93-21 vam 7 januari 1993. Enguéléguété 1998, p. 292 e.w. Zie over de vakbonden 5.4. Grondrehten. 
De rechtspositie van de magistraten wordt geregeld bij of krachtens een zogenaamde organieke wet, de wet op het statuut wan de magistratuur. Voor de loi organique geldt een zwardere procedure dan voor een normale wet. Dit onderscheld ambtenaren van de rechterlijke macht wan andere ambtenaren, wier positie bij of krachtens een gewone wet is geregeld (art. 64 Const). ${ }^{72}$ Voor een groot deel komt de rechtspositie van de leden van het OM overeen met die van de rechters. De scholing, de wijze van carrière maken, de bezoldiging, de uitoefening van de grondrechten en de aansprakelijkheid zijn geneenschappelijk met de zittende magistratur. Een afwijkende regeling geldt voor de benoeming, de functiewijziging, de overplaatsing, het disciplinair regime en de schorsing.

\subsection{Rekrutering en eerste benoeming}

Toegang tot de rechterlijke macht is op gelijke wijze geregeld voor leden van het OM en rechters. De overgrote meerderheid van de magistraten volgt voorafgaand aan de benoeming een opleiding aan de Ecole nationale de la magistrature. Daarnaast is het mogelijk yoor bepaalde categorieën ambtenaren of personen met een jarenlange juridische ervaring om direct benoemd te worden (art. 22 e.v. ord.). Na de opleiding worden de betrokken magistraten op een ranglijst ingeschreven. Op volgorde van deze lijst kunnen zij intekenen op een aanbod wan door het ministerie voorgestelde eerste posten. Op grond hiervan doet de minister van Justitie voorstellen tot benoeming. Deze voorstellen worden voorgelegd aan de CSM die een negatief advies kan uitbrengen. Ten aanzien van leden van het $O M$ is dit advies niet bindend, dit in tegenstelling tot het advies betreffende de benoemingsvoorstellen voor rechters. Op voorstel van de minister van Justitie benoemt de President vervolgens de magistraten. Deze benoeming door de President is een gebonden bevoegdheid. ${ }^{73}$ De beginfunctie van een nieuw benoemd lid van het $\mathrm{OM}$ is die van substituut (art. 15 e.v. en 26 ord.). Alle magistraten leggen bij hun aanstelling dezelfde eed af (art. 6 ord.).

\subsection{Verdere benoeming en overplaatsing}

Om de twee jaar wordt een magistrat beoordeeld mede met het oog op een mogelijke bevordering. Voor het OM vindt de beoordeling plaats door de procureur-generaal van het ressort. ${ }^{7 / 4}$ Om een andere functie te krijgen dienen magistraten zich via de procureur-generaal te kandideren voor de bevorderingstabel. Deze wordt jaarlijks opgesteld door een bevorderingscommissie. Voor sommige functies is het nodig om ingeschreven te stan op een specifieke geschiktheidslijst. De bevorderingscommissie stelt ook deze

72 Favoret 1996, p. 76. De l.org. op het statuat van de magistrathum werd al genoemd in 2.1. OM en rechterlike macht. Voor de organeke wetsprocedure zie att. 46 Const. Er gelli een termijn van 15 dagen tussen het troment wan undiening en behandeling van het wetswoorstel. In geval de beide kamers niet tot overenstemming komen, kan de Assemble de tekst alleen met een meerdertheid van diens leden aannemen, in plats van bij gewone meerderheid.

73 Zoller 1999, p. 466

74 A.t. 12.1 ond; art. 18 a. décret n. $93-21$ van 7 januari 1993. 
lijsten op. De commissie toetst man criteria van onder andere professionaliteit en ervaring of zij een magistraat in de tabel of in een lijst opneemt. ${ }^{75}$

Op grond van deze lijsten doet de minister van Justitie een benoemingsvoorstel, dat werspreid wordt onder de betrokken magistraten. Vervolgens dient de minister het advies te vragen van de sectie OM van de CSM. Nadat de minister advies heeft ontvangen doet hij een definitief voorstel. Op grond hiervan benoemt de President de magistraten bij decreet. ${ }^{76}$ Voor leden van het $\mathrm{OM}$ is het advies geenszins bindend. De minister volgt echter in de meeste gevallen wel het advies van de Raad. Deze laatste geeft slechts in een paar procent wan de gevallen een negatief advies, dat in nog geen wijfde van die zaken niet wordt opgevolgd. Vanaf halverwege 1997 hebben mimisters van Justitie het op zich genomen de adviezen van de Raad voortaan op te volgen. Publicatie van de ministeriêle afwijkingen van adviezen in het jaarverslag van de CSM veroorzaakte in eind 1995, begin 1996 publieke opschudding. Nadien lijkt het voor de minister moeilijker om voorbij te gaan aan de adviezen. Minister Perben heeft zich vanaf 2002 echter weer anders opgesteld. Zo ging hij reeds enkele malen voorbij aan de CSM-adviezen. ${ }^{77}$

Leden van de rechterlijke macht zijn ingedeeld in zogenaamde graden. Ze beginnen in de tweede graad. Na zeven jaar ervaring in de magistratuur kan men benoemd worden tot de eerste graad. Aan deze graad zijn bepaalde belangrijkere of zwaardere functies voorbehouden. Het is ook mogelijk direct in de eerste graad benoemd te worden op grond van ervaring buiten de magistratuur. Om tot de eerste graad toe te treden dient men ingeschreven te staan in de bevorderingstabel. ${ }^{78}$

75 Deze commission d'avancement bestaat uit veertien magistraten, die vrijwel allemaal voor drie jasr gekozen worden door de rechterlijke macht. De verhouding tussen leden van het $O M$ en rechters is gelijk. Daarnaast is de inspecteur wan de rechterlijke diensten lid cover de inspecteur zie 6.1. Bewoegdhedem omtrent informatievoorziening). Art. 13-1 e.v. en 35 ord. Voor de bevorderingsprocedure: art. 27. 34,36 ord; aurt. 22 e.v. en 29 décret n. $93-21$ van 7 januari 1993. Een voorbeeld van een geschiktheidlijst is die woor benoeming tot parkethoofd van de kleinere parketten (art. 3 décet n. 93-21). Vour benoeming tot parkethoofd wan de grotere parketten statan zwaardere eisen. Zie hierna.

76 Art. 26 e.v. ord. Voorbeelden wan benoemingsdecreten zijn Décet van 3 rebruari 2000 portant nomination d'un magistrat en décret wan 21 december 2001 portant nomination (magistrature).

77 De werklaring van minister Guigou werd bij monde van de premier gegeven: 10 AN CR1 19 jun 1997 . déclaration de politique générale de Jospin. Vgl. Boudon 1997, p. 9; Volm 1998, p. 32. Opschuddiag veroorzaakte CSM 1995. In de periode van half 1995 tot half 1997 werden een grool deal van de negatiewe adwiezen niet opgevolgd. CSM 1998, p. 29 en 34. Zo ging de minisier in atgustus 1995 nog voorbij aan een advies tegen de benoeming van een voormalige naste medewerker van de minister tot de procureur van Nanterre, een vrij belangrijk parket. Zie Bouvier, Jacquin \& Vogelweith $199 \%, \mathrm{p} .153$. De toenmalige minister Toubon had dan ook niet toegezegd dat hij de adviezen van de CSM zou opvolgen, hetgeen zijn voorganger Méhaignerie overigens weer wel had gedan. Jean 1999, p. 31. Voor de houding wan Perben: Le Monde 21 december 2002.

Tot l.org. 25 januari 1992 gaf de CSM in het geheel geen advies over benocmingsvoorstellen, Vanar die datum gaf een Commission consultative du parquet hierover adviezen. Deze commissie bestond voor de helft uit magistraten gekozen door het $\mathrm{OM}$ en voor een andere helft uil magistraten werkzaam bij het ministerie, aangewezen door de minister. Rassat 1993, p. 231. Slechts vanaf l.const. n. $93-952$ wan 27 juli 1993 geeft de CSM zelf de adviezen.

78 Art. $23,41-9$ ord. Tot de tweede grand behoren voor het OM met name de substitut van de procureur: van de Republiek en de procureur van de Republiek van de kleinere parketten. Onder de twëede groep van de eerste graad vallen de procureurs van middelgrote parketten en de sulbstituten-generaal (art. 2-3 décret n. $93-21$ van 7 januari 1993 ). 
Een derde niveau van magistraten wordt "buiten de hiërarchie" genoemd (hors hierarche). Voor het OM zijn dit de advocaten-generaal bij het Hof van cassatie en de hoven van beroep, de procureur en adjunct-procureurs bij het tribunal de grande instance wan Parijg en de procureurs bij een par dozijn belangrije parketten. Voor deze groep buiten de hierarchie geldt de bevorderingstabel niet. Voor het overige worden zij op dezelfde manier benoend. Door het ontbreken van de tabel heeft de minister van Mastitie - in samenspraak met de President - een ruimere keuzemarge voor het doen wan benoemingswoorstellen. De noodzaak van het advies van de CSM beperkt echter de politieke speelruimte. De voorgestelde kandidaat dient wel op objectieve gronden geschikt zijn woor de functie. Dit neemt niet weg dat de minister bijvoorbeeld voonmalige pollitieke medewerkers kan voorstellen. ${ }^{79}$ Ook de procureurs-generaal staan hors hierarchie. Voor hen geldt de bevorderingstabel dus eveneens niet. Zij kennen evenwel een bijzondere procedure.

Voor de benoemingen van procureurs-general bij de hoven van beroep en het Hof van cassatie wordt de Raad in het geheel niet gehoord. In de procedure is er ook geen enkel overleg met de CSM. Formeel benoemt de raad van ministers de procureurs-generaal. Als voorzitter vam de ministerraad ondertekent de President deze benoemingen. In feite vindt de keuze plaats in samenspraak tussen de minister van Justitie, de minister-president en de President. Ten tijde van cohabitation heeft deze laatste geen doorslaggevende stem. De benoeming van de procureurs-generaal is sterk politiek van aard. De politieke gezindheid van de regering heeft een door de betrokkenen onderkende invloed op de persoonskeuze. Linkse regeringen kiezen over het algemeen voor meer 'progressieve", rechtse voor meer "conservatieve" kandidaten. ${ }^{80}$

Leden van het OM kumnen verder te allen tijde verzoeken om overplaatsing naar een rechtsprekende functie en andersom. Daarbij gelden geen bijzondere voorwaarden."

Naast de bovenstaande vormen wan functiewijziging bestaat de mogelijkheid van 'overplaatsing in het belang van de dienst'. De minister kan biermee een lid van het OM overplaatsen, zonder dat nader te hoeven motiveren. De CSM wordt hierin niet betrokken. ${ }^{82}$ Het gebruik van de overplatatsing is uitzonderlijk. Sinds lange tijd is het gebruik dat overplaatsingen niet geschieden dan op verzoek van de betrokkene - tenzij het een disciplinaire maatregel betreft. Een dreiging van het gebruik van het middel van de overplaatsing blijft evenwel bestaan. ${ }^{33}$

79 Art. 38 e.x. ord Voorbeelden van procureurs van de Republiek die tot deze categorie behoren zijn Lyon; Merseille en Straatsburg art. 3 ord. Eén en ander blijkt uit gesprekken net OM-leden.

80 Art. 13 en 65 lid 7 Const.; art 38 ord.; art. 1 ord. $58-1136$ warn 28 november 1958. Vgl: Turcey 1996, p. 128, Enguéliguẻes 1998, p. 297. Dit blijkt ook uit gesprekken met OM-leden. In julli 1996 benoemde de regering bijwoorbeeld personen verwant asn de toenmalige meerderheid op de posten van procureurgeneral bij het Hof van cassatie en bij het Hof van beroep van Parijs, Martin 1997. p. 779. Deze ruime discretie voor do regering betreti alle benoemingen die in de ministerraad plaatswinden. Andere vool-beelden zijn de prefecten en ambassadeurs. Dupuis 1987, p. 584; Zoller 1999, p. 466-467. Leden van de rechtsprekende macht worden overigens slechts op een contorm advies van de $\mathbb{R}$ aad benoemd. Voor de hoogste functies doet de Rad zelf de woorstellen aan de President (art. 65 Const.; art. 28 ord.).

81 Art. 1 lidd 2 ord.

82. Décet 28 jamuari 1969. CSM 1998, p. 51 . Verder is het mogelijk dat het parkethoofd zijn substituten intern an andere taken toewijst. Zie 2.2 lnterne organisatie.

83 Thtrey 1997, p. 181. De auteur spreekt van vier of viji gevallen in vifftien jaar. Volff 1998, p. 33. Vgl. 


\section{$5.3 \quad$ Bezoldiging}

Het régime indemnitaire van de magistraten is afhankelijk van de graad waartoe hun functie behoort. Binnen de tweede graad bestaan tien schalen (échelons), terwijl de eerste graad elf schalen heeft, verdeeld over de twee groepen waruit de graad bestaat. De indeling en de progressie in schalen volgt de anciënniteit van de magistraten in de betrokken functies. Zo staat er bijwoorbeeld twee jaar voor om in de tweede graad van de vijfde naar de zesde schaal over te gaan. De vergoedingen zelf zijn bij regeringsdecreet bepaald. ${ }^{84}$

\subsection{Grondrechten}

Leden van de staande en de zittende magistratuur dienen zich in uitingen van 'politieke' aard gereserveerd op te stellen. Dit devoir de réserve houdt in dat zij geen polemische, maar eventueel wel "constructieve" kritiek kunnen geven op instituties. Directe kritiek geuit buiten functie en gericht tegen het regeringsbeleid is evenwel niet mogelijk. $^{85}$

Franse magistraten worden formeel geacht om niet in staking te gaan. Bij gelegenheden zijn stakingen wel voorgekomen. ${ }^{86}$

Niets verbiedt procureurs om lid te zijn van een vereniging, vakbond of politieke partij. Zij kunnen echter geen nevenfuncties hebben, behoudens uitzonderingen als het geven van onderwijs. Indien een lid van de rechterlijke macht voor de Senaat, de Kamer van Afgevaardigden of het Europees parlement gekozen wordt, dient hij te kiezen tussen de twee functies. Voor een lokaal kiezersmandaat geldt dat hij niet in hetzelfde district twee functies kan uitoefenen. Ook binnen vijf jaar na afloop van zijn mandaat kan een magistraat geen functie in het betreffende de district hebben. Dit geldt ook binnen 3 jaar na zijn kandidatuur, indien hij daarbij niet gekozen wordt (art. 8-9 ord.).

In Frankrijk bestaan drie grote vakbonden voor leden van de rechterlijke macht. Eén van links, de Syndicat de la magistrature (SM), een rechtse, de Association professionnel des magistrats (APM), en een meer neutrale vakbond, de Union syndicale des magistrats (USM). Meer dan veertig procent van de magistraten is lid van een vakbond. In vergelijking met andere ambtelijke beroepsgroepen in Frankrijk is dat redelijk veel. De meeste leden van de rechterlijke macht zijn lid van de USM. De vakbonden laten hun

Lemesle \& Pansier 1998, p. 49.

84 Art. 12 e.v. décrei n. 93-21 wan 7 januari 1993; art. 42 ord. Leden van de rechterlijke mach zijn hierbij net als andere ambtenaren ingedeeld in groepen van "indices" (annexen bij decret n. 85-1148 wan 24 oktober 1985 meermaals gewijzigd, "relatif à la rémunération des personnels ćvills et militaires de l'État el des personnels des collectivités territoriales'); décret n. $48-1108$ van 10 juli 1948.

85 Art. 6 en 10 ord Angibaud 1999, p. 42. Een voorbeeld wan een meningsuiting met disciplinaire gevolgen is de affaire Apap uit 1987. Hierin had de gelijknamige procureur zich kritisch uitgesproken over het drugsbestrijdingbeleid tijdens een toespraak over de gang wan zaken in het ressort. In een disciplinaire procedure werd besloten dat de kritiek binnen de bovengenoemde normen was geblewen. J. Robert 1988, p. $18-38$.

86 Art. 10 ord. Guinchard 1990, p. 922-923. Kritiseh over dit stakingsverbod: Angibaud 1999, p. 43. Stakingen vonden plaats in 1976, 1979, 1981, 1990 (drie mal) en 2001. 
meningen horen over rechtspositionele zaken, maar ook over wetgevingsvoorstellen en affaires in strafzaken. ${ }^{87}$

\subsection{Aansprakelijkheid}

Voor zover personen schade lijden dis gevolg van fouten in de uitoefening van een strafrechtelijke functie zijn magistraten tegenover hen niet persoonlijk aansprakelijk. Daarentegen is de staat zelf wel aansprakelik, maar enkel in geval van ernstige fouten (faute low de) of rechtsweigering. Van deze laatste kan bij leden van het $\mathrm{OM}$ geen sprake zijn. Zij kunnen wel een faute lourde begaan wanneer een fout dermate grof is dat een ambtenaar die 'normale zorg' draagt over zijn plichten de fout niet gemaakt zou hebben. De benadeelde moet de staat aanspreken voor de civielrechtelijke rechter. De staat kan zich vervolgens in enkele gevallen civielrechtelijk verhalen op de betrokken magistraat. Dit kan alleen wanneer deze de bedoeling had de benadeelde te schaden. Voorbeelden van dergelijke verhalsacties zijn niet bekend. ${ }^{88}$

\subsection{Disciplinair regime}

Hetgeen een disciplinaire owertreding vormt is zeer algemeen omschreven. Aspecten van het privé-leven kunnen daar onder vallen. Ook handelen in strijd met ministeriéle aanwijzingen kan een disciplinaire overtreding vormen. De mimister van Justitie kan als enige het initiatief nemen tot een disciplinaire procedure. Hij richt zich daarvoor tot de CSM die de minister een advies geeft in elke zaak. De minister moet om een nieuw advies vragen indien hij een 2 waardere sanctie op zou willen leggen dan de Raad. De minister is niet gebonden aan het advies van de Raad. ${ }^{89}$ Gezien de autoriteit van de Raad zou de minister evenwell een conflict met deze willen vermijden. De laatste jaren volgt de minister van Justitie dan ook elk advies op. ${ }^{90}$ Sinds 2000 publiceert de Raad alle adviezen in haar jaarverslag. Sancties lopen van een waarschuwing tot ontslag met inhouding van pensioen. In de praktijk komen er maar weinig gevallen van disciplinaire procedures voor. Jaarlijks zijn het er gemiddeld niet meer dan acht ten aanzien van alle magistraten. ${ }^{91}$

Een bevoegdheid die los staat van een disciplinaire procedure, maar die daaraan raakt, is de warschuwing. De procureur-generaal kan deze geven aan leden van het OM onder zijn gezag. Welke gevallen een dergelijke formele waarschuwing zou moeten be-

87 Enguéléguét 1998, p. 77 c.v. De USM is overigens de voortzether van de oude Union federale des magistrats, omgezet in 1972. Deze wakbonden worden wel gehoord over wetsvoorstellen. Zie bijwoorbeeld: Vallini, 10 AN 16 juni 1999. Rapport n. 1702, relatil ả H'action publique en matiére pënale et modifiant le code de plocedure penale Over de verkiezingen wan CSM-leden zie 2.1. OM en rechterlijke macht.

88 Art. L.781 COJ an 11-1 ord. Vincent ea. 1999, p. 207-211 en 546-547

89 Voor de disciplinaire overtreding; art. 43 ord. Rassat 1993, p. 228, Vincent e.a. 1999, p. 555; Perrot 1998, p. 39. Voor de procedure: art 65 Const, ; art. $58-1-66$ ord.

90 Perrot 1998, p. 321; Vincent e.4. 1999, p. 558. Voor de ministeriële praktijk contom aan de CSM zie: CSM $\| 998$, p. 39. Leden wan de rechisprekende macht kumnen overigens slechts een disciplinaire sanciie opgelegd krijgen toor een beslissing van de Hoge Raad zelf (art. 65 Const.).

91 Voor de santies: art. 45 ord Voor de praktijk: Maymier \& Casorla 1993, p.545; CSM 1998, p. 23 en 74. 
treffen is niet omschreven. Dit wordt aan de procureur-generaal overgelaten. De procureur-generaal kan van deze bevoegdheid gebruik maken wanneer hij geen reden zitet voor een disciplinaire procedure, maar hij wel enige reactie op zijn plaats acht (art. 44 ord.).

\subsection{Schorsing en ontslag}

De minister van Justitie kan magistraten van het OM schorsen. Hij kan dit doen in ungente gevallen waarin hij een disciplinaire procedure tegen de magistraat wil beginnen. De minister handelt op voorstel van het relevante parkethoofd of de procureur-generaal en na advies van de CSM. De schorsing kan duren tot de definitieve beslissing in de disciplinaire procedure. Een schorsing van een parketlid komt zelden voor. ${ }^{92}$

Leden van het OM zijn niet onafzetbaar. Voor de rechters bepaalt de grondwet uitdrukkelijk de onafzetbaarheid in artikel 64. De afzetbaarheid van de leden van het OM blijkt uit de hiervóór behandelde mogelijkheid van overplaatsing in het belang van de dienst, ook tegen hun will in. Procureurs kunnen echter slechts ontslagen worden als straf in een disciplinaire procedure - net als rechters. ${ }^{93}$

\subsection{Rechtspositionele rechtsbescherming}

Tegen beslissingen in rechtspositionele zaken kunnen leden van het $O M$ in beroep gaan bij de Raad van State. In principe is de raad bevoegd over besluiten genomen door administratieve organen; zoals de minister van Justitie. Dit geldt onder meer voor de benoemingsbesluiten, de overplaatsingen en de disciplinaire maatregelen. ${ }^{94}$

In geval van een beroep tegen een overplaatsing controleert de Raad van State onder andere of het middel niet oneigenlijk is gebruikt, bijvoorbeeld als een soort gecamoufleerde disciplinaire maatregel. ${ }^{95}$ De toetsing van de Raad van disciplinaire besluiten is evenwel zeer lacuneus. De raad acht zich namelijk onbevoegd ten aanzien van handelingen die gedaan zijn in de uitoefening van een "functie van de rechterlijke macht". Over het strafrechtelijke handelen van het $O M$ dat aanleiding heeft gegeven tot de pro* cedure spreekt de raad zich niet uit. Daarom bekijkt hij nuet of de vervolgingsbeslissing in strijd is met een ministerieel aanwijzing. De raad kan dan hoogstens de feiten zelf verifiëren. Voor dergelijke gevallen toetst hij in feite niet of er een disciplinaire overtreding is. Het beroep op de raad heeft vrijwel alleen zin voor disciplinaire feiten gepleegd buiten de vervulling van de functie van het $O \mathrm{M}^{96}$

92 An. 58-1 ord, Zie bijv. JO SR QR 27 novembet 1997, p. 3320, n. 2456. CSM 1998, p. 38.

93 Voor de overplatsing, zie: 5.2 . Verdere benoeming on overplatsing.

94 Décret 28 januari 1969 .

95 CSM 1998, p. 51.

96 CE 26 juni 1953, Dorly, S 1954, 3, 1, note A de Laubadere, ICP 1953, 1], 78 10, note L. Carlou; RTD civ., 1954, 144, obs. P. Hébraud; CE 21 februari 1968, Auburtin. A.JDA 1968, p. 477, Rassall: $1993, p$. 232; Volff 1998, p. 40; Mathias 1999, p. 175 e.v.; Pradel 2000, p. 127-128. Over deze casus Dorly in detail: Rassat 1967, p. 49.

Vanaf 1958 adviseerde een commission de discipline du parquet de minister over een he disciplineren lid van het OM. De commissie bestond uit parketleden benoend door de minister op voorstel van het 


\subsection{Conchusie}

Op het maken van carrière in het OM kan de invloed van de politiek groot zijn. De benoemingen tot procureur-generaal zijn met mame onveranderlijk politiek van aard. Ook op de rechtspositie van andere leden van de groep 'buiten de hiërarchie' hebben de politieke organen een grote greep. De invloed van de politiek op de rechtspositie van het OM is het sterkst bij de belangrijke benoemingen. De procureurs hebben daarnaast een zwakke juridische positie wat betreft de disciplinaire regeling. Deze geeft de minister het laatste woord in het sanctioneren van ongewenst strafrechtelijk handelen door het OM. In de praktijk legt de minister zich well bij het advies van de CSM neer. Het schaarse gebruik van de disciplinaire procedure lijkt de impact die deze kan hebben op het handelen van het OM te verkleinen. Dit geldt ook voor de zeldzame optie van een overplaatsing van een procureur.

\section{Functionele ministeriêle bevoegdheden}

In het voorgaande kwamen de bevoegdheden aan de orde van politieke organen betreffende de rechtspositie van leden van het OM. Welke ministeriële bevoegdheden hebben nu rechtstreeks betrekking op het handelen zelf van het OM? De centrale vraag is in hoeverte de minister gerechtigd is in te grijpen in de uitoefening van strafrechtelijke bevoegdheden door het OM. Wat voor bevoegdheden heeft de minister daartoe? Een prealabele kwestie is hoe de minister op de hoogte kan geraken van een bepaald handelen van het OM. Hoe communiceert cle minister met het OM?

\subsection{Bevoegdheden omtrent informatievoorziening}

Veelal is men van mening dat het OM een plicht heeft tot het geven van informatie, het doen van verslag en het afleggen van verantwoording aan de minister. Deze plicht zou impliciet zijn aan de hièrarchische relatie tussen minister en OM. De ministeriêle aanwijzingsbevoegdheid zou zo een plicht meebrengen voor het OM om de minister te informeren. ${ }^{97}$ Volgens Rassat zou het OM echter niet de plicht hebben om op eigen

OM. Met de wet wan 17 juli 970 was de commissic exclusief bevoegd om zich uit to spreken over het bestaan van en disclplinare wertreding. De minister sprak zich slechts wit over de sanctie. Was hij het oneens met het oorded van de commissie, dan kon lij deze aanvechten bij een commission speciale. De minister was gebondlen an he oordeel wan deze uit leden van het parket bij de Hoge Razd bestatande commissie. Vanaf 5 rebrati 1994 adwiseade de $C S M$ zell. De minister is evanwel niet meer gebonden aan dicns oordeol ovet het bestan wan de overtreding. Over deze "regression statuaire" Mathas 1999, 178.182

97 Milibert 1994, p. 11; Falleti 1996, p. 76, Volff 1998, p. 37; Vincent a. 1999, p. 554, Pradel 2000, p. 127. Do Commission de réllexion str la Justice neert evenwel dat de ministeriele "verannoordelijkbreid voor hel bepalen van het vervolgingsbeleid" informatievoorziening door de parketten impliceart. 1997. p. 32. Ook de ciroulaire van I mant 1993 gaat bij de vitleg van de annwijzingsbevoegdheid uit wan een "strich devoir d"intormation" over stratzaken. De circulaire am 1 marrt 1993 is getiteld "commentant, articla par article, la loi n. 93-2 du 4 janvier 1993 portant réforme de la procédure pénale". Zue wok arrete van 18 jumi 1999, wanmee een geautomatiseerd systeem is gecreerd voor gegevens van individuele dossiers bij elko procureur-general. Ambtenaten van het ministerie wan Justithe hebben hier locgang toe. 
iniriatief de minister van informatie te voorzien. Enkel op verzoek van de minister zou het parket gehouden zijn hem te informeren. Deze minderheidspositie spoort: niet met de hierna te noemen praktijk. ${ }^{98}$

Geen enkele wettekst of andere rechtsregel schrijft rapportage of verantwoording voor. Wel bestaan er enkele circulaires die het $O M$ voorschrijven om ten aanzien van bepaalde delicten het ministerie te informeren omtrent een zaak. Dit zijn echter oude richtlijnem, vaak in onbruik geraakt of met onduidelijke gelding. Het is overigens onjuist te stellen dat een plicht voor het $\mathrm{OM}$ om de minister informatie te verschaffen op deze circulaires gebaseerd is. De grondslag van de circulaires zelf is al problematisch. Ook voor deze rechtsfiguren lijkt er geen expliciete wettelijke basis te bestaan. ${ }^{99}$

Ten aanzien van de informatievoorziening gelden geen inhoudelijke beperkingen. Het $O M$ is gehouden aan een beroepsgeheim om informatie die op strafzaken betrekking heeft niet te verspreiden (art. 11 CPP). Procureurs-generaal zijn evenwel niet gehouden aan dit geheim tegenover de minister. Zowel wanneer de opsporing nog in gang is, als wanneer een gerechtelijk onderzoek loopt dient het OM de minister zonodig op details te informeren.

Alleen procureurs-generaal van de hoven moeten de minister op de hoogte te houden van relevante zaken. Andere leden van het OM dienen de procureur-general van hun ressort te informeren. Lagere parketten en hun parkethoofden worden geacht geen directe contacten te hebben met het ministerie.

Er lijkt geen juridische plicht voor het parket te bestaan om naast de informatieverschaffing om instructies te vragen. Pradel lijkt wel te suggereren dat het OM daartoe gehouden is. Volgens Volff echter zouden procureurs niet om instructies hoeven vragen. Rassat meent zelfs dat zij daartoe het recht niet hebben. ${ }^{100}$ Deze plicht blijkt ook niet uit wetteksten.

In de praktijk geschiedt de informatieverschaffing van geval tot geval naar gelang het belang van de zaak. Veel parketten zijn gewoon om te rapporteren over alle ernstige of 'politiek gevoelige' zaken. De mate waarin dit gebeurt vormt een gevarieerde praktijk. Informatieverschaffing van het $\mathrm{OM}$ aan de minister gaat vaak vergezeld van het verwijzen naar eventueel nog te geven instructies door de minister. Het gebeurt wel dat de procureur de situatie mededeelt en zijn intenties beschrijft met een toevoeging als 'behoudens instructies in andere zin". Na afwachting van een bepaalde tijd gaat het OM dan tot het aangekondigde handelen over. In sommige gevallen verzoekt het parket uitdrukkelijk om instructies of 'technisch advies' ten aanzien van een beslissing zoals die overwogen wordt door de procureurs. Vervolgens wacht men dan een beslissing van het ministerie af voordat een volgende stap gezet wordt. Zo kunnen zij zich indekken tegen hetgeen later geïnterpreteerd zou kunnen worden als een faux pas. ${ }^{101}$

98 Rassat 1967, p. 112;1993, p. 228; 1996, p. 105.

99 Over het ontbreken van wetteksten: Rassat 1967, p. 112; Angibaud 1999, p. 31. Over de circulaires waarin om informatievoorziening verzocht wordt: Terrier, Commission de reflexion sur la Justice, Annexes 1997, p. 103; Angibaud geeft een lijst van relevante grevallen die door circulaires bestreken worden, 1999 , p. 31. Pradel 2000a, p. 26. Over het rechtskarakter wan de circulaires, zie 6.3. I. 1. Circulaires.

100 Rassait 1967, p. 112; Volff 1998, p. 37; Pradel 2000, p. 127.

101 Rassat 1996, p. 106; Basse 1996, p. 164; Commission de réflexion sur la Justice 1997, p. 25; Bouvier. Jacquin \& Vogelweith 1997, p. $149 ;$; Angibaud 1999, p. 31-32. In een wer verteden zond het ministerie 
Sinds enkele jaren leveren de procureurs een jaarverslag in bij de procureur-generaal. Deze combineert de documenten in een eigen jaarverslag dat hij naar het ministerie zendt. Deze verwerkt de verslagen vervolgens in een interne notitie, hetgeen een jaarverslag ontrent de vervolgingspolitiek vormt. Dit verslag wordt overigens ook weer onder de parketten verspreid. ${ }^{102}$

Daarnaast bestaan er ontmoetingen tussen de procureurs-generaal gezamenlijk en de minister. ${ }^{103}$ Enkele malen per jaar konen de procureurs-generaal tezamen met de minister en enkele ambtenaren bijeen. Men praat er in zeer algemene termen over aspecten van het vervolgingsbeleid. Deze vergadering heeft geen juridische betekenis of gevolgen. Bij gelegenheid bezoekt de minister verder enkele rechtbanken of hoven. De minister spreekt met het parkethoofd, maar ook met de president van de rechtbank of het hof:

Uit eigen initiatief informeert of controleert het ministerie maar in zeer bescheiden mate. Het controleert bijvoorbeeld niet of het handelen van het OM ten aanzien van een type delict overeenstemt met ministerieel beleid. ${ }^{104}$ Wel voert de ministeriële inspectie voor de rechterlijke diensten 'controlemissies' uit. Deze doen onderzoek naar het functioneren van parketten en rechterlijke colleges. Een enkele keer doet de inspectie een algemeen onderzoek op een bepaald onderwerp. Het ministerie heeft grote aandacht voor specifieke strafzaken. Het volgt enkele dozijnen individuele zaken van dichtbij. Zoals gezegd lopen functionele contacten van de minister van Justitie met het OM voornamelijk via de Directie strafrechtelijke zaken en gratie en eventueel het ministeriele cabinet. Deze contacten zijn vaak verbaal en telefonisch. ${ }^{105}$

Met behulp van de hierboven beschreven informatievoorziening is de minister in staat om het hier volgende bevoegdhedenarsenaal te gebruiken. Dit bestaat uit een variëteit van hiërarchisch beroep, aanwijzings- en toestemmingsbevoegdheden en enkele zijdelings relevante beïnvloedingsmogelijkheden.

zal fs een par keer circulisires die de parkenten zelfs aanspoorden om minder te rapporteren en naar goed geweten te beslissen (curculaires van 24 november 1930 en 31 maart 1949). Rasssat noemt enkele oude circulaires die het parket bepalde feiten niet laten vervolgen of geen vervolging toelaten zonder voorafgand verslag te hebben uitgebracht, $1967, \mathrm{p} .90$. Een voorbeeld is de circulaire van 30 juni 1971 (11. 71.998), waarin de minister he OM opdraggt om hem te informeren voorafgand aan de beslissing on de verdachte in staat wan beschuldiging te stellen in abortuszaken. Destijds was er wetgeving in de makak die de abortuspraktijk zou legaliseren.

102 Zie bijv. 'Rapport au Garde des sceaux sur la politique pénale menée en 1999" uit 2000. Eén en ander blijkt uit gesprekken met OM-leden. Daarnaast brengen rechterlijke colleges en parketten aan het begin van jaar een verskg van hun werkzamlheden uit middels een toespraak. In een officiële bijeenkomst spreekt dan het parkethoofd de aanwezigen toe, wak over een thema dat onder de aandacht staat in thet ressori (art R7 $11-2$ COIJ.

103 Commission de réflexion sur la Justice 1997, p. 20.

104 Jacquin \& Vogellweith (Bot) 1997.p. 10.

105 Lemesle d Painsier 1998, 13. 36; Angibaud 1999, p. 32. Zo blijkt ook wit gesprekken met OM-leden. Voor de Inspectie: decrex in. 64-754 wan 25 juli 1964 en décret n. 65-1 van 5 januari 1965: Verder over de Inspectie, de Directie strafrechtelijke zaken (DACG) en het kabinet, zie 4. Minister en ministerie van Justitie ev President. 


\subsection{Hièrarchisch beroep}

Bij het beschrijven van de bevoegdheden van het OM kwam het zogeheten hidrarchische beroep (recours hiérarchique) van belanghebbenden op de parketchef en de procureur-generaal al aan de orde. De minister is de laatste instantie waar belanglrebbenden in beroep kunnen gaan tegen beslissingen van het $\mathrm{OM}$.

Hieromtrent is evenmin iets wettelijk geregeld. Een vaste volgorde van beroep hoeft men niet te volgen. Het is tevens mogelijk zich direct tot de minister te richten. De minister kan het beroep doorzenden naar de procureur-generaal, om hem daarop te laten beslissen. Wanneer de minister evenwel zelf een beslissing wil nemen op het beroep, kan dat slechts door gebruik te maken van zijn aanwijzingsbevoegdheid. In feite vormt het hiërarchisch beroep dus geen afzonderlijke juridische procedure. Het is eigenlijk enkel een wijze van informatievoorziening aan de minister. Jaarlijks beklagen velen zich velen op deze wijze bij de minister. ${ }^{106}$

\subsection{Aanwijzingsbevoegdheid}

Op grond van de wet staan de Franse magistraten van het parket hiërarchisch onder de minister van Justitie. De minister heeft de wettelijk geregelde bevoegdheid om het OM aanwijzingen te geven (art. 5 ord. en art. $36 \mathrm{CPP}$ )..$^{107}$ De vraag naar de grondslag van deze aanwijzingsbevoegdheid is geen kwestie in Frankrijk. De functionele onderschikking van het $\mathrm{OM}$ leidt de doctrine af uit de betrokken wetsartikelen. ${ }^{108}$ Geen enkele Franse auteur veronderstelt een onderschikking los van de specifieke aanwijzingsbevoegdheid. Hypothetisch gezien zou de minister zonder de wettelijke regeling geen bevoegdheid hebben om het $O M$ aanwijzingen te geven.

De minister kan algemene aanwijzingen oftewel circulaires geven, en aanwijzingen ten aanzien van specifieke zaken. Na een soortsgewijze bespreking van deze aanwijzingen volgen enkele opmerkingen aangaande hun procedure en vorm.

\subsubsection{Soorten aanwijzingen}

Aanwijzingen bestaan in verschillende typen naar gelang de inhoud. Wanneer zij een algemene, beleidsmatige strekking hebben heten zij in Frankrijk circulaires. Daarnaast zijn verschillende aanwijzingen mogelijk ten aanzien van specifieke strafzaken. Achtereenvolgens stel ik ze hieronder aan de orde.

106 Falletti ${ }_{2}$ Commission de réflexion sur la Justice, Aunexes 1997, p. 78; Volfr 1998, p. 64, 95. Een voarbeeld bij Chrestia 2000, p. 765. Eén en ander bilijkt uit gesprekken met OM-leden.

107 Art. 5 ord. - "Les magistrats du parquet sont placés sous lla direction et le contrôle de leurs chefs hierar" chiques et sous l'autorité du garde des sceatix, ministre de la justice. A l'audience, leur" parole est libre." A.rt. 36 CPP - 'Le ministre de la justice peut dénoncer au procureur général les infractions a la loi pénale dont il a comaissance, lui enjoindre, par instructions écrites et versées au dossier de la procédure, d"engager ou de faire engager des poursuites ou de saisir la juridiction compétente de telles réquisitions écrites que le ministre juge opportumes."

108 Wel is de specifieke grondslag voor circulaires een vraagpunt. Zie 6.3.1.1. Circulaires. 


\subsubsection{Circulaires}

De minister kan het OM algemene aanwijzingen geven door middel van circulaires. De precieze bevoegdheidsgrondslag hiervoor is onduidelik. De bevoegdheid daartoe wordt volgens sommigen ontleend aan artikel 5 ord en artikel 20 Const. Artikel 5 noemt echter alleen bepaalde specifieke aanwijzingen. Omtrent beleidsaanwijzingen meldi het hets. Artikel 20 Const, stelt slechts dat de regering de nationale politiek bepaalt. De strafrechtelijke politiek zou dan gezien moeten worden als een onderdeel hiervan. Op grond van deze interpretatie zou de minister het OM algemene aanwijzingen moeten kumnen geven. Een wettekst die de minister deze bevoegdheid uitdrukkelijk toekent ontbreekt in ieder geval. Accomando suggereert zelfs dat de grondslag voor circulaires in het gewoonterecht ligt. ${ }^{10 \%}$

Het OM is volgens veel auteurs niet strikt gebonden aan de letter van de circulaires. De formulering van de beleidslijnen is vak in zeer algemene bewoordingen gesteld. Parketten kunnen ze vervolgens 'aanpassen' aan de lokale situatie. De procureur-generaal kan voor zijn eigen ressort aangeven welke aspecten van een circulaire van belang zijn of niet. Hij interpreteert ze als het ware naar de lokale situatie toe. " Een ministeriele circulaire van 1 maant 1993 preciseert echter dal de circulaires niet de status hebben van aanbevelingen, maar wan bevelen. In een circulaire van 9 mei 2001 zegt de minister weer nadrukkelijk dat de procureur-generaal en de lokale parketten het nationale vervolgingsbeleid kunnen aanpassen aan lokale eisen. Overigens is het opwallend dat circulaires zo de binding van andere circulaires pogen te preciseren.

Circulatres komen tot stand op de Directie strafrechtelijke zaken (DACG) van het ministerie van Justitie. Bij overleg voorafgaand aan het opstellen van circulaires zijn soms leden van de parketten betrokken. Circulaires komen evenwel niet tot stand op voorstel van leden of organen van het OM. Wel kont het voor dat parketten zelf een bepaalde werkwijze ontwikkelen, die vervolgens overgenomen wordt in een circilaire. ${ }^{12}$

De inhoud van circulaires is gevarieerd. Circulaires betrefien zowel inhoudelijke kwesties zoals prioriteiten, maar ook organisatorische en procedurele aspecten. Inhoudelijke circulaires richten zich vaak op een bepaalde groep delicten. Zij betreffen echter vrijwel nooit posterioriteiten. De minister is uiterst terughoudend met dergelijke circulaires. Zij lijken, zeker in de heersende culturr, als not done te gelden. In de praktijk

109. Acconando 1997a, p. 92. Over art. 5 en 20: Lemesle \& Pansier 1998, p. 37.

Art 20 Const. - "Le Gouvenement détermine et conduit la politique de la Nation (...)'.

Art. 5 ord. -.- "Les magistrats du parquet sont placés sous la direction at le contrôle de leurs chefs hierar" chiques et sous l"autorite du garde des sceaux, ministre de la justice. A l'audience, leur parble est libre." De vraag is of ar. 20 de furidische grondslag is voor de beleidsanwijzingen of dat de bepaling niet eerder de theoretische ratio daaracher wormt: doel wan de aanwijzingsbevoegdheid zou zijn het mogelijk maken van de nationale politiek. Zie voor kritiek verder hoofdstuk 6, 4.3. Vervolging als een regeringsatngelegenheid. De suggestie van het gewoonterecht komt van: Mallibert 1994, p. I 1 .

110 Malibert 1994, p. 11; M. Robert 1996, p. 204; Zirnhelt 1996, p. 207; Volff 1998, p. 35. Dit blijkt ook uit gesprekken met OM-leden.

III Over de circulaine van I maat 1993 zie 6.1. Bevoegdheden omtrent informatievoorziening. De circulaire van 9 mei 2001 is genaand 'Action publique et sécurité".

112 M. Robert 1996, p. 202-203. 
wordt er geen algemene, samenhangende strafrechtelijke politiek gevoerd. De circulaires die wel een dergelijk breed beleid inhouden zijn zeer zeldzaam en sinds 1981 inexistent. ${ }^{113}$

Tot in de jaren negentig richtte de regering zich weinig op thet vervolgingsbeleid. In plaats daarvan volgde zij een aantal individuele strafdossiers en het beleid ten aanzien van politiediensten. Zoals hiema zal blijken werd de politiek eind jaren negentig zeer voorzichtig met het geven van de bijzondere aanwijzingen. Nadien zijn er wel algemene circulaires voorgekomen die een wat specilieke inhoud hadden. Zo zond de minister in enkele bovenlokale sociale conflicten in 1997 in korte tijd meerdere circulaires. De actie van de verschillende parketten conformeerde zich hierdoor op homogene wijze aan het verloop van de conflicten. ${ }^{114}$

\subsubsection{Specifieke aanwijzingen}

Naast circulaires kan de minister aanwijzingen geven in individuele strafzaken (art. 36 CPP). Van de bevoegdheid hiertoe maken zij slechts in uitzonderlijke zaken gebruik. Zo zou het volgens een circulaire uit 1993 moeten gaan om gevallen waarin het 'belang van Justitie" ('intérêt de la justice') op het spel zou staan, of de principes omtrent de persoonlijke rechten en vrijheden, of intemationale plichten die Frankrijk is aangegaan. Ten slotte zou de minister specifieke aanwijzingen kunnen geven wanneer hij een interpretatie omtrent het recht in een strafzaak aan de rechter zou hebben willen voorleggen. 115

Het beleid van de afgelopen jaren zwalkt tussen de opvattingen van verschillende ministers omtrent aanwijzingen in individuele gevallen. Nallet en Vauzelle, voorgangers

113 Over posterioriteiten: Jacquin (Colleu) 1997, p. 10. De laaste overkoepelende beleidscitculaire was die van 21 oktober 1981 van múnister Badinter. M. Robert 1996, p. 201 ; Accomando $1997 a$, p. $92 ;$ Bot vien, Jacquin \& Vogelweith 1997, p. 41. Voorbeelden van organisatorisch-procedurele de circulaires zijn die over de Conseils départemental de prévention de la delinquance: circulaires var 3 september 1993 ca 2 januari 1997. Lemesle \& Pansier 1999, p. 60. Over de Conseils zie: 3.1. Opsporing Een voorbeedd van een meer inhoudelijke circulaire is die van 1 december 1998 over delicten gepleegd in hel verband wan sektert.

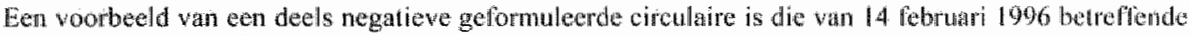
openbare ambestedingen. Het OM werd hierin verzoch on bepalde onde, man nog niet verjacurde zaken te seponeren. Ook werden prowureurs angespootd om geen gerechtelijk onderzoek lo doen be girnmen in bepaalde financielle zaken, maar zich zoweel mogelijk te beperken tot opsporingsonderzocken. Dit beleud mot gezien worden in de toenmalige context van de vele zaken die bovenkwamem van frande door politici. Aangezien een dieel van deze zaken personen betroffer die politiek werwant waren awn de regerende bewindslieden, kan deze cireulaire met enig wantrouwen bekeken worden. Mouwier, Jacquin \& Vogelweith 1997, p. 197; Vogelweth 1997, p. 13. Een ouder voorbet betreft de circulaire witgevaardigd na indiening van een voorstel dat de strafbarheid van abortus op zou heffen. Zie Du Truche 1992 , p. 257-258. De wetswajziging omitrent abortus betnof n. 75 - 17 van 17 januari 1975 .

114 Over de gerichtheid op individuele strafzaken en de politie: Maynier \& Casorla 1993, p. 546; M. Robert 1996, p. 201; Falletti, Commission de réflexion sur la Justice, Annexes 1997, p. 83; "Terrier, idem, p. 101; Accomando 1997, p. 1065; Bouvier, Jacquin \& Vogelweilh 1997, p. 43, Over de lireguentio wan chrculares: Lemesle \& Pansier 1998, p. 38. Anders: Nallet, Commission de reflexion sur la flustice, Annexes 1997, p. 40. Oyer de "specifieke" circulaires: Jean 1999, p. 33. In 1997 bazaten stakers verschillende westigingen wan de Agence nationale pour l'emploi (ANPE).

115 Art. C36 van circulare van I maart 1993. Over de circulaire: 6. 1. Bewoegdheden omtrent informatic. voorziening. 
van deze ministers, hebben zich nog publiekelijk het recht voorbehouden om individuele aanwijzingen te geven.De ministers wan Justitie van de afgelopen jaren, en met name de ministers Guigou en Lebranchu hebben toegezegd niet langer gebruik te maken van de bevoegdheid aanwijzingen te geven in individuele, lopende zaken. Overigens heeft minister Guigou ook pogingen ondernomen om de aanwijzingsbevoegdheid af te schaffen. Méhaignerie en Toubon, beïde minister vóór Guigou, verplichtten zich enkel om geen aanwijzingen tot niet-vervolging te geven. De laatste minister, Perben, heeft weer uitdrukkelijk niet uitgesloten dat hij specifieke aanwijzingen zal geven. ${ }^{116}$ In het verleden zijn interventies van het ministerie van Justitie in individuele zaken zeldzaam geweest. Wel betroffen de gevallen waarin het gebeurde meestal ernstige of "gevoelige" zaken. In de twintigste eeuw heeft het ministerie zich wel lang met name geconcentreerd op de behandeling van de vervolging in individuele zaken. De aandacht voor beleidsvoering was daaraan ondergeschikt.

Aanwijzingen ten aanzien van individuele zaken zijn te onderscheiden in een viertal soorten: aanwijzingen ten aanzien van de opsporing, aanwijzingen tot vervolging of om rechtsmiddelen te gebruiken, aanwijzingen tot niet-vervolging en aanwijzingen ten aanzien van het requisitoir. Enkel de aanwijzingen tot niet-vervolging hebben in Frankrijk een afzonderlijke discussie opgeleverd. Deze zal ik eerst behandelen. Daarna volgt een korte bespreking van de andere specifieke aanwijzingen.

\subsubsection{Aanwijzing tot niet-vervolging}

Het Franse recht is niet eenduidig over de vraag of de minister een aanwijzing tot nietvervolging kan geven. De tekst van artikel 36 CPP lijkt deze mogelijkheid niet te geven, maar zij sluit die ook niet uitdrukkelijk uit. De meeste Franse schrijvers zijn van mening dat de minister deze bevoegdheid niet heeft. In het algemeen is men van mening dat op grond van de huidige wettekst de minister geen aanwijzing tot nietvervolging kan geven. ${ }^{118}$

116 De minister vóór Nallet. Arpaillange, claimde het gebruik van deze aanwijzingsbevoegdlleid niet publickelijk, mar malkte or wel gebruik van. Hij was minister tijdens de Urba-affaire. Zie hierover: 6.3.1.3. Aamwijzing tot niet-vervolging. Voor Nallet: Bouvier, Jacquin \& Vogelweith 1997, p. 7. Voor Vauzelle: JO AN CRI 6 oktober 1992, p. 3366. JO SR CRI 17 november 1992, p. 3166. Voon Guigou: verklaring wan premier Jospin (namens de regering, mede voor minister Guigou) JO AN CRI 19 juni 1997, cléclaration de politique générale; Verklaring vän Guigou tegenower de ministerraad, 29 oktober 1997; Betoog van Lebranchu, Congrès de I'Union syndicale des nagistrats, Chamberry, 20 oktober 2000. Vgl ook Tuncey 1996, p. 126; 1997, p. 182. Voor Méhaignerie en Toubon, zie 6.3.1.2. Aanwijzing tot niet-vervolging. Voot Perben: Le Monde 16 mei 2002; Figaro 11 juli 2002 . Zo stelde het OM recentelijk beroep in tegen de Papon-uitspraak. Met nadruk werd gesteld dat dit was gedaan "op verzoek' vat de minister. Volgens de betreffende procureur-generaal Nadal is het beroep ingesteld na een analyse van de diensten van het ministerie en het parket. Le Monde 20 september 2002 . Nadal werd overigens benoemd onder de linkse regering Jospin.

117 Over de zeldzaamheid van aanwijzingen: Maynier \& Casorla 1993, p. 545; Jeol 1996, p. 59; Pradel \& Laborde 1997, p. 141; Turcey 1997, p. 11; Boudon 1997, p. 13; Foyer, Commission de réflexion sur la Justice, Annexes 1997, p. 27; Falletti, idem, p. 85. Jacquin (Colleu) 1997, p. 11. Dit blijkt ook uit gesprekken mei OM-leden. Over de concentratie op indwiduele zaken, zie 6.3.1.1. Circulaires.

118 Rassati 1967, p. 103; 1996, p. 102; Commission de prévention de la corruption 1993, p. 51; Malibert 1994, p. 8: Pradel \& Laborde 1997, p. 143; Conmission de réflexion sur la Justice 1997, p. 33; Béteille, Commission de reflexion sur la Justice. Annexes 1997, p. 60; Volff 1998, p. 35, 47; Lemesle \& Pansier 
Mathias concludeert tot deze onbevoegdheid op grond van de scheiding der nachten. De onafhankelijkheid van de rechterlijke macht zou meebrengen dat de regering har geen aanwijzingen zou kunnen geven en dat de regering zich niet in de plaats zou kunnen stellen van de rechterlijke macht. De regering zou aldus niet kunnen besluiten om een zaak niet door de rechterlijke macht te laten beslissen, aldus deze auteur. ${ }^{10}$

Minder auteurs zijn expliciet of impliciet van mening dat de minister deze bevoegdheid wel bezit. Binnen het Franse OM zelf is de mogelijkheid van een aanwijzing tot nietvervolging tot het einde van de vorige eeuw nooit weersproken. ${ }^{120}$ Uit de praktijk zijn enkele zaken bekend waarin de minister feitelijk een aanwijzing tot sepot gegeven heeft. Er zouden zelfs vaker aanwijzingen tot niet-vervolging dan tot vervolging gegeven zijn. ${ }^{21}$ De laatste vijf ministers (Mehaignerie, Toubon, Guigou, Lebranchu en Perben) hebben evenwel verklaard dat zij niet langer een dergelijke aanwijzing zullen geven. $^{122}$

Een bedekte vorm van de aanwijzing tot niet-vervolging is de aanwijzing om gen gewoon opsporingsonderzoek te beginnen in plaats van een gerechtelijk onderzoek te doen openen. Een nadeel van die laatste is dat de procureur geen beslissingsbevoegdheid meer heeft over de opportuniteit van de zaak. Deze zal voor de rechter komen, tenzij die om technische redenen niet te vervolgen is. Indien de actie van het OM zich daarentegen beperkt tot een opsporingsonderzoek kan een rechterlijke beslissing over de zaak worden uitgesteld of eventueel voorkomen. Dit effect is vergelijkbaar met dat van een aanwijzing tot niet-vervolging. Tot voor kort was de Franse geschiedenis niet geheel verschoond van een dergelijk gebruik van de aanwijzingsbevoegdheid. ${ }^{23}$

1998, p. 34; Angibaud 1999, p. 29; Pradel 2000, p. 126. Sommigen roepen daamast een zeer oud arrest in herinnering: Crim 22 decernber 1827, B.C. n. 118; Dalloz, 1828.1.67. Herin stelt het Hof van cassatie uitdrukkelijk dat de minister deze bevoegdheid niet zou hebben. In een meer recente uitspraak geeft het hof impliciet toe dat de minister die bewoegdheid zou hebben. Cass. crim. 12 mai 1992, D 1992, p. 427, note D. Mayer. Kritisch zowel de noof als Mathias 1999, p. 200-201. De circulaine van I mitarl 1993 somt de bevoegdheden van de minister ex art. 36 analytisch op en laat daarbij een bevoegdheid to het gewen van een aanwijzing tot niet-wervolging achterwege. Enkelen menen overigens dat de tekst van art. 36 CPP deze aanwijzingen uitdrukkelijlk zou moeten werbieden. Zie verder hoofdstuk 7 , Hervormingen. Voor de wettekst van art. 36 CPP zie 6.3. Aanwijzingsbevoegdheid.

119 Mathias 1999, p. 203.

120 Expliciet: Du Truche 1995, p. 167; André-Coret 1996, p. 135; Cotte, Conmission de téflexion sur lat Justice, Annexes 1997, p. 72; Carbonmier, idem, p. 158; Perrot 2000, p. 39 en 397. Impliciel: DelmasMarty 1994, p. 153; Jél 1996, p. 69-71; Foyer, Commission de reffexion sur la fustice, Annexes 1997. p. 28; Nallet, idem, p. 43-44; Terrier, idem, p. 104-105, Over de vroegere opvatting binnen het OM: Terrier, idem, p. 104

121 Pradel 1991, p. 25. Een geval betrof in 199 \& de SORMAE affaire (of affaire var de fausses facumes du Sud-Est). Het ministerie van Justitie zou een aamwijzing to seponeren gegeven hebben op de grond dall de feiten zouden vallen onder de amnestiewet van jul 1988. Het zou aldus een technisch sepot zijn geweest. Het delict zou een onwettige financiering van een verkiezingscampagne betreffen. Een andere lezing van deze gebeurtenis is dat de minister een verbloemd sepot om opportunileitsredenen bevolen zou hebben om politieke wrienden te beschermen. Bouvier, dacquin \& Vogelweith 1997, p. 23.

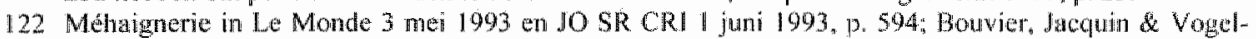
weith 1997, p. 32. Toubon in een toespraak op 23 mei 1995. Zie Basse 1996, p. 165; Bouvier, Jacquin \& Vogelweith 1997, p. 142; Falletti, Commission de réllexion sur la Justice, Arnexes 1997. p. 79. Ministers Guigow en Lebranchu hebben verklatd in het geheel geen aanwijzingen meer te geven, zic 6.3.1.2. Specifieke aanwijzingen. Perben, zie Le Monde 16 mei 2002.

123 Minister Arpaillange zou in de Urba-affaire uit 1989 aan de procureur wan Marseille een dergelijke aan- 


\subsubsection{Overige aanwijzingen}

Netast de mogelijkheid van een aanwijzing tot niet-wervolging zijn andere spechieke aanwijzingen mogelijk. Zo zijn anwijzingen denkbaar ten aanzien van de opsporing, een aanwijzing tot vervolging of on techtsmiddelen te gebruken en aanwijzingen ten aanzien van het requilsiloir. Achtereenvolgens komen zij hier aan de orde.

Een ministeriele bevoegdheid om een aanwijzing te geven om van opsporingsbevoegdheden gebruik te maken ljjkt in Frankrijk wel aanwezig. Wettelijke teksten die deze mogelijkheid uitdrukkelik noemen of uitshiten ontbreken. Geen enkele auteur leidt een dergelijke bevoegdheid af uit het bestasande hiërarchische stelsel. Evenmin wordt het bestaan van de bevoegdheid echter weersproken. In de praktijk heeft de minister bijvoorbeeld eens een aanwijzing gegewen een verdachte te arresteren. Verder is het zoals hiervoor bleek voorgekomen dat de bewindspersoon het OM een gewoon opsporingsonderzoek liet beginnen in plaats van een gerechtelijk onderzoek. ${ }^{124}$

De wet stat de minister van Justitie wel met zoveel worden toe dat hij een aanwijzing tot vervolging geeft (art. $36 \mathrm{CPP}$ ). Het is daarvoor niet nodig dat de te vervolgen persoon al een verdachte is volgens de politie of het $O M^{125}$ Een bevoegdheid aanwijzingen te geven om in hoger beroep of in cassatie te gaan lijkt evenzeer te bestaan. Evenmin als ten aanzien van de aanwijzingsbevoegdheid in de opsporing verschaffen wetsteksten hier enige duidelijkheid. Sommige schrijvers veronderstellen echter wel de geoorloofdheid van dergelijke aanwijzingen. De minister zou daarentegen geen aanwijzing kunnen geven om niel van een rechtsmiddel gebruik te maken. ${ }^{126}$

Als de vervolging een aanvang heeft genomen kan de Franse minister aanwijzingen ten aanzien van het requisitoir geven. Zo kan hij het OM de aanwijzing geven ontslag van rechtsvervolging of vrijspraak te eisen. De minister kan het OM echter slechts verplichten een bepaalde schriftelijke conclusie te nemen. Over de mondelinge overwegingen van het parketlid heeft de minister geen zeggenschap. ${ }^{27}$

wijzing lubben gegeven. De zakk betrof onder meer een illegale worm wan financiering aan de socialistische parti, dic op da monent regewe. De procureur zou voorgesteld hebben on een gerechteljk onderzoek to openen. Zie Bow wier, Maguin \& Vogelweith 1997, p. 19-21. Een bijzonder geval betrof in 1906 de beslissing van de ministers wan Justhe en van Binnenlandse zaken on on helikopter naar de Wimalaya to sturen. Daarmes wilden zij natar eigen zeggen bij een parkethoofd van Evry (Dawenas), die was op wakantie was, verifieren of een beslissing wan een parkellid wel 'procedureconform' was. Deze had besloten een geneohtelujk vooronderzok te doen openw tegen de vrouw van burgenteester 'Tiberi vam Parjis. Zij zou zich hebben laten betalen voor een fictieve functie. Het parkethoofd had 'slechts' een gwwoon opsporingsonderzoek ingestald. In zijm afwezigheid had de adjunch-procureur Dujardin een gerechtelijk onderzoek doen instellen. Zie: Glavany en Derosier JO AN CRI 13 novemben 1996, p. 6872

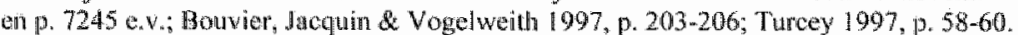

1242 6.3.1.3. Anwijaing tot niet-verwolging. Een woorbeeld van een arrestatiebevel betrof dat van Nallet in 1991. Hij liet het OM Michel Kemmache wresteren, die in wheid het begin van zijo proces afwachte. Volgens enkele critici was dit bedoeld om te voorkonten dat hij in persoon voor het Europees Hof voor de Rechten van de Mens zou verschijnen. Bij dit hof had hij eem procedure adngespannen tegen de lange dutar van de voorlopige hechtenis. Door te voomkomen dat Kemmache aanwezig zou zijn zou de Franse statt en de minister minder snel verlegenheid gebracht kunnen worden. Bouwier, Jacquin \& Vogelweith 1997, p. 33-34.

125 Mathias 1999, p. 194.

126 Rassat 1996, p. 104. Terrier, Commission de réfexion sur la Justice, Annexes 1997, p. 104.

127 Rassat 1967, p. 102; Malihert 1994, p. 8; Lemesle \& Pansier 1998, p. 37; Angibaud 1999, p. 29; Pradel 


\subsubsection{Aanwijzingsvorm}

De minister heeft slechts de bevoegdheid om zich via de betreffende procureurs-generaal tot parketten te richten. Hij zou dus niet direct aan het hoofd of een substituut van een rechtbankparket een aanwijzing kunnen geven. De minister van Justitie is verder de enige minister die het $\mathrm{OM}$ aanwijzingen mag geven. Noch andere ministers noch de minister-president zijn daartoe bevoegd. ${ }^{128}$

Voor algemene aanwijzingen of circulaires bestaan geen vormvereisten. Ze zijn feitelijk echter altijd in schriftelijke vorm gegeven. De meeste circulaires worden gepubliceerd in het Bulletin Officiel du nimistère de la Justice.

Vormvereisten gelden wel ten aanzien van aanwijzingen in specifieke zaken. Sinds 1993 dient een ministeriële aanwijzing altijd in schriftelijke vorm gegeven te worden. Dit document moet vervolgens altijd toegevoegd worden aan het procesdossier. Een mondelinge of telefonische aanwijzing is daarom niet bindend. Een dergelijke mededeling vormt formeel hoogstens een advies. Het OM kan om schriftelijke bevestiging van die mededeling vragen voordat het daar enige uitvoering aan geeft. Uitzonderingen op deze vormplichten bestaan niet. Zij gelden ongeacht de aard van de strafzaak, de persoon van de verdachte of de eventueel vereiste spoed. ${ }^{129}$

\subsubsection{Rechtswaarborgen bij aanwijzingen.}

De constitutionele 'onafhankelijkheid' van de vervolgende organen van de rechterlijke macht (art. 64 Const.) is beperkter dan die van de rechtsprekende organen. Uit het bovenstaande blijkt het $\mathrm{OM}$ onder de aanwijzingsbevoegdheid van de minister van Justitie te staan. Het Franse recht kent wel een viertal mechanismen die (mede) de functie hebben om ministeriële aanwijzingen te beperken of te begrenzen. Achtereenvolgens bespreek ik de kJacht, de rol van de procureur-generaal, de eigen bevoegdheid en de spreekvrijheid van het $\mathrm{OM}^{130}$

Ten eerste kan het hierboven besproken instituut van de klacht door het slachtoffer een waarborg vormen tegen sommige arbitraire sepots om politiek gelijkgezinden te beschermen. ${ }^{131}$ In het geval dat de minister de aanwijzing geeft niet te vervolgen, staat het

2000, p. 126. Over de mondelinge condusie, zie 6.3.3. Rechtswaarborgen bij amwijzingen.

128 Ari. 36 CPP. Rassat 1967, p. I17; Malibert 1994, p. 8; Volff 1998, p. 47; Angibaud 1990, p. 29. Over de exclusiviteit van de ministeriele bevoegdheid: Volff $1998, p .48$.

129 Art. 36 CPP, gewijzigd bij art, 4 wet to, 93-2 van 4 januari en art. I wet n, 93-1013 van 24 augustus 1993 . Jéol 1994, p. 1364; Volff 1998; p. 35.

130 Over het begrip 'onafhankelijkheid" in de grondwet zie 2.1. OM en rechterlijke macht. Een nuet geünstitutionaliseerde waarborg bij anwijzingen kan men verder zien in de media. Het feit dat de media grote interesse blijken te hebbern voor affaires en schandalen een zekere watarborg zijin tegen het wegmoffelen van strafzaken op politiek-opportunistische gronden, Bartolomei 1996, p2, 120-121; Foyer, Comnission de réflexion sur la Justice, Annexes 1997, p. 28.

131 Mathias $1999, \mathrm{p} .97,161$ en 245. Daarnaast vormt de rechtsfigu ur een middel om het handelen vant het OM zelf te controleren en een ewentuele onjuiste technische interpretatie van de zatk te corrigeren. Malibert 1994, p. 30; Cotte, Commission de réhexion sur la Justice, Arnexes 1997, p. 72; Vincent e.di. 1999 , p. 512. Deze auteurs zijn overigens degenen die tevens wan mening zijn dal de aanwijzingsbevoegdhetd wan de minister een waarborg wormt tegen thet handelen wan het $O M$. Zie loofdstuk $6,6.1$. 
een belanghebbende vrij om een klacht in te dienen. De onderzoeksrechter beslist over de klacht, terwijl het parket dan niet kan seponeren. Deze rechter kan ook niet op grond van opportuniteitsredenen de klacht afwijzen. De onafhankeligheid van de onderzoeksrechter kan zo een belangrijke waarborg vormen tegen partijdige invloeden van politieke organen gericht op voorkoming van vervolging. Dit geldt echter niet in gevallen zonder belanghebbende, of wanneer deze geen klacht indient.

Ten tweede is de procureur-generaal de verplichte tussenschakel tussen de minister en het lagere OM. De procureur-generaal kan eventueel weigeren om de ministeriële aanwijzing door te geven an het parkethoofd bij de rechtbank. ${ }^{132}$ In dat geval loopt de procureur-generaal wel de kans dat de minister een disciplinaire procedure tegen hem begint. Het lijkt in het algemeen wel minder waarschijnlijk dat disciplinaite actie tegen hem dan tegen een lager parketlid ondernomen wordt. Een dergelijk initiatief tegen de procureur-generaal zou grote ophef kunnen veroorzaken. De schakelpositie van de procureur-generaal is evenwel niet een eenduidige waarborg. De procureur-generaal wordt mede op grond van een politieke verwantschap met de regering benoemd. In het geval zijn politicke kleur overeenstemt met die van de regering van de minister, is een weigering om een aanwijzing aan het lagere parket door te geven minder waarschijnlijk.

Ten derde hebben de lokale parkethoofden een powwoir propre. De wet attribueert hen rechtstreeks een eigen bevoegdheid. De pouvoir propre heeft twee elementen of gevolgen: het recht van verzet (droit de résistance) en de onmogelijkheid voor een superieur om in zijn plaats te handelen. 133

Dit laatste onderdeel van de pouvoir propre wordt wel het verbod van substitutie genoemd. Het bepaalt dat de minister niet de bevoegdheid heeft om in plaats van een procureur-generaal of een lager parket te handelen. Evenmin kan de procureur-generaal handelen in de plaats van het lagere parket. Deze verboden gaan een grote concentratie van macht bij de minister tegen. Het verzetsrecht houdt in dat parkethoofden het recht hebben om zich te onthouden van de uitvoering van een aanwijzing van hum procureurgeneraal. Ook als de aanwijzingen oorspronkelijk - via de procureur-generaal - van de minister komen is dit mogelijk. Het verzetsrecht kan evenwel alleen onder bepaalde voorwaarden uitgeoefend worden. Procureurs kunnen dit in ieder geval doen als de uitvoering van de aanwijzing in strijd zou zijn met het recht. In de praktijk heeft het verzetsrecht maar weinig betekenis gezien het besproken disciplinair regime en het benoemingenstelsel. Ingaan tegen de al dan niet litdrukkelijke wens van de minister houdt een professioneel risico in voor de carrière van OM-leden. ${ }^{134}$ Ministeriële aanwijzingen die niet opgevolgd worden zijn zeldzaam. In de praktijk gehoorzamen de leden van het OM vrijwel altijd aan de minister. ${ }^{135}$

Reehubescherming en reehtmatigheidscontrole. Over de klacht: 3.8 Rechtenlike controle op het OM.

132 Rassut 1996, p. 104.

13. Rassat 1967, p. 113; 1993, p. 228; Malibert 1994, p. 10; Lemesie de Pansier 1998, p. 44; Volff 1998, p. 36; Perrot 1998, p. 409; Mathias 1999, p. 172 174; Angiband 1999, p. 30; Vincent e.a. 1999, p. 555; Pradel 2000, p. 129; Stefani, Levasseur \& Botloc 2000 , p. 136.

134 Mathias 1999, p. 174. Een en ander blijk wit gesprekken met OM-leden Zie ook 5.2 . Verdere benoeming en overplastsing en 5.6. Disciplinair regine.

135 Angiband 1999, p. 30; Pradel 2000a, p. 26. 
Een vierde waarborg vonnt de mogelijkheid voor het OM om zich ter zitting mondeling vrij uit te drukken. Tijdens de terechtzitting heeft het lid van het OM de wettelijk gewaarborgde vrijheid van spreken. Dit wordt uitgedrukt met het adagium 'la plwne est serve, mais la parole est libre". Ook als de minister hem een aamwijzing heeft gegeven zou de procureur zich desgewenst tegen ziljn schriftelijk requisitoir kunnen uitspreken. Daamaast kan hij alle documenten overleggen die hij nuttig acht bij de betreffende zaak. De minister kan het presenteren wan dergelijke documenten niet tegenhouden. ${ }^{136}$ Het komt maar zeer zelden voor dat een procureur zich tijdens de zitting uitspreekt in contrast met een ministerieel aanwijzing. ${ }^{137}$

De analyse van de Franse doctrine laat zien dat het adagium van la parole est libre eigenlijk van weinig nut is. Dit heeft praktische redenen, en is daarnaast een gevolg van de pouvoir propre van het parkethoofd.

Ten eerste is het feitelijk al onmogelijk om woord voor woord het mondeling requisitoir voor te schrijven. Hetgeen ter zitting ter sprake komt kan de strekking van het requisitoir namelijk beïnvloeden. Ten tweede kan het parkethoofd, indien hij een aanwijzing tot vervolging gekregen heeft, al op grond van zijn verzetsrecht besluiten deze helemaal niet uit te voeren. Een aanwijzing voor het requisitoir komt dan niet ter sprake. Het gebruik van het verzetsrecht kan voorkomen dat het spreekrecht toepassing krijgt. 138

Het is evenwel denkbaar dat de procureur de anwijzing tot vervolging toch niivoert om redenen die buiten de zaak liggen (loyaliteit aan de minister, carrièreplannen, vrees voor een disciplinaire procedure). Vervolgens kan dan eveneens een aanwijzing ten aanzien van het requisitoir gegeven worden. Als het echter zover komt dat de procureur on de hiervoor genoemde redenen de aanwizing tot wervolging heef uitgevoerd, zal hij wel evenzo geneigd zijn om zijn nondeling requisitoir aan de ninisteriele wensen te conformeren. Van zijn wrijheid van spreken zal hij dan geen gebruik willen maken. Het adagium is dan niet van belang. Als het parket een aanwijzing heeft gekregen om in een bepaalde zin te requreren, kan het hoofd besluiten deze aanwijzing niet uit te voeren op grond van zijin verzetsrecht. Als hij de aanwijzing datrentegen wel zou vitvoeren, is er geen reden waarom hij zich wervolgens in zijn mondelinge conclusie zou willen thegenspreken. ${ }^{139}$

In theorie beschermt het adagium ook de substituten tegenover het hoofd. Gehouden als zij zijn om diens aanwijzingen uit te voeren, genieten zij wel de vrijheid van spreken. Het parkethoofd zelf heeft echter ruime bevoegdheden over zijn ondergeschikten. Desgewenst kan hij voorkomen dat een substituut ter zitting verschijnt. Hij kan een ander daartoe aanwijzen of zelf conclusie nemen. De substituut kan eventueel weigeren om te

136 Art. 5 ord. Art. 33 CPP -.. "Ill est fenu de prendre des réquisitions écrites conformes aux instructons qui lui sont données dans les conditions prévues aux articles 36, 37 et 44 . Il développe librement les observations orales qu'il croit convenables au bien de la justice." Crim. 13 mai 1976, B.C. n. 157. Malibert 1994, p. 10; Vincent e.a. 1999, p. 555; Pradel 2000, p. 129. Het adagium zelf ligt niet met die identieke woorden vast in wetteksten.

137 Pradel \& Laborde 1997, p. 143. In 1994 sprak de advocaat-generaal in de affaire Alcatel fijcens de zitting: "Jai requis sur ordre". Bouvier, Jacquin \& Vogelweith 1997, p. 206.

138 Rassat 1967, p. 119-120; 1996, p. 104.

139 Rassat 1967, p. 120. 
zeggen hoe hilj mondeling zal requireren maar dat zal voor het hoofd een voldoende duidelijk teken zijn on actie te ondememen. 140

Het belang van het adagum beperkt zich zodoende tot wee gevallen. Het rechtvaardigt do weigering van het parket om de minister voor de zitting de teneur van zijn mondeling requisitoir mede te delen. Jevens geeft het de procureur de mogelikheid om mondeling een beoordelings fout te herstellen wanneer hij een aanwijzing ten aanzien van het schiftelifke requisitour heeft uitgevoerd, Al met al heeft de parole libre een praktisch uiterst bepent toepassingsbereik.

\subsubsection{Conclusie}

De ministeriele aanwijzingsbevoegdheid blijkt een verreikend interventiemiddel ten aanzien van het handelen in strafzaken. De bevoegdheid kent wel enkele inhoudelijke beperkingen, waarvan de belangrijkste is de onmogelijkheid van aanwijzingen tot nietvervolging. Enige procedurele beperkingen gelden slechts ten aanzien van individuele aanwijzingen. Rechtswaarborgen bij deze ministeriële bevoegdheid spelen geen grote rol. In de praktijk hebben aanwijzingen met name in de opsporingsfase wel een belang gehad. De houding van ministers van Justitie over specifieke aanwijzingen is wisselend. Wel geeft de minister geregeld algemene circulaires uit op een veelvoud aan strafrechtelijke terreinen.

\subsection{Toestemming voor vervolging}

Voor de uitoefening van bepaalde strafrechtelijke bevoegdheden ten aanzien van personen in hoge staatsambten is de toestemming (awtorisation) nodig van een staatsorgaan. Dit is het geval ten aamzien van leden van het parlement, de President, ministers en staatssecretarissen. Leden van andere overheidsorganen zijn in principe zonder beperkingen onderworpen aan vrijheidsbenemende maatregelen en vervolging. De Franse minister, de regering en de President hebben in deze beslissingen geen rol, Om de vergelijking met de andere wee landen te vervolledigen echter, bespreek ik hieronder de betreffende procedures. ${ }^{142}$

Wat betreft de leden van het parlement is alleen toestemming vereist voor het opleggen van een vrijheidsbeperkende maatregel, zoals een arrestatie. Voor het uitoefenen van de vervolging zelf hoeft geen toestemming gegeven te worden. In de procedure doet de ressortprocureur-generaal de betreffende kamer een verzoek via het ministerie van Justitic. Een speciale commissie van de parlementskamer beslujt over de verlening van de toestemming. De plenaire vergadering van de kamer kan echter besluiten om zowel het opleggen van de vrijheidsbeperkende maatregel als de vervolging jegens het kamerlid te schorsen voor de duur van de kamersessie. Kamerleden worden wel voor de gewone

140 Rassat 1967, p. 121:1993, p. 230; 1996, p. 10月.

141 Rassat 1996, p. 105.

142 Tot 1. n. 93-2 van 4 januani 1993 golden ook speciale regelingen ten aanzien van bepaalde ambtenaren, magistraten en eategorieern wan de politiediensten (zie de voormalige art. 679 en $688 \mathrm{CPP}$ ). 
rechterlijke colleges vervolgd. Gedurende de vijfde Republiek is in het grootste deel van de tientallen verzoeken de verzochte toestemming verleend. ${ }^{143}$

Voor handelingen in functie verricht kunnen ministers en staatssecretarissen alleen via een speciale procedure vervolgd worden. Bij delicten gepleegd buiten hun functie gelden geen procedurele beperkingen. In de speciale procedure moet de aanklacht geschieden door de verzoekschriftencommissie van het Hof van justitie van de Republiek (Cour de justice de la République). Deze commissie kan daartoe besluiten op vordering van de procureur-generaal bij het Hof van cassatie, of op grond van een klacht van een slachtoffer. De commissie kan eveneens besluiten om te seponeren. Tegen deze beslissing is geen beroep mogelijk. Als de commissie een minister aanklaagt, oordeelt het genoemde Hof over de aanklacht. Het Hof bestaat uit twaalf parlementariers, in gelijke getale gekozen uit de twee kamers en drie magistraten. Tegen de uitspraak is beroep in cassatie mogelijk. Via deze procedure is in één zaak in 1999 een uitspraak ten gronde gedaan. In het verleden van de Vijfde Republiek zijn daarnaast wel een aantal zaken begonnen via een oude, vóór 1993 geldende procedure. In deze zaken kwam het nooit tot een uitspraak van het destijds ook voor bewindslieden conpetente Hate Cour de la justice, ${ }^{144}$

Voor de President geldt een zeer afwijkende, sterk politieke regeling. Tijdens zijn ambtstermijn kan hij in het geheel niet vervolgd worden, tenzij er sprake is van hoogverraad. In dat geval kan hij in staat van beschuldiging gesteld worden door met elkaar overeenstemmende besluiten van beide kamers van het parlement, aangenomen bij meerderheid wan de leden. Een bijzonder rechtscollege, het Hoge Hof van Justitie (Haute Cour de justice) oordeelt over de aanklacht. Dit Hof bestaat uit door de twee parlementaire kamers paritair gekozen leden. Na beëindiging van de ambtstemijn is vervolging gewoon mogelijk, ook voor delicten gepleegd tijdens die termijn. Geen President in functie werd ooit vervolgd. ${ }^{145}$

De beperkende gevolgen wan deze toestemmingsregelingen op de vervolging zijn klein te noemen. Het aantal zaken en personen waar deze procedurele beperkingen voor gelden is uiterst gering. Verder zijn de beperkingen groter naarmate de ambten waat-

143 Art. 26 Const; 30 rt. 80 RAN; art 105 RS. Een partementaire sessie loopt wan du eerste werkdag an oklow ber tot de lagtste in juni, art. 28 Const. Deze beperkingen gelden niet ten amzien van eventute mathplegers, Pradel 1997, p. 438. De huidige regeling is het gevolg van ewn grondwetswijziging bij l.const. 17. 95-880 van 4 augustus 1995. Hierwón konden parlementariérs ook niet wervolgd wonden zonder toestemming, en werd deze verleend door de plenatre kamer zelf. Zie Chrestia 2000, p. 753 e.v.

144 De verzoeksehriftenconmissie bestaat uil drie leden van do hoogst rang van zithende magistratuur. twee leden van de Raad wan State en twee leden van het Cour des comptes, allem respectievellijk gekozen uit hun midden. Art. 68-1 - 68-3 Const; loi org. n. 93-1252 23 november 1993. Deze procedure is sterk gewijzigd door een wijziging war de grondwet van 1993, licorst. n. 93-9.52 wan 27 juli 1993. Woorheen konden ministers alleen op grond van een parlementair thesluit vervolgd worden voon het Haute Cour de la justice. Over dat hof, zie hierna. Zie verder over de strafrechtelike ministeriethe werantwoordelijkheid 7.2. Verantwoordingsproces.

145 Art. 67 en 68 Const. Chrestia 2000, p. 750 . Recentelijk werd de vervolgingsimantuniteit van de President tem aanzien van gewone delicten nog eens bevestigd door de Hoge Rvad ten abraten van President Chirac. Cass crim. 10 oktober 2001. 
voor ze gelden Kleiner van personele omvang zijn: voor de President gelden de sterkste waarborgen, voor de parlementsleden de minst sterke.

\subsection{Gezag over opsporingsorganen}

In de opsporing stan de betrokken ambtenaren van de politie onder het functionele gezag wain het OM Het OM geeft leiding aan de opsporingsdiensten. Opsporingsambtenaren moeten bevelen van magistraten uitwoeren. Wel bepalen de genoemde ministeries mede het strafrechtelijk beleid door hun bevoegdheden ten aanzien van de organisatie en financiering van de opsporingsdiensten. Zo bepalen zij de verdeling van het personeel. De ministerielle diensten hebben zeggenschap over het aantal en het soort ambtenaren dat ze toebedelen aan de opsporing.

Opsporingsambtenaren maken verder wel onderdeel uit van de administration. Zij zijn rechtspositioneel athankelijk wan het ministerie waar hun politiedienst onder valt. De ministeries van Binnenlandse zaken en van Defensie nemen alle besluiten ten alanzien van de carriere van de respectievelijke politiekorpsen en gendarmerie. Deze afhankelijkheid vormt voor de relevante ministeries een mogelijkheid om de vervolging te kunnen conditioneren. Zoals gezegd heeft het OM evenwel enige invloed op de rechtspositie van politieambtenaren. De procureurs-generaal hebben namelijk de bevoegdheid om politicofficieren jaarlijks te beoordelen. Daarnaast kumnen zij politieambtenaren eventueel discip heid van opsporingsdiensten bestaan. ${ }^{146}$

Administratieve organen die onder andere ministeries vallen hebben eveneens ingrijpende bevoegdheden ten aanzien van de vervolging. Deze bevoegdheden zijn evenwel slechts gericht op een aantal specifiek aangewezen delicten.

Sommige strafbare feiten kunnen slechts op een aangifte, klacht of conform advies van deze organen vervolgd worden. Zo is een bestuurlijke klacht nodig voor sommige belastingdelicten. Een conform advies is bijvoorbeeld nodig voor vervolging van bepaal.de maritieme delicten en voorkennisdalicten. In millitaire zaken dient het OM de minister van Defensie eveneens on advies te vragen, mar dit is geenszins bindend. ${ }^{147}$

Bij sommige delicten hebben administratieve organen zelf de bevoegdheid tot instelling en ook uitoefening van de vervolging. Dit is het geval voor belastingdelicten waar enkel een boete op stat, voor douaneovertredingen, voor post- en telecommunicatiedelicten, voor overtredingen van inbreuken op het wegenbeheer en delicten tegen de

146 Hof verleden kent wel enkele gevallen warin politieambtenaren een onderzoek bemoeilijkten of dwars boomden ter beschernigg van politieke vienden. In 1996 gat de politiedirecteur foll aanwizingen aan politionbtenaren on niet nee le werken aan een huiszoeking doot een onderzoekstechter ten huize ran da burgeneester van Parijs. De minister van Binnenlandse zaken verklaarde achteraf zijn steun aan deze beshissing. Dit soot acties zijn echter in strijd met ant. R I CPP. Turcey 1997, p. 54-58; Allt 1998, p. 5-6; Voll 1998, p. 60. Voor de bevoegdineden wan het OM over de politie zie 3. I. Opsporing.

147 Voor belastingdelicten: art. 228 Live des Procéddures lascales; Pradel 2000, p. 478-479. Deze klaclut is nodig now dalicten die met gevangenisstraf bestraft kunnen wouden. Voor maritieme zaken en voorken nisdelicten; Padel 2000, p. 482-483. Voor militaine zaken: art. 698-1 CPP. 
boswet. Bij de met boete bedreigde belastingdelicten en de douaneovertredingen heeft het bestuur zelfs de exclusieve bevoegdheid tot vervolging. ${ }^{148}$

Daarnaast hebben enkele bestuursorganen ook de bevoegdheid tot transactie. Door betaling van een opgelegde geldsom vervalt vervolgens het recht tot vervolging. Wanneer de vervolging al is ingesteld kan een transactie alleen plaatsvinden met toestemming van het $\mathrm{OM}$. Voor enkele sectoren is de transactie in de praktijk van groot belang. De douane bijvoorbeeld maakt in negentig procent van de zaken gebruik van deze hem toekomende bevoegdheid. ${ }^{149}$

Voor bepaalde categorieën van delicten kunnen sommige bestuursorganen een soort boete opleggen (amende forfaitaire). Het gaat dan onder andere om sommige verkeersdelicten, vergrijpen met betrekking tot het openbaar vervoer en bepaalde landbouwdelicten. Wanneer de verdachte de 'boete' betaalt, vervalt het recht op strafvordering. Wanneer de verdachte een eis tot vrijstelling indient, wordt de zaak doorverwezen naar het OM. Dit kan besluiten te seponeren of alsnog te vervolgen. Jaarlijks worden ruim tien miljoen van dergelijke boetes opgelegd. ${ }^{150}$

De betrokken bestuursorganen zijn hiërarchisch ondergeschikt aan de minister van Financiën, de minister van Post en telecommunicatie, de minister van Openbare werken en de minister van Milieu. Deze ministers hebben zeggenschap over de uitoefening van de beschreven bestuurlijke bevoegdheden. In deze sectoren heeft de regering aldus zelf de mogelijkheid vervolgingen te voorkomen, te initiëren of op een bepaalde wijze te bepleiten voor de rechter. ${ }^{151}$ Deze ministeriële bevoegdheden kunnen hier een vergelijkbaar effect bereiken als dat wat met aanwijzingen behaald kan worden.

\subsection{Bevoegdheden ten aanzien van budget en organisatie}

De parketten vallen net als de rechterlijke colleges en de CSM onder het kopje Services judiciaires van de begroting van het ministerie van Justitie. De minister wijst de budgetten niet rechtstreeks aan de afzonderlijke parketten toe. De budgetten zijn voor de zittende en staande magistratuur in het district gezamenlijk, het ministerie maakt zelf geen verdeling. Die vindt plaats door de dyarchie van de president van het hof en de procureur-generaal. Deze voeren het beheer over het budget. Ook op het niveau van de rechtbanken delen de president en de parketchef de zeggenschap over de toegewezen gelden. In uitzonderlijke gevallen worden wel bijzondere, supplementaire budgetten toegekend aan bepaalde jurisdicties. Met deze budgetten worden administratieve zaken

148 Respectievelijk art. 237 Liwre des Procédures Fisuales, art. 343 Code des doundnes, art. 28 Code des Postes et Telecommunications, art. $116-1$ e.k. Code de la voirie routiere en art. $153-1$ Code foresticr. Stelani, Levasseur \& Bouloc 2000, p. 144 e.v.

149 Alt 1998, p. 5. Art. 248 Livre des Procédures Fiscales, art. 350 Code des douanes, art, 28 Code de: Postes et Telecommunications, art. 116 m Code die la worre routière, art $153-2$ Code forestiar en art. 330 -9 Code de l'aviation civile. Voor delicten legen de Code forestie en de Code de l'aviation is overigerss in alle gevallen toestemming wan het OM nodig.

150 Art. 529-530-3 CPP. Zie ook bijv. art. 1215-4 Code rural. Ministère de la Justice $2002, \mathrm{p} .103$.

151 Alt 1998, D. 5. De genoende douane- en belastingsadministratie vallen overigens onder het toezich wan de procureur-generaal, en staan vercler onder admimistratieve leiding wan een magistraat (art. 28-1 ClPp sinds loi n. $99-515$ van 23 juni 1999). 
gefinancierd. De verdeling van financiole middelen wordt niet expliciet gebruikt voor de prioritering van en inhoudelijk vervolgingsbeleid. ${ }^{52}$

De minister voorziet daanaast in de regeling van de organisatie van het $O M$. De rechterlijke organisatie kent naast een wettelijk vormgegeven deel een partie réglementaire. Regeringsdecreten genomen op voorstel wan de minister van Justitie bepalen hierin zaken als de installatie en vervangingsregelingen Verder stelt een regeringsidecreet op voorstel van de minister de bezetting bij de parketten vast. ${ }^{153}$

\subsection{Informele invloed}

Het bestaan van formele ministerielle (aanwijzings)bevoegdheden doet niet af aan het bestaan van informele relaties. Wanneer procureurs-generaal het ministerie mondeling informeren vindt vaak overleg plats. ${ }^{154}$ In telefonisch of mondeling overleg zou een bepaalde toon al genoeg kunnen zijn om het OM duidelijk te maken hetgeen van hem verwacht wordt. Ook een niet-antwoorden door de minister op uitdrukkelijke verzoeken van het OM kan al een voldoende duidelijke suggestie betekenen. Procureursgeneraal zouden zo instructies lezen in het enkele zwijgen van de minister. De minister hoeft ook niet te laten blijken dat een vervolging om bijvoorbeeld partijpolitieke redenen ongewenst zou zijn. In plaats daarvan kan hij de technische aspecten van de zaak ter discussie stellen. Een overleg over juridische obstakels kan zo een zaak uitstellen of eventueel doen stranden. 155

Naast deze contacten zouden staande magistraten uit eigen initiatief een handelswijze gevolgd hebben ton gunste van de executieve. Een belangrijke reden zou zijn gelegen in de wetenschap dat hun carrière afhankelijk is van de minister van Justitie. Zo zouden

152 Zie bijw. loi de finances n. 2000-1352 wan 30 december 2000 . Een en ander blijkt uit gesprekken met OM-ledern.

153 Voor de partie reglementaire art. R213-21-R213-26, R311-9, R31 I-34-R311-37, R751-1 COJ. Voor

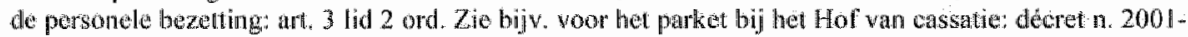

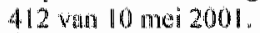

154 Commission de weftexion sur la Justice 1997, p. 25. Een en ander bijkt ook uit gesprekken met OMbeden. Zie ook 6. B. Bevougdheden omtrent intomatievoor hiening.

155 Basse 1996, p. 165: Bartolomei 1996, p. 120; Bow wer, Jacquin \& Vogelweith 1997, p. 44. Verder kan de minister via ardere kanalen van zich laten horen. Op 5 juli 1995 bijwoorbeald meld de minister van Justicic aan de media in de afläre van de Parijse appartementen dar de toenmalige premier Juppé geen onregelmagheden to verwijten zijn. Het OM houdt zich op dat moment bezig met de zatak, maar heeft dan nog geen beshlissing genomen. Een patr dagen later saponeert het OM de zak. De mimister-presim

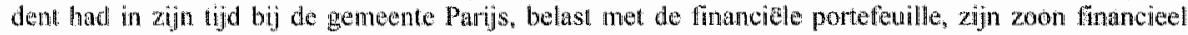
bevoordeetd. Hij that destijds persconlijk gezorgd voor verlaging van de huur wan zijn zoons appartement dat it gemeentebexit was. Ondat het appartement niet aan de premier zelf toekwam meende het OM dat hier geen strafbare vorm van belamgenverstrengeling annwezig was. Bouvier, Jacquin \& Vogel weith 1997, p. 162 e.v.; Turcey 1997, p. 46 e.v.

Parlijrelaties worden ook wel een informele vorm van invloed toegedicht. 20 werd. in 1999 een substituat van de fleiding van een onderzoeksgroep afgehald die zich bezig hield met de MNEl en DSK zaker. Hierin zou de toenmalige minister wan Economische zaken en financien Stranss-Kahn bi] betrokken geweesi zijn. Het parkethoofd dat de bestissing nam om de substituut op andere werkzaamheden te zetten was een maste madewerker geweest wan een vorige socialistische minister van Justitie. Haby 2000 , p.118 o.v.; JO SR CRI 4 november 1999, p. 5707. 
zij een dienende houding hebben gehad zonder dat specifieke aanwijzingen gegeven hoefden te worden. ${ }^{156}$ Wel is de mentaliteit onder de vervolgende magistraten de laatste decennia van de twintigste eeuw veranderd. Parketleden zijn zich minder 'eerbiedig" gaan opstellen tegenover de hiërarchie en de ministeriële autoriteit. Volgens sonmigen heerst vanaf de jaren negentig onder de leden van het OM hebben een min of meer "onafhankelijke cultuur'. 157

\section{$6.8 \quad$ Conclusie}

De minister van Justitie heeft dominerende bevoegdheden over het handelen van het OM. Hij is een verzamelpunt van informatie en de verdeler van de financiële middelen. Hij kan het vervolgingsbeleid en beslissingen in specifieke strafzaken bepalen. Verder zijn belangrijke ambtsdragers beschermd tegen vervolgingen. Collega-ministers hebben zeggenschap over de opsporing.

Aanwijzingen tot niet-vervolging zijn echter niet toegestaan en parkethoofden hebben een erkend verzetsrecht. Ministers hebben geen eenvormige houding ten aanzien van het geven van individuele aanwijzingen. Hun algemene circulaires zijn verder van dien aard dat zij de prioritering aan het OM zelf overlaten.

\section{Verantwoording voor het $\mathrm{OM}$}

In het voorgaande zijn de bevoegdheden van het $O M$ en van de minister jegens het $O M$ uiteengezet. Hoe verhoudt de uitoefening van deze bevoegdheden zich nu tot de controle van de Franse volksvertegenwoordiging? Waarvoor is de minister precies verantwoordelijk en hoe legt hij daarvoor verantwoording af tegenover het parlement? In het navolgende behandel ik de de grondslag en reikwijdte van de politieke verantwoordelijkheid en het functioneren van het verantwoordingsproces. Daarna schenk ik enige aandacht aan de directe contacten tussen parlement en OM.

\subsection{Grondslag en reikwijdte veramtwoordelijkheid ${ }^{158}$}

De ministeriële verantwoordelijkheid is een confuus begrip in de Franse doctrine. Het ondervond tot eind jaren negentig weinig specifieke bestudering of theorievorming.

156 Bouvier, Jacquin \& Vogelweith 1997, p. 6. Volgens Collew zou deze 'zellcensultr" echter verdwenca

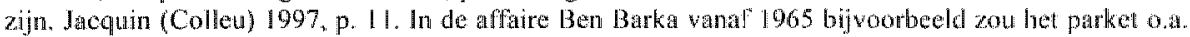
hebben nagelaten de plats van de moord op de betrokkene te doen verzegelen. Een personage ual de kring rond de president zou betrokken züjn geweest in de zaak, vgl. Gerber 1990, p. 57 e.v.

157 féol 1994, p. 1364; Boudon 1997, p. 9 en 13; Jacquin (Colleu) 1997, p. 11. Hel beperken war de vervolging om een raison d'Ëat is vanaf de jaren negentig bijwoorbeeld munder verdedighaar geworden. Tekenend hierwoor zijh de vele vervolgingen tegen poltici en eaptains of industry vanaf die tijd. Angibuud 1999, p. 60

158 Naast de politicke verantwoordelijkheid bestater een civiele en comptabele ministeriele verantwoordelijkhejd. Voor de civiele zie art. 5 wet 10 angustus 1922 (2onder nummer). Deze hekst heeft now toepassing gevonden. Voor de comptabele verantwoordelijkheid ziet art. 60 XI wet n. 63 - 156 van 23 februari 1963 . Enkele ministers en staktssecretarissen zijn op gnond hierwan veroordeeld. Het bokendste voorbeeld betreft de affaite Nucei. Vgl. Dewos-Nieq $1999, \mathrm{p} .165 \mathrm{ck}$. 
Verder geven schrijvers niet altijd een definitie van hetgeen deze verantwoordelijkheid onvat. Waar deze wel gegeven wordt, blijkt dat er lang geen overeenstemming over het begrip is. De doetrine is grosso modlo in twee groepen onder te verdelen. Volgens een eerste groep auteurs kenmerkt de ministeriele verantwoordelijkheid zich door de Juridische mogelijkheid voor het parlement om het aftreden van de regering te verkrijgen. Deze doctrine beperkt zo de beschrijving van de verantwoordelijkheid tot die van de grondwettelijke procedures die tot aftreden van de regering kunnen leiden. Het begrip verantwoording ontbreekt geheel in deze definities. ${ }^{159}$

Een tweede groep schrijvers geeft een meer omwattende visie op het begrip. Ségur omschrijft - met instemming van Beaud - de politieke verantwoordelijkheid als een 'juridisch mechanisme voor toekenning van een waarde aan regeringshandelen'. Dit impliceert voor hem de verplichting van de regering om zich te verantwoorden tegenover het parlement (répondre de), een evaluatie van het regeringshandelen en de mogelijkheid van een juridische sanctie. Avril omschrijft het begrip als de werplichting van de regering om af te treden wanneer haar politiek niet meer de steun vindt van een parlementaire meerderheid. Ook hij stelt dat dit een bepaald politiek gedrag inpliceert van regering en parlement, waarmee hij op de verantwoording doelt. Op vergelijkbare manier schrijft Zoller dat de politieke verantwoordelijkheid bestaat uit de verplichting rekening af te leggen (rendre compte). Dit wijst op twee aspecten: ministers moeten hun handelen en beslissingen uitleggen; èn ministers dienen de parlementaire kritiek in acht te nemen en maatregelen te nemen om de gebreken te verhelpen. De politieke verantwoordelijkheid drukt zich zo uit door de parlementaire controleprocedures en de eventuele motie van wantrouwen. ${ }^{160}$ Deze laatste groep definities heeft gemeenschappelijk dat allen de verantwoording als onderdeel van de verantwoordelijkheid zien. Deze groep betreft een aantal gespecialiseerde auteurs die een meer gedetailleerde, volledige versie van de Franse ministeriële verantwoordelijkheid lijken te geven. In het onderstaande ga ik uit van deze uitgebreide definitie van deze verantwoordelijkheid.

Enkelen specificeren waarvóór de regering precies verantwoordelijk is. Dit zou het 'regeringshandelen' zijn, handelingen verricht door bewindslieden in de uitoefening van hun functie. Privé-handelingen zouden hier buiten vallen. Bewindslieden zijn verantwoordelijk op grond van hun bevoegdheden of competentie. Natuurlijk valt hier het functionele handelen van de ministers individueel en alls regering gezamenlijk onder. Tevens vallen de handelingen van de ambtenaren van ministeries en van de administratieve organen in het algemeen onder dit bereik. Ten aanzien van de handelingen van andere organen is de doctrine niet eenduidig. Men makt geen onderscheid tussen het

159 Bijvoorbeeld Bidégardy \& Eneri 1998, p. 23 ex.; Chrestia 2000, p. 740. Zie verder de doctrine in de vele Franse thundboeken van constitutioneel recht systematisch weergegeven bif Bonnotte 2000, p. 40 e.v. en Scgur 1999, p. 1600 (voorbeelden zijn Gicquel 1999, p. 662 en Turpin 1999, p. 504 e.v.).

160 Segur 1998, p. 17; 1999, p. 1616-1617; Beaud 19996, p. 204. Het opleggen van de sanctie is precies de 'toekenning van de warde' an het handelen. De term "sanctie" zou niet enkel als negatief gezien moeten worden. Ook uitingen van vertrouwen in het regeringshandelen zouden daaronder vallen. Sëgur is overigens én wan de zeer weinige auteurs die een omwattende beschrijving van de politieke verantwoordelijkheid heef ontwikkeld, 1999, p. 1600 e.v. Avril 1999, p. 86 e.v. Zoller 1999, p. 491. Ook Jiang ziet in de politieke verantwoordelijkheid èn de 'obligation de rendre compte' èn de mogelijkheid voor het parlentent de regering tot aftreden te dwingen. Jang $2000, \mathrm{p} .101$. 
verantwoordelijk zijn voor de uitoefening van hiërarchische bevoegdheden ten aanzien van andere organen en verantwoordelijkheid voor het handelen zelf van die organen. Het handelen zelf van het OM lijkt wel onder de politieke verantwoordelijkheid van de minister van Justitie geschaard te kunnen worden.

De minister wordt in ieder geval niet verantwoordelijk geacht op grond van het feit dat het orgaan tot de "uitvoerende macht' behoort. Evenmin gebruikt men de 'ondergeschiktheid" van het betreffende orgaan als criterium. Ook berust de ministeriele verantwoordelijkheid niet op de notie van 'schuld'. De minister draagt ook verantwoordelijkheid voor een handelen als hij daar feitelijk niet persoonlijk bij betrokken was. Beaud onderstreept in dit verband wel het feit dat de verantwoordelijkheid in grote mate fictief is. De minister heeft praktisch beperkte invloed op het functioneren van andere ambten, maar dit functioneren wordt hem wel toegerekend. De auteur verbindt evenwel geen negatief oordeel aan deze fictiviteit: ${ }^{161}$

De functie van deze verantwoordelijkheid is in de visie van sommigen die van een verificatie tussen de volkswil en het regeringshandelen. Het handelen van de regering kan via het mechanisme van de politieke verantwoordelijkheid gecontroleerd worden op de overeenstemming met de 'volonté nationale'. Het is zo een middel om de staatsinstellingen te beschermen tegen beschadiging of belemmering van functioneren. Verder ziet. men wel een functie in de bijdrage van de verantwoordelijkheid aan de effectiviteit en de coördinatie van de ambtenarij. De toerekening van het ambtelijk handelen aan de minister kan leiden tot eenheid in dat handelen. ${ }^{162}$

Overigens is het aangaande de Franse verhoudingen niet correct te spreken van politieke verantwoordelijkheid van de regering tegenover de President. In de staatkundige praktijk komt het wel voor dat de regering aftreedt op verzoek van de President. Echter, hij heeft deze mogelijkheid alleen indien hij gesteund wordt door een meerderheid in het parlement. De zogenaamde verantwoordelijkheid van de regering ten opzichte van de President is hierdoor niet structureel, maar enkel van conjuncturele aard, gebaseerd op de parlementaire verhoudingen. ${ }^{163}$

\subsection{Verantwoordingsproces}

De minister van Justitie legt verantwoording af voor het handelen van het OM. De minister doet dit op eigen initiatief en op verzoek van het parlement.

161 Voor de "attributions": Stght 1998, p. 14-15. Avril spreckt van "pouvoirs discretionnates' als object van verantwoordelijkheid, 1999, p. 87. Beand enkel van "potwoin", 1999, p. 206; Fevrier gebulki het begrip "competence", 2000 , p. 222. Een uitdrukkelijke uitsluting van het priwe-handelen bij Euzet 2000 , p. 134. Expliciet over de verantwoordelijkheid voor ambtenaren en de administratieve organen: Avrili 1977. p. 9; Beand 1999b, p. 206-207. Over de irrelevantie van schuld: Segur 1999, p. 1608; Bealud $1990 \mathrm{~b}, \mathrm{p} .209$. Over de fictiviteit van de werantwoordelijkheid: Beaud $\| 999, \mathrm{p}, 114 ; 19996,1,214$.

162 Over regeringshandelen en de volkswil: Ségur 1999, p. 1607. Op p. 1623 noemt de schrijwer overigers in verband met de volonte nationale of génerale ook expliciet Rousseatu. Over de aenvormigheid Bealud 1999. p. 115. Daamaast wormt het een tegenwicht tegen de bevogdheid wan kamerontbinding. Deze vindi plaais bij besluit van de President ma consultatie wan de premier en de kamervoorzilters. Art. 12 Const. Ségur 1998, p. 15; Chrestia 2000; p. 740 . Sinds 1958 kwam ontbinding vijt mal voor: 1962. $1968,1981,1988$ en 1997.

163 Segur $1999, \mathrm{p} .1619$ 
Aan het begin van en nieuwe kabinetsperiode lat de regering haar intenties blijken aangaande de strafrechtelijke politiek in brede $z \mathrm{in}$ : Zij ontvouwt hierbij onder andere plannen voor strafwetgeving en toename van het aamtal magistraten. ${ }^{164}$ Daarnaast presenteert de minister van Justitie jaarlijks het justitiebudget. Daarin stelt de minister plannen woor ten behoeve van personeelsaantallen van magistraten, administratieve ondersteuning en zaken als huisvesting. Hierbij wordt geen verslag gegeven van de werkzamheden van het $\mathrm{OM}$ of het toekomstbeeld van het vervolgingsbeleid. Wel bundelt een interne ministeriele notitie sinds eind jaren negentig jaarlijks de verslagen van procureurs-generaul aan het ministerie. Deze notitie legt de minister echter niet als zodanig aan het parlement voor. ${ }^{165}$ Verder geeft het ministerie van Justitie jaarlijks een statistisch overzicht uit wan de zaken die door het parket en de rechterlijke colleges zijn afgehandeld, de Anmaire statistique de la Justice. ${ }^{16}$ De minister doet het parlement echter niet jaarlijks verslag over de 'staat van Justitie'.

Meestentijds geschiedt de werantwoording omtrent de vervolging op verzoek van het parlement. Het heaft daartoe verscheidene controle- en informatiemiddelen. De kamers zijn bevoegd de minister zowel schriftelijk als mondeling vragen voor te leggen.

Bovendien kunnen de vaste kamercommissies, de enquêtecommissies en de zogenaamde missies een rol spelen. Deze middelen komen achtereenvolgens aan de orde.

Elk kamerlid heeft het recht vragen te stellen. Schriftelijk stellen de parlementariërs samen jaarlijks ruim twintigduizend vragen. De mondelinge vragen kennen twee varianten: de questions orales en de questions d'actualité au gouvernement. Wekelijks vindt op vrijdag een kamerzitting plaats warin parlementariërs questions orales aan. verscheidene ministers kunnen stellen. Vooraf omschrijven de kamerleden de vragen. schriftelijk. Tijdens de zitting van de kamer zetten zij de vraag nog eens kort uiteen, waarna de minister antwoordt. Vervolgens kan de parlementariër nog even het woord nemen. Samen stellen de kamers bijna zevenhonderd questions orales per jaar.

De tweede mondelinge soort vragen, de questions au gouvernement, voert men op tijdens een vragenuur. In de Assemblée vindt dit wekelijks tweemaal plaats op dinsdag en woensdag, in de Senat twee keer per maand op maandag. De minister krijgt deze vragen slechts een uur van tevoren. Na het stellen en beantwoorden van de vraag kunnen andere fracties eveneens het woord nemen. De kamers stellen jaarlijks bijna negenhonderd questions au gouvernement. ${ }^{16 \%}$

164. Zie de hoi de programme n. 95-9 wan 6 jantari 1995. Varklating van prember Jospin (bamens de regering, thede vor minister (ntigow) IO AN CHR 19 juni 1997, décharation de politique generale. Verkla

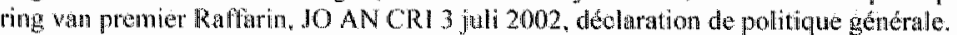

165 Voor de begrotmg zie bijv. Budget de la justice, Projet de Loi de finarnees pour 2002 ("le blau budgetaire"): loi n. 2001 - 1275 van 28 december 2001 . Zie de presentatie van minister Lebranchu 10 AN CRl Conmission das Lois 30 oktober 2001. Over de interne notitie zle 6.1. Bevoegdheden ontremt inPormatievoorzioning.

166 Zie bijv. Ministente wan Justitie 2001

167 Art. 48 lid 2 Const; art 132-151-1 RAN; art. 74-83ter RS. Avril \& Giequel 1996, p. 235-240; Turpin $1999 \% 504-506 \%$ Favoreu e.a. 2000, p. $707 \%$. De questions d actualite zijn aiet geregeld in de (grond)wet, maar enkel in het kamerreglement van de Seraat (art, 75 bis RS). 
De Assemblée stelt veruit de meeste vragen in vergelijking met de Sẻnat, ook in relatieve zin. Algemene vragen over wetgeving, de functionering van procedures en personeelssterkte worden altijd schriftelijk gesteld. Vragen over individuele strafzaken zijn daarentegen in vrijwel alle gevallen mondeling. Bij uitzondering antwoordt een andere minister voor de minister van Justitie, wanneer deze afwezig is. ${ }^{165}$

Het parlement stelt met name vragen over te wijzigen strafwetgeving, de personeelssterkte van parketten en individuele strafzaken. Verzoeken over strafrechtelijke hervormingen betreffen bijvoorbeeld het creëren van nieuwe delicten, instanties of informatieprocedures. Ten aanzien van het parketpersoneel vraagt men vrijwel altijd om vervulling van vacatures of uitbreiding van het aantal posten. Met betrekking tot specifieke strafdossiers bekritiseren parlementariërs doorgaans de werkelijke of veronderstelde invloed van de minister. Vrijwel nooit vragen ze om een ministeriele interventie. Vragen ten aanzien van het requisitoir van het OM zijn eveneens uitzonderlijk. Opvallend is verder dat vragen over het eigenlijke strafrechtelijke beleid maar mondjesmaat gesteld worden. ${ }^{169}$

De behandeling van de schriftelijke parlementaire vragen gebeurt in principe door het ministerie zelf. In voorkomende gevallen vragt het ministerie op zijn beurt informatie aan het betreffende parket, via de procureur-generaal. Hierbij krijgt het parket waak ook de vraag van het parlement te lezen. Het parket voorziet het ministerie dan van de benodigde informatie. De minister kan zich bij de beantwoording beroepen op het secret défense of secret d'Etat om te weigeren antwoord te geven (art. 139 lid 6 RAN). ${ }^{170}$ Behalve door het stellen van vragen, controleert het parlement de ministers via enquètecommissies en vaste commissies. In principe is een commissie gericht op informatievoorziening aan de kamer.

De kamers kunnen beide parlementaire enquêtecommissies instellen. Deze kunnen informatie verzamelen over bepaalde gebeurtenissen of het functioneren van overheidsorganen, waaronder het OM. Een kamer kan echter geen enquête houden ten aanzien van feiten ten aanzien waarvan strafrechtelijke vervolging is ingesteld. Wel kan een enquête een meer algemene situatie betreffen, waarvan lopende strafzaken een onderdeel kunnen zijn. De commissies kunnen documenten opvragen, zich ter plaatse begeven en personen horen. Het verschijnen voor de commissie kan met een boete maar ook met de sterke arm worden afgedwongen. De te horen personen leggen een eed af. Ministers en administratieve organen kunnen zich wel beroepen op het staatsgeheim, hetgeen geregeld gebeurt. Sinds 1958 hebben ongeveer tachtig commissies een enquête

168 Hoogstens worden de schriftelijke vragen over algenene zaken omgezet in mondelinge vragen nadat de regering lang geen schriftelijk antwoord gegeven heef (art. 75 lid 3 RS), bijw. Guyard, JO AN CRL 2 mei 1996 , pp. 2738 e.\%. Een uitzondering van een schrifticlijke wragg over een specifieke zaak: Brunhes, JO AN QR 19 juni 1995, p. 2722, n. 27492. Voorbedden watarbij een ander minister antwoordt: Guyard, JO AN CRI 2 mei 1996, p. 2738 e.v. en Glavany, JO AN CRI 13 november 1996, p. 6872.

169 Een wan de weinige voorbeelden wan een verzoek on interventie: Brunhes, JO AN QR 19 juni 1995, p. 2722 , n. 27492 . Een uitzonderlijke vraag ten aanzien wan het mondelinge requisitoir: Haenel, JO SR QRR I1 maart 1999, p. 750, n. 14733. Voorbeelden warbij wel iets over de strafrechtelijke politiek gewraagd wordt: Dominati, JO AN OR 15 december 1997, p. 4606, n. 7897 en Marsadon, JO AN QR II jantuari 1999, p. $225, n .20540$. Een voorbeeld wan een waag over het gebruik wan bevoegdheden fen aanzien wan de rechtspositie van het OM: JO SR QR 27 november 1997, p. 3320, n. 2456.

170 Favoreu e.a. 2000, p. 707. Eén en ander blijkt uit gesprekken met OM-leden. 
gehouden. Pas sinds de jaren zeventig gebruiken de kamers het middel veelvuldig. Enkele onderzoeken raakten mede het gevoerde strafrechtelijk beleid (bijvoorbeeld de enquete over de financiering van politieke partijen in 1991, over de maffia in Frankrijk in 1992, over het veiligheidsbeleid in Corsica van 1999). Het functioneren van (delen van) het $O M$ zelf of diens relaties met de minister zijn daatin wel eens onderwerp van onderzoek geweest. Verscheidene leden van het $O M$ zijn door enquêtecommissies gehoord. Vragen ten aanzien van individuele strafzaken kunnen parketleden pareren door te refereren aan hun beroepsgeheim (art. $11 \mathrm{CPP}$ ). ${ }^{171}$

Naast de enquêtecommissies hebben ook de vaste kamercommissies een functie in het verantwoordingsproces. De vaste commissies kumnen zogeheten 'missies' (missions) instellen, hetgeen zij veelvuldig doen. Deze doen onderzoek met zeer beperkte enquêtebevoegdheden. De commissie kan iedereen horen inclusief ambtenaren. Wel moet de commissie het staatsgeheim en de 'scheiding tussen de autorité judiciaire en de overige machten' respecteren. Leden van het OM kunnen in principe wel gehoord worden. Men heeft de plicht voor de commissie te verschijnen. Deze plicht kan echter allleen afgedwongen worden door een boete. Enkele tientallen tmissies worden jaarlijks gehouden. Voorbeelden met relevantie voor de strafvervolging waren de missie over de onschuldpresumptie en het strafrechtelijke onderzoeksgeheim in 1995, die over de obstakels voor de repressie van tinnanciële delicten in Europa, en de missie over de middelen van rechterlijke macht; de laatste twee in 2001 . Het handelen van het OM komt hierin indirect wel ter sprake. ${ }^{172}$

\subsubsection{Sanctionering ministeriële verantwoordelijkheid}

Het is mogelijk de verantwoordelijkheid van de regering te sanctioneren. Het zijn evenwel enkel de motie van wantrouwen en de motie van goed- of afkeuring van het regeringsprogramma die als sanctie op de politieke verantwoordelijkheid gezien worden (art. 50 Const.). De laatste blijft hier buiten beschouwing. ${ }^{173}$ Buiten deze mogelijkhe-

171 Art 6 ordorg. N. 58-1100 wan 17 november 1958; art. 140-144 RAN. Avril G Gicquel 1996, p. 243246: Turpin 1999, p. 506-507, Favoneu a. 2000, p. 711-712. Het vethod te anquencen over strafrechtelijke zakan ond roind kritiek. Het kan ertoe bijdragen dat de polatieke varantwoonding van de minister vermindent, terwijl diens strafrechiblike werantwoordelijkhed ingeroepen wordt: Beaud 1998 , p. 1560-1561. Het verbod heet het parlennent edter niat verthinderd om cen engute over het velligm heidsbeted wan Corsica in te stellen, tewijl nog een antal relevate zware stratraken liepen. De zaak Sperone werd datuin bijwoorbeeh besproken, terwijl een gerechtelijk onderoek gaande was. De betrokken procureur-genemal beriep zich op het secret dingtruction, man gaf wel informatie op hootalinen Wan de zak JO AN 10 november 1999, Rapport $n .1918$.

Tot 1991 bestond er een versohil hissen commissions d'enquete en commissions de controle, wathbij de ecrste meer bevoegdheden beztl Hel genoemale antal gehouden commissies omvat beide soorten.

172 Art. Sbis en 5ter ord.org. n. 58-1100 van 17 november 1958; art. 145-145-6 RAN. 7oller 1999 , p. 493;

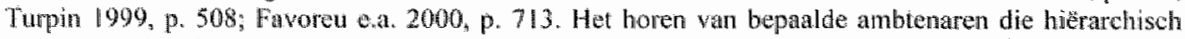
onder een minister starn is wel cens problematsch geweest. Awril Gioqued $1996, p .241$ :

175. Volgens att. 49 lid 1 Const. zou de itegering het vertouwen van de Assemblee dienen te vragen over diens regeringsprogramma en tgemene politike verklangen. De vertrouwanswiag word op initiatief wan de regering gesteld ter verificatie van de has steunende meerderheid. Zj doet dat alleen wanneer zij zeker is dat de vramg positief beantwoord zal worden. De praktijk is sterk wisselend geweest in consistentie. Nieuw angetreden regeringen hebben niet altijd de vertroumenswragg gesteld. De vraag is nooit negatief beaniwoord. De docmine is niet eensludend over de elassificatie van de vertrou- 
den zijn er slechts een paar vast omlijnde varianten van moties nogelijk, die de wetsprocedure betreffen. Moties over het eigenlike vervolgingsbeleid zijn bijvoorbeeld niet mogelijk. Andere vormen van partementaire activiteiten met sanctionerende aspecten blijven zonder gevolg. Resoluties kan een kamer alleen aannemen voor zover deze de interne werkzaamheden aangaan. ${ }^{174} \mathrm{De}$ uitoefening van bevoegdheden als verwerping of amendering van een wetsvoorstel of zelfs de begroting ziet men in Frankrijk niet als mogelijke sanctie op de verantwoordelijkheid. Een verklaring hiervoor kan liggen in het arsenaal van bevoegdheden dat de regering achter de hand heef om het parlement tot medewerking te bewegen. Het gebruik van deze bevoegdheden of de dreiging daarmee vormt een sterke beperking op de mogelijkheden tot sanctionering door het parlement via alternatieve wegen. ${ }^{175}$

De Franse motie van wantrouwen zou alleen ten aanzien van de ministeriele verantwoordelijklheid kumnen gelden. Het lijkt voor het parlement niet mogelijk om het vertrouwen in de regering op te zeggen om een reden gelegen buiten diens verantwoor" delijkheid. ${ }^{176}$ Sanctionering door middel van een motie van wantrouwen kan enkel door de Assemblée geschieden. Om een dergelijke motie te presenteren is de handtekening nodig van een tiende van de kamer, ofwel 58 leden. Een zelfde kamerlid kan niet meer dan drie keer per jaar een dergelijke motie ondertekenen. Na presentatie van de motie dient er een termijn van 48 uur gewacht te worden voordat gestemd kan worden. Voor het aannemen is de meerderheid van de leden van een kamer nodig. De politieke ministeriële verantwoordelijkheid is alleen collectief, niet individueel of persoonlijk. Er is geen motie van wantrouwen mogelijk tegen een enkele minister, zoals die van Justitie. Een motie brengt voor de regering de grondwettelijke plicht mee om af te treden. ${ }^{177}$ In de praktijk zijn er wel tientallen moties voorgesteld en in stemming gebracht, maar sinds de grondwet van 1958 is slechts én regering gevallen op grond van een motie

wenskwestie onder de ministeriële verantwoordeljjkheid. Avril \& Gicquel 1996, p. 222-223; Turpin 1999 , p. 514-515; Favoreu e.a. 2000, p. 714-716. Contra Ségur 1998, p. 45. Het is overigens theoretisch wel denkbaar dat de regering de vertrouwenskwestie zou stellen ten aamzien van bijwoorbedd een voorgenomen vervolgingsbeleid. In praktijk zijn de verklaringen die de vertrouwensvrag betreffen algemeen wan aand. De ondenkbaarheid van een negatief beantwoorde vertrouwensvrag maken verdere behandeling van deze optie zinloos.

174 Avril \& Gicquel 1996, p. 138-141.

175 Een markant voorbeeld van het overwicht van de regeringspositie is de vote bloquée. Bij de stemming in de Assemblée over een tekst kan de regering kan de vertrouwenskwestie stellen ('engager la res. ponsabilite du gouvernement"). Een beslissing daartoe in de ministerraad moet hiersan woorafgan. Als de kamer in de daarop volgende 24 uur geen motie van waritrouwen stelt, ge ld de tekst als aangenomen (art. 49 lid 3 Const. ). De regering kan zo werwerpingen van woorstellen of ongewenste amendementen doen vermijden. De vertrouwenskwestie werd vele tientallen malen gesteld, watk herhaaldelijk ten ananzien wan een zelfde tekst (maar in een ander stadium van de procedure), In ongeveer de helf van de gevallen werd een motie van wantrouwen gesteld, matr deze werd nooit aangenomen. Turpin 1999, p. 516-518; Favoreu e.a. 2000, p. 718-719.

176 Segur $1998^{\text {, p. } 40}$

177 Art. 49 lid 2 en 50 Const; art. 152- 156 RAN. De beperking tot drie moties per kamerlicl is meer precies een beperking tol drie keer per parlementaire sessie, en één keer tijdens een eventuele buitongewone sessie. Een sessie loopt van de eerste werkdag in oktober tot de faatste in juni, art. 28 Const. De beperking tot drie keer stamt overigens pas uit l.const. 4 augustus 1995. Ségur 1998, p. 55; 1999, p. 1609; Zoller 1999, p. 490. 
van wantrouwen. ${ }^{17}$ "Het indienen van deze moties lijkt veeleer een middel geworden om een politiek debat te stimuleren. Met name kan de oppositie zo de publieke opinie haat afwijzende stanclpurit duidelijk maken ${ }^{179}$

Het is wel voorgekomen dat er een conflict plaats wond tussen het parlement en de regering, waarbij de President de laatste om aftreden verzocht. Individuele ministers treden daamaast wel af on persoonlijke, politiek-tactische redenen of op grond van interne politicke onenigheid. Dit gebeurt op eigen initiatief of dat van de premier. Deze laatste heeft echter geen formeel recht van ontslag. Ook komt het voor dat regeringen aftreden indien er buiten perioden van cohabitatie onenigheid is tussen premier en President. Op verzoek van de laatste maakt de regering dan plaats voor een andere. Verder verzocht de President de regering enkele malen om af te treden omdat de publieke opinie tegen haar gekant leek. 180

Ministers van Justitie zijn nooit afgetreden door gebleken onenigheid met of een blijk van verminderd vertrouwen van het parlement. Redenen met betrekking tot het door de minister gevoerde beleid waren bij hun aftreden niet aan de orde. Het functioneren van het OM of de relatie tussen deze en de minister is evenmin een kwestie geweest bij het aftreden. Drie keer traden ministers van Justitie af omdat er een herschikking plaatsvond van de ministersposten binnen de regering (Michelet in 1961, Joxe in 1968 en Guigou in 2000). Twee maal werden ministers benoemd bij belangrijke staatsorganen (Badinter in 1986 en Arpaillange in 1990). Ten slotte trad een enkele minister van Justitie af om redenen wan partijpolitieke loyaliteit (Capitant in 1969). ${ }^{181}$

\subsubsection{Sanctioneringsproblematiek ministeriële verantwoordelijkheid}

Het mechanisme van de politieke verantwoordelijkheid wordt door velen gezien als weinig effectief. De werking van de politieke verantwoordelijkheid wordt bemoeilijkt door een aantal factoren.

Allereerst zijn er procedurele factoren. De zware vereisten voor een motie van wantrouwen en de onmogelijkheid van een individuele motie verminderen de kans op het volgen van deze procedure. ${ }^{152}$ Een praktische rol van betekenis speelt het steeds veelvuldiger voorkomen van schadelijke beleidseffecten, waarvan de late ontdekking een gebruik van bijvoorbeeld een motie van wantrouwen zinloos makt. Immers, als de toenmalige bewindshieden niet langer in functie zijn kan hun vroegere politieke verantwoordellikheid niet meer gesanctioneerd worden. ${ }^{183}$ Verder bestaan er politieke rede-

178 Sdgur 1998 , p. 56 a.v. en p. 64; 1999, p. 1621; Chresta 2000, p. 740. Het betrot de regering Pompidou op 5 oktoley 1962. Overigens volgde hiepop kamerontbinding, tussentijds nog cen populair en door de Prosident voorgesteld reterendum en titeindelijk nienwe kamerwerkiezingen. Hiama aamvardde de Prosident het ontslag van de regering en kon hegelijkertijd op basis van de - voor de regering positiaf aitgevalen -.. verkiangen en nicuwe regering benoenen, onder dezelfde premier.

Op 1 jun 1992 schedde thet overigens mar drie stemmen dat de regering Beregovoy niet viel. Gicquel $1999,0.664-665$.

179. Art. 49 Const. Avril \& Gicquel 1996, p. 226; Favoret a.a. 2000, p. 717.

180. Segu| $1998,0.82-84,86-87$

181 Dolez 1999, p. 281 a.

182 Ségur 1998. p. 64 en 68.

183 Stgur 1999, p. 1622. 
nen voor de ineffectiviteit van het mechanisme. De partijbanden tussen de regering en de haar steunende meerderheid in het parlement vormen een obstakel. De parlementaire meerderheid is vrijwel altijd solidair met de regerende coalitie, hetgeen een effectieve controle kan belemmeren. Een sanctionering van de verantwoordelijkheid is dan zeer uitzonderlijk. ${ }^{184}$ Een volgende politieke factor zou liggen in de huidige staatsrechtelijke praktijk om de verantwoordelijkheid op ondergeschikten af te schuiven. Bij enkele politiek belangrijke affaires hebben hoge ambtenaren hun functie moeten neerleggen, terwijl de betrokken ministers aanbleven. ${ }^{185}$

Bovendien lijkt de werking van de strafrechtelijke ministeriële verantwoordelijkheid het functioneren van de politieke te vervangen. Strafprocessen waarin de minister ter verantwoording is geroepen, komen wel voor. In een aantal gevallen treden ministers af wanneer zij aan een strafrechtelijk onderzoek onderworpen zijn. Overigens kan wat dat betreft volgens de Franse doctrine niet van een constitutionele conventie gesproken worden. ${ }^{186}$ In bepaalde gevallen wordt zo de politieke verantwoordelijkheid "gepenaliseerd" en de strafrechtelijke gepolitiseerd. Het Franse Hof van Justitie interpreteert het begrip 'handelingen' waarvoor bewindslieden vervolgd kunnen worden zeer ruim. In feite zouden ministers strafrechtelijk ter verantwoording geroepen worden voor hun politieke keuzes, aldus sommige auteurs. ${ }^{187}$

Ook ziet men de positie van de President als een oorzaak van het gebrek aan functionering van de ministeriele verantwoordelijksheid. De President heeft enkele belangrijke bevoegdheden, maar is politiek niet verantwoordelijk. Buiten perioden van cohabitatie heeft hij tevens de belangrijkste politieke rol, waarbij hij leiding geeft aan de regering.

184 Alt 1998, p. 6 (speciffek met betrekking tot de aninister van Justitie); Ségur 1998 , p. 72 e.v.; 1999, p. 1622; Gicquel 1999, p. 662; Bigaut \& Chantebout 2000 , p. 79.

185 Deze ontwikkeling hangt in sommige gevallen samen met de positie van de President. Zie hiema. Zo bijwoorbeeld in de affaire Habache in 1992, waarin hoge ambienaren werden ontslagen, terwijl de minister van Buitenlandse zaken aanbleef, conform de: wens van de President. De premier zou echter liever sancties tegen de minister zelf hebben geziem. Tijdens een periode van cohtrabitatie in de affaire SclullerMaréschal van $\| 995$ beschermde de minister-president de mimister var Binnenlandse zaken door een hoge ambtenaat te ontslaan. Vgl. Beaud 1998, p. 1555 e.w.; 1999, p. 206 e.k; 2000, p. 17 e.w.; Beaud $d$ Blanquer 1999:, p. 9 ; Pujas 2000 , p. 168.

Een andere politieke factor van het disfunctioneren van de ministeriële verantwoordelijkheid ziet men wel in het in onbruik raken van de vertrouwensvraag aan het parkement van een nieuw benoemde regering. Beaud \& Blanquer 1999 a, p. 8. Over de vertrouwenswrag zie hierbowen, noot 173.

186 In de Vijlde Republiek zijn de volgende ministers on deze reden afgetreden: Dechlittre (maar voor een aanstaande veroordeling) in 1972, Tapie in 1992. Carignon, Longuet en Roussin in 1994 en StraussKahn in 1999. Geregeld bleven ministers aan, zoals Juppé in 1995 en Guigou in 1997. Opmerking verdient dat Roussin en Carignon aftraden twee dagen voór dat zij in staat van beschuldiging gesteld werden. Dolez 1999, p. 288-289; Bigaut \& Chantebout 2000, p. 80 . Zie ook de verklaring van President Chirac, Le Monde 23 mei 1995.

187 Degoffe 1996, p. 395 e.v.; Beaud 1999a, p. 8 en 419 e.v.; Pujas 2000, p. 175; Chrestia 2000, p. 740 e.v. Een recent voorbeeld van de politisering van de strafrechtelijke ministeriele verantwoordelijkheid is de âffaire du sang contaminé. Hierin werden de (woormalige) ministerwpresident, minister van volksgezondheid en dito staatssecretaris verwolgd woor het nalater van ingrijpen in het toedienen van met het AIDS-virus besmet bloed onder hun indirecte leiding. Bij arrest 9 maarl 1999 werd de statssecretaris werd weroordeeld, de anderen vrijgesproken. De veroordeling hield geen strafoplegging in. Deze zaak laat zien dat de interferentie tussen politieke en strafrechtelijke verantwoordelijkheid met mame kan spelen indien er sprake is van een omissie, in plaats wan een bewust handelen, Chrestia $2000, p .766$ e,$v$. 
Er lijkt dan een praktijk te ontstaan waarbij de 'verantwoording' aan de President de verantwoording aan het parlement gaat vervangen. Een aantal ministers zijn dan ook in feite door de President zelf aan de kant gezet. ${ }^{188}$

\subsection{Verantwoording OMaan het parlement}

Het parlement heeft op een aantal gebieden een meer directe relatie met het OM. Naast enkele algemene bevoegdheden hebben (onderdelen van) de kamers enkele specifieke mogelijkheden om informatie te vergaren.

De voorzitters van de parlementaire kamers benoemen elk een lid van de CSM. Dit lid zit in de formatie die bevoegd is in de rechtspositionele zaken van leden van het OM. Daarnaast beslist het parlement jaarlijks over de begrotingswet die de financiering regelt van onder meer het $O M^{189}$

Daarnaast worden leden van het OM zoals gezegd wel gehoord in enquêtecommissies. Yerder benaderden parlementariërs soms een parkethoofd ten gunste van hun kiezers. Het zou in deze gevallen enkel gegaan zijn om een uitwisseling van inlichtingen. Sinds eind jaren negentig schijnt dit niet meer voor te komen. Parlementariërs zouden zich nog slechts tot de minister richten. ${ }^{190}$

\subsection{Conclusie}

De rol van het parlement is enigszins bescheiden. De kamers roepen de minister wel met vragen ter verantwoording over zijn contacten met het $\mathrm{OM}$. Op verzoek verantwoordt de minister zich wel, maar op eigen initiatief richt hij zich weinig tot het parlement. Het parlement lijkt weinig kijk te hebben op het vervolgingsbeleid en houdt zich daar feitelijk niet mee bezig. De verantwoording over vervolgingszaken heeft nooit negatieve consequenties gehad voor de politieke positie van de minister van Justitie. Daarnaast vormt het $\mathrm{OM}$ voor het parlement wel een zekere bron voor vergaring van informatie.

\section{Samenvatting en conclusie}

De Franse relatie tussen het $O M$ en de minister is in beweging. De politiek trekt zich aarzelend terug, terwijl de magistratuur in opkomst is. Het recht geeft de minister een

188 Dit was bijwoorbeeld het geval met Soustelle in 1960, Debre in 1962, Mauroy in 1984 en Rocard in 1991 (Chirac stapte in 1976 vrijwillig op, maar on dezelfde reden). Segur 1998, p. 64 en 84 ; Beaud $\| 998$, p. 1555 e.w.; Gicquel 1999, p. 662; Bigaut \& Chantebout 2000, p. 79-80. De doctrine is overigens niet eensluvidend van mening dat de ministers verantwoordelijk zijn tegenover de President, Bonnotte $2000, p .51$ e.v.

189 Over de CSM zie 2.1. OM en rechterlijke macht. Over de begroting: ord. $1.59-2$ van 2 januari 1959.

190 Over het boren wan leden van het $O M$ in de wetsprocedure: Commission de reflexion sur la Justice 1997, p. 17. Zie bijvoorbeeld Jolibois, JO SR 18 juni 1998, Rapport n. 511, relatif au Conseil supérieur de la Magistrature et modilication de l'article 65 de la Constifution. Fauchon, IO SR 25 april 2001 , Rapport n. 281, relatil au siatut des magistrats et au Conseil supérieur de la magistrature. Over enquêtecommissies, zie 7.2. Verantwoordingsproces. Over informatieverzoeken van parlementarièrs ann het OM: VolfT 1998, p. 49. Eén en ander binjkt uit gesprekken met OM-leden. 
sterke positie, terwijl deze door zijn eigen beleid soms afgezwakt wordt. Het OM neemt plaats in een rechterlijke macht met een wat lage status. De minister heeft een ruime aanwijzingsbevoegdheid en beslissingsmacht over de rechtspositie van OMleden. Feitelijk is het OM rechtspositioneel veeleer afhankelijk van de CSM, komen nauwelijks specifieke aanwijzingen voor, en is het OM redelijk vrij in het stellen van zijn prioriteiten.

Het Franse OM maakt deel uit van een rechterlijke organisatie die de naam 'macht' niet mag dragen. Dit bepaalt de context waarin de dubbelzinnige rechtspositie en de functionele onderschikking van het OM gezien kunnen worder.

Binnen het $\mathrm{OM}$ prevaleren hiërarchische, eenvormige structuren. Parkethoofden hebben uitgebreide bevoegdheden over hun ondergeschikten. Op landelijk niveau is het OM structureel verdeeld. De procureur-generaal heeft daar vooral een één op één relatie met de minister.

De parketten hebben een sterke positie tegenover opsporingsdiensten en een ruime keuze in hun strafrechtelijke reactie op strafbare feiten. Een rechter komt daar niet noodzakelijkerwijs aan te pas. Wel kunnen belanghebbenden, en via hen de onderzoeksrechter hierbij een belangrijke rol spelen.

De minister van Justitie fungeert onder de politieke inkapseling van de minister-president en de President - buiten perioden van cohabitatie. Ook de leiding van het ministerie van Justitie is politiek gekleurd. Het gegeven dat hier tevens magistraten deel van uitmaken doet hier niet aan af.

De 'uitvoerende macht' heeft een beleidsmatig licht getemperde invloed op de carrière van de leden van het $\mathrm{OM}$. De regering en de President hebben juridisch het laatste woord over benoemingen en disciplinaire procedures, maar hun bemoeienis is veranderlijk van intensiteit. De procureurs-generaal ontkomen echter niet aan deze politieke dominantie. OM-leden genieten daarnaast een zwakke rechtspositionelle rechtsbescherming.

De functionele bevoegdheden van de minister zijn verstrekkend. Hij heeft een goede informatiepositie en zeggenschap over het vervolgingsbeleid en het handelen in lopende strafzaken. De reikwijdte van zijn aanwijzingen kent echter belangrijke beperkingen. Daarnaast geven ministers weinig of geen specifieke aanwijzingen meer. Algemene circulaires vaardigen zij wel uit, hoewel een samenhangend nationaal vervolgingsbeleid ontbreekt.

Het parlement kan zich redelijk laten informeren over vervolgingszaken, maar heeft daar weinig invloed op. De minister stelt zich in de verantwoording vrij passief op. Voor parlementaire sanctionering van zijn handelswijze jegens het OM hoeft hij dan ook niet te vrezen.

Het Franse OM heeft een gefragmenteerde, politiek georiënteerde top en een autonome werkvloer. De minister kan zich goed doen informeren en domineert het parlement. Hij zet enige beleidsaccenten, maar zijn invloed over individuele strafzaken en de rechtspositie van het $O M$ is onderhevig aan beleidsschommelingen. 



\title{
Hoofdstuk 4
}

\section{Verhouding tussen OM en minister van Justitie in Italië}

\author{
'Cesareee!l! Ti cerca Berlusconi: \\ dice di tenerti pronto a fare il ministro della giwstizia." \\ Guliano Ferrara, Corriere della Sena 10 oktober 1998
}

\section{Inleiding}

Rond de opkomst van Berlusconi is de relatie tussen Justitie en politiek een bewogen onderwerp van debat geworden. De gedachte dat één van zijn advocaten, Cesare Previti, minister van Justitie zou worden is een schrikbeeld voor de linkse partijen. Dit staat in verband met plannen van de rechtse partijen voor scheiding van de 'carrières' van rechters en pubblici ministeri. Dergelijke ideeën bevinden zich volgens 'links' en de rechterlijke macht op een schuine helling op weg naar de afgrond die invoering van onderschikking van het $O M$ zou betekenen.

Dit hoofdstuk analyseert de juridische verhouding tussen de uitoefening van opsporings- en vervolgingsbevoegdheden en politieke verantwoording in Italië, in het bijzonder de relatie tussen het $\mathrm{OM}$ en de minister van Justitie. Hieronder beschrijf ik allereerst de belangrijkste strafrechtelijke bevoegdheden en de organisatie van het $O M$. Daarna wijd ik enkele woorden aan de positie van de minister van Justitie. Vervolgens behandel ik de wijze waarop de minister invloed uit kan oefenen op de rechtspositie en het functionele handelen van het OM. Tenslotte komt het proces van politieke verantwoording van het handelen van het $O M$ aan de orde.

\section{Organisatie van het $\mathrm{OM}$}

Het Italiaanse OM is in relatief los van elkaar staande eenheden georganiseerd. Deze organisatie-autonomie correspondeert met de onafhankelijke relatie die het $\mathrm{OM}$ heeft met de politiek. Met het rechtsprekende deel van de rechterlijke macht heeft het $O M$ een nauwe verwantschap, met name op het vlak van de rechtspositie.

\subsection{OM en rechterlijke macht}

Volgens de grondwet maakt het OM onderdeel uit van de rechterlijke macht. Dit blijkt uit een samenhang van bepalingen. Het OM komt aan de orde in titel 4 van de grondwet met het opschrift 'De magistratuur'. Deze titel stelt de Hoge Raad voor de Rechterlijke macht (Consiglio Superiore della Magistratura, CSM) in. Deze raad neemt rechtspositionele beslissingen voor rechters en leden van het $\mathrm{OM}$. Leden van het Italiaanse OM maken deel uit van de raad, warover meer hierna.

De grondwet garandeert het OM volkomen rechtspositionele onafhankelijkheid. De CSM neemt alle besluiten dienaangaande. Benoemingen, overplaatsingen, bevorderingen en disciplinaire beslissingen zijn aan de raad voorbehouden. Als magistraten genieten leden van het OM zelfs onafzetbaarheid. De minister van Justitie krijgt in de grond- 
wet wel het recht toebedeeld om een disciplinaire procedure te beginnen (art. 104-107 Cost.).'

De grondwet is minder expliciet over de functionele relatie tussen de minister en het OM. De verdere waarborgen laat de grondwet yolgens artikel 107 lid 4 over aan de gewone wet. De meeste Italiaanse auteurs en het Italiaanse Constitutionele hof zijn evenwel van mening dat ook de functionele onafhankelijkheid van het $O M$ door de grondwet zelf gewaarborgd wordt. Artikel 107 lid 4 Cost. zou in systematisch verband zo gë̈nterpreteerd moeten worden dat het hoogstens vormen van interne ondergeschiktheid toe zou staan. Exteme vormen, zoals een aanwijzingsbevoegdheid voor politieke organen, zouden uitgesloten zijn. ${ }^{2}$ De grondwet opent titel 4 met de bepaling dat rechters enkel aan de wet onderworpen zijn (art. 101 lid 1). Impliciet zou dit ook gelden voor de leden van het $\mathrm{OM}^{3}{ }^{3}$ Verder zou het legaliteitsbeginsel geen ruimte laten om het OM onder leiding van wellke andere macht dan ook te stellen. ${ }^{4}$

Volgens anderen laat de grondwet wel ruimte om de functionele onafhankelijkheid van het $O M$ te beperken. Gesteld wordt dat de grondwetgever hieromtrent geen standpunt in heeft willen nemen. Hij zou hoogstens de rechtspositionele onafhankelijkheid hebben willen garanderen door instelling van de CSM ${ }^{5}$

Zoals gezegd heeft de Italiaanse CSM een centrale rol ten aanzien van vooral de rechtspositie, maar ook ten aanzien van de organisatie en werkwijze van het OM. De CSM bestaat uit zevenentwintig leden, waarvan zestien gekozen door magistraten en acht door het parlement. De president en de procureur-generaal van het hof van cassatie zijn van rechtswege lid. De President is de symbolische voorzitter van de raad. ${ }^{6}$

De raad is bevoegd secundaire regelgeving uit te vaardigen op het terrein van de rechterlijke organisatie. ${ }^{7}$ Op dat gebied geeft de raad technische circulaires aan de rechterlijke macht, waaronder het OM. Deze circulaires hebben een uniformerende rol ten aanzien van de werkwijze van de parketten. ${ }^{8}$ Theoretisch gezien zou de CSM eventueel een richtlijn kunnen uitvaardigen aan de hoofden van de parketten om aan te geven welke prioriteiten zii dienen te stellen. In de praktijk doet de raad dit vrijwel niet. Hoogstens stelt de CSM met grote vaagheid dat de rechterlijke macht met woortvarend-

1 Sommige atuteurs menen echter dat de grondwet de mogehijhtheid open laat dat de wer een verschil in

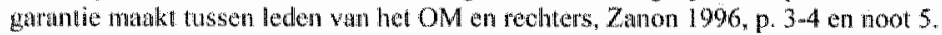

2 Carabia 1974, p. 89-90; Zagrebelsky 1974, p. 193; 1979, p. 13-14; Nuvolone 1983, p. 375; Spagna Musso 1987. p. 1228; Noppi Modlon 1987, p. 64; Corte Cost. 1991, 11. 72; Devoto 1996a, p. 2025; Gustapsine 1999, p. 246 .

3 Corto Cost. 1991, n. 88; Caraba 1974, p. 89; Cavallari 1974, p. 148; Neppi Modona 1987, p. 64; Gusidpane 1999, p. 227; Grevi 1999, p. 81. Anders: Dominioni 1979, p. 72 .

4 Soaparone 1994, p. 276; Gustapane 1999, p. 224.

\$Pizzorusso 1979, p. 32; Dominioni 1979, p. 67 e.w. Bramcaccio 1994, p. 243; Cordero 2000, p. 190.

6 De huidige CSM bestagt sinds 1959, op grond van artike 104 e.v. Cost. en de Wet op de instelling en het functioneren van de CSM (1.24 maart 1958, n. 195, sindsdien gewijzigd). Zie werder Albers Voemans 1999, p. 59 a.v. Sindsdien is de samenstelling wan de CSM wan achtenwintig naar zestien leden teruggebrax int on is het k"usstelsel voo de leden wan de CSM enigszins gewijzigd, zie 1. 28 maant $2002, \pi, 44$.

7 Art. 17 lid l sub dil. 23 augustus 1988, n. 400 . Pizzorusso 1990, p. 26-27, 106.

8 Pinzorusso 1990, p. 108; Di Federico 1991, p. 189.19\%; Zanom 1996, p. 245. Over de circulaires van de CSM: Verde 1990, p. 121 
heid zou moeten handelen in een bepaalde materie. Het stellen van prioriteiten is geen onderwerp van CSM-beslissingen. ${ }^{9}$.

Verder kan de CSM invloed uitoefenen op het functioneren van het OM via rechtspositionele bevoegdheden. Dit kan bijwoorbeeld via de disciplinaire procedure en het toewijzen van extra magistraten. Het is ten eerste denkbaar dat een parkethoofd naar de mening van de CSM volgens sterk irrationele prioriteiten zou handelen. Het hoofd zou dan zijn ambtsplicht niet nakomen. In een disciplinaire procedure zou de raad hem een disciplinaire sanctie op kunnen leggen. ${ }^{10}$ Ten tweede heeft de raad de bevoegdheid om tijdelijk magistraten aan een om personeel verlegen parket toe te wijzen. Bij haar beslissingen omtrent de behoefte van personeel van parketten ontkomt de CSM er niet aan om prioriteitsoverwegingen te hanteren. " De rol van de CSM ten aanzien van de rechtspositie van het OM komt in paragraaf 5 nader aan bod.

De Italiaanse grondwet deelt het OM expliciet in bij de rechterlijke macht. Via de CSM geeft de hoogste wet het OM uitgebreide rechtspositionele waarborgen. Deze rad heeft eveneens zeggenschap over de werkwijze van het OM.

\subsection{Interne organisatie}

Het OM behoort dus tot de rechterlijke macht. Dit sluit uit dat het organisatorisch een onderdeel is van het ministerie van Justitie. ${ }^{12}$ Het $\mathrm{OM}$ heeft een eigen organisatiestructuur die ik hieronder beschrijf. Daarbij geef ik een weergave van de verscheildene onderdelen van het $\mathrm{OM}$, de relaties tussen de parketten en de verhoudingen binnen een parket.

De organisatie van het OM is overgelaten aan de gewone wet. De Regeling op de rechterlijke organisatie deelt het $O M$ in volgens de structuur van de rechterlijke colleges. ${ }^{13}$ $B i j$ het hof van cassatie en de 26 hoven van appel zetelt een procureur-generaal. Deze wordt bijgestaan door advocaten-generaal en substituut procureurs-generaal. Deze parketten behandelen met name zaken respectievelijk in cassatie en in hoger beroep. Bij de 166 rechtbanken is het parket gezeteld van de "procureur van de Republiek", eventucel bijgestaan door toegevoegde procureurs of substituut procureurs. Zij nemen de vervolging in eerste aanleg voor hun rekening, zowel voor de rechibanken als de vrederechters. De berechting van bepaalde zware delicten valt onder competentie van het hof

9. Carcano 1998 , p. 1492. Eén van de weinge voorbeelden wit de praktijk is de publicalic van de beslissing wan het CSM tijdens de jaren wan het terrorisme in Italie, dat hel opportun zou zijn het werk binnen de rechterlijke masht zodanig in the richten dat de ernstige processen voortvarmon bethandeld zouden worden, CSM 1977, p. 5. Zue ook Zagrebelsky 1994, p. 106. Voor de discussie over prioriteiten, zie 3.4. "OM-beleid".

10 Commissie Gallo 1994, p. 1102. Over de disciplinaire procedure zie 5. Rechtspositie varn het OM.

11 Ant. 10 lid 3 ond.giud. Zagrebelsky 1994, p. 104. Deze besluiten worden genomen op verzoek van de procureur functiewrigiging.

12 Van deconcentratie" spreekt men overigens niet in relatie tot het OM in Italia. Het begrip vindi enkel toepassing bij de indeling van ackministratieve organen.

13 Rd. 30 januari 1941 , n. 12 , (Ordinamento giudiziario). De indeling zou impliciet ook wel af te leiden zijn uit artikel 108 lid 2 Cost, Zanon 1996, p. 2 . 
van assisen. Bij dit hof bestaat geen afzonderlijk parket. Het OM wordt hier vertegenwoordigd door het parket bij de rechtbank die territorial competent is voor het betrokken delict. Voor het hoger beroep in deze zaken is het hof van appel van assisen bevoegd. Het parket bij het hof van appel is voor de vervolging in dit beroep aangewezen."

De vervolging van maffazaken vormt een uitzondering op deze organisatie. Bij de rechtbank van elke districtshoofdstad hebben de betreffende procureurs een antimaffiadistrictsdirectie ingesteld. Deze directie vormt een onderdeel van het rechtbankparket. De leden hiervan behandelen een aantal wettelijk opgesomde delicten die specifiek met activiteiten van de maffia samenhangen. Voor deze delicten is er eveneens een Nationale antimafhia-directie ingesteld bij het parket van de procureur-generaal van het hof van cassatie. De nationale antimaffia-procureur voert de leiding over de Nationale directie onder toezicht van de procureur-generaal. De Nationale directie coördineert de activiteiten van de distrietsprocureurs ten aanzien van maffiose delicten. ${ }^{15}$

In totaal heeft de rechterlijke organisatie meer dan tienduizend magistraten. Meer dan een kwart daarvan zijn leden van het 0 M. $^{16}$

14 Art. 70 ord.giud. en 51 c.p.p. De vrederechters berechten lichte zaken als belediging en betreding van verboden terrein, d.lg, 28 agustus $2000, n$. 274. De hoven van assisen berechten delicten als terrorisme. genocide en delicten tegen de Stakt (art, 5 c.p.p.). Hier gelden voor wat betreft het OM geen speciale procedturegels, zie 1. 10 april 1951, n. 287 (Riordimamento dei giudizi di Assise).

In de zetelplaats wan elk hof wan beroep zijn afzonderijke rechtbanken voor minderjarigen, en secties van het thof voor het beroep in die zaken. De vervolging in deze zaken is in handen van specifieke parketten bij deze rechibanken en in berowp door het gewone parket bij het hof (artt. 70 en 71 ord.giud.). De marginale afwijkingen in de procedure voor wat betreft het OM kunnen hier onbehandeld blijven. Er zijn verder speciale parketten van het OM bij de militaire rechtbanken met straftechtelijke functies, die geheel buiten beschouwing worden gelaten, 1.7 mei 1981, n. 180.

Tot 1. 19 februari 1998, n. 51 bestond de pretuur (pretura), een lager getecht wal lichte feiten berecht werclen. Vanaf 1998 worden deze zaken behandeld door de rechtbank in een enkelvoudige kamer (art. 549 (4. c.p.p.). Het respetic valike OM was en bijit hew parket bij de rechbank wan het betreffende districe. Onder tyel oude CPP hed de pretuur mede een verwolgingsunctio woor die zaken (art. 74 ).

Bij veel rechbanken en enkele howen zijn werder afgezonderde secties die zaken berechtern woor wen ded wan hel district van dat organ. Er is cen sectio bij drie hoven en 220 secios verdeeld over de 166 rechtbanken. Voor de vervolging bij de hovet zijn er apate secties van het parken wan de procuretargeneraal. Bij de sectus van de rehtbanken is het gewone parket daamee belast (Tabel B bij rd, 30 juknari $941, n, 12)$.

15. Voor de delicten die onder ale competentie van de dnecties vallen: artt. 70-bis ord.giad. en 51 lid $3 \mathrm{mb}$ c.p.p. Voot de Notionate antimafhe-directie: art. 76-bis ord giud. en 371 -bis c.p.p. Deze is ingesteld bij d. I. 20 november 1991, 367, omgezet in 1. 20 jamuari 1992, n. 8. Zie verder ower de organisatie van de

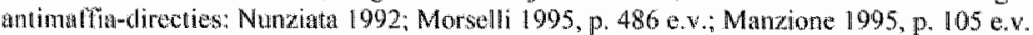

16 In total 26 procureurs-generual, 21 ad vocaten-general en 218 substitut procureums-generaal bij de hoven: 29 procureurs en 76 substitu ut procureurs bij de rechibanken voor minderjarigen; 164 Procureurs, 95 vicempocureurs en 1595 substituut procureurs bij de rechtbanken. Zie tabel B bij 1.9 augustus 1993, n. 295 a tabellen A, B on C bij d.m. I juni $\| 999$ jo 1. 16 juni 1998 , n. 188 jo art. 33 d.lg. 19 febrari 1998, n. 51 jo H. 16 juli 1997, n. 254 en I. 13 rebuari 2001 , n. 48 ; tabel D bij d.m. 7 april 2000 jo art. 7

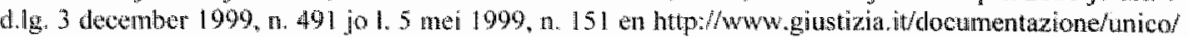
dm 070400 magmetr.hm. Overigens werken 241 magistraten, met behoud wan hun positie en garanties, buiten de rechterligke macht, woomamelijk bij thet ministerie van Justitie, zie 4. Minister en ministeries van Justitic en President. 
De onderlinge verhouding tussen de diverse parketten kan niet eenduidig als hiërarchisch worden beschouwd. Er lijkt niet te zijn gekozen voor éen leidend organisatorisch principe. ${ }^{17}$ De procureurs-generaal hebben geen algemene aanwijzingsbevoegdheid, maar wel interventiemogelijkheden op verschillende terreinen. Hun relatie met de procureurs kan worden bezien aan de hand van de beslissingen ten aanzien van de competentieverdeling, de coördinatie, de behandeling van sepotzaken en het beroep.

Parketten maken in eerste instantie onderling uit wie de competentie heeft over een bepaalde zaak. Indien parketten het onderling niet eens worden, besluit de procureur-generaal bij het hof van beroep, of indien het parketten in werschillende districten betreft, de procureur-generaal bij het hof van cassatie. De procureur-generaal bij het hof van cassatie heeft naast het beslissen over de toewijzing van de competentie tussen parketten geen bevoegdheden ten aanzien van andere parketten binnen het OM. Wel heeft hij op rechtspositioneel gebied de bevoegdheid een disciplinaire procedure te beginnen. ${ }^{18}$

De rechtbankparketten worden geacht onderzoeken die met elkaar verband houden onderling te coördineren. Onderzoeken naar zware zaken en gezamenlijke onderzoeken worden gemeld aan de procureur-generaal bij het hof van beroep. Indien de coördinatie niet effectief blijkt kan de procureur-generaal bij het hof van beroep de procureurs bijeen roepen, en zonodig het onderzoek overnemen in bepaalde zware zaken. Als dit maffiazaken zijn kan ook de nationale antimaflia-procureur het onderzoek overnemen. De procureur-generaal bij het hof van beroep neemt het onderzoek ook over als er niet tijdig een vervanger is aangewezen voor een procureur die zich moet onthouden van een zaak. ${ }^{19}$

De rechtbankparketten unformeren de procureur-generaal bij het hof tevens wekelijks over de zaken waarin (nog) geen vervolging is ingesteld of om sepot is gevraagd. Deze procureur-generaal kan het onderzoek overnemen als de procureur geen vervolging instelt of om een sepot vraagt binnen de wettelijke termijnen. In dat geval kunnen de verdachte en de door het delict benadeelde persoon de procureur-generaal verzoeken om overname van de zaak. Procureurs kunnen tegen het overnemen beroep instellen bij de procureur-generaal van het hof van cassatie. ${ }^{20}$ Alleen de nationale antimaffia-procureur kan aanwijzingen geven aan de districtsprocureurs antimaffia, maar alleen om de coördinatie in het onderzoek te bevorderen. Daarnaast kan hij tijdelijk magistraten toewijzen aan een antimaffia-parket voor complexe mafliazaken. ${ }^{21}$

17 Zagrebelsky 1992, p. 33; Zanon 1996, p. 62.

18 Over de competentiebeslissingen: art 54-54-bis c.p.p. Voor de disciplinutre proce dure zie: 5.6. Disciptineir regine.

19 Voor de onderlinge coôrdinatie art. 371 c.p.p. Voor de bevoegdheden van de procureur-generaal: ant. 18-bis att; art 372 lid 1 -bis jo 407 lid 2 sub a c.p.p; 371 lid I c.p.p. Woor de nationale antimaffiaprocureur" art. 371 -bis lid 3 en 4.

20 Voor de informatieplicht: art. 127 att. Voor het overnemen: art. $412-413$ c.p.p.. Voor het beroep: art. 70 lid 6 ord.giud. Onder het oude wetboek van strafvordering uit 1930 , dat lot 1988 gold, had de procureur generaal bij het hof van beroep een potentieel actievere rol door de bewoegheid om zelf een op sporingsonderzoek te stanten (art. 234), een algemene bevoegdheid zaken oner te nemen (art. 392 lid 3), en de mogelijkheid het beroep wan procureurs te doen beëindigen (art. 206 lid 2). Hij kon echter green aanwijzingen geven om bijwoorbeeld bepaalde proceshandelingen te verrichtait. In de prakijk werd overigens weinig gebruik gemaakt van dit soort hierarchische bevoegdhedem, Zanon 1996, p. 66-70.

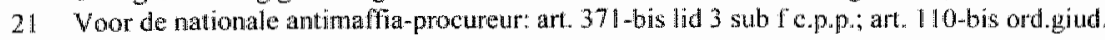


De interne structuur van elk parket is deels hiêrarchisch. Een procureur van de Republiek staat aan het hoofd van het parket die de activiteiten leidt en de organisatie regelt. Dit betekent ook dat hij in principe de bevoegdheid heeft om richtijnen te geven voor de te volgen prioriteiten in de vervolging. In de praktijk geeft het OM echter vrijwel geen uitdrukkelijke, inhoudelijke prioriteiten. ${ }^{22}$ In de interne relatie tussen hoofd en substitutt-procureurs moet onderscheid worden gemaakt tussen de onderzoeksfase en de terechtzitting. In die eerste fase kan het hoofd vragen vooraf op de hoogte gesteld te worden van proceshandelingen en zich mengen in de keuze van bijzondere procedures. $^{23}$ Tijdens elke zitting is de procureur vrij in zijn functioneren. ${ }^{24}$ In uitzonderingsgevallen dient een procureur ter zitting vervangen te worden door het hoofd Het gaat dan om zaken waarin het parketlid zich moet onthouden om redenen van belangenvermenging. Hieronder vallen niet de gevallen waarin het hoofd het inhoudelijk oneens is met de substituut. ${ }^{25}$ Ieder lid van het $\mathrm{OM}$ is door de wet met eigen bevoegdheden bekleed. Deze zijn dus voor de substituut-procureurs niet afgeleid van de bevoegdheden van het hoofd. ${ }^{26}$ In de praktijk maken de hoofden van de parketten nawwelijks of geen gebruik van hun hiërarchische bevoegdheden. Geaccepteerd wordt dat substituten hun functie zonder aanwijzingen van het hoofd uitoefenen. ${ }^{27}$

Het Italiaanse $\mathrm{OM}$ is samengevat een horizontaal netwerk van parketten met procureurs-generaal als contactpunten. $Z$ ij zijn meldpunten die de randvoorwaarden van het handelen van het $O M$ in het district handhaven, maar inhoudelijk de tweede viool spelen. Zij hebben weinig hiërarchische bevoegdheden, die ook nog onder directe rechterlijke controle staan. De nationale antimaffia-procureur heeft een effectievere rol, die een mate van inhoudelijke leiding mogelijk maakt. Binnen de parketten zelf gelden hiërarchischere relaties, maar geen bevelsstructuur.

\section{Bevoegdheden van het $\mathrm{OM}$}

$\mathrm{Na}$ deze beschouwing over de organisatie van het $\mathrm{OM}$ wil ik de strafrechtelijke functies van dit ambt beschrijven. Voordat ik de verhouding tussen deze strafrechtelijke be-

22 Art. 70 lid 3 ord.gind. Beslissing disciplinaire sectic CSM, Cass. pen. 1997, n. 936. Carcano leidt uit de uitsprakk af dat het hoofd zet's de plicht heeft criteria te stellen, 1998, p. 1490. Tegen het affeiden van deze bevogdheid: Nannucci 1991, p. 1671; D'Elia 1998, p. 1881. Over de priaritering: 3.4. 'OMbeleid".

23 Cass sez, un. civ., 18 november 1992, n. 12339, For. it. 1993, 1, p. 2598; Morselli 1995, p. 489; Zanon 1996, p. 35; Cordero 2000, p. 208.

24. Artt. 70 lid 4 ord giud. en 53 c.p.p. Zanon makt een vergelijking met de regeling voor het Franse OM 1996, p. 37. Hij onderstreept echter niet dat aldat la parole well libre is, maar la plume est serve; ma. de schriftelijke eis kan de subsituu opgelegd zijn. Zie hoofdstuk $3,6.3,3$. Rechtswaarborgen bij aanwijzingen. Cordero meent darentegen vreend genoeg dat het hoofd de substituut-procureur ook atanwijzingen mee kan gewen hoe te handelen op de zitting, 2000, p. 208.

25 Art. 53 lid 2 jo 36 lid 1 c.p.p. Manzione 1995, p. 133 e.v.

26 Art. 70 lid 3 ord.gind zegt dat het hoofd zelf kan vervolgen of procureurs kan 'aanwijzen' voor bepailde zaken, lerwijl yỏor d.lg. 28 juli 1989, m. 273 het hoold persoonlijk vervolgde of door middel van "Ondergeschikte" magistraten. Manzione 1995, p. 132; Cordero 2000, p. 208.

27 Dominioni 1979, p. 79; Zanon 1996, p. 23. Een prakkijkvoorbeeld bij Di Federico 1991, p. 178-179. 
voegdheden en de politieke invloed daarop en verantwoording daarover behandel, breng ik eerst de bevoegdheden zelf in kaart.

De taak van het Italiaanse OM is een veelvormige. Het oefent bevoegdheden uit in zowel het burgerlijk proces als het strafproces ${ }^{28}$ In het civiele recht geeft het $\mathrm{OM}$ onder meer conclusies in cassatiezaken, doet het vorderingen zoals tot afgifte van een verklaring van vermoedelijke dood, en tor benoeming van een bijzondere curator. Deze taken blijven hier buiten beschouwing. ${ }^{29}$

Het strafproces is het belangrijkste werkterrein van het OM. Het leidt de opsporing en is belast met de vervolging en de executie van rechterlijke oordelen. Over de vervolging heeft het $\mathrm{OM}$ een monopolie. Belanghebbenden of andere burgers kunnen geen vervolging instellen of beroep indienen opdat het OM verplicht wordt tot vervolgingshandelingen. Zij kunnen wel een aangifte indienen, of de procureur-generaal verzoeken de zaak over te nemen. ${ }^{30}$

\subsection{Legaliteitsbeginsel}

In het Italiaanse strafproces geldt het legaliteitsbeginsel. ${ }^{31}$ De grondwet zelf bepaalt in artikel 112 dat het $\mathrm{OM}$ de plicht heeft de vervolging in te stellen. Theoretisch gezien vermijdt dit beginsel elke beslissingsvrijheid van het $O M$ in de vervolging. Wel heeft het $O M$ de vrijheid van interpretatie van feiten en normen, zoals de rechter die heeft. ${ }^{32}$ In de praktijk functioneert het legaliteitsbeginsel verder echter niet op een volkomen manier, in de zin dat alle strafbare feiten vervolgd worden. Het principe laat het OM in de praktijk veel discretionaire ruimte. ${ }^{33}$ Deze keuzewrijheid van het OM wordt allereerst gegeven door verschillende, algemene factoren: de beperkte middelen en capaciteiten, de voortdurende toename van de criminaliteit en de bevolking, de verzwaring van bepaalde categorieën van zaken; de discretie die de wetgever laat door het stellen

28 Het OM bij de Rekenkamer en bij. de militaire rechtbanken blift hier geheel buiten beschouwing. Het cerste neent conclusies, vergelijkbaar met de functie die het $O M$ in het civiele recht heeft. Het $O M$ bij de militarre rechtbanken houd zich bezig met do vervolging van miliairen, ook in vredestijd.

29 Voor conclusies in cassatieraken zie: art. 70 lid 2 c.p.c). Voor de verklaring van vermoedelijke dood: art. 62 c.c. Voor de bijzondere curator: art. 79 c.p.c. Zie verder o.a. de taken in anti. 69 e.v. c.p.c. 50 , $85,102,2409,2907$ c.c., 75 ord giud.

30 Over de procureur-generaal: 2.2. Interne organisatie. Over de aangife: art. 336-340 c.p.p. Theoretisch gezien zou elke gegronde aangifte wel tot vervolging door het OM leiden, gezien het hiema te behande. len legaliteitsbeginsel. Dat in de praktijk dit vanzelfsprekend niet het geval is zal ik verderop tevents toelichten. Overigens sluit de grondwet niet uit dat de vervolging ook door andere subjecten uitgeoefend. zou kunnen worden. Deze optie is echter niet in de wet mogelijk gemakt. Corte Cost. 1979, ถ. 84; 1982 , n. $114 ;$; 1993, n. 474; Neppi Modona 1987, p. 5\| e.,.

31 Het betreft hier het legaliteitsbeginsel (obbligatorieta) ten aanzien van de vervolging, in tegenstelling tot het opportuniteitsbeginsel. Het (nuterieel) straftechtelijk legaliteitsbeginsel (principio di legalita) eist een voorafgaande wet om een feit stralbaar te doen zijn (art. 25 lid 2 Cost., vgl. art. I WvSr in Nederland). Het strafvorderlijk legaliteitsbeginsel houds in dat strafwordering alleen op wettelijke wijze geschiedt (art. I c.p.p., vgl. art. I WwSv in Nederland). Voor verschillende definities van het legatiieitsbeginsel, zie Guarnieri 1984, p. 132-133.

32 Zanon 1996, p. 182.

33 Ricci 1982, p. 118; Guarnieri 1984, p. 143 e...; De Luca 1991, p. 221: Vitalone 1991; p. 293-294; Corso 1993, p. 236; Marzaduri 1994, p. 145; Morisi 1999, p. 93 e.\%.; Gasperini, in: SdR, R.s.C.g. 19 juli 2000 . 
van vage normen en de neiging van de wetgever om nomen vooral met strafisancties te liandhaven. ${ }^{3.4}$

De discretie wan het OM is meer specifiek te analyseren in de drie strafrechtelijke fasen vón het eigenlike proces. Ten eerste in de onderzoeksfase, ten tweede warneer het beslist over wel of geen vervolging en ten derde in de beslissing welke processtrategie te kiezen. ${ }^{35}$

\section{3:2 : Opsporing}

Opsporing kan beginnen naar aanleiding van een aangifte, of op initiatief van de politie en het $\mathrm{OM}$.

Omtrent aangiftes bestaat een wrij uitgebreide regeling. Van anonieme aangiftes mag ten eerste geen gebruik gemaakt worden. Wel kunnen ze een spoor zijn dat uiteindelijk leidt tot Kennisneming van een delict. ${ }^{36}$ Een feit dat het OM ter ore komt via informele en vaak oncontroleerbare bronnen, zoals krantenartikelen, radio- of televisie-uitzendingen, open brieven en de 'publieke opinie' verplicht ook niet tot handelen. ${ }^{37}$ In al deze gevallen is het OM vrij om geheel af te zien van actie. De doctrine is verdeeld over de vraag wat gedaan moet worden met zogenaamde "pseudo-aangiften". Dit, zijn berichten die absurd zijn, of anderszins overduidelijk niet kwalificeerbaar als delict, hoewell de berichtgever het feit wel als delict ziet. ${ }^{38}$

Berichten van mogelijk strafbare feiten, anonieme documenten en berichten die geen strafbaar feit behelzen worden in drie respectievelijke registers opgenomen. De anonieme aangiften en informatie "die geen strafbaar feit inhoudt" worden alleen ingeschreven en verder niet gebruikt. De eigenlijke arangiften worden onderwerp van een procedure. Zoals in de volgende paragraal duidelijk wordt controleert de rechter de beslissing over deze aangiften. De rechter krijgt echter niet de berichten uit de andere twee registers onder ogen. Het OM heeft ten aanzien van deze anonieme informatie en de aangifte "die geen strafbaar feit inhoudt" feitelijk een eigen bevoegdheid tot (technisch) sepot." In sommige parketten wordt een kwart van de meldingen in dit laatste register opgenomen. ${ }^{40}$

34 Guarieri 1984, p. 140.141; Valentini Reuter 1994, p. 40; Chiawario 1994, p. 85; Di Federico 1995, p. 426; Bettiol 1998, p. 264.

35 Voor eon beschriving wan het Italianse sirnfproces (in her Engels), zie Corso 1993, p. 223 e.v., en recenter (in het frans), Delmasm Marty 1995.

36 Arti. 240 an 333 lid 3 o.p.p. Fumu 1991, p. 136

37 Caprioli 1994, p. 393 394 ; Cordero 2000, p. 419

38 Cuprioli 1994, p. $393-394$ en 398.

39 Nannucei $199 \%, p, 1670$; kritisch. Castelli 1990, p. 98; "technisch sepot" betreft het afzien van actio bij gebrek aan bewijs of ontbrek van voorwarden woor de vervolging. Dit in tegenstellirg lot beleidssopot wabuj het OM zou kumen seponeten on opportumiteitsredenen, ook al zou verwolging met verorduling mogelijk zilir. Deze latste optie is in het geheel niet geregeld. Zle verder 3.3. Beslissing over de venolging. Zie voot het register voor berichten van stratbare feiten model 21 , art. 335 c.p.p. en d.m. 30 septenber 1989 (Approvazione dei registri in materia penale) en het register voor berichten die geen shafbaar feit inhouden (model 45 zelfde dected), en het register voot anonieme docunnenten art 108 att. jo art. 5 d.m. 30 september 1989, n. 334.

40 Castelli 1990, p. 98. Caprioli 1994, p. 406. 
De meerderheid van de parketten, en daaronder zeker de grotere, kan niet alle angiften of berichten onderzoeken. ${ }^{41}$ De praktijk geeft verder gevallen waarin parketten een voorselectie hebben gemaakt, door meldingen wan bepaalde strafbare feiten van beperkt belang niet te accepteren: ${ }^{42}$

De politie en het OM zijn verder bevoegd zelf op onderzoek te gaan naar strafbare feiten. Aan het OM wordt de afweging overgelaten tussen de kosten en de duur van het opsporingsonderzoek en de zwaarte van het delict, ${ }^{43}$ Ook kan het OM in principe ervoor kiezen onmiddellijk strafrechtelijke actie te ondernemen, of de zaak tijdelijk te laten rusten. ${ }^{4}$

Het OM heeft bij de opsporing de leiding over de gerechtelijke politie (polizia giudiziaria). Bij elk rechtbankparket bestaat een sectie van deze politie. De sectie bestaat uit ambtenaren die deel uitmaken van de verschillende politiediensten. Deze politie moet onverwijld het OM bericht geven van ter kennis gekomen strafbare feiten. Het OM kan de politie aanwijzingen geven. Deze zijn evenwel bedoeld ter coördinatie van opsporingsonderzoeken. Parketten geven geen expliciete aanwijzingen voor een opsporingsbeleid. ${ }^{45}$

De procureur-generaal heeft daamaast enige toezichthoudende bevoegdheden over de gerechtelijke politie. Zo is zijn positieve advies nodig voor promotie van politieambtenaren. Verder kan hij disciplinaire procedures tegen hen beginnen. Disciplinaire feiten zijn onder andere het niet opvolgen van een bevel van een magistraat. Tenslotte is in sommige gevallen de instemming van het OM nodig voor overplaatsing van de leiding van de politiesectie. 46

Het OM kan zelf een deskundigenonderzoek laten verrichten. Hij kan personen oproepen en met de sterke arm laten voorbrengen voor verhoor. Het OM is bevoegd een schouw te houden, een lichamelijk onderzoek of een fouillering te laten verrichten, huiszoeking te doen en zaken in beslag te nemen. ${ }^{47}$

Het OM kan de onderzoeksrechter vragen om een opname van telecommunicatie. In de opsporingsfase kan het OM de onderzoeksrechter ook vragen om een gerechtelijk bewijsonderzoek (incidente probatomio). Hierin kunnen getuigen gehoord worden en een deskundigenonderzoek plaatsvinden. ${ }^{4}$

41. Zagrebelsky 1994, p. 103.

42. Fumu 1991, p. 138. Spangher wijst op een praktijk war het OM "grenzen" heeft vaststelde wantonder bepalde delicten niet geregistreerd hoeven te worden, 1991, p.129. Chiavario noemi het bestaan wan gewallen warin het OM remmende anwizingen an de politie theef gegeven, Chiavario 1994, 9.73.

43. Zagrebelsky 4979, p. 9 .

44 Zagrebelsky 1979, p. 10; Neppi Modona 1987, p. 53.

45 Art. 109 Cost. art. 58, 327, 347 en 371 lid l c.p.p.; art. 5 e.v. alt; art. 12 d.1. 13 mei 199 , n. 152 , conv. in $\| .12$ julli 1991, n. 203. Overigens heeft ook de politie ext discretionaire rumte, die net altijd gecontroleerd wordf door hel OM, Chiavario 1994, p. 73. In zekere zin is thet OM afhankelijk van de politie voot de te vervolgen zaken, Carabba 1974, p. 101. Volgens Di fodtrico zou in een geval een pattket besloten hebben systamatisch de inwoners wan een stad te controleren op de mogeljke overtreding wan een bepalde norm. 1991, p. 178. Ower de politiediensten zie ook 6.3. Gezag over opsporingsorganen.

46 Art. 15-17 att.

47 Art. 244, 247, 253, 359, 375 c.p.p.

48 Art. 267,392 c.p.p. 
Hij kan de verdachte in hechtenis laten nemen voor delicten van een zeker gewicht. Binnen 48 uur dient het OM de 'onderzoeksrechter' (gitudice per le indagine preliminari) te vragen om bekrachtiging van de hechtenis. Hierbij kan het vragen om oplegging van een vrijheidsbenemende maatregel. ${ }^{49}$ Feitelijk heeft het $O M$ grote invloed op de beslissing hierin. De rechter heeft feitelijk weinig ruimte om de bewijselementen die het OM aandraagt ten gronde te evalueren. Verder heeft het OM met name in de opsporingsfase ten opzichte van de rechter een positie van een autoriteit, of anders van een naaste collega. ${ }^{36}$ Het $O M$ kan verder verzoeken dat de rechter conservatoir beslag legt op goederen van de verdachte. ${ }^{51}$ De keuze om wel of geen toepassing van dwangmiddelen te vragen betreft een andere vorm van discretionair optreden in de onderzoeksfase. $^{52}$

\subsection{Beslissing over de vervolging}

Als een bericht in het hierboven genoemde register voor berichten van strafbare feiten is ingeschreven heeft het $O M$ een keuze uit slechts twee alternatieven van handelen. Het $O M$ vervolgt, tenzij er gronden zijn voor een vordering tot een technisch sepot (archiviazione) (art. 50 c.p.p.).

Het OM verzoekt de onderzoeksrechter om sepot indien er geen delict gepleegd is (de notitic criminis was ongegrond), het feit is verjaard, het feit niet strafbaar is of er een (andere) voorwaarde voor vervolging ontbreekt. De door het delict benadeelde persoon wordt van de beslissing in kennis gesteld en kan hiertegen bij de rechter bezwaar maken. $^{53}$

De rechter kan het verzoek om sepot toewijzen en met een gemotiveerd decreet, zonder (raadkamer)zitting, besluiten dat het $O M$ de zaak archiveert. Indien hij het verzoek niet honoreert of het slachtoffer gegrond bezwaar maakt, beveelt hij een raadkamerzitting (udienza preliminare). De rechter kan hier zonodig het OM bevelen nader onderzoek te doen, en in een volgende zitting een beslissing nemen. Hier kan de rechter eventueel bevelen dat het $\mathrm{OM}$ een dagvaarding formuleert, ${ }^{54}$ of alsnog de vordering van het $\mathrm{OM}$ toewijzen. In de praktijk lijkt de controle van de onderzoeksrechter niet erg effectief te zijn. $^{5.5}$

49 Art. 384,391 jo 291 c.p.p.

50 Amodio 1994, p. 212: Di Federico 1998 , p. 238

51 Art. 316 c.p.p.

52 Neppi Modona 1987, p. 53.

53 Aft. 408-411. De benadeelde en de verdachte kunnen de procureur-general bij het hof eventueel verzoeken on de zask over te nemen, indien het OM niet binnen een bepaalde termijn seponeert of vervolgt (art. 413 c.p.p. zie ook 2.2. Inteme organisatio).

54 De preliminaire zittingstechter kan niet het feit en de verdachte aanwijzen waarvoor en ten aanzien van wie vervolgd moet worden, Cass. 9 februari 1990.

55 Art. 408-41: c.p.p. Anodio 1994, p. 210-122. Twij fel ontrent de onpartijdigheid van de onderzoeksrechter bij lohino 1994, p. 229 e.v. Di Federico meidt dat de rechters (ook in deze fase) sterk conform de eis van het OM beslissen, 1998, p. 239. Het is echter moeilijk uit dit gegewen direct de conclusie te trekken dat rechters het OM daarom niet sterk (kunnen) controleren. Wellicht doet het OM zijn werk meestal goed. In het verleden is de controle van de rechter op het sepot niet als een effectief middel gezien om her legaliteitsbeginsel effectief te maken, Pizzorusso 1979, p. 35; Guarnieri 1984, p. 43 noot 58. Anders: Neppi Modona 1987, p. 54. 
Zoals gezegd wordt de procureur-generaal bij het hof wekelijks geinformeerd over de zaken waarin (nog) geen vervolging is ingesteld of om sepot is gevraagd. Deze procureur-generaal kan het onderzoek overnemen als de procureur geen vervolging instelt of om een sepot vraagt binnen de wettelijke termijnen. De verdachte of de belanghebbende kunnen bij de procureur-generaal daartoe ook een verzoek indienen. ${ }^{56}$

Bij de bespreking van de aangiftes kwam aan de orde dat het $\mathrm{OM}$ in bepaalde gevallen niet hoeft te handelen, en dus zelfs geen vordering tot sepot hoeft in te dienen. Dit is in ieder geval mogelijk indien de aangifte anoniem is, als het feit bericht is via informele en oncontroleerbare bronnen, en wellicht in het geval van 'pseudo-aangiften'. Het uitblijven van vervolging in dergelijke situaties kan men zien als een impliciete omzeiling van het legaliteitsbeginsel. ${ }^{57}$

Als het $\mathrm{OM}$ niet om sepot vraagt, vordert hij bij de onderzoeksrechter de verwijzing naar de terechtzitting of doet hij een vordering voor een bijzondere procedure. De onderzoeksrechter neemt in deze vervolgens een beslissing. ${ }^{58}$

De vorderingen moet het OM doen binnen zes maanden na de inschrijving van de naan van de verdachte in het eerder genoemde register. Voor zwaardere delicten is deze termijn een jaar. Het OM kan de onderzoeksrechter vragen de termijn te verlengen, tot maximaal respectievelijk achttien maanden en twee jaar. Deze vervolgingstermijnen staan los van de gewone verjaringstermijnen, die veel langer zijn. De verjaring begint in principe te lopen vanaf het moment van het plegen van het delict, terwijl de vervolgingstermijn ingat vanaf de registrering ervan. ${ }^{39}$ De beperkingen die de vervolgingstermijnen geven, maken de keuze van de tijdsbesteding door het OM pregnanter. Het OM heeft zoals gezegd in beginsel de keuze tussen twee alternatieven: sepot of vervolging. Echter, het $\mathrm{OM}$ dat kennis heeft van een strafbaar feit zal niet altijd de tijd en middelen hebben om actie te kunnen ondernemen. In zaken waarin helemaal geen actie wordt ondernomen verlopen de vervolgings- of verjaringstermijnen. ${ }^{6 i)}$

\section{4 'OM-beleid'}

Het OM is genoodzaakt op enige manier prioriteiten te stellen - al dan niet uitdrukkelijk. De prioriteiten kunnen behandeling inhouden volgens de chronologische volgorde van binnenkomst, of het criterium van het toeval. Het OM kan ook meer rationeel geachte prioriteiten stellen, ingedeeld naar bijwoorbeeld het gewichl van het feit. ${ }^{61}$ De verscheidene, individuele houdingen van de parketten produceren zo in de praktijk tezamen een strafrechtelijk beleid. ${ }^{62}$

6) Conso $1979 \mathrm{~g}$, p. XVI; Brancaccio 1994 , p. 245 . In zijn witspraak van 20 juni l997 stelt de disciplinaire sectie ven de CSM exphict dat het toeval of de chronologie geen tationele criteria zijn.

62 Dominion 1979, $\mathrm{p} .54$. De circulaire wan 15 januari 1990 var de Procturetur General van Torino (Pieri) deelt zaken in naar complexiteit tan belang. Hij indiceert hel wragen wan sepot voor bepalde zaken warin het opsporingsonderzoek niet is voltooid, op de grond dat er min woldoende bewigs is De cir 
Het stellen van prioriteiten in de behandeling wan berichten van strafbare feiten wordt niet geacht in strijd te zijn met het legaliteitsbeginsel. De tedenering daarachter is dat het mogelijke inactief blijven niet voort komt uit opportuniteitsoverwegingen ten aanzien van de individuele zaak. Het niet handelen volgt daarentegen uit de beperkte mogelijkheden om actie te ondernemen. ${ }^{63}$

De noodzaak tot het stellen van prioriteiten heeft tot gevolg dat de hiervoor genoemde controle van de onderzoeksrechter van minder invloed kan zijn dan zij formeel gezien lijkt. Doordat bepaalde zaken niet onder de (impliciete) prioriteiten vallen, zal hierin geen onderzoek gedaan worden door het $O M$. Deze zaken kunnen op twee gronden voor sepot worden voorgedragen. Ten eerste kan het OM deze gevallen na afloop van de vervolgings- of verjaringstermijn voordragen. De rechter is dan genoodzaakt aan het sepotverzoek te voldoen. Ten tweede zou het OM kunnen pleiten dat de aangifte ongegrond is - terwijl nader onderzoek eventueel de gegrondheid zou kunnen aantonen. De onderzoeksrechter heeft hiervoor de bevoegdheid nader onderzoek in te doen stellen. Hij bevindt zich evenwel in een problematische positie. In feite heeft hij de discretionaire keuze om telkens nader onderzoek te bevelen als de ongegrondheid van de aangifte niet duidelijk lijkt. Zo zou hij het prioriteren van het $O M$ effect kunnen ontmemen, maar zou hij het strafproces overladen met tijdrovende processen. Een noodzakelijk gevolg thiervan zou zijn dat er nog minder tijd over zou blijven voor het doen van vervolgingen. De rechter kan dus niet anders dan zich zoveel mogelijk terughoudend opstellen, en het OM laten seponeren, zeker als de benadeelde geen bezwaar maakt. De rechter zal dus het proces in andere, door het OM geprioriteerde, zaken voortgang laten krijgen, ook om het strafrechtsysteem niet te overladen.

Deze analyse legt het gegeven bloot dat de rol van de belanghebbende van belang kan zijn voor de vervolging in een zaak. De belanghebbende kan tegen de inertie van het

culaire wordt gepresenteerd als een noodmatregel, zonder dat duidelijk is na weike termijn de nood geleegd zal ziju. De circulaire wan 16 november 1990 wan de procurenur van de Republiek van een districtsaldeling van het parket bj de rechtbank van Torino (Zagrebelsky) is een ander voorbeeld van prioriteisstelling. Nog exn voorbeeld uit de praktijk bij Di Federico 1991, p. 179-180. Hier kiest het parket niet welke de "minder belangrijke" zaken zijn om te vervolgen, maar blijft het inert om motieven van sociale onrust.

63 Maddalena 1991, p. 161; Zagrebelsky 1992, p. 31; 1994, p. 105; Chiakario 1994, p. 95; Neppi Modona 1994, p. 124; Di Federico 1995, p. 411. Deze auteurs verbinden hun standpunt overigens direct aan de mening dat dezo priorileiten door het parkement gesteld zouden moeten worden (zie hoofdstuk $7,3.5 .2$. Zeggenschap door volks vertegenwoordigingen).

De disciplinatire sectic van de CSM heelt bevestigd dat er van strijd geen sprake is (20 jumi 1997). Opvallend is dat de sectie Zagrebelsky citcert. Kritiseh: Nannucei 1991, p. 1670 e.v.; Caliendo 1994, p. 141. Afwijzend ook de procureur-generaal in zijn conclusie bij de geciteende uitsprak. In de wetgeving wordt pas woor het eerst over prioriteiten gesproken in de tijdelijke norm van art. 227 d.g. n. 51, 1998. Hierin wordi het hoofd wan het parket opgedragen criteria te stellen voor het afdoen van processen die amhangig zijn op het monent wan imwerkingtreding wan de wet. Kritisch Pera, SdR, R.s.C.g. 7 december 1999, volgens de senator is er sprake van strijd met het legaliteitsbeginsel.

Enkelen beschouwen het stellen van prioriteiten als een tijdelijke noodoplossing woor de huidige periode, die een uitzonderingssituatie genoend wordt, Rovelli 1994, p. 269; D'Ela 1998, p. 1879 e.v. Deze atuteurs zijn voorstanders wan hervormingswoorstellen van endo-processuele aard, of met betrekking tot de interne organisatie. Zie daarvoor hoofdstuk 7. 3. Hervormingsvoorstellen in drie landen.

$\mathrm{Vgl}$, minister Fassino over prioriteitscriteria door het OM: La Repubblical 15 januari 2001. 
OM weerwerk bieden. Als het $O M$ de termijnen laat verlopen kan hij de procureurgeneraal hierop wijzen. Wil het $\mathrm{OM}$ een mogelijk haalbare zaak seponeren, dan kan de belanghebbende bij de onderzoeksrechter bezwaar maken.

\subsection{Vervolgingsstrategie}

Het derde keuzemoment voor het $O M$ betreft de te volgen processtrategie.

Indien het $O M$ besluit tot vervolging, vordert het bij de rechter dat de zaak ter zitting gebracht wordt of het verzoekt om een van de bijzondere procedures. Als het OM om een terechtzitting verzoekt, belegt de preliminaire zittingsrechter altijd eerst een raadkamerzitting. Hij kan eveneens nader onderzoek gelasten, en uiteindelijk de zaak naar de zitting verwijzen of een vonnis uitspreken dat er geen grond is voor vervolging. Dit soort vonnissen is echter zeer zeldzaam, waardoor deze raadkamerzitting feitelijk neerkomt op een soort rechterlijke ondersteuning van de beslissing van het $\mathrm{OM}^{64}$

Naast vervolging via deze gewone procedure ter zitting kan het $O M$, eventueel op initiatief van de verdachte besluiten tot een vordering van een bijzondere procedure. De bijzondere procedures zijn, ondanks hun naam, bedoeld voor tachtig procent van de zaken, maar in de praktijk lijkt deze verhouding op ongeveer de helft van de zaken te liggen. ${ }^{65}$ Er zijn vijf bijzondere procedures.

Ten eerste kan de verdachte om een verkorte procedure vragen, met instemming van het OM. Als het verzoek toelaarbaar is houdt de onderzoeksrechter een raadkamerzitting waar hij de zaak beslist. Indien de verdachte wordt veroordeeld vermindert de rechter de straf met een derde (gindizio abbreviato, art. 438-443 c.p.p.).

Als tweede procedurele optie kunnen zowel de verdachte als het OM de onderzoeksrechter of de rechter ter terechtzitting verzoeken om het uitspreken van een door de partijen overeengekomen straf, verminderd met een derde. Dit kan alleen bij delicten waarvan de strafmaxima binnen bepaalde grenzen liggen. Het verzoek kan tot het eind van de raadkamerzitting aan de onderzoeksrechter gericht worden (patteggiamento, art. 444-448 c.p.p.). ${ }^{65}$

Een derde bijzondere procedure is mogelijk indien de verdachte aangehouden is op heterdaad, of als hij bekend heeft. Dan kan het OM de zaak direct voor de rechter brengen. Deze beslist in een raadkamerzitting, waarin hij de zaak kan terugwijzen voor een andere wijze van athandeling (gindizio direttissimo, art. 449-452 c.p.p.).

Het OM heeft als vierde mogelijkheid de onderzoeksrechter te verzoeken onmiddellijk op de zaak te beslissen, indien het bewijs evident lijkt en de verdachte ondervraagd is, of daartoe is uitgenodigd. De rechter beslist zonder raadkamerzitting bij decreet of weigert en geeft de zaak terug aan het OM voor een andere afhandelingswijze (giudizio immediato, art. $453-458$ c.p.p.). ${ }^{67}$

64 Art. 405, 416-433 c.p.p. Corso 1993, p. 247.

65 Dit blijkt mede uit gesprekken. Zie werder Corso 1993, p. 251; Devoto 1996a, p. 2038

66 Dit werschilt van het zgn. plea bargaining onder andere in de zin dat de verdachte geen echte schuldbekentenis doet.

67 De verdachte kan voor het debal in ees giudizio direntissimo of na afloop van een gitudizio immediato eventueel nog om toepassing van het gitudizio abbreviato verzoeken (arit. 452 lid 2 en 458 lid 1 c.p.p.) 
Als laatste heeft het OM de bevoegdheid de onderzoeksrechter te vorderen bij decreet een bepaalde geldstraf op te leggen. Deze straf kan ook de helft minder bedragen dan de minimum vastgestelde straf, ${ }^{65}$. De verdachte kan hiertegen bij de rechter bezwaar maken en vragen om toepassing van één van de andere bijzondere procedures (procedimento per decreto, art. $459-464$ c.p.p).

Het Italiaanse strafprocesrecht kent zo vele opties voor het $\mathrm{OM}$ om de vervolging vorm te geven, waarbij de keuze voor een bepaalde procedure niet wettelijk is voorgeschreven. In de praktijk is er dan ook bij de processtrategie variatie in de wijze waarop leden van het $\mathrm{OM}$ met de bijzondere procedures omgaan. ${ }^{69}$

\subsection{Functie OM ter zitting}

De zitting wordt geleid door de rechter. Het $O M$ is daar aanwezig en kan de rechter, net als de verdachte, verzoeken doen. Het kan vragen om het horen van getuigen of deskundigen en het houden van een schouw. Het kan bewijsdocumenten in het zittingsdossier doen opnemen, Tenslotte neemt het een conclusie ten aanzien van de te nemen rechterlijke beslissing. ${ }^{70}$

\subsection{Rechtsmiddelen door het OM}

De procureur van de Republiek en de procureur-generaal hebben de bevoegdheid tegen de beslissing van de (onderzoeks)rechter in eerste aanleg beroep in te stellen bij het hof van beroep. Daarbij is niet van belang welke conclusies het $O M$ in eerste aanleg heeft genomen. Beiden kunnen beroep in cassatie instellen. Alleen de procureur-generaal kan vragen om herziening van een vonnis tot veroordeling. ${ }^{71}$

\subsection{Rechterlijke controle op het OM}

Wraking is alleen tegen de leden van rechtsprekende colleges mogelijk. Leden van bet OM zijn in sommige gevallen van belangenvermenging wel verplicht zich te onthouden van een zaak. Het parkethoofd en de procureur-generaal dienen hierop toe te zien. ${ }^{72}$ Voor handelingen van het OM kan bij de civiele rechter alleen de Staat aangesproken worden. De bestuursrechter biedt de burger geen enkel soelaas. Het OM behoort name-

of on en pattegiamento (art. 4.46 lid 1 e.p.p.). De verdachte heef damanast nog de mogeligheid on te Kiozen woor het anbieden van her betalen wan en boete (obinzione) ten bedrage van de helt van de maximumstraf. Hij doet dit arthod tegenover de rechter voor het debat ter zitting. Deze mogelijkheid bestat alleen voor owertred hingen met een bepande straf (art. 162 c.p.). Het OM kan de verdachte wijo zen op deze botevorm en adviseert de rechter bij diens beslissing op het verzoeh (art. 141 att.).

68 Het liahanse Waboek van Strafrecht kent een systeem waarin bij veel delicten een minimum- en maximuntrat is angegeven. Verkrachting wordt bijvoorbeeld bestraft met een gevangenisstraf van vijl tot tian jaan (art. 609 bis o.p.).

69 Catclani 1994, p. 148. Op deze nogelijkheid willst ook Zanon 1996, p. 36-38.

70 Ait. $468,482,523$ c.p.p.

7 Art 570, 608,632 c.p.p.

72 Art 36 jo 53 c.p.p. Zie ook 2.2. Interne organisatie. 
lijk zoals eerder bleek niet tot het bestur. Alleen tegen de handelingen van de laatste staat beroep open op de administratieve rechtbank. ${ }^{73}$

Bij de strafrechter kan een belanghebbende niet terecht indien het $\mathrm{OM}(\mathrm{nog})$ geen besluit heeft genomen of dit geheel uitblijft. In dat geval kan de burger wel bij de procureur-generaal een verzoek indienen. Indien de beslissing van het lagere parket te lang uitblijft kan het hogere parket de zaak vervolgens overnemen. De verdachte heeft eveneens deze mogelijkheid van een verzoek. Voor het overige bestaan geen vormen van hiërarchisch beroep.

Wanneer het $\mathrm{OM}$ de onderzoeksrechter om sepot verzoekt kan een bellanghebbende daartegen bezwaar maken bij deze rechter. Ook instellingen en verenigingen die belangen vertegenwoordigen die geschonden zijn hebben deze mogelijkheid. ${ }^{74}$

Besluit het OM daarentegen tot vervolging en dagvaarding, dan kan de verdachte zijn bezwaren laten horen in de raadkamerzitting voorafgaand aan de terechtzitting. ${ }^{75}$

\subsection{Conclusie}

Hoewel het Italiaanse OM formeel onder de processuele plak van de (onderzoeks)rechter zit, is hij in de praktijk min of meer de baas in het poorthuis van het strafproces. Bij alternatieven voor gewone vervolging heeft het $\mathrm{OM}$ wel altijd de zegen van de rechter nodig. Belanghebbenden zijn enigszins afhankelijk van initiatieven van het $O M$. Op de opsporingsdiensten kan het $\mathrm{OM}$ een directe greep hebben, al blijkt niet van een expliciet opsporingsbeleid.

\section{Minister en ministerie van Justitie en President}

Onder de politieke ambten van de centrale overheid heeft vooral de minister van Justitie bevoegdheden tegenover het OM. De rol van de President jegens het OM is vooral symbolisch van aard. Hieronder beschouw ik eerst de algemene positie van deze ambten.

Het parlement in verenigde vergadering kiest de President bij meerderheid van de leden. De persoon van de President is meestal niet uitgesproken politiek gekleurd. Tijdens de zevenjarige duur van zijn mandaat legt hij geen politieke en nauwelijks strafrechtelijke verantwoording af. Besluiten van de President worden gecontrasigneerd door een minister die daarvoor verantwoordelijkheid draagt. Wanneer beslissingen ten aanzien van de rechterlijke macht de vorm van een presidentieel decreet hebben, draagt de minister van Justitie deze verantwoordelijkheid. Op de President rust tenslotte het symbolische voorzitterschap van de CSM. ${ }^{76}$

73 Voor beroep op de burgerlijke rechter zie 5.5. Aansprakelijkheid.

74 Ari. 90-95 c.p.p. Zie eveneens reeds 3.3. Beshlissing over de verwolging.

75 Art. 416 e.v. c.p.p.

76 Art 83-85 Cost. Voor de presidentiele verkiezing wordi de verenigde vergadering uilgebreid met af. gevalardigden gekozen wit de regionale roden. Bij de eerste wee stemmingen is een weederde theerderheid nodig voor werkiezing van de President. Voor de vervolging van de President zie 6.2.4. Vervol- 
De Itailaanse minister van Justitie heeft een sterke constitutionele positie. Hij is de enige minister clie de grondwet expliciet vermeldt. Zijn relatie tot de rechterlijke macht is hierin op hoofdlijnen gegeven. De tekst geeft zijn bevoegdheden weer ten aanzien van de disciplinaire procedure en de organisatie van de rechterlijke macht (art. 107 lid 2 en $(10)$.

De minister van Justitie wordt benoemd door de President op voorstel van de premier. Hij is lid van de ministerraad en de regering. Als lid van de regering dient hij het vertrouwen van de beide parlementaire kamers te hebben. De regering bestaat dan ook meestal uit exponenten van de partijen die de meerderheid in het parlement hebben. ${ }^{77}$

De ministerraad bepaalt de algemene beleidslijnen, waaraan de minister zich in zijn handelen dient te houden. Dit geldt ook ten aanzien van de grondwettelijk aan de minister van Justitie toegekende bevoegdheden. De keuze voor het gebruik van zijn bevoegdheden kan niet geheel losstaan van de algemene politieke overwegingen van de regering. ${ }^{78}$ De mimister-president kan een belangrijke rol spelen in de regering. Hij kan de minister aanwijzingen geven en te nemen ministeriële besluiten opschorten om ze voor te leggen aan de ministerraad. Feitelijk kunnen de individuele ministers well een ruime marge aan vrijheid behouden. De premier kan verder de President voorstellen om een minister te ontslaan. In de praktijk gebeurt het alleen dat ministers zelf besluiten ontslag te nemen. ${ }^{79}$

Ter coördinatie van het handelen van de regering bestaan ministeriële comités. Er bestaat evenwel geen comité op het gebied van de opsporing of de veryolging. Dit stemt overeen met het gegeven dat de minister van Justitie in deze vrijwel geen zeggenschap heeft.

De minister staat aan het hoofd van het ministerie van Justitie. Dit bestaat uit vier departementen, waarvan twee in het bijzonder te maken hebben met strafrechtelijke procedures en het $\mathrm{OM}$. Het Departement voor justitiële zaken verzorgt handelingen op het gebied van internationale strafrechtelijke samenwerking en bereidt andere besluiten voor in de functionele relatie met het OM. De rechtspositionele en organisatorische bevoegdheden van de minister worden ambtelijk ondersteund door het Departement voor de rechterlijke organisatie, het personeel en de diensten. De minister wordt bijgestaan door een kabinet met een meer politieke functie. Dit onderhoudt met name de contacten

gingstoestemming voor de President. Over de CSM zie 2.1. OM en rechterlijke macht, 5. Rechtspositie van the $O M$ en 6.1 . Bevoegdheden ontrent in formatievoorziening.

77 Art. $92-94$ Cost. Een meer "techuische' samenstelling van de regering betrof onder meer het kabinet Dini (1995-1996) en het kabinet Crampi (1993-1994).

78 Art. 2 I. 23 augustus 1988, n. 400. Donati 1997, p. 198 en Zanon 1996, p. 239; anders: Piwetti 1995, p. 26: Pisaneschi 1996, p. 1262. Donati lijkt dit standpunt ook af te leiden uit de uitsprazk van het Corte Cost. 1996, 11.7. Mijns inziens zijn deze conclusies niet direct uit het vonnis te trekken, in 1995 waren de centrum-rechtse partijen in de Senaat en minister Mancuso overigens van mening dat de minister ututonoom is in de uttoefening van zijn functies die hij door de Grondwet krijgt toebedeeld. Deze autonomic zou gelden zowel in relatie tot de andere leden van de regering als tot bet parlement. Dini, die destijds premier was, stelde dat de minister wel autonoom is in relatie tot de regering, maar niet tot het partement, vgl. Donati 1997, p. 185-192. Over de verwikkelingen rond Mancuso zie 7. Verantwoording voor het $O M$.

Ant. 51.23 augustus $1988, \mathrm{n} .400$. 
met het parlement en de CSM en draagt bij aan de beleidsvorming. Tenslotte heeft de minister de beschikking over een Inspectiedienst. Deze voert op aanwijzing van de minister (of de CSM) onderzoeken uit naar het functioneren van onderdelen van de rechterlijke macht. ${ }^{80}$

Het is van belang op te merken dat het Italiaanse ministerie van Justitie een bijzondere samenstelling heeft. De leidinggevende posities worden vaak bekleed door magistraten, met een tijdelijke aanstelling. Voor die duur behouden zij op het ministerie hun rechtspositionele waarborgen. 81 Hierdoor heeft de minister in vergelijking met zijn bevoegdheden over andere ambtenaren enigszins beperkte mogelijkheden om via rechtspositionele aspecten invloed uit te oefenen op het handelen van de ministerièle magistraten. Dit kan een verdere beperking vormen ten aanzien van de ministeriele invloed op het OM.

\section{Rechtspositie van het OM}

Met het bepalen van de rechtspositie van leden van het OM begin ik de behandeling van de relatie tussen het OM en andere staatsorganen. Leden van het OM hebben een grote mate van onathankelijkheid qua rechtspositionele status. Deze is gewaarborgd door de regeling op de rechterlijke organisatie (ord.giud.), de Wet op de Hoge Raad voor de Rechterlijke macht (Wet CSM), de uitvoeringsregeling daarop en de Wet waarborgen voor de rechterlijke macht. ${ }^{82}$

De minister van Justitie heeft maar zeer beperkte mogelijkheden tot beïvloeding van de leden van het OM via hun rechtspositie. Een eerste algemene bevoegdheid van de minister is die om bij de CSM verzoeken of voorstellen in te dienen in alle rechtspositionele zaken van magistraten waar de raad over beslist. Van deze mogelijkheid makt de minister vaak gebruik. Verder kan hij het woord voeren op de vergaderingen van de CSM op verzoek van de voorzitter, of wanneer hij dat wenselijk vindt. Dit gebeurt alleen bij uitzondering, zoals bij officiële gelegenheden, in het bijzonder na de benoeming van een nieuw kabinet. ${ }^{83}$

Hierna bespreek ik de specifieke regeling van de belangrijkste onderdelen van de rechtspositie van het OM. Achtereenvolgens komen aan bod: de wijze van benoeming, de overplaatsing, de bezoldiging, grondrechten, de aansprakelijkheid, de disciplinaire regeling, schorsing en ontslag en de rechtsbescherming. Voor zover van toepassing

80 Voor het ministerie: D.p.5. 6 wart 2001, n. 55. Voor de inspecle zde 6.1. Bevoegdheden omtrent informatiewoorziening. Het ministerie is overigens in 1999 wan mam veranderd in Ministero dalla giusrizia, terwijl dat vóór 16 lid 1 d. Ig. 30 juli 1999 , n. 300 Ministero della grazia e della giustizia was.

81 Zamnotti 1981, p. 53 e.x.; Overigens is het aantall magistraten dat niet in een rechtspuekende of vervolgende functie is, recent sterk beperkt tot 50 , op een personeelsbestand van het ministerie van dustitic vant rum 50.000 , warvan overigens meer dan 40.000 ambtenoren woor gerechtelijke instanties werken (art. $19 \mathrm{~d} . \lg .30$ juni 1999, n. 300 ).

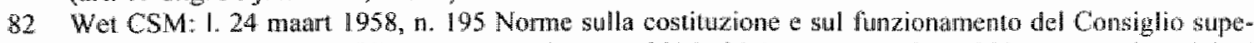
riore della magistratura, Uitvoeringsregeling wet CSM: d.P.R. 16 september 1958, n. 916 Disposizioni di atuazione e di coordinamento della llegge 24 marzo 1958, n. 195, Wet wararbotgen: r.d.lg. 31 mei 1946, n. 511 , Guarentigie della magistratura.

Artt 11 lid 1 en 16 Wat CSM, art. 110 ord.giud. 
geef ik daarbij de interventiemogelijkheden weer van de minister van Justitie. Deze gelden overigens op alle onderdelen gelijkelijk ten aanzien van alle magistraten, rechters en leden van het $\mathrm{OM}$.

\subsection{Benoemingen}

Net als rechters worden leden van het OM door een concours (concorso), een soort sollicitatie-examen, geseleeteerd. De CSM organiseert dit examen via een door haar ad hoc benoemde onderzoekscommissie voor aanstellingen en promoties. ${ }^{84}$ Deze commissie, die voornamelijk uit magistraten bestaat, stelt een ranglijst op na het sollicitatieexamen. De minister van Justitie en de belanghebbenden kunnen daar desgewenst bewaar tegen indienen bij de CSM. Na onderzoek van deze bezwaren wijzigt de CSM zonodig de lijst en stelt hem vast. De kandidaten worden aangenomen naar gelang hun positie op de ranglijst voor het aantal posten waarvoor het examen is gehouden. De toewijzing van de eerste en volgende functies geschiedt via een puntensysteem waarmee voor elke opengevallen functie een speciale ranglijst wordt opgesteld. Factoren waarvoor magistraten punten krijgen zijn de positie op de ranglijst van het toegangsexamen, de leeftijd, gezondheidsredenen, etc. ${ }^{85}$

De hoofden van de parketten, inclusief de nationale antimaffia-procureur, worden benoemd middels een speciale procedure. Hiervoor bestaat een commissie bestaande uit drie leden van de CSM, twee gekozen door magistraten en één door het parlement. De commissie doet een voorstel in overeenstemming met de minister van Justitie. Hierop neemt de CSM de beslissing, waarbij deze van het voorstel kan afwijzen en een nieuw voorstel gedaan moet worden. De minister heeft hier de mogelijkheid de procedure desgewenst geheel te blokkeren door geen instemming te verlenen. In de praktijk speelt de minister op dit punt geen grote rol. ${ }^{86}$

\subsection{Overplaatsing en functiewijziging}

Magistraten kunnen in uitzonderingsgevallen tegen hun wil worden overgeplaatst. Dit kan voorkomen in geval van incompatibiliteiten, disciplinaire sancties en het opheffen of inkrimpen van een parket. Verder kan de CSM vaststellen dat het functioneren van de magistraat in een bepaalde positie schadelijk is voor 'het prestige van de rechterlijke macht".8?

Daarnaast kunnen leden van het OM tijdelijk worden toegevoegd aan een ander parket indien dat om personeel verlegen zit. De instemming van de betrokkene is alleen nodig voor een toevoeging buiten het district van de magistraat, of wanneer deze langer duurt dan een half jaar. Indien dit parket zich in hetzelfde district bevindt als waar de betrokkene zijn functie heeft, beslist hierover de betrokken procureur-generaal. Toevoegingen

\$4 Art. 106 lid 1 Cost.; art. 10 lid I Wet CSM; art. 125 ord.güud.

85 Art. 12 Wet CSM. Deze regeling geld op grond wan een serie circulaires opgesteld door de CSM op grond van art. 10 Wet CSM, zie Pizzorusso 1990, p. 204 e.v.

\$6 Art. 11 lid 3 Wet CSM. Pizzontsso 1990, p. 206; Verde 1990, p. 5 H.

87 Art. 2 Wet warborgen. De raad heef deze bevoegdheid nader genormeerd in cireulanes, Pizzorusso $1990, p, 209$. 
tussen twee districten geschieden door de CSM, op verzoek van de betreffende procureur-generaal of van de minister. De nationale antimaffia-procureur is bevoegd leden van zowel de Nationale directie als de antimaftia-districtsdirecties tijdelijk toe te voegen aan een andere directie.

Voor het overstappen wan een rechtsprekende naar een vervolgende functie of anderson dient de CSM op verzoek van de betrokkene vast te stellen dat deze daarvoor de geschikte professionele kwaliteiten voor de nieuwe functie heeft. In de praktijk valt deze beslissing zelden negatief uit. ${ }^{89}$

\section{$5.3 \quad$ Bezoldiging}

De bezoldiging van leden van het $O M$ is net als voor rechters verbonden aan hun rang, niet aan hun functie. Leden van de rechterlijke macht kunnen na een aantal jaren in rang stijgen. Op verzoek van de betrokkene bevordert de CSM hem in een hogere rang. Daartoe stelt de raad vast of de magistraat een voldoende professioneel niveau heeft. In het oordeel wordt de CSM geadviseerd door een raad van magistraten van het betreffende district, behalve voor de hoogste rang. ${ }^{90}$ In de nieuwe rang ontvangt deze het daaraan verbonden stipendium. De functie die het lid daarbij uitoefent is voor de hoogte daarvan irrelevant. Het is dus goed mogelijk dat een persoon bij het parket van een rechtbank werkt met de rang van magistraat van het hof van beroep. Zo wordi men na twee jaar stage rechtbankmagistraat, na elf daarop volgende jaren bereikt men de rang van hofmagistraat, na nog zeven jaren cassatiemagistraat, en acht jaren daarna cassatiemagistraat met leidinggevende kwalificatie. De wijze van financiele promotie is aldus enkel verbonden aan de ervaring, waardoor men na 28 jaren dienst het hoogste bezoldugingsniveau bereikt. ${ }^{91}$

\subsection{Grondrechten}

Er bestaan geen expliciete uitzonderingen op de grondrechten van magistraten. In principe kunnen zij zonder beperkingen gebruik maken van bijwoorbeeld hun vrijheid van vergadering, vereniging, en meningsuiting. Wel kunnen sommige uitingen een disciplinair feit opleveren. Het wordt voor de institutionele relaties opportuun geacht als leden

88 Arti. 110 en 110-bis ord gud., ant. 11. 21 februani 1989, n. 58. Pizzonusso 1990, p. 135-136.

89 Art. 190 ord.gint.

90 Bij elk hof bestaat werder een. "nechterlijke rad" (consiglio giudiziario) besteande uit de president en de procureur-generaal van het hof en acht andere leden gekozen door de magistraten wit hei dismict (art. 6 Wet warborgen). Deze raad heeft als belangrijkste tak magishaten te beoordelen op hun geswhike heild woor hun promotie naar een hogere rang. Verder ziet de raad toe op stages en geef zij adviezen af over organisatorische zaken van de rechterlyke colleges en de parkethen. Deze adviezen dienen in awmerking te worden genomen bij besluiten over onder mer thjelijke toevoegingen van magistraten aan andere parketten, en functicwijzigingen. Plzzorusso 1990, p. 109 e.x.

91 De respectievelijke promoteregelingen zijn woor rechtbankmagistrabal art. I c.v. I. 2 april 1979, n. 97. voor hofnagistrat art. I e.v. 1.25 juli 1966 , n. 570 , voor cassatiemagistrat art. 41.20 december 1973 , n. 831 en voor de leidinggevende kwalificatie art. 16 van die wet. Krifisch: Pizzorusso 1990, p. 204. De bezoldiging is geregeld in 1.19 februari $1989, n .27$. Voor stagianes en rechtoankmagistraken is et werigens nog voorzien in een tussennivea wan bezoldiging, respectievelijk na zes matanden stage en na dric jaar rechtbankrang. 
van het OM zich terughoudend opstellen. Dit geldt des te meer indien specifieke procureurs grote publieke populariteit genieten. ${ }^{97}$ Procureurs hebben zich in de praktijk wel meerdere malen uitgesproken voor een wijziging van de strafwetgeving, of zelfs voor politieke hervormingen. ${ }^{93}$ Enkele malen gingen magistraten in groten getale in staking om daarmee hun mening kracht bij te zetten. ${ }^{94}$ Verder mogen leden van het $\mathrm{OM}$, net als rechters, lid zijn van een politieke partij. $\mathrm{Z}_{\mathrm{ij}}$ zijn verkiesbaar indien zij hun functie binnen een bepaalde termijn woor de betreffende verkiezingen neerleggen. ${ }^{95}$ In de jaren negentig zijn verscheidene procureurs lid geworden van het parlement of zelfs de regering. ${ }^{96}$

Bijna alle magistraten zijn lid van de Nationale vereniging van magistraten. De vereniging spreekt zich als belangenvertegenwoordiger uit over zaken als voorgestelde wetgeving en organisatorische veranderingen. Binnen deze vereniging bestaan georganiseerde facties. Deze vormen kiesverenigingen die kandidaten voor de CSM voorstellen. Daarnaast nemen zij binnen de ANM deel aan de meningsvorming. De facties zijn niet uitgesproken politiek gekleurd, maar wel ruwweg in te delen over een links-rechts spectrum."?

\subsection{Aansprakelijkheid}

De Italiaanse Staat kan aangesproken worden voor onrechtmatig veroorzaakte schade door handelingen of beslissingen van het OM. Dit is slechts mogelijk als het lid van het OM grove schuld of opzet te wijten is. De interpretatie van het recht of de waardering van bewijzen kunnen niet tot aansprakelijkheid leiden. De Staat is vervolgens gerechtigd een vordering op de betrokken magistraat te doen. ${ }^{98}$ Los van deze vorderingen kunnen benadeelden schadevergoeding eisen in het geval van ongegronde vrijheidsbeneming (art. 643 e.v. c.p.p.).

92 Voor de grondrechten zite: art. 13-2॥ Cost. Pizzorusso 1990, p. 215; Zanon 1996, p. 256-260. Kritisch bijwoorbeeld Giovanardi, CdD, R.s. 6 maart 1997, p. 13477-13478, waar de parlementarièr de kritick van een lid wan het $O M$ over een wet in een dagblad negatief beoordeelt.

93 Appello al Parlamento 1995, p. 421 e.v.; Leijendekker 1996, p. 83-86

$940 \mathrm{p} 20$ juni 2002 gingen magistraten in staking tegen plannen voor institutionele hervormingen van de regering Berlusconi. Op 3 december 1991 protesteerden zij middels een staking tegen de houding van President Cossiga.

95 Art. 8 d,P.R. 30 maart 1957, n. 361 (Kieswet woor de Kamer wan gedeputeerden, meerdere malen gewijzigd). De grondwet maakt het wel mogelijk de inschrijving bij politieke partijen te beperken voor bepaalde ambienaren, art. 98 lid 3 Cost.

96 De begin jaren negentig zeer populaire substituut procureur van Milaan Di Pietro werd bijvoorbeeld achtereenvolgens senator en minister van Publieke Werken, Zanon 1996, p. 261. Dit kwam hem overigens te stan op felle kritiek van rechtse partijen en politici, die hij als lid van het OM had wervolgd.

97 Binnen de Associazione Nazionale dei Magistrati (ANM) bestaan de facties Unità per la Costituzione (Unicost), Magistratura democratica (Md), Movimento per la Giustizia en Magistratura indipendente (MI). Unicost is de grootste en meer neutral op het centrum gericht. Ml is principieel niet politiek geaffilieerd, maar is wel als conservatief te schetsen. De andere twee zijn meer progressief georiezteerd.

98 Zie 1.13 april 1988, n. 117. 


\subsection{Disciplinain regime}

Ten behoeve van eventuele disciplinaire sancties oefenen de procureurs-generaal bij de hoven van beroep toezicht uit op de leden van parketten in het betreffende district. De procureur-generaal bij het hof van cassatie ziet toe op de leden van zijn parket en op de Nationale antimaffia-directie. De minister van Justitie houdt eer algemeen toezicht op de lleden van het $\mathrm{OM}$.

De minister van Justitie en de procureur-generaal bij het hof van cassatie hebben de bevoegdheid disciplinaire sancties voor te stellen ten aanzien van leden van het OM en rechters. De minister heeft daarin een discretionaire bevoegdheid. Hij heeft niet de plicht een disciplinaire actie te beginnen ook al meent hij dat daar gronden voor aanwezig zijn. ${ }^{100}$ Indien de minister disciplinair optreden opportuun acht, verzoekt hij de procureur-generaal bij het hof wan cassatie daartoe een eis in te dienen. Deze is verplicht een disciplinare actie in te stellen bij de CSM. Dit is het enige geval waarin de minister een lid van het OM een aanwijzing kan geven. In veruit de meeste gevallen is het de minister die het initiatief neemt. ${ }^{101}$

De gevallen waarin sprake is van een disciplinair strafbaar feit zijn uiterst ruim onschreven. Laakbaar is een officier "die tekortschiet in zijn verplichtingen, die in of buiten de uitoefening van zijn functie een gedrag vertoont dat hem het vertrouwen en achting die hij moet genieten onwaardig makt, of die het gezag van de rechterlije macht compromitteert". 102

De disciplinaire sectie van de CSM neemt namens de raad het besluit over de gegrondheid en oplegging van de sanctie. ${ }^{103}$ De straf kan oplopen van een berisping tot ontslag. De betrokkene, de minister en de procureur-generaal bij het hof van cassatie kumnen beroep instellen bij het hof van cassatie. ${ }^{104}$ In de praktijk vinden jaarlijks tientallen disciplinaire procedures plaats.

99 Artt. 16 Wet warborgen en art. 69 en 76 -ter. ard ggud.

100 Arti. 107 lid 2 Cost; art. 14 sub I Wet CSM. Corte Cosi. 1992, n. 196; 2anon 1996. 19. 226. Wen plich om een disciplinaire actie un te stellen is ook moetlijk in te denken, data de gevallen wastun ean sanctie opgelegd wordt of kan worden, niet scherp omsehreven zijn, zie hienth. Disciplinaire acties kunnen overigens een vervolg zijn op ministeriele inspecties wan cen parket. Damover in 6.1. Bewoegdheden ontrem in formalievoorziening.

101 Art. 59 Uitwoeringswet. Bartole 1964, p. 182; Devoto 1996a, p. 2042; Zanon 1996, D. 230. In het verteden gaf de minister er de voorkeur an het mithatic tot disciplinaire actie over te laten an de procureurgeneraal bij het hof van cassatie, Zagrebelsky 1979, p. 23; Guamieri 1984, p. 23.

102 Art. 18 Wet warborgen. Voor de leden van de rechterlijke macht bustat overigens en enthische code: Codice Etico van het Comitato Direttivo Centrale wan de ANM, zoals woorgeschenen door wrt. 58 bis lid 4 d.lg. 3 februari 1993, n. 29. Zie Manzione 1995, p. 104. Over de. ANM zie 5.4. Grondrechten. Zile ook de gedragscode voor magistraten van de ANM, http//www.giustizincarialilarchmag/codice etico htm

103 Art. 10 lid I sub 3 Wel CSM. Voorziter is de wice-voorzitter wan de CSM, en verder zign lid, wee door het parlement gekozen leder en zes door en uit magistraten gekozen leden (art.4 Wet CSM).

104 Voor de straffen: art. 19 Wet warborgen. Voor het beroep: arti. 17 Wet CSM en art 60 Uitvoeringsregeling. 


\subsection{Schorsing en ontslag}

Magistraten kunnen door de disciplinaire sectie worden geschorst indien tegen hen een disciplinaire procedure is gestart. Dit gebeurt op verzoek van de minister van Justitie of de procureur-generaal bij het hof van cassatie. Als een van een strafbaar feit verdachte magistraat een vrijheidsbeperkende maatregel opgelegd krijgt is hij van rechtswege geschorst. In andere gevallen kan hij op verzoek van de hiervoor genoemden geschorst worden. Tenslotte kan in geval wan ernstige ziekte een magistraat door de CSM geschorst worden. ${ }^{105}$

Op hun zevenenzestigste jaar gaan magistraten met pensioen. Voordien kunnen zij alleen ontslagen worden bij disciplinaire straf, bij permanente ziekte of gebleken ongeschiktheid, zoals vastgesteld door de CSM ${ }^{106}$

\subsection{Rechtspositionele rechtsbescherming}

Bij de administratieve rechtbank te Rome is beroep mogelijk tegen alle handelingen van de CSM ten aanzien van de rechtspositie van magistraten, anders dan de disciplinaire handelingen. Bij de Raad van State is vervolgens hoger beroep mogelijk. Tegen disciplinaire beslissingen staat beroep open bij het hof van cassatie (art. 17 Wet CSM).

\subsection{Conclusie}

Italiaanse parketleden zijn vrijwel geheel gevrijwaard van ministeriële interventies ten aanzien van hun rechtspositie. Zelfs bij de twee belangrijkste bevoegdheden van de minister is hij woor de besluitvorming afhankelijk van de CSM. De minister kan slechts in overeenstemming met een CSM-commissie voorstellen doen voor benoeming van magistraten in leidinggevende posities. In de disciplinaire procedure heeft hij enkel het initiatief. In beide gevallen is het de CSM zelf die beslist. OM-leden zijn aldus veeleer afhankelijk van deze raad. Binnen de CSM vormen de niet-magistratelijke leden sterk een minderheid. Rechtspositioneel gezien regeert de magistratuur zichzelf.

\section{Functionele ministeriële bevoegdheden}

Nu ik de discretie in bevoegdheden van het OM heb besproken, en zijn autonomie in de organisatie en rechtspositie heb bepaald, kan ik bezien welke functionele relaties het OM heeft met politieke organen. Daarmee doel ik dan in deze allereerst en met name op de minister van Justitie, maar zijdelings ook op de regering en de President. In een volgende paragraaf beschrijf ik de vormen van politieke controle en verantwoording tegenover het parlement door de minister.

In deze paragraaf behandel ik ten eerste de informatie- en inspectiebevoegdheden van de minister. Hoewel zij niet specifiek of primair daartoe zijn bedoeld, kunnen zij op 
enige wijze van invloed zijn op de vervolging. Herna beschrijf ik enkele specifieke bevoegdheden die de minister heeft ten aanzien van bepaalde gevallen van verwolging.

\subsection{Bevoegdheden omtrent informatievoorziening}

De minister beschikt over bevoegdheden om feiten en gegevens te verkrijgen van het OM. Daamaast krijgt hij ook informatie op het initiatief van ambten van het OM en de CSM. Afzonderlijke behandeling verdienen de mogelijkheden voor de minister om zijn opvattingen kenbaar te maken aan het $\mathrm{OM}$.

De minister heeft de bevoegdheid om bij de presidenten van de rechterlijke colleges om informatie te vragen over de daar werkzame magistraten, waaronder de leden van de respectievelijke parketten. De presidenten geven deze vragen vervolgens door aan het hoofd van het betreffende parket. Informatieverzoeken over ambtenaren van het $\mathrm{OM}$ lijken vaker voor te komen. ${ }^{107}$ In de praktijk benadert de minister het $O M$ vrijwel alleen op grond wan parlenentaire vragen om informatie. 108 De rechterlijke organen, waaronder het OM, zijn gehouden de betreffende informatie te verschaffen, tenzij deze onder het onderzoeksgeheim valt. Dit is in beginsel het geval zolang de verdachte geen kennis kan hebben yan de informatie. Het OM kan dan geheel of gedeeltelijk weigeren. de minister de betreffende gegevens te verschaffen. ${ }^{109}$ De informatieverzoeken van de minister lijken het OM feitelijk niet te conditioneren of onder druk te zetten. ${ }^{110}$

Naast het opvragen van gegevens kan de minister algemene en bijzondere inspecties doen houden. Elke drie jaar vindt een algemene inspectie plaats. Wat betreft de magistraten beperkt het onderzoek zich enkel tot statistische informatie. Een evaluatie of waardering over de afzonderlijke magistraten is uitgesloten. Daarnaast kan de minister bijzondere inspecties bevelen wanneer hij daartoe aanleiding acht. In dit geval wordt een bijzonder administratief onderzoek ingesteld naar het personeel van een parket. In dit onderzoek bekijkt de inspectie ook het functioneren van magistraten, aan de hand van geleverde prestaties, getoonde capaciteiten en andere zaken die vatbaar zijn voor een eventuele disciplinaire beoordeling. "Het gebruik van deze bevoegdheid is in de praktijk door de betrokken magistraten, enkele politieke partijen en een deel van de

107 Ant 4 sub 2 Wet CSM en ant. 56 Uhtvoeringswet. Piveti 1995, p. 32. Oxerigens kan het ministerie van Bimnentandse zaken ook on informatie vragen bij recherlike organen, incluager het OM. Het kan ehter slechts specifiek gan on onmisbare informatie ter prewentie van bepaade eware misclijuen (art. 118 c.p.p.).

108 Verde $1990,0.233$.

109 Art. 329 o.p.p. Vgl. Verde 1990, p. 249. Voorbeelden in 7.2. Verantwoordingsproces. In een enkel geval heedt een rechterijg organ om andere redenen geweigerd de infornatio te geven. Hicr ging het om hot handelen wan een anderzoeksrechter, die destijds in het strafworderlijk systeem een atcieve rol werwulde, op punten vergelijkbar met de functic van het OM. In ha CPp wan 1988 is deze figtur opgeheven: Destijds betrof het het uitvaandigen van een bevel tot gevangenneming h hel voomalige CPP kon de onderzoeksrechter ook zonder initatief van het OM een dergetijk bevel uitwardigen (art. 25:) irit thet huidige wetboek kan de rechter dit slechts op initiatief van thet OM doen (anti. 292 e. $\mathrm{V}_{\text {. }}$. De onderzoeksrechter wond het werzoek destijds "een ernstige inmenging van de politiek in het nechterlijke handelen". Bartole 1984, p. 342 e.v.

110 Verde 1990, p. 234.

111 Art. 7-12 1. 12 augustus 1962, n. 1311 (Wet Inspectie Justitie: Organizzacione e funzionamentio detl'Ispettorato generale presso il Ministero di grazia e giustiziaj; ook Albers \& Voermans 1999, p.61. 
publieke opinie wel eens beschouwd als een onwenselijke politieke inmenging in de rechterlijke macht. Een opmerkelijk geval was de inspectie van het belangrijke parket van Milaan gehouden op instigatie van minister Biondi in 1994. ${ }^{12}$

Tenslotte bestaat de gewoonte dat de minister per toerbeurt de parketten en rechterlijke colleges in het land bezoekt. Hij spreekt bij deze gelegenheden met de betrokken hoofden van de parketten. De gesprekspartners maken bij dergelijke bezoeken hun wensen duidelijk aangaande het functioneren van de instantie die het betreft.

Uit eigen initiatief zijn de procureurs-generaal bij het hof van cassatie en bij de hoven verplicht jaarlijks aan de minister van Justitie en de Raad voor de rechterlijke macht te rapporteren over de gang van zaken bij Justitie. Deze rapporten of een samenvatting daarvan worden publiekelijk voorgedragen bij de opening van het gerechtelijk jaar. De procureurs-generaal bij de hoven geven hoofdzakelijk informatie over hun eigen district. ${ }^{113}$ De CSM maakt eigen jaarverslagen op en geeft regelmatig rapporten uit 'over de staat van Justitie?.114 De raad en de procureurs-generaal spreken zich in dergelijke documenten uit over aangelegenheden als nieuwe of vereiste wetgeving en de organisatorische stand van zaken.

Andersom heeft de minister van Justitie de institutionele mogelijkheid om mededelingen aan het $\mathrm{OM}$ te doen toekomen. De bewindsman heeft daartoe een algemene bevoegdheid om zich te richten tot de presidenten van de rechterlijke colleges en - formeel via de laatste - tot de respectievelijke parketten. De minister geeft zijn mededelingen geregeld de vorm van circulaires. Normaliter hebben deze betrekking op onderwerpen aangaande de organisatie van de parketten en personeelszaken. ${ }^{115}$

Daarnaast kan de minister zich uitspreken over het functionele handelen van het OM. $Z_{0}$ is het voorgekomen dat een minister van Justitie zich tot de parketten van het $O M$ heeft gericht om te wijzen op het feit dat een ander land van mening was dat er weinig werd opgetreden tegen een bepaald soort strafbare feiten, en dat dit land daarom economische sancties oplegde. De signalering riep impliciet op tot prioritering van delicten, hoewel deze niet de ernstigste waren in termen van strafmaxima. ${ }^{116}$ In een ander geval deed de President een mededeling in overeenstemming met de minister van Justitie. De

112 Zantin 1996, p. 231 en Domati 1997, p. 184. In 1994 beval rainuster Biondi een dergelige inspectie wan het parket bij de rechtbank wan Milan. Enkele burgers, verwikkeld in sthafrechtelike procedures, hadden bij de minister van Justitis klachten ingediend over ouregelmatigheden die het parket van Milan began zou hebben. De leiten op grond warwa tot een onderzoek werd overgegaan, waren vagg gefor" muleerl en nuwelijks substantheel van and. Verder was de manier wan handelen wan de inspecteurs

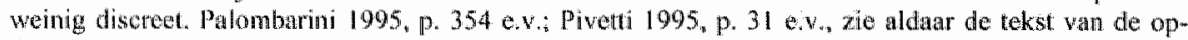
drach var de minister to de inspectio: Dusi $1995, \mathrm{p} .364 \mathrm{e} . \mathrm{r}$. Zie verder 7.2 Verantwoordingsproes.

113 Art. 86 ord.gitad. 41 lid I Uitvoeringsregeling wet CSM.

114 Art 28 Wet CSM. Rapporten bracht de CSM wit vanaf de jaren zeventig. Vgl. Bartole 1984, p. 370; Pizzortsso 1900, p. 107.

115 An. 14 sub 2 Wet CSM. Bijv. Crrculare van het Dipartimento dell'organizzzione giudiziaria, del personale dei servizi van 14 januari 2002 met een verzoek over aanstellingen voor bepaalde tijd. Circulate wan de Direzione genenale della giustizia penale wan 20 december 1999 met uitleg over de registers vor strafbure reiten.

116 Zagrebelsky 1994, p. 106. Het betrof hier de mening van de Verenigde Staten over de delicten ter bescheming wan auturstechten van 1. 22 april $1941, n .633$, en met name de overtredingen van bepalingen zoals gewijzigd bij 1.20 juli 1985 , n. 400 en d. lg. 26 december 1992 , n. 518 . 
President riep een aantal procureurs-generaal bijeen om zich, met hun instemming de noodzakelijk geachte informatie omtrent enkele strafrechtelijke zaken te verschaffen. Hierna richtte de President zich in een officiële boodschap tot de procureurs-generaal, de rechters in het gebied, de minister van Binnenlandse zaken en de parlementaire commissie antimaffia om zich in te zetten voor de bestrijding van de georganiseerde misdaad. ${ }^{117}$

\subsection{Bevoegdheden ten aanzien van de vervolging}

Het Italiaanse OM heeft een sterke mate van functionele onafhankelijkheid in de uitoefening van de vervolging. Weinig ministeriële bevoegdheden kunnen daarin cen doorslaggevende rol spelen. Hieronder analyseer ik de mogelijkheden die de minister heeft om direct ten aanzien van het strafproces werkende beslissingen te nemen.

De Italiaanse minister van Justitie heeft geen algemene bevoegdheid on het OM aanwijzingen of bevelen te geven voor diens handelen. Ministeriële aanwijzingen over het vervolgingsbeleid zijn niet mogelijk. Zoals gezegd in de vorige paragraaf kan de minister wel circulaires uitgeven ten aanzien van administratieve, organisatorische zaken die parketten aangaan.

De minister kan geen aanwijzing tot vervolging geven. Wel kan het ministerie het $O M$ in kennis stellen van gebleken strafbare feiten. Het gaat dan om een normale aangifte, bijvoorbeeld om delicten die in het ministerie of die door ministeriële ambtenaren gepleegd zijn. Indien de minister kennis neemt van andere strafbare feiten zal hij die evenzeer aan het OM mededelen. In alle gevallen besluit het OM zelf welk gevolg aan deze gegevens moet worden toegekend.

Aanwijzingen tot niet-vervolging kunnen evenmin worden gegeven. Wel heeft de minister bevoegdheden om te beslissen of bij bepaalde soorten delicten de vervolging wordt ingezet. Dit kan hij doen middels de rechtsfiguren van het verzoek en de toestemming.

\subsubsection{Ministerieel verzoek}

Vervolging vindt in sommige zaken alleen plats op verzoek van de minister om tot vervolging over te gaan (richiesta di procedimento). Dit is het geval bij de hieronder volgende strafbare feiten.

Ten eerste verdienen sommige in het buitenland gepleegde delicten de aandacht. Een ministerieel verzoek is nodig bij door een staatsburger of een buitenlander in het buitenland gepleegde delicten die een buitenlandse staat of buitenlander geschaad heb-

117 Over deze gebeurtenis Verde 1990, p. 119; Chimenti 1991, 279-281; Devoto 1996a, p. 2031. President Cossiga stond overigens bekend om zipn - in vergelijking met ziju woorgangers - relatief interventerende rol ten anzien vam verschilende statisonganen. Verwijzingen ower de conflicten fussen Presidem en CSM in de jaren tachtig bij Verde 1990, p. 15 . Over de onschendbare President en de verantwoordelijke ministers artt. 89 en 90 Cost. 


\section{HoOfDstuk 4}

ben. ${ }^{118}$ Verder is een verzoek nodig bij in het buitenland gepleegde politieke delicten, uitgezonderd de delicten tegen de Staat. Dit is in feite een marginale restcategorie. De bedoelde delicten zijn moeilijk te concretiseren. ${ }^{119}$

De procedure voor dergelijke verzoeken is als volgt Eerst doet een buitenlander of buitenlandse instantie aangifte van het strafbare feit. Het betrokken buitenlandse ministerie van Buitenlandse zaken neemt kemnis van het bericht, en geeft het door aan het Italiaanse ministerie van Buitenlandse zaken. Dit presenteert op zijn beurt de aangifte aan het ministerie van Justitie. Indien dit ministerie vaststelt dat geen verzoek nodig is, stelt zij het OM enkel in kennis van het feit, onder toezending van de documenten. Indien wel een verzoek vereist is, doet het ministerie dit aan het OM feitelijk in alle gevallen. Na toezending en behandeling door het OM kan het ministerie vragen om inlichtingen over de afloop van de procedure. Dit doet het alleen wanneer de toezendende buitenlandse instantie daarom heeft gevraagd. In sommige gevallen informeert het OM uit eigen initiatief het ministerie over de uitkomst. ${ }^{120}$

Ten tweede is een verzoek vereist voor de vervolging van enkele in Italië zelf gepleegde delicten. Zo is het de minister die een verzoek tot vervolging doet bij klachtdelicten tegen de President. Deze regeling beschermt het beeld van het anbt van het staatshoofd. Zij kan in verband gezien worden met de ministeriële verantwoordelijkheid voor en onschendbaarheid van de President. Het is daarbij niet uitgesloten dat bij een conflictrelatie tussen President en minister de laatste de vervolging van een klachtdelict zal kunnen beletten. ${ }^{121}$

Verder is een verzoek nodig bij de delicten van vrijheidsbeneming en belediging van een buitenlands staatshoofd, belediging van buitenlandse vertegenwoordigers of van een buitenlandse vlag of buitenlands embleem. Deze delicten hebben echter zelden of nooit tot strafrechtelijke stappen geleid. ${ }^{122}$

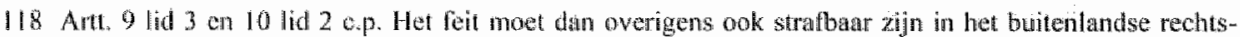
stebsel, Rivello 1997, p. 197. Doos een statsburger of en buitenlander in het buitenland gepleegde

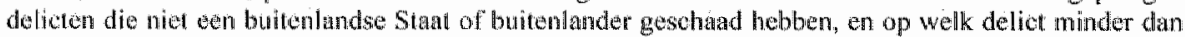

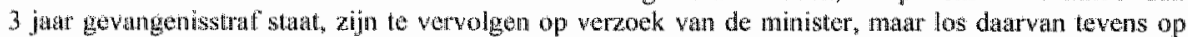
verzoek van de benadeelde burger (art. 9 lid 2 en 10 lid $1 \mathrm{c}, \mathrm{p}$.).

Er is ook eet minsteried verzoek nodig voor het ophieur instellen van een strafproces, indien in het buthenland th een vonnis is gewezan voor de hiervoor genoemde delicten, en voor delicten legen de staat en de statsveilighed (art. II lid 2 c.p.). De werking wan deze bepaling is echter sterk beperkt door hei ne bis in dem principe van het betreffende Europese verdrag van Brussel van 25 marar 1987, dat in 1989 door Itatio is gerationerd.

119 Art. 8.9 c.p. Rivello 1997, p. 195. Corte Cost. 1971, n. 65 (over ant. 8 c.p.), 1989 n. 289 (over art 9 ).

120 Art. 342 c.p.p.

121 Art 127 c.p. Ruvello 1997, p. 198.

122 Art. $296-299$ jo 313 c.p. Firndaca \& Musco $\| 997$, p. 30 e.v. en 106 e.v. Voor deze delicten geldt dat zij tevens in de buitenlandse staat stabar gesteld dienen te zjin. Naast de hier genoemde delicten zigh er een vergelifkbare serie strafbare feiten tegen internationasl beschermde personen die afhankelijk zijn van ministerieel verzoek (zie de Conventic van New York van 14 februari 1973, door labie in 197\% ge-

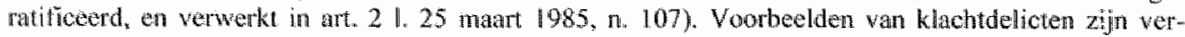
knchting (ant. 609-bis c.k. c.p.), bedreiging (art. 612) wen sommige gevallen ran mishandeling (art. 582 e. $)$ en zaaksvernicling (art. 635 ). 
Voor de vervolging van militairen voor sommige zware delicten geldt een vergelijkbaar verzoek als hier behandeld. Een voorbeeld is het delict van niet nakoming van de plicht voor de commandant om als laatste het schip te verlaten. Het verzoek dient in deze gevallen echter niet uit te gaan van de minister van Justitie, maar van zijn collega van Defensie. De vervolging wordt hier uitgeoefend door het $\mathrm{OM}$ bij de militaire rechtbanken. ${ }^{123}$

In al deze binnenlandse gevallen gaat de minister na melding bij hem van een delict over tot een verzoek aan het competente OM. Daarnaast is het mogelijk dlat het OM een aangifte ontvangt, en deze doorzendt naar het ministerie voor een eventueel verzoek. ${ }^{124}$

\subsubsection{Toestemming door de minister en andere ambten}

Voor een serie strafbare feiten moet het OM de minister om toestemming vragen (autorizzazione a procedere). Daarnaast is toestemming van bepaalde andere ambten nodig voor de vervolging van sommige ambtsdragers. De betreffende toestemmingsprocedures zijn min of meer gelijk.

De delicten waarbij toestemming vereist is zijn onder meer van militaire aard. Het gaat hier bijwoorbeeld om het in oorlogsgevaar brengen van de staat, het op enige wijze benadelen van de staat in oorlogstijd of de onrechtmatige uitoefening van een politieke of militaire functie. De bedoelde delictsbepalingen zijn feitelijk in onbruik geraakt. Er zijn praktisch geen procedurele voorbeelden bekend van deze delicten, afgezien van voorbeelden van vóor de naoorlogse grondwet. ${ }^{125}$

Andere delicten die onder de ministeriële toestemming vallen zijn vrijheidsbeneming en belediging van de President, belediging van de Republiek, de regering, de rechterlijke macht of het leger. De ontwikkeling van de vrijheid van meningsuiting heeft geleid tot een afnemend belang van deze bepalingen. Vrijheidsbeneming van de President is nooit voorgekomen. Wel zijn er jaarlijks enkele zaken van belediging van de President of de Republiek. ${ }^{126}$

De ambtsdragers van de belangrijkste constitutionele organen ondervinden bescherming van toestemmingsregels. Zo kunnen de leden van het parlement miet onderworpen worden aan vrijheidsbeperkende strafrechtelijke maatregelen zonder voorafgaande toe-

123 Art. 260 Codice penale militare di pace. Rivello 1997, p. 200 e.v.

124 Art. 342 c.p.p.

125 Delicten die de staat in oorlogsgevaar brengen (art. 2444245 jo 313 lid 1 en 2 c.p. j; vormen van benadeling van de stat of bevoordeling wan de vijand in oorlogstijd (antt. 247-252, 265 en 267 c.p.); beschadiging van de staat vanuit het buitenland (art. $269 \mathrm{c.p.}$ ); onrechtmatige uitoefening wan een politieke of militaire functie (art. 287 e.p.); burgers inlijwen of bewapenen ten dienste van een buitenlandse stat (art. 288 c.p.). Orlandi 1994, p. $16 \mathrm{en}$ 30; Filandaca \& Musco 1997, p. 114 e.w. Hoewel ook toestemming nodig was voor wervolging van artt. 273 en 274 (oprichting van internationale organisaties zonder regeringstoestemming of het deelnemen aan een dergelijke organisatie) heeft Corte Cost. 3 juli $1985, n$. 193 deze delicten ongrondwettelijk verklatard.

126 Artt. 277-279, 290 jo 313 lid 3 c.p. Fiandaca \& Musco 1997, p. 29 e.v. Voor de delicter gepleegd door eenieder van belediging vam het Constitutionele hof of een kamer van het parlement, is de toestemming wan het betreffende college nodig voor verwolging (airt. 290 jo 313 lid 3 c.p.); Cortte Cost. 1969, ni. I5. 
stemming: Deze is niet nodig in geval van heterdaad bij een zwaar delict, waarvoor hechtenis verplicht is. De toestemming wordt verleend op verzoek van het OM aan de kamer waar het lid toe behoort. Voor de enkele vervolging van parlementariërs is geen toestemming nodig. De periode van de jaren negentig gaf bijzonder veel voorbeelden van matregelen en vervolgingen tegen kamerleden. ${ }^{127}$ Dezelfde garanties bezitten overigens de rechters van het Constitutionele hof. Voor vrijheidsbeperkende maatregelen is de toestemming van dat hof nodig. ${ }^{128}$

Voor de vervolging van ambtsdelicten gepleegd door ministers is vooraf toestemming nodig van de Senaat, of van de Kamer van Afgevaardigden, als de ministers daar lid van zijn. Bij deze toestemmingsvorm gelden enkele afwijkende procedureregels. Het OM bij de rechtbank in de hoofdstad van het district zendt daartoe een eis naar de zogenaamde "rechtbank van de ministers'. Dit is een college ingesteld bij de rechtbank van de districtshoofdstad. Na een onderzoek kan de rechtbank de eis toewijzen. Het OM stuurt zijn bevestigde eis dan naar de voorzitter van de parlementskamer die het aangaat. In tegenstelling tot andere toestemmingsregelingen is de onderhavige negatief geformuleerd: het parlement verleent de toestemming, tenzij het deze afwijst bij meerderheid van de leden. Voor andere dan ambtsdelicten kunnen ministers overigens op normale wijze vervolgd worden, tenzij ze tevens lid zijn van een kamer. In dat geval gelden de toestemmingsregels voor kamerleden. ${ }^{129}$

Vervolging van (ex-)ministers voor ambtsdelicten kwam in de jaren negentig naar verhouding zeer veel voor. Ook ministers van Justitie en premiers waren onderwerp van dergelijke strafrechtelijke procedures. ${ }^{\mid 30}$

\subsubsection{Toestemmingsprocedure}

Voor het overige is de toestemmingsprocedure als volgt. Voor het verlenen van toestemming is een initiatief van het OM nodig. Een eventuele 'spontane toestemming' van een ambt wordt niet toelaatbaar geacht. Het OM moet het betrokken ambt om toestemming vragen voordat dwangmiddelen mogen worden toegepast, tenzij de verdachte op heterdaad wordt gearresteerd voor zware feiten, waarbij hechtenis verplicht is (bijvoorbeeld wapendiefstal). Indien een antwoord op het verzoek om toestemming untblijft, kunnen aan een langdurig stilzwijgen dezelfde rechtsgevolgen van de toestemming worden verbonden. ${ }^{131}$ Indien toestemming geweigerd wordt, kan die later alsnog gegeven worden. Mogelijk wordt het OM dan door het tijdsverloop niet meer ontvan-

127 Art. 68 Cost; art. 18 a. . RC; art. 19 RS Dezellde garantie als voor leden wan het parlement geldt voor do ltaliatnse laden van het Europees parlement. Andere leden genieten volledige stralrechterlike immuniteit, 2 ie art. 10 Protocol betreffende de voorrechten en immuniteiten wan de Europese Gemeenschappen vary aprill 1965 jo an. 9 Verdrag wan Amsterdam.

128 Art 3 1. cost. 9 febritari 1948, n. 1 jo art. 68 Cost.

129 Art. 96 Cost; 1 .cost. 16 januari 1989 , n. 1.

130 Zo werd minister Martelli in 1993 aangeklaagd voor cormptiedelicten. In 1994 werd premier Berlusconi angemerk als verdachte en dater vervolgd voor deelnare aan corruptie. In 1997 werd ex-premier Amdrenti vervolgd voor het doen verdwijnen van officielle stukken. Verder was ex-minister Darida in 1988 en 1993 verdachte in een opsporingsonderzoek.

131 Art. Avtl 343-344 c.p.p. Tranchina 1987, p. 383. Indien de toestemming onrechtmatig is gegeven, zon het OM kolgens deze auteur zelts bij de administratieve rechter an beroep kunnen gaan, $\mathrm{p} .385$. 
kelijk verklaard in het strafproces. ${ }^{132}$ Indien het ambt geen toestemming verleent of verzoek indient is het denkbaar dat het OM hiertegen in beroep kan gaan bij het Constitutioneel hof op grond van een bevoegdhedenconflict. ${ }^{133}$

\subsubsection{Vervolgingstoestemming voor de President}

Voor vervolging van de President gelden geheel eigen regels. De President kan tijdens zijn mandaat slechts vervolgd worden voor hoogverraad of aanslag op de grondwet. De toestemmingscommissies van de beide kamers houden daartoe eerst een gezamenlijke vergadering. Indien zij vervolging gegrond achten beslist het parlement in een verenigde vergadering van de kamers over de aanklacht. Tenslotte dient het Constitutioneel hof over de zaak te oordelen. Voor andere delicten gepleegd tijdens zijn mandaat kan de President na afloop daarvan zonder speciale procedure vervolgd worden. ${ }^{134}$

\subsection{Gezag over opsporingsorganen}

In Italië bestaat een veelheid aan opsporingsorganen, die elk onder gezag staan van een minister. De ministers van Binnenlandse Zaken, Financiën en Defensie staan aan het hoofd van respectievelijk de politie (polizia di Stato), de financiële politiedienst (guardia di finanza) en de carabinieri. Dit zijn de belangrijkste organen in de opsporing. ${ }^{135}$ De minister van Justitie heeft geen enkele zelfstandige bevoegdheid over de politie, ook niet bij diens taak tot strafrechtelijke handhaving.

De ministers aan het hoofd van opsporingsorganen nemen beslissingen met betrekking tot aanstellingen, overplaatsingen, bevorderingen en sommige disciplinaire beslissingen. Hoge benoemingen geschieden in de ministerraad. Individuele ambtenaren zijn zo voor hun carrière in beginsel afhankelijk van (leden van) de regering. De organisatie en financiële positie van de opsporingsorganen hangen tevens af van de respectievelijke ministers. Door gebruikmaking van deze bevoegdheden hebben deze ministers inyloed op de opsporing, en kunnen zij een vorm van strafrechtelijke politiek bedrijven. Dergelijke initiatieven brengen zij uit in beleidsplannen en verslagen. Ministers stellen echter geen inhoudelijk beleid op met opsporingsprioriteiten ten aanzien van categorieën van delicten. ${ }^{136}$

132 Orlandi 1994, p. 14.

133 Zanon 1996, p. 206. De auteur spreekt van een theorelische optie, niet van eer bestaande praktijk. Over het bevoegdhedenconflict: art. 134 Cost. en artt. 37 e.v. 1.11 maart 1953, n. 87.

134. Art. 90 en 134 Cost.; l.cost. 11 maart 1953, n. I.

135 Polizà di Stato: I. 1 april 1981, n. 121. Guardia di linanza: d.lg. 1999, n. 300; 1. 23 april 1959, n. 189. Carabinieri: art. $3, c 0.2 \times 3$ d.lg. 2000 , n. 297 . Sommige onderdelen van de carabinieri vallen functioneel onder andere ministers, zoals die van Volksgezondheid. Een ander belangrijk orgaan in de opsporing is de antimaffia onderzoeksdirectie (direzione investigativa antimafia). Deze is onderdee van het ministerie van Binnenlandse Zaken Art. 3 d.I. 15 janutari 1991, n. 34.5, conv, in 1. 30 december 1991, n. 401.

136. Voor de bewoegdheden van de ministers zie de regelingen in de vorige noot. Voorbeelden van werslagen en beleidsdocumenten: 'Relazioni al Parlamento sui progranuni di protezione ai collaborattori di giustizia", vanaf 1997; 'Rapporto annuale fenomeno criminalità organizzata", 1999 en 2000; "Rapporto sallo stato della sicurezza in Italia', $2000_{*}^{*}$ 'Programma Operativo Nazionale Sicureza per lo Sviluppo del Mezzogiono d'Italia", 2000. 
In de praktijk van de laatste jaren lijken deze invloeden de strafrechtelijke initiatieven van het $O M$ in ieder geval niet te belemmeren, zelfs niet in de corruptieonderzoeken. Wel conditioneren zij het handelen van het $\mathrm{OM}$ in meer algemene zin. ${ }^{137}$

\subsection{Bevoegdheden ten aanzien van budget en organisatie}

Buiten hetgeen valt onder de competentie van de CSM is de minister voor het overige bevoegd op het gebied van de organisatie en het beheer van de rechterlijke macht. Hij geeft op dit terrein ininisteriêle besluiten en circulaires uit. De belangrijkste bevoegdheden van de minister betreffen de uitwoering van de wetgeving omtrent de vaststelling van de personeelsaantallen van magistraten. Verder regelt hij de aanstelling en overplaatsing van het ondersteunende, administratieve personeel van het $\mathrm{OM}$. Tenslotte voorziet de minister in organisatorische zaken als informatisering. ${ }^{138}$

Externe ambten bepalen de financiën van het OM. De regering legt jaarlijks de begroting aan de kamers ter goedkeuring voor. De begroting yan de minister van Justitie is daar onderdeel van. De uitgaven van de rechterlijke macht vallen weer onder die van het ministerie. De minister is belast met de uitvoering van financiële regels. De algemene financiële ruimte van het OM wordt aldus bepaald door de minister en het parlement. Daarnaast zijn de lokale gemeenten verplicht te delen in de financiering van de kosten van de gerechtelijke gebouwen. ${ }^{139}$

\subsection{Informele invloed}

Naast deze formele bevoegdheden lijken informele wijzen van beïnvloeding door politieke organen en andere machtscentra te bestaan. Volgens sommigen zouden leden van het OM (en rechters) in het verleden meerdere malen zijn tegengewerkt door politici. Enerzijds is druk uitgeoefend op het OM. Procureurs ontvingen 'telefoontjes", en kregen adviezen om 'niet te hard van stapel te lopen'. Leden van het OM zijn bedreigd of geïntimideerd. Of politieke ambtsdragers achter dergelijke handelingen zaten is echter niet met stelligheid te zeggen. Ten slotte hebben verschillende leden van de rechterlijke macht politieke functies gekregen, als lid van het parlement of de regering. De suggestie is gewekt dat dit geschiedde op grond van bewezen diensten voor de politiek. Vragen naar de werkelijke redenen zijn moeilijk eenduidig te benantwoorden. ${ }^{40}$

137 Brutti Liberati 1999, p. 74, Cavallari sprak echter nog van een conditionering van de rechterlijke macht. door de exceutieve, door middel van de politie, 1974, p. 156.

138 Art. 110 Cost.; art. 14 sub 3 Wet CSM. Voor de personeelsaantallen, zie bijv. tabellen A, B en C bij d.m. 1 juni 1999 jo 1.16 juni 1998 , n. 188 jo art. 33 d.lg. 19 februari 1998 , n. 51 jo 1.16 julli 1997 , n. 254. Over het administiatief personeel: bijw. D.p.c.m. 20 december 2004 , genomen op voorstel van de minister wan Justitie. Verder kan de oninister van Justitie in overeenstemming met die van fínanciën territorialal losstande secties woor een rechtbank (parket) instellen, na de CSM gehoord te hebben (art. 48ter ord.giud.). Voor de inlormatisering zie bijwoorbeeld "Piano Triennale per l'Informatica 2001/2003", hievan maakt onderdeel uit d.m. 27 maant 2000 n. 264.

139) Art. 81 Cost,; 1. 1978, n. 468.; 1. 1988, n. 362; d.lg. 1997, n. 279. Bijw ant. 51 . 28 december 2001 , n. 449: 1. 23 december 2000, n. 389 . Voor de gemeentelijke tinanciering art. 2, co. 1. 24 april 1941, n. 392; d.P.R. 4 mei 1998 n. 187.

140 Neppi Modona 1982, p. 30 e.v.; Leijendekker 1996. p. 87-91. Over het Romeinse parket ook Devoto 
Daarnaast hebben politici bij veel gelegenheden beweerd dat het OM een vorm van 'politiek' bedreef. Bepaalde parketten zouden zich ten onrechte met name richten op bepaalde strafbare feiten, die vooral gepleegd worden door politici. Procureurs zouden opsporingsonderzoeken hebben gedaan die overwegend in de richting wezen van zekere politieke partijen. Dergelijke stellingen komen echter vrijwel altijd uit de politieke stroming op wie de betrokken vervolgingen betrekking hebben. Het realiteitsgehalte van deze beweringen is aan twijfel onderhevig. ${ }^{141}$

Het bestaan van informele invloed van politici - waaronder de minister - op het $O M$ is onzeker, maar kan niet worden uitgesloten. De mogelijkheid van actieve beïnvloeding door politici lijkt sinds de jaren negentig in ieder geval sterk verkleind. De indruk van politiek gemotiveerd handelen van het OM leeft voort.

\subsection{Conclusie}

In de functionele relatie met het $O M$ heeft de minister eigenlijk alleen zeer algemene en uiterst specifieke bevoegdheden. Enerzijds stelt hij de randvoorwaarden vast voor het handelen van het $\mathrm{OM}$ met besluiten aangaande de organisatie en financiën. Anderzijds is voor de vervolging van bepaalde delicten zijn toestemming of verzoek nodig. Deze strafbare feiten spelen echter nauwelijks een praktische rol. Ambten zoals de parlementaire kamers en het Constitutioneel hof hebben enkele vergelijkbare bevoegdheden. Medebewindslieden hebben daarnaast enige zeggenschap over de opsporingsdiensten. De belangrijkste meer specifieke bevoegdheid is die on inspecties bij het $O M$ te houden. Een dergelijke inspectie kan ingrijpend zijn voor de leden en het functioneren van het OM. Dit is met name zo gezien het feit dat op grond van dat onderzoek aanleiding kan bestaan voor disciplinaire procedures. De inspectie is eveneens een kernaspect in de parlementaire verantwoording.

\section{Verantwoording voor het $\mathrm{OM}$}

De uiteenzetting over de ministeriële bevoegdheden is een goed aanknopingspunt om de parlementaire verantwoording van de minister voor het handelen van het OM te bekijken. Daarbij bespreek ik eerst de grondslag en reikwijdte van de ministeriële verantwoordelijkheid. Vervolgens behandel ik bet proces van verantwoording van de minister tegenover de kamers. Democratische controle op het OM valt echter niet samen met het proces van politieke verantwoordelijkheid wan de minister van Justitie. Het parlement oefent eveneens enige directe controle uit over het OM. Deze directe wijze van verantwoording van het $\mathrm{OM}$ aan het parlement bezie ik in een laatste subparagraaf.

19964, p. 2044.

141 Ex-premiers Andreoti, Craxi en Berlusconi hobben bijvoorbeeld neerdere malen de onpantijdigheid van leden van het OM in twijfel getrokken, en gesuggereerd dat hun handelen politick gemotiveerd was of dat ze in opdracht van politieke tegenstanders zouden handelen. 0.a. NRC Handelsb lad 29 nowember" 1999, p. 6, Attacks on Justice 2000, p. 229. Zie ook: SdR, R.3.C.g., 11 september 1996, Citami bekladgl zich ower "instrumenteel" gebruik wan het legaliteitsbeginsel door parketten. Ident, 5 mei 1998, Scopelliti stelt dat het legallieitsbeginsel tijdens mani pulite nist op een 'onpartigdige' wijze is loegepast. 


\section{I Grondslag en reikwijdte verantwoordelijkheid}

In de analyse van de Italiaanse verantwoordelijkheid van de minister van Justitie voor het OM ga ik de volgende aspecten na. Ik bekijk eerst waarvoor de minister verantwoordelijk is, wat in feite de grondsllag is voor zijn verantwoordelijkheid. Daarna volgen enkele opmerkingen over de vraag tegenover wie de verantwoordelijkheid geldt. Vervolgens noem ik de verhouding tussen verantwoordelijkheid en verantwoording.

In Italië gaat men uit van het principe dat de reikwijdte van de ministeriële verantwoordelijkheid in het algemeen correspondeert met ministeriële bevoegdheid: elke uitoefening van bevoegdheid behoeft verantwoording. ${ }^{142}$ Een minister kan echter wel politiek verantwoordelijk worden gehouden voor elke handeling of omissie, los van de vraag of deze onder zijn bevoegdheden valt. ${ }^{143}$

De minister is verantwoordelijk voor alle handelingen en besluiten van de ambtenaren die onder zijn ministerie vallen. ${ }^{144}$ In het algemeen draagt hij verantwoordelijkheid voor het handelen van derden die 'om politieke redenen aan hem verbonden zijn'. Irrelevant is of de minister sehuld heeft aan datgene waarvoor hij ter verantwoording wordt geroepen. De minister wordt geacht verantwoordelijk te zijn om het enkele feit dat hij een bepaald ambt bekleedt, dat van minister. ${ }^{146}$

Ministers zijn collectief verantwoordelijk voor het handelen van de regering en individueel verantwoordelijk voor handelingen van hum ministerie en voor hun eigen handelen (art. 95 lid 2 Cost.). In de discussie in de grondwetgevende vergadering werd gesproken over het opnemen van een specifieke bepaling voor de verantwoordelijkheid van de minister van Justitie. Een nadere bepaling werd overwogen om uit te sluiten dat de CSM door het parlement ter verantwoording geroepen zou worden. De bepalling werd echter overbodig geacht, aangezien deze verantwoordelijkheid geacht werd te zijn geregeld door het genoemde, algemene artikel $95 .{ }^{147}$

De ministeriële verantwoordelijkheid geldt alleen voor de ministers en de regering tegenover het parlement. De minusters zijn niet verantwoordelijk tegenover de President. ${ }^{148}$ Het parlement bestaat uit de Kamer van Afgevaardigden (Kamer) en de Senaat van de Republiek (Senaat). De Kamer heeft in politieke termen een enigszins belangrijkere rol dan de Senaat. Het ministeriële zwaartepunt van de verantwoording ligt tegenover de Kamer. Hierop bestaan evenwel belangrijke uitzonderingen. ${ }^{149}$

De verantwoordelijkheid houdt tevens in het voor eigen rekening nemen, en het afleggen van rekenschap. Het doen gelden van de politieke verantwoordelijkheid omvat

142 Rescigno 1967, p. 131 e., 1988, p. 1349; De Luca 1991, p. 220; Curatola 1994, p. 262; Donati 1997, p. 2; Verde 1990 , p. 20 en 251. T'osato in Donati 1997 p. 88, noot 10; Silvestri 1997, p. 221.Guarnieri noemt de verantwoording "retorisch" gezien de beperkte ministeriêle bevoegdheden, 1984, p. 25.

143 Rescigno 1967, p. 85, Donati 1997, p. 3.

144 Art. 95 Cosi. Rescigno 1967, p. 229.

145 Neppi Modona 1994, p. 9-10.

146 Neppi Modona 1994, p. 7, 10

147 Domali 1997, p. 87 (ook noot 4) en 197, noot 88 .

148 Rescigno 1967, p. 218 .

149 Zie in het bijzonder de verantwoording van minister Mancuso tegenover de Senaat op 11 mei 1995. Meer over deze zaak bij 7.2. Verantwoordingsproces. 
niet alleen de motie van wantrouwen, maar ook de uitoefening van informatiebevoegdheden door het parlement, zoals het vragenrecht. ${ }^{150}$ Ministeriele verantwoordelijkheid veronderstelt het ter verantwoording roepen van de minister. ${ }^{15 !}$

De Italiaanse doctrine noemt de hierboven beschreven verantwoordelijkheid 'institutioneel' van aard. Zij onderscheidt deze van de 'diffuse' politieke verantwoordelijkheid. De laatste doelt op de algemene kritiek en roep om verantwoording door de publieke opinie, maar ook door andere ambten, zoals de CSM. ${ }^{152}$ Sommigen stellen daarentegen dat deze vorm geen eigenlijke politieke verantwoordelijkheid is. Juridische mechanismen of regels om deze kritiekuitingen te laten gelden ontbreken. ${ }^{153}$ Deze verantwoordelijkheidsvorm leent zich hoe dan ook slecht voor een afgebakende analyse. In het navolgende laat ik die vorm buiten beschouwing en richt ik mij op de institutionele politieke verantwoordelijkheid.

\subsection{Verantwoordingsproces}

De minister van Justitie legt op eigen initiatief geen verantwoording af over het strafrechtelijke handelen zelf van het $\mathrm{OM}$. Wel ontwikkelt hij beleidsplannen aangaande organisatorische zaken van de rechterlijke macht en de in te dienen strafivetgeving. De minister presenteert en verdedigt dit beleid vervolgens in het parlement. In de vaste commissies van Justitie van de kamers geeft hij een verklaring en gaat hij een debat aan. Onderwerpen die aan de orde komen zijn versoepeling van het strafproces, het personeelsbestand van magistraten en infrastructurele voorzieningen, zoals automatisering van Justitie. ${ }^{154}$ Daarnaast zendt de minister het jaarlijkse rapport van de CSM over 'de staat van Justitie' naar de kamers door. ${ }^{155}$

150 Rescigno 1967, p. 218-219. Over het voor rekening nemen: p. 134.

1.51 Pitruzzella 1997, p. 297.

152 Een soort van diffuse politieke verantwoordelijkheid of een vergelijkbare vorm van verantwoordelajkheid is de "institutioneel-vrije" politieke verantwoordelijkheid. Deze houdt de kritiek in door politieke esponenten via de media, die kan leiden tot een delegitimerende campagne van de publieke opinie tegen ambisdragers. Rescigno 1988, p. 1348; Neppi Modona 1994, p. 14.

153 Pitruzzella 1997, p. 298.

154 Voorbeelden van beleidsplannen: "Piano d"Azione Gustizia' van minister Fassino, Consiglio del Ministri $n .15$ van 7 juli 2000 bestande wit een serie wetgevingsplannen ten aunzien van de organisatie en het functioneren van Justitie. Beleidstijnem van minister Diliberto: Direttive generalli del Ministro su cobiettivi, programmi e prioritå per il 2000, D.M. 10 januari 2000; Direttive generali de: Ministro su objettivi, programmi e priorită per il 1999, D.M. 4 jamuari 1999. Beleidslijnen van minister Flick: Direttive generali del Ministro su obiettivi, programmi e priorita per il 1998, D.M. 10 januari 1998 ).

Voor de besprekingen in het parfement: Minister Castelli's 'Programma per la giustizia', gepresenteerd voor de Commissione Giustizja della Camera (24 en 31 juli 2001 ) en voor de Commissione Giustizia del Senato (26 juli 2001). Fassino's beleidspresenteatie voor de Commissione Gilistizáa alla Cannera dei Deputati (31 mei 2000), voor de Commissione Giustizia del Senato (22 juni 2000); over zijn "Piano d'Azione Giustizia' voor de Commissione Giustizia del Senato (12 juli 2000). Beleidspresentatie van Ditiberto an de Commissione Giustizia del Senato (1/ november 1998).

De minister van Binnenlandse Zaken geef het parlement daamaast jaarlijks een verslag van de activiteiten van de politie en over de georganiseerde criminaliteit (Relazione al parlamento sull'attivita' delle forze di polizia e sullo stato dell"ordine e della sicurezca pubblica nel territorio nazionale, art.113 I. 1 april 1981, n. 121; Rapporto anmuale sulla criminalità organizzata, ary. 51 . 30 dicembre 1991, n. $4 \| 0$ ).

$155 \mathrm{Zie}$ 6.1. Bevoegdheden omtrent informatievoorziening. Over het doorzenden Camera di Depulati, XI legislatura, interpellanza n. 2/00502. 
Voor de volledigheid meld ik dat ministers verder beleidsmatige verklaringen geven bij de jaarlijkse opening van het gerechtelijk jaar. Elk gerecht houdt een dergelijke ceremonie in januari, terwijl de minister aanwezig is in én van de grotere gerechten. De presentatie van de minister doet qua aard en omvang niet onder voor een parlementaire voordracht. Hij behandelt in feite met dezelfde uitvoerigheid dezelfde onderwerpen. ${ }^{156}$

De ministeriële verantwoording voor het eigenlijke strafrechtelijke handelen van het OM vindt plaats op initiatief van het parlement. Elke parlementariër heeft het recht om de minister vragen te stellen. ${ }^{157}$ Het parlementair stelsel kent drie soorten vragenrechten. Ten eerste kan men schriftelijke vragen stellen, met naar keuze van het kamerlid een schriftelijke of mondelinge beantwoording. In de Kamer wordt het eerste deel van elke zitting gereserveerd voor de beantwoording van deze vragen. In de Senaat vindt deze slechts één keer per week plaats. De mondelinge beantwoording kan ook plaatsvinden in de vaste commissies van de kamers.

Een tweede soort vragen betreft het zogenoemde 'question time'. Elke woensdag in de Kamer en in ieder geval één keer per maand in de Senaat hebben kamerleden de gelegenheid met de regering een kort vraag- en antwoordgesprek aan te gaan. In de commissies van de Kamer vindt ook twee keer per maand een question time plaats. Leden van de Kamer leveren de dag daaraan voorafgaand de kort gestelde vraag in. In de Senaat stelt de conferentie van fractievoorzitters alleen de specifieke onderwerpen vast waarover vragen gesteld zullen worden.

De interpellatie (interpellanza) is een derde vraagwijze. Het tijdstip en de gelegenheid voor het houden van de interpellatie moeten apart besloten worden. De betreffende parlementariër dient de interpellatie vooraf schriftelijk in. Deze vorm van vragen is politiek gezien van zwaardere aard. Hij is met name gericht op het informeren naar de motieven en de bedoelingen van de regering. ${ }^{158}$

Een gestelde vraag kan door de kamervoorzitter ontoelaatbaar geacht worden, omdat de vraag bijvoorbeeld de regering niet aangaat. De kamer kan hierop de uiteindelijke beslissing nemen. In de praktijk hebben kamervoorzitters bijna nooit vragen ontoelaatbaar geacht, en voor zover ze de rechterlijke macht betroffen altijd toegelaten. Het oordeel hierover wordt in feite aan de regering overgelaten, en uiteindelijk aan het OM zelf, dat de informatie aan de regering moet geven. ${ }^{159}$

Het onderwerp van een vraag kan op verschillende manieren het $\mathrm{OM}$ aangaan. Er lijkt geen onderscheid te bestaan tussen verantwoording over het handelen van de rechter of van het $\mathrm{OM}$, hoewel vragen over zaken omtrent opsporing en vervolging vaker voorkomen. ${ }^{160}$ De kamers stellen vragen over rechtspositionele zaken van het $\mathrm{OM}$, zoals

156 Minister Castelli, 12 januari 2002. Fassino, 13 januari 2001. Minister Diliberto 15 januari 2000.

157 Over het vragenrecht: artt. 128,135 -bis en $136 \mathrm{RC}$, art. 145,151 en $154 \mathrm{RS}$

158 Voor de schriftelijke vrang (interrogazione): art. 128-135 RC, 145-153 RS. Question tine: art. 135-bis RC, 151 bis RS. Interpellatio: art. 136-138-bis RC, 154-156-bis RS.

159 Art. 136 jo 89 RC en art. 146 RS. Manzella 1972, p. 417; Bartole 1984, p. 357-358; Verde 1990, p. 230 en 249. Anders over de praktijk van de toelaabahareid: Albers \& Voermans 1999, p.61.

160 Zanon 1996, p. 241 ; over die frequentie: Pivetti 1995, p. 32. 
benoemingen of meningsuitingen. ${ }^{16}$ Veelwuldig komen vragen aan de orde over het strafrechtelijke handelen van het $\mathrm{OM}$, waaronder ook specifieke zaken. Daarbij wordt het vermelden van details niet geschuwd. ${ }^{162}$ Vragen over een gevolgde strategie of 'beleidslijn' door een parket zijn problematisch, aangezien het OM formeel geen beleid voert. Voor zover er een beleidslijn bestaat of zou bestaan, zou de minister daar overigens geen zeggenschap over kunnen hebben. Het zou moeilijk voor hen zijn daar verantwoordelijkheid voor te dragen. Well is bij uitzondering een vraag gesteld over het feit dat een parket prioriteiten had opgesteld, niet zozeer over de inhoud daarvan. ${ }^{163}$ In de vragen verlangen parlementariërs wel uitleg over het handelen van het $\mathrm{OM}$. De minister wordt ook wel gevraagd om zijn oordeel uit te spreken over dit handelen. Meestal hangt dit samen met de vraag of de minister geen disciplinair initiatief denkt te ondernemen, of een inspectie wenst te laten houden. ${ }^{164}$ In enkele gevallen uiten parlementariërs zich zelts in zulke bewoordingen, dat zij bepaaide straffechtelijke beslissingen uitdrukkelijk voor rekening van de minister laten komen. ${ }^{165}$

161 Bijv. SdR, R.s.s., 16 september 1999, Fascicolo n; 129, 4-09272 (Contestabile w.a.), over cen gesehorsi decreet tot benoeming van het hoofd wan een parketonderdeel te Rome. Het kamerlid vind het woortduren van de uitoefering wan de functie van het benoemde hoofd onwettig, en vraagt welke maturegelen de minister dienaangaande zal ondernemen of heeft ondernomen. De minister beschrijtt de zaak waarin de Hoge raad voor de rechterlijke macht een hemieuwde benoeningsbeslissing woor het huidige hoofd zou hebben genomen; waama uiteindelijk een ander lid van het OM benoend is. CdD, R.s., 30 jumi 1999, 3-03980 (Manzione e.w.), over een witlating in de medis van een lid van het OM; mede in reactie op een uitlating van een staatssecretaris en op een handelen wan de President. Het kanerlid vraggt de mening van de regering over de uitlating en vraagt of het niet opportuun is on inspectie en diseplinaire actie te ondememen. De vice-premier antwoordt dat al na publicatie een preliminair onderzoek is ingesteld. SdR, R.s.C.g. 16 juli 1998, 3-01716 (Pera) informatie over de wijze wan behandeling van disciplinaire procedures tegen leden van het $O M$.

162 Bijw. SdR, R.s.C.g., 17 maart 1998, 3-01609 (Boco), informatie over de zel lmoord van verdachte Rossi in haar cel en het handelen van het OM in de procedure. CdD, R.s., 28 juni 1999, Allegato B, 4-17887 (Scalia), over een zaak waarin een bewaker zelfmoord zou hebben gepleegd, en het OM heeft laten seponeren. Het kamerlid beschrijft feiten die moord annemelijk zouden maken en vratgt de minister of hij niet vindt dat hij een inspectie moet bevelen. De minister beschrijft de zaak en stelt vast dat er geen grond is voor inspectie.

CdD, R.s., 21 juli 1998, 4-19015 (Matacena), over een witsprak van het OM tijdens een ondervraging. Kamerlid en ninister citeren hier letterlijke passagex uit een proces-verbat.

163 Zanon 1996 , p. 242. CdD, R.s., 13 juli 1999, 3-02825 (Taradash), over de Zagrebelsky-circolare. Het kamerlid vraagt of de minister wil verifierren of handeling parket it owercensiemming met recht is, en of niet een ander orgaan prioriteiten zou moeten stellen. Minister stelt dat het tandelen weltelijk is, dat er geen disciplinaire feiten begaan zijiri. Hij onderstreept de noodzaak van depenalisatie en institutionele herworming. Taradash benadrukt het gebrek aan verantwoording en hoopt op cen toekomstige verkiezing van leden van het OM. Zie over dergelijke prioriteiten 3.4. "OM-beleid".

164 CdD, R.s.C.g., 21 oktober 1997, p. 41, 5-00540 (Borromeli e.a.), met kritiek op de wijze wan het gebruik van de ondervraging in de zaak Necci. De bewindspersoon ziet geen reden tot inspectie. CdD, R.s.C.g, 11 dicembre 1996, 5-00730, 5-00732 (Cito), mel kritiek op de algemene handelswijze van en de beslissing tot inbeslagname door procureur Ghizzardi. De bewindspersoon vindt de feiten te algemeen of onproblematisch en heeft geen reden om nader onderzoek te verrichter. CdD, R.s.C.g, 24 maart 1998 , p. 43, 5-01984 (Altea), over de strafrechtelijke afhandeling door thet OM van een lek van informatie onder onderzoeksgeheim. Volgens de bewindspersoon is er geen reden voor disciplinaire maatregelen. CdD, R.s.C.g., 26 november 1996, p. 21 e.w, 5-001 I / (Mantowatho e.a.), ower de processuele beslissingen wan het $\mathrm{OM}$ (en de rechter) in de zaak. Bargone en de veronderstelling dat het OM daarmee een politieke partij zou steunen. De bewindspersoon ziet geen reden tot mader onderzoek.

165 Bartole 1984, p. 340 e.w. 
Verder kan een minister uiteraard gevraagd worden zijn eigen handelen uit te leggen en te motiveren. Veelbesproken zaken uit het recente verleden zijn de inspectie gehouden op gezag van minister Biondi in 1994 en de disciplinaire actie ingesteld door minister Mancuso in 1995. Deze leidden tot het houden van vele vragen en interpellaties. De ministers moesten zich verdedigen tegen beschuldigingen van delegitimerend optreden tegenover het Milanese parket. ${ }^{160}$

Naast informatie kan het parlement de minister om een bepaald gebruik van zijn bevoegdheden of ander handelen vragen. Door de vraag om informatie wordt de minister natuurlijk al verzocht van zijn bevoegdheid gebruik te maken om het $\mathrm{OM}$ om informatie te verzoeken. In bepaalde gevallen sporen parlementariërs de minister verder aan om door middel van zijn beheersbevoegdheden een zeker doel te bereiken. ${ }^{167}$ Verder geven kamervragen de minister zoals gezegd veelvuldig in overweging om een disciplinaire actie of inspectie te ondernemen.

Aansporingen tot handelen nemen in enkele zeldzame gevallen de vorm van een motie aan. Eén van de weinige aangenomen moties is die waarin minister Mancuso in 1995 werd aangezet tot een verbetering van de relatie met het $\mathrm{OM}$; onder meer op het gebied van de te houden inspecties, en om haast te maken met de uitvoering van een wetgevingsprogramma. ${ }^{168}$

Parlementaire vragen over strafzaken roepen bij sommige schrijvers kritiek op. Parlementariërs zouden in veel gevallen het stellen van vragen enkel gebruiken om aan de zaak ruchtbaarheid te geven, of om de interesse van de publieke opinie te wekken. ${ }^{16.9}$ Formeel zouden de vragen gericht zijn aan de regering, maar volgens sommige analisten kunnen ze indirect bedoeld zijn voor andere organen, zoals het $O M$. Materieel zou dan het effect teweeggebracht kunnen worden dat de vraag druk uitoefent op het $\mathrm{OM}^{170}$

Voor het antwoord op kamervragen wint de minister informatie in bij het OM. Aan de hand van een ambtsbericht stelt het ministerie vervolgens zelfstandig een antwoord op. Dit is meestal bondiger dan de vraag. De minister verwijst in zijn antwoord wel eens letterlijk nat hetgeen het OM hem heeft medegedeeld. ${ }^{171}$ In sommige gevallen antwoordt de minister door de informatie van het OM op te sommen en daaraan toe te voegen dat er gezien deze informatie geen redenen zijn om initiatieven te ondernemen. ${ }^{172}$ In enkele gevallen geeft de minister uitdrukkelijk een inhoudelijk oordeel over het handelen van een magistraat. ${ }^{13}$

166 Zatk Biondi: CdD, R.s., 16 decenber $1994,2-00354,2-00355,2-00362,3-00282,3-00382,3-00383,3-$ 00387. Zuak Mancuso: SdR, R.s.s., I1 mei 1995, p. 4 e. $v_{n} 2-00247$ t/m 2-00257, 3-00625, 3-00626, 300633. vgl. Donali 1997, p. 184. Over de zaak Biondi zie 6.1. Bevoegdheden ontrent informatiewoorziening.

167 Bartole 1984, p. 349-350.

168 Motie Sulvi, SaR, R.s.s., 31 mei 1995, 1-00008, p. 5.

169 Batolk 1984, p. 353.

170 Bartole 1984, p. 355; Verde 1990, p. 217 en $231 ;$ Zanon 1996, p. 242.

171 Verde geeft vele voorbeelden, 1990, p. 226 e.v.

172 Verde 1990, p. 228.

173 Di Ciolo 1983, p. 336; Bnrtole 1984, p. 342; Verde 1990, p. 224. Bijw. CdD, R.s., 22 juni 1999, 2-01819 (Mancuso), over inera OM ten aanzien wan Scalfaro in de SISE-zaak. De minister legt uit waarom het 
In hun antwoorden stellen ministers soms, onder vernelding van processuele feiten, dat de regering geen informatie of oordeel kan geven over het handelen. Soms wordt dit gemotiveerd met het feit dat het onderzoek nog gaande is, en dat ook het enkele antwoorden een verstoring zou kunnen betekenen. ${ }^{174}$ In de doctrine wordt gesteld dat over lopende sirafrechtelijke procedures slechts vragen om informatie behandeld zouden moeten worden, en dan alleen indien er naar het oordeel van de regering geen "instrumenteel' gebruik van gemaakt zal worden. Wanneer het strafproces ten einde is zou de ruimte voor beantwoording van vragen groter kunnen zijn, voor zover deze geen inbreuk maken op de privacy, en als er dienaangaande tenminste geen disciplinaire proces aanhangig is. Ook voor vragen met betrekking tot de organisatie van de parketten zou alle ruimte mogelijk zijn. ${ }^{175}$ De 'elasticiteit' van het oordeel of de vraag beantwoord kan worden, zou de minister overigens de gelegenheid geven om zich te verschuilen achter de juridische toelaatbaarheid, indien hij om politieke redenen liever geen antwoord geeft. ${ }^{176}$

De vergaring van informatie kan ook in de vaste commissies plaatsvinden. Hierin kan ten eerste de beantwoording van parlementaire vragen geschieden. Verder kunnen minister, ambtenaren - waaronder die van het $\mathrm{OM}$ - en anderen gehoord worden. Niemand is evenwel verplicht gehoor te geven aan een oproep van een dergelijke commissie. ${ }^{177}$

Daarnaast kunnen beide kamers enquêtecommissies instellen. De kamers beslissen bij meerderheid tot het houden van een enquête. De samenstelling van de betrokken commissie spiegelt zich aan die van de algemene vergadering. De commissie heeft in haar onderzoek dezelfde bevoegdheden en beperkingen als de rechterlijke macht. Zij kan onder andere personen met de sterke arm voor zich laten verschijnen en documenten opvragen. Personen met een geheimhoudingsplicht hoeven echter niet te getuigen in strijd met die plicht. Een enquête vindt geregeld plaats in samenwerking tussen de twee kamers. Desgewenst neemt het parlement in dergelijke gevallen een wet aan die de enquêtecommissie de bevoegdheid geeft ook bepaalde geheimhoudingsplichten te omzeilen. ${ }^{178}$

OM tot de aanklaclyt is gekomen, en zegt zelf ook von mening ta zijn dat er geen grond is om ath te nemen dat de anklacht een middel is om andere personen af te dekken (". . cosi come a me pare privo di fondamento..." ).

174 Di Ciolo 1983, p. 336, Bartole 1984, p. 345-346; Verde 1990, p. 224. Zie 6.1. Bevoegdheden ontren informatievoorztening.

175 Bartole 1984, p. 360-311.: Verde will vragen over hangende zaken geheel witsluiten; 1990, p. 219. Een woorbeeld: CdD, R.s., 30 augutstus 1993, 4-01473. Hierin heef de minister het over het onderzodkgeheim (segreto istruttorio) en de privacy van de verdachten, welke beide in de weg staun an het gewen van meer en meer gedetailleerde informatic.

176 Bartole 1984 , p. 362 e.r. Hel zou wolgens deze anteur daanom bater zijn als de voorziturer wan de betreffende kamer sterker zou controleren op de toelatbartheid wan wragen, zodat de minster mindes gelegenheid zou hebben on een antwoord te weigeren. Hierdoor zou het thebu tussen kamerleden en de minister een meer politiek karakter krijgen. Zoals Hartole zelf observert zou aen te strikte houding van de voorzitter parlementaire echter initiatieven kumen blokkeren, die onregelmatigheden in het handelen van het OM aan de kaak stellen.

177 Artt 143-144 RC; arti. 46-48 RS.

178 Art. 82 Cosi; art. 140-142 RC; art. $162-163 \mathrm{RS}$. Voorbeelden van omzeiling van de geheimhoudng zie 


\subsubsection{Sanctionering ministeriele verantwoordelijkheid}

Tenslotte kan worden overgegaan tot sanctionering van de yerantwoordelijkheid van de minister van Justitie. De uiterste sanctie daarop is het aannemen van een motie van wantrouwen. Andere instrumenten zijn evenzeer denkbaar. Zo kan een negatieve stemming over de begroting of over een wetsvoorstel van de regering of het stellen van een vraag voldoende zijn. In de Italiaanse politiek is slechts cén enkele maal een expliciete motie aangenomen tegen een enkele minister, en wel tegen een minister van Justitie. In 1995 werd het wantrouwen uitgesproken tegen en het aftreden verzocht van minister Mancuso. De reden hiervoor lag in de - naar de mening van de Senaat - sterk conflictueuze houding van de minister tegenover het $\mathrm{OM} .{ }^{180}$ Mancuso was van mening dat het parlement zich met de motie buiten de perken van zijn bevoegdheden begaf, en stelde beroep in bij het Constitutionele hof. Het hof bevestigde in deze zaak dat de controlebewoegdheden van het parlement ook ten aanzien van de grondwettelijke bevoegdheden van de minister van Justitie niet beperkt zijn. De motie van wantrouwen gericht tegen een individuele minister achtte het hof toelaatbaar. ${ }^{181}$

De Italiaanse doctrine heeft lage verwachtingen over de sanctionering van de ministeriêle verantwoordelijkheid ten aanzien van het OM. Deze kritiek geldt in zijn algemeenheid, ook los van de mogelijke ministeriële bevoegdheden over het OM. Men acht het hoe dan ook onrealistisch te denken dat een minister of zelfs een heel kabinet zijn lot zou verbinden aan de wijze waarop de vervolging wordt uitgeoefend in individuele zaken. ${ }^{182}$

De uitzonderlijkheid van de motie van wantrouwen neemt niet weg dat individuele ministers of hele regeringen wel zijn opgestapt, nadat was gebleken dat zij niet meer

att. 41. 10 april 1997, n. 97; art. 41. 31 oktober 2001 , n. 399 , beide met betrekking tot de "Witwascommissie' (Commissione parlanentare di inchiosta sul ciclo dei rifiuti sulle atrivita illecite ad esso connesse). Zie verder 7.3. Verartwoording ON aan parlement.

179 Neppi Modona 1994, p. 10-11; Donati 1997, p. 5.

180 Molie Satwi, SAR, R.s.8. 11 mei $1995,1-00113 ;$ vgl. Donati 1997, p. 187-188, war ook de volledige tekst van de motie is opgenomer. De minister had eender dat jagr een opzienbatrende disciplinane actie en inspetie geeist tegen leden wan het parket in Milan. Dit leidde tot kritiek vanuit het parlement (zie

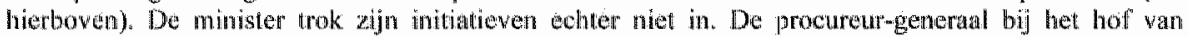
assatie begon op instigatie van de minister een proedure tegen leden van het oM, maar eiste sepondung van dezo disciplinaine zak. De minister lewerde verwolgens publiekelijke kritiek op deze handelgwijze. Danmast ageende lij openlijk legen de premier, die hem onvoldoende antonomie zou hebben gelaten. Volgens de molie wan de Senat had de ministen zich niek gehouden aan de door die kaner geuite weris om de "institutionele serendteit" te herwinnen en de strafirebtelijke finctionaliteit te verbeteren en zich conflictueus opgesteld tegenover de premier en de President Deze zak moet echter gezion worden in de bijbehorende politieke contex. Mancuso makte deel wit vain een "technische" regering, die wlleen gedoogsteun genoot in het parlement. Een dergelijke motie maakte daarom al meer kans.

181 Conte Cos. 1996, 17.7. Düt vonnis bevestigde tevens dat de minister vervolgens de mogelitheid heeft in beroep ta gatm tegen het indienen en annemen van ean dergelijke motie, door een zogenaand bevoegdheidscontlict op te werpen bij het Constitutioneal hof. Dit rechtsniddel baat hem echter alleen ten aanziven wan procedurele zaken, angezien het hof het polvtieke oondeel nowet respecteren. Over bewoegdheidsconflicten zie Bevoegdheden ten anzien van de vervolging Over de motie tegen individuele ministers orok art. II 5 RC.

182 Zagrebelsky 1979, p. 18-19; Bellone 1986, p. 212; Zanon 1996, p. 211. 
het vertrouwen vain de kamers genoten. Geen gevallen zijn bekend waarbij dit op enige wijze samenhing met een vorm van verantwoording voor het handelen van het OM. Individuele ministers van Justitie stapten telkens om andere redenen voortijdig op (Reale in 1971, Sarti in 1981, Vassalli in 1991, Martelli in 1993). ${ }^{183}$

De ministeriële verantwoordelijkheid heeft volgens menigeen een gebrekkige werking in Italiè. Ministers zouden niet genoeg hun consequenties trekken uit de oordelen die het parlement over hen geeft. ${ }^{184}$ Wel volgen de kabinetten elkaar in hoog tempo op. Dit belemmert echter een effectieve wijze van het afleggen van rekenschap. De steeds weer nieuwe bewindslieden zijn weinig geneigd zaken van hun vele voorgangers voor hun rekening te nemen. Verder veranderde tot de jaren negentig de partijsamenstelling van de kabinetten maar nauwelijks. ${ }^{185}$

De wijziging van de kieswet in 1993 deed het partijsysteem meer naar bipolariteit evolueren. Sindsdien kenschetsen de achtereenvolgende kabinetten zich iets meer door partijenwisseling van links naar rechts en vice versa. ${ }^{186}$ Verder moet onderstreept worden dat de persoon van de ambtsdrager van minister van Justitie in het verleden veel minder vaak veranderde dan de achtereenvolgende regeringen. Onder andere de ministers Gonella, Reale en Bonifacio bleven onder drie kabinetswisselingen op hun post zitten.

\subsection{Verantwoording OMaan het parlenent}

De ministeriële verantwoording is niet de enige wijze waarop het handelen van het $O M$ politiek wordt gecontroleerd. Naast de verantwoording die het pariement van de minister vraagt over het handelen wan het $O M$ hebben de kamers mogelijkheden om directe controle uit te oefenen op het OM. Deze vormen kunnen gezien worden als een parallel verantwoordingsproces.

Ten eerste kiest het parlement acht van de zesentwintig leden van de CSM. Zoals gezegd neemt deze onder meer belangrijke besluiten ten aanzien van de rechtspositie van het OM. Daaronder vallen de beslissingen in de disciplinaire zaken tegen leden van het

183 Reale trad met partigenoten af om onenigheid met het politieke belleid wand de regering. Sarti en Martelli traden af na zware strallechtelijke beschuldigingen. Vassalli trad af om een paar maanden later rechter: bij het Constitutioneel hof te worden.

184 Zagrebelsky 1979 , p. 19; Castelli 1990, p. 102. De verantwoording wan de minister van Justitie zou echter niet gewaardeerd moeten worden aan de hand van de huidige wasrin de minister zich bevindt; meent Dominioni 1979 , p. 85. Indien de minister meer functionele zeggenschap zou hebben, lijki de gedachte te zign, zou de verantwoording wellich beter functioneren. Echter, de kritiek op het functionefen van de ministeriële verantwoordelijkheid is algemener gerich, ook op de zaken wasrin de minister wel bevoegheden bezit.

185 Zagrebelsky 1979, p. 18-19; Guarnieri 1984, p. 44 era 184.

186 Zanon 1996, p. 211. Vór 1993 gold eern proportionteel kiesstelsel voor de kamers. Onder het huidige systeem wordt driekwart van de leden van beide kamers volgens een meerderheidsstelsel en én kwart volgens en proportioneel stelsel gekozen, 1. 10 december 1993, n. 515. Dit heefl tot effect gehad diat. er ruwweg twee "polen" zijn ontstaan, "links" en "rechts", waataan de meeste partijen zich hebben verbonden. 
OM. Zo controleren door het parlement gekozen leden via de CSM de positie en het handelen van het $O \mathrm{M}^{187}$

In de tweede plaats oefent het parlement met name directe institutionele controle uit via parlementaire enquêtecommissies. Reeds noemde ik deze commissies als middel tot vergaring van informatie in het kader wan de verantwoording door de minister. Hier wil ik echter wijzen op het feit dat sommige van deze commissies vele jaren- of zelfs deceminalang functioneren, zij het met enkele onderbrekingen. Meerderen onder hen zijn op bicamerale basis ingesteld. De quasi-permanente aard van de enquêtecommissies maakt hen tot min of meer zelfstandige instrumenten van verantwoording.

Twee van deze commissies trekken met name de aandacht. De ene commissie is sinds 1962 herhadicle malen ingesteld, met de naam 'voor het fenomeen van de maffia en andere vergelijkbare criminele organisaties'. De andere is genaamd 'enquêtecommissie over het terrorisme in ltaliè en over de redenen voor het falen in het aanwijzen van de verantwoordelijken". Deze was sinds 1988 in functie, maar is in ruste sinds eind jaren negentig. Een nabije heropstanding van deze commissie ligt weer sterk voor de hand gezien onder meer de aandacht voor terrorisme na 11 september 2001. De instellingswetten gaven beide commissies de bevoegdheid ook in strijd met het onderzoeksgeheim stukken op te vragen bij het $O M^{188}$ De commissies hebben zich sterk bezig gehouden met de opsporing en vervolging op het terrein van de maffia en het terrorisme. Daarbij bestudeerden zij de dossiers van belangrijke strafzaken. Tevens hielden zij hoorzittingen waarin zij leden van het OM ontvingen. Hierin stelden parlementariërs hen direct vragen over bijvoorbeeld de organisatie en bemensing van bepaalde parketten. Ook kwamen vragen aan de orde over het precieze verloop van individuele zaken en het handelen van het OM daarin. ${ }^{189}$

\subsection{Conchusie}

Deze verantwoording is opmerkelijk in zijn alomtegenwoordigheid. Van de meest algemene kritieken over wetgeving tot de inhoud van een proces-verbaal komt praktisch alles wat het $O M$ aangaat aan de orde. Op verzoek geeft de minister gedetailleerde uileg en een oordeel over de juistheid van strafrechtelijke beslissingen. Zijn bevoegdheden tot disciplinaire actie en inspectie zijn daarbij een referentiepunt voor parlementariërs. Alleen over het eigenlijke "beleid" van het $\mathrm{OM}$ volgen geen verantwoordings-

187 Over de CSM verder 2.1. OM en rechterlijke macht.

188 Respectievelijk de Commissione parlamentare d'inchiesta sul fenomeno delia mafia e delle altre associazitoni criminali similari, ingesteld bij 1.19 oktober $2001, n$. 386 (voorheen geregeld bij 1.20 december 1962 , n. $1720 ; 1.23$ naart 1988 , n. 94; art. 25-culunquies e.v. d.I. 8 junil 1992, n. 306, omgezet in wet bij 11. 7 augustus 1992, n. 356; 1. 1 oktober 1996, n. 509), en de Commissione parlanentare d'inchiesta sul terrorismo in Italia e sulle cause della mancata individuazione dei responsabili delle stragi, geregeld bij 1. 17 mei 1988, n. 172 met opvolgende verlengingen tot laatsi 1. 25 juli 1997, n. 243 . Een commissie die 'pas' sinds 5 jaar bestaat is de 'Witwascommissie' (Commissione parlamentare di inchiesta sul ciclo dei rifiuti e sulle attività illecite ad esso connesse), 1. 10 april 1997, n. 97; 1. 31 oktober 2001, n. 399.

189 Terrorismecommissie, XIII legislatura, 27 februari 1997 (opwallend is dat leden van het OM zich hier op eigen initiatief presenteerden om gehoord te worden). XIII legislatura, $40 \mathrm{a}$ seduta, 22 september 1998; 41 a seduta, 29 september 1998; $42 \mathrm{a}$ seduta, 20 oktober 1998 . Mafflacommissie, XIII legislatura, 4 a seduta, 21 januari 1997; 10a seduta, 18 februari 1997; 29 a seduta, 26 september 1997. 
debatten. De minister stelt zich wat betreft vervolgingsbeleid en individuele strafzaken volkomen passief op tegenover het parlement. De kamers zelf zien op bepaalde terreinen ook direct toe op de opsporing en vervolging. Enquêtecommissies met een welhaast permanente status controleren zo het handelen van het $\mathrm{OM}$.

\section{Samenvatting en conclusie}

De relatie minister-OM in Italië is tegenstrijdig en onevenwichtig. Het Italiaanse $\mathrm{OM}$ is een sterk onafhankelijke instantie, maar heeft verstrekkende bevoegdheden. Het voert een prioriterend beleid, maar is wel onderworpen aan het legaliteitsbeginsel. De Itallaanse minister van Justitie heeft vrijwel geen greep op het $O M$, maar legt wel een belangrijke mate van verantwoording af voor de vervolging. De bewindspersoon draagt de naam van 'Justitie', maar is feitelijk slechts een minister van wetgeving en strafrechtelijke financiën.

De Italiaanse rechterlijke macht staat sterk in relatie tot andere constitutionele ambten. Het parlement heeft invloed via de CSM, maar als de magistraten de rijen sluiten hebben zij het laatste woord. De samensmelting tussen OM en rechters is hecht. Afgezien van een scheiding van functies bestaan geen noemswaardige institutionele verschillen tussen beide.

Een OM bestaat eigenlijk niet in Italië. De parketten staan organisatorisch geheel los van elkaar. Een gemeenschappelijk beleid is niet aanwezig en onderlinge contacten zijn strikt informeel. De weinige bevoegdheden van de procureurs-generaal bieden slechts coördinatie voor individuele zaken. Alleen op het gebied van de maffiabestrijding kent het OM een zekere eenheid. De positie van de nationale antimaffia-procureur is vrij invloedrijk tegenover de directies in de districten.

Dit 'ongeorganiseerde' OM heeft ruime bevoegdheden in de opsporing en de vervolging. Politie en andere opsporingsambtenaren staan functioneel onder gezag van de parketten. Een serie dwangmaatregelen staat ter beschikking van de procureurs. De zeggenschap over vervolging of sepot ligt de facto grotendeels in hun handen. Een beleid dat die naam mag dragen voeren de parketten echter niet. Min of meer impliciet stellen zij wel prioriteiten in de vervolging. Dit staat in een moeizame verhouding tot het legaliteitsbeginsel. Formeel zou het stellen van prioriteiten daarmee niet in strijd zijn, materieel beperkt deze de reikwijdte die aan het beginsel wordt toegedicht. Zeer veel zaken blijven liggen om andere dan technische redenen. Ook als het OM tot vervolging beslluit heeft het vaak nog een keuze in de te volgen procedure. Komt het niet tot een gewone terechtzitting, dan is bij de alternatieve afdoeningswijze wel telkens een rechter betrokken.

De minister van Justitie staat binnen de regering meestal alleen tegenover het OM. Het kabinet beperkt zich tot het meebeslissen over wetgeving op het terrein van het strafrecht of de rechterlijke organisatie. Het ministerie van Justitie verleent de minister evenmin een krachtige positie. Aldaar werkzame magistraten kunnen een matigende tussenschakel vormen in relatie tot het $\mathrm{OM}$.

Enkele belangrijke bevoegdheden heeft de minister op het rechtspositionele vlak. De voomaamste zijn de ministeriële instemming met voorstellen voor benoemingen voor 
leidinggevende functiles, en de bevoegdheid een disciplinaire procedure te doen starten. Deze laatste lijkt de leden van het $O M$ nog het meest te raken. Die bevoegdheid vormt tevens het aanknopingspunt voor verantwoordingsprocedures in het parlement.

In functionele zin is de minister voor het OM vooral een penningmeester. Hij heeft nauwelijks specifieke bevoegdheden van enig belang ten aanzien van het strafrechtelijk handelen. Evenmin is hij goed op de hoogte van lopende strafzaken. De meest ingrijpende bevoegdheid is die om een inspectie in een parket te houden.

Kamerleden verwijzen in hun vragen pertinent naar de inspectiebevoegdheid, maar ook naar de disciplinaire procedure. Actieve verantwoording van de minister van vervolgingshandelingen komt niet voor. Evenmin is de beleidsinhoud onderwerp van discussie. Individuele zaken worden wel breed uitgelicht. Tenslotte hebben parlementaire commissies zelf een vrij permanent en direct toezicht op sonmige strafrechtelijke terreinen.

Onafhankelijkheid, organisatorische zelfstandigheid en strafvorderlijke legalliteit kenschetsen het Italiaanse OM. De minister karakteriseert zich vooral door kaderbepaling en rechtmafigheidscontrole. Grote afwezige in de verhouding tussen minister en $O M$ is het inhoudelijke vervolgingsbeleid. Het gebrek daaraan dekt het OM af met "rationele keuzes', terwijl de minister voor invulling zorgt door wetgevingsprogramma's, het creeren van extra posten voor magistraten en dergelijke. 


\section{Hoofdstuk 5}

\section{Vergelijking van onderschikking en autonomie}

\section{Inleiding}

In de Nederlandse literatuur bestaan slechts enige aanzetten tot rechtsvergelijking op het onderhavig onderwerp. Enkele auteurs vermelden instituties uit België, Duitsland, Engeland, Frankrijk en Italië. Men gaat vervolgens echter niet over tot het eigenlijke vergelijken van de buitenlandse met de Nederlandse rechtsfiguren.' Enkelen suggereren dat een vergelijking weinig zinvol kan zijn. ${ }^{2}$ Ten onrechte, zoals uit het navolgende zal blijken.

In enkele buitenlandse werken vindt wel een min of meer geïntegreerde vergelijking plaats. Deze is evenwel altijd gericht op het OM zelf. De relatie tussen het OM en de politiek komt daarbij maar zijdelings aan bod. ${ }^{3}$ Enkele Franse auteurs betrekken het Italiaanse systeem nog wel eens in een betoog over de relatie tussen OM en politiek. Dit doen zij vrijwel uitsluitend om daar kritiek op te leveren. Critici zien in een onafhankelijk OM een gevaarlijke, excessieve macht, die democratische legitimiteit van zijn handelen ontbeert. In veel gevallen baseren zij zich in vage bewoordingen en zonder verwijzingen op kritiek en desillusies die er ten aanzien van het functioneren aan de overzijde van de Alpen zouden bestaan. ${ }^{4}$ Een eigenlijke analyse van de Italiaanse situatie ontbreekt daarbij.

Het navolgende wil een rechtsvergelijkende aanvulling betekenen. Daarin neem ik de volgende hoofdvragen onder de loep. Ten eerste will ik een vergelijking maken van de gradatie van ondergeschiktheid en autonomie van het $\mathrm{OM}$ in de drie landen. Welke overeenkomsten bestaan in de mate van autonomie van het OM? Welke bevoegdheden

1 Duisterwinkel 1968, p. 33-35 over enkele landen. Remmelank 1991, p. 171, 177, over 0.a. Belgie, Duitsland en Engeland. "t Hart 1994a, p. 322.321 over Belgie, Frankrijk en Italie; 1999, p. $196-197,0 v e r$ Italiè, Belgie, Frankrijk en Engeland. De Doelder 1995, p. 56-59, over Duitslend. Corshensi 1999a, over Frankrijk.

2 Bockwinkel 1968, p. 85; Enschedé 'zou in dit verband meer watarde hechten aan de onwikkeling van ons eigen constitutionele recht dan atan vergelijkingen met hel buitenland, "1968, p. 79. Corstens 1999 a, p. 99: "Maar daaran moet onmiddellijk worden toegewoegd dat de Franse trad itie wel een andere is dan de Nederlandse". Vgl. minister Sorgdrager, Kamershkken II 199697, 25392, mr. 7, p. 24. Anders: "t Hart 1999 , p. $113 ; 2001$, p. 88 .

3 Zie Fionda 1995; Brants \& Field 1995; Delmas-Marty 1995, p. 352-393; Delmas-Marty/Chiavario 1998, p. 340-395; Mathias 1999; Jehle 2000; Fijnat, Van Daele \& Panmentier 2000; Parrodet 2001. Guarnieri 1984 bestudeert wel in het bijzonder de relatie tussen het OM en politieke organen. Hij richt zich echter met name op de discretie van het $O M$ en betrekt niet een vergelijking van de politieke verantwoordelijkheid in zijn analyse. Daamaast is zijn boek onderhand sierk verouderd.

4 Jeol 1994, p. 1365; 1996, p. 69; Mazeaud 1996, p. 66; Martin 1997, p. 753; Boudon 1997, p. II en 14: Chalandon, Commission de reflexion sur ta Justice, Annexes 1997, p. 22: Foyer, idem, p. 27: Dragon idem, p. 161; Jacquin \& Vogelweith (Mény) 1998, p. 5. Zite ook Vauzelle in Le Monde 1 september 1992. Well meent een enkeling dat bet ltaliaanse systeem en de corruptieonderzoeken als onthullend zouden hebben woorbeeld gediend voor Frankrijk: Accomando 1997a, p. 97. 
brengen de belangrijkste verschillen in ministeriële zeggenschap mee? Daartoe leg ik allereerst de rechtsposities van het $\mathrm{OM}$ en de ministeriële bevoegdheden naast elkaar. Vervolgens stel ik de vraag welke juridische factoren hier directe invloed op hebben. In hoeverre dragen het belioren tot de rechterlijke macht, de organisatie van het OM of de positie van de minister en zijn ministerie bij aan de autonomie of onderschikking van het OM?

Een tweede hoofdvraag is de volgende: gaat de aanwezigheid yan een mate van autonomie vergezeld van zekere juridische elementen in de betrokken rechtssystemen? Deze vraag is evenmin betogend bedoeld, maar analytisch. Het doel hiervan is tweeledig. Een vergelijking van de feitelijke correspondentie tussen de reikwijdte van de onderschikking en het bestaan wan enkele hierna te noemen rechtsfiguren kan veronderstellingen bevestigen of ontkrachten. Dit is relevant voor argumenten waarop de ratio achter en de kritiek op de relatie tussen de minister en het $O M$ zich baseren.

Een tweede doel is van minder verstrekkend belang. De antwoorden op de hoofdvraag vormen een indicatie van de voorspelbaarheid van het samengaan van ministeriële zeggenschap met andere rechtsfïguren. Deze constateringen zijn echter niet noodzakelijkerwijs van verstrekkende betekenis. Het beperkte aantal landen dat ik hier in de vergelijking betrek beïnvloedt de voorspelbaarheidswaarde van het antwoord op deze vraag.

De vraag valt in onderdelen uiteen. Welke relatie bestaat tussen het deel uitmaken van de rechterlijke macht en het bezitten van aspecten van autonomie? Correspondeert het bestaan van een zekere organisatie van het OM met een bepaalde vorm van onderschikking? Heeft een onafhankelijk OM minder discretie dan een ondergeschikt OM? Hangt de staatsrechtelijke positie van de minister samen met zijn zeggenschap over het OM? Is er verband tussen de wijze en diepgang van de verantwoording en de bevoegdheden van de minister?

Hiema laat ik eerst een afzonderlijke vergelijking volgen van de functionele ministeriële bevoegdheden en de rechtspositie van leden van het OM. Na deze losstaande vergelijking behandel ik de factoren uit de twee hoofdvragen geïntegreerd met betrekking tot elk onderwerp. Deze analyse schept de voorwaarden voor een algemeen vergelijkende conclusie. Hierin kan ik de genoernde factoren gezamenlijk betrekken op de eerdere vergelijking.

\section{Vergelijking functionele ministeriële bevoegdheden}

De Italiaanse minister van Justitie en regering hebben in vergelijking met Frankrijk en Nederland zeer weinig bevoegdheden ten aanzien van het handelen van thet $O M$. In de laatste twee landen hebben de ministers wel een scala aan formele bevoegdheden, maar ze gebruiken die vrij weinig.

\subsection{Bevoegdheden omtrent informatievoorziening}

Het grootste effectieve verschil tussen de functionele bevoegdheden van de ministers van Justitie wan Nederland en Frankrijk aan de ene kant en die van Italië aan de andere 
kant betreft de informatieplicht. Het OM hoeft de Italiaanse minister van het handelen in individuele strafzaken niet actief op de hoogte te houden. In Nederland en Frankrijk is dit wel vereist. In beide landen heeft het $O M$ de plicht de minister te informeren over specifieke strafzaken en beleidsaangeleggenheden. De omvang van deze plicht is in zeer vage termen omschreven. In feite bepaalt de minister in hoeverre hij op de hoogte moet of had moeten worden gehouden. In Nederland bestaan daarnaast uitgebreide specifieke informatieplichten met betrekking tot tal van gevoelig geachte zaken. De Franse en met name de Nederlandse minister oefent door deze plichten een relatief grote controle uit over het $\mathrm{OM}$.

Wel kunnen alledrie de ministers op eigen initiatief informatie van het OM opvragen. De Italiaanse minister doet dit echter vrijwel enkel wanneer het parlement hem vragen stelt over individuele strafzaken.

\subsection{Aanwijzingsbevoegdheid}

Zowel in Nederland als in Frankrijk heeft de minister een algemene en bijzondere aanwijzingsbevoegdheid.

De Nederlandse minister heeft juridisch evenveel zeggenschap als de Franse over het beleid van het OM. De Franse minister gebruikt de algemene circulairebevoegdheid veelvuldiger dan de Nederlandse. De feitelijke impact van de Franse beleidsregels is minder groot in vergelijking met die in Nederland. Het Nederlandse College overlegt vaak met de minister voordat het zelf beleid vaststelt. De minister bepaalt in sterkere mate de inhoud van dat beleid dan de Franse. Nederlandse en Franse ministers laten het stellen van posterioriteiten echter over aan het OM. Hun Italiaanse collega kan geen algememe aanwijzingen geven, maar voert enkel een actief strafrechtelijk wetgevingsbeleid. $^{5}$

Slechts in Nederland en Frankrijk hebben ministers aanwijzingsbevoegdheden ten aanzien van bepaalde individuele strafzaken. De Italiaanse minister heeft deze niet, maar bezit wel enkele andere bijzondere beslissingsbevoegdheden, waarover hiema. De bijzondere aanwijzingsbevoegdheid van de Nederlandse minister is verstrekkender dan die van zijn Franse colllega. Deze laatste kan geen bevelen tot niet vervolgen geven. Tevens moet hij de vrijheid van het mondelinge requisitoir van het $O M$ respecteren. In Nederland geldt dit niet. ${ }^{6}$ Grote verschillen bestaan aldus tussen de juridische opties voor de ministers om in individuele zaken in te grijpen.

Aparte vermelding behoeft de - als rechtsregel bestempelde - plicht tot terughoudendheid van de minister in met name specifieke strafzaken. Deze vormt een theoretische,

5 Een interessante vraag is of Italianse strafbepalingen veclvuldiger an verandering onderhevig zijn dam Nederlandse of Franse. Mogelijk reageert het ltalianse stelsel vaker met wetswijzigingen, waar in Nederland en Frankrijk beleidswijziging geïnitieerd wordt. Een onderzoek, naar cen antwoord op deze vraag zou moeilikk af te bakenen ziljn, en is hier dan ook niet uitgevoerd.

6 Volgens sommigen zou in Nederland het adagium gelden van 'la plume est serve, la parole est libre'. Osinga $\| 992$, p. 76; MinkenhofReijntjes 2002, p. 49. Zie ook hoofdsuk 2, 6.2.2.6. Aanwijzing len aanzien van het requisitoir. 
juridische beperking op het handelen van de Nederlandse minister, die zijn Franse collega niet kent. Een beperking van de aanwijzingen tot bijzondere gevallen is wel als beleidsindicatie bekend in Frankrijk. De opeenvolgende ministers verschillen daarin echter van opvatting. Zij bevestigen in ieder geval wel dat ze geen aanwijzing tot nietvervolging kunnen of zullen geven. $Z 0$ vormt de deelname van thet Franse OM aan de rechterlijke macht geen juridiseh-logische aanleiding tot terughoudendheid?

Wat ten slotte het feitelijk gebruik van de specifieke aanwijzingsbevoegdheid betreft; bestaat grote overeenstemming tussen de drie landen. De Nederlandse en Franse ministers maken bijzonder weinig gebruik van de individuele instructiebevoegdheid. Sinds eind jaren negentig hebben zij zelfs geen enkele bijzondere aanwijzing meer gegeven. De praktijk van de individuele aanwijzingsbevoegdheid lijkt mitsdien sterk op de Italiaanse situatie waarin de minister die bevoegdheid niet heeft. ${ }^{8}$

\subsection{Aanwijzingsprocedure}

De algemene aanwijzingsbevoegdheid is in zowel Frankrijk als Nederland vormloos. Voor de bijzondere aanwijzingsbevoegdheden bestaan well specifieke formele vereisten. In de meeste opzichten komen deze met elkaar overeen. In beide landen geldt dat slechts de minister van Justitie de aanwijzing mag geven, en dat hij die alleen aan de top van het OM mag geven. Ook bepaalt de Nederlandse en Franse wetgeving dat de aanwijzing schriftelijk wordt gegeven en in het procesdossier van de zaak gevoegd wordt. Voor eén aanwijzingsvorm geeft de Nederlandse wet een bijzondere regeling, terwijl op een enkel aspect de Franse eisen verder gaan.

Aan de Nederlandse aanwijzing moet namelijk een advies van het College voorafgaan. Het procesdossier bevat ook dit advies. In theorie vormt dit een extra obstakel. In feite is het een formele omschrijving van wat toch al gebeurt: de minister pleegt overleg met het OM over individuele strafzaken. Het is ondenkbaar dat ook de Franse minister niet eerst door bespreking het gewenste resultaat zal proberen te bereiken. In de praktijk geven beide ministers dan ook geen formele aanwijzingen (meer) in specifieke zaken. Beslissingen over belangrijke individuele zaken worden genomen in dialoog tussen de minister en het $O M$. Mede de aanwezigheid van het overleg maakt een formele aanwijzing onwaarschijnlijk.

Anders dan de Franse bevat de Nederlandse wet daarnaast een bijzondere regeling ten aanzien van de aanwijzing om niet te vervolgen of op te sporen. Dit zou theoretisch gezien de controlle daarop sterker maken dan in de Franse situatie. Voor deze extra waarborg geldt echter evenzeer het bovengestelde. Het gesprek tussen minister en OM zeeft de noodzaak uit voor een aanwijzing.

De Franse eis van de schriftelijke vorm gaat daarentegen verder dan de Nederlandse. Die laatste staat uitdrukkelijk toe dat in geval van spoed de minister de aanwijzing slechts achteraf op schrift stelt." In Frankrijk kunnen aanwijzing en overleg daarom iets

7 Zic over en vergelijking van de nomatieve consequenties van dit begrip 5.1. Rechterlike macht.

8 Europa kent een variöteit an relaties russen regering en OM. In Portugal, Spanje, Schotland en Scandinavie - net nizondering van Finland - is het OM functioneel onathankelijk. Pradel 1995, p. $326-328$.

9 Corstens 1999 a, p. 98 stelt dan ook ten onrechte dat het Nederlandse vereiste van schriftelijke vorm eenvoudigweg correspondeet met het franse. 
beter van elkaar onderscheiden worden. Wederom onderstreept de Nederlandse wet hier de boventoon die het vormeloze overleg voert. De uitzonderingsclausule laat de Nederlandse minister een ruimere mogelijkheid voor informele beînvloeding dan de Franse. $^{10}$

\subsection{Rechtswaarborgen bij aanwijzingen}

De juridische waarborgen bij aanwijzingen lopen langs twee lijnen in Nederland en Frankrijk. In beide landen bestaat een vorm van indirect rechterlijk beroep en heeft het OM een optie om de aanwijzing niet op te volgen.

Wanneer de minister een aanwijzing geeft om niet te vervolgen, en het $O M$ vervolging achterwege laat, kan een belanghebbende in Nederland beklag doen bij het hof en in Frankrijk een klacht deponeren bij de onderzoeksrechter. Beide rechterlijke instanties beslissen of juridische gronden voor vervolging aamwezig zijn. Enkel het Nederlandse hof heeft evenwel de mogelijkheid om het beklag op opportuniteitsgronden te verwerpen. Dit gebeurt echter zelden. Voor het overige blijkt niet van een verschil in de aard van de juridische toetsing door de Franse en Nederlandse rechters. Evenmin lijkt de kring van beroepsgerechtigden in één van de landen beduidend groter te zijn.

De tweede waarborg ligt in de toetsing van de aanwijzingen aan het recht door het $O M$, gevolgd door de mogelijke weigering om de aanwijzing niet op te volgen. In Frankrijk heeft deze erkenning gevonden onder de specifieke naam van droit de résistance, als onderdeel van de pouvoir propre. In Nederland bestaat niet een met zoveel woorden erkend recht: De toetsingsmogelijkheid heeft het $O M$ hier echter wel. In beide landen brengt een weigering het risico mee van rechtspositionele consequenties, waaronder een disciplinaire sanctie.

Twee verschillen zijn aanwijsbaar. De Franse substituten kunnen zich niet beroepen op een droit de résistance. Gewone Nederlandse officieren van justitie of advocaten-generaal hebben daarentegen niet minder of meer mogelijkheid een aanwijzing naast zich neer te leggen dan een parkethoofd. Dit verschill ontspringt aan de verschillende wijze van bevoegdheidsverlening. De Nederlandse leden van het OM krijgen ieder hun bevoegdheden rechtstreeks uit de wet toebedeeld. Hun Franse collega's vervangen als het ware hun parkethoofd, aan wie de wet refereert.

Verder lijkt de Franse procureur-generaal feitelijk eerder geneigd te zijn een betwiste ministeriële aanwijzing door te spelen aan het lagere OM. Bij gelegenheid vormt hij veeleer een doorgeefluik. Hem wordt ook geen uitdrukkelijk droit de résistance toegedicht. Het Nederlandse College is veel sterker de (eerst-)geadresseerde van de aanwijzing. De Franse toetsing heeft zo met name op het niveau van het parkethoofd betekenis, terwijl in Nederland de toetsing door het College de doorslag geeft. Als deze zijn oordeel heeft gegeven blijft er voor de lagere لeden van het OM praktisch geen ruimte over om de uitvoering van de aanwijzing te weigeren. 


\subsection{Overige bevoegdheden omtrent de vervolging}

Naast de Nederlandse en Franse aanwijzingsbevoegdheid bestaat in alledrie de landen een variatie aan ministeriële zeggenschap rond de strafvervolging. Het gaat hier om toezeggingen, mededelingen omtrent de strafbaarheid van feiten, toestemmingen, verzoeken, gezag over opsporingseliensten, en financiële en organisatorische kaderbepaling.

De mogelijkheden voor de Nederlandse minister om toezeggingen en mededelingen omtrent de strafbaarheid te doen zijn uniek in vergelijking met de andere landen. De facto lijkt ook het gebruik van deze bevoegdheid uitzonderlijk. Het verschil met Frankrijk en Italie is op dit gebied meer theoretisch van aard.

Alledrie de stelsels kennen specifieke procedureregels voor vormen van vervolging van bepaalde soorten ambtsdragers. Deze gelden in ieder geval voor het staatshoofd, de ministers en staatssecretarissen en de leden van het parlement. Alleen in Nederland heeft de minister in de besluitvorming daaromtrent een rol, als onderdeel van de regering. In Frankrijk en Italië zijn telkens andere, wel veelal politieke ambten daartoe bevoegd.

De ltaliaanse minister heeft daarnaast wel verzoeks- of toestemmingsbevoegdheden ten aanzien van enkele soorten buitenlandse strafbare feiten en een aantal uitzonderlijke delicten. Voor de feiten die in het buitenland gepleegd zijn vormt het ministerie echter feitelijk een automatisch doorgeefluik naar het $\mathrm{OM}$ toe. De andere, bijzondere delicten zijn dermate uitzonderlijk dat ze welhaast nooit toepassing lijken te vinden. Het gebruik van de weinige Italiaanse bevoegdheden vormt of een automatisme, of zij leiden een theoretisch bestaan.

Zaken die onder deze procedures vallen komen in alledrie de landen zelden of nooit voor. De bijzondere procedurevereisten spelen daarom slechts een beperkte rol. Een belangrijke, maar tijjelijke uitzondering vormt de veelvuldige toepassing ervan in het

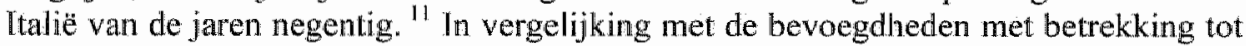
de informatievoorziening en de rechtspositie hebben deze regelingen dus kwantitatief weinig betekenis.

Door hun zeggenschap over politieorganen hebben ministers in alledrie de landen beïnvloedingsmogelijkheden ten aanzien van de opsporing. In de praktijk is van specifieke ministeriele interventies weinig of niets merkbaar. De inbreng van de ministers lijkt veeleer van budgettaire of beheers-organisatorische aard.

In Nederland en Frankrijk hebben bepaalde administratieve organen die onder een minister vallen transactiebevoegdheden. Sommige Franse bestuursorganen hebben de bevoegdheid voor bepaalde delicten de vervolging in te stellen of zelfs vit te oefenen. Voor de vervolging van enkele Franse delicten is een klacht nodig van een administratief orgaan. Deze administratieve invloed op de handelingsreikwijdte van het Franse $O M$ is groter dan in Nederland. Van daadwerkelijke ministeriële bemoeienis met het handelen van deze bestuursorganen blijkt evenwel niet. Feitelijk lijkt zo wat betreft

1 Ciedoeld wordt op de goll" van zaken in de "operatie" noni pulire. 
politieke zeggenschap geen verschil te bestaan met de situatie in Italië, waar onder ministers vallende ambten dergelijke bevoegdheden niet bezitten.

Ten slotte bepaalt de minister in samenspraak met het parlement in de drie onderhavige landen de nadere organisatie en financiële speelruimte van het $O M$. Deze zeggenschap is van zeer algemene aard. Zij heeft geen specifiek aanwijsbare consequenties voor de beleidsprioriteiten van het $\mathrm{OM}$, laat staan voor individuele strafzaken.

\subsection{Informele invloed}

In alledrie de landen lijken informele vormen van politieke invloed te bestaan. Aanwijzingen van actieve beïnvloeding van dien aard door politici zijn echter zeer schaars. Indicaties van zelfcensuur door het OM zijn nauwelijks sterker onderbouwd. Op basis van het voorgaande is het trekken van gefundeerde conclusies op dit punt niet goed mogelijk.

\section{$2.7 \quad$ Conclusie}

De belangrijkste feitelijke zeggenschap van de Nederlandse en Franse minister bestaat uit de actieve informatieplicht van het OM. In Nederland heeft de minister verder een bijzonder invloedrijke positie. Anders dan zijn Franse collega staan hem vele specifieke informatiestromen ter beschikking en kan hij in principe ook mondelinge aanwijzingen geven. Meer theoretisch gezien heeft hij daamaast een veel verderstrekkende aanwijzingsbevoegdheid en mogelijkheden om toezeggingen te doen, en mededelingen te geven omtrent de strafbaarheid van feiten. Vanuit dit formele gezichtspunt heeft ook de Italiaanse minister nog enige specifieke opties. Deze zijn echter sterk beperkt in hun toepassingsgebied. Voor het overige heeft de Italiaanse bewindspersoon alleen zeer algemene zeggenschap.

\section{Vergelijking rechtspositie van het $\mathrm{OM}$}

$\mathrm{Na}$ een confrontatie van de functionele ministeriële bevoegdheden volgt nu een vergelijking van de rechtspositionele zeggenschap van de minister.

De rechtspositie van leden van het OM wordt gekenmerkt door een vrij diametrale tegenstelling tussen enerzijds Nederland en Frankrijk en anderzijds Italie. ${ }^{12}$ In het Italiaanse stelsel zijn beslissingen in zaken van benoeming, promotie, overplaatsing, disciplinaire straffen, schorsing en ontslag geheel voorbehouden aan de rechterlijke macht. De minister heeft daarin hoogstens een initiërende, geen beslissende bevoegdheid. De CSM beslist. Zijn Nederlandse en Franse collega's zijn op deze terreinen juist geheel beslissingsbevoegd.

12 De grondrechtenregelingen in Nederland, Frankrijk en falie lijken minder afwijkend. De leden wan het OM zijn in alledrie de landen aan slechts atan nogal vag aangegeven grondrechtenbeperkingen onderworpen. Feitelijk genieten de procureurs en ruime vrijheid van meningsiting en vergadering. 
Deze zeggenschap wordt enigszins getemperd door adviesbevoegdheden van respectievelijk het Nederlandse College en de Franse CSM. Het College adviseert slechts over benoemingen en promoties. De CSM doet dat eveneens in de disciplinaire procedure. De geldende praktijk heeft verder vooral een matigende invloed. In Frankrijk geldt de laatste jaren het beleid dat de minister zich veelal voegt naar de adviezen van de CSM op rechitspositioneel gebied. In de Nederlandse rechiscultuur lijkt de minister zich veelal te onthouden van sterk politieke rechtspositionele ingrepen. Deze beperkingen zijn echter niet van systematische, algemene aard. Enerzijds doen sommige Nederlandse gevallen twijfelen aan de muisteriele matiging, met name wat betreft disciplinaire straffen en ontslag. Anderzijds blijven de Franse procureurs-generaal onderhevig aan politieke benoemingen.

Opvallend is verder het verschil in de bezoldigingsregeling. Nederland en Frankrijk relateren het inkomen van leden van het $O M$ aan de aard van de functie. In Italië geldt enkel de anciënniteit. Dit onderscheid versterkt het verschil aan zeggenschap over promoties binnen het OM. De ministeriële beslissingsbevoegdheden over de carrière zijn hierdoor sterker van belang dan die van de Italiaanse CSM. De Nederiandse en Franse ministers besluiten met de promotie tevens over een verhoging van de geldelijke beloning, terwijl de CSM in Italiè zich beperkt tot functietoeling.

Ten slotte bestaat geen samenhangende relatie tussen de eenheid of scheiding van de carrières van rechters en leden van het $O M$ en de onafhankelijkheid of onderschikking van de laatste. ${ }^{14}$ Hoewel in de drie landen een gezamenlijke opleiding bestaat en functiewisseling mogelijk is, heeft het OMf een zeer verschillende mate van autonomie. In Italiê worden ideeen voor een scheiding van carrières evenwel vaak gezien als de opmaat naar onderschikking van het $\mathrm{OM}$ aan de minister. Deze veronderstelling wordt in ieder geval geenszins ondersteund door rechtsvergelijkende argumenten.

\section{Conclusie rechtspositie en functionele positie}

Vanuit theoretisch gezichlspunt heeft de rechtspositie van het OM geen noodzakelijk verband met zijn functionele positie. Men kan zich een rechtssysteem voorstellen waarin onafzetbare en in hun statuut beschermde procureurs de plicht hebben bepaalde bevelen op te volgen. Andersom is een vervolgingsorgaan denkbaar dat rechtspositioneel ondergeschikt, maar functioneel geheel autonoom is. ${ }^{15}$

Uit de uitgevoerde landenanalyse blijkt evenwel dat in de onderzochte landen een juridisch zwakke rechtspositie teitelijk samen gaat met een vergaande onderschikking en

13 Benoeming van deden van he OM is de normale manier van instelling in Europa. In de regel is het statshootid degene die het betoemingsbeshit officieel neent. In enkele landen doet de nationale procufow" general dit. Sons dient het statshoofd vootat advezen te nemen van staatsorganen. Pradel 1995 , p. 323 324. In sommige staten van Dutsland zijn de puouneurs-generaal ook politieke functionarissen, dis op elk moment, ook zonder motivate, uit hun functie gezet kunnen worden. Naast benoenning doon owerhelisongmen komt buiten Europa wel het systeem war verkiezing van procureturs voor. Onder meen op thet niveau van de staten in de VS is dat het meest gebrikte systeem. Jurg 1993, p. 25.

14 Brutit Litorati $1999, \mathrm{p}, 7 \%$.

15 Rasian 1967, p. 52 
andersom. Het Nederlandse stelsel heeft slechts een zeer beperkt aantal rechtspositionele waarborgen, terwijl onder meer elke soort aanwijzingen gegeven kan worden. In de Franse situatie zijn meer controlemomenten ingebouwd ten aanzien van het statuut, terwijl geen aanwijzingen mogelijk zijn om niet te vervolgen en geen aanwijzingen ten aanzien van het mondeling requisitoir. De onafhankelijke Italiaanse rechtspositie correspondeert ten slotte met een vrïwel volledige functionele autonomie.

Welke gevolgen nu hebben de rechtspositionele ministeriële bevoegdheden voor de functionele? In de Nederlandse en Franse stelsels blijkt dat de aard van de rechtspositie een versterkende invloed heeft op de werking van de functionele ministeriele bevoegdheden. ${ }^{16}$ De Franse gewoonte om politieke benoemingen te doen op met name de functies van procureur-generaal vergroot de functionele ministeriële zeggenschap. Zo kan hij een zwaardere rol spelen in relatie tot de top wan het OM bij het overleg en het gebruik van aanwijzingsbevoegdheden.

In Nederland schept de minder politiek gekleurde samenstelling van het College betere voorwaarden voor een autonome houding van het OM. Deze samenstelling bevordert de toetsing van aanwijzingen aan het recht. Wel lijken het gebruik van disciplinaire straffen en de ontslagbevoegdheden het Nederlandse OM enigszins te kunnen conditioneren.

Concluderend is het Italiaanse OM juridisch het meest autonoom van de politiek; het is functioneel sterk en rechtspositioneel vrijwel geheel onaflhankelijk. In Nederland is het OM volledig rechtspositioneel en functioneel ondergeschikt, aan de minister. Het Franse OM ten slotte, is functioneel minder sterk ondergeschikt dan het Nederlandse, en kent rechtspositioneel gezien een iets zwakkere onderschikking. Formele beslissingsbevoegdheden van de Nederlandse en Franse minister komen meer overeen ten aanzien van de rechtspositionele dan ten aanzien wan het functionele handelen van het $O M$.

De facto genieten de leden van het $O M$ in alle landen van een zekere rechtspositionele autonomie, met name wat betreft de lagere benoemingen. Verder bestaat feitelijk een algehele functionele overeenkomst wat betreft het ontbreken van individuele aanwijzingen en beleidsaanwijzingen omtrent posterioriteiten.

Deze conclusie omtrent rechtspositie en functionele ministeriële bevoegdheden dient werbonden te worden met systeemfactoren die de relatie tussen het $O M$ en de minister omgeven. De mate van autonomie van het OM wordt mede bepaald door aspecten als de organisatie van het $\mathrm{OM}$, zijn behoren tot de rechterlijke macht en de positie van de minister.

16 Zie met name hoofdstuk $2,6.8$ en hoofdstuk $3,6.7$, beide getiteld Informele invloed. Z je voor het comesponderen van de redeneringen acher de aard van de rechtspositie en de functionele positie: hooldstuk $6,2,2$. Samenwaller functionele en rechtspositionele ratio. 


\section{Factoren in de relatie tussen minister en het $\mathrm{OM}$}

Hierboven werd duidelijk in hoeverre de bevoegdheden van de ministers van Justitie over het OM overeenkomen en van elkaar afwijken. Een volgende vraag is hoe deze verschillen samengaan met specifieke aspecten van het rechtsstelsel van elk van de landen. In het onderstaande loop ik de belangrijkste juridische elementen na. Zo bespreek ik het begrip rechterlijke macht, de interne OM-organisatie, de positie van de minister en het ministerie, bevoegdheden en diseretie van het $O M$ en de ministeriële verantwoordelijkheid.

Tevens bekijk ik welke invloed op de zeggenschap van de politiek uitgaat van het behoren tot de rechterlijke macht, de organisatie van het $\mathrm{OM}$ en de aard van minister en ministerie.

\subsection{Rechterlijke macht}

De vraag is hier hoe het behoren van het $\mathrm{OM}$ tot de rechterlijke macht of hoe de gemeenschappelijke carrière met rechters zich verhoudt tot de relatie met politieke organen. Enerzijds bezie ik of dit behoren tot de rechterlijke macht de juridische invloed van de politiek beperkt. Anderzijds en allereerst analyseer ik of een 'rechterlijk' OM gewoonlijk samengaat met een mate van autonomie.

In alledrie de onderzochte landen zijn het $O M$ of diens leden onderdeel van de rechterlijke macht. Dit wordt in de grondwet van Frankrijk en met name in die van Nederland maar nauwelijks gewaarborgd. Die van Italië is daar meer expliciet in. De Nederlandse literatuur en de Franse rechtspraak laten evenwel geen twijfel bestaan over het behoren van (de leden van) het OM tot de rechterlijke macht. ${ }^{17}$

Dit deel uitmaken van de rechterlijke macht heeft geen aanwijsbare samenhang met de relatie tussen OM en minister. Deze relatie warieert sterk ondanks de gemeenschappelijke 'rechterlijke' benaming. Het OM kan ondanks zijn kwalificatie als deel van de rechterlijke macht een geheel ondergeschikte of een onafhankelijke positie hebben.

Deze kwalificatie heeft niettemin enkele gevarieerde gevolgen voor de juridische relatie tussen OM en politiek.

Italie acht de benaming van grote systematische betekenis. Het behoren tot de rechterlijke macht hangt samen met een veelvoud aan grondwettelijke bepalingen, waaronder die betreffende de rechtspositionele en functionele onafhankelijkheid van het $\mathrm{OM}$. Het wijzigen van één van deze aspecten zou gevolgen hebben voor het hele grondwettelijke systeem. Het behoren tot de rechterlijke macht van het Italiaanse OM sluit daarom invoering van ministeriële zeggenschap met een gewone wet uit. In Nederland zien velen het behoren tot de rechterlijke macht als een aanwijzing voor het bestaan van een plicht

17 Over het algeneen in Europa vormen onkel rechters de rechterljke macht, terwijl de organisatie van heit OM darbutiten valt. Pradel 1995, p. 325; Voor Spanje en Portugal: Accomando \& Guéry 1996, p. 35. In Spanje, Engetand en Duitsland kwalfficeet men leden van het OM zelfs miet alls magistraten, maar als functionarissen of gewome ambtenaren. Accomando \& Guery 1996, p. 35; Favoreu 1996, p. 78-79. Dit is overigens ook zo in Canda en Zwitserland. 
tot terughoudendheid voor de minister. Het vormt een rechtsgrond om te eisen dat hij slechts zelden aanwijzingen mag geven. Voor de rechtspositie heeft het echter geen aanwijsbare betekenis. Het Franse stelsel heeft omgekeerde effecten. Het OM heeft well een enigszins versterkte rechtspositie door het behoren tot de rechterlijke macht. Daardoor geeft de CSM ook over de leden van de parketten rechtspositionele adviezen. Voor de functionele bevoegdheden van de minister heeft het daarentegen geen gevolgen.

Hoewel de leden van het OM dus telkens tot de rechterlijke macht behoren, gaat dit samen met sterk uiteenlopende juridische constellaties. Het vormt in alle landen wel een beperkende factor die op verschillende wijze en in verschillende mate autonomie medebewerkstelligt.

\subsection{Organisatiestructurr}

Een volgende vraag is of de interne organisatie van het $O M$ een factor van invloed is ten aanzien van de zeggenschap van de minister. Eerst stel ik vast welke verschillen in interne hiërarchie bestaan, en in hoeverre deze feitelijk samengaan met een mate van onderschikking aan de politiek. Daarna ga ik in op de gevolgen van de organisatie voor de zeggenschap van de minister.

De aard van de interne organisatie van het OM heeft geen abstract-logische relatie met diens functionele positie. Een hiërarchisch systeem van parketten hoeft niet onder de uiteindelijke autoriteit van de minister te vallen. Onderling niet met elkaar verbonden vervolgingsorganen zouden in principe elk op zich ondergeschikt kunnen zijn aan de regering. ${ }^{18}$

De facto verhoudt de relatie tussen hogere en lagere organen binnen het OM zich nauw met de aard van de relatie tussen minister en die hogere organen. Het Nederlandse College heeft verdergaande bevoegdheden dan de Franse en zeker de Italiaanse procureurs-generaal. Anders dan de Franse procureur-generaal kan het Nederlandse College aanwijzingen geven tot niet-vervolging en ten aanzien van het mondelinge requisitoir. Tevens kan een collegelid functies van het lagere OM uitoefenen. De Franse procureurgeneraal zit weer in een sterkere positie dan zijn Italiaanse collega. Deze kan geen algemene of specifieke aanwijzingen geven. Anders dan in Frankrijk en Nederland kan hij wel zelf zaken overnemen. Dit is alleen mogelijk indien de coördinatie van een zaak slecht loopt of het lagere $\mathrm{OM}$ inert blijft. In vergelijking met aanwijzingen biedt de overname verder weinig ruimte, oundat het lagere OM daartegen direct beroep op de rechter kan aantekenen. ${ }^{19}$ Deze verschillen corresponderen met de indeling in zeggenschap van de respectievelijke ministers. Des te verder de bevoegdheden van de minister gaan, des te hiërarchischer blijkt bet OM georganiseerd. ${ }^{20}$

18. Rassal 1967 , p. 54

19. Hierarchische onderschikking van lagere aan hogere parketten lijkt overigens gemeengoed te zijn in Eunopa. In het algemeen kunnen hogere organen beleidsregels geven aan de andere parketten. Pradel 1995, p. 326; Accomando \& Guéry 1996, p. 35.

20 Een historische rechtsvergelijking laat een uitzondering zien in het parket onder thet Franse ancien régime. Hierover: Rassat. 1967 , p. 55-60 
Deze analyse spiegelt zich niet geheel aan een vergelijking van de hiërarchie binnen de parketten zelf. Op dit niveau hebben de Nederlandse en Franse parkethoofden vrijwel gelijke mogelijkheden. De Franse hoofden hebben niet de bevoegdheid om een aanwijzing tot niet-vervolging of ten aanzien van het requisitoir te geven. Wel kunnen zij hetzelfde effect bereiken door de zaak aan een ander over te dragen of zelf over te nemen. Binnen het Italiaanse parket kan het hoofd een substituut slechts vervangen om formele redenen. Inhoudelijk kan hij slechts aanwijzingen van algemene aard geven. ${ }^{21}$ De gradatie van ministerièle zeggenschap in de drie landen gaat zo niet op volkomen wijze samen met de gradatie van hiërarchie binnen de parketten. Niettemin kan voorzichtug geconcludeerd worden dat parkethoofden in de landen met grotere ministeriële invloed meer bevoegdheden hebben dan waar het OM onathankelijk is.

Een andere vraag is welke invloed de organisatiestructuur van het $\mathrm{OM}$ heeft op diens relatie met de minister. De aard wan de organisatie binnen en rond het OM bepaalt in hoge mate de aard van hiërarchie tussen OM en minister. ${ }^{22}$ Een bepalende factor hier is de aard van de contactpunten die de minister ter beschikking staan. In Nederland is dit enkel het College. In Frankrijk de afzonderlijke procureurs-generaal en de CSM. In Italiè op uitzonderingen na alleen de CSM.

In rechtspositionele zaken heeft de Nederlandse minister slechts voor enkelle aspecten te maken met het College. Dit geldt voor de aanbevelingen, benoemingen of promoties. De Franse minister moet op belangrijke onderdelen handelen in relatie tot de CSM. Deze geeft zwaarwegende adviezen bij benoemingen en in disciplinaire zaken. De Italiaanse minister heeft in alle zaken met de CSM van doen. Het bestaan van een CSM biedt met name de Jtaliaanse, maar in enige mate ook de Franse leden van het OM een zekere waarborg tegen vergaande ministeriële invloed. In Nederland ontbreekt een dergelijke institutionele voorziening. Hier kan enkel de rechtscultuur het OM voor politisering behoeden.

Wat betreft het functionele handelen heeft de Nederlandse minister enkel met het College van doen. In Frankrijk heeft de minister bij de beslissingen over specifieke strafzaken contact met individuele procureurs-generaal. De aard van de gesprekspartner biedt de Franse minister feitelijk een sterkere positie dan de Nederlandse. Aangezien de laatste met een collegiaal orgaan van doen heeft, zal hij minder makkelijk een overvleugelende invloed kunnen uitoefenen. Ten aanzien van algemene beleidszaken is de situatie ongekeerd. Voor de Nederlandse minister is het eenvoudiger zijn mening te doen gelden tegenover een vijftal collegeleden dan de Franse minister tegenover 35 procureurs-generaal.

De functionele ministeriele verhouding met de OM-top werkt de facto door op het handelen van de lagere parketten. Aangezien het minder eenvoudig is een collegiaal orgaan aan te sturen, beperkt dit het effectieve gebruik door de minister van de sterkere interne OM-hietrarchie in Nederland. Indien het College medewerking weigert, kan de strakke

21 De relatie tussen het hoofd en zijn parket is in Frankrijk en Italie dus hiërarchischer van aard dan de relatie tussen hogere organen en lagere parketten. In Nederland bestaat geen enkel verschil tussen de hiararehische bevoegdheden van het College en die van het hoofd.

22 In algemene zin: Brutti Liberati 1999, p. 79. 
bevelsstructuur niet in werking treden. De sterkere schakel tussen de Franse minister en de procureurs-generaal wordt verzwakt door de beperktere relatie tussen de procureurgeneraal en de lagere parketten. Zo zal de Franse minister makkelijker dan de Nederlandse een aanwijzing tot vervolging of ten aanzien van het schriftelijke requisitoir uitgevoerd kumnen krijgen door de lagere parketten. De Nederlandse rechtbankparketten daarentegen worden sterker gedomineerd door ministeriële wensen aangaande het vervolgingsbeleid dan de Franse.

\subsection{Minister en ministerie van Justitie}

In de onderhavige paragraaf bekijk ik in hoeverre de rol en samenstelling van de executieve de aard van de ministeriele zeggenschap beînvloeden. Daana overweeg ik wat hierbij de betekenis is van de inrichting van het ministerie van Justitie. Ten slotte stel ik aan de orde welke correspondentie bestaat tussen de staatsrechtelijke positionering van de minister en zijn bevoegdheden over het OM.

De institutionele posities van de ministers van Justitie laten gematigde verschillen zien. De Nederlandse, Franse en Italiaanse ministers van Justitie zijn lid van de regering en de ministerraad. De andere ministers, waanonder de minister-president, hebben in de raad medezeggenschap over de strafrechtelijke politiek. In ltalië beperkt deze invloed zich echter tot regelgeving. De regering kan niet over het eigenlijke vervolgingsbeleid besluiten. De Franse en Nederlandse regeringen nemen tevens beslissingen over het vervolgingsbeleid zelf, over individuele strafzaken en sommige benoemingen. De minister van Justitie is in beide landen formeel wel de enige beslissingsbevoegde om het $O M$ aanwijzingen te geven. In rechtspositionele zaken gaat ook de formele zeggenschap van zijn collega's verder. De Franse en Nederlandse regeringen hebben een beslissingsbevoegdheid over respectievelijk de meeste of de belangrijkste benoeningen. Materieel gezien kunnen de genoemde politici desgewenst een overheersende functionele invloed hebben. Het Nederlandse en met name het Franse OM staan mitsdien mede onder zeggenschap van de andere ambten van de executieve.

Het Franse politieke stelsel kent echter een scherpere politieke tweedeling dan het Nederlandse. In verband daarmee staat dat Franse politieke leiders in de executieve een zwaardere rol hebben dan de Nederlandse. Als leider van de meerderheid, bekleed met belangrijke bevoegdheden domineert de Franse premier over de minister. Deze maakt deel uit van zijn linkse of rechtse politieke stroming. Buiten tijden van cohabitatie bepaalt de Franse President hoofdlijnen van de politiek. Deze overvleugelt dan evenzeer de minister van Justitie. Een gevolg van deze invloeden lijken de meer politiek geinspireerde benoemingen van de top van het OM in Frankrijk. In Nederland kan de invloed van andere leden van de regering een matigende invloed hebben. De coalities hebben hier een politiek meer uiteenlopende samenstelling. Zonder een digitale linksrechts tegenstelling is een bepaalde persoonskeuze niet vrijwel automatisch negatief in de ogen wan de oppositie.

Een in Italie, maar vooral in Frankrijk belangrijk onderdeel van het ministerie is het ministerięle "kabinet". Dit bestaat uit leden die politiek zeer nauw verwant zijn aan de minister. Het kabinet onderhoudt onder andere contacten met de CSM en het parle- 
ment. In Frankrijk heeft het kabinet tevens invloed op het handelen van het $O M$, via de directies en diensten van het ministerie. De Nederlandse minister heeft geen politiek kabinet on zich heen.

Verder zijn veel ambtelijke functies en met name de leidinggevende posities binnen het Franse en Italiaanse ministerie bezet door magistraten. Deze status vormt echter, zeker in Frankrijk, geen beperking op de leiding van de minister. Wanneer een Franse regering met een andere politieke kleur aantreedt, leidt dit meestal tot benoemingen van andere magistraten. In Italië en Nederland is een wisseling van de wacht minder duidelijk zichtbaar. Wat dit betreft lijkt de relatieve stabiliteit van leidinggevende magistraten van het Italiaanse ministerie meer op die van de Nederlandse ambtenaren.

Een institutioneel versehil met Frankrijk en Italiě is het ontbreken van een inspectiedienst in het Nederlandse ministerie van Justitie. Niet blijkt evenwel dat de Nederlandse minister hierdoor zelfs in vergelijking met zijn Franse collega een informatieachterstand heeft. De vele inlichtingenplichten en de praktijk van het intensieve contact tussen College en minister waarborgen minstens zoveel informatie.

De Franse minister heeft kortom een grotere politieke greep op het ministerie dan de Italiaanse, en zeker de Nederlandse. Daarnaast zijn andere organen van de Franse executieve zoals gezegd nauwer betrokken bij het handelen van het $\mathrm{OM}$. Dit betekent dat in Frankrijk meer condities aanwezig zijn voor een meer politiek partijdig gebruik van ministeriële bevoegdheden. Daarentegen vormen het minder politiek gedomineerde Nederlandse ministerie en de grotere speelruimte in relatie tot de premier een zeker tegengewicht voor politieke interventies.

Weinig feitelijke correspondentie is aan te wijzen tussen de aard van de relaties bimnen de executieve of de organisatie van het ministerie en de mate van formele zeggenschap over het OM. Zo heeft de minister niet minder bevoegdheden naarmate binnen het ministerie meer politiek personeel werkt. Evenmin gaat de zwaarte van de rol van de premier samen met een bepaalde zwaarte van de bevoegdheden van de minister. Waar de rol van de minister-president relatief minder geprononceerd is, heeft de minister van Justitie niet meer of minder zeggenschap over het OM. Hoogstens correspondeert de politieke zeggenschap van andere regeringsambten over OM-zaken met het bestaan van grote zeggenschap van de minister van Justitie. Waar de minister het $O M$ aanwijzingen kan geven hebben andere bewindslieden via hem evenzeer invloed op het handelen van het $O M$.

\subsection{Bevoegdheden en discretie wan het $O M$}

In hoeverre verschilt de speelruimte van het $\mathrm{OM}$ in de drie landen? Hebben verschillen een relatie met de functionele bevoegdheden die de minister heeft over het OM? Kan dus een verband gelegd worden tussen de bevoegdheden van het $O M$ en die van de minister ten aanzien van het $O M$ ? Hier stel ik niet aan de orde of bepaalde ministeriële bevoegdheden noodzakelijk of wenselijk zijn als het OM bepaalde soort bevoegdheden heeft. Normatieve redeneringen omtrent ministeriële zeggenschap komen in het volgende hoofdstuk aan bod. Hier wijs ik slechts analytisch op feitelijk zichtbare verbanden. 
In zowel Nederland, Frankrijk als Italië heeft het OM de leiding over de opsporing. Het kan de politie richtlijnen geven over haar werkwijze. Het staat aan het hootd van individuele opsporingsonderzoeken. In de praktijk lijkt het Nederlandse OM wel grotere controle te hebben over het handelen van de politie. Het bepaalt mede de uitdrukkelijke prioriteiten die de politie volgt in haar handelen. In Frankrijk zou dit juridisch mogelijk zijn, maar gebeurt het feitelijk niet. In het Italiaanse stelsel zou het theoretisch zijn toegestaan, maar niet uit opportuniteitsoverwegingen. ${ }^{23}$ Deze situatie correspondeert met het gegeven dat de Nederlandse münister de meest effectieve invloed kan uitoefenen op de prioriteitenstelling. De Italiaanse en Franse bewindslieden kunnen dit niet of feitelijk nauwelijks.

Uit de vergelijking komt geen rechtlijnig verband naar woren tussen de reikwijdte van de onderzoeksbevoegdheden van het $\mathrm{OM}$ en diens mate van autonomie. Vergaande bevoegdheden van het $\mathrm{OM}$ gaan niet eenduidig samen met een hoge gradatie van ondergeschiktheid. Zo heeft het OM in Italië net als in Nederland belangrijke zelfstandige bevoegdheden ten aanzien van dwangmiddelen (onderzoek aan lichaam en kleding, huiszoeking en inbeslagname). In Frankrijk kunnen dergelijke handelingen normaliter alleen via de onderzoeksrechter geschieden.

Wel heeft het Nederlandse $O M$ ten aanzien van sommige handelingen meer ruimte dan in de andere landen. In Italië en Frankrijk kan het OM bijvoorbeeld een verdachte voor de duur van hoogstens 48 uur vasthouden zonder dat deze gehoord hoeft te worden door een rechter. In Nederland moet de rechter-commissaris de aangehoudene op zijn laatst pas horen na drie dagen en vijftien uur. Het Nederlandse OM kan ook het gebruik bevelen van bijzondere opsporingsbevoegdheden als infiltratie en pseudo-koop. Aan de Franse en Italiaanse parketten staan die bevoegdheden niet (expliciet) ter beschikking: Deze gradatie van bevoegdheden correspondeert wel enigszins met een vergrote ministeriële zeggenschap. Ten aanzien van de uitoefening van sommige bijzondere opsporingsbevoegdheden (zoals burgerinfiltratie) heeft het Nederlandse OM namelijk specifieke informatieplichten.

Het OM in de drie landen heeft de mogelijkheid om in ieder geval op juridische gronden niet te vervolgen. Het Italiaanse $O M$ is ondanks het legaliteitsbeginsel echter net als in de andere landen feitelijk genoodzaakt om technisch vervolgbare zaken te laten liggen. Bij de keuze tussen zaken worden onvermijdelijk overwegingen van opportuniteit gedaan. Deze discretie is verder niet gebonden aan een door de politiek vastgelegd vervolgingsbeleid. Hierdoor heeft het $\mathrm{OM}$ in Italië in vergelijking met het Franse en met name het Nederlandse OM een grotere vrijheid van beleidsvoering.

Niet alleen onder het legaliteitsbeginsel wordt afgezien van vervolging op grond van de onmogelijkheid om alle zaken te vervolgen. Deze reden geldt eveneens voor rechtssystemen met het opportuniteitsbeginsel. In dergelijke stelsels kan men technisch vervolg-

23 In praktisch alle landen leidt of controleert het OM het handelen van de politie. Iung 1993, p. 21. Jung wijst wel op de specifiteiten wan Engeland. In de praktijk beschikt de politie well over een ruime marge van autonomie, p. 23. Deze marge is en zeer geprononceerd in Engeland, maar ook vrij ruim in Duilsland, Accomando \& Guéry 1996, p. 35. 
bare zaken in theorie ook los van de capaciteitsredenen seponeren. Praktisch gezien staat een dergelijk sepot evenwel niet los van de vervolgingscapaciteit. Een capaciteitssepot is een opportuniteitssepot het brengt feitelijk de ruimte mee om geprioriteerde zaken wél te vervolgen.

Verder brengt het stellen van prioriteiten onder het legaliteitsbeginsel tevens een serie posterioriteiten met zich. Deze kunnen impliciet blijven, of expliciet worden geformuleerd. Wanneer het $O M$ een zaak behandelt zal het bezien of het onder de posterioriteiten of prioriteiten valt. Deze ongang met de vervolgingsbevoegdheid wijkt weinig af van de situatie in een land met een opportuniteitsbeginsel. In een dergelijk land zijn de prioriteiten en opportuniteitsgronden wel veelal geẻxpliciteerd in beleidsregels. Hel: verschil tussen het legaliteits- en opportuniteitsbeginsel ligt dan vooral in het principiële uitgangspunt.

Een samenhang tussen het gebruik van opportumiteitsgronden en ministeriële zeggensehap over het $O M$ is dus in abstracto wel an te wijzen. Praktisch gezien heeft dit echter geen betekenis. Ook het onafhankelijke ltaliaanse OM moet posterioriteiten hanteren.

Een oppervlakkig verschil met de andere twee stelsels bestaat uit de Italiaanse rechterlijke controle op het OM. Aan de ene kant lijkt dit de sluitende waarborg tegen willekeurige sepots. Aan de andere kant kan de rechterlijke toetsing niet anders dan uiterst marginaal zijn, om niet overspoeld te worden door werklast. In feite hangt veel af van een initiatief van een eventuele belanghebbende en de pertinentie van diens bezwaar tegen het sepot. Daar komt nog bij dat een aantal zaken pas na of tegen het eind van de verjaringstermijn de rechter bereiken. Daarom lijkt weinig verschil te bestaan tussen de effectiviteit van de Italiaanse rechterlijke controle en het praktisch gebruik van de Franse en Nederlandse rechterlijke controle via een klacht van een belanghebbende.

Formeel juridisch kan zo een samenhang geschetst worden tussen. sluitende rechterlijke controle en onathankelijkheid van het OM. De facto kan dit verband niet onderbouwd worden. De discretie van het Italiaanse OM is niet geheel omsloten door rechterlijke toetsing.

Eén van de ogenschijnlijk belangrijkste verschillen is de mogelijkheid voor het Franse en Nederlandse OM om expliciet op grond van opportuniteitsredenen af te zien van vervolging. Het beleid van het Italiaanse $O M$ in deze blijft impliciet. Deze verschillen corresponderen met het bestaan van de ministeriële aanwijzingsbevoegdheden. Waar het OM uitdrukkelijk tot een beleidssepot kan besluiten, kan de minister beleidsregels geven en de vervolging bevelen.

Bijzonder opvallend in dit verband is het gegeven dat de bewindslieden vrijwel nooit in het algemeen aangeven welke zaken niet of minder vervolgd moeten worden. Ministers bepalen hoogstens hoe het OM in bepaalde zaken dient te handelen en welke prioriteiten het moet volgen. Dit beleid beperkt de vrijheid van het $\mathrm{OM}$ wel in diens vervolgend handelen. Expliciete posterioriteiten blijven in Nederland en Frankrijk echter onuitgesproken. De algemene sepotcriteria geven daartoe geen houvast voor een specifiek te volgen beleid. Deze situatie roept weer een sterke gelijkenis op met de positie van het Italiaanse $\mathrm{OM}$. In alle landen blijft het onduidelijk welk beleid van niet-vervolging 
het $O M$ voert. Dit zou slechts indirect afgeleid kunnen worden uit het geheel van hetgeen het $O M$ wèl vervolgt. In de praktijk hebben alledrie de bestudeerde vormen van OM een onomkaderde wrijheid van beleidsvoering over het niet handelen.

Wanneer het OM besluit tot een vorm van repressief handelen heeft het in alledrie de landen de keuze tussen een reeks van procedures. In Italië dient het OM uiteindelijk steeds om een rechterlijke beslissing te vragen. In Nederland en Frankrijk bestaan afdoeningsmogelijkheden waar geen rechter aan te pas komt: Hierbij kan een eventuele belanghebbende wel telkens beklag instellen, respectievelijk een klacht deponeren bij de rechter. Zonder tussenkomst van de rechter kunnen het Nederlandse en Franse OM beide besluiten tot een waarschuwing, een voorwaardelijk sepot of het doen van bemiddeling. Het opmerkelijkste verschil is de transactie door het Nederlandse OM. De transactievoorwaarden zijn in vergelijking met die van de alternatieve wegen in Frankrijk meer vergaand van aard. In Frankrijk en Italië bestaan wel enigszins vergelijkbare vormen, maar deze vereisen teikens rechterlijke bezegeling. Het OM in Nederland heeft zo een grotere discretie in het stellen van voorwaarden voor niet-vervolging. Voor het gewone voorwaardelijke sepot, de bemiddeling en de transactie is wel de medewerking van de verdachte nodig. Desgewenst kan deze de zaak toch nog op een proces laten uitdraaien. Verder is het OM gehouden aan de beleidsregels die omtrent deze procedures gelden.

Wederom is een verband te leggen met de aanwijzingsbevoegdheden van de minister. Waar het OM buiten rechterlijke beslissing de zaak jegens de verdachte kan afdoen, heeft de minister de bevoegdheid in ieder geval een aanwijzing tot vervolging te geven ten aanzien van specifieke strafzaken. De transactiemogelijkheden gaan daarnaast samen met een speciale plicht de minister in te lichten omtrent bepaalde hoge transacties.

Een duidelijk verschil tussen het Franse en Nederlandse systeem bestaat ten aanzien van de gevolgen van een gerechtelijk (voor)onderzoek. Als een Franse onderzoeksrechter zich over de zaak ontfermd heeft, heeft het OM geen discretie meer ten aanzien van de opportuniteit. Na afloop van een Nederlands onderzoek kan het parket evenwel besluiten om eventueel niet te vervolgen op grond van de enkele opportuniteit van de zaak. In zaken waarbij een gerechtelijk onderzoek plaatsvindt lijkt het Franse stelsel zeer sterk op het Italiaanse.

Dit verschil tussen enerzijds het Franse en Italiaanse en anderzijds het Nederlandse stelsel komt overeen met de enkel in Nederland voorkomende aanwijzing tot nietvervolging. Waar het OM bij een gerechtelijk onderzoek de optie behoudt van een sepot om opportuniteitsredenen, heeft de minister de bevoegdheid om een dergelijk niet vervolgen te bevelen. De reikwijdte van de remmende ministeriële zeggenschap wordt in deze versterkt door de langlopende mogelijkheid van een opportuniteitssepot.

Voor alle onderzochte landen geldt dat als het $O M$ eenmaal vervolging heeft ingesteld bij de rechter, er geen mogelijkheid meer bestaat om de procedure te doen staken. De procureur kan hoogstens in negatieve zin requireren, mocht hij na de instelling van de vervolging van gedachten veranderen. De beslissing is evenwel aan de rechter. De 
eigenlijke discretie van het $O M$ is zo beperkt tot de fase voorafgaand aan het strafproces. ${ }^{24}$

Gezien deze overeenkomsten tussen de drie landen blijkt niet van enige correspondentie met het bestaan of de reikwijdte van een aanwijzingsbevoegdheid ten aanzien van het requisitoir.

Concluderend is in het algemeen de traditionele tegenstelling tussen opportuniteit en legaliteit verzwakt. Elementen die hiertoe bijdragen zijn de diversificatie van strafrechtelijke procedures en het gebruik van vormen van controle (motivering sepots, richtlinen). Het lijkt beter te spreken in termen van gecontroleerde opportuniteit en gedifferentieerde legaliteit. In beide soorten systemen moeten keuzen gemaakt worden ten aanzien van de te geven strafrechtelijke reacties. ${ }^{25}$

Ten aanzien van het Italiaanse systeem menen ook enkele auteurs in de andere twee landen dat het legaliteitsbeginsel in de praktijk niet geheel wordt toepast, maar dat prioriteiten gesteld worden. ${ }^{26}$ Volgens verscheidene Italiaanse auteurs ten slotte is het onderscheicl tussen systemen met een opportuniteits- of legaliteitsbeginsel in de praktijk miniem. ${ }^{27}$

Wat de bevoegdheden van het OM betreft lijken veel keuzemogelijkheden in de onderhavige landen niet sterk te verschillen. Het bestaan van grote discretionaire ruimte in de drie systemen is in ieder geval een sterke overeenkomst. Deze overeenkomstigheid loopt niet geheel parallel met het verschil in de reikwijdte van de ministeriële bevoegdheden ten aanzien van het OM. Ook al heeft het Italiaanse OM evenzeer een ruime marge van discretie, de minister is niet bevoegd aanwijzingen te geven. ${ }^{2 B}$ Waar de bevoegdheden van het Franse en Nederlandse OM verder gaan bestaat wel enige nadere ministeriële zeggenschap.

24 Deze conclusie getdt verder voor vrijwel alle Europese landen. Pradel 1991, p. 20.

25 Pradel 1991, p. 21 e.v; Delmas-Marty 1992, p. 300; 1994, p. 151; Jung 1993, p. 19; Accontando \& Guéry 1996, p. 32-34; Accomando 1997, p. 1064. De opvatting dat het praktische versehil in de werking van het legaliteits-en opportunteitsbeginsel beperkt is, wordt gesteund door vergelijking met de Duitse situatic. Hoewel or vele uizonderingen op bestatan, geldt aldaar in principe het legaliteitsbeginsel. In de praktijk blijkt vervolgens dat er kwantitatief geen verschil is met de verwolging in bijvoorbeeld Frankrijk. Sterker nog, in Duitsland lijkt waker geseponeerd te worden om opportuniteitsredenem. Mathias 1999, p. 153 e.v. Jung stelt dat geen kwalitatief verschil bestaat tussen de twee prineipes: de beslissingen van het OM moeten volgens beide op de wettelijke gronden grbaseerd zijn. Jung 1993; p. 19. Wat betreft internationale normen aangaande de opportuniteif-negaliteit, zie de canbeveling wan de Ruat van Europa, Rec. n. 87-18.

26 Pradel \& Laborde 1997, p. 143. Corstens 1999a, p. 94. Wel zijn volgens sommige Franse schrijkers onder het legaliteitsbeginsel "beperktere keuzes' mogelijk. Delmas-Marty 1994, p: 151; Turcey 1997, p. 192. Aguila meent dat onder het legaliteitsbeginsel geen echt beleid mogelijk is, 1994, p. 10.

27 Guarnieri 1984, p. 151; Falcone 1990, p. 165; Morselli 1995, p. 484, noot 8; anders (impliciet) Borrelli 1994, p. 34.

28 In normatieve zin wordt de atrd van de bevoegdheden of de reikwijdte van de discretie van bet OM door velen juist gezien als dé factor van betekenis voor de relatie tussen minister en OM. Deze discretie wordt in lialië wol aangegrepen om zekere hervormingen wan de relatie tussen OM en minister te bepleiten. Zie hoofdstuk 6,4 .6. Belleidswrijheid en hoofdstuk 7 . 


\subsection{Verantwoording voor het $O M$}

Correspondeert de aard van de ministeriële verantwoording voor het OM met de reikwijdte van de ministeriële zeggenschap? Heeft deze reikwijdte gevolgen voor de ministeriële verdediging en het voor rekening nemen van het handelen van het OM? In deze paragraaf leg ik daartoe de doctrines van de politieke verantwoordelijkheid naast elkaar en vergelijk het verantwoordingsproces.

Een onderscheid bestaat in de begrippen van politieke verantwoordelijkheid van enerzijds het Franse en Italiaanse en anderzijds het Nederlandse stelsel. Ondanks de gelijkluidende terminologie omvat de responsabilité politique en de responsabilità politica zowel de Nederllandse verantwoordelijkheid als de vertrouwensregel. In Frankrijk en Italië bestaat geen aparte term voor deze laatste regel. De twee begrippen hangen daar veel sterker met elkaar samen. Dit verschil betreft echter een definitiekwestie die geen aanwijsbare gevolgen meebrengt voor de verantwoordingspraktijk.

De regeling en werkwijze ontrent de verantwoording in Nederland, Frankrijk en Italië zijn namelijk sterk vergelijkbaar. Alle systemen gaan uit van een zekere samenhang tussen bevoegdheden en de verantwoordelijkheid van de minister. In Frankrijk en Italiè stelt men echter niet uitdrukkelijk - anders dan velen in Nederland beweren - dat dit betekent dat het parlement de minister niet ter verantwoording kan roepen daar waar hij niet bevoegd is. Gezien het feitelijke verantwoordingsproces is de minister in alle landen op vergelijkbare zaken aan te spreken, ondanks verschillen in bevoegdheden.

Met name in Italië lijkt het parlement de relatie tussen bevoegdheid en verantwoording voor Nederlandse begruppen op ruime wijze uit te leggen. Italiaanse parlementariërs kunnen vragen stellen en de minister om een oordeel vragen over zaken die slechts in ruime zin een ministeriële bevoegdheid betreffen. De betrokken bevoegdheid is namelijk vaak die om een inspectie in te stellen, om een disciplinaire actie te ondememen of de algemene bevoegdheid om een nieuwe wettelijke regeling te ontwerpen.

De vragen hebben wel verschillende accenten in de drie landen. In Nederland ligt een accent op het bevorderen van vervolging of meer overleg, of op het creëren van nadere controllemogelijkheden. In Frankrijk beticht het parlement regelmatig de minister van oneigenlijke interventies in strafzaken. Daarnaast is de personeelsbezetting van het OM onder de aandacht. Een parlementair verzoek om optreden door de minister is in Italie vooral gericht op een disciplinaire reactie, een betere personeelsbezetting of op het invoeren van een andere strafrechtelijke regeling. Afgezien van deze voorkeuren leggen de ministers in alledrie de landen rekening en verantwoording af voor het handelen van het OM.

Kamerleden in alle landen vragen de minister geregeld om een beoordeling van het handelen van het OM. In Italië gebeurt dit meestal expliciet in het kader van de suggestie dat de minister een disciplinaire procedure start. Een dergelijke verwijzing komt nauwelijks voor in de Nederlandse of Franse vragen. Verder beoordeelt de Nederlandse minister een handeling van het $\mathrm{OM}$ vaker uitdrukkelijk positief in plaats van dubbele ontkenningen te gebruiken. De Italiaanse minister zal eerder slechts te zeggen dat hij een handeling niet onjuist acht. 


\section{Hoofdstuk 5}

De vragen die leden van het parlement in de drie landen stellen verschillen niet principieel van elkaar. Afgezien van zaken die vallen onder een staats- of onderzoeksgeheim lijken er geen onderwerpen te zijn waar een parlementariër geen antwoord op een vraag kan krijgen. In Nederland is de hoeveelheid vermelde details in de verschafte informatie verhoudingsgewijs wel opvallend.

Parlementariërs in alle besproken landen kunnen stukken inzien ondanks geheimhoudingsplichten aangaande het strafrechtelijke onderzoek. Een verschil is wel dat dit in Italiè alleen in sommige enquêtes voorkomt. Het Italiaanse OM kan namelijk weigeren de minister vertrouwelijke informatie te verschaffen. Daarentegen hebben bij wet ingestelde enquêtecommissies vaak de mogelijkheid deze geheimhouding te laten vervallen. In Nederland en Frankrijk kan de minister kamerleden dergelijke strafrechtelijke stukken vertrouwelijk in laten zien.

De Nederlandse minister richt zich in de praktijk meer op eigen initiatief tot de kamer. Hij betrekt de kamer actief bij onderwerpen van het vervolgingsbeleid. Dit spiegelt zich aan zijn feitelijk relatief grote greep op dit beleid. In Italie komt dit niet voor, afgezien van het wetgevingsbeleid, en in Frankrijk maar weinig.

Andersom controleert het Italiaanse parlement het handelen van het OM vaker in directe zin. Sommige Italiaanse enquêtecommissies op strafrechtelijk gebied hebben een zeer langdurig bestaan. De informatieverschaffing aan het parlement kan hierdoor op sommige onderwerpen intensief zijn. Ook in Frankrijk wordt vaker - maar op minder permanente wijze - van het enquêterecht gebruik gemaakt.

De mogelijkheden tot sanctionering in Italië en Nederland zijn staatsrechtelijk op vrijwel dezelfde wijze geregeld, met als ultieme mogelijkheid het opzeggen van het vertrouwen. In Nederland en Italië kan dit ook ten aanzien van een individuele minister van Justitie. Dit gebeurde slechts een enkele keer, in Italië, maar wel om een aangelegentheid rond het OM. Een heel kabinet is nergens ooit opgestapt om een dergelijke zaak.

De Franse minister zelf kan niet worden weggestemd. Daarnaast is de formele regeling voor een motie van wantrouwen tegen de regering daar ook veel zwaarder dan in de andere landen. Ten derde worden andere parlementaire handelingen dan een motie in Frankrijk niet gezien als een mogelijke sanctie op de ministeriële verantwoordelijkheid. De regering heeft dan ook een sterke positie tegenover het parlement, dat eventueel afgehouden kan worden van voor de regering negatieve beslissingen.

Op eigen initiatief is geen regering in één van de drie landen ooit afgetreden om zaken die het $\mathrm{OM}$ aangingen. Enkele keren had in Nederland het aftreden van een individuele minister van Justitie wel mede betrekking op het handelen van het OM.

De slotsom van deze paragraaf is, dat de besproken verantwoording in Nederland, Frankrijk en Italiẻ naar mijn mening vrij nauw naet elkaar overeenkomt. De uitzonderlijk goed gewaarborgde rechtspositie van het Italiaanse OM en de naar verhouding beperkte bevoegdheden van de minister vormen geen beletsel voor het plaatsvinden van verantwoordingsprocessen zoals die in Nederland en Frankrijk. De Italiaanse minister heeft een relatief beperkte informatietoevoer, maar deze kan gecompenseerd worden door verhoudingsgewijs sterke enquêtecommissies. 


\section{Concluderende vergelijking}

Het is nu zaak de conclusies uit paragraaf vier omtrent de onderschikking en de autonromie van het OM aan te vullen en bij te stellen in het licht van de bovenstaande factoren. Eerst geef ik een overzicht van de feitelijke samenhang die zichtbaar is tussen de graad van onderschikking van het $O M$ en de hierboven onderzochte elementen. Daarna geef iik een meer compleet beeld van de mate van de autonomie van het OM, gecontigeerd aan de hand van de behandelde aspecten.

Zoals eerder gezegd valt op, dat een grote reikwijdte van functionele ministeriële bevoegdheden coëxisteert met sterke invloed op de rechtspositie van het OM. Daaraan kan worden toegevoegd dat een grotere mate van onderschikking samengaat met een sterkere hiërarchie tussen hogere en lagere parketten. De reikwijdte van bevoegdheden van het OM gaat op onderdelen min of meer samen met die van de bevoegdheden van de minister. Zeggenschap in de vorm van beleidsaanwijzingen en aanwijzingen tot vervolging correspondeert ook met de aanwezigheid van de bevoegdheid van het $\mathrm{OM}$ om expliciet op gronden van opportuniteit af te zien van vervolging. Ten slotte valt het bestaan van afdoeningsmogelijkheden door het OM buiten de rechter om samen met ministeriële invloed in de vorm van aanwijzingen tot vervolging.

Feitelijk bestaat daarentegen geen relatie tussen een opportuniteits- of legaliteitsbeginsel en de verhouding iussen minister en OM. Ook de aard van de rechterlijke controle heeft geen betrekking op die verhouding. Verder vertonen het behoren tot de rechterlijke macht, het uitoefenen van discretie door het $\mathrm{OM}$, de positie van de minister of zijn ministerie en de wijze of mate van verantwoording geen samenhang met een mate van autonomie.

De gradatie van onderschikking in termen van ministeriële bevoegdheden over de rechtspositie en het handelen van het $O M$ in de drie landen besprak ik reeds in paragraaf vier. Gezien de eerder beschreven juridische factoren moet dit beeld bijgesteld worden.

De factor van de rechterlijke macht vergt geen bijstelling van de eerdere conclusie. De invloed van het behoren tot die rechterlijke macht beperkt zich tot het meebepalen van bij de behandeling van de rechtspositionele en functionele relaties reeds genoemde beperkingen. Voor Nederland brengt het een plicht tot terughoudendheid mee ten aanzien van ministeriële aanwijzingen. Voor Frankrijk leidt het tot rechtspositionele adviezen wan de CSM. Voor Italië ten slotte is het behoren tot de rechterlijke macht geheel verweven met de rechtspositionele en functionele onafhankelijkheid.

De collegiale samenstelling van de top van het Nederlandse OM betekent een belangrijk verschil in ministeriële invloed in specifieke strafzaken. Verder biedt de meer politiek-neutrale samenstelling van het Nederlandse ministerie de minister een minder directe greep op het OM. Ten slotte brengt de minder sterk politieke rol van de andere leden van de executieve in individuele gevallen meer autonomie mee voor het OM. Als gevolg hiervan lijkt de zelfstandigheid van het Nederlandse $O M$ in specifieke zaken groter te zijn dan in Frankrijk. 
In Frankrijk brengt de eén op één relatie een zwakkere positie mee voor de procureurgeneraal tegenover de minister. De politieke positie van de premier en de President dragen daaraan bij. Daar komt bij dat het Franse ministerie voor de minister een politieke handschoen vormt, die zijn belangen tegenover het OM kan behartigen. Door deze factoren kan de politiek de procureurs-generall sneller overvleugelen in concrete zaken. Het Franse OM heeft wel een grotere mate van vrijheid van beleidsprioriteiten. Het doorloopt geen planmatige beleidscyelus die de minister nauwgezet volgt. Het grote aantal procureurs-generaal maakt beleidscontrole een veef moeizamere zaak dan in Nederland.

Wel bestaat in alle behandelde landen een enigszins vergelijkbare vrijheid van beleidsvoering bij de keuze van de posterioriteiten door het OM. Hiervoor is zelfs in de Nederlandse politiek vrijwel geen aandacht. Het OM kan zo zelf bepalen welke posterioriteiten het stelt. 


\section{Hoofdstuk 6}

\section{Ratio en kritiek}

\section{Inleiding}

Quis custodiet psos custodes?

Decimus Junius Juvenalis, Satires, VI, 347

De kwestie van de autonomie of ondergeschiktheid van het OM ten opzichte van de minister van Justitie is gegrondvest op contrasterende rechtsbeginsellen. Deze voeden een niet aflatend debat met telkens terugkerende argumenten van legitimiteit en onpartijdigheid. Een meer systematische bespreking hierwan ontbreekt. Hieronder will ik niet zoals wel gebruikelijk is een opsomming geven van auteurs met hun standpunten. Veeleer wens ik een inhoudelijke indeling van redeneringen te hanteren. Dit draagt bij tot een structuur in de discussie, hetgeen het innemen van overwogen standpunten bevordert. In aansluiting op de voorgaande, meer beschrijvende delen is dit hoofdstuk sterk betogend van aard. Terwijl ik de argumentatie in de drie landen langsloop definieer ik een visie op de noodzaak van een mate van politieke zeggenschap over en autonomie van het OM. Dit hoofdstuk vormt de brug van de analyse van het bestaande recht naar een beschouwing over wenselijke wetswijzigingen. De conclusie leidt tot de wens van zekere aanpassingen van de geldende juridische verhouding tussen minister en OM.

Ik begin met het bezien van de ratio achter de invloed van de minister op de rechtspositie van leden van het OM. Het nauwe verband dat deze ratio heeft met die van de functionele ministeriële bevoegdheden, leidt tot een uitgebreide bespreking van die laatste. Hierbij komt een serie van argumenten aan bod waarvan er drie van veelomvattend belang zijn. Enerzijds bestaat de gedachte dat het handelen van het $O M$ democratische legitimatie behoeft. Anderzijds eist men dat dit orgaan onpartijdig functioneert. Een derde, tussenliggende idee ziet voor de minister een rol weggelegd bij de rechtsbescherming en -ontwikkeling. Een vergelijking en een afweging van deze standpunten leidt tot een conclusie over de wenselijkheid van onderschikking en autonomie van het $\mathrm{OM}$ in relatie tot de minister.

\section{Ratio ministerièle bevoegdheden ten aanzien van de rechtspositie van het om}

Waarom dient de minister al dan niet te beslissen over zaken als de benoeming van de leden van het $O M$ ? Expliciete argumentatie voor deze ministerièe zeggenschap is vrijwel niet alzonderlijk voorhanden. De reden voor rechtspositionele invloed lijkt ver bonden met die voor functionele invloed.

\subsection{Informatieschaarste over ratio rechtspositie}

$\mathrm{Bij}$ het verhelderen van het nut van mimisteriële beslissingsbevoegdheden over de rechtspositie van het OM valt een gebrek aan documentatie op.'

$1 \quad$ Op dit punt zou het interessant kunnen zijn om rechtsvergelijkend historisch onderzoek te verrichten 
Dit geldt woor alle landen, met op een onderdeel een symbolische uitzondering in Frankrijk.

De Neder andse literatur en de wetsgeschiedenis hebben weinig te melden over de redenen voor de vormgeving van de rechtspositie van leden van het OM. In de hedendargse discussie over de relatie tussen het OM en de minister speelt de rechtspositie van de eerste geen rol. De reente wetsgeschiedenis eind jaren negentig met betrekking tot de functionele bevoegdheden van de minister tegenover het OM spreekt zich evenmin uit over die rechtspositie. Deze situatie is opvallend. Terwijl de doctrine, de actoren en de wetgewende organen zich het hoofd braken over de aanwijzingsbevoegdheid van de minister, ontbrak ten enenmale een debat over de rechtspositie van het $O M$.

Een dergelijke houding is tevens zichtbaar in de recente rechtspositionele affaires van Drenth, Steenhuis en Docters van Leeuwen. De discussie in de zaak Drenth behandelde alleen de inhoudelijke kwestie, die van de gegrondheid van de aanwijzing. De vraag of en waarom de leden van het $O M$ door de minister disciplinair gesanctioneerd moeten worden speelde geen rol. Een zelfde lijn volgde men in de zaken Steenhuis en Docters van Leeuwen. Het onderwerp van discussie daarin was het gezag van de minister over het $\mathrm{OM}$ en de vraag of Steenhuis geen schijn van belangenverstrengeling had gewekt. De kwestie of de minister leden van het OM moet kunnen overplaatsen (Steenhuis) of ontslaan (Docters van Leeuwen) bleef buiten beschouwing. Hoogstens de wenselijkheid van het gebruik van die middelen in casu kwam aan de orde. ${ }^{2}$

Over de Franse redenen van de politieke bevoegdheden ten aanzien van de rechtspositie van het OM bestaan evenzeer weinig aanwijzingen. De literatuur richt zich met name op de argumentatie voor de bestaande beperkingen op die bevoegdheden. Auteurs en bewindslieden onderstrepen vaak de ratio voor nog door te voeren beperkingen. Daamee worden de onafhankelijkheid van de rechterlijke macht en een onpartijdige uitoefening van de vervolging geacht gediend te zijn. ${ }^{3}$ Waarom de minister en de President hun huidige bevoegdheden bezitten blijft daarbij buiten beschouwing. Weinigen geven blijk van een gedachtegoed omtrent het bestaan van deze bevoegdheden.

Voor de wijze van benoeming van de Franse procureurs-generaal bestaat nog wel cen specifieke reden. De benoeming door de President, via de ministerraad zou bedoeld. zijn om dit feit met plechtigheid te omgeven. Tevens zou het hun autoriteit vergroten ten aanzien van gedecentraliseerde organen en andere staatsorganen. ${ }^{4}$

In thalis ten slotte blijkt evenmin een afzonderlijke rechtspositionele argumentatie te bestaan. Veelal zet men rechtspositionele en functionele onafhankelijkheid tezamen

Voor de meningsbepaling in dit hoofdstuk is dit echter niet nodig. Zoals ik hieronder zal betogen geef de ratio achter de functionele ministeriële bevoegdheden namelijk de ratio achter de rechtspositionele bewogdheden. Voor de albakening van dit onderzoek in historisch opzicht, zie hoofdstuk 1, 2.6. Rechtsluistorie.

2 Zle over deze zaken hoofdstuk 2, 5.2. Overplatatsing en functiewijziging 5.6. Disciphinaire straffen en 5.7. Sehorsing en ontslag.

3 Zie 7. Rechisstatelijke ratio voor autonomie.

4 Jacquin (Colleu) 1997, p. 12; Nallet, Commission de réflexion sur la Justice, Annexes 1997, p. 45;

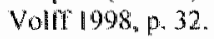


scherp af tegenover rechtspositionele en functionele onderschikking. In feite vormen de rechtspositionele en functionele redeneringen één geheel. Een losstaande redengeving achter de rechtspositie op zich komt aldus niet naar voren. ${ }^{5}$

Internationale aanbevelingen omtrent de positie van het $\mathrm{OM}$ nemen nauwelijks op expliciete wijze stelling omtrent de rechtspositionele verhouding tussen regeringen en vervolgende ambten. Sommige verklaringen eisen wel eerlijke procedures, objectiviteit en redelijkheid in besluitvorming omtrent selectie, bevordering, bezoldiging en disciplinaire straffen. Daarbij blijft onderbelicht wat dit voor gevolgen zou moeten hebben voor de zeggenschap van politieke ambten in rechtspositionele beslissingen. ${ }^{6}$

\subsection{Samenvallen functionele en rechtspositionele ratio}

Een zelfstandige ratio achter de rechtspositie van het OM lijkt aldus vrijwel niet geexpliciteerd. Een vraag is of de ratio voor de functionele positie van het $\mathrm{OM}$ welicht betekenis heeft voor diens rechtspositie. In het vorige hoofdstuk bleek namelijk reeds dat de facto de aard yan de rechtspositie de aard van de functionele relatie beïnvloedt. Nader bezien lijkt de ratio achter de rechtspositie van het $O M$ in feite samen te vallen met de ratio achter de functionele ministeriële bevoegdheden ten aanzien van het $\mathrm{OM}$.

Een dergelijke conclusie volgt in Nederland wel impliciet uit de ministeriële stellingname in de aanloop naar de wijziging van de Wet RO eind jaren negentig. Minister Sorgdrager beweerde dat in 1827 de aanwijzingsbevoegdheid zou zijn opgenomen "om zeker te stellen dat, evenals de niet voor het leven benoemde ambtenaren van het $O M$, ook de voor het leven benoemde ambtenaren onderworpen waren aan de zeggenschap van de uitvoerende macht'. De procureurs-generaal en de hoofdofficieren van justitie waren in de grondwet van 1815 namelijk nog voor het leven benoemd. ${ }^{8}$ Afgezien van de onjuistheid van de stelling, ${ }^{9}$ valt een verborgen redenering te ontwaren: de benoe-

5 Deze koppeling van de aard wan de rechtspositie en de functionele positie is meestal verbonden an de tegenstefling tussen het opportuniteits- en legaliteitsbeginsel. Zie 4,5.2. Discretie door opportuniteitsbeginsel.

6. Arit. $2,6,7,21$ en 22 van de aanbeveling van de VN (hierna: VN), art. 5 van de aubbeveling van de Raad van Europa (hierna: RvE) en art. 6 van de Standards van de International Association of Prosecutors (hierna: LAP). Deze laatste noemt de rechtspositionele eisenn wel in de context van de bescherming tegen willekeurig handeten door regeringen. Alleen art. 6 van de Decharation de principes sur le minis. tère public van de Magistrats Européens pour la Dénocratie et les Libertés (hierna: MEDEL) eist dat een Conseil Supérieur de zeggenschap moet hebben over de rechtspositie van hel OM. De conclusies van de European Union Noordwijk conference (hierna: EU) melden niets specifiek ontrent de rechtspositie. Over al deze aanbevelingen: hoofdstuk $1,2.7$. Internationaal recht.

7 Hoofdstuk 5, 4. Conclusie rechtspositie en functionele positie.

8 Kamerstukken II 1995/96, 24034, nr. 13, p. 4; vgl. cok Pieterman 1997, p. 144. Art. 186 Giw' 1815 - 'De leden en ministers van den Hoogen Raad, de provineiale Geregtshoven en criminele Regtbanken, benevens de Prokureurs-Generaal, en Hoofdofficieren bij dezelve, worden woor hun leven aangesteld. - De wet regelt den tijd der bediening van andere regters en regterlijke ambtenaren. - Geen regter mag gedurende den bepaalden tijd zijner bediening, wan zijnen post worden ontslagen, dan op eigen verzock of bij regterlijk vonnis". Bij de grondwetswijziging van 1848 werd alleen nog de procureur-generaal bij de Hoge Raad woor het leven benoemd.

9 De minister ziet in haar "kleine historische excursie" overigens over het hoofd dat nast de anwijzings- 
ming voor het leven van die leden van het OM destijds zou blijkbaar een obstakel voor ministeriële beïnwloeding gevormd hebben. Hadden deze leden dus geen rechtspositionele bescherming gehad, dan had de regering het handelen van het $\mathrm{OM}$ kunnen beinvloeden via ontslagbevoegdheden. Impliciet erkent de minister hier dat rechtspositionele bevoegdheden het doel kunnen hebben om het handelen van het $O M$ te sturen. De vraag waarom de minister aan het functionele stuur van het $\mathrm{OM}$ zou moeten zitten wordt niet gescheiden wan de ratio achter de rechtspositie.

Men stelt in Nederland echter niet dat de ratio van de rechtspositie van het Nederlandse $O M$ in verband staat met de ratio achter functionele bevoegdheden van de minister. Doctrine en wetgever lijken er eigenlijk vanuit te gaan dat die bevoegdheden geen invloed van betekenis hebben op het handelen van het OM. Onduidelijk is echter waarom de minister dan wèl rechtspositionele bevoegdheden ten aanzien van het OM zou moeten hebben. Als die bevoegdheden geen functionele relevantie hebben kan de rechtspositie van het OM dan niet evengoed gemodelleerd worden naar die van de rechtsprekende leden van de rechterlijke macht? ${ }^{10}$

Een enkele Franse auteur - Rassat - zegt expliciet in de aard van de functionele bevoegdheden van de minister een verklaring te zien voor diens rechtspositionele bevoegdheden. De minister is op zich namelijk niet in staat om de leden van het OM te dwingen zijn bevelen feitelijk uit te voeren. Dit zou een verklaring vormen voor de sterke rechtspositionele onderschikking van het $\mathrm{OM}$. Zonder deze onderschikking zou de regering de gewenste uitoefening van de vervolging niet kunnen afdwingen." Andere Franse schrijvers zijn niet dermate expliciet. Wel zien zij dat rechtspositionele ministeriële bevoegdheden ook functionele invloed hebben. Het doel achter functionele bevoegdheden wordt zo mede nagestreefd door middel van rechtspositionele bevoegdheden. ${ }^{12}$

bevoegdheid een artikel 12 We RO werd ingevoerd. In deze bepaling werd 'de Koning' de bevoegdheid gegeven leclen van het OM, gehoond de Hoge Rad, te ontslam. Dit was mede mogelijk bij "merkelijke achkeloosheid. Gexien de onbepaldheid van dit begrip zou het de minister weinig moeite hebben gekost wen gewersst ontslag op deze grond te motiveren. Bij de totstandkoming van de wet RO wees de kamer wel op de strijdigheid met de grondwet, die deze bepaling opleverde. Volgens artikel 186 zou "geen regter" kunnen worden ontslagen dan bij rechterlijk vonnis of op eigen verzoek. De minister was van mening dat de grondwetsbepaling alleen voor leden wan de rechtsprekende colleges gold.

A t. 12 Wet RO 1827 "Elke Regter of Griffier die tot eene correctionele straf mogt zijn weroordeeld, kan, op requisitoir van den Procureur Generaal, door den Hooge Raad worden ontzet, wa in zijne belangen te zijn gehoord. - Gelijke ontzetting kan op dezelfde wijze worden geworderd en uitgesproken Megens wangedrag, onzelelijkheid of merkelijke achuteloosheid. - Indien een ambtenaar van het $O M$. zich in een der gevallen wan dit artikel mogt bevinden, als deszelfs ontzetting, na dat de Hooge Rand daaromtrent zal zijn gehoord, door den Koning kunnen gedaan worden'. De kamer: Bijlage Handelingen II 1826/27, hr. XIII-3A, p. 382,390, 409. De minister: Bijlage Handelingen II 1826/27, nr. XIII3 B, p. $447-448$.

Uit deze analyse blijkt dat de artikel 5 niet ingevoerd is omdat de belangrijkste leden wan het $O M$ woor het leven benoend waren. Zie nede hoofdstuk 2,6.2,1. Grondslag aanwijzingsbevoegdheid.

10 Zie 9. Samenvating en conclusie en hoofdstuk 7,6.2. Hervorming van de rechtspositie van het $O M$.

11 Russat 1967, p. 53,251. Impliciet zo: Boudon 1997, p. 9.

12 Zie met name 7.4.1. Partijdigheid door ministeriêle invloed. 
De ltaliaanse doctrine legt ook een verband tussen de ratio van de functionele relatie en die van de rechtspositie van het $O M$. Zoals gezegd in de vorige paragraaf gaan voor de meeste auteurs die twee logischerwijs samen. De onafhankelijkheid van ministeriêle bevelen hangt bijna vanzelfsprekend samen met rechtspositionele onafhankelijkheid. Als de minister daarentegen een aanwijzingsbevoegdheid zou krijgen zou hij volgens sommigen ook bevoegdheden ten aanzien van de rechtspositie moeten bezitten. Anders zouden de andere bevoegdheden van de minister een dode letter blijven. Het OM zou twee heren moeten dienen - de minister en het recht - en in een conflictpositie komen. ${ }^{13}$ Enkelen menen dat een functioneel ondergeschikt $O M$ wèl rechtspositionele onathankelijkheid zou behoeven. Hiermee zou het OM zich kunnen weren tegen een arbitrair gebruik van rechtspositionele sancties, als reactie op een weigering door het OM van een bepaald handelen. ${ }^{14}$ Deze auteurs gaan blijkbaar eveneens uit van de veronderstelling dat de bedoelde rechtspositionele bevoegdheden het handelen van het OM beĩnvloeden Deze opvatting sluit aan bij de gedachte dat de ratio achter de functionele en rechtspositionele bevoegdheden eén geheel vormt.

\subsection{Conchusie}

In de drie landen bestaat vrijwel geen afzonderlijke ratio achter de rechtspositie van leden van het OM. Frankrijk en Italie huldigen de opvatting dat de functionele ratio direct samenhangt met de rechtspositionele. Het doel van de functionele relatie tussen het $\mathrm{OM}$ en de minister wordt mede nagestreefd door rechtspositionele bevoegdheden. De redeneringen achter de functionele en rechtspositionele aspecten van het stelsel vallen aldus samen. Deze conclusie sluit aan bij de vaststelling uit het vorige hoofdstuk dat de vormgeving van de rechtspositionele relatie die van de functionele beïnvloedt. Het huidige Nederland volgt deze gedachtegang nergens met zoveel woorden. De rechtspositie van leden van het $\mathrm{OM}$ is in feite geen issue. Een discussie hierover moet zich in feite baseren op argumenten die pleiten voor of tegen functionele bevoegdheden van de minister. Dan is het dus nu van belang deze functionele ratio zelf te onderzoeken.

Wanneer ik de redenering achter de functionele relatie tussen minister en OM heb besproken, kan ik daar tevens conclusies uittrekken ten aanzien van de rechtspositie. De vraag is dan wat de steekhoudendheid van de functionele argumentatie voor gevolgen moet hebben voor de inrichting van de rechtspositie. De normatieve gerechtvaardigdheid van een bepaalde functionele relatie brengt consequenties mee voor de wenselijkheid van een bepaalde rechtspositie. In paragraaf $9 \mathrm{ga}$ ik hier nader op in.

13 Neppi Modona 1987, p. 67-68; Caravita 1991, p. 307; Devolo 1996a, p. 2043; Zanon 1996, p. 208-209. Overigens wijst men erop dat toekeming van rechtspositionele bevoegdheden zou betekenen dat de artl. 104-107 Cost. over de status wan magistraten tevens gewijzgd moeten worden, omdat een dergelijk systeem in strijd zou zijn met de grenzen vain de huidige grondwettelijke retatie tussen minhster en OM.

14. Dominioni 1979 , p. 77. Specifiek ten aanzien van de bewoegdheid een disciplinaire atctie in te stellen: Cambba 1974, p. 103. 


\section{Ratio functionele relatie minister en $\mathrm{OM}$}

Functionele ministerite bevoegdheden over het $\mathrm{OM}$, of het ontbreken daarvari, weten zich gesteund door een reeks samenhangende argumenten. Deze kumen in een gestructureerd betoog grofweg uiteenvallen in twee redeneerlijnen. Een eerste wijst in de richting van de rechtswaarde van democratie. Een tweede baseert zich uiteindelijk op het beginsel van de rechtsstaat.

Zoals betoogd in de inleiding is het hier niet mijn bedoeling het gedachtegoed omtrent rechtsstaat en democratie uiteen te zetten. ${ }^{15}$ Noch wil ik hier een eigen algemene visie toevoegen. In het navolgende richt ik mij slechts op enkele specifieke eisen die in verband gebracht kunnen worden met érn van de of beide concepten. Ten behoeve van een overzichtelijke structuur behandel ik argumenten voor onderschikking onder de vlag van de democratie. Redeneringen voor autonomie groepeer ik onder de wimpel van de rechtsstaat. Hoewel deze rechtswaarden in het algemeen niet geheel gescheiden gezien kunnen worden, wil ik hier wel voor de inzichtelijkheid van een analytische beschouwing een onderscheid maken.

Eén groep opvattingen voor ondergeschiktheid is minder klip en klaar in te delen. Het betreffen de ideeën die de minister tegenover het OM de taak van rechtsbescherming, rechtmatigheidscontrole en rechtsontwikkeling toebedelen. Deze argumenten behandel ik dan ook afzonderlijk.

Meer concreet richt de eerste redenering zich op de eis van een democratische grondslag van het handelen van het $\mathrm{OM}$. Ter voldoening aan die eis zou het OM onder zeggenschap van een minister moeten staan. Deze legt op zijn beurt verantwoording af tegenover een door het volk gekozen parlement. Het OM en de uitoefening van zijn bevoegdheden worden aldus democratisch gelegitimeerd: een volksvertegenwoordigend ambt, of een ambt dat van laatstgenoemde afhankelijk kan de beslissingen van het OM alsdan inhoudelijk bepalen. Ministerięle zeggenschap dient op deze wijze democratische legitimatie of legitimiteit. ${ }^{16}$

De tweede denkwijze heefit het oog gericht op de rechtsstatelijkheid van de positie van het OM. In samenhang met de eisen van onafhankelijkheid van de rechterlijke macht, fair trial en de bescherming van grondrechten geldt de eis van een onpartijdigheid van het $\mathrm{OM}$ in het strafproces. Deze onpartijdigheid zou gewaarborgd kunnen worden door een onafhankelijke positie van het $O M$ in relatie tot de regering: het $O M$ zou objectieve beslissingen kunnen nemen, vrij van institutioneel bepaalde partijpolitieke inmenging.

I5 Zio hoofdstuk 1, 2.5. Rechtsfilosofie.

16. Democratsche legitumatie en legitimiteit worden hier als synoniemen gebrukt, aangezien dit hoofdstuk normatiel van toon is. In een meer neutral beschrijvende takst zou een ondersoheid gemakt kunnen worden ussen de vragg naar de legitimatie: "hoe handhate de overheid zich, hoe verkrijgt zij) (feitelijk) legitimiteit?" an de vragg naar de legitimiteit. 'heeft een overheid(shandelen) recht van bestaan?' (normatiel). Zie verder 4. Legitimiteit: ratio voor onderschikking. 
Vormen van autonomie, waaronder onafhankelijkheid, staan aldus in functie van de onpartijdigheid."

Zo geformuleerd zouden deze twee eisen tot een botsing leiden van twee ogenschijnlijk onverenigbare rechtsfiguren: ondergeschiktheid en politieke verantwoording tegenover onafhankelijkheid en onpartijdigheid.

Een derde categorie van gedachtestromen loopt hier nog doorheen. Zij ontspringen niet eenduidig uit een democratieidee of een rechtsstaatconcept. Genoemde gedachten monden uit in ministeriële rechtmatigheidscontrole over het $\mathrm{OM}$ en een ministeriële taak tot rechtsontwikkeling.

De onderzoeksvraag in de volgende paragrafen is naar de steekhoudendheid van deze redeneringen. De aan de genoemde botsende stelsels ten grondslag liggende rechtswaarden of eisen zijn niet op zich al onverenigbaar met elkaar. Geen van beide begiselen prevaleert principieel boven de andere. Kan een minder digitale "of-of" redenering een samenhangende uitkomst bieden? Zijn rechtsfiguren denkbaar die tegemoet komen aan beide eisen? Voor een antwoord dienen de volgende dilemma's opgelost te worden: hoe is onpartijdigheid mogelijk bij ondergeschiktheid? Of hoe is legitimatie mogelijk bij onafhankelijkheid?

In de praktijk van de drie bestudeerde landen wordt steeds gepoogd recht te doen aan deze eisen. Zo bestaat een Nederlandse tegemoetkoming aan de onpartijdigheidseis uit de gewoonte van de minister om vrijwel geen algemene en bijzondere aanwijzingen te geven aan het OM. Frankrijk sluit daarenboven bepaalde specifieke aanwijzingen uit. In Italië legt de minister tegenover het parlement verantwoording af voor het handelen van het $O M$ zoals dat in de andere twee landen gebeurt.

Is de verscheidenheid in de stelsels gegrond in afwijkende opvattingen over legitimiteit en onpartijdigheid? Hoe zijn de genoemde argumenten vormgegeven? Zij verschijnen in een serie onderbouwde subargumenten die ik nader wil beschouwen. Ik begin hier met de legitimatie-eis. Na een algemene beschouwing over dit onderschikkingsconcept in paragraaf vier, spits ik mijn betoog toe op de legitimatie van specifieke strafrechtelijke handelingen in een vijfde paragraaf. In paragraaf zeven behandel ik rechtsstatelijke redeneringen ten faveure van autonomie. Daarvóór richt ik mij echter in paragraaf zes op een derde gedachtegang met betrekking tot ministeriële rechtsbescherming, rechtmatigheidscontrole en rechtsontwikkeling.

\section{Legitimiteit: ratio voor onderschikking}

Waarom moet de politiek het handelen van het OM kunnen bepalen? Welk aspect van de aard van het $\mathrm{OM}$ of diens handelen vereist een band met de minister of het parlement? De legitimatiekwestie is complex en moeilijk met precisie te duiden. Een eerste afbakening kan beginnen met het aangeven van uitersten. Bestaat een algemene eis dat al het overheidshandelen onderwerp moet zijn van ministerêle verantwoording? Dia-

17 Onathankelijkheid is in de hier gebruikte terminologie dus geen doel op zich, maar kan zowel de objectieve (institutionele) als de subjectieve (persoonlijke) onpartijdigheid dienen. Zie verder 7.4. Onpartijdige partij. 
metraal daartegenover staat de vrag of het legitimatieconcept ten aanzien van het $O M$ niet enkel een formeel begrip is. Na een bestrijding van deze extremen behandel ik de eigenlijke legitimatieargumenten.

Moef ten eerste elke handeling van de centrale overheid democratisch gelegitimeerd worden via de ministeriële verantwoordelijkheid? Een reeks Nederlandse auteurs bestrijdt dit. ${ }^{18}$ Het bestaan van onafhankelijke rechters en zelfstandige bestuursorganen bewijst de ongegrondheid van de stelling. Dientengevolge kan daarmee niet tot onderschikking van het OM worden geconcludeerd. Franse critici zijn van mening dat er geen democratisch principe bestaat dat in het algemeen eist dat het handelen van het OM door de regering gecontroleerd moet worden. ${ }^{19}$ In Italie hoort men nog wel dat 'het" principe van de democratie met zich brengt dat vormen van uitoefening van bevoegdheden zonder democratische legitimatie zoveel mogelijk uitgesloten moeten worden ${ }^{20}$ Maar er is geen grond voor de algemene stelling dat een systeem meer of minder democratisch is indien het OM ondergeschikt is aan politieke organen of onafhankelijk. ${ }^{21}$ Het OM behoeft dus geen onderschikking aan de politiek enkel omdat het deel uitmaakt van de overheid en bevoegdheden uitoefent: een zo algemene eis van verantwoording valt niet te onderbouwen.

Enkele Franse auteurs onderstrepen omgekeerd dat de legitimatievraag een fundamentele, maar in wezen een formele kwestie is. Het antwoord hierop kan dan eveneens formeel zijn. Zij zijn dan ook van mening dat de legitimiteit van het $O M$ in feite op grond van de wet verzekerd wordt. Het handelen van de leden van het OM heeft zijn basis in en moet conform zijn aan de op democratische wijze tot stand gekomen wet. De legitimiteit zou in deze visie verbonden zijn aan fundamentele beginselen van de rechtsstaat, zoals de onafhankellijkheid van de rechterlijke macht van de regering. Waarborgen van rechtmatigheid en objectiviteit zouden het $O M$ een vorm van legitimiteit kunnen geven die niet onder zou doen voor andere vormen. ${ }^{22}$

Deze extreme positje overtuigt niet. Onduidelijk is wat men verstaat onder een 'formele kwestie". Als men daarmee zou doelen op het procedurele karakter van de legitimatie snijdt de redenering geen hout. Geeft de wet dan "legitimerende procedures"? Welke (strafrechtelijke) procedure legitimeert de beleidswoering van het OM? Wellicht be-

18 Duisterwinkel 1968a, p. 111: Van der PodDonner 1968, p. 315; Warmelink 1994, p. 115; Den Boet 1999.0 .6$.

19 Bouwier, Jacquin \& Vogelweith 1997 , p. 38.

20 Pizzorusso 1979, p. 36 en 41, zie ook de ltalianse auteurs in hoofdstuk 4, 7. Verantwoording voor het OM.

21 Nuvolone 1983 , p. 375 , Valentini Reuter 1994, p. 39.

22 Maynier \& Casorla 1993, p. 544; Ph. Robert 1996, p. 155; Pradel \& Laborde 1997, p. 142; Accomando 1997 a, p. 94. Pradel \& Latborde menen echter dat het hoofd van het OM gekozen moet worden door het parlenent tel behoeve van een bepaslde democratische legitimatie. Voor het overige zou het $O M$ rechispositionele en functionele onathankelijkheid kunnen bezitten, zie hoofdstuk 7,3.6. Procureurgeneraal "de Ia Nation". Accomando accepteert wel de ministeriele bevoegdheid tot het geven van algemene aamwijzingen. Sommige auteurs gaan verder in hurn kritiek en zien in het opwerpen wan de legitimiteitskwestie zelfs een politieke manouvre on een partijdige controle op gevolige zaken te rechtwardigen. Bouvier, Jacquin \& Vogelweith 1997, p. 36-37. 
doelt men dan slechts met "formeel" dat de kwestie praktisch niet erg wan belang is. Maar een dergelijke stelling zou enkel de vraag ontwijken of en warom het handelen van het $\mathrm{OM}$ wel voldoende gelegitimeerd zou zijn. Waarom zou hetzelfde net moeten gelden voor bijvoorbeeld gewone ministeries? Democratie een formeel begrip noemen vormt kortom geen helder pleidooi voor een autonoom OM.

Tuussen deze twee uitersten wil ik nu de legitimatiedoctrine bespreken. Deze valt unteen in een reeks subargumenten die elk het handelen of de rol van het $O M$ betreften. Achtereenvolgens behandel ik hier het argument van de rechter als anomalie en de opvatting van het OM als regeringsvertegenwoordiger. Dan volgen de stellingen van het handelen van het OM als regeringszaak, als politieke aangelegenheid of zaak van algemeen belang. Aansluitend noem ik de gevolgen toegedicht aan het opportuniteitsbeginsel en het argument van de beleidsvrijheid.

\subsection{Onahankelikheid van de rechter als anomalie}

Een eerste argument is de vooral in Nederland opgeworpen gedachte dat de onafhankelijke rechter eigenlijk een anomalie zou zijn in de democratische staat. Ter compensatie zou het OM ondergeschikt moeten zijn aan de minister. Deze redenering vormt in feite een wegcijferen van rechtsstatelijke eisen.

Sommigen Nederlandse auteurs meenden daarom dat de onafhankelijke strafrechter zou bestaan 'bij de gratie van een athankelijk OM'. "Ondat de strafrechter niet tot democratische verantwoording is gehouden, en ondat die rechter anderzijds onder controle staat van het $\mathrm{OM}$, juist daarom dient mijns inziens in een democratische staat dat OM zijnerzijds weer te staan onder een zeker gezag van de kant van de regering". 24 In deze redenering zou er geen onafhankelijke rechter kunnen zijn, zonder een daaraan gekoppeld OM dat afhankelijk is van de minister. Hiermee hangt samen dat de rechter afwacht of een strafzaak aan hem wordt voorgelegd. Het initiatief tot een strafrechtelijke procedure ligt bij het OM. In die zin 'controleert' het OM het handelen van de rechter. Alleen als het OM afhankelijk is van de regering zou de onathankelijkheid van de rechter zijn te rijmen met de democratie.

Ook enkele Italiaanse auteurs gaan zover te stellen dat een onafhankelijk OM het moeilijker maakt de onafhankelijkheid van de rechter te rechtvaardigen. Dit wordt beargumenteerd met de eis dat de uitoefening van bevoegcheden in beginsel democratisch gelegitimeerd dient te zijn. De volledige onafhankelijkheid van de rechter zou enige vorm van institutionele afhankelijkheid van het $O M$ met zich moeten brengen. Het OM zou zo een tegenwicht kumnen vormen voor de macht van de rechters. ${ }^{25}$

23 Hartsuiker 1968, p. 73

24 Enschede 1968 , p. 78-9. Vgl. Oranje 1976, p. 25; Corstens 1997, p. 224. Corstens spreckt met betrekking tot de rechter van een "corpus altenum in de democratische rechtsstaait."

25 Guarnieri 1984, p. 158-159; De Luca 1991, p. $221-222$. 
Met Duisterwinkel is het mij echter niet duidelijk waarom een onafhankelijke rechter een afharkelijk OM behoeft. ${ }^{26}$ Fundamenteel is de vraag of nog van een democratische (rechts)staat gesproken kan worden als de rechters daarin niet onafhankelijk zijn. De onafhankelijkheid wan de rechter is een algemeen aanvaard beginsel dat op zich staat, (ook) los van de vraag naar de institutionele positie van het OM. Het is dan wat vergezocht om de afhankelijkheid van het OM als een vereiste te zien voor die rechterlijke onafhankelijkheid. De legitimatiekwestie van de rechter is niet afhankelijk van het onderschikkingsvraagstuk van het $\mathrm{OM} .^{27}$

Overigens bestaan wel een aantal Europese democratieën waar het OM niet onder het gezag van de regering valt: Voorbeelden zijn, naast Italiê: Finland, Portugal, Slowakije en Zweden. Moeilijk valt vol te houden dat zij alle anomalistische rechtssystemen zijn.

\subsection{Bestuursorgaan of regeringsvertegenwoordiger}

Een volgende redenering in zowel Nederland als Frankrijk is te stellen dat de regering het OM moet aansturen omdat het een bestuursorgaan is of een regeringsvertegenwoordiger. Een dergelijk orgaan zou als vanzelfsprekend onder de zeggenschap van de regering moeten staan. Het belangrijkste bezwaar tegen het onderhavige argument is het in Nederland en Frankrijk voortdurende debat over de kwalificatie van het OM als een bestuursorgaan - of niet.

In Nederiand zou er in het algemeen "geen bestuursorgaan (zijn) dat een bevoegdheid kan uitoefenen zonder dat op die uitoefening controle bestaat'. Dit zou ook gelden voor het $\mathrm{OM}$, dat gecontroleerd zou moeten worden door de minister. ${ }^{28}$ Men volgt twee redeneringen om te concluderen dat het $\mathrm{OM}$ een bestuursorgaan is. Enerzijds via de aanwijzingsbevoegdheid, anderzijds door een inhoudelijke vergelijking met andere ambtelijke diensten.

Het OM wordt regelmatig een 'bestuursorgaan' genoemd, met allerlei variaties in de naamgeving daarop. Het OM zou in wezen niet anders zijn dan een 'rijksdienst', 'de vertegenwoordiger van de centralle overheid', 'de vertegenwoordiger van het bestuur bij de rechter", 'deel van de administratie', 'een administratief orgaan' of een 'bestuursdienst'. Deze kwalificaties worden steevast beargumenteerd met het bestaan van de ministeriële aanwijzingsbevoegdheid. ${ }^{29}$

27 Inapliciet kumnen voorstanders van dit argument doelen op het feit dat het OM besluit over het al dan miet nemen van het initiatief tot verwolging, en dat het daarbij een zekere discretie vitoefent. Zie daarover: 4.6.1. Discretie en initiatief.

28 Hirsch-Baltin. Kamerstukken II 1992/93, 22800 VI, ar. 2, p. 7. De wrage of al het optreden wan de centrate overheid an mimisteriële verantwoordelijkheid onderworpen dient te zijn kwam eerder aan bod. Zie 4. Legitimiteit: ratio voor onderschikking. De vragg of die controle in de handen van de minister een vorm van rechtsbescherming of rechtmatigheidscontrole kan vomnen komt hierna aan bod. Zie 6.1. Rechtsbescherning en rechtmatigheidscontrole.

29 Rijksdienst: Stellinga 1953, p. 418. Vertegenwoordiger van de centrale overheid: Duisterwinkel 1968 , p. 202; 1965, p. 5. Vertegenwoordiger van het bestuur bij de rechter: Mostert 1968, p. 310; De Beaufort 1979, p. 167. Administratie: Wiewel 1991 , p. 13 (hij noemt mede het disciplinair toezicht als argumentatie). Administratief orgaan: Osinga 1992, p. 71. Bestuursdienst: Elzinga 1994, p. 534; Elzinga \& 
Ik behandel hier niet de vraag of de aanwezigheid van een ministerièle aanwijzingsbevoegdheid een instelling tot een bestuursorgaan maakt. Het volstaat te noteren dat de onderschikking van het OM hier als reden dient voor de kwalificatie "bestuursorgaan". Logischerwijs kan het zijn van bestuursorgaan dan niet dienen als reden voor de onderschikking. Dat zou een cirkelredenering vormen.

Andere Nederlandse auteurs kijken meer inhoudelijk naar de rol of het handelen van het OM, om te concluderen dat het een bestuursorgaan is. Wat dit betreft zou er geen verschii zijn met andere, 'gewone' ambtenaren, die aan de regering ondergeschikt zijn. Ook andere ambtenaren moeten grond- en mensenrechten en de algemene beginselen van behoorlijke procesorde respecteren. $\mathrm{Zij}$ dienen zich te richten naar de maatstaven die de rechter bij de toepassing van de wet aanlegt. Gewone ambtenaren en die van het OM zouden kortom dezelfde houding (moeten) hebben. De onjuistheid van deze redenering zal ik in paragraaf 7 bespreken. ${ }^{30}$

Het OM wordt ten slotte vaak uitdrukkelijk geen bestuursorgaan genoemd. Geregeld wordt het $\mathrm{OM}$ in Nederland een bijzondere middenpositie toegekend. Het $\mathrm{OM}$ is dan een orgaan van een geheel eigen soort, dat een plaats heeft tussen rechter en bestuur in, een rechterlijk orgaan én een bestuurlijk orgaan of een gedeconcentreerd gerechtelijk bestuursorgaan. " Verscheidene malen noemde men het $\mathrm{OM}$ ten slotte een zelfstandig bestuursorgaan avant la lettre, een verzameling in hoge mate zelfstandige bestuursambtenaren of gewoon een zelfstandig bestuursorgaan. ${ }^{32}$

In Frankrijk loopt een vergelijkbaar debat. De magistraten van het Franse OM worden wel de vertegenwoordigers of de woordvoerders van de executieve bij de rechtbanken of de woordvoerders tegenover de rechterlijke macht genoemd. Drago stelt dat de vervollging ingesteld wordt in naam van de staat, vertegenwoordigd door de regering. De bovenstaande kwalificaties van het OM worden vervolgens impliciet of expliciet in verband gebracht met de functionele hiërarchische bevoegdheden van de minister over het OM. Als het OM de vertegenwoordiger is van de regering, moet deze laatste de eerste toch instructies kunnen geven, is de (niet altijd even uitgesproken) redenering. ${ }^{33}$

Koopman 1994, p. 230; Brennirkmeijer 1995, p. 211; RPF tractie in Kamerstukken II 1997/98, 25392, nr. 6, p. 5. Bestuursorgaan: Kamerstukken II 1995/96, 24034, nr. 13, p. 7-8; Roben 2001, p. 93.

30 Zie de auteurs genoemd in 7.4.2. Onpartijdigheid als andere ambtenaren?

31 Orgaan van een geheel eigen soort: Hartsuiker 1978, p. 123. Een plasts tussen rechter en bestur: Mostert 1968, p. 314; Hartsuiker 1978, p. 123, Herstel 1978, p. 72; Singer-Dekker 1982, p. 116. Rechterlijk orgaan én een bestuurlijk orgaan: Jaarverslag OM 1986, p. 17; Meijers 1987a, p. 125; De Doelder 1996a, p. 297. Gedeconcentreerd gerechtelijk bestuursorgaan: Enschedé 1980, p. 87. De Doelder 1994, p. 450 stelt dat de bestuurlijke met de "magistratelijke" positie kan samengaan.

32 Avant lat lettre: Enschedé 1980, p. 89. Een verzaneling in hoge mate zeltstandige bestuursambtenaten: Van Maarseveen 1983, p. 176. Zelfstandig bestursorgaan: Borman 1981, p.103-104; minister Korthals Altes noemt het OM eveneens zo, maar vindt vervolgens weer dat het beter in de callegoric "buittendiensten" valt, omdat de beinvloedingsmogelijkheden van de minister niel door de wetgever beperk. zijn, 1988, p. 370-371.

33 Woordwoerders van de executieve: Jéol 1994, p. 1364; Béteille, Commission de réflexion sur la lustice, Annexes 1997, p. 58; Pinot de Villechenon 1997, p. 824; Perrot 1998, p. 39 (natar miet de vertegenwoor. diger wan de staat, p. 404); Zoller 1999, p. 343; Vincent e.a. 1999, p. 120 en 556; Stefian, Levasseur \& Boulloc 2000 , p. 133 De laatsten gebruilken elders, p. 137, zelfs het begrip "dienaars van de executieve", Deze auteurs zijn overigens weer wel wan mening dat de wervolging in naam van de matschappij 
Daarentegen kwalificeert een andere groep auteurs het Franse OM in mildere termen: als de vertegenwoordiger of zelfs de advocaat van de natie, de Republiek of de maatschappij, of ook de vertegenwoordiger van de wet. Enkelen die deze kwalificatie verdedigen, menen dat het OM mede daarom functionele of rechitspositionele autonomie moet bezitten. Anderen gebruiken deze termen evenzeer om ministerielle inwloed op het OM te verdedigen. Sommigen gebnuiken beide typen van termen om het $O M$ te kwalificeren, ${ }^{34}$

Deze verschillen in kwalificaties van het OM zijn opmerkelijk. Het is verder de vraag hoe het $O M$ de vertegenwoordiger van de regering tegenover de rechterlijke macht genoemd kan worden als het zelf deel van uitmaakt van die macht. De terminologie wordt dan inconsistent gebruikt:

De uitdrukking van 'vertegenwoordigers van de executieve" stamt overigens uit een Franse wet van 1790 die geen gelding meer heeft. Dit woordgebruik zou in feite een historische vergissing betreffen. Vòor de revolutie waren de leden van het toenmalige OM de 'vertegenwoordigers van de Koning'. De Koning was destijds houder van de soevereiniteit (pouvoir souverain). De revolutionairen deden de soevereiniteit van de Koning op 'de natie' overgaan, niet op de executieve. De procureurs hadden dan ook als de "vertegenwoordigers van de natie" gekwalificeerd moeten worden. De traditionele conceptie van het $O M$ als vertegenwoordiger van de regering kan in ieder geval met recht anachronistisch genoemd worden. ${ }^{35}$

platsvindl. Andere auteurs gebruiken dit begrip echter juist om te zeggen dat het OM juist niet de vertegenwoordiger van thet $\mathrm{OM}$ is. Deze begripsvermenging benadrukt de beperkte relevantie van dergelijke temen. hn naam van de staat vertegenwoordigd door de regering: Drago, Connnission de réllexion sur la Justice, Annexes 1997, p. 163.

34 Vertegenwoordiger wan de natie/Republiek maatschappij: Rassat 1967, p. 141; Rassat 1993, p. 235; Aguila 1994, p. 10; Malibert 1994, p. 4 en 7; Chalandon, Commission de réflexion sur la Justice, Annexes 1997, p. 22; Foyer, idem, p. 26; Béteille, idem, p. 55; Josserand 1998, p. 315; Volff 1998, p. 20-23; Chrestia 2000, p. 773; Perrot 1998, p. 413: Stefani, Levasseur \& Boulloc 2000, p. 127 stellen enkel dat do vervolging zelf in nam van de mastschappij geschedt. Vertegenwoordiger van de wet: Bigot 1992, p. 590 . Met name Rassat is voor afschaffing wan individuele adumijzingen en een autonome rechtspositio. Dit latatse wordt ook door Volff ondersteund. Foyer en Béteille bijwoorbeeld verdedigen de bevelsbevoegdheid in individuele zaken. Overigens is de terminologie gebruikt in bepalde belasstingriaudezaken met betrekking tot tabak opmerkelijk. In ten groot deel van de zaken is het de belasthighadministratie zelf die belastingdelicten vervolgt, terwijl het OM de vervolging doet waar delicten met gevangenissuf bedreigd worden (zie hoofdstuk 3,6.5 Gezag over opsporingsorganen). In bepaalde gevallen van labaksbelastingfraude is het evenwel het OM dat verwolgt in nam van het bestuur. Deze specitheke kwalificatie lijkt erop te wijzen dat het $O M$ nomaliter niet in natam van de administratie handelt. Deze conclusie is dan een stap verwijderd van de stelling dat het OM in thet algemeen niet in naam wan de regering handelt (die gezag drangl over de administratie).

Vgla ari. 237 Live des procédures fiscales - Dans le cas de fabrication de tabacs, de détention, de vente ou de colportage de iabaes fabriqués, s'il résulte de l'instruction que d'autres individus ont coopéré à lá fratude comme entrepreneurs de contrebande ou intéressés, les proces-verbaux sont transmis au procureur de la République qui exerce les poursuites an nom de l'administration (curs. PPvadL).

35 Att. 1 time VIII décret-loi wan 16-24 augustus 1790: 'Les officiers du ministere public sont les agents du pouvoir exécutif dexant les tribunanx:. Rassat 1967, p. 61; 1996, p. 107-108. Turcey 1997, p. 197. 'Turcey gebruikt woor de weergave van de traditionele opvatting de woorden 'dienaar van de Prins' in zing boek Le Prince ot ses juges. 
De hier gebruikte terminologie van bestuursorgaan of regeringsvertegenwoordiger is aldus noch in Nederland, noch in Frankrijk concludent. De begrippen zij.jn wankel onderbouwd en worden weinig eenvormig gebruikt. De kwalificaties variëren sterk. Zij vormen geen draagkrachtige argumentatie voor een bepaalde verhouding tussen de minister en het $\mathrm{OM}$.

\subsection{Vervolging als een regeringsaangelegenheid}

Een andere Nederlands-Franse bewering voert aan dat het handelen van het OM zo nauw samenhangt met het regeringsbeleid, dat het in feite onderdeel is van de taak van de regering. Daarom zou de regering als vanzelfsprekend aanwijzingen moeten kumnen geven. Deze redenering spoort slecht met de geldende beperkingen van de ministeriele zeggenschap. Voorts moffelt zij de verschillen weg tussen landelijke en lokale politiek.

Het Nederlandse vervolgingsbeleid zou bij uitstek een 'publieke' zaak zijn. Het beleid dat het OM voert hangt samen met en heeft invloed op het regeringsbeleid. Voor het effectieve functioneren van het beleid van de regering zou het nodig zijn dat deze zeggenschap heeft over het OM-beleid. ${ }^{36}$

In Frankrijk menen sommigen dat aangezien het bewaren van de openbare orde en veiligheid een 'regeringsaangelegenheid' is, het 'natuurlijk" zou zijn dat het OM ondergeschikt is aan de regering. Men meent ook wel dat de verwolging simpelweg een zaak van de regering zou zijn, een executieve functie. ${ }^{37}$ De regering zou zich gewoonweg niet afzijdig kunnen houden van zaken waarin de vervolging de publieke opinie beroert. $^{38}$

Het is evenwel vreemd de vervolging een regeringsaangelegenheid te noemen, terwijl het $\mathrm{OM}$ bijzondere autonomie geniet in vergelijking met de administratie. Deze autonomie vormt dan een tegenstrijdigheid. Wanneer het handelen van het OM enkel een zaak van de regering zou zijn, zou deze daarover volledig gezag dienen te hebben. Er is geen reden warom het Franse parket een pouvoir propre of een parole libre zou moeten hebben. Het mondeling requisitoir maakt evengoed deel uit van de vervolging. ${ }^{30}$ En waarom zou de Nederlandse minister zo terughoudend moeten zijn met aanwijzingen ten aanzien van een regeringsaangelegenheid? Juist de beschreven beperkingen op de ministeriele bevoegdheden maken duidelijk dat het handelen van het OM niet alleen of niet geheel en al een regeringsaangelegenheid is. Dit geldt met name ten aanzien van de individuele strafzaken.

De Franse grondwet biedt nog een nader element om de stelling te verdedigen dat in het bijzonder het vervolgingsbeleid een zaak van de regering is. De redenering achter

36 De Wildt 1968, p. 64; Van Eijkert 1968, p. 94; Corsiens 1974, p. 41; Oranje 1976, p. 25-26; Cliteur $1996 \mathrm{a}$, p. 86.

37 Een regeringsaangelegenheid: Jéol 1996, p. 7J; Foyer, Commission de réllexion sur la Justice, Annexes 1997 , p. 26 ; Chrestia 2000 , p. $772-773$.

38 Nallet, Commission de réflexion sur la Justice, Annexes 1997 , p. 44.

39 Rassat 1967, p. $139-140$. 


\section{Hoombs 1UK 6}

ministerièle circulaires begint waak bij artikel 20 , volgens hetwelk de regering "détermine et conduit la politique de la Nation'. Daarbij moet de strafrechtelijke politiek volgens menigeen gezien worden als onderdeel van de nationale politiek, zoals die bedreven wordt door de regering. Het beleid dat gevoerd wordt door de procureurs en procureurs-general wordt dan gezien als een specificering, een aampassing van de nationale strafrechtelijke politiek aan de locale eisen en bijzonderheden. De grondwet vormt zo een argument voor de aanwyzingsbevoegdheid van de minister. ${ }^{40}$

In een algemene analyse over artikel 20 meent Zoller echter dat de bepaling gericht is tegen het parlement. Het doel van de bepaling is in die visie om duidelijk te maken wie de leidende rol in de nationale politiek heeft in de relatie tussen regering en parlement. ${ }^{41}$ In een dergelijke interpretatie zou artikel 20 niet betrokken worden op de relatie tussen de regering en derde organen, zoals het OM.

De vraxg is verder in hoeverre het beleid van de parketten onderdeel uitmaakt van de nationale politiek. Men kan namelijk evengoed stellen dat het nationale en lokale handelen twee verschillende sootten van strafrechtelijke politiek zijn. Voor zover de beleidskeuzen van het lokale parket afwijken van het landelijk beleid zijn zij daar in feite aan tegengesteld. Het idee van het lokale strafrechtelijke handelen als specificatie van het nationale beleid is dan ejgenlijk een fictie. Daarbij komt dat niet alle nationale politiek neer geheel bepaald wordt door de regering. De relatief recente zelfstandige bestuursorganen (autorités administratives indépendantes) nemen bijwoorbeeld deel aan deze politiek. ${ }^{42}$

Verder kan onder het begrip politique pénale of strafrechtelijke politiek ook meer verstaan worden dan het eigenlijke vervolgingsbeleid. Sommigen verstaan hieronder mede de strafrechtelijke activiteit van de wetgever. Het vervolgingsbeleid is dan enkel een element van deze politiek. ${ }^{43}$ In een dergelijke definitie is het niet enkel de regering, maar ook de wetgever zelf die de strafrechtelijke politiek bepaalt. De regering heeft in dit begrip van de strafiechtelijke politiek al niet overal de doorslaggevende stem in. Waarom zou zij dan en niet het parlement of de wetgever de beleidslijn moeten vastleggen?

Het is kortom onvoldoende het vervolgingsbeleid als nationale politiek te kwalificeren om daaruit de reden voor zeggenschap van de minister over het OM af te leiden.

40 Delmas-Marly 1994, p. 151; M. Robert 1996, p. 201; Mazoaud 1996, p. 66: Lemesle \& Pansier 1998, p. 37. Overigens lijkt het in praktijk vak nief de regering te zijn die de politiek besluti en uitwoert. Buiten

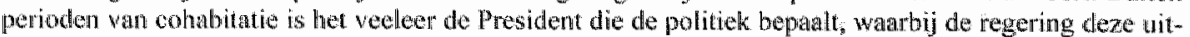
voert. Duwerger 1987, p. 577-579; Favoreu e.a. 2000, p. 652-653. Over de aanassing wan het lotale aran de nationale vervolgingsbeleid: Mazatud 1996, p. 66-67; Lemesle pansier 1998, p. 58 .

411 Zoller 1999, p. 480 .

42 Accomando $1997 \mathrm{a}$, p. 92-94. De fictic van het lokale strafrechtelijke handelen ats specificatie van het nationale beleud gebruken sommigen om indiviclue anwijzingen te rechtwardigen. Zie 5.1 . Beleidsm controle. Over de zeifstandige bestursorganen: Accomando $1997 \mathrm{a}, \mathrm{p} .97$.

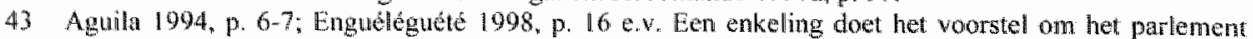
direci het vervolgingsbeleid te laten bepalen. Zie hoofdsuk 7, 3.5.2. Zeggenschap door volksvertegenwoordiging geth. 


\section{4}

Politieke keuze of algemeen belang

In alledrie de landen stellen sommigen dat bij het handelen van het OM het algemeen belang, of het staatsbelang, of een politieke keuze in het geding is. Dit zou moeten leiden tot onderschikking van het $\mathrm{OM}$ aan de legitieme hoeders van het algemeen belang. De onbepaalde aard van het 'algemeen belang' of de 'politiek' maken dit echter in zijn algemeenheid een onhelder argument.

Enkelen in Nederland achten de kwalificatie van het vervolgingsbeleid als 'politiek' van belang. Grote stukken vervolgingsbeleid zouden te belangrijk, 'te politiek geladen' zijn dan dat de staat zich zou kunnen permitteren dit stuk politiek aan de parlementaire controle te onttrekken. Bij de beslissing omtrent de vervolging kunnen "belangrijke politieke momenten meespelen' of de beslissing kan 'verregande politieke gevolgen' hebben. ${ }^{44}$

De kwalificatie 'politiek' duikt eveneens enkele malen op in de Franse literatuur. Enkele auteurs menen dat de beslissing omtrent de opportuniteit van de vervolging bij uitstek een politieke bevoegdheid is. Sommigen kwalificeren de benodigde verantwoordelijkheid voor deze beslissingen eveneens als een politieke. Bepaalde strafzaken zouden een wezenlijk politieke dimensie hebben. De verantwoordelijkheid voor dergelijke politieke beslissingen kan in het Franse systeem alleen bij de regering liggen. Door de hiërarchische ondergeschiktheid van het $\mathrm{OM}$ aan de minister zou dan aan deze eis voldaan worden. De minister dient aldus een bevelsbevoegdheid te hebben omdat het $O M$ politieke bevoegdheden bezit. ${ }^{45}$

De keuze die het OM heeft in zijn functie, wordt ook in Italië wel een politieke keuze genoemd. Deze kwalificatie heeft als gevolg dat de keuze eigenlijk door of in onderschikking aan een politiek orgaan zou moeten geschieden, zoals het parlement of de minister van Justitie. ${ }^{46}$

De kwalificatie 'politiek' of 'algemeen belang' verheldert het debat niet, wanneer dat gevoerd wordt op hoofdijnen, zoals hier. Het woordgebruik bepaalt in deze al a priori de conclusie. Het is onduidelijk wat onder die definitie valt, en in zekere zin zou elke uitoefening van bevoegdheden als politiek of van algemeen belang gekwalificeerd kunnen worden, Een juridische kwestie zou een politieke kwestie kunnen worden zodra de politieke organen zich er over buigen. De minister en kamerleden beslissen zelf welke kwestie zij aan politiek debat onderwerpen. De naamgeving 'politiek' zegt dan niet zozeer iets over de aard van de kwestie die het betreft als over de aard van de ambten die

44 Oranje 1976, p. 26; Stroink 1978, p. 156, 159, 161. Stroink noemt abortus, bezetingen van umbassades, het bestuursstraffecht.

45 Boudon 1997, p. 15; Guichard, Commission de réflexion sur la Justice, Annexes 1997, p. 36; Lemeste Pansier 1.998, p. 35.

46 Bognetti 1994, p. 446; Devoto 1996a, 2043 (deze laatste refereert aan een system met het opportuniteitsbeginsel). Sormmige auteurs stellen dat de keuzes in de opsporing of een prioriteitssielling slechts politieke beslissingen "in ruime zin' of een 'fechnische discretie" betreffen. Dit in tegenshelling tot de beslissing niet te vervolgen on opportuniteitsredenen. De kwestie van politieke verantwoordelijkheid komt dan alleen bij de laatste ter sprake, Funit 1991, p. 136; Zanon 1996, p. 182. 
de kwestie behandelen. Men maakt zo niet duidelijk waarom dit argument wel geldt voor het handelen van het $O M$, maar niet voor bijvoorbeeld rechters. Maken zij niet eveneens "politieke keuzes' of nemen zij geen beslissingen warbij thet algemeen belang" speelt? In paragtaaf 5.5 wil ik hier op terug komen.

\subsection{Opportuniteitsbeginsel}

Het opportuniteitsbeginsel is één van de meest genoemde redenen voor onderschikking van het $\mathrm{OM}$ aan de minister. Een onafhankelijk $\mathrm{OM}$ zou daarentegen vanzelfsprekend zijn onder een strafvorderlijk legaliteitsbeginsel. Dit onderwerp splitst zich in twee aspecten. Een opportuniteitsbeginsel zou ten eerste noodzaken tot coördinatie en ten tweede het $O M$ discretie geven.

\subsubsection{Ministeriële coördinatie door opportuniteitsbeginsel}

Ten eerste zou gezien het bestaan van het opportuniteitsbeginsel volgens sommige Franse schrijvers een coördinerende politiek nodig zijn. Waar het $O M$ beslissingen zou nemen op opportuniteitsgronden, zou deze besluitvorming coördinatie vergen. ${ }^{47}$

Deze stelling is onvolledig en suggestief in de zin dat deze noodzaak niet voortkomt uit de gelding van het opportuniteitsbeginsel in tegenstelling tot het legaliteitsbeginsel. Ook waar een legaliteitsbeginsel geldt bestaat behoefte aan coördinatie. Al zou de denkbeeldige situatie bestaan waarin alle gemelde delicten strafrechtelijke behandeling zouden krijgen, dan nog zou coördinatie van de verschillende opsporingsinitiatieven nodig zijn.

Wel kan men stellen dat door toekenning van een circulairebevoegdheid aan de minister een gecoördineerde strafrechtellijke politiek mogelijk is. Er is een grote verscheidenheid aan onderwerpen ten aanzien waarvan het $O M$ handelt. Los van elkaar functionerende parketten zouden keuzes kunnen maken die onderling geen samenhang zouden vertonen. Door een coördinatie van de vervolging in een strafrechtelijk beleid kunnen ongerechtvaardigde verschillen of ongelijkheden worden voorkomen. Ministeriële circulaires kunnen daarbij van mut zijn. ${ }^{45}$

De vraag is echter waarom de circulaires door de minister gegeven zouden moeten worden. Ook indien een centraal, hiërarchisch bovengeschikt ambt geen bewindspersoon zou zijn, zou het een gecoördineerd beleid kunnen voeren. Het orgaan zou dan geen democratische legitimatie geven. Vaak noemt de Franse doctrine de coördinatie en de democratische legitimatie evenwel in één adem. Een verklaring hiervoor zou kunnen liggen in het grote aantal procureurs-generaal dat het land kent. De tientallen

47 Terrier, Commission do reflexion sur la Justice, Annexes 1997, p. 99; Mathias 1999, p. 220.

48 Du Truche 1992, p. 257; M. Robert 1996, p. 199-200; Botndon 1997, p. 14; Chalandon, Commission de: thexion sur la Justice, Annexes 1997, p. 22; Taitinger, idem, p. 48; Favoreu, idem, p. 166; Pertot

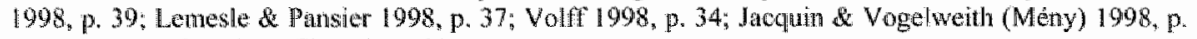
5; Mathise 1999, p. 221; Chrestia 2000, p. 773 .

Dit argument wordt owerigens ook wel in lallie gehoord: Guamier 1984, p. 167; Dominioni 1979, p. 6\%. Alleen de laatste is werkelijk een woorstander van onderschikking van het $O M$ aan de minister. 
deelnemers maken de landelijke bijeenkomsten van procureurs-generaal tot een moeizaam functionerend orgaan. Een landelijk beleid gevoerd door het $\mathrm{OM}$ zelf lijkt in deze vorm nog niet denkbaar.

Het is wel noodzaak te onderstrepen dat coördinatie ook mogelijk is zonder legitimiteit. Coördinatie vormt hierom geen argument om de minister invloed te geven op het $O M$.

\subsubsection{Discretie door opportuniteitsbeginsel}

Het tweede aspect van dit onderwerp is de stelling dat het opportuniteitsbeginsel het OM een mate aan discretie zou laten. Onder het legaliteitsbeginsel zou daarwan geen sprake zijn. Het bestaan van een opportuniteitsbeginsel zou daarom politieke zeggenschap over het OM moeten meebrengen. Echter, aangezien de facto ook het legaliteitsbeginsel het OM keuzevrijheid laat, is deze conclusie onjuist.

Sommigen in Nederland zijn van mening dat de gelding van het opportuniteitsbeginsel betekent dat de vervolging onder democratische controle moet staan. Deze zou dan via de minister moeten geschieden. Als daarentegen een legaliteitsbeginsel zou gelden, zou een onafhankelijk OM nog mogelijk zijn. In dat gevall zou er namelijk sluitend rechterlijk toezicht zijn. ${ }^{49}$ Gelet op het opportuniteitsbeginsel 'kunnen en moeten' niet alle feiten voor de rechter gebracht worden. Daarom is nadere verantwoording en controle nodig middels de relatie tussen het $O M$ en de minister. ${ }^{50}$

Ook in Frankrijk zien enkelen de legitimiteitswraag opdoemen waar het OM onder het opportuniteitsbeginsel handelt. Dit opportuniteitsbeginsel zou een zekere onderschikking van het $O M$ aan de politiek met zich brengen. In landen met een legaliteitsbeginsel zou het - in ieder geval in theorie - eerder denkbaar zijn dat het OM geheel onafhankelijk is. ${ }^{51}$

Vice versa ziet Italie het legaliteitsbeginsel als een manier om te voldoen aan de eis dat vervolgingsbevoegdheden niet op willekeurige wijze gebruikt dienen te worden. De achterliggende bedoeling is om de gelijkheid van de burgers te doen respecteren bij het ondergaan van de uitoefening van vervolgingsbevoegdheden. ${ }^{52}$ Volgens het Constitutionele hof en vele auteurs is het legaliteitsbeginsel hier zelfs de enige manier on de gelijkheid in de rechtshandhaving te bewaren. Het zou essentieel zijn in het Italiaanse systeem, nauw verbonden met het beginsel van de gelijkheid voor de wet (art. 3 lid 1 Cost.) en het strafrechtelijke legaliteitsbeginsel (art. 25 lid 2 Cost.). ${ }^{5.3}$

49 Cliteur $1997 \mathrm{a}, \mathrm{p}, 94$

50 Hisch Ballin 1991, p. 197, Muller 1994, p. 81.

51 Du Truche 1992, p. 256-257; Vogelweith 1997, p. 12, Mathias 1999, p. 220; Aguila 1994, p. 10. Voorzichiger: Guery \& Accomando 1996, P. 32-33.

52 Falcone 1990; p. 165; Di Federico 1991, p. 174; Curatola 1994, p. 261; Gustapane 1999, p. 224.

53 Corte Cost. 1991 , n. 88 ("il principio di legalita (ant. 25, secondo comma), che rende doverosa la repressione delle condotte violatrici della legge penale, abbisogna, per la sua concretizzzione, detla legaluta nel procedere, a questa, in un sistena come il nostro, fondato sul principio di eguaglianza di tutti if citudini ci frone alla legge (im particolare, alla legge penale), non può essere salvaguardata che attraverso l"obbligatorietà dell'azione penale."); Zagnebelsky 1974, p. 191; Colli 1975, p. 17; Nuvolone 1983 , p. 376; Maddalena 1991, p. 145; Scaparone 1994, p. 273; Devoto 1996;, p. 2040; Silvestri 1997, p. 104. D'Elia 1998 , p. 1884; Gustapane 1999, p. 224; Grevi 1999, p. 76. In de huidige organisatio wan 
Het Italiaanse legaliteitsbeginsel wordt in feite de functie toegedicht om de vervolging los te maken van het bereiken wan welk doel dan ook. Het beginsel is logischerwijs in strijd met het concept van de politieke keuze voor een bepaald doel. ${ }^{54}$ Als er geen keuze gemaakt hoeft te worden tussen te vervolgen feiten, hoeft enkel de wet gehandhaafd te worden, en is geen criminele politiek mogelijk of nodig. Men stelt het OM wat dit betreft in feite gelijk met de rechter, door te menen dat het $O M$ zijn legitimatie krijgt uit diens onderwerping aan de wet en het recht. ${ }^{5 s}$

Doordat het OM verplicht is tot vervolging kunnen externen buiten de rechterlijke macht geen invloed op de vervolging uitoefenen. Het legaliteitsbeginsel geeft het OM een middel om zich te weren tegen externe druk gericht op het afclekken van strafbare feiten. ${ }^{36}$ In het vigerende stelsel is het legaliteitsbeginsel de bron van de onafhankelijke positie van het $O M$, dat als het onmiddellijke gevolg van het beginsel gezien wordt. Uit het legaliteitsbeginsel wordt logischerwijs of noodzakelijkerwijs de keuze voor een onafhankelijk OM afgeleid.

Ook meent men in Italie wel dat toekenning van de leiding van het $\mathrm{OM}$ aan de minister van Justitie noodzakelijkerwijs een opportuniteitssysteem mee zou moeten brengen. Verder zou, andersom, onder gelding van een opportuniteitsbeginsel, het $O M$ onder verantwoordelijkheid van een politiek orgaan als de minister moeten vallen. Dit zou mede nodig zijn om te woorkomen dat de minister zijn verantwoordelijkheid zou verschuilen achter een plicht tot vervolging. ${ }^{5 /}$

In de laatste decennia is in Italië de vraag opgeworpen of de keuze voor het huidige systeem van onafhankelijkheid niet te zeer bepaald is geweest door het toenmalige historische perspectief. Pogingen tot hervorming zijn lange tijd sterk geconditioneerd geweest door negatieve ervaringen met opportuniteitsbeslissingen onder het vroegere stelsel van strafvordering. ${ }^{59}$ Verder bracht de keuze van de grondwetgever vervolgens een overtuiging met zich van de realiseerbaarheid van het legaliteitsbeginsel. ${ }^{60}$

het $O M$ in Italie kan het stellen vari afwijkende prioriteiten door de vele parketten overigens al wrjwing met het getijkheidsbeginsel opleveren, D'tlia 1998, p. 1880 en 1885 .

54. Curbone 1982, p. 79; Rovelli 1994, p. 268; Devoto 1996a, 3. 2050; Silvestri 1997, p. 101.

55 Corte Cosi. 1991, n. 88; 1993, n. 462; Brutti Liberati 1999, p. 6 .

36 Chiavario 1994, p. 98; Morisi 1999. p. 93.

57 Calumandrei, Assemblea Costituente 1991. p. 1991; Zagrebelsky 1979, p. 8; Corte Cost. 1979, n. 84; 1991 , w. 88; 1995, n. 420" Amato 1995, p. 3293; Nuwolone 1983, p. 376; Neppi Modona 1987, p. 68; Chavario 1994, p. 70; Devoto 1996a, p. 2043; Silvestri 1997, p. 99; Gustapane 1999, p. 224. Voor deze combinatie is de Italianse grondwet uniek, Devoto 1996, p. 376: 1996a, p. 2025.

58 Cahamendren, Assemblea Costituente 1991, p. 1993; Zagrebelsky 1979, p. 8 en 19; Riaci 1982, p. 118; Neppi Modona 1987, p. 68; Dovoto 1996a, p. 2043; Silwestri 1997, p. 103 an 128. Anders: Leone, Assemblea Costituente 1991, p. 1993; Conso 1979, p. XVI; Dominioni 1979, p. 75; Cordero 2000, p. 190 en 418. Dat zou wel betekenen dat een grondwetswijziging nodig zou zijn. Dominioni lijkt het niet onmogelijk dat een dergelijke hervorming zonder grondwetswijzing plaats kan vinden: Dominioni $1979, \mathrm{p}, 83$. Maddalena is van mening dat er in de Italiaanse samenleving geen ruimte is voor een opportuniteitsbegitsel, 1991 , p. 162.

59. In het licht van lhet huidige parlementaur democratische stelsel zou de positie van het $O M$ wellich kumnen worden herzien. Dominioni 1979, p. 49; Patrono 1992, p. 1378 en 1390; Zanon 1996, p. 212; Di Federico 1995, p. 406.

Chiavario 1994, p. 70; Di Federico 1998, p. 233; Zanon 1996, p. 183. 
In hoofdstuk 4 heb ik evenwel vastgesteld dat het Italiaanse strafrechtelijk systeem feitelijk gekenmerkt wordt door ruime discretie voor het $\mathrm{OM}$ in de uitoefening van diens bevoegdheden. In de praktijk geldt het legaliteitsbeginsel niet volkomen. Het wasthouden aan het beginsel is een emblematisch voorbeeld van de ongevoeligheid van de (grond)wetgever voor operationele resultaten. ${ }^{6 !}$ In Italiê is de erkenning van de beperkte effectiviteit van het legaliteitsbeginsel echter lang belemmerd door diepgewortelle overtuigingen in de juridische cultuur ${ }^{62}$ Aangezien het legaliteitsbeginsel het $\mathrm{OM}$ toch discretie laat, zou dit volgens sommigen ruimte creëren voor een institutionele binding aan politieke organen. ${ }^{6.3}$ Enkelen wijzen er verder op dat ook in landen waar het opportuniteitsbeginsel geldt, tegelijkertijd het gelijkheidsbeginsel gerespecteerd kan worden. ${ }^{64}$

De vergelijking in hoofdstuk 5 onderstreepte eveneens de relativiteit van het onderscheid tussen het opportuniteits- en legaliteitsbeginsel. Het opportuniteitsbeginsel vormt zo geen steekhoudende argumentatie voor hiêrarchische onderschikking van het $\mathrm{OM}$. De discretie zelf die het OM bezit is daarentegen een beter argument, zoals ik nu zall betogen.

\subsection{Beleidsvrijheid}

De belangrijkste factor in de onderhavige discussie is de overweging dat het OM macht of beleidsvrijheid bezit. Deze vergt een mate van democratisch gelegitimeerde zeggenschap. De discretie moet indirect ook voor de auteurs uit de voorgaande paragraaf de eigenlijke reden zijn voor politieke invloed. Met het argument van het opportuniteitsbeginsel verwijzen zij naar de discretie die los van dat beginsel feitelijk bestaat.

Zo wordt in Nederland wel gesteld dat het OM een sterke machtspositie heeft. Deze zou politieke zeggenschap vergen. ${ }^{65}$ Men concludeert dat de beslissingsmacht omtrent het gebruik van opsporings- en vervolgingsbevoegdheden onder potentiële controle van de minister zou moeten staan. De legitimatie van de macht van het OM kan zo slechts gevonden worden in de democratie. ${ }^{66}$ Het OM moet 'afhankelijk' zijn, ondat de macht die het $O M$ als vervolgingsmonopolist en hoogste opsporingsautoriteit vertegenwoordigt via de minister onder democratische controle zou moeten staan. ${ }^{67}$ Verder bestat

61 Meppi Modona 1994, p. 122

62 Di Federico 1991, p. 175 176; 1995, p. 407 408, De Italiatrise juridische cultur wordt gekenschetst als zeer formalistisch, niet zozer gericht op effectieve oplossingen als wel op mominalistische, formele, Di Federico 1995, p. 423, Devoto 1996a, p. 2052.

63 Uberti en Leone, Assemblea Costituente 1991, p. 1992; Dominioni 1979, p. 75; Condero 2000, p. 190. Zie verder de laliaanse auteurs in thoofdstuk 7,3.5. Autonome rechispositic met beperkte aanwijzings" bevoegdheid.

64 Zagrebelsky 1979, p. 6 (enigszins in tegenstelling tot Zagrebeikgy 1974, p. 19:4; Curgtola 1994, p. 260 .

65 'Hert 1999, p. 113 .

66 Linthorst 1996, p. 287.

67 Kamerstukken: II 199596,24034, nr. 13, p. 8; Cliteur 1997a, p. 94. Cliteur vindl zells dal "een

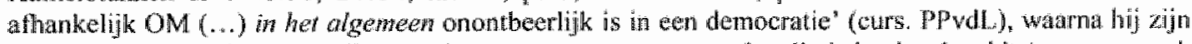
stelling verzwakt door te stellen dat in een systeem waar een legaliteitsbeginsel geldt "nog aen zaak (zou) zijn te makerv voor een var de uitvoerende mecht ona hankelijk werkernd OM". 
binnen het strafrechtelijk systeem geen echte beleidscontrole. De parlementaire controle via de minister is woor beleidszaken een geschikte en eigenlijk de enig denkbare beleidscontrole. ${ }^{68}$

In Frankrijk is nog een echo te horen van Rousseau's democratietheorie. Sommigen stellen daar dat onderschikking van het OM conform zou zijn aan 'de democratische theorie' volgens welke alle macht direct of indirect uit 'de will van het volk' zou moeten voortkomen. De macht moet conform die wil worden uitgeoefend. ${ }^{69}$

Zelfs in Italië wordt wel de vraag gesteld of de autonome positie nog te rechtvaardigen is. Nu het legaliteitsbeginsel geen effectieve gelding heeft, maakt het $\mathrm{OM}$ vrije keuzes in onafhankelijkheid. ${ }^{70}$ Volgens sommigen maakt deze discretie het wenselijk het OM te onderwerpen aan een mate van politieke verantwoording, aan democratische legitimatie. $^{71}$

Het Italiaanse legaliteitsbeginsel vormt nu een belemmering voor een open discussie over wat de beleidslijnen zouden moeten zijn voor de vervolgingspolitiek. De keuzes die onder gelding van het legaliteitsbeginsel toch gemaakt worden, worden niet duidelijk gemaakt. ${ }^{72}$

\subsubsection{Discretie en initiatief}

Het OM oefent dus discretie uit. Dit geldt echter voor veel, zoniet alle overheidsambten. Zijn de handelingen van het $\mathrm{OM}$ bijvoorbeeld minder vastomlijnd bepaald dan die van de rechter? In Nederland stelt men wel dat in vergelijking met andere vormen van deconcentratie de bevoegdheidsuitoefening van het OM een minder gebonden karakter zou hebben. Het OM zou over een grotere inherente afwijkingsbevoegdheid beschikken dan andere overheidsorganen. ${ }^{73}$ Het $\mathrm{OM}$ zou beschikken 'over een aanzienlijke mate van beleidsvrijheid (...) die zich niet volledig in regels laat programmeren' $7^{4}$ De afwegingsruimte die het $O M$ heeft is zelfs volgens sommige Italianen praktisch niet verschillend van de ruimte die karakteristiek is voor de gewone administratie. ${ }^{75}$

De discretie op zich is echter niet het doorslaggevende verschil tussen het handelen van het OM en de rechter. De veronderstelling dat het handelen van de rechter weinig dis-

68 Duisterwinkel 1968a, p. 109, Ormjie 1976, p. 26; '1 Hart 1976, p. 21 .

69 Beteille, Commssion de teflexion sur let Justice, Annexes 1997, p. 58-59; Favoren, Commission de rellexion sur lat Justice, Anexes 1997, p. 166. Vgl. art. 3 Const.: "La souverainete mationale appartient au peuple $(\ldots)^{\mathrm{s}}$

70 Falloone 1990, p. 165, Di Federico 1991, p. 181.

7. Gumrieri 1984, p. 157 en 160; Betiol 1998, p. 267.

72 Dominitioni 1979, p. 67, Di Federico 1991, p. 172; Valentini Reater 1994, p.43.

73 Strywer 1976, p. 173; Stroink 1978, p. 159, Osinga 1992, p. 83.

74 Commissie Sehweltema 1993, p. 44-45. Overgenomen door minister Songdrager, Kamerstukken Il $199697,25392, \mathrm{nr}, 3, \mathrm{p}, 21-22$. Vgl. Muller 1994, p. 81: "uitgebreide discretionaire bevoegdheid".

75 Pizzartisso 1979, p. 34-36 en 41: Dominioni 1979, p. 56. De rechter heeft echter ook voor een groot deel dezolfot keuzevrijheder als het OM. Zagrebelsky 1979, p. 10. ln het bijzonder kan gewezen worden op de mogelijkheid di de onderzoekstechter heeft on onderzoek te laten wemichten in plaats van te seponerin op vordering van het OM. Deze speelrumte geeft de wechter een enigszins vergelijkbare discretie die het OM in het opsporingsonderzoek heef, zie Hoofdstuk 4, 3.3. Beslissing over de vervolging en 3.4. "OM-beleid". Overigens $\mathrm{kan}$ in redelijkheid gesteld worden heeft het OM onder het huidige systeen cen veel grotere discretie heeff dan onder hei otde, Maddalena 1991, p. 154. 
cretionair is, is ook niet de reden of aanleiding voor zijn onathankelijkheid. ${ }^{76}$ Die reden ligt eerst en vooral in zijn positie als buiten het procesgeschil staande derde. Hij is de geschillenbeslechter. Dit brengt mee dat de rechter nooit het initiatief neemt tot een proces. Hij oordeelt over hetgeen hij krijgt voorgelegd. Het $\mathrm{OM}$ daarentegen heeft de leiding over de opsporingen en besluit over het instellen van de vervolging. Het verschil met de rechter ligt dan ook vooral in de discretie van het $O M$ bij het initiëren van de vervolging. Het $O M$ in alledrie de landen is genoodzaakt een selectie te maken tussen strafzaken. Hierbij neemt het in sommige zaken niet het initiatief tot vervolging om andere zaken wel te kunnen vervolgen. ${ }^{77}$

\subsubsection{Beleidsvoering en individuele zaken}

De discretie en het initiatief van het $\mathrm{OM}$ hoeven niet automatisch te leiden tot algehele ondergeschiktheid van dat orgaan aan de minister. Het feit dat de werkzaamheden van het OM 'niet programmeerbaar' zijn noopt nog niet tot de conclusie dat de minister in principe moet kunnen ingrijpen ten aanzien van elke handeling. Er zijn namelijk redenen die in de weg kunnen staan aan ministeriële interventie. ${ }^{78}$ Welke vormen van het optreden van het $\mathrm{OM}$ vragen nu met name om ministeriële verantwoording? Tot op welke hoogte zou de politiek invloed op het OM moeten hebben?

Voor de beantwoording van deze vraag maak ik eerst een onderscheid tussen de beleidsvoering en individuele zaken. Het maken van deze onderscheiding zelf wordt wel bekritiseerd. De gedachte achter deze kritiek is dat sommige specifieke strafzaken belangrijke beleidsaspecten hebben. ${ }^{79}$ Dit idee kan echter niet voorbij gaan aan het feit dat een besluit in een concrete strafzaak en een beleidsregel aparte beslissingen zijn. De ene kan volgen op de andere, maar het is ook mogelijk dat beslissingen in strafzaken worden genomen op een terrein waar geen beleid ontwikkeld is. Dit laatste vormt nog geen reden voor het laten vallen van het onderscheid.

76 Guximuri $1984,0.157$.

77 Vgl. in Nederland Enschede 1968, p. 78. In Itahe: Lo Coco 1974, p. 227; Guamien 1984, p. 158 met verwijzingen, ook naar veel buitenlandse atuteurs, waronder $T$. Koopmans (!); Di Federico 1995 , 0.419.

78 Zo is de mate van onderschikiking van administratieve organen ook nogat eans onderwerp van debal. In alle drie de landen heeft men dan ook vormen wan zelfstandige bestuursorganen ingevoerd. Programmeerbastheid van activiteiten is bijvoorbeeld geen verciste voor thet oprichten van zelfstandige bi stuursorganen. Deze stelt men onder neer in voor bepalde taken of activiteiten die zich nata hun aurd

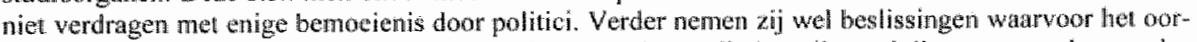
deel wan deskundigen beslissend behoort te zijn, beslissingen die "gevijuaral dienen the worden van in w menging op grond wan andere overwegngen'. Commissie Scheltema $1993, \mathrm{p}$. 43. Vgl. Scheltema 1974, p. 10. Een dergelifk aspect komt hierna aan de onde bij 7.4. Onpartijdige pantij.

79 Dusterwinkel meent 'dat alyemeen beleid en incidenteel beleid niet he seheiden ziju daar het in be. paralde gevallen juist de vrabg is, in howerre het algemene beleid incidented moet toegepast worden". 1977. p. 134-135. Dit kan een toepasselike vrag zijn. Het algemene beleid bestar evenwel reeds woor de incidentele toepassing ervan. De toepassing en het beleid zijn zo te onderischeiden. Bestaat er geen witrukkeligk algeneen beleid woordat het OM een beslissing in aen individueel geval moet memen, dan is er naturlijk geen onderscheid mogelijk. Dan gaat het slechts om Duisterwinkels "incidenteel beleid". Vgl. De Doelder 1996, p. 121. 
Laten wij nu allereerst kijken naar de zeggenschapskwestie over het beleid. De democratische legitimatie wordt in Nederland met name geëist ten aanzien van het geven wan de algemene beleidslijnen voor het $\mathrm{OM}$. In het bijzonder ziet men de noodzaak daarvan woor het stellen van prioriteiten, in mindere mate voor het beleid over de wijze van hantering van bepaalde bevoegdheden. ${ }^{80}$ Veel Fransen menen eveneens dat juist het beledsmatige handelen van het $\mathrm{OM}$ deze democratische legitimiteit wel behoeft. Ondersolikking aan de politiek verleent democratische legitimiteit aan het beleid van het OM. Voor zover men ten slotte in Italie politieke invloed bepleit, acht men deze wrijwel alleen wenselijk ten aanzien van de sepoteriteria en het algemene beleid. ${ }^{22}$

Internationale aanbevelingen omtrent de positie van het OM eisen niet dat een extern ambt algemene aanwijzingen zou moeten kunnen geven. Sommige belangrijke documenten onderstrepen wel de noodzaak van vervolgingsrichtlijnen, maar laten in het midden of deze opgesteld zouden moeten worden door het OM zelf of een ander orgaan. Overigens worden dergelijke richtlijinen met het oog op de rechtsgelijkheid aanbevolen, niet ter bevordering van de democratische legitimatie. Een paar verklaringen laten de keuze voor al of geen beleidsregels uitdrukkelijk open. Een enkele aanbeveling keert zich ten slotte met zoveel woorden tegen elke vorm van aanwijzingen. ${ }^{83}$

De opvatting dat beleidsvorming democratische controle behoeft wil ik hier onderschrijven. Dergelijk beleid geeft in algemene zin de discretionaire keuzes weer, die het OM zal volgen bij beslissingen over het al dan niet in gang zetten van de vervolging. Voor" de algemene keuzes welke soorten feiten het OM wèl gaat vervolgen, heeft het in principe geen nadere legitimatie nodig. Deze legitimatie geeft de wet, die deze feiten stratbaar stelt, en het OM de rechtshandhaving opdraagt. Het in abstracte zin bepalen welke categorieën het $\mathrm{OM}$ minder of nier gaat vervolgen, vormt echter een discretie die om legitimatie vraagt. Waar (mede) door democratisch gelegitimeerde ambten tot stand

80 Dusterwinkel 1968\%, 10, 109; Corsters 1999, 19.94.

81 Jacquin (Colleu) 1997, p. 10, Volf 1998, p.46; Mathias 1999 , p. 5. Zie ook de vootstanders var het voorstel voor een antonome rechtspositie met beperking wan individuele bevelen in hoofdstuk $7,3.5 .1$. Sledhts ankele fronsen zien in de cinculaires een soort excus woor de ininister om onder het mom van beleid in individuele zaken in te kunnem grijpen. Zij stellen dat de diseretie van het OM mar wan beperkte ard is, wardoot er weinig rumte is voor een ministerieel vervolgingsbeleid. Verder meent men dat algemene circulaires van negatieve aard een risico van partijdige toepassing inhouden. In deze derkwize zou de exeeutieve zich voor het woeren van een strafrechtelijk beleid tot de wetgever moeten richten door wetswoorstellen dawtoe in te dienen. De Montgoltier 1996, p. 170. Over de partijdige toepassing van eirculaires: Vgl. Jacquin \& Vogelweith (Meny) 1998, p. 8. Zhe de circulaine van 14 februari 1996 in hookstuk 3, 6.3.1.1. Circulaires. Ower de beperkte discretie: Bouvier, Jacquin \& Vogelweith $1997, \mathrm{p}, 40-41$. Zle verder over het beleidsargunnent om in indiwiduele zaken in te grijpen: 5.1 . Beleidscontrole.

82 Zie de voorstanders in hoofdstuk 7, 3.5. Autonone rechtspositie net beperkte ananijzingsbevoegdheid.

83 De noodzalk wan richtijnen word benadrukt door at. $17 \mathrm{VN}$ en art. $35 \mathrm{RvE}$. Explietet neutraal tegen. over atgemene anwijzzngen zijin art. 111.9 EU and art. 2.2 IAP. Tegen elk worm van aanwijzingen is art. 2 MEDEL.

84 In doze specifieke zin volg ik wel de genoende Franse auteurs, die menen dat de legitimatiekwestie in de wet zijn oplossing windt. Vgl. 4. Legitiniteit: ratio voor ondersichiking. 
gebrachte wettelijke bepalingen beleidsmatig de toepassing ontnomen wordt, dient daarover verantwoording aan dergelijke ambten afgelegd te worden. ${ }^{85}$

Minder eenstemmigheid bestaat over de politieke invloed in specifieke strafzaken. Als de minister al aanwijzingen kan geven ten aanzien van het beleid, waarom dient hij dan nog specifieke instructies te kumen geven? De discretie in specifieke zaken kan omgeven zijn door beleidsregels. Het OM neernt beslissingen met inachtneming van deze regels. Desgewenst kan de politiek met nadere beleidsaanwijzingen de handelingsruimte van het $O M$ verder inperken.

Desondanks neemt het OM ontegenzeggelijk discretionaire initiatieven in individuele zaken. Het kan voorkomen dat voor een geval geen beleidsaanwijzingen bestaan, terwijl de minister de zaak wel beleidsmatig van belang acht. In de praktijk bestaan in Frankrijk en Nederland, behalve algemene sepotcriteria, weinig beleidsregels die aangeven wanneer vervolging niet of minder gewenst is. Daarom is het $\mathrm{OM}$ genoodzaakt dit zelf te bepalen. Specifieke aanwijzingen zouden in deze situatie het gebrek aan beleid "corrigeren'.

Een feitelijk afwezig beleid kan echter geen systematisch argument vormen voor een bijzondere aanwijzingsbevoegdheid. Andersom kan juist het ontbreken van een dergelijke bevoegdheid aanzetten tot het formuleren van een samenhangend vervolgingsbeleid. Als de minister geen individuele aanwijzingen zou kunnen geven, zou hij genoodzaakt zijn om vooraf zijn opvattingen in algemene beleidsregels neer te leggen.

Ook waar wel beleid is vastgelegd blijft een discretionaire ruimte bestaan. Enerzijds dekt het beleid niet alle mogelijke situaties, en anderzijds heeft het OM de aan het beleid inherente bevoegdheid daarvan af te wijken. Wat te doen met deze resterende discretie? Moet deze gelegitimeerd worden door politieke zeggenschap of overgelaten aan de onpartijdigheid van een autonoom OM?

Geen enkele internationale aanbeveling omtrent de positie van het $\mathrm{OM}$ suggereert dat de politiek aanwijzingen in individuele zaken moet kunnen geven. Enkele verklaringen laten het bestaan van deze optie uitdrukkelijk open, waarbij vaak beperking wenselijk wordt geacht. Daarbij meldt men dat individuele aanwijzingen vergezeld moeten gaan van specifieke procedureregels. Sommige documenten spreken zich tegen dergelijke aanwijzingen uit. ${ }^{86}$

Op dit specifieke punt lijken democratische en rechtsstatelijke eisen in het bijzonder te botsen. De rechtsstatelijke aspecten voor autonomie bespreek ik nader in paragraaf zeven. Hieronder geef $i k$ eerst de bijzondere redenen vóór aanwijzingen in specifieke strafzaken. In paragraaf vijf ga ik in op de argumenten die zich verankeren in de legitimatie van de minister. Paragraaf zes stelt de redeneringen aan de orde die een reden zien voor onderschikking van het $\mathrm{OM}$ met betrekking tot concrete zaken in de noodzakelijk geachte ministeriële, juridische controle en rechtsontwikkeling door de minister.

85 Verder over de argumentatie tem anzien van de beleidsworting: 7.3. Rechtszekerfuid.

86 Art. III.9 EU, ar. 13 RvF en art. 2.2 LAP zijn neutraal over deze aanwijzingen. De VN sproekt zich hicr niet over uit. Naast het hievwor genoemde MEDEL, keert ook art. 2.5 IAPL zich tegen bijzondere anwijzingen. 


\section{Legitimiteitsargumenten voor individuele aanwijzingen}

Voor bevelen van de minister in een specifieke strafzaak geeft men bijzondere redenen die zich baseren op het argument van legitimiteit. De belangrijkste reden is die van de beleidscontrole. Daarnaast vormen wensen omtrent anticipatie van wetgeving een pleidooi voor aanwijzingen. Verder noemt men de wens goede buitenlandse betrekkingen te onderhouden als argument. Ten slotte geven overwegingen omtrent de politieke aard van bepaalde individuele beslissingen aanleiding om ministeriële zeggenschap te verdedigen.

\subsection{Beleidscontrole}

Eén van de belangrijkste redenen genoemd voor bijzondere aanwijzingen is de controle op het OM-beleid. Met een specifieke aanwijzingsbevoegdheid zou de minister de naleving van het beleid door het OM kunnen afdwingen. Echter, deze gedachte lijkt het bestaan van bijzondere omstandigheden te miskennen. Verder is de aanwijzing op zich als dwangmiddel onvoldoende en onnodig.

In Nederland noemt men aanwijzingen, waaronder die tot niet-vervolging, noodzakelijk voor het voorkomen van vervolging in strijd met het vervolgingsbeleid. ${ }^{87}$ "Niet zelden" zou een incident wel aangegrepen worden 'vanwege de achterliggende diepere betekenis ervan" voor het beleid. ${ }^{88}$

Met name in Frankrijk ziet men de specifieke aanwijzingsbevoegdheid als een middel om de toepassing van het door de minister bepaalde beleid te garanderen. Als de minister het nationale vervolgingsbeleid kan bepalen zou er een mechanisme van sanctionering dienen te bestaan. De regering zou in een specifiek geval moeten kunnen preciseren wat zij heeft bedoeld met een algemene circulaire. ${ }^{89}$

De onderhavige redenering is deels principieel onjuist en praktisch gezien misplaatst.

De gedachtegang is gebaseerd op de veronderstelling dat het lokale thandelen van het OM enkel een specificering is van het nationale beleid. Zoals hierboven besproken is in Frankrijk wel aangevoerd dat deze gedachte een fictie is. Deze kan op zichzelf geen bevoegdheid tot het geven van individuele aanwijzingen rechtvaardigen. ${ }^{90}$

87. Kamerstukken 111996967,25392, nr. 3, p. 26.

88 Orinje $1976,0.28$.

89 Minister Vatuelle, 10 AN CRI 6 oktober 1992, p. 3366, foyer, Comumission de reflexion sun la Justice, Amoxes 1997, p. 27, Guichard, idem, p. 36; Béteille, idem, p. 60; Volto 1998, p. 48; Mathias 1999. p. 221,1999 a. p. 6; Lemesle \& Pansien 1998,, 118 . Delmas-Marty is van mening dat als de minister verantwondelijk is voor de strafrechtelijke politiek, dat hij de dar ook moet kerinen afdwingen middets an het OM te geven instructies. Hierin lijkt het in Nederland wel gehoorde "alls verantwoordelijk, dan bewoegd" in door te klinken. De vrage wasom do minister verantwoordelijk is wordt hier niet gè steld. Delmaw Marty 1994, p. 153. Mogelijk bedoolt Delmas-Marty zoals de andere auteuns her juist te zeggen da als de minister bevoegd is de strafrechelijke politiek wast te stellen, dat hij dan middelen moet hebben on dezt te doen uitveren. De begrippen "bevoegd" en "verantwoordelijk" worden dan echer - zoals well waker - door elkaar gebrukt. Boudon noent zelfs dinect de benoemingsbevoegdheid als middel om thet beleid te doen toepussen. $1997, \mathrm{p}, 9$

90 Zis over dere hetie: 4.3. Vervolging als een regeringsangelegenhe 
Verder ligt het in de aard van het beleid dat het in bijzondere omstandigheden niet toegepast wordt. Het is wenselijk en juridisch verplicht dat in voorkomende gevallen afgeweken wordt van beleid. Het OM moet in beginsel kunnen vervolgen ondanks dat voor bepaalde feiten een beleidsposterioriteit geldt. Wel dient politieke zeggenschap te bestaan om vervolging in te laten stellen wanneer het OM niet vervolgt, in afwijking van het beleid. De nadere redenering hierachter behandel ik verderop. ${ }^{91}$

Anderzijds zijn er tegenargumenten van meer praktische aard. Men kan ten eerste veronderstellen dat de parketten zich over het algemeen zullen conformeren aan het nationale beleid. Daarnaast is een aanwijzing niet strikt nodig voor de naleving van het beleid. Een voorgenomen afwijking van het beleid kan al onder ogen van het College komen voordat het bericht eventueel naar de minister zou gaan. Dit orgaan heeft mede tot taak om beleidscontrole uit te voeren. De procureurs-generaal zouden een afwijkende beslissing kunnen doen wijzigen. Wel kan het voorkomen dat de procureurs-generaal een afwijking van het beleid juist achten, terwijl de minister een andere opvatting is toegedaan. Daarnaast kan het College met de minister van mening verschillen over de vraag of een geval onder het bestaande beleid past.

Aansluitend kan de rechter controleren of het handelen van het $O M$ in een specifiek geval in overeenstemming is met het vervolgingsbeleid. Vervolgt het $O M$, terwijl dit beleid een andere beslissing voorstaat, dan kan de rechter daar gevolgen aan verbinden. De minister kan echter ook beleidscontrole uitoefenen met zijn algemene aanwijzingsbevoegdheid. Wanneer hij meent dat het $\mathrm{OM}$ het beleid niet op de gewenste manier uitvoert, zou de minister het beleid ad hoc, via een nieuwe, gedetailleerdere circulaire kunnen preciseren. Indien de minister op dat moment een duidelijke beleidsvoorkeur heeft, hoeft de formulering en het uitvaardigen van een dergelijke algemene aanwijzing geen (tijds)problemen op te leveren. Het is daarentegen mogelijk dat de minister geen eenduidige beleidsopvatting over dit soort zaken heeft, en de gewenste nieuwe beleidsvorming meer tijd kost. Dit brengt mee dat het OM vrij is om binnen de ruimte van de wet een beslissing te nemen. In een dergelijke situatie handelt het $\mathrm{OM}$ in een zekere beleidsvrijheid. Het is dan niet nodig dat de minister zeggenschap heeft over het handelen in dat incident. Dat kan evengoed een aanknopingspunt vormen voor beleidswijziging als de minister niets over dat specifieke handelen in die zaak te zeggen heeft. Daarnaast kan via de disciplinaire weg gereageerd worden op een tekort schieten van OM-leden. ${ }^{92}$ Het eigenlijke afdwingen van de aanwijzingen geschiedt ook nu uiteindélijk door (de dreiging met) disciplinaire sancties. ${ }^{93}$

Ten slotte zijn andere sturingsconcepties denkbaar dan (alleen) die van de hiërarchie., De beleidstoepassing hoeft niet per se door functionele onderschikking gegarandeerd te worden. Bepaalde methoden van management - waaronder eenvoudig overleg - zouden de traditionele hiërarchische praktijken kunnen vervangen. ${ }^{95}$ Een enkel preciseren van het nationale beleid zou tevens in een eenvoudige dialoog tussen OM en ministerie

91 Zie 5.42. Aanwijzingen tot vervolging.

92 Rassat 1996, p. 109-110; Accomando 1997a, p. 95.

93 Zie 9. Samenvating en conclusie.

94 Frissen 1998, p. 728.

95 Jéol 1994, p. 1365. 
kunnen plaatsvinden, zonder dwangmiddelen. Evengoed zouden andere middelen gebruikt kunnen worden, zoals de controle op jaarverslagen van het $O M^{96}$ In Nederland heeft deze vervanging van hiërarchische door andere middelen al feitelijk grotendeels plaatsgevonden.

Samengevat is de specifieke aanwijzingsbevoegdheid een onnodig en onvoldoende instrument voor de beleidscontrole, dat de aard wan het beleid zelf miskent.

\subsection{Anticipatio wan wetgeving}

Het belang wan de aanwijzing om niet te vervolgen wordt in Nederland onderstreept thet het argument van de wetsanticipatie. De minister kan het OM opdragen bepaalde zaken niet op te sporen of te vervolgen als aanpassing van beleid of regelgeving in voorbereiding is. Instellen van vervolging zou voor die aanpassing 'een belemmering' opleveren. De minister zou daarom aanwijzingen tot niet vervolgen moeten kunnen geven. ${ }^{97}$

Ook in Frankrijk stelt men wel dat ministeriële instructies tot niet-vervolging nodig kunnen zijn in het geval het ministerie nieuwe wetgeving voorbereidt. In het vooruitzicht van deze nieuwe bepalingen kan de regering het $\mathrm{OM}$ verhinderen te vervolgen op grond van de oude wetgeving. Daartoe kan een circulaire aan het $\mathrm{OM}$ gericht worden. ${ }^{98}$

Totdat een wet gewijzigd is gelden echter de oude wetsbepalingen. Het OM kan rekening houden met toekomstige wetgeving, maar ook rechtmatig beslissen tot vervolging op grond van overtreding van die wetsbepalingen. Een aanstaande wetswijziging is een factor die het parket zal moeten betrekken in zijn beslissing.

Verder geldt ook hier, net als ten aanzien van het argument van de beleidscontrole, dat de hiërarchie binnen het $O M$ hier evengoed controle uit zou kunnen uitoefenen. Vervolgens zou de rechter zonodig op een komende wijziging in beleid of regelgeving kumnen anticiperen. De rechter zou in zijn beslissing rekening kunnen houden met deze vactor.

Ten behoeve van wetsanticipatie zou de minister eveneens een beleidsregel kunnen uitbrengen. Het valt evenwel niet in te zien waarom de minister daartoe ook individuele aanwijzingen zou moeten kunnen geven. Wanneer beleidsaanwijzingen mogelijk zijn bestaat daar eenwoudigweg geen noodzaak toe.

\section{$5.3 \quad$ Buitenlandse betrekkingen}

Diplomatieke betrekkingen vormen een apart argument voor de individuele aanwijzingsbevoegdheid. Een buitenlandse staat zou zich bij de regering kunnen beklagen over het gegeven dat een bepaald feit wel of niet vervolgd zou worden. Zou de staat dan genoegen nemen met de opmerking dat de regering daar niets an kan doen, omdat

96 Rassat 1096, p. 109: Accomando 1997a, p. 95.

97 Kamersinkken II 1996/97, 25392, nr. 3, p. 26. Vgl. Duisterwinkel 1965, p. 9-10.

98 Terver. Commission de rélexion sur la Justice. Amexes 1997, p. 105. Tevens kunnen aanwijzingen een instrument zijn watmee de minister zijn witleg van pas gewijzigde of geldende wetgewng uiteenzett. Masse 1996, p. 164. 
het vervolgend orgaan wat dat betreft onathankelijk is? De minister zou dan een specifiek bevel moeten kunnen geven. De besluitvorming van het OM zou immers schadelijk kunnen zijn voor de buitenlandse betrekkingen. ${ }^{99}$

In een kritiek op deze stelling mak ik onderscheid tussen het geval dat het OM niet vervolgt en dat waarin het besluit wel te vervolgen. Voor dat eerste geval: waarom zou de buitenlandse staat in geval van niet-vervolging bij de regering aankloppen? In bepaalde gevallen zou deze staat of een buitenlandse burger als rechtstreeks belanghebbende beklag in kunnen stellen over de niet-vervolging. Zou het buitenland niet klagen wanneer de rechter het beklag afwijst, of wanneer de rechter de verdachte niet veroordeelt? Deze kritiek blijft in elk geval mogelijk. Niemand verdedigt op deze grond dat de onafhankelijkheid van rechters moet worden opgeheven.

Voor het geval. het OM besluit te vervolgen is het de vraag welke relevantie de vervol. gingsvraag heeft voor de buitenlandse betrekkingen. In Nederland worden de diplomatieke relaties in ieder geval met even grote vanzelfsprekendheid los gezien van de vervolging. De ministers Van Mierlo en Sorgdrager en de Tweede Kamer gingen nog verder in de zaak Bouterse. $\mathrm{Zij}$ meenden dat, zonder belemmering van redenen van buitenlandse politiek, het recht of de rechtsgang zijn loop moet hebben. ${ }^{100}$ De algemene aard van deze opvatting en het gegeven dat die breed gedeeld werd, doen concluderen dat voor aanwijzingen tot niet vervolgen in dit verband in ieder geval geen behoefte of noodzaak bestaat.

Overigens hebben landen waarin het OM van de regering onafhankelijk is, geen bijzonder problematische diplomatieke relaties met de internationale gemeenschap. Veeleer Wijkit de soms grote internationale reikwijdte van strafrechtelijke bepalingen - zoals bijvoorbeeld in Belgie - problematisch in buitenlandse betrekkingen.

\subsection{Vervolgingsbeslissing als een politieke keuze, van algemeen belang}

De beslissing om wel of niet te vervolgen kan zoals gezegd "politiek" genoemd worden, een besluit waar het "algemeen belang" mee gemoeid is. In paragraaf 4.4 besprak ik al de zwakte in deze argumentatie in algemene zin. Zij wordt evenwel ook nadrukkelijk gebruikt om individuele aanwijzingen te bepleiten. Deze overwegingen wil ik hier

99 Schuering 1968, p. 68. Vgl. Minister Sorgdrager, Kamerstukken II 1997/98, 25392, nr, 3, p. 25-26, 46 en Handelingen 11 \$ $997 / 98$, p. 4841. In Frankrijk noemt Boudon de problematiek rond diplomaten, 1997, p. 13.

100 "Bij het formuleren van het antwoord heeft de regering zich laten leiden doon het uhitgangspunt dat de rechtsgang in een rechisstakt ongehinderd door politieke inmenging hat lwop moet hebben. (...) De billaterale relatie tussen beide landen moet los worden gexien wan de zaak-Bouterse." Minusiters Van Mierlo en Sorgdrager, Kamerstukken II 1996/97, 25467, nr. 1, p. 1. Van Mierlo neende in de Bouterse zaak "dat het recht zijn loop moet hebben", Van Mierlo, Handelingen il 1996/97, p. 7017. Sorgdrager stelde in algemene temen: "Een strafproces moet natuutlijk zijn loop hebben wn een strafproces heef? alteen te maken met buitenlands politieke zaken als het in het belang is wan datistrafproces. Hei mag das niet zo zijn dat buitenlandpolitieke owerwegingen een belemnerende invloed hebben op de loofs wan het strafproces." Sorgdrager, Handelingen 111996197, p. 7035. In de Tweede Kamer was een zelfde gelüld te horen, b. w: 'Dat impliceent dat buitenland-politicke overwegingen en aspecten, hoezeer die in aen zak als deze ook als relevant behoren we worden meegewogen, hiet doorslaggevend kunnen en mogen zijn. Het recht moet inderdaad zijn loop hebben." Rowvoet, Handelingen II 199697, p. 7081. 


\section{Hoofostuk 6}

meer in het bijzonder behandelen. Eerst beschouw ik de kwestie ten aanzien van de aanwijzing tot niet-verwolging, ten weede ten aanzien van de aanwijzing tot vervolging.

\subsubsection{Aanwijzingen tot niet-vervolging}

Velen in Nederland achten een aanwijzing tot niet-vervolging gerechtvaardigd wanneer het belang of de veiligheid van de staat geschaad kan worden. ${ }^{101}$ In het bijzonder de beslissing om niet te vervolgen, met name in het geval er geen belanghebbende in de zaak is ziet men in Nedenland als een politieke aangelegenheid, of een zaak waarbij de politieke invalshoek zou prevaleren. De ministeriele afweging zou daarom uiteindelijk doorslaggevend moeten ziju.

Ook in Frankrijk zijn enkelen (soms impliciet) van mening dat de minister om reden van het algemeen belang een bevel tot niet-vervolging zou moeten kunnen geven. ${ }^{103}$

Om te beginnen een precisering: als men meent dat de politiek 'het laatste woord' zou moeten hebben, waar het OM overweegt om niet te vervolgen, dan pleit dit hoogstens voor een aanwijzingsbevoegdheid tot vervolging - niet voor één tot niet-vervolging. Hier is aan de orde of de politiek moet kunnen ingrijpen in de (voorgenomen) beslissing van het $O M$ om wél te vervolgen.

Wanneer de minister het 'algemeen belang' gebat acht bij niet-vervolging, kan dit trouwens alleen beschermd worden wanneer een slachtoffer geen beklag of klacht indient, of bij delicten waarbij geen belanghebbenden kunnen zijn. In gevallen waar wel sprake is van een klagend slachtoffer, is de bescherming van het belang bij nietvervolging afhankelijk van het oordeel van de rechter.

In Nederland is deze vrij het belang van klagende belanghebbenden voor te laten gaan op een eventueel algemeen bellang. De opvatting van de rechter over de verhouding van dit particuliere tot het algemeen belang gaan voor op die van de minister. In Frankrijk kan de rechter in het geheel niet om redenen van algemeen belang de klacht afwijzen.. In deze gevallen heeft de minister al geen greep op de bescherming van het algemeen belang zoals hij dat interpreteert. Het recht biedt de visie van de minister op het algemeen belang dan geen bescherming. Het is opmerkelijk dat de bescherming van het algemeen belang zoals gezien door de minister dus afhangt van het soort delict of de toevallige afwezigheid van belanghebbenden. Deze zeggenschap van het slachtoffer en de rechter - eventueel in strijd met de ministeriële opvatting over het algemeen belang - wordt in het huidige systeem algemeen aanvaard. De bescherming van het algemeen belang vormt dan slechts een gelegenheidsargument voor de beredenering van een aanwijzingsbevoegdheid.

101 College van procureurs-gmenal 1997, p. 2; NVWR 1997, p. 4; VWD-fractie, Kamerstukken II 1997/98, 25392, nt. 6, p. 19. Minister Sorgdrager, Kamerstukken II 199798,25392, nr. 3, p. 25, 46; nr. 7, p. 38 .

102 Kalsbek-Jasperse, Handelingen II, 1997/98, p. 4790, 4801-4802; Korthals, Handelingen 11 , $1997 / 98$, p. 4791; Dittrich. Handelingen $11.1997 / 98$, p. $4791-4792$; Rabbae, Handelingen II, 199789, p. 4792 .

103 Jeol 1996, p. 71; Boudon 1997, p. 13, Tetrier. Commission de reflexion sur la Justice, Annexes 1997, p. 105; Carbonnier, idem, p. 158. 
Verder kunnen institutionele problemen ontstaan wanneer een kamer van oordeel is dat vervolging in een zaak achterwege kan en dient te blijven. Indien vervolgens beklag bij het hof wordt ingesteld, en dit oordeelt dat vervolging wel geïndiceerd is, zou er "tegenspraak" ontstaan tussen de kamer en het hof. "Met het oog op het gezag van parlement én rechter' lijkt het beter een dergelijke situatie te voorkomen. ${ }^{104}$ Een dergelijke 'conflictsituatie" zou de relatie tussen de staatsmachten danig op het spel zetten. Met het uitsluiten van aanwijzingen tot niet-vervolging kan dit probleem worden voorkomen.

Daarbij komt het nogal gezocht over om de veiligheid van de staat in het geding te brengen als argument voor een aanwijzing tot niet-vervolging. Voor de bescherming van dit belang bestaat reeds een serie waarborgen. Zo bestaan geheimhoudingsplichten en specifieke strafrechtelijke bepalingen, is behandeling met gesloten deuren of in de raadkamer mogelijk en hebben de inlichtingen- en veiligheidsdiensten die bescherming tot taak. ${ }^{105}$ Desgewenst kumnen deze diensten gegevens in hun bezit, via de minister van Binnenlandse zaken of Defensie, aan het OM doorgeven. Daar is echter geen algemene plicht toe, "het betreft hier derhalve een discretionaire bevoegdheid van de betrokken minister.' Verder plegen het College en de diensten waar nodig overleg. ${ }^{106}$ Het geheel van deze waarborgen maakt het ondenkbaar dat een vervolging de veiligheid van de staat schaadt.

Daarnaast kan het voorkomen dat de belangen van de verdachte juist in positieve zin zijn betrokken bij de vervolging. Het is te eenzijdig om te stellen dat hij alleen maar belang heeft bij niet-vervolging. Zo zou een rechterlijke uitspraak hem van verdenking kunnen ontheffen. ${ }^{107}$

Overigens bestaat geen noodzaak om in gevallen die 'het algemeen belang' raken te reageren met een specifieke aanwijzing tot niet-vervolging. Een in Frankrijk veel genoemd geval als een nationale staking gepaard gaand met delicten zou ook anders behandeld kunnen worden. De minister zou in een dergelijk geval evengoed zijn visie in een ad hoc circulaire op kunnen nemen. In de recente Franse praktijk is dit reeds voorgekomen. Waarom deze optie een bevel tot niet-vervolging niet zou kunnen vervangen blijft onduidelijk in de bovengenoemde redeneringen.

Ten slotte kan de wetgever toestemmingsvereisten creëren voor bepalde soorten delicten of personen. Voor een aantal gevallen bestaan in de drie landen al regelingen waarin de minister, de regering of een parlementskamer een besluit moet nemen alvorens vervolging kan plaatsvinden. Dergelijke voorzieningen kunnen zonodig worden uitgebreid.

104. Corstens 1974, p. 57.

105 In Nederland: art. 80quater, $98-98 \mathrm{c}$ Sr: art. 22,218 en $269 \mathrm{Sw}$.Zic verder bijw de Wet bescherming staatsgeheimen en de Aanwijzingen voor de beveiliging van statsgeheimen en vitale onderdelen bij de rijksdilenst.

106 Kamerstukken II $1997 / 98,25877$, nr. 3, p. 58 . Art. 38 en 61 Welt op de inlichtingen- en weiligheidsdienstern.

107 De Doelder 1995, p.62. Vgl. in algemene zin Corstens 1999, p. 504.

108 Overigens zou de houding van de mirister wan Justitic bij grote sociale conflicten ook wel juist actief op vervolging gericht geweest zijn. De Montgolfier 1996, p. 171. Ower het gebruik van ad hoc circulaires ler gelegenheid van een serie delicten bij een nationale geloe urtenis zie hoofdstuk 3, 6.3.1.1. Circulaires. 
Het bestaan van een bevoegdheid on aanwijzingen tot niet-vervolging te geven wordt evenmin geeist door internationale aambevelingen ontrent de positie van het OM. Integendeel, deze wordt vaak afgeraden. Sommige zwaarwegende (intergouvernementele) verklaringen laten deze bevoegdheid wel toe, maar eisen daaromheen sterkere beperkingen en warborgen dan voot andere individuele aanwijzingen. ${ }^{109}$ Curieus is in dit verband te noemen de bijlage bij de aanbeveling van de Raad van Europa van 2000. Deze noemt expliciet de Nederlandse procedure voor een aanwijzing tot niet-vervolging als voorbeeld. Nederland heeft zich op dit punt blijkbaar de uitzonderlijkheid wan haar aanwyzingsbevoegdheid tot niet-vervolging gerealiseerd. De vermelding in de bijlage wijst op de inwloed die het land heeft gehad op de formulering van de bepaling die aanwijzingen tot miet-vervolging toelaat. ${ }^{110}$

\subsubsection{Aanwijzingen tot vervolging}

Het algemeen belang noemt men in Nederland een reden woor het bestaan van de bevoegdheid aanwijzingen te geyen tot vervolging. De minister is dan degene die zal moeten beoordelen, of het staatsbelang bij de verwolging van een feit een rol speelt. Hij zou moeten kunnen ingrijpen in een zaak wanneer de vervolging het belang van de staat zou raken." Ook in individuele zaken zou het oordeal van de minister uiteindelijk de voorrang moeten krijgen boven dat van het OM, omdat de minister een beter zicht zou hebben op "wat de raison d'état eist."1'2 "De Regering moet in staat zijn een beslissing van de rechter uit te lokken". Anders "zou het conflict tussen het algemene en het particuliere belang buiten de rechtszaal terecht komen tussen de Regering en het OM en tevens onoplosbaar worden ${ }^{* 113}$

Ook de Fransen zijn veelal van mening dat er soms situaties zijn warin het vanuit het oogpunt van het algemeen belang of de handhaving van de openbare orde noodzakelijk is dat het ministerie kan ingrijpen. Dit zou mede noodzakelijk zijn omdat het de regering is die de gevolgen draagt van eventuele misstappen. ${ }^{114}$ Aangezien de regering belast is met de behartiging van het algemeen belang, zou het voor de hand liggen dat zij vervolging in zou kunnen doen stellen. Analoog aan de klacht bij de onderzoeksrechter" van een belanghebbende burger, zou de regering een impuls moeten kunnen geven waar een algemeen belang in het geding is. 11 s

109 Art. $111.9 \mathrm{EU}$, art. $13 \mathrm{RvE}$ en art. $2.3 \mathrm{MA}$. De latste eist overigens geen zwardere warborgen dan voor andere specifieke anwijzingen. MEDEL en IAPL wijzen zoals gezegd alle individuele anwijzingen all.

110 Vethay stult veelbetekenend dat de Nederlandse weigeving in de aanbeveling wordt "gesauveerd", 2001 , p. 188

$11 \|$ Schuening 1968, p. 69. NVvR 1996, p. 320, College van proctureurs-general 1997, p. 2; NVVR 1997, p. 4: VVD-fractie, Kamerstukken II 1997/98, 25392, nr. 6, p. 19. Opvallend is overigens dat Schuering vervolgens stall dat in geval een offeier beroep instelt tegen een disciplinäne maatregel na een niet opgevolgde amwijzing, de CR vB zou noeten ondarzoken of de minister ziclu inderdaad op statsbelang kon betoepen. Z luierover hoofdstuk 2, 6.2.4. Rechtswarborgen bij aanwigingen.

112 Corstens 1999, p. $95,99$.

113 Mostert $1968, \mathrm{p}, 310$

114 . Wel 1996, p. 71; Boudon 1997, p. 13 en 14: Terrier, Commission de reflexion sur la Justice, Annexes 1997, p. 105; Carbonnier, idem, p. 158.

115 Matagrin 1996, p. I 15 
Zoals gezegd in paragraaf 4.4 lijkt hier het taalgebruik zelf al een conclusie te suggereren. Is niet bij elke bevoegdheidsuitoefening het algemeen belang betrokken? Met betrekking tot de ratio van individuele aanwijzingsbevoegdheden wil ik dit hier nader overwegen. In paragraaf 4.6 stelde ik dat hetgeen thet $O M$ van de rechter onderscheidt de discretie van zijn initiatief is. Moet nu aan het $O M$ de vrijheid gelaten worden te beslissen niet het initiatief te nemen tot vervolging op gronden ontleend aan het algemeen belang?

Eisen van democratische legitimatie rechtvaardigen in ieder geval niet dat de minister de vervolging opdraagt van een zaak die technisch onhaalbaar is. Een ministeriefe beslissing tot vervolging, eventueel gesteund door een parlementaire meerderheid mag niet botsen met de afwezigheid van juridische gronden voor een veroordeling. Ook beslissingen in het algemeen belang moeten in overeenstemming zijn met het recht. De vraag is dan wie bepaalt of een zaak technisch haalbaar is. De wetgever en andere regelgevende ambten - waaronder de minister - maken in beginsel uit welke normen in abstracto gelden. In concreto zijn de professioneel daartoe geëigende ambten het OM en de rechterlijke colleges. Deze competentie moet dan doorslaggevend worden geacht boven die van de minister. Niet valt in te zien wat de legitimatie van de minister hieraan zou kunnen toevoegen. Daarom meen ik dat aanwijzingen tot vervolging op grond van het algemeen belang uitgesloten moeten zijn voor de gevallen waarin niet-politieke ambten om technische redenen vervolging uitsluiten. ${ }^{116}$

De belangrijkste internationale aanbevelingen omtrent de positie yan het $\mathrm{OM}$ vereisen dat het OM geen vervolging begint of voortzet als een onpartijdig onderzoek vaststelt dat de aanklacht ongegrond is. ${ }^{17}$ Hierin kan een indicatie gelezen worden dat in dergelijke gevallen voorbij gegaan moet worden aan het oordeel van een politiek ambt, dat per definitie geen onpartijdige rol heeft.

Daarnaast is het mogelijk dat het OM een zaak technisch haalbaar acht, maar niet opportuun om te vervolgen. Het OM kan daartoe besluiten op gronden van algemeen belang ontleend aan sepotcriteria en aan posterioriteiten uit bestaand beleid. Het is vanuit het oogpunt van democratische legitimatie wenselijk dat deze gronden zoveel mogelijk in algemeen beleid zijn vastgelegd. Het OM heeft echter ook de bevoegdheid om op andere gronden dan die vastliggen in beleid te besluiten om niet te vervolgen.

Moet de minister nu een vervolgingsbevel kunnen geven als het $O M$ overeenkonstig het beleid besluit af te zien van vervolging, of niet vervolgt om redenen buiten het beleid om? Moet de minister kunnen uitmaken of in dat specifieke geval het algemeen belang toch vervolging eist? In deze situatie meen ik dat de opvatting van de minister de doorslag moet geven. Een dergelijke conclusie sluit aan bij mijn eerder uiteengezette

116 Ean dergelijke gedachte slüt overigens aan bij een element in de Nederlandse vegeling ontrent de overdracht van strafverwolging aan buitenkandse alloriteiten (art. 552 bb Sw). Hierin moet de minister de overdracht weigeren als "naar het oordeel wan hei OM in Nederland geen strafvervolging plaats kan hebben wegens het ten laste gelegde feit." Omtrent de haabaarheid van de wervolging heeft de ministe. hier evenmin zeggenschap. De minister kan miet alsnog tot overdracht bestuiten ondail hij cen andere opwatting lneeft over die haalbaarheid dan het $O M$.

117 Art. $14 \mathrm{VN}$, art. $111.5 \mathrm{EU}$ en art. $26 \mathrm{RvE}$. 
redenering omtrent de beleidsvoering. ${ }^{1 / 8}$ Het betreft hier een besluit wan het $\mathrm{OM}$ om nief het initiatief tot vervolging te nemen, ondanks dat democratisch gelegitineerde ambten het feit strafbaar hebben gesteld. Het buiten toepassing laten wan strafbepalingen, anders dan om technische redenen, is een uitoefening van diseretie die een democratische correctie moet kunnen krijgen. Met het oog daarop dienen politieke ambten te kunnen bewerkstelligen dat in dergelijke gevallen vervolging ingesteld wordt.

Wel moet het risico vermeden worden dat het $\mathrm{OM}$ onder het mom van het algemeen belang worde aangezet om te vervolgen, terwijl daar naar het oordeel van het OM en de rechterlijke colleges technisch geen gronden voor zijn. Dit risico is aanwezig als de minister een niet nader omschreven bevoegdheid heeft aanwijzingen tot vervolging te geven. ${ }^{119}$ Om te verzekeren dat alleen in haalbare gevallen vervolgd zal worden, dient de opvatting van de minister op andere wijze tot vervolging leiden. Hoe één en ander in juridische vormen gegoten zou kunnen worden bespreek ik in het volgende hoofdstuk. ${ }^{120}$

\section{Ministeriële rechtsbescherming, rechtmatigheidscontrole en rechtsontwikkeling}

In de vorige paragrafen behandelde ik argumenten vór een specifieke aanwijzingsbevoegdheid die in min of meer directe zin verwijzen naar een principe van democratische zeggenschap. In paragraaf 7 wil ik redeneringen aan de orde stellen die zich richten op de rechtsstaatgedachte. Tussen deze twee categorieën in beschouw ik nu enkele stellingen die niet eenduidig naar één van deze rechtswaarden van democratie of rechtsstaat verwijzen. Deze tweeslachtigheid vormt meteen de belangrijkste zwakte van de argumentatie. Enerzijds betreft het hier de idee dat de noodzaak van rechtsbescherming tegen en rechtmatigheidscontrole over het $\mathrm{OM}$ tot ministeriële zeggenschap moeten leiden. Anderzijds wordt een individuele aanwijzingsbevoegdheid nodig geacht voor de bevordering van de rechtsontwikkeling door de minister.

\subsection{Rechisbescherming en rechtnatigheidscontrole}

De ministeriele aanwijzingsbevoegdheid en de betrokken parlementaire controle zien Nederlanders en Fransen ook wel uitdrukkellijk als een vorm van rechtsbescherming of rechtmatigheidscontrole. De minister zou deze controle effectief kunnen uitoefenen middels aanwijzingen tot vervolgen, niet vervolgen en ter aanzien van het requisitoir. Zoals zal blijken veronderstelt een dergelijke redenering ten onrechte dat de minister een soort rechterlijke controle zou kunnen uitoefenen.

118 Zie 4.6.2. Beleidsvoring en individuele zaken.

119 Ower het risico van partijpolitiek nisbruik van aamwijzingsbevoegdheden, zie 7.4.1. Partijdigheid door ministerise imvloed.

120 Te denken valt an een ministeriele klach bij de rechter, of aan rechterlijke controle over elke aamwin-

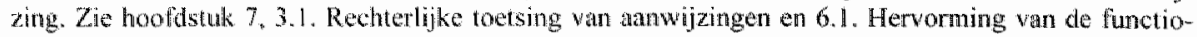
nele relatic ussen OM en minister. 


\subsubsection{Aanwijzing tot vervolging en niet-vervolging}

Aangezien niet bij elk handelen van het Nederlandse OM de rechter is betrokken, zou controle op een andere wijze nodig zijn, via de minister. De waarborg van parlementaire controle zou in zekere zin een compensatie vormen voor het feit dat de rechter zich niet altijd over de rechtmatigheid van de zaak zal kunnen uitspreken. De partementaire controle zou een van de garanties tegen willekeur zijn in het handelen van het OM. ${ }^{121}$ Zonder aanwijzingsbevoegdheid en verantwoordelijkheid zou "de deksel wel eens veel steviger op de doofpot kunnen blijken te zitten dan in het geval er wel politieke verantwoordelijkheid is. ${ }^{122}$ In de Nederlandse visie is verder specifiek genoemd dat er bij het optreden van het OM 'fundamentele rechtsgoederen' in het geding zijn, die door ministeriële zeggenschap als het ware beschermd moeten worden.

De Franse bevelsbevoegdheid van de minister is wel gezien alls een correctief of een garantie tegen mogelijk misbruik van het opportuniteitsbeginsel door het $\mathrm{OM}$. De minister zou zo de wet kunnen doen handhaven. Door de bijzondere bevelen zou de minister ongelijkheden in de vervolging kumnen tegengaan. Daartegen zouden niet voldoende waarborgen zijn, aangezien niet altijd een klacht door bijvoorbeeld een slachtoffer mogelijk is. ${ }^{124}$ Het bevel tot vervolging zou dan een tegenwicht zijn van de beslissing tot sepot van het $\mathrm{OM} .^{125}$

Het is evenwel de vraag of de controle van de minister of het parlement die van de rechter kan compenseren. ${ }^{126}$ Zowel democratische als rechterlijke controle kunnen een geval in de openbaarheid brengen en gelegenheid geven voor kritiek. De rechter is echter functioneel gericht op toetsing aan het recht, het parlement toetst veeleer de politieke wenselijkheid. "Op het moment dat het gaat om individuele belangen (...) bemoeit de kamer zich er uitsluitend mee, wanneer dit voor een groepering in de kamer politiek interessant is. ${ }^{127}$ De vraag is of rechtmatigheidsaspecten niet in het gedrang zullen komen. ${ }^{128}$ Weinig parlementariërs zullen overigens gespecialiseerd zijn in het

121 Van Binsbergen 1968, p. 92; Corstens 1974, p. 50; Hirsh Ballin 1991, p. 197; Clitur 1997a, p. 95; Minister Sorgdrager, Kamerstukken 11 1997/98, 25392, nr. 7, p. 24; Van der Fliei 1999, p. 744; Milken.

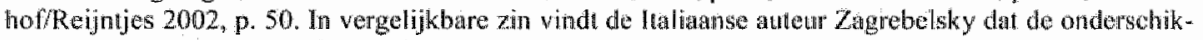

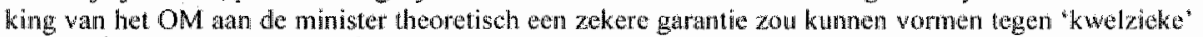

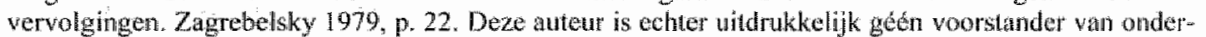
schikking.

122 Corstens 1999, p. $95,97,99$.

123 Commissie Scheltema 1993, p. 44-45; Kamerstukken II 1996/97, 25392, nr. 3, p. 21-22. De commissie

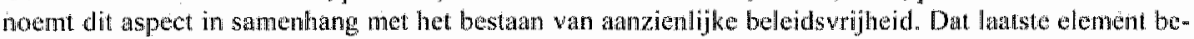
handalde ${ }^{k}$ hiervor atzonderlijk.

124 Malibert 1994, p. 30; Mazeaud 1996, p. 68; Cotte, Commission de réflexion stu lastice, Annexes 1997, p. 72 .

125 Gunchard \& Buisson 2000 , p. 498.

$126 \mathrm{Vgl}$. Koekkoek, Handelingen II 1997/98, p. 4789; 't Hart 1999, p. $116 ; 2001$, p. 21. In het algemeen over het oneigenlijk gebruik van politieke verantwoorlelijkheid als rechtsbescherming: Stroink 1978, P. \#4, Overigens stelde men bij de totstandkoming van het WwSw mog uitdrukketijk dat de ministeriele verantwordalikheid een te zwar wapen zou zijn woor cen regelonatig toezicht op gewallon van nietvervolging, Kamerstukken $111913 / 14,286$, nr. 3, p. 32

127 Duisterwinkel $1968 \mathrm{a}$, p. 109.

128 Glastra wan Loon, Handelingen $1,1998 / 99$, p. 1187. 
strafrecht. "25 "Lands vergaderzaal leent zich in beginsel niet voor een discussie over individuele strafzaken. "30 Een bepaalde zaak is niet geschikt voor verantwoording in het parlement, daar de burgers wie het aangaat zich daar niet kunnen verweren. ${ }^{131}$ Sterker nog, de bemoeienis van de minister zal het gevaar van willekeur kunnen vergroten. Een van de politiek autonoom OM zou juist de kans groter maken dat vooral in de eerste fase van een strafzaak de rechtmatigheidsaspecten niet verwaarloosd worden. In voorkomende gevallen zou de minister onregelmatigheden juist verergeren. ${ }^{132}$

Het idee van ministeriêle rechtsbescherming haalt de tegenstelling tussen onpartijdige rechtshandhaving en gelegitimeerde politiek overhoop. Legitimatie geeft een minister geen technische competentie voor een onpartijdige beslissing.

Waarom het $O M$ door de ministerièle bevoegdheid en verantwoordelijkheid de deksel minder stevig op een eventuele doofpot zou kunnen houden blijkt verder niet. Ook in het huidige stelsel is de minister voor de informatievoorziening sterk afhankelijk van het OM. Daarbij komt, dat het denkbaar is dat de informatievoorziening aan de minister toch behouden blijft, ook wanneer deze geen bijzondere aanwijzingsbevoegdheid heeft. Bovendien staat het handelen van het OM al onder interne hiërarchische controle. Zowel het parkethoofd als de procureur-generaal of het College houden toezicht.

Dat er bij optreden van het OM fundamentele rechtsgoederen in het spel zijn is geen sterke argumentatie om ministeriële zeggenschap te rechtvaardigen. De minister is niet het geëigende orgaan om fundamentele rechtsgoederen te bewaken. De fundamentele aard van de goederen en de potentiële schade die de vervolging kan aanrichten maken professionele waarborgen nódzakelijk. De autonomie van het OM kan één van deze waarborgen vormen. ${ }^{133}$ Juist bij principieel zwaarwegende zaken zou de minister zijn politieke oordeel achterwege kunnen en moeten laten in een aanhangig gemaakte zaak. $^{134}$

Het argument van de rechtsbescherming is in het bijzonder twijfelachtig ter onderbouwing van een eventuele aanwijzing tot niet vervolgen. Wanneer het $O M$ op onjuiste gronden tot vervolging overgaat, vormt de rechter juist een waarborg van controle en rechtsbescherming. Een ministeriële waarborg tegen het instellen van willekeurige vervolging door het $\mathrm{OM}$ is uit de aard van het strafproces overbodig.

\subsubsection{Aanwijzing ten aanzien van het requisitoir}

Een in het Nederlandse stelsel veel besproken aspect van rechtmatigheidscontrole is die ten aanzien van het requisitoir. Ministeriële invloed zou hier vooral bij zwaardere of principieel zwaarwegende zaken, zoals euthanasiegevallen noodzakelijk zijn. ${ }^{135}$ Het

129 De Doelder 1988a, p. 375.

130 Oravje 1976, p. 4.

131 Singer-Dekker 1982, p. 129.

132 In Nederland: Peters 1983, p. 364; Remmelink 1991, p. 177. In Frankrijk: Rassat 1967, p. 147; Jacquin \& Vogelweith (Mény) 1998, p. 7.

133 Silvestri 1997, p. 105.

134 Vgl over euthanasie: Boorsma 1996, p. 9.

135 Kamerstukken II 1996/97, 25392, nr. 3, p. 24. 
OM zou bijwoorbeeld niet-ontvankelijkheid in een strafzak willen eisen. De aninisize zou daarvan minder overtuigd $z i j n$. Met het oog op onder meer de eventwete noodzant. tot wetswijziging zou hij een rechterlijke uitspraak in hoogste instante wensen. De minister zou dan een aanwijzing willen geven fom te requireren op een wize die het door de minister gewenste resultaat dichterbij brengt:" "Een vergelijkbaar geval botrof de zaak Drenth uit 1996. Hierin was de minister echter niet op de hoogte van het vootnemen van officier van justitie Drenth om niet-ontvankelijkheid te eisen. De procureurgeneraal had dit wel ten sterkste ontraden. De minister had evenwel enkel bepaald dat het OM vervolging diende in te stellen. Drenth werd berispt wegens plichtsverzum. De Centrale Raad van Beroep was van cordeel dat de vordering tot niet-ontvankelijkverklarimg niet te verenigen was met de strekking van de opdracht om uitvoering te geven aan de aanwijzing. De Raad gaf geen nadere redenen voor deze onverengbaarheid. 37

De minister en de Centrale Raad zijn niet te volgen in hun redenering. De vordering van de officier van justitie heeft feitelijk wel enige invloed op de rechter. Bij de uitspraak is hij echter vrij om te beslissen op de rechtsvragen, waronder die omtrent de niet-ontvankelijkheid. Een aanwijzing ten aanzien van het requisitoir heeft geen rechtsgevolgen voor de rechterlijke uitspraak. ${ }^{3 \%}$ Hoogstens zou de aanwijzing een feitelijke invloed op het rechterlijke oordeel kunnen hebben. De rechter zou beinvloed kunnen worden door het feit dat de minister zich in de zaak heeft uitgesproken. Daar zou hij bijvoorbeeld van onder de indruk kunnen zijn en vonnissen conform de door de minister aangewezen vordering. Het hoeft nauwelijks betoog dat dit gevolg van de aanwijzing strijdig is met de rol of de functie van de rechter. Hij dient op juridische gronden, niet op autoriteitsargumenten te beslissen.

Rechtmatigheidscontrole door de minister vormt aldus een dubbelzinnig pleidooi. Een bijzondere ministeriële aanwijzingsbevoegdheid kan evenzeer rechtsbescherming als partilidige inmenging meebrengen.

\subsection{Proefproces en rechtsontwikkeling}

Enkel in Nederland komt men redeneringen tegen voor bijzondere aanwijzingen ten behoeve van de rechtsontwikkeling. Ik behandel afzonderlijk de verdediging van de aanwijzing tot vervolging en die van de anwijzing ten anzien van het requisitoir.

\subsubsection{Aanwijzing tot vervolging}

Een ratio van de aanwijzing tot vervolging die wel opgeld doet betreft het proefproces. De minister zou het wenselijk kumnen achten om een proces te houden over een kwestie waar de politiek niet uit komt, zoals bijvoorbeeld euthanasie. Een uitspraak van

136 Kamerstukken I 1998/99, 25392, nr. 46c, p. 1-2.

137 Zie voor de zagk eveneens hoofdstuk 2,6.2.2.6. Aanwigzing ten aanzien wan het reqühitoir.

138 Constems 1996, p. 386; De Winter 2001, p. 81. Daamaast had de minister de anwijzing preciezer kunnen formulleren, zie de paragraaf genoemd in de vorige noot. 
de rechter zou van dienst kumen zijn woor de rechtsontwikkeling. ${ }^{139}$ Het kan voorkomen dat het OM meent dat een zaak technisch niet haalbaar is, terwijl de minister meent van wel, of daaraan twijfelt. Zelfs als hij het oordeel van het OM dat de zaak niet haalbaar is zou delen, zou hij een rechterlijke uitspraak kunmen wensen. Daartoe zou een aanwijzingsbevoegdheid kunnen dienen.

Deze redenering strookt niet met het verschil in taak van de wetgever en de minister. Het is primair de taak van de wetgever om de burgers bindende regelingen vast te stellen. De minister zou niet zijn aanwijzingsbevoegdheid als een "eenvoudige alternatieve wetgevingsprocedure" moeten gebruiken. Inhoudelijke nomen dienen in wettelijke regelingen te worden vastgelegd, indien de minister tot rechtsontwikkeling wenst te komen. Het strafproces moet niet gezien worden als een middel om een wetgevingskwestie op te lossen, ten koste van een verdachte. "Als in geval van een politieke patstelling de hete kastanje naar de strafrechter rolt, kan het de taak wan het O.M. zijn die rechter te behoeden dat hij zich in dat wespennest steekt. 140

Het aanwijzen van categorieën waarin proefprocessen gehouden kunnen worden zou beter in beleid kunnen worden neergelegd. Als de minister immers een bevoegdheid heeft beleidsaanwijzingen te geven, kan hij in dat beleid bepalen in welke gevallen in leder geval vervolging ingesteld moet worden. Dit draagt bij tot de consistentie en de rechtszekerheid voor de betrokken burgers. In specifieke zaken kan het OM dan zonodig rekening houden met de bijzondere omstandigheden van het geval.

De proefprocesratio is in feite wat eenzijdig bepaald door een instrumentele visie op het strafrecht. Het strafproces ziet men daarin vooral als een middel om de politiek van de minister te voeren. Aspecten van rechtsbescherming voor met name de "proef-verdachte" kunnen hierbij ondergesneeuwd raken.

\subsubsection{Aanwijzing ten aanzien van het requisitoir}

Ten aanzien van de aanwijzing betreffende het requisitoir wordt in Nederland iets soortgelijks angevoerd. De minister zou bijvoorbeeld met het OM van mering kunnen verschillen over de ontvankelijkheid van het OM. Het is denkbaar dat de officier ontslag van rechtsvervolging zou willen eisen. Voor de minister zou het van belang zijn dat als de rechter de eis zou overnemen, 'de mogelijkheden tot instelling van hoger beroep en cassatie voor het OM praktisch gezien tot een minimum zou(den) zijn gereduceerd'. Dit achtte de minister ongewenst 'met het oog op de rechtsontwikkeling'. 41

De eis van het Nederlandse OM in eerste instantie kan de mogelijkheden in hoger beroep en cassatie echter slechts in beperkte mate reduceren. Een beperking kan het ge-

139 Minister Korthals, Kamerstukken \$1998/99, 25392, n. 460 , p. 1. Minister Korthals noemt een vergetijkbar, hypothetisch vootbedd. Verder werden in de Bloementhove-zak abortusvertichtingen an de rechter voorgelegd in een context warin onzekerheid speelde ontrent het geldende recht en nieuwe wetgeving in de mak was. Kamerstukken 11197475,13161 , n. 1.

140 De Bcaufort 1983, p. 159. Over de envoudige altemathe wetgevingspocedure: Viering \& Kummeling 1996, p. 596 .

141 Minister Korthats, Kamerstukken I 1998/99, 25392, n: 46c, p. 11 
volg zijn indien eerst vrijspraak of niet-ontvankelijkheid gevorderd is, de rechter overeenkomstig beslist en vervolgens hoger beroep ingesteld wordt. Op grond van misbruik van procesrecht zou het $O M$ in hoger beroep niet-ontvankelijk verklaard kunnen worden, als het bijvoorbeeld in hoger beroep een veroordeling eist. Volgens de Hoge Raad kan onder omstandigheden het aanwenden door het $\mathrm{OM}$ van het rechtsmiddel van hoger beroep strijd opleveren met beginselen van een goede procesorde. Voor nietontvankelijkverklaring is dan echter slechts plaats in uitzonderlijke gevallen. Daarbij valt te denken aan die gevallen waarin door het optreden van het OM 'doelbewust of met grote veronachtzaming van de belangen van de verdachte aan diens recht op een eerlijke behandeling van zijn zaak is tekortgedaan'. Tevens kan gedacht worden aan het geval dat bij de verdachte op grond van door het OM gedane - of aan deze toe te rekenen - toezeggingen de gerechtvaardigde verwachting is gewekt dat hij niet zou worden vervolgd of dat het instellen van hoger beroep achterwege zou blijven. ${ }^{142}$ Dergelijke gevallen zijn zeldzaam.

Overigens kan men binnen het $\mathrm{OM}$ zelf eveneens rekening houden met overwegingen met betrekking tot de rechtsontwikkeling. Verder zou de minister wederom een algemene aanwijzing kunnen geven met betrekking tot het houden van requisitoiren. Ten slotte is een minister die de rechtsontwikkeling wil bevorderen ook gerechtigd om de procureur-generaal bij de Hoge Raad te verzoeken om cassatie in het belang der wet in te stellen.

\section{Rechtsstatelijke ratio voor autonomie}

In het voorgaande kwamen verschillende, kritisch beschouwde argumenten aan de orde voor onderschikking van het $O M$. In het navolgende beschouw ik de argumentatie voor een zelfstandig OM, die zich richt op de rechtsstaatidee. De redeneringen die ik noem pleiten ofwel tegen een aanwijzingsbevoegdheid, ofwel voor een 'terughoudend gebruik' van een bestaande bevoegdheid. Hoewel dit naar intensiteit verschillende gevolgtrekkingen zijn, vloeien zij voort uit inhoudelijk gelijksoortige ideeën. Daarom beschrijf ik deze redeneringen hier in samenhang. Dit is evenwel niel de plaats om de vraag te behandelen of de minister rechtens gehouden is tot terughoudendheid tegenover het OM. Deze vraag kwan eerder aan de orde ten aanzien van het Nederlandse stelsel. ${ }^{143}$ In deze paragraaf bespreek ik slechts de wenselijkheid van of de ratio achter terughoudendheid of autonomie.

I $k$ noem achtereenvolgens opvattingen die men in de discussie betrekt omtrent de machtenscheiding en omtrent het rechterlijke in de taak van het OM. Verder behandel $i k$ het argument de rechtszekerheid bij het vervolgingsbeleid op thet spel staat. Ten slotte beschouw ik de eis van onpartijdigheid van het $O M$.

142 HR 19 december 1995, NJ 1996, 249 (Charles Z), m.nt. Sch. Vgl. HR I april 1997, NJ 1998, 287, m.nt Sch. HR I juni 1999, NJ 1999, 567 , m.nt. Sch.

143 Zie hoofdstuk $2,6.2 .5$. Plicht to tenughoudendheid. 


\subsection{Machtenscheiding}

De theorie van de machtenscheiding speelt een zeer bescheiden rol in het debat over de relatie tussen regering en OM. Deze theorie zou mee kunnen brengen dat andere machten zich zouden moeten onthouden van inmenging in de rechterlijke macht, waarvan het OM deel uitmaakt. De onzekere reikwijdte van deze theorie pleiten echter tegen het trekken wan een dergelijke conclusie.

In Nederland komt geen verdediging voor ten behoeve van autonomie voor het $\mathrm{OM}$ op grond van een machtenscheidingtheorie. ${ }^{1.44}$ Wel vormt het enkele deel uitmaken van de rechterlijke macht door het $O M$ in ieder geval een juridisch interpretatiekader voor de ministeriêle terughoudendheidseis. ${ }^{145}$ Wel is denkbaar dat het behoren tot de rechterlijke macht daarnaast een ratio voor terughoudendheid of autonomie zou kunnen vormen. Het begrip van de 'séparation des pouvoirs' komt ook nauwelijks naar yoren in het Franse debat over de executieve en het OM. Turcey is van mening dat niets in de theorie van de scheiding der machten de interventie van de minister van Justitie in strafzaken rechtvaardigt. ${ }^{146}$ Taittinger stelt echter dat de machtenscheiding zodanig moet worden opgevat dat zij vormen van wederzijdse controle omvat. Vanuit dit uitgangspunt zou het OM juist niet onafhankelijk gemaakt moeten worden. ${ }^{147}$ Het feit dat het OM onderdeel uitmaakt van de rechterlijke macht wordt verder niet expliciet gebruikt als kritiek of ratio voor een bepaalde verhouding met de executieve.

Verschillende Italiaanse auteurs menen wel met zoveel woorden dat het OM niet aan politieke verantwoording zou moeten worden onderworpen, ondat dat in strijd zou komen met de machtenscheiding of het evenwicht tussen de machten. Dit principe zou logischerwijs de onafhankelijkheid of autonomie van de rechterlijke macht met zich brengen. Vandaar dat het OM, als onderdeel van de rechterlijke macht, onafhankelijkheid zou dienen te bezitten. ${ }^{148}$

Problematisch aan de stellingen over machtenscheiding is dat de voorstanders ervan niet uitwerken wat zij onder het begrip verstaan. Zonder dat men de betekenis van de term uiteenzet, gebruikt men hem om een stelling te adstrueren. Consensus over de pre-

144 Nicolaï werdedigde in een krantenartikel nog wel dat de scheiding der machten beperkingen oplegt aan het partemen. De "controlerende en uilvoerende macht zouden wolgens hem voldoende geseheiden moeten zijn. Dit zou meebrengen dat de parlenentaire kamers zich niet moeten 'bemoeien' met het opsporings- en verwolgingswerk van het $O M$ in indivichele lopende zaken. Wel zouden ze de minister ter verantwoording kunnen roepen over beleidsmatige zaken. NRC Handelsblad 20 april 2001 , p. 7.

145 Zie hoofdstuk 2, 6.2.5.2. Terughoudendhe id om het behoren tot de rechterlijke macht.

146 Turcey $1997, \mathrm{p} .195$. Mathias meent dat de bevelsbevoegdheid tot niet-vervolging in de huidige regeling in strijd is met de machtenscheiding. Hij ziet strijd met de onathankelijkheid van de rechterlijke macht. Deze onathankelijkheid is deel van de machtenscheiding, 1999, p. 202-205. Zie hoordstuk 3, 6.3.1.3. Aanwijzing tot niet-vervoliging.

147 Taittinger, Commission de réflexion sur la Justice, Annexes 1997, p. 48.

148 Osnato 1974, p. 217; Colli 1975, p. 16; Nuvollone 1983, p. 376; Castelli 1990, p. 102; Catelani 1994, p. 64; Pivetti 1995 , p. 24. Venvijzingen inzake de machtenscheiding bij Verde 1990 , p. 11 . 
cieze inhoud van het begrip bestaat niet. Zelfs in de theorie van Montesquieu is het niet duidelijk onder welke van de drie machten het $\mathrm{OM}$ valt: ${ }^{149}$

Positiefrechtelijk is het behoren tot de rechterlijke macht met name in Nederland en ltalië nog wel van belang. Het vormt een reden voor respectievelijk terughoudendheid en onafhankelijkheid. De traditioneel wat lage 'status' van de Franse rechterlijke nuacht zal de reden zijn dat die kwalificatie daar niet van vergelijkbaar belang gevonden wordt. ${ }^{150}$

\subsection{Rechterlijke taak}

In de Nederlandse doctrine grijpt men de specifieke, 'rechterlijke" aard van de taak van het $\mathrm{OM}$ aan als argument voor autonomie. Redeneringen in deze vorm zijn niet terug te vinden in Frankrijk of Italië. Dit rechterlijke in het handelen van het OM zou pleiten tegen ministeriële zeggenschap. Problematisch is echter dat geen overeenstemming bestaat over hetgeen onder de kwalificatie "rechterlijk" moet worden verstaan.

Het OM heeft een taak, die dicht aanleunt tegen die van de rechter. Het OM zou "rechterlijk werk' verrichten of een 'magistratelijke functie' hebben of een 'rechterlijke oriëntatie'. Beslissingen omtrent het gebruilk van dwangmiddelen zouden volgens een aantal auteurs 'rechterlijke trekken' hebben, waarbij het OM zich op 'magistratelijke, onafhankelijke wijze' van zijn taak zou moeten kwijten. Het gebruik van de transactiebevoegdheid of het doen van een voorwaardelijk sepot wordt wel een 'rechterlijk moment' genoemd in de taakuitoefening van het OM. Het 'rechterlijke' zou verder domineren in zijn optreden ter terechtzitting. Deze 'rechterlijke taak' zou uit haar aard veel vrijheid vereisen. ${ }^{151}$

Sommigen noemen de beslissing omtrent de vervolging en de toepassing van het opportuniteitsbeginsel echter juist een bestuurlijke taak. Het bestuurlijke zou blijken uit het gegeven dat er in de beslissing met veel belangen rekening gehouden moet worden. ${ }^{152}$

149 if y a, dans chaque État, trois sortes de pouvoirs; la puissance législative, la puissance exécutrice des choses qui dépendent du droit des gens, ef la purissance exécutrice de celles âui dépendent du droit civil. (...) On appellera cette demière la puissance de juger, et l'autre simplement la puissance exécutrice de I'Etat.'. De l'esprit des lois, 1748 L. XI, chap. VI. 'Nous avons aujourd'hui une loi adnirablie, c'est. celle qui veut que le Prince établi pour faire exécuter les lois prépose un officier dans chaque triburnal pour poursuive en son nom tous les crimes, de telle sorte que la fonction des délateurs est inconnue parmi nous. (...) La partie publique veille pour les ciloyens; elle agit, at ils sont tranquilles. ", L. WI, chap. VIII.

150 Voor een vergelijking zie hoofdstuk 5, 5.1. Rechterlijke mach.

151 Over "rechterlijk werk": Remmelink 1968, p. 171, 194. Vgl. Blok 1908, p. 16; De Vries 1960, p. 704. Over "magistratelijke functie' en "rechterlijke orientatie": Schalken 1991, p. 180, 182. Over 'rechterlijke trekken': Meijers 1987, p. 26. Vgl. Wan Ween 1977, p. 264. Over 'magistratelijke, onafhankelijke wijze" Buruma 1993, p. 165, 171 en 267. Over het sepot en de transactie: Van der fieltz \& Moons 1969, p. 11 en Van Veen 1975, p. 329 en 333; Remnelink 1968, p. 173; Tak 1981, p. 373. Over de terechtzitting: Remmelink 1968, p. 172; Van Veen 1977, p. 265.

152 Hartsuiker 1978, p. 121; Buruma 1993, p. 267. Andere beslissingen noemt Buruma weer "meer magistratelijk", zoals die tot huiszoeking conform art. 97 Sw. Minkenhofkeijntjes 2002, p. 45 noemt trans- 
Het is nist eenvoudig te definižren wat precies onder 'rechterlijk' of 'bestuurlijk "verstaan moet worden. De taken van de rechter en bestuursorganen zijn veelomvattend en divers, net als die van het $O M$. Een inhoudelijke vergelijking kan daarom al moeilijk leiden tot de conclusie dat de taken gelijksoortig zijn. Daarbij is de bepaling van de kenmerken van de taak van het OM mede afharkelijk van de visie op het strafrecht. Een bijzondere taak en status worden wel aan het OM toegekend in een autonome visie op het strafrecht. Daarin onderscheidt men bij het strafrecht eigen, domeinspecifieke kenmerken, andere dan in het bestuursrecht bijwoorbeeld. Het strafrecht heeft dan een zelfstandige plaats binnen het geheel van het recht. De taak van het OM wordt daarin als een rechterlijke of magistratelijke opgevat. In een heteronome visie ziet men het strafrecht als een overheidsactiviteit als alle andere. Zij is dan uitwisselbaar met andere wijzen van handhaving. Het OM wordt vervolgens meer als een bestuursorgaan gezien. $^{153}$

Deze woordenwisseling is kortom op zichrelf niet concludent. Zij kan hoogstens een terminologische ondersteuning vormen voor een meer inhoudelijke argumentatie.

\subsection{Rechtszekerheid}

Ook enkel in Nederland gebruikt men de redenering dat het volgen van "de waan van de dag' de rechtszekerheid ten aanzien van de uitoefening van de vervoiging kan schaden. Voor een zo groot mogelijke consistentie in het beleid zou het minder gewenst zijn dat het OM afhankelijk is van de "politieke kleur" van de minister. De wenselijkheid van rechtszekerheid brengt mee dat snelle wisselingen van beleid, al naar gelang de politieke kleur van de minister, ongewenst zijn. ${ }^{154}$

Deze stellingen zijn erg algemeen van aard. Mogen wijzigingen van het vervolgingsbeleid minder snel doorgevoerd worden dan andere vormen van beleid? Hier lijkt men in feite geen andere eis te stellen dan die ten aanzien van elk soort beleid geldt. Een te snelle beleidswisseling kan in het algemeen verwachtingen schenden die gerechtvaardigd zijn. Dit geldt ten aanzien van elk geval van beleidstoepassing. De hier aangevoerde argumenten gaan alle vormen van bevoegdheidsuitoefening aan die met beleid zijn ongeven. Zij geven algemene regels waar het OM zich aan moet houden. Daarentegen geven zij geen bijzondere redenen voor een zelfstandig $O M$.

\section{$7,4 \quad$ Onpartijdige pariij}

Het belangrijkste argument voor een vorm van onafhankelijkheid voor het OM vormt de eis van diens functionele onpartijdigheid. In de drie onderzochte landen is het OM weliswaar procespartij, maar dient het onpartijdig te handelen. Politieke zeggenschap kan leiden tot een partijdig functioneren van het OM. Waar dit feitelijk (nog) niet het geval is, kan ondergeschiktheid van het $\mathrm{OM}$ aan de minister een schijn van partijdigheid meebrengen. Verder betrek ik in de onderhavige analyse van de onpartijdigheid

actie en sepot bestuurlijk van karakter ("Daar ko(m)t geen rechter aan te pas. ")

153 Hartmann \& Van Russen Groen 1998, p. 39.44.

154 Singer-Dekker 1982, p. 130; Osinga 1992, p. 77. 
een vergelijking met de houding van andere ambtenaren. Daamaast komen enkele functies van de onpartijdigheid aan de orde.

Het Nederlandse OM dient de onpartijdige hoeder van de rechtsorde te zijn. Het heet tot taak een onpartijdige en niet vooringenomen bijdrage te leveren aan de waarheidsvinding en behoort in te staan voor de rechtmatigheid van de opsporing en de varvolging. ${ }^{155}$ Het OM moet het oog open houden voor mogelijke verzachtende omstandigheden en de onschuld van de verdachte. ${ }^{156}$

Het Franse OM wordt gekwalificeerd als 'partij' (partie), maar wel een 'bijzondere partij'. Het is partij bij het proces, maar niet de systematische tegenstander die enkel op een veroordeling uit is. ${ }^{157}$ Het is en dient een orgaan te zijn dat in een strafzaak partij kiest, maar objectief en niet partijdig handelt. ${ }^{158}$ Het OM heeft bijvoorbeeld (net alls de onderzoeksrechter) de plicht om te zoeken naar aanwijzingen ten aanzien van de onschuld van de verdachte. ${ }^{159}$ Met de rechters maken de procureurs deel wit van dezelfde cultuur van onpartijdigheid. $\$ 160$

Hoewel de Italiaanse procureur in het strafproces "partij" bij de zaak genoemd wordi, dient hij zijn functies op een objectieve manier te vervullen. Hij wordt geacht op onafhankelijke en onpartijdige wijze te handelen. ${ }^{161}$ Het OM is gehouden om ook feiten en omstandigheden te onderzoeken in het voordeel van de verdachte (art. 358 c.p.p.). ${ }^{162}$ Voor een aantal omstandigheden waarin een rechter gewraakt zou kunnen worden, geldt dat een procureur door het parkethoofd vervangen moet worden (art. 53 c.p.p.). In de onderzoeksfase wordt het OM zelfs in het geheel niet gedefinieerd als partij. ${ }^{16 .}$

In dit hoofdstuk noemde ik reeds enkele malen de bestaande internationale aanbevelingen omtrent de positie van het OM. Al deze verklaringen hebben als voornaamste

155 Meijers 1988, p. 142 e.v.; 1991, p. 173; Onpartijige hoeder van de rechtsorde: Donker \& Van Eck 1991 , p. 95; Onpartijdige en niet wooringenomen bijdrage, etc.: Kamerstukken 11 1997/98, 25392, 01: 3, p. 3; nr. 4, p. 2; MinkenhofReijntes 2002, p. 43. Onpartijdig, objectief: ant. I sub 4 Gedragscode OM.

156 Harewinkel-Suringa 1953, p. 144-145;" "Hart 1994a, p. 269-274; Minkenhofrajutjes 2002, p. 53.

157 Vincent e.a. 1999, p. 520,567; Stefan, Lewasseur \& Gouloc 2000, p. 139; "partic originale" door mij vertaald als "bijzondene partij") Prade: 2000, p. $131-132$

158 Accomando 1997a, p. 97.98; Mathias 1999, p. 29, 104, 229 en 242.

159 Conmission de réfexion sur la Justice 1997, p. 60; Mathias 1999, p. 29. Contra: Josserand 1998, p. 315 e.v. Zij meent dat het OM tijons de opsporingsfase en de beslissing ten anmien van de vervolging een partijdixe houding heeft en dient te thebbeth. Het beslist dan enkel op basis wan do stukken at charge. Tijdans het zittingstequisitoir zou de procureur echter gehtel onpartijdig handelen en dienen to bandelen. De auteur trekt overtrokken conchusies ut de kwalificatie "partij" wat betreft de voorfase. Hw is praktisch ondenkbaar dat het parkel een dergelijke schizofrene wijze van functioneren heet, tenzij pertinent verschillende personen bij het onderzok dan wel bij de zithing betrokken zijn.

Oxerigens zou volgens somnigen de ambtenaren van administratieve organen eveneens onpartijdig en neutraal moeten zijin, Beaud 1999 b, p. 208.

160 Volff 1998, p. 37; Angibrud 1999, p. 18

161 Corso 1993, p. 229-230; Gustapane 1999, p. 231.

162 Het OM bij de daarboven ressorterende rechterlike instantie beslist vervolgens over de gegrondheid wan onthouding, art. 52 c.p.p.

163 Cass. 18 augustus 1992, Cass. pet. 1993, p. 1502; Consoli 1994, p. 236, Manzione 1995, p. 96; Morselli 1995, p. 501; Devoto 1996a, p. 2031. Een procureur kan zich als een rechter van een zaak doon onthouden als hij daar bepaalde ernstige redenen voor heeft (art. 52 c.p.p.). 
onderwerp en als meest gedeelde overeenkomst de eis dat het OM onpartijdig en objectief dient te handelen. Aanbevelingen die dat niet doen eisen simpelweg een vorm van onafhankelijkheid van de anklager. ${ }^{164}$ Veel standards, waaronder de belangrijkste, stellen yerder dat het OM het recht moet doen toepassen, moet handelen in het algemeen belang en de mensenrechten moet beschermen. ${ }^{165}$

\subsubsection{Partijdigheid door ministeriële invloed}

Het $O M$ wordt aldus geacht onpartijdig te handelen in strafzaken. Bevoegdheden van de minister ten aanzien van het OM zouden evenwel een partijpolitieke houding in de vervolging teweeg kunnen brengen.

Volgens Nederlandse auteurs zou met name de schijn van partijdigheid kunnen optreden. De 'indruk' zou gemakkelijk gewekt kunnen worden 'dat politieke maatstaven en niet matstaven van recht en billijkheid een rol spelen'. ${ }^{166}$ Verder zou de vervolgingsvraag ook werkelijk in de sfeer van de partijpolitiek kunnen komen. '(H)et 'in volle omvang" betrekken van de partijpolitieke strijd bij de vitvoering van het beleid van het O.M. (zal leiden) tot ongewenste ingrepen'. ${ }^{167}$ Door de aanwijzingsbevoegdheid zou dreigen 'dat uit niet helemaal aan de rechtsorde ontleende overwegingen wèl of dat uit verwerpelijke overwegingen niet vervolgd (zou worden). ${ }^{168}$ Rechtshandthaving zou niet "te zeer dienares van het dagelijkse beleid (moeten) worden". 169 " De strafsanctie zou het gevar kunnen lopen "politieke oogmerken te moeten dienen". ${ }^{170}$ Vanwege het vereiste van gelijkheid van rechtsbedeling zou "incidentele interventie" door de minister bezwaarlijk zijn. ${ }^{171}$ Kwesties zouden enkel om redenen van politieke opportuniteit aan de rechter kunnen worden voorgelegd. ${ }^{172}$ Burgers zouden de indruk kunnen krijgen dat zij vanwege de minister of de Tweede Kamer vervolgd zouden worden, in plaats van vanwege het $O{ }^{1} .^{173}$ In het Nederlandse stelsel bestaat juist een combinatie van een sterke machtspositie van het $\mathrm{OM}$ en volledige ministeriële zeggen-

164 Ant. 13 sub a en b VN, ant. 23 sub a RvE, art. 111.1, II.3, II1.4 EU, art. 2.5. 1.APL, art. 3 MEDEL en art. 3 IAP. Onafhankelijkheid wondt geesist door ant 29 van de Draft van de Internationall Commission of Iuringrts.

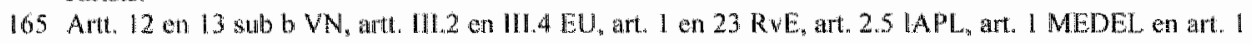
an $\$ A P$.

166. Duistenwinkel 1968, p. $232-233$.

167 De Beaulori 1983, p. 160.

168 Lenngermeijer $\| 968, \mathrm{p}, 100$.

169 Van Eijkern 1968, p. 94.

170 Van Dullemen 1958, p. 18. Vgt. Corstens 1999, p. 98: 'Zo zou, als poltici zich gaan bemoeien met concrete vervolgungsbeslissingen het gevar kunnen dreigen dat partijpolitieke motieven worden gebruikt'. NICM 1996, p. 984: "Is deze distantie (tot de uitwowende macht) onvoldoende aanwezig, dan bestuat het gevasar var politiek misbruik。"

171 Oratie 1976, p. 23

172 "1 Hart 1976, p. 22-23. Hij noemi aen voorbed waarin het OM zou gebruikt kunnen worden om bij een gedoogsinatie die na verloop wan tijd politieke onrust veroonzakt de "zwarte piet" toegespeeld te krijgen om te beslissen over vervolging.

173 De Doelder 1996, p. 124. 
schap. Juist in deze combinatie zou een gevaar dreigen van politisering. ${ }^{174}$ Dergetijke gevaren zouden in ieder geval dreigen in "roerige" of 'slechte' tijden met "dubieuze bewindslieden". ${ }^{175}$ De druk op het $\mathrm{OM}$ om iemand te vervolgen, zou 'in andere tijden' groter kunnen worden dan de kracht van het gegeven dat de zaak op haalbaarheidsgronden zou moeten worden geseponeerd. ${ }^{176}$

Sommige fracties in de Tweede Kamer wonden in 1997 dat de mimister per definitie niet meer zou moeten interveniëren als de zaak onder de rechter is. Het zou de verhouding tussen het $\mathrm{OM}$ en de rechterlijke macht verstoren en "de politieke factor" in een individuele strafzaak introduceren. ${ }^{177}$ Dat de minister bevoegd zou zijn een aanwijzing te geven na aanvang van de zitting betekende volgens minister Sorgdrager daarentegen "niet dat daarmee (...) "de politieke factor in een individuele strafzaak" wordt geïntroduceerd, maar het betekent dat moet worden vermeden dat er een periode bestaat waarin de ministeriële verantwoordelijkheid voor het optreden van een lid van het $\mathrm{OM}$ niet kan worden waargemaakt'. ${ }^{178}$ De minister praatte hier om het argument heen. De (mogelijke) introductie van "een politieke factor" werd niet inhoudelijk bestreden. Het waarmaken van ministeriële verantwoordelijkheid sluit niet uit dat een strafzaak gepolitiseerd raakt. Sterker nog, juist wanneer de minister bevoegdheden tegenover het OM gebruikt om zijn verantwoordelijkheid "waar te make" ligt introductie van de politieke factor in de zaak voor de hand.

Parlementaire verantwoording kan gelijksoortige negatieve gevolgen meebrengen voor een strafzaak. De kamer zou zich kunnen gaan uitspreken over een zaak die onder de rechter ligt. ${ }^{179}$ Zo zou een doorkruising van strafrechtelijke en parlementaire procedures dreigen, zeker wanneer de zaak omgeven zou zijn door "publicitair geweld", via media-aandacht. ${ }^{180}$

In Frankrijk bestaat onder de publieke opinie een zeker wantrouwen ten aanzien van het handelen van het OM. Dit gevoelen zou worden veroorzaakt door de twijfelachtige relatie tussen $\mathrm{OM}$ en politiek. In bepaalde gevallen zou het handelen van het OM partijdig zijn, doordat politieke functionarissen op enige wijze invloed uitoefenden in indi-

174 De Doelder 1996, p. 116-118; 't Hart 1999, p. 113.

175 Renmelink 1968, p. 171; 1991, p. 172; Datdder 1991, p. 90.

Zie voor een praktisch woobeeld de mondelinge vragg Jammat, ower juridische stappen tegen de AFA (Anti-Fascistische Akte) naar andeiding van withangen van gebruik wan gewald, Handelingen II 199697, p. 3197. Het kamertid stelt: 'Wij krijgen sterk de indruk dat de ragering er een selectief vervolgingsbeleid op nahoudt. Als er politieke partijen zijn die frontale kritiek op de regering hebben - wij rekenen ons dantoe - dan wordt niets nagelaten on zo "w organisme dwars te zituen." "Hart 1999 ,

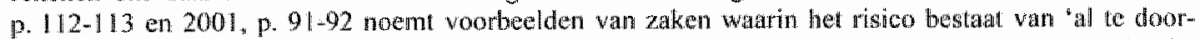
slaggevende politieke detemineringen". De Doelder noem gevallien van mogelijk ongewenste politieke beinvloeding, 1995, p. 58; 1996, p. 124.

176. Corstens 2002, p. 497 .

177 Argumenten van de VVD-fractie; vgl. afwijzing van de QPV-fractic, Kamershkken $11 \quad 1997 / 98,25392$, ni. 6, p. 2 en 24 .

178 Kamersukken II $1997 / 98,25392$, n. 7, p. 29.

179 Dittrich, Handelingen II 1997/98, p. 4794.

180 Minister Sorgdrager, Handetingen II 199798, p. 4826-482\%. 
viduele gewallen. ${ }^{183}$ Sommigen zien in zowel de individuele bevelsbevoegdheid als de benoemingsbevoegdheden van de regering de bron van het wantrouwen. ${ }^{182}$

De Franse kritiek ageert in het bijzonder sterk tegen de partijpolitiek die de minister bedrijft in de rechtspositionele zaken van het OM. In eerdere hoofdstukken gaf ik reeds een kritische analyse van de rechtspositie van het Franse OM. De opmerkingen die nu volgen baseren zich daarop. ${ }^{183}$

Voornamelijk het politieke karakter van de benoemingswijze voor de hogere posten ligt onder vuur. Deze leidinggevende functies krijgen daardoor een zekere politieke aard, hetgeen wantrouwen kan veroorzaken ten aanzien van de uitoefening ervan. ${ }^{184}$

Weerstand is er ook tegen de zogenoemde "overplaatsing in het belang van de dienst". Gesteld wordt dat er geen evident verband is tussen de rol van de minister ten aanzien van de strafrechtelike politiek en zijn bevoegdheid om leden van het OM over te plaatsen in het belang wan de dienst. De bestaande praktijk waarin overplaatsing eigenlijk alleen met instemming van de betrokkene plaatsvindt biedt geen juridische waarborg. 185

De disciplinaire procedure staat eveneens onder scherpe kritiek. Het beroep op de Raad van State tegen de disciplinaire beslissing is vrijwel ineffectief. De beshissing wordt in feite overgelaten aan de discretie van de minister. De magistraten van het OM bevinden zich zo in een kwetsbare positie aangaande het disciplinaire regime. De huidige praktijk waarin de minister zich conformeert aan het advies van de CSM vormt slechts een tijdelijke compensatie. Dit ministeriële beleid vormt geen blijvende waarborg. Een dis-

181 Du Truche 1995, p. 167; Jéol 1996, p. 72; Accomando 1997a, p. 97; Turcey 1997, p. 180; Boudon 1997, p. 2 e.v.; Maynier, Conmission de réflexion sur la Justice, Annexes 1997, p. 92; Commission de réflexion sur la Justice 1997, p. 25; Angibaud 1999, p. 92. Het wantrouwen ten aanzien van Justitie blijkt mede uit vaak aangehaalde enquêtes uit 1991 en 1997 door het onderzoeksbureau Sofres. Voor de laatste, zie Le Monde 311 januari 1997. Het regeringsvoorstel ter aanpassing wan de relatie tussen minister en OM noemt het bestaende wantrouwen als de reden voor een hervorming, Exposé des motifs, JO AN 3 juni 1998, projet de loi n. 957. Zie hoofdstuk 7, 3.5.1. Ministeriede zeggenschap. Het fenomeen zou vooral zijn oorzalak hebben in affaires uit de latste decennia van de vorige eeuw. Sommige hiervan besehreef ik in hootdstuk 3, 6.3.1.2. Speelfieke anwijzingen.

182 Rassat 1967, p. 251; Accomando 1997a, p. 98. Volgens Mathias echter is "partijdigheid" van het OM het gevolig van zijn strafprocessuele positie, en niet zijn functionele of rechtspositionele relatie met de uirvoerende macht. Aangezien het $\mathrm{OM}$ in het huidige strafproces een partipositie heeft handelt het "subjectief". Dit rechtwardigt dan weer een ondergeschikte relatie met de executheve. Mathias 1999, p. 236,243 en 245 . Deze opvatting is geheel gebaseerd op een vergelijking van het Franse met het Duitse stelsel. Hoewel het Duitse OM ondergeschikt is an de minister, ziet men diens handelen als objectief. Mathies ziet uitsluitend in de Franse rechtsfiguur van de klacht door het slachtoffer de oorzaak van de subjectiviteit.

183 2 ie hoofdstuk 3, 5. Reehtspositie en hoofdsink 5, 4. Conclusie rechtspositie en functionele positie.

184 Ten slotte bergt dit werschil in benoemingsmethode het risico in zich van een tweespalt in thet $O M$. Een onderscheid tussen "politieke" en "professionele" leden kan een risico vormen woor de eenheid van de instelling. Jéol 1994, p. 1365; Volff 1998, p. 32. Zie verder de vele auteurs in thoofdstuk 7 , paragrafen 3.3 tot en met 3.6. Een hier minder ter ralke doend argument is dat het Franse benoemingenstelsel incoherent is in zoverre dat de hoofden van de reehibankparketten niet op gelijksoortige wijze benoend worden. Zoals gezegd is het verlenen van autoriteit een ratio achiter de benoeming doon de regering. De wragg is dan waarom or niet een gebrek aan autoriteit blijkt woor de lagere parkethoofden. Deze parketten onderhouden everneens relaties met andere stats- of gedecentraliseerde organen ten opzichte warven zij antoriteil zonden moten bezitten.

185 Delmas-Marty 1994, p. 153; Volff 1998, p. 33. 
ciplinaire procedure voor het OM vergelijkbaar met die voor rechters zou verder niet schadelijk zijn voor de effectiviteit van de functionele band van de minister met het $\mathrm{OM}^{\mathrm{s} 86}$

In het huidige Franse systeem van rechtspositionele onderschikking kan zo de onpartijdigheid van de leden van het $\mathrm{OM}$ in gevaar komen. Voor een onpartijige houding lijkt het stelsel sterk te moeten leunen op een al dan niet aanwezige onafhankelijke cultuur binnen het OM. Het systeem vertrouwt op een houding van zelfontkenning bij de betrokken procureurs. Zij moeten eigenlijk hun carrière zonodig "opofferen" ten bate van de onpartijdigheid. Wat dat betreft is het stelsel voor verbetering vatbaar. Het zou te ver voeren om het gevaar van partijdige beïnvloeding van de hand te wuiven door te hopen dat de leden van het $O M$ volharden in hun professionele mening. ${ }^{187}$ Ook wanneer een onathankelijke cultuur wan het OM standhoudt, kan diens rechtspositie een grond voor wantrouwen vormen. Wat er ook zij van de praktijk, het OM kan gezien het. rechtspositionele stelsel de schijn van partijdigheid tegen $z i c h$ hebben. ${ }^{188}$

In Italië stelt men dat het OM wellicht nog meer dan de rechtsprekende organen garanties vam onafhankelijkheid nodig heeft. Strafrechtelijke normen kunnen in contrast komen met de wisselende belangen van parlementaire regeringen. Het gevaar bestaat dat politieke organen hun invloed op het OM gebruiken om ongewenste vervolgingen te verhinderen, of om bepaalde zaken met meer of minder ijwer te behandelen, naar gelang het in hun belang is. Het is kortom niet ondenkbaar dat de minister misbruik zou maken van zijn aanwijzingsbevoegdheid. ${ }^{189}$ In de Italiaanse literatuur wordt nog regelmatig teruggegrepen op negatieve historische ervaringen verbonden aan de voormalige ondergeschiktheid van het OM aan de politiek. Die periode haalt men dan aan om de onwenselijkheid van een dergelijke positie van het OM te onderstrepen. ${ }^{190}$

In de verantwoording van de minister aan het parlement over het handelen van rechterlijke organen, waronder het $\mathrm{OM}$, ligt het risico dat onder de schijn van enkel informatieve doeleinden het parlement zich gaat mengen in strafrechtelijke procedures. De parlementaire meerderheid, kan door een bepaald gebruik van de informatievergarende bevoegdheden, met de medeplichtigheid van de regering, druk uit oefenen op het OM en diens onafhankelijke positie in gevaar brengen.'

Kortom, vele auteurs uiten hun bezorgdheid over de schijn van partijdigheid die over het handelen van het OM hangt door de ministeriële interventiemogelijkheden. Daarnaast acht men de kans reëel dat de minister daadwerkelijk tot partijpolitieke bevoor- of

136 Martin 1997, p. 777 ; Mathias 1999, p. 177 ,en 182 ; Pradel 2000, p. 127.

187 Tircey 1997, p. 183.

188 Boudon 1997, p. 13. Het vóóromen van wisselinger in politieke kleur wan de elkaar opvolgende regeringen zou wolgens Colleu nog wel een warboug vomen. Hierdoor zou het benowningenstelsel even. wichtig blijven, Jacquin (Colteu) 1997, p. 12

189 Zagrebelsky 1974, p. 194, 196; Del Vecehio 1982, p. 74; Neppi Modona 1982; p. 32; Nuvolone 1983, p. 376; Zanon 1996, p. 209; Dewoto 1996a, p. 2043; Sivestri 1997, p. 107.

190 Zagrebelsky 1979, p. 20; Neppi Modona 1983, p. 124 en 382; Spangher 1991, p. 128. Zagrebelsky moemt echter ook de fenomenen in de huidge periode van lotizzazione, 1991, p. 311 .

191 Burtole 1984, p. $350,335$. 
benadeling overgaat. Deze kritieken blijken sterk gericht te zijn op de beslissingen van het OM in individuele strafzaken. Juist daarin is onpartijdigheid van het OM met name vereist. Ten behoeve daarvan moet voorkomen worden dat het OM enkel om (partij) politieke redenen seponeert of vervolging instelt.

Dit is enerzijds het geval wanneer het OM meent te kunnen vervolgen, maar de minister vervolging onwenselijk acht. Een anwijzingsbevoegdheid gericht op niet vervolgen kan een schijn yan partijdigheid laten vallen over de vervolgingsbeslissing. Dergelijke aanwijzingen zouden daarom uitgesloten moeten worden: ${ }^{192}$

Anderzijds zou de minister vervolging kunnen wensen, terwijl het $\mathrm{OM}$ meent dat de betreffende zaak niet haalbaar is. Een aanwijzing tot vervolging zou in een dergelijk geval enkel partijpolitieke doelen dienen ten koste van de betrokken verdachte. Deze situatie moet vermeden worden in het belang van de vereiste onpartijdigheid. Seponeert het OM echter om opportuniteitsredenen, dan kan vervolging op instigatie van de minister niet partijdig genoemd worden. De minister doet dan (tevens) de wet handhaven die het gepleegde feit strafbaar stelt. ${ }^{193}$

\subsubsection{Onpartijdigheid als andere ambtenaren?}

Zoals gezegd dient het OM onpartijdig te zijn en zouden de bevoegdheden van de minister een negatieve invloed kunnen hebben op die rol. Maar geldt niet dat alle ambtenaren onpartijdig moeten handelen? Hieronder wil ik deze vraag ontkennend beantwoorden.

Met name in Nederland benadrukt men wel dat de genoemde onpartijdigheid van het OM niet zou verschillen van die van andere, 'gewone' ambtenaren. Ook andere ambtenaren zijn dienaren van de wet. Zij dienen grond- en mensenrechten en de algemene beginselen van behoorlijke procesorde te respecteren. Zij moeten zich richten naar de matstaven die de rechter bij de toepassing van de wet aanlegt. Ze behoren alle betrokken belangen mee te wegen en onpartijdig te zijn. Ook de rechtsbeschermende functie van het OM geldt voor het bestuur. Het bestuur moet namelijk met haar beslissing evenmin afbreuk doen aan de rechten van de betrokken burger. ${ }^{194}$

Enkele Italiaanse sethrijvers menen eveneens dat de onpartijdigheid die op het OM betrekking heeft een plicht is die in principe evenzeer geldt voor alle overheidsfunctionarissen. ${ }^{195}$ De onpartijdigheid van het OM verwijst naar de eis om niet arbitrair te handelen, terwijl de rechter de rol heeft van de onpartijdige derde. Het OM heeft niet de rol van derde in het strafproces, en zou om deze reden niet een onafhankelijke status hoeven te hebben. ${ }^{196}$

192 Zie ook 5.4.1. Annwijzingen tot niet-vervolging.

$1932 \mathrm{e}$ ook 5.4.2. Aanwijzingen tot vervolging en 5.1. Beleidscontrole.

194 Suywer 1976, p. 166; Stroink 1978, p. 158; Osinga 1992, p. 64; Daalder 1991, p. 90; Wiewel 1991, p. 13 14; Roording 1994, p. 172; Roben 2001, p. 93-94; Verhey 2001, p. 181. Osinga meent daarop volgend evenwel dat er ten behoeve van de onpartijdigheid een "zo groot mogelijke distantie" nodig is van de politiek, p. 77. Blijkbaar dient het OM toch weer wel een bijzondere onpartijdigheid te bezitten.

195 Brancaccio 1994, p. 242; Dominioni 1979, p. 80.

196 Guarnieri 1984, p. 155-156, Illuminati 1994, p. 222. 
Andere Nederlandse auteurs stellen daarentegen terecht dat het OM geen procespartij is zoals een willekeurig bestuursorgaan. De beslissingen van het OM $2 \mathrm{iju}$ in de eerste plaats op het recht afgestemd en niet overwegend bepald door overwegingen van bestuurlijke aard. Voor andere bestunrsorganen zijn overwegingen van rech veeleer randvoorwaarden. ${ }^{197}$ Het OM dient niet rechtstreeks politieke doeleinden, het staat primair in dienst van de rechtsorde: In de "gewone" bureaucratie worden beslissingen juist ten eerste beoordeeld op hun bestuurlijke gevolgen. ${ }^{198}$ De eed die rechterlijke ambtenaren afleggen eist uitdrukkelijk dat zij 'hun posten met (..) onzijdigheid, zonder aanzien van personen, zullen waarnemen'. In de eed voor andere rijksambtenaren komt geen verwijzing voor naar orpartijdigheid of onzijdigheid. ${ }^{199}$ De eis van onpartijdigheid voor Nederlandse bestuursorganen betekent enkel dat degenen die een besluit nemen daar geen persoonlijke belangen bij hebben (art. 2:4 Awb). Het betreft hier dus enkel de subjectieve onpartijdigheid.

Onder de Nederlandse auteurs die eventuele verschillen tussen het OM en bestuur minimaliseren, menen enkelen nog wel dat de onpartijdigheid en de daarmee verwante aspecten bij de taakuitoefening van het OM wel bijzonder nauw histeren. Er zou mitsdien slechts een gradueel, geen wezenlijk verschil bestaan tussen de rol van het OM en die van andere ambtenaren. ${ }^{200}$

Een dergelijke opvatting is alleen houdbaar als duidelijk zou zijn wat het wezen van of het wezenlijke in de rol van het OM en die van andere ambtenaren zou zijn. Dit is niet het geval. Daarom kan over een wezenlijk verschil geen uitspraak gedaan worden. De kwalificatie 'wezenlijk' heeft enkel betrekking op de bedoeling die de betrokken auteurs in gedachte hebben met de vergelijking tussen OM en andere ambtenaren. ${ }^{201}$ Met even goed recht is vol te houden dat de rol van het OM wezenlijk anders is, juist omdat die onpartijdigheid zo nauw luistert.

Overigens zou een vergelijkbaarheid qua onpartijdigheid nog niet noodzakelijkerwijs meebrengen dat het $O M$ dezelfde onderschikking alls andere ambtenaren ten deel zou moeten vallen. Integendeel, een dergelijke vergelijkbaarheid zou ook voor deze ambtenaren kunnen pleiten voor een mate van autonomie in individuele zaken.

\subsubsection{Functies wan de onpartijdigheid wan het OM}

De onpartijdigheid wan het OM dient in ieder geval drie specifieke functies. Deze betreffen de controle van overheidsorganen, de bescherming van parlementaire minderheden en het gezag van of het vertrouwen in het $\mathrm{OM}$.

197 Verburg 2001, p. 98 .

198 De Doelder 1994, p. 450, Buruma 1999, p. 1888. Zo ook minister Sorgdrager, Kamerstukken 111996 97. 24034, n.r. 1, p. 3: "Het onderscheidt zich wan de andere bestuursorganen doordat het geen politieke doelstelling heett."

199 Voor de eed zie art. 5 Wet RO. Voor de eed voor andere rijksambtenaren, zie Bujhage bij de Vaststel. lingsregeling formulier eed/oelofte rijksambtenaren.

200: Roording 1994, p. 173; Verhey 2001, p. 181. Deze auteurs gebruilken het begrip "wezenlijk" in enige vorm. Daalder ontikent dat er sprake is van een "principieel" verschil. Dadilder 1991, p. 90

201 De Winter $2001, \mathrm{p} .80$. 
Niet moet uit het oog verloren worden dat het $\mathrm{OM}$ mede een controlefunctie heeft ten opzichte van opsporingsorganen, ministeries en andere bestuursorganen. Het OM kan dan tussen de burger en deze organen in staan.

In Nederland stelt men bijwoorbeeld dat het $\mathrm{OM}$ zou moeten kunnen optreden als "waakhond van de rechtsstaat". ${ }^{202}$ Het dient "het juridisch geweten van het bestuur' te zijn. ${ }^{203}$ Bijzonder aan de talk van het $\mathrm{OM}$ is dat het moet oordelen over het handelen van overheidsorganen en overleidsfunctionarissen, en hen eventueel vervolgen. Deze taak vereist dat het $O M$ enige zelfstandigheid bezit. 'Het gegeven dat het OM, indien noodzakelijk, ook overheidsorganen en ambtenaren dient te vervolgen als deze strafbare feiten hebben gepleegd brengt met zich mee dat het als bestuursorgaan een zo onafhankelijk mogelijke positie dient te bezitten'. ${ }^{204}$ Minister Korthals Altes was ook van mening dat juist in dat soort gevallen de minister grote terughoudendheid zou moeten betrachten, en deze zaken 'aan de prudentie van het OM (zou) moeten overlaten'. ${ }^{205}$

In Italië onderscheidt men evenzeer verschillende functies die de vervolging heeft. In één opzicht is de vervolging een instrument waarmee de politiek zijn institutionele taak van regulering van het openbare leven uit kan oefenen. Onder een ander gezichtspunt heeft de vervolging de functie van controle van de politiek. ${ }^{206}$ Men gelooft niet dat een ondergeschikt $O M$ zo onpartijdig en actief zou kunnen optreden tegen delicten gepleegd door ambtenaren en politici. ${ }^{207}$ Vanaf begin jaren negentig ondernam het $O M$ bijvoorbeeld cen veelvoud aan initiatieven tegen de wijdverspreide corruptie onder politici en ambtenaren. Verscheidene Italiaanse auteurs hebben zich afgevraagd of die actie wel zou hebben plaatsgevonden als het OM niet onafhankelijk zou zijn geweest. ${ }^{20 \mathrm{~s}}$

Een tweede nader te noemen functie van de onpartijdigheid van het $O M$ is de bescherming van parlementaire minderheden.

Verschillende Nederlandse auteurs noemen een zekere zelfstandigheid van het OM van belang woor de minderheid in het parlement, de oppositie. 'Het zou een kwalijke zaak kunnen zijn als een meerderheid, maar ook als een minderheid in de meerderheid, waartoe de minister van Justitie behoort, het vervolgingsbeleid naar haar hand zou kunnen zetren" ${ }^{209}$ De Nederlandse aanwijzingsprocedure vormt hierbij een onvoldoende waarborg. "Tegenstanders van een sepot zullen redeneren dat het informeren van dege-

202 Meijers 1987 a. p. 130.

203 De Beartort 1983, p. 156 .

204 Osinga 1992, p. 77, 83. Vgl. Van Veen 1977, p. 265; Schalken 1991, p. 183.

205 Korthals Altes 1988, p. 372. Natiw hierbij asanslutend is her voorstel van de commissie Roelvink om ten atanzien van dit soort gevallen de annwijzingsbevoegdheid uit te slutiten. Zie hoofdstuk 7, 3.2. Beperkitie aarwijzingsbevoegdheid en ministerieel beklag. Volgens minister Sorgdrager zou daar geen bijzondere aarileiding toe zijin, maar zou wel "dezelfde terughoudendheid" moeten worden betracht. Kamerstukken II 1997198,25392, nr. 7, , 3. 24

206 Cavallari 1974, p. 150; Zagrebelsky 1979, p. 19, Brancancio 1994, p. 244; Orevi 1999, p. 83.

207 Scoti 1982 , p. 56.

208 Catclani 1994, p. 99; Neppi Modona 1994, p. 121; D'Ambrosio 1994, p. 134; Scaparone 1994, p. 276; Devoto 1996a, p. 2027; Bruti Liberati 1999, p. 68.

209 Van Veen 1977, p. 274. Vgl. Van Marseveen 1983, p. 188; De Doelder 1995, p. 58; 1996, p. 117.118: $2002 a_{n}$ p. 6. 
nen die in meerderheid de regering steunen, geen soelaas biedt." ${ }^{210}$ Het $\mathrm{OM}$ kan dus een nuttige opposant zijn van de meerderheidspolitiek.

De vervolging ziet men ook in Italie wel als een warborg waardoor minderheden beschermd kunnen worden en het handelen van overheidsinstellingen gecontroleerd kan worden. Zo kan de wet gehandhaafd worden, ook eventueel in contrast met de politieke belangen van de meerderheid of daaraan verbonden personen. ${ }^{211}$ Het OM heeft 20 mede een taak om de democratische instellingen te verdedigen. ${ }^{212}$

Ten clerde dient de onpartijdigheid het gezag van en het vertrouwen in het OM - dit in relatie tot andere overheidsinstanties en burgers. Dit aspect komt men alleen tegen in de Nederlandse discussie.

Het OM zou zijn inwloed, prestige en gezag in het driehoeksoverleg kumen verliezen indien de minister teveel greep zou hebben op het OM. Diens prestige ontleent het voor een groot deel aan zijn 'zelfstandigheid". 21 ;

Tevens staan het vertrouwen van de rechter in het OM en de geloofwaardigheid van de laatste op het spe』. Het benadrukken van de hiërarchische onderschikking van het OM kan afdoen aan de onpartijdige positie van het OM in het strafproces. Het kan bij de rechter een reactie oproepen als zou de officier van justitie ook alleen maar door het bestuur "gestuurd" zijn. De officier zal door de uitoefening van het ministeriele gezag aan geloofwaardigheid inboeten. Een sterke binding van het OM aan politieke besluiten kan de vertrouwensrelatie tussen het $O M$ en de rechter schade berokkenen. ${ }^{214}$

Verder zouden burgers zelf in hun wertrouwen geschokt kunnen worden. Wanneer het OM "maatschappelijk uiterst belangrijke strafbepalingen als verlengstuk van de minister buiten werking stelt door eigenmachtig (...) in het algemeen recht vast te stellen in de concrete maatschappelijke situatie, zoals een minister dat telkens (anders) ziet", dan zou het OM op deze wijze 'elk maatschappelijk gezag' ontberen. ${ }^{215}$

\subsubsection{Overdreven wantrouwen en voldoende waarborgen?}

De onpartijdigheidseis ondervindt op zich geen bestrijding. Op tweedrlei wijze bekritiseert men echter de stelling van de mogelijke partijdigheid door ministeriele invloed. Enerzijds zou het wantrouwen te zwaar zijn aangezet. Anderzijds zouden de bestande procedurele en culturele waarborgen voldoende zijn.

Sommigen noemen de vrees voor inbreuken op de onpartijdigheid overdreven. Ten eerste maken de Nederlandse en Franse ministers duidelijk dat de aanwijzingsbevoegdheid zelden of nooit gebruikt wordt en zal worden. Minister Sorgdrager meende "dat

210 Corstens $2002 \mathrm{a}, \mathrm{p} .1049$

21॥ Zanon 1996, p. 186-187.

$2 / 2$ Ricei 1982, p. 117. Onder dit gezichtspunt zou men de onpartijdigheid ook als eis van de democratie kunnen behandelen.

213 Fasseur 1996, p. 60.

214 Singer-Dekker 1982a, p. 87; Donker \& Van Eck 1991, p. 95; Kamerstukken II 1996\%7, 25392, B, p. 2; 't Hart 1999, p. 106, Corstens 1999, p. 100.

215 Duisterwinkel 1977, p. 129. Vgl. 1968 a, p. 108. 
zich in het verleden nawwelijks conflicten hebben voorgedaan', ondanks een zekere spanning tussen de ministeriële verantwoordelijkheid en de rol van het OM in het strafproces. "Er is geen reden om aan te nemen dat dat in de toekomst anders zal zijn. Daarvoor is wel nodig dat alle betrokken partijen - Staten-Generaal, minister en OM - zich rekenschap blijwen geven van elkaars staatsrechtelijke positie'. Minister Korthals vroeg om het "vertrouwen' dat de samenwerking tussen de minister en het OM goed zal verlopen: ${ }^{216}$

De stelling dat er "nauwelijks conflicten" geweest zijn heeft beperkte betekenis als deze gepaard gaat met de vaststelling dat aanwijzingen in individuele gevallen uitzonderlijk waren. Als de conflicten juist in die gevallen plaatswonden, dan vormde de aanwijzingsbevoegdheid zelf blijkbaar een probleem. De laatste jaren zijn enkele conflicten voorgekomen tussen de minister en ambtenaren van het $O M$, getuige de affaires uit de jaren negentig. Minister Sorgdrager deed het recente verleden zo wel heel makkelijk af. 217

In Frankrijk en Nederland stelt men verder dat ingrijpen wellicht uitzonderlijk zal zijn, naar juist plaatsvindt in de precaire gevallen 'waar het erop aankomt'. Daarbij komt, dat het zinloos is te stellen dat het OM feitelijk autonoom handelt, onder de vermelding dat de bevelsbevoegdheid slechts zelden gebruikt wordt. Het bestaan van enkele zeer zeldzame gevallen kan al grond geven voor een algemeen wantrouwen dat het $\mathrm{OM}$ mogelijk partijdig handelt. Het feit dat het $\mathrm{OM}$ in de meeste gevallen onafhankelijk handelt doet daaraan niet af. Het enkele bestaan van de bevelsbevoegdheid zelf vormt al een bron van wantrouwen. ${ }^{218}$

Het is opmerkelijk dat met name veel Nederlandse auteurs een relatief stevig vertrouwen in de (Nederlandse) politieke organen lijken te hebben. Juist de zaken met verdachten uit de politiek en het bestuur in Frankrijk en met name Italië zouden Nederland kunnen tonen dat een mate van autonomie nodig is. ${ }^{219}$

Een tweede kritiek op het benadrukken van de onpartijdigheidseis is dat de bestaande waarborgen voldoende moeten zijn. In Nederland heet het dat misbruik in 'onze open democratie' en in 'onze cultuur van transparantie en overleg' snel openbaar en afgestraft zou worden. ${ }^{220}$ Ook sommige Fransen menen dat het gevaar van het in de doofpot stoppen van zaken gezien de bestaande waarborgen niet erg groot zou zijn. ${ }^{221}$

216 Kannerstukken II 199697, 25392, nu. 3, p. 30; Handelingen I, 1998/99, p. 1195-1196.

2117 Vgl. N.ICM 1996, p. 984.

218 In Nederland: "t Hart 1999, p. |12-1 13;2001, p. 90-91. In Frankrijk: Boudon 1997, p. 14; Nallet, Commission de réflexion sur la Justice, Amexes 1997, p. 41; Accomando 1997a, p. 98.

219 De Doelder 1994, p. 449. Hij wijst dearbij op het voorkomen van corruptiezaken in Nederland.

220 Van Dullemen 1958, p. 16; Corstens 1997, p. 224; 1999a, p. 97; Roben 2001, p. 94. Corstens meent later $(2002 \mathrm{a}, \mathrm{p} .1049)$ dat het wantrouwen niet gemakkelijk zal worden weggenomen door het bestaan wan de huidige atanwijzingsprocedue.

221 Foyer, Commission de reffexion sur th Justice, Annexes 1997, p. 28; Nallet, idem, p. 40. 
Op de procedurebepalingen van met name het Nederlandse systeem uitte ik mijn kritiek reeds in het betreffende hoofdstuk. ${ }^{222}$

De culturele transparantie wordt verder vooral gewaarborgd door min of meer toevallige maatschappelijke initiatieven om bepaalde kwesties aan te kaarten. Dit toont de zwakte van het systeem: ${ }^{223}$ Daarbij komt dat overlegvormen vaak juist het tegendeel van transparantie teweegbrengen, zoals bleek in de hoofdstukken over Nederland en Frankrijk. Het informele contact tussen minister en OM krijgt ten slotte een zeker dwingend karakter door het bestaan van formele zeggenschap. ${ }^{22}$

\subsection{Autonomie $O M$ als bescherming wan de onafhankelijkheid van de rechter}

Ten slotte vormt de zelfstandigheid van het OM een versterking van de onafhankelijkheid van de rechtspraak. Dit argument is nauw verbonden met de functie van de onpartijdigheid van het OM voor de controle op de overheid. Het gaat hier niet om de waarborg dat de rechter niet tegen de belangen van de regering in over een zaak kan oordelen. Wel kunnen aanwijzingen meebrengen dat de rechter niet kan oordelen over zaken, waneer die tegen de belangen van de regering in gaan. Tevens kunnen zij tot gevolg hebben dat de rechter, overeenkomstig de wens van de regering, over een zaak moet besllissen, hoewel die technisch onhaalbaar is.

Maar weinigen in Nederland zien een mate van autonomie voor het $O M$ als een waarborg voor de onafhankelijke rechter. ${ }^{225}$ Het feit dat de rechter uitdrukkelijk geconfronteerd wordt met een ministerieel standpunt in het strafproces ziet men niet als bezwaar. Er bestaat geen vrees dat de rechter daardoor sterk onder druk gezet zou kunnen worden. ${ }^{226}$ In Frankrijk en Italië denkt men hier anders over.

Het wantrouwen in de Franse relatie tussen minister en OM zou kunnen overslaan op de rechters. Het kan de rechtspraak in aanzien doen dalen en het beeld van de rechterlijke macht schaden. De zelfstandigheid van het $O M$ is dus vereist opdat de beslissingen van de rechter verschoond kunnen blijven van elk wantrouwen van afhankelijkheid. ${ }^{227}$ Verder is het de functie van het parket on zaken voor de rechter te brengen. De onafhankelijkheid en onpartijdigheid van de rechter zijn zinloos wanneer deze niet over een zaak kan beslissen. Indien zaken om partijdige redenen bij de rechter weggehouden worden, doet dit afbreuk aan de functie van de onafhankelijkheid van de zittende magistratuur. ${ }^{228}$

222 zie hoofdstuk 2, 6.2.3. Wijze van aanwijzen en 6.2.4. Rechswarborgen bij anwijzingen.

223 De Doelder 1995, p. 64 .

224 Over deze zaken: hooldstuk $2,6.8$ en hoofdstuk $3,6.7$, bende getiteld informele inwloed.

225 Rapport relatie OM-zittende magustratur $1981, \mathrm{p} .125$.

226 Corstens 1999, p. 98 . In het verleden stelde hij echter dat het denkbar zou zijn dat rechters zich wel hets wh - in dat geval desiijds - kritiek op hun functioneren zouden aantrekken. De rechspositionele onafhankelijkheid wan rechters is in Nederland namellijk beperkt, Corstens 1988, p. 226; 1988a, p. 301.

227 Pradel \& Laborde 1997, p. 141" Connwssion de reflexion sur la Justice 1997, p. 25 en 37; Perrot 1998 , p. 39 en 453; Angiband 1999, p; 92. De Commission de reflexion sur la Justice deed on dexe reden onder meer het woorstel om het OM een meer aulonome rechtspositio te geven en on bevelen in indiv: duele zaken af te schaffen. Zie hoofdstuk $7,3.5 .1$. Ministeriede zeggenschap.

228 Vgl. Bartolomei 1996, p. 121; Bouwer, Jacquin \& Vogelweith 1997, p. 6. 
De Italianen redeneren op een soortgelijke manier. Een autonoom OM kan de positie van de rechter als derde verstevigen, en de onpartijdigheid en onafhankelijkheid van de reelhtspraak beschermen. Om de onpartijdige rol van de rechter te garanderen dient het OM functioneel onafhankelijk te zijn. Volgens het Constitutionele hof behoort het OM tol de organen van de rechtsspraak (giurisdizione) in ruime zin. De besluitvormende activiteit van de rechter en de vervolgingsactiviteit verhouden zich in een relatie van 'organische verbondenheid' Het OM werkt mee aan de totstandkoming van het rechterlijk oordeel; zijn handelingen zijn functioneel gericht op de uitspraak. ${ }^{229}$

De onafhankelijkheid van de rechter is niet voldoende om het strafproces tegen externe invloeden te beschermen als die in feite de reikwijdte van het vonnis beperken door een selectie in de feiten, de verdachten of de te gebruiken bewijzen. ${ }^{230}$ De onafhankelijkheid van het OM zou onmisbaar zijn ten behoeve van één van de doelen van het strafproces, het vaststellen van de 'materiêle waarheid'. Bewijsvervuiling of zuivering van de feiten op aanwijzing van politieke organen zouden de onafhankelijkheid van de rechter nutteloos maken. ${ }^{237}$ Ook indien er belangen van de staat of een overheidsfunctionaris op het spel staan kan de vordering in het huidige Italiaanse systeem van een onafhankelijk orgaan komen, dat handelt op grond van een objectieve en onpartijdige afweging van de wettelijke normen, en niet op grond van politieke overwegingen van belanghebbenden. Het OM geeft zo mede de onafhankelijkheid van de rechterlijke macht gestalte. ${ }^{232}$ Als het OM niet onathankelijk zou zijn van politieke organen, zou de rechter met andere woorclen in volkomen onafhankelijkheid alleen een oordeel vellen over de zaken die de politiek hem toelaat. ${ }^{233}$

\section{Vergelijking ratio en kritiek}

In de vergelijking van het denken over de ratio van de relatie tussen minister en OM zijn de volgende lijnen te ontdekken. In alledrie de landen dicht men aan het opportuniteitsbeginsel onjuiste gevolgen toe voor de onderschikking van het $O M$. Het gevolg van de discretie is daar én van. Daarmee samenhangend noemen auteurs in alle landen het wel steekhoudende argument van de beleidsvrijheid. Deze factor wijst op een zeer breed gedeelde eis van politieke zeggenschap over het vervolgingsbeleid.

Enkel in Nederland en Frankrijk noemt men nog nadere redenen voor politieke invloed op thet OM. Beide landen kennen de opvatting van het $\mathrm{OM}$ als regeringsvertegenwoordiger, van het handelen van het $\mathrm{OM}$ als regeringszaak, van de vervolging als politieke aangelegenheid of zaak van algemeen belang. Specifiek voor bijzondere aanwijzingen bestaan in deze landen redeneringen omtrent beleidscontrole, rechtsbescherming, buitenlandse betrekkingen en het anticiperen op wetgeving. Dergelijke opvattingen worden in ltalië niet genoemd. De nadruk op het legaliteitsbeginsel en het diepe

229 Corte Cost. 1975, a. 96. Spagna Musso 1987, p. 1222. In Corte Cost. 1995, n. 420 word het OM autorita giudiziaria, "rechterlijk orgaan' genoemd. Gustapane 1999, p. 225

230 Devoto 1996a, p. 2042.

231 Caraba 1974, p. 94. Over de waarheid als doel: Corte Cost. 1992, n. 255; Devoto 1996a, p. 2033.

232 Devoto 1996, p. 376: Gustapane 1999, p. 225 en 238-239; Grevi 1999, p. 84; Brutti Liberati 1999, p. 67.

233 Carbone 1982, p. 79. 
wantrouwen tegenover de politiek zijn hier waarschijnlijk debet aan. Het rechtsbeschermingsargument zou om deze redenen zelfs absurd overkomen.

Alleen in Nederland zijn de redeneringen te horẹn van de rechter als anomalie, de noodzaak van proefprocessen en het bijdragen aan de rechtsontwikikeling. In Frankrijk wordt de afwijkende positie van de rechterlijke macht wel onderstreept. Het argument van de anomalie zou in dit Franse perspectief daarom wel in te passen zijn. Proefprocessen en rechtsontwikkeling buiten het woeren van algemeen beleid zijn echter geen taken die men aan de Franse minister van Justitie toeschrijft.

Tegen bepaalde vormen van onderschikking pleit in alle landen de uitgedragen politieke onpartijdigheid van het OM. Dit argument vormt hierom duidelijk een gemeenschappelijk richtsnoer bij de inrichting van de relatie tussen de minister en het OM. In alle landen ziet men verder enkele redeneringen omtrent de machtenscheiding, maar deze spelen een opmerkelijk kleine rol.

In Nederland en Italië benadrukt men de controlefunctie van het $\mathrm{OM}$ op de overheid en de bescherming van minderheden. Het blinde Franse oog voor deze stellingen ligt waarschijnlijk deels in de ongelijkwaardige status van de Franse rechterlijke macht.

Alleen in Italië en Frankrijk komt het argument naar voren van de bijdrage aan de onafhankelijkheid van de rechter. Fransen en Italianen redeneren dat politieke invloed op het OM kan leiden tot het wantrouwen van de rechterlijke onpartijdigheid. Nederland ziet de rechter wellicht meer als onaantastbaar en plaatst het wantrouwen daarom hoogstens tussen de rechter en het OM. In Nederland zijn verder nog het gezag van het OM en de rechtszekerheid in het vervolgingsbeleid een issue.

\section{Samenvatting en conclusie}

In het voorgaande besprak ik de argumentatie achter de positie van het $O M$ in relatie tot de minister van Justitie. Deze argumenten blijken vrijwel geheel gericht op de functhonele invloed van de minister. Zijn rechtspositionele bevoegdheden vinden in feite hun grond in de functionele ratio. Ik behandelde vervolgens het gedachtegoed voor en tegen de functionele ministeriële zeggenschap. Het belangrijkste dilemma hier is de strijd tussen legitimiteit en onpartijdigheid.

Het legitimatieargument vindt enkel vaste grond in de beleidsvrijheid en de initierrende rol van het OM. Andere redeneringen in de lijn van legitimatie zijn onjuist of inconcludent. Zo vormt de onafhankelijkheid van de rechter geen abnormale inbreuk op de democratie, die rechtvaardiging krijgt door onderschikking van het $\mathrm{OM}$ aan de politiek (4.1). Het OM krijgt allerlei etiketten opgeplakt. Termen als 'bestuursorgaan' of 'regeringsvertegenwoordiger' wijzen wellicht in de richting van ministeriële aanwijzingsbevoegdheden, maar andere namen lijken zich te richten op zelfstandigheid (4.2). De strafrechtelijke politiek is niet of niet alleen een regeringsaangelegenheid, zo blijk uit de bestaande beperkingen op regeringsinvloed. Verder omvat die politiek in feite mede de strafwetgeving en heeft zij noodzakelijkerwijs ook lokale verschijningsvormen (4.3). Het 'algemeen belang' is bij de vervolging evenzeer betrokken als bij vormen van bevoegdhedenuitoefening waarin de minister niet kan interveniëren. Vervolgingsbeslissingen "politiek" noemen heeft evenmin een onderscheidende functie (4.4). Het 
opportuniteitsbeginsel zelf vormt geen reden voor onderschikking. Onder het legaliteitsbeginsel is ook coördinatie van vervolging nodig, en moet het OM de facto evenzeer besluiten om zaken niet te vervolgen (4.5), Sterker is het punt van de beleidsvrijheid. In combinatie met de initiërende rol vormt deze de reden om politieke zeggenschap te aanvarden over de beleidsvoering van het $\mathrm{OM}(4.6)$.

Argumenten die pleiten voór aanwijzingen in specifieke zaken lijken mij slechts gedeeltelijk overtuigend. Voor beleidscontrole zijn undividuele aanwijzingen overbodig en ontoereikend. Verder moet de minister de noodzaak erkennen van zowel lokaal beleid als de inherente afwijkingsbevoegdheid (5.1). Voor anticipatie van wetgeving hoeft een minister ook niets anders dan een algemene aanwijzing te geven (5.2). Buitenlandse betrekkingen hoeven niet noodzakelijkerwijs betrokken te worden bij de individuele vervolgingsbeslissing. Overigens kunnen buitenlandse belanghebbenden zonodig beklag instellen tegen niet-vervolging (5.3).

Het 'algemeen belang' of het 'politieke' in de beslissing tot vervolging hoeft niet tot aanwijzingen tot niet-vervolging te leiden. De minister kan desgewenst beleidsregels geven. Voor de bescherming van de staatsveiligheid bestaan al de nodige warborgen. Ten slotte, als het algemeen belang volgens de minister gebaat is bij niet vervolgen, kan een klacht door een slachtoffer al roet in het eten gooien (5.4.1). Voor de aanwijzing tot vervolging ligt dit anders. Waar het $\mathrm{OM}$ om opportuniteitsredenen niet het initiatief neemt tot vervolging, moet de politiek vervolging kunnen bewerkstelligen. Het niet handhaven van strafbepalingen moet democratisch gecorrigeerd kunnen worden (5.4.2).

De juridische controletaken die aan de minister worden toegerekend tegenover het $\mathrm{OM}$. bevreemden door hun dubbelzinnigheid. De interne hiërarchie van het OM en de rechterlijke colleges behartigen die taken al. Voor rechtsbescherming of rechtmatigheidscontrole is de minister een twijfelachtige instantie. Zijn politieke aard kan hier in strijd komen met zijn welhaast 'rechterlijke' pretenties (6.1). In plaats van proefprocessen te laten houden kan de minister beter wetgevingswijziging initiëren. Een bijzondere aanwijzingsbevoegdheid heeft hij hier in ieder geval niet nodig als hij al beleidsaanwijzingen kan geven. De rechtsontwikkeling wordt verder niet gediend met bijzondere aanwijzingen ten aanzien wan het requisitoir (6.2).

De redenen voor autonomie zijn evenmin alle gegrond. De theorie der machtenscheiding is door haar algemeenheid niet conclusief (7.1). Het handelen van het $\mathrm{OM}$ is verder niet eenduidig 'rechterlijk' te noemen, terwijl het onduidelijk is wat voor gevolgen aan een dergelijke kwalificatie gehecht moeten worden (7.2). Eisen omtrent rechtszekerheid geven wel algemene regels omtrent beleidsuitvoering, maar pleiten niet in het bijzonder voor een autonoom OM (7.3).

Anders is het met de onpartijdigheidseis. Deze kan in het gedrang komen door ministeriẻle bevoegdheden ten aanzien van individuele zaken. In ieder geval brengen deze bevoegdheden een schijn van partijdigheid met zich. Politieke invloed op het vervolgingsbeleid is niet in strijd met de vereiste onpartijdigheid. Deze onpartijdigheid gaat verder dan voor gewone ambtenaren, en is in het bijzonder van belang in een strafrechtelijke procedure. Daarbij moet men in aanmerking nemen dat het OM mede een 
strafrechtelijke controletaak heeft jegens de overheid. Het $O M$ dient tevens individuele beslissingen te kunnen nemen die ingaan tegen de eigen belangen van de regerende meerderheid. De onpartijdigheid dient verder het gezag van en het vertrouwen in het OM: De kritiek dat de partijdige inmenging zelden of nooit voor zal komen mist doel. Wantrouwen jegens de minister is niet gegrond in het vaak voorkomen van individuele aanwijzingen, maar al in de enkele mogelijkheid en de zeldzame ingreep. De bestaande, onder meer procedurele waarborgen zijn hierbij ontoereikend (7.4).

Deze conclusies worden gedeeltelijk gevolgd, althans niet tegengesproken door internationale aanbevelingen omtrent de relatie tussen de politiek en het OM. De vraag of de pollitiek algemene aanwijzingen of aanwijzingen tot vervolging zou moeten kunnen geven blijft vaak, al dan niet expliciet, open. De bevoegdheid on aanwijzingen tot nietvervolging te geven wordt internationaal nauwelijks gewaardeerd. Algemeen aanvaard is echter de eis dat het OM onpartijdig moet handelen, en dat objectiviteit moet heersen in rechtspositionele aangelegenheden.

De huidige individuele aanwijzingsbevoegdheden in Nederland en Frankrijk zijn in strijd met de bovenstaande argumentatie. De aanwijzingen ten aanzien van het requisitoir en tot niet-vervolging dienen dan ook afgeschaft te worden. Ministeriële zeggenschap die tot vervolging leidt kan blijven bestaan. Het laten instellen van vervolging door de minister moet wel anders ingericht worden. Vervolging op initiatief van de minister mag alleen plaatshebben als rechterlijke ambtenaren (van het OM en eventueel een rechterlijk college) de zaak juridisch haalbaar achten. In Italië vormt de afwezigheid van politieke besluitvorming over het eigenlijke vervolgingsbeleid een manco. Hier ligt het dan voor de hand om de minister of het parlement de gelegenheid te geven om vervolgingsprioriteiten te stellen.

Deze overwegingen met betrekking tot de functionele relatie kunnen nu betrokken worden op de rechtspositie. Dit volgt uit de eerdere conclusies dat enerzijds de aard van de rechtspositie de mate van onderschikking beïnvloedt, en anderzijds de ratio van de functionele relatie die van de rechtspositie bepaalt (2.3). Welke rechtspositie is nu wenselijk?

Uit paragraaf 4 blijkt dlat politieke invloed op het beleid geindiceerd is. In specifieke strafzaken moet onpartijdigheid zoveel mogelijk gegarandeerd worden, zoals blijkt uit paragraaf 7. De minister kan in beginsel het vervolgingsbeleid bepalen zonder beslissingsbevoegdheden te hebben omtrent de rechtspositie van het OM. Indien hij de bevoegdheid heeft algemene aanwijzingen te geven, zijn de meeste rechtspositionele bevoegdheden in deze niet noodzakelijk. Andersom is het denkbaar dat de minister door (een dreiging met) een bepaald gebruik van deze rechtspositionele zeggenschap de onpartijdige houding van het $O M$ in een specifieke zaak beschadigt. Gezien deze overwegingen verdient het de voorkeur de rechtspositionele beslissingsbevoegdheden niet aan politieke organen over te laten. Bewindslieden zouden wel initiërende bevoegdheden gelaten kunnen worden, bijvoorbeeld met betrekking tot de disciplinaire procedure. 
In de huidige stelsels voldoet de Italiaanse rechtspositionele onafhankelijkheid aan deze conclusie: Verder spoort daarmee de (wisselvallige) beleidsmatige autonomie op onderdelen van de rechtspositie van het $O M$ in Frankrijk en Nederland. In dit licht negatief te beoordelen zijn de juridische beslissingsbevoegdheden van de minister en de regering aldaar. In Nederland zijn met name de disciplinaire en ontslagbevoegdheden te bekritiseren. Het grootste Franse mance vormen de politieke benoemingen van de procureurs-generaal.

Deze conclusies vormen mede een kritiek op de bestaande rechtsstelsels in Nederland, Frankrijk en Italië. Aangezien de ratio voor sommige bevoegdheden, rechten en plichten aangevochten wordt, dringt de vraag naar alternatieve systemen zich op. In het volgende hoofdstuk bespreek ik daarom de belangrijkste hervormingsvoorstellen en wil ik beschrijven op welke wijze onvolkomenheden weggenomen kunnen worden. 


\section{Hoofdstuk 7}

\section{Hervormingen}

\section{Inleiding}

Kritiek op de bestaande relatie tussen het $\mathrm{OM}$ en de minister mondt met name in Frankrijk en Italië vaak uit in voorstellen voor verandering. Aan de hand van de overwegingen in het voorgaande hoofdstuk kunnen deze ideeën op hun merites worden beoordeeld. Een korte analyse van de constitutionele grenzen moet daaraan voorafgaan. In hoeverre staan de grondwetten aan institutionele verandering van de relatie tussen minister en $\mathrm{OM}$ in de weg? Na deze hindernis beschouw ik de hervormingsvoorstellen zelf. Daarbij valt op dat verscheidene plannen in verschillende landen overeenkomst vertonen. Daarom behandel ik de voorstellen gebundeld nat inhoudelijke kenmerken. Hierop volgt een algemene vergelijking van de beschreven hervormingsideeën. Aansluitend aan de analyse van deze nationale plannen bespreek ik in kort bestek de voorstellen voor een Europees Openbaar Ministerie. Na dit supranationale uitstapje keer ik terug naar het landelijk niveau met een oordeel over de meest geschikte ideeën voor de drie landen. Uitgebreide overwegingen schenk ik daarbij aan een voorstel voor aanpassing van het Nederlandse stelsel.

\section{Grondwettelijke belemmeringen}

Een eerste vraag is in welke mate grondwetswijzingen nodig zouden zijn voor hervorming van de relatie tussen minister en OM. De grondwetten van Nederland, Frankrijk en Italië zijn kort of zwijgzaam over de functionele zijde van deze relatie. De rechtspositionele verhoudingen komen er iets beter vanaf.'

Over functionele of rechtspositionele bevoegdheden van de regering of de minister meldt de Nederlandse grondwet niets. Uit de grondwet is enkel af te leiden dat de leden van het OM deel uitmaken van de rechterlijke macht. Er worden geen eisen gegeven ten aanzien van de onathankelijkheid van de rechterlijke macht in het algemeen.

De Franse grondwet spreekt zich wel uit in functionele zin, zij het zeer summier. 'De President van de Republiek staat borg voor de onafhankelijkheid van de rechterlijke macht' (art. 64). Dat het OM onderdeel uitmaakt van de rechterlijke macht impliceert echter niet dat het onafhankelijk dient te zijn van politieke organen. De 'onafhankelijkheid' laat onverlet dat het $O M$ onder bevel staat van de minister. Wel ziet men bestaande beperkingen op de aanwijzingsbevoegdheid als uiting van die onafhankelijktheid. De grondwet lijkt geen algehele functionele onderschikking toe te staan.

Vanuit rechtspositioneel gezichtspunt geeft de grondwet meer gedetailleerde regels. Hierin ligt vast dat de CSM slechts een advies geeft over de benoemingen van de leden

1 Zie ook hoofdstuk $2,2.1$, hoofdstuk $3,2.1$, hoofdstuk 4,2.1, alle geheten: OM en rechterlike macht. 
wan het OM en de op te leggen disciplinaire sancties. Anders dan voor de rechters blijkt niet dat de minister of de regering dat advies op moeten volgen. Verder zegt de tekst dat sommige leden zonder advies door de ministerraad aangewezen worden. Theoretisch is denkbaar dat de wetgeving omtrent de rechterlike organisatie verder gaat dan de grondwet. De wet zou kunnen bepalen dat de minister of de regering conform het advies moet bes luiten. Het is echter waarschijnlijk dat een dergelijke regeling niet in owereenstemming geacht zal worden met de grondwet. Deze lijkt darom in de weg te staan aan een meer autonome rechtspositie wat betreft de benoeming en het disciplinair regime.

De ltaliaanse regeling poneert kort en krachtig de functionele onafhankelijkheid van de rechterlijke macht inclusief het OM. Aangezien er hier gewoonweg weinig functionelle relaties tussen de politieke organen en de rechterljke macht bestaan, kan de grondwet daarover ook niet werder uitweiclen. De rechtspositie van het Italiaanse OM is wel uitgebreid voorzien van grondwettelijke eisen. Deze bepalen dat de CSM beslunit over benoemingen, overplaatsingen en disciplinaire straffen. De Italiaanse grondwet laat zo weinig ruimte voor institutionele wijzigingen.

Voorstellen voor werandering van de verhouding tussen minister en OM pogen vaak binnen de bestaande grondwettelijke beperkingen te blijven. Deze grondwettelijke regelingen van Frankrijk en Nederland lijken geen probleem te vormen woor beperking van de functionele relatie tussen de minister en het OM. De Franse grondwet zou hoogstens in de weg kunnen staan aan nog verdergaande onderschikking van het OM aan de minister. In Italië lijkt de grondwettelijk geproclameerde onafhankelijkheid vrijwel elke soort functionele bevoegdheid van de regering of het parlement tegenover het $\mathrm{OM}$ uit te sluiten. Verder staan de belangrijkste rechtspositionele verhoudingen in Frankrijk en Italie grondwettelijk vrij vast omschreven. De Nederlandse grondwet laat veranderingen van de rechtspositie van het $\mathrm{OM}$ ongemoeid.

\section{Hervormingsvoorstellen in drie landen}

Na de voorgaande blik op de constitutionele randvoorwaarden richt ik mij op de inhoud van de gedane hervormingsvoorstellen. Daartoe begin ik met een overzicht in de drie landen. In de daaropvolgende subparagrafen behandel ik de aangedragen plannen afzonderlijk. Deze gaan achtereenvolgens over invoering van rechterlijke toetsing van ministeriële aanwijzingen; beperking van de bevoegdheid om aanwijzingen te geven; een autonome rechtspositie voor het $\mathrm{OM}$; een combinatie van deze laatste met é̉n van. de voorgaande voorstellen; een nationale procureur-generaal, en ten slotte vermeld ik voor de volledigheid nog enkele zeer vergaande hervormingen, die vrijwel geen steun genieten.

Kritiek op thet Nederlandse stelsel van onderschikking mondt welhaast altijd uit in een pleidooi voor matiging van de functionele ministeriële invloed, nauwelijks of niet voor de afschaffing daarvan. In maar zeer schaarse gevallen leidt geleverd commentaar tot ideeën voor institutionele verandering. Een breed gedeelde voorkeur voor een specifieke soort hervorming bestaat niet. 
In Frankrijk zijn juist zeer verscheidene voorstellen gedaan om het bestaande stelsel te herzien. De meeste ideeërn richten zich in ieder geval op een meer autonome rechtspositie: In veel gevallen stelt men verder een inperking van de ministeriële zeggenschap aan de orde. Twee hervormingsplannen krijgen de meeste bijval. Velen bepleiten de instelling van een autonome, nationale procureur-generaal, maar de meeste steun bestaat voor beperking van de aanwijzingsbevoegdheid en een meer autonome rechtspositie voor het OM. Zelden worden strafprocessuele oplossingen voorgestaan, on de spanning in de verhouding tussen $O M$ en minister te verminderen. ${ }^{2}$

De Italiaanse rechtswereld draagt juist vaak hervormingen aan met betrekking tot de strafrechtelijke procedure. Daarnaast doet men wel meer organisatorische voorstellen van interne aard en structuurvoorstellen met betrekking tot de relaties tussen het OM en politieke organen. ${ }^{3}$ De eerste twee typen wil ik op deze plaats kort behandelen, gezien het belang dat de Italiaanse doctrine hieraan hecht. De voorstellen aangaande de structurele verhoudingen tussen politiek en OM komen aan bod in de daarna volgende subparagrafen.

Wat betreft de meer 'endo-processuele' hervormingen richt men zich onder meer op de reductie van het aantal strafbaarstellingen (zgn. depenalizzazione) en de introductie van straffeloosheid wanneer het delict geen of weinig schade heeft toegebracht. Verder denkt men aan een groter gebruik wan de klacht als voorwaarde voor vervolging en uitbreiding van de bijzondere strafrechtelijke procedures als de procedure per decreet (procedimento per decreto). Daarnaast behoort invoering van de verplichte poging tot bemiddeling, evenals het recht voor burgers om vervolging in te stellen tot de opties.

2 Een enkeling bepleit wel het legaliteitsbeginsel, ingebouwd in het voorstel voor een autonome rechtspositie voor het $\mathrm{OM}$ in combinatie met de beperking van individuele aanwijzingen. De auteut stelt echter nadrukkelijk dat daarbij wel belangrijke vitzonderingen moeten gelden. Vauzelle, Commission de reflexion sun la Justice, Annexes 1997, p. 51 . Een ander stelt wel voor meer divensificatio in de strat rechlelike reactic wan het OM op delicten. Er zouden meer alternatieve procedures ontwikkeld mosten worden nast de vervolging. Zo zouden de sepots op grond van de enkele oppotumicit minder nodig worden. Mathias 1999a, p. 7-8. De auteur pleit elders wel voor het voorstel dat word genoend in 3.3. Autonome rechlspositie.

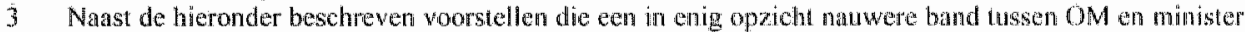
of parlement behelzen, zijn er vooral in hel verleden lewens voorsteller gedan die een verderganda onafhankelijkheid woorsteat (zgh. personalizzazione dalle funzioni). Deze worden hier buitun beschouwing gelaten. Zie dastroor o a. de (vroegere) mening wan Zagrebelsky dat proctireurs ook untern in het parket onathankelijk moeten zijn wan the hoofd. De vormen van hiërarchic binnen het OM zouden (verder) verminderd of opgeheven moeten worden, wastoor de kans verninderd wordt at worvolgingen verhinderd worden, 1974, p. 195; 1979, p. 26. Voor diens huidigo zienswijze zie Zinguebelsky 1994.

4 Zagrebelsky 1974, p. 195, 1994, p. 114; Spagna Musiso 1987, p. 1229; Neppi Modon: 1987, p. 55; Caliendo 1994, p. 140; Daniele 1994, p. 235; Chiavario 1994, p. 87; Curatola 1994, p. 262; Scaprama 1994, p. 274; Di Federico 1995, p. 427; Grevi 1999, p. 77 e.w. Een neductie van de stralbaratsillingen heeft platsgevonden door de 1. 24 nowember 1981 , n. 689, . . 28 december 1993, n. $561,1.25$ juni $\| 999$, n. 205 en d.lg. 30 decenber 1999, n. 507 . Voor de genoemde straffelobsheid zie ook al art. 49 lid 2 a.p. en verdergatand, woor minderjarigen art. 27 lid I d.p.r. n. 448, 1988; kritisch: Zanon 1996, p. 184 185 , Een uitbreiding van de voonwarde van de klachi heeft plaatsgevonden bij 1. 25 juni 1999, 11. 205. Grotere mogelijkheden voor procedures per deceet schiep 1. 16 december 1999, n. 449, Ten atanzien van het vervolgingsrectht woor burgers constateert Carabba simpelweg dat het OM al moet handelen op 
Deze voorstellen vormen allen een poging om de bestaande discretie van het Italiaanse OM te beperken. Deze beperking zou de spanning tussen de eisen van onpartijdigheid en legitumiteit veminderen. Dergeljke hervormingen zouden de discretie in het handelen van het $O M$ echter niet opheffen, De beleidswrijheid die hier zou blijven bestaan zou vragen om een vorm van verantwoording

Naast deze processuele varianten zijn in ltalie wel plannen opgeworpen die beleidsbepaling bimnen de rechterlijke macht officieel mogelijk zouden maken. Zo zou de CSM de bevoegdheid kunnen krijgen om het strafrechtelijk beleid te bepalen. ${ }^{6}$ In zekere zin heeft de raad daarop nu ook al enige invloed door de meer technische circulaires die zif uit doet gaan. De CSM heeft evenwel maar een zeer beperkte democratische legitimatie, en zij is niet politiek verantwoordelijk. Slechts een derde van de leden is door het parlement gekozen, en deze kunnen zelden een doorslaggevende inwoed hebben op de besluitvorming. Het voorstel zou daarom geen verbeterde democratische verantwoording van het handelen van het $\mathrm{OM}$ betekenen. ${ }^{7}$ Het voorstel zou overigens ook in strijd zijin met de huidige grondwet, die de vervolging tegen (aan het OM) externe beinvloeding zou beschermen, en de bevoegdheden van de CSM nauwgeret opsomt.

Sommige ltaliaanse auteurs menen expliciet dat bovenstaande voorstellen, op zich of in combinatie, afdoende zijn on tegemoet te komen aan de legitimatieproblematiek. ${ }^{9}$ Veel schrijvers zijn echter voorstander van verdergaande hervormingen met betrekking tot de relatie tussen het $O M$ en de politiek. De meeste steun ondervinden de ideeen omtrent parlementaire controlecommissies en parlementaire aanwijzingen gericht aan het OM.

In het navolgende komen de nu kort genoemde voorstellen meer uitvoerig aan bod.

\subsection{Rechterlijke toetsing vaw aanwijzingen}

Een in Nederland wel verdedigd idee betreft de verplichting voor de minister om het oordeel van het gerechtshof te vragen over een aanwijzing. Met nathe zou een oorcleel gevraagd moeten worden over een aanwijzing tot niet of niet verdere opsporing of ver-

een angifle, en dan dat rech daarom al nutteloos zou zijn, 1974, p. 95. Het abstracte formalisme in deze mening is sprekcnd. Over de rechtertijke boete an de procedure per decret zie ook hoofdsuk $4,3.5$. Vervolghngstrntegte. Zagrebelsky werwachte niet veel van en vervolgingsredut voor burgers gezien het gekoesterde wantrouwen tegenover da rechterdijke macht wat men er soms juist van weerhoudt om

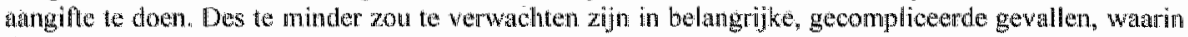
diepgand onderzok nodig zou zijn om tot een ankiaht ta komen, 1979, p. 25.

5 Guanieri 1984, p. 186-187. In zijn conclusies nemt hij geen standpunt in ten faveure van een bepaald hervormingsvoorstel. Hij somt een antal mogelijkheden op met hum woor en nadeler. Verder Castellj 1990, p. 99, Betiol 1998, p. 265, Fakone 1990, p. 166.

6. Voorgesteld door Chiavario 1994, p. 95-96. Voor de bestande invioed, zie hootdstuk 4, 2.2. Interne organisatio.

7 Ctstalli 1900, p. 102; Zanon 1996, p. 246-247.

8 Canvita 1991, p. 307; Nannucci 1991, p. 1670; Zanon 1996, p. 244. Anders: Chiavario 1994, p. 95.

9 Neppi Modona 1987, p. 55-56; Spagna Musso 1987, p. 1229; Cascini 1993, p. 424; Rovelli 1994 , p. 269; Devoto 1996a, p. 205 I e.v.; D'Elia 1998, p. 1879. 
volging. ${ }^{10}$ In een andere versie zou het OM witdrukkelijk het recht krijgen on een aanwijzing naast zich neer te leggen. Hiena zou de minister daarover het oordeel van de rechter kunnen uitlokken. Deze zou zich dan kunnen buigen over de vraag of het OM terecht een aanwijzing naast zich neer heeft gelegd. "Een derde optie zon zijn on het OM de gelegenheid te geven om een aanwijzing voor te leggen aan het hof. Dit zou in leder geval mogelijk moeten zijn indien de minister contrair zou willen beslissen aan het advies van het College. ${ }^{12}$

De kritiek hierop luidde onder meer dat het beter zou zijn als de minister politieke verantwoording zou afleggen over een dergelijke aanwijzing. Deze verantwoording zou juist uitgehold worden door de rechterlijke controle. ${ }^{3} \mathrm{Nu}$ is het echter al mogelijk dat, als er cen belanghebbende is, een rechter de beslissing tot niet-vervolging controleert in de beklagprocedure. Ook wanneer de minister een aanwijzing geeft om niet te vervolgen in een strafzaak met een belanghebbende, dient de minister politieke verantwoording af te leggen voor zijn handelen. De rechterlijke controle die dan kan volgen in een beklagprocedure, zou deze verantwoording evenzeer doorkruisen.

Minister Korthals stelde in dit verband nog dat het weglaten van rechterlijke controle zou voorkomen dat de kamers 'een andere mening zouden hebben' dan de rechter. ${ }^{14}$ Dit is in het huidige stelsel echter al niet gegarandeerd. Wanneer de kamer oordeelt dat geen vervolging mag plaatsvinden kan zoals gezegd een beklagprocedure volgen. De rechter kan daarin een tegenovergesteld besluit nemen, door de verwolging bevelen.

Verder zou rechterlijke controle procedurele complicaties geven: "eerst de adviesprocedure bij het college, daarna de toetsing van de aanwijzing door de rechter, ten slotie nog de artikel-12-procedure en uiteindelijk nog de politieke controle. Ik vind dat eerlijk gezegd wel een beetje erg veel van het goede' " Deze opsomming van minister Sorgdrager wekt verbazing. Waarom zou het nodig zijn om de rechter tweemaal over dezelfde vervolgingskwestie te laten buigen? Het ligt bij invoening van rechterlijke toetsing van aanwijzingen tot niet-vervolging voor de hand om eventuele belanghebbenden daarbij te betrekken. Vervolgens is een beklagprocedure overbodig in een dergelijke zaak. In het huidige systeem is juist wanneer er geen belangheblsende is die de klachtprocedure van artikel 12 in gang zet geen rechterlijke toetsing mogelijk. Van procedu rele complicatie is in het onderhavige voorstel geen sprake.

Minister Sorgdrager meende nog dat de procedure de beslissingstermijn zou verlengen., waardoor een grotere kans zou bestaan dat de redelijke termijn zou worden overschreden. ${ }^{16}$ Het is evenwel de vraag wat voor rol de overschrijding van de redelijke termijn

10 SGP-fractic, Kamerstukken II 199798, 25392, nr, 6, p. 22; Van den Berg, Handetingen. II 1997/98, p. 4837; Koekkoek, Handelingen II, 199798 , p. 47904791, 4801, 4806, 4836 4837; idem, Kamerstk ken II $1997 / 98,25392$, nr. 18.

11 NVUR 1996, p. 321

12 Glastra wan Loon, Handelingen $1,1998 / 99,1174$.

13 Kalsbeek-Jaspersw, Handelingen II, 1997/98, p. 4836-4837, Rabbae, Handelingen II, 1997/98, p. 4792. 4793

14 Handelingen 1, 1998/99, p. 1195.

15 Minister Sorgdrager, Handelingen II $1997 / 98$, p. 4828 .

16 Minister Sorgdrager, Kanerstukken II 1997/98, 25392, nr. 3, p. 30. 
zou spelen. Als de minister cen aanwijzing tot verwolging geeft en de rechter dient deze eerst te controleren, ontstaat inderdaad tijdverlies. Echter, dit verlies bestaat nu ook als het OM tot handelen aangezet moet worden via een beklagprocedure. Waarom zou het OM een ministerieel initiatief tot vervolging sneller moeten uitvoeren dan dat van een belanghebbende burger? $\mathrm{Bij}$ een aanwijzing tot niet-vervolging daarentegen zou overschrijding van de redelijke termijn slechts ter sprake kunnen komen als die aanwijzing de rechterlijke controle niet zou doorstaan. Immers, als de rechter het beroep van het OM tegen de aanwijzing zou afwijzen, zou het OM overeenkomstig de aanwijzing niet vervolgen. Acht de rechter de aanwijzing onjuist dan moet het $O M$ vervolgen. Pas voor het daarop volgende proces kan een termijnoverschrijding negatieve consequenties hebben. Deze situatie heeft echter de voorkeur boven een zaak waarin in het geheel geen proces volgt; omdat de minister een onjuiste aanwijzing gaf.

In het licht van de bovenstaande verwerpingen van de kritieken zou rechterlijke toetsing van aanwijzingen wel nut kunnen hebben. Het belangrijkste bezwaar tegen de bijzondere aanwijzingsbevoegdheid is namelijk de eerder behandelde eis van politieke onpartijdigheid. Deze zou een waarborg vinden in de voorgestelde rechterlijke controle die op de aanwijzing zou volgen. Op deze toetsing kom ik terug in paragraaf vijf.

\subsection{Beperkte aanwijzingsberoegdheid en ministerieel beklag}

De Nederlandse en de Franse doctrine hebben zich zelden ingespannen om de enkele afschaffing van de aanwijzingsbevoegdheid te bepleiten. Voor zover men in Nederland beperking wenste legde men zich met name toe op het geven van een beperkende interpretatie van de bestaande bevoegdheid. Zo waren sommigen van mening dat de minister bepaalde aanwijzingen niet kon geven. Dit gold met name voor de aanwijzing ten aanzien van het requisitoir en in mindere mate voor die tot niet-vervolging.

Smid, De Doelder en Boek stelden wel dat de minister geen bijzondere aanwijzingsbevoegdheid zou moeten hebben. Hij zou slechts algemene aanwijzingen kunnen geven. Indien de minister daarentegen vervolging zou wensen, zou hij in de visie van Smid en Doelder gebruik moeten kunnen maken van de bekllagprocedure van artikel $12 \mathrm{~Sv}$. De Doelder meende verder dat de Raad van State een instantie zou kunnen worden die eventuele conflicten over de vraag of iets een algemene of bijzondere aanwijzing is zou kunnen beslechten. De Doelder stelde een 'hardheidsclausule' wan gevallen voor waarin vervolging zou kunnen worden verhinderd. De minister zou in deze gevallen de Raad van State een toetsing kunnen laten verrichten. Verdere controle op het OM zou naast de bestaande klacht bij de ombudsman - verzekerd kunnen worden door een Raad van Toezicht of een Raad van de Magistratuur of de gewone rechter. De mogelijkheid van een klacht bij een dergelijk orgaan zou de ministeriële controle kunnen vervangen."

Verder kwam de commissie Roelvink met een zeer beperkte hervormingsvariant. Zij deed dit met het oog op de invoering van strafrechtelijke aansprakelijkheid van publiekrechtelijke rechtspersonen. Het was de wens van de commissie om daarbij de 
ministeriele zeggenschap over deze gevallen uit te shiten. De minister zou nog wel algemene aanwijzingen kunnen geven over het beleid van de vervolging van deze organisaties. Minister Korthals wille de commissie op dit punt niet volgen. Volgens hem was "de volledige politieke verantwoordelijkheid van de Minister van Justitie voon" het handelen van het openbar ministerie - óok in individuele strafzaken - een wezenlijk element," waarna hij zich haastte de vanzelfsprekendheid van de ministeriele terughoudendheid te benadrukken. ${ }^{18}$

Vos en Van Spanje opteren daarom voor een zogenaamde ongekeerde artikel 12procedure', die - blijkbaar - in de plaats zou moeten komen van de bevoegdheid om aanwijzingen tot niet-vervolging te geven. De minister zou in die procedure het gerechtshof kunnen verzoeken een oordeel te geven over de opportuniteit van een door het OM geëntameerde vervolging. De vervolgingsbeslissing zou aldus 'uit de politieke sfeer worden gehaald'. Aanwijzingen tot vervolging zou de minister klaarblijkelijk wel kunnen geven. ${ }^{19}$

Dergelijke voorstellen sluiten individuele aanwijzingen gedeeltelijk uit, in de lijn van de conclusies uit het vorige hoofüstuk. De optie Roelvink is echter wat eenzijdig, aangezien deze alleen één soort delicten betreft, én de zeggetschap te rigoureus uitshit. De minister zou de vervolging moeten kummen bevorderen wanneer het OM een zaak tegen een publiekrechtelijke rechtspersoon seponeert.

Het voorstel Vos en Van Spanje is dubbelzinnig. Moet de toetsing van het hof zich beperken tot de technische haalbaarheid van de zaak? En zoniet, aan de hand van welke criteria moeten de raadsheren gaan bepalen of een vervolging mogelijk niet wenselijk is? Een rechter moet niet opgezadeld worden met een dergelijke selecteerfunctie.

Het idee van Smid, De Doelder en Boek heeft juist een brede toepassing tot onderwerp. De vervanging van de bevoegdheid aanwijzingen te geven door een beklagprocedure komt tegemoet aan eerder genoemde eisen van rechtmatigheid en onpartijdigheid. De 'hardheidsclausule' voor aanwijzingen tot niet-vervolging daarentegen zou een bron van conflicten kunnen worden. Aanwijzingen tot niet-vervolging kumnen beter afgeschaft worden. 20

\subsection{Auronome rechtspositie}

Enkele Franse auteurs hebben voorstellen gedaan die alleen de rechtspositie van de leden van het OM zouden betreffen. Het gaat dammin om een scheiding van de rechtspositionele zeggenschap over het OM van de functionele. De minister van Justitie behoudt in dit voorstel zijn hiërarchische bevoegdheden ten aanzien van de functies die het $O M$ uitoefent. Een enkeling is van mening dat de minister van Justitie zelfs bevelen tot sepot zou moeten kunnen geven. ${ }^{21}$ Tegelijkertijd krijgt het OM een meer autonome rechtspositie. Benoemingen en overplaatsingen zouden vergezeld moeten gaan van een

18 Conmissie Roelwink 2002, p. 33-37; minister Korthalls, Kamerstukken II 2001-2002, 25204, nr. 15, p.2.

19 Vos \& Van Spanje 2002, p. 1063.

20 Zie verder 6. 1. Hervorming van de functionele relate ussen oM en minister.

21 Mathigs $1999, \mathrm{p} .221$ 
bindend advies van de CSM. Deze raad zou ook beslissen in de disciplinaire procedure. ${ }^{22}$

Deze rechtspositionele ideeën komen tegemoet aan een in het Franse systeem bestaand wantrouwen aangaande de invloed van de minister. In Nederland vindt men daarentegen noch deze ideeën, noch dit wantrouwen terug. Vooralsnog lijkt hier het vertrouwen te regeren dat politisering van de rechtspositie van de leden van het Nederlandse OM buiten de rechtscultuur valt. Een hervorming als hier bedoeld zou ingrijpende institutionele herziening nodig maken. Een ambt als de Franse of Italiaanse CSM bestaat in Nederland (nog) niet. De nu functionerende Raad voor de rechtspraak heeft zelfs geen functie ten aanzien wan de rechtspositie van de met rechtspraak belaste leden van de rechterlijke macht. De aanpassing hiervan of oprichting van een ander orgaan zou weer tot een ingrijpende institutionele herziening noodzaken. De rechtsprekende leden van de rechterlijke macht worden in het huidige stelsel benoemd door de regering. Zolang dit het geval is, is het weinig consistent om te eisen dat de leden van het OM op een meer onafhankelijke wijze benoemd worden.

In andere Franse voorstellen komen eisen van rechtspositionele waarborgen nog terug, zoals zal blijken in de nu volgende subparagrafen: De enkele verzelfstandiging van de rechtspositie van de leden van het OM zou voor deze auteurs onvoldoende zijn.

\subsection{Autonome rechtspositie met toetsing van aamwijzingen}

In Frankrijk stelde de commissie Delmas-Marty voor, het OM de mogelijkheid te geven in beroep te gaan tegen een bevel bij de procureur-generaal bij het Hof van cassatie. Deze zou vervolgens beslissen ten aanzien van de eventuele vervolging. Tevens zou hij uit eigen beweging controle kunnen uitoefenen. De minister zou dan ter zitting schriftelijke requisitoiren in kunnen brengen of zich kunnen laten vertegenwoordigen door een adwocaat. Daarnaast zou een orgaan onafhankelijk van de minister controle moeten uitoefenen op disciplinaire sancties en overplaatsingen. ${ }^{23}$

In een ander, vergelijkbaar voorstel zou de CSM beslissen op beroepen omtrent bevelen. Het OM zou bij deze Raad beroep kunnen aantekenen nadat een ministerieel bevel is gegeven. Vervolgens zou de beslissing van de Raad het OM verplichten overeenkomstig het bevel te handelen, of te ontheffen van zijn plicht. Daarnaast zou de benoeming van leden van het $O M$ vergelijkbaar moeten zijn met die van rechters. ${ }^{24}$

22 Du Tructue 1992, p. 259 (in algemene termen); Turecy 1996, p. 128; J60l 1996, p. 72; Volff 1998, p. 99, 121; Mathias 1999, p. 221 en 254 e.v; CSM 2002. Mathias ziet meer specifiek iets in een Raad voor de reohtspraak bij ellk. Hof van beroep. Belanghebbenden zouden zich tot deze Raad kunnen wenden tegen onregelmatige sepots, met beroep op de CSM. Hij is daamaast van mening dat het instituut van de klacht door het slachtofter kan verdwijnen. Jéol doet well enkele beperkte voorstellen woot de functionele verthouding tussen minister en OM. Niet alleen de specifieke bevelen, maar ook de volledige cor. respondentie tussen mintisterie en OM ten aanzien van een zaak zou toegevoegd kunnen worden aan hei dossier. Om een neiging tot alontegenwoordige interventie te voorkonen zou het volgens hem verder goed zijn een dialoogcultuur te bevorderen tussen parketten en ministerie. 1996, p. 72.

23 Commissie Delmas-Marty $1990, \mathrm{p} .136 \mathrm{e} . \mathrm{v}$. Deze commissie was ingesteld om een herziening van het wetboek van strafyordering voor te stellen. Het rapport heeft niet geleid tot een algehele herziening. Ad hoc wijzigingen zijn soms mede gebaseerd op het onderhavige rapport.

24 Terrier. Commission de réflexion sur la Justice, Annexes 1997, p. 105 en 107. 
Deze ideeën combineren de voordelen uit de vorige paragrafen. Dergelijke plannen hebben echter verder geen weerklank gehad in Frankrijk. Wellijkt datar iets van doof te echoën in de wat verdergaande voorstellen van de volgende paragraaf.

\subsection{Auronome rechtspositie met beperkte aanwizingsbevoegdheid}

In twee varianten bepleit men in Frankrijk en Italië een beperkte mate van zeggenschap doon politieke organen in combinatie met een autonome rechtspositie yoor de leden van het OM. Ten eerste zou de minister een beperkte aanwijzingsbevoegdheid kunnen hebben. Een tweede mogelijkheid is om het parlement of decentraal gekozen raden beleidsmatige bevoegdheden uit te laten oefenen over het OM.

\subsubsection{Ministeriële zeggenschap}

Het in Frankrijk belangrijkste en meest ondersteunde initiatief is on de ministeriële bevelsbevoegdheid ten aanzien van individuele zaken te beperken in samenhang met een meer autonome rechtspositie voor de leden van het OM. Daarbij worden als derde element nadere rechtsfiguren ingebouwd, die vervolging kunnen bewerkstelligen los van een bevelsbevoegdheid. Het voorstel zou het bestaande wantrouwen wegnemen ten aanzien van de politiek, en in het bijzonder de minister van Justitie. Het voorstel is onder andere voorgedragen door de commissie Du Truche, de CSM en de regering Jospin. De drie factoren, beperking van aanwijzingen, nadere vervolgingsmechanismen en autonome rechtspositie, worden hieronder na elkaar besproken.

Wat betreft de bevelsbevoegdheid is de meest genoemde variant dat de minister in het geheel geen bevoegdheden meer zou hebben ten aanzien van individuele zaken. Verscheidene van deze voorstellen geven een meer specifieke invulling aan de verdere relatie tussen minister en OM. Zij suggereren dat de communicatie tussen het OM en het ministerie wel in stand zou kunnen blijven, ook over specifreke dossiers. Hierdoor zou de minister hoogstens een 'advies' kunnen geven. Verder zon de minister het vervolgingsbeleid moeten coördineren en schriftelijk landelijke prioriteiten kunnen stellen. Jaarlijks zou de minister een rapport moeten presenteren aan het parlement met bijdragen van de procureurs-generaal. Over dit jaarverslag en de strafrechtelijke politiek zou vervolgens eventueel een parlementair debat gehouden kunnen worden. ${ }^{25}$

25 Turcey 1997, p. 194 e.w., Lyon-Cen 1997, p. 29. Accomando 1997a, p. 99; 130udon 1997, p. 14 c.v.; Nallet, Commission de reflexion sur la Justice, Anmexes 1997, p. 43 e.t.; Vanzelle, idem, p. 50 ; Terret; idem, p. 102 e. ; Commission de reflexion sur la Justice 1997, p. 18, 30, 34-35; CSM 1998, p. 43 e.v. Voor het regeringsvoorstel zie JO AN 3 juni 1998, projer de loi n. 957 : "relatif à l"action publique en matière penale et modifiant le code de procédure pénale". Deze tekst is vervolgens sterk gezmendeend door de Senaat. In feite behelst het aen geheel ander soort herwormingsvoorstel. Zie 3.6. Proctrear-generaal "de la Nation". Dil hervormingsplan ligt op dil moment stil bij de Assernblé (NO AN 27 oktober 1999, projet de loi n. 1886). Het was onderdeel van eer pakket aan samenhangende woorstellen. Een daavan betrof een grondwetswijziging aangande herwoming van de CSM UO AN 15 april 1998, projet de doi constitutionelle si. 35 relatil au Conseil superieur de la magistrature), het andere een wetswoorstel aangaande de onschuldpresumptie. Dit wetsvoorstel en dat met betrikking tot de verwolging en het OM werden op 26 oktober 1999 door beide kamers in een eerste lezing anavand. Op 27 oktober besloot de Presidert om voor 24 januari 2000 het Congres bjeen te roepen voor de door le voesen 
Enkelen zien in dit verband meer in de beperking van de bemoeienis van de executieve in bepaalde soorten individuele gevallen. De bevelsbevoegdheid zou dan niet geheel afgeschaft worden. Een bevel tot niet-vervolging zou overigens wel uitgesloten worden of blijven. Concreet zou de regering zich bijvoorbeeld alleen niet kunnen bemoeien met zaken die leden van de regering of politieke ambtenaren betreffen. Een vergelijkbare suggestie is om slechts in gevallen die aan bepaalde criteria voldoen de mogelijkheid tot ingrijpen te geven. Deze criteria zouden onder meer als volgt kunnen luiden. Interventie zou mogelijk zijn "wanneer het belang van 'Justitie in het spel is", "wanneer principes aangaande de vrijheidsrechten de zaak aangaan" of "wanneer de internationale verplichtingen gecompromitteerd zouden lijken'. Een ander idee is om de minister enkel de bevoegdheid te laten om sec de vervolging te bevelen, zonder dat hij een delictskwalificatie of een modus operandi zou kunnen geven. Deze laatste aspecten zouden dan ter vrije beoordeling staan van het $\mathrm{OM}^{26}$

Deze vormen van beperkte bevelsbevoegdheden bevatten echter onvolkomenheden. In de praktijk zouden dergelijke beperkungen toepassingsproblemen en mogelijk opportunistische interpretaties tot gevolg kunnen hebben. Criteria zouden zo onbepaald zijn dat vrijwel alles er wel onder zou kunnen vallen. De beperkingen zouden zo niet effectief functioneren. Het zou daarom beter zijn de bevelsbevoegdheid van de minister in individuele zaken af te schaffen. ${ }^{27}$

In de meeste hiervoor genoemde voorstellen zijn warborgen ingebouwd opdat vervolging ingesteld kan worden zonder toevlucht te nemen tot een bevelsbevoegdheid.

Zo stelt men in dit verband voor om meer belanghebbenden de mogelijkheid te geven tegen niet-vervolging beroep aan te tekenen bij een onafhankelijk orgaan. Het zou hier dan om een ruimer begrip van belanghebbenden gaan dan het slachtoffer en de verenigingen die nu al een klacht kunnen indienen. ${ }^{28}$ Sommige voorstellen geven ook de minister expliciet de mogelijkheid on bij een onathankelijk orgaan beroep aan te tekenen tegen beslissingen van het $\mathrm{OM} .^{29}$ De belangrijkste voorgestelde optie is om ingeval van sepot door het OM de minister de bevoegdheid te geven om bij bijzonder besluit een zalak aanhangig te maken bij de rechter. Een advocaat of een magistraat van het ministerie zou de minister ter zitting kunnen vertegenwoordigen. Deze mogelijkheid werd voorgestaan door de regering Jospin. ${ }^{30}$ Dit onderdeel van het voorstel zou volgens

grondwetswijziging ten behoeve van het voorstel m.b.t. de CSM. Op 20 januari evenwel besloot de President de bijeenkomst van het Congres uit te stellen. Op 30 mei 2000 stemde de Senat overigens wel defunitief in met het voorstel betreffende de onschuldpresumptie (wet n. 2000-516 van 15 juni 2000 ).

26 Over de beperking in zaken van politieke ambienaren en regeringsteden: Boudon 1997, p. 16. Over de criteria: Terrier, Commission de reflexion sur la Justice. Annexes 1997, p. 104. Over het bevel tot vervolging sec: Cotte, Commission de réflexion sur la Justice, Annexes 1997, p. 72.

27 CSM 1998, p. 46, 47.

28. Turcey 1997, p. 199; Nallet, Commission de rétlexion sur la Justice, Annexes 1997, p. 44; Vatuzelle, idem, p. 51; Conmission de reflexion sur la Justice 1997, p. 28-29; CSM 1998, p. 49-50. Nallet heeft de huidige chambre d'accusation in gedachten. De commisste denkt an een orgaan vergelijkbaar met de commission des requêtes de la Cour de justice de la République. De CSM hieeft het oog op een beroep op de procureur-generaal.

29 Lyon-Caen 1997, p. 29; CSM 1998, p 49-50.

30 Commission de réflexion sur la Justice 1997, p. 34-35; art. I van projet de loi n. 957 (art. 30-2 CPP). 
eritici - waaronder de CSM - slecht passen in het Franse stelsel. Het zou de rol van het OM zelf op het spel zetten. De vervolging zou niet slechts aan de rechterlijke macht meer toebehoren, maar mede aan de uitvoerende macht. De functies van minister en vervolgend orgaan zouden niet verenigbaar zijn in én persoon. ${ }^{31}$

Ten slotte zou in samenhang met het bovenstaande de rechtspositie van de leden van het OM moeten veranderen. Net als de Franse rechters zouden zij slechis conform advies van de CSM benoemd kunnen worden. Een overplaatsing in het belang van de dienst zou eveneens conform CSM-advies plaatsvinden. In de disciplinaire procedure zou de raad niet langer een advies uitbrengen, maar zelf beslissen over de gegrondheid van de aanklacht en de op te leggen sanctie. De organisatie van de CSM zelf verandert in veel voorstellen van samenstelling, in de zin dat de magistraten in elke samenstelling in een minderheid zouden verkeren.

Een variatie aan meningen bestaat over de vraag wie het initiatief mag memen in de nieuwe disciplinaire procedure. Naast de minister zouden ook de procureur-generaal en de president van het Hof van cassatie een dergelijke actie kunnen ondernemen. De bevoegdheid hiertoe zou tevens aan de procureurs-generaal bij de hoven kunnen worden toegekend. Een andere optie is om het initiatief daamaast aan alle belanghebbende burgers toe te kennen. ${ }^{3.3}$

Het Franse voorstel voldoet zo aan tegengestelde eisen. Aan de ene kant beantwoordt het aan het wantrouwen over ingrepen in individuele zaken en benoemingen. Partijdige interventies worden dienaangaande uitgestoten. Aan de andere kant behoudt de minister de beleidsbepaling en de nogelijkheid strafzaken te beginnen.

In Italie werden eveneens voorstellen gedaan die rechtspositionele autonomie combineerden met een zeer beperkte ministeriêle aanwijzingsbevoegdheid. Enkele llaliaanse auteurs deden het voorstel het OM onder de beperkte leiding van de minister van Justitie te stellen. Dit zou het handelen van het OM legitimeren, en de homogeniteit van de beslissingen kunnen bevorderen. Tevens zou het de te maken keuzes transparanter vormgeven dan onder het huidige stelsel het geval is. ${ }^{34}$ De minister zou geen aanwij-

31 CSM 1998, p. 48, Jacquin \& Vogetweitl (Meny) 1998, p. 7, Mathias 1999a, p. 7. Men heef de nimister in alit verband ook all een toekomstige "super-procureur" genoend, Dutfour 1998, p. 5 .

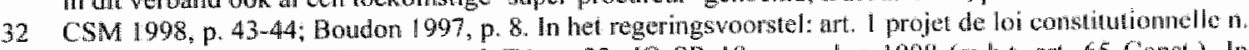
835, JO AN 15 aprill 1998 en art. 2 TA n. 23, JO SR 18 november 1998 (no b.t. ar. 65 Const.). In samenhang met een hervorming wan de relate minister-OM $x a$ de compositic van de CSM veranderen. beze hervorningen gatan allew in de richting wan een witbreiding van het atintal leden van buiten de rechterlijke macht. Deze butenstaanders krijgen zo een meerderbetid binnen de CSM. Hierdoor zow corporatisme binner die machti tegengegan kummen worden. Bartolomei 1996, p. 122; Pradel \& L-inborde 1997. P. 142; Conférence nationate des procureurs géneraux, Commission de réflexion sur la Justice, Annexes 1997 , p. 400 .

33 Woor toekenming aan de procureut-generaal en de president van het Hof yan cassatie: Commission de reflex hon sur la Justice 1997 , p. 49 e.w. Voor toekenning aan de procurenrs-generaal: CSM 1998, p. 45. Voor toekenning an belanghebbenden: Accomando 1097a, p. 95. In hel regeringsvoorstel is thet disciplinair initiatiel niet geregeld. Deze kwestie zal in de wet op hel statunt van de magistraturt (ord.) anders geregeld kunnen worden. Tot dan bijf enkel de minisier bevoegd. 
zing tot nief-vervolging kunnen geven, gezien het legaliteitsbeginsel. In de terechtzitting zou het OM vrij gelaten dienen te worden om de objectiviteit van de vervolging te waarborgen. Een eventuele aanwijzing zou de uitkomsten van het proces in deze fase niet kunnen beoordelen, en daarom al objectiviteit missen. Wel zou de minister een bevel mogen geven tot vervolgen of het doen wan opsporingshandelingen. ${ }^{35}$ Het $\mathrm{OM}$ zou wel rechtspositionele onafhankelijkheid behoeven om zich te weren tegen een arbitrair gebruik van rechtspositionele bevoegdheden, als reactie op een weigering door het $\mathrm{OM}$ van een onwettelijk of onwenselijk handelen, ${ }^{36}$

Dit idee heef in Itallie weinig steun gevonden. Daarvoor lijkt het wantrouwen jegens de mogelijke rol van de minister te groot. Meer sympathie daarentegen wekt de hierna te noemen variant.

\subsubsection{Zeggenschap door volksvertegenwoordigingen}

Een voomamelijk ltaliaans voorstel is om het parlement de bevoegdheid te geven periodiek aanwijzingen van strafrechtelijk beleid te geven. Dit zou kunnen gebeuren in de vorm van een wet of parlementair besluit ter gelegenheid van de bespreking van de begroting van Justitie, of een resolutie goedgekeurd door éen of beide kamers. Tevens zou dit kunnen geschieden aan het eind van de discussie over een jaarlijks rapport van de CSM over de verkregen resultaten van de parketten. ${ }^{37}$ Tussen procureurs-generaal, parlement en regering zou een directe relatie gecreëerd moeten worden ter verkrijging van cle relevante informatie. ${ }^{38}$

Een enkel Frans voorstel richt zich op een soortgelijke oplossing. Dit combineert een onafhankelijk. OM met het meer bij het strafrechtelijk beleid betrekken van het parlement. Op voorstel van de regering zouden de kamers in een wettekst de sepotcriteria kunnen opnemen. De wenselijkheid van sepot ten aanzien van bepaalde typen delicten

p. 167. De latulste auteurs noemen thet slechts als een optie, zonder expliciete keuze. In algemene zin vóór: Cordero 2000 , p. 209.

35 Dominioni 1979, p. $81-83$.

36 Dominioni 1979, p. 77. Anders: Neppi Modona 1987, p. 67-68; Caravita 1991, p. 307; Devoto 1996a, p. 2043; Zanon 1096, p. 208-209. Zij redeneren dat de minister ook bevoegdheden ten aanzien van de rechisposilie moten bezitten on een anwijzingsbewoegdheid te kunnen effectueren. Zij zijn echter geen voorstander van onderschikking van het $\mathrm{OM}$ aan de minister. Ook bij de Galeotti krijgt de minister rechtspositionele bevoegdheden, 1983, p. 661-662,

37 Chimenti 1991, p. 288; Chiavario 1994, p. 95; Gaito 1991a, p. 19; Zagrebelsky 1991, p. 313; 1994, p. 115, Neppi Modona 1994, p. 124; Brancaccio 1994, p. 245; Scaparone 1994, p. 274; Bettiol 1998, p. $267-268$ (hij stelt overigens voor de bevoegdheid tot het aanwijzen van prioriteiten aan een parlementaine conmissie te geven); Grevi 1999, p. 77. De Commissie voor de hervorming van de rechterlijke organisatie heeft dit voorstel gesuggereerd, hoewel dit aspect butten het werkgebied van de commissie viel, Commissie Gallo 1994, p. 1101. Over het parlementair besluit, het ordevoorstel (ordine del giomo): artt. 88 RC en $95 \mathrm{RS}$ Voor de resolutie: art. 117-1118 RC en 50 RS. Voor een aantal van de voorstanders van endo-processuele hervormingen kan deze oplossing slechts een tijdelijke zijn, gebonden asm de uitzonderlijkheid van de huidige periode, totdat de andere hervormingen zijn doorgevoerd: D'Ambrosio 1994, p. 176; Caliendo 1994, p. 140.

Chimenti 1991, p. 288.289. 
zou zo tot uitdrukking kunnen komen. De strafrechtelijke politiek zou zo niet enkel door de regering bedreven worden. ${ }^{39}$

In Italie noemt men de instelling van toezichthoudende commissies als variant of als een toevoeging aan het onderhavige voorstel. De regionale, wolksvertegenwoordigende raden zouden deze commissies kiezen. Tegenover hen zouden de parkethoofden zich moeten verantwoorden. De commissies zouden ofwel geheel uit magistraten bestaan, ofwel mede uit leden gekozen uit decentrale organen of vakorganisaties. De commissies zouden de regionale raden en het parlement informeren over het handelen van het OM. Eventueel zouden de commissies net als het parlenent resoluties kumnen aannemen ten aanzien van de vervolging. De regionale aanwijzingen zouden dan bininen de grenzen van de nationale aanwijzingen gegeven worden. Daarnaast zouden de commissies disciplinaire actie kunnen ondernemen. ${ }^{40}$

De parlementaire aanwijzingen leveren vragen op met betrekking tot de vorm. ${ }^{41} \mathrm{Het}$ begrip 'beleid' wordt vrijwel nog niet gebezigd ten aanzien van de ltaliaanse rechterlijke macht. Daardoor is het moeilijker de aanwijzingen in te passen in het bestaande stelsel. In het Nederlandse en Franse stelsel daarentegen is beleidsbepaling door en voor het OM een officieel feit. Enkele Italiaanse auteurs stellen daarentegen dat het parlement zich alleen met wetten kan richten tot de rechterlijke macht. Vooropgesteld dat het $O M$ een rechterlijke functie heeft, zou het parlement zich niet tot het $O M \mathrm{kun-}$ nen richten met resoluties of moties. Een wettelijke prioriteitenstelling door het parlement zou slechts (theoretisch) toelaatbaar zijn als die de gehele nomstelling zou omvatten. Het systeem van wettelijke strafbepalingen zou steeds gewijzigd moeten worden. $^{42}$ Anderen zien hier geen problemen, aangezien de prioriteitenwet het gevolg zou kumen hebben dat de niet aangewezen delicten door de wet tijdelijk afgeschaft worden. ${ }^{43}$ Een derde groep auteurs stelt dat wetsvorm in het geheel niet nodig is, omdat de prioriteiten geen aanwijzingen tot niet vervolgen zouden kunnen beyatten.

De huidige Italiaanse parlementaire besluiten zijn echter enkel gericht aan de regering, niet aan derde organen. Zonder invoering van een afzonderlijke procedure is het ook in Nederland en Frankrijk ondenkbaar dat het parlement zich rechtstreeks tot andere or w ganen richt. De wetsvorm gebruikt men in de drie landen wel voor planmatige documenten, vooral op economisch terrein. Een "wet op het vervolgingsbeleid' zou dan nog

39 Vogelweith 1997, p. 13; Bouvier, Hacquin \& Vogeweith 1997, Conchsion. Overigens is het wolgens de uitleg van de Consell Constitutiontel in het franse stelsel nict mogelijk dat cen kamer cen resolutie athneemt die een verdere strekking heet dan de regeling van de interne werkzhamberden. Datrentegen neent het partement op onder meer economisch terrein wel plamen ten beleidsijnen aan in wetsvorth (lois de plan en loüs d'orientation). Avril \& Gicquel 1996. 13. 138-139.

40 Ghara 1971, p. 785 e.v.: Cawallari 1974, p. 154; Vigorili 1974, p. 302, Phz7ortusso 1979, p. 42; Neppi Modona 1982, p. 32; Bettiol 1998, p. 268.

41 Een problematiscli aspect aan dit voorstel is verder dat het volgens sommigen un strijd zou kunnem zijn met de huidige onafhankelijke positie wan het Italiasise OM, zoals geganandect door de grondwei. Scaparone 1994, p. 275. Zanon 1996 , p. 218 . Anders: Chimenti 1991, p. 288.

42. Camavita 1991, p. 306-307; Zanon 1996, p. $215-216$.

43 Scaparone 1994, p. 275.

44 Zagrebelsky 1994, p. 116; Commissie Gallo 1994, p. 1101. 
het meest woor de hand liggen. Voor Frankrijk en Nederland zou het vervolgingsbeleid van de minister dan binnen het kader van die wet moeten vallen. De wetsprocedure heeft evenwel als nadeel dat zij zwaar en langdurig is. Deze duur zou afbreuk doen aan de noodzakelijke snelle veranderingen van beleid. Een wet zou wel de algemene sepotcriteria kumien opnemen. Voor meer Franse en Nederlandse parlementaire zeggenschap over de eigenlijke prioriteiten lijkt het beter de kamers eenvoudigweg meer te betrekken bij het ministeriële beleid. In de bestaande Franse en Nederlandse praktijk ontbreekt een ministeriële stellingname en een parlementair debat over de hoofdlijnen van het vervolgingsbeleid. Parlement en met name regering laten zich in sterke mate verleiden tot beleidsbepaling in afzonderlijke sectoren.

\subsection{Procureur-generaal 'de la Nation'}

In alle drie de landen zijn ideeën ontwikkeld voor stelsels waarin politieke organen de leiding van het $\mathrm{OM}$ zouden benoemen. Deze zou het handelen van het $O M$ verantwoorden alan die organen, maar voor het overige zou het OM een autonome positie hebben.

In Nederland suggereerde Duisterwinkel een stelsel met een min of meer zelfstandig OM onder leiding van de procureur-generaal bij de Hoge Raad. Deze zou het handelen van de procureurs-generaal bij de hoven coördineren, terwijl deze laatste dat ten aanzien van de officieren van justitie zouden doen. Het OM zou overleggen met de minister of de regering als het verwachtte dat het eigen oordeel tegen dat van de regering in zou gaan. De regering zou alleen bevelen mogen geven in uitzonderingsgevallen, maar dan bij koninklijk besluit. Dit zou meebrengen dat 'de kaarten (en verantwoordelijkheid) op tafel komen te liggen." Een aanwijzing tot vervolging en tot nietvervolging zouden in dergelijke uitzonderlijke gevallen mogelijk zijn.

Wat dit aspect van het voorstel betreft, wordt eigenlijk niet duidelijk op welke aspecten het OM zelfstandig zou moeten worden. De toegestane uitzonderingen maken in beginsel geen verschil met de bestaande mogelijklieden tot het geven van aanwijzingen. ${ }^{45}$ Verder zouden de benoeming en rechtspositie van de ambtenaren van het OM niet hoeven te veranderen, behalve voor de procureur-generaal bij de Hoge Raad. Diens benoening zou analoog aan die voor de leden van de Hoge Raad geschieden. De zittende procureur-generaal zou een aanbevelingslijst van zes kandidaten naar de Tweede Kamer sturen. Deze zou een voordracht van drie personen aan de regering doen. Vervolgens zou deze de procureur-generaal bij koninklijk besluit benoemen. In een uiterste geval zou het mogelijk moeten zijn dat de procureur-generaal ontheven wordt, indien de kroon van oordeel is dat hij 'niet te handhaven' zou zijn. ${ }^{46}$

46 Duisterwinkell 1968, p. 236-242; 1968a, p. 113,118. Hij vermeldde dat rechterlijke controle op zowel het vervolgen als het niet verwolgen niet zou mogen ontbreken, maar vulde niet in hoe deze eruit zou moeten zien. 
De namen voor de procureur-generaal in de Franse variant van dit voorstel variëren van procureur-général de la Nation, of de la République, of d'Etat, tot zelfs Chancelier de justice. De ambtsdrager zou benoend kunnen worden door de President, op voorstel of eventueel conform advies van de CSM en na advies van de parlementaire kamers. Deze procureur-generaal zou de functionele leiding hebben over het $\mathrm{OM}$. De leden hiervan zouden benoend moeten worden conform advies van de CSM. De minister van Justitie zou wel algemene aanwijzingen kumnen geven, op de naleving waarvan de procureurgeneraal zou kunnen toezien. Een procureur die zich systematisch niet zou houden aan beleidsaanwijzingen zou een disciplinair feit begaan. In een disciplinaire procedure zou hij hierop aangesproken kunnen worden. De CSM zou oordelen in de disciplinaire procedure. ${ }^{47}$

Daarnaast zou volgens sommige Franse auteurs wel een ministerieel interventiemiddel moeten bestaan in geval van niet-vervolging. De minister zou ofwel een klacht kunnen indienen bij de onderzoeksrechter, ofwel zelf direct de vervolging initiëren. Hij zou zich dan bij de rechter kunnen laten vertegenwoordigen door ad hoe functionarissen. Deze zouden de visie van de regering op de betrokken zaak uiteen kunnen zetten. ${ }^{48}$

Ook in Italie heeft men de aanwijzing van het hoofd van het OM geopperd door het parlement of de regering. Dit zou de procureur-generaal bij het Hof van cassatie kunnen zijn of een zogenaamde parlementaire commissaris. De benoeming zou door de President kunnen plaatsvinden uit een voordracht van kandidaten door het parlement of de regering. Het hoofd zou tegenover het parlement of de regering verantwoordelijk zijn woor de vervolging. Het parlement zou hem eventueel kunnen dwingen ontslag te nemen door een bijzondere motie van wantrouwen. Ter bescherming van parlementaire minderheden zouden de voordracht en de motie met een gekwalificeerde meerderheid aangenomen moeten worden. ${ }^{49}$

47 Maynier \& Casorla 1993, p. 540 e.v.; Pradel 1990, p. 302; 2000, p. 128; Rassat 1996 , p. 109; Malagrin 1996, p. 116-117; Pradel \& Laborde 1997, p. 142 e.w; Confếrenae nationale des procureurs généraux, Commission de réflexion sur la Justice, Amexes 1997, p. 400, Angibaud 1999, p. 94. Ook Toubon deed in 1993 het onderhavige woorstel. Zie Turcey 1997, p. 187-189, Casorla 1999, p. 43. Ook Casorla 1981. p. 285.

Buj de Assemblée ligt nu nog altijd een werswoorstel met de bovenstaunde strekking. Het voorstel is oorspronkelijk door de regering ingediend met de strekking van én automone rechtspositic met beperkte aanwijzingsbevoegdheid (zie 3.5.1.). De Senat heeft de tekst sindsdien dusdanig gewijzigd dat het overeenkom met het alhier besproken voorstel. Hierin wordt de procureur général de la Républiques benoemd door de President op een voorstel van drie personen door de CSM. In geval van ernsitige tekortkomingen van zijn verplichtingen kan de procureur-generaal uit zijn finctie gezet worden. De mimister wan Justitie verzoekt de CSM daartoe cen besl issing te nemen, waarna de President een einde makkt aan de functie van de betrokkene. Zie JO AN 27 oktober 1999, projet de Joi n. 1886.

48 Voor de ministeriête klacht: Maynier \& Casorla 1993, p. 541 . Voor de ministeriêle vervolging: Rassat: 1996, p. 109. In deze variant lijkt het onderhavige voorstel sterk op hed voorstel 3.5. Autonome rechispositie met beperkte aanwijzingsbevoegdheid. In het hiervoor genoende senaatsvoorstel heeft de minister de de mogelijkheid voor de minister om bevelen in individuele zaken te gevern ten aanzien van cen groep zware delicten ("anteintes aux intérêts fondamentaux de la nation" en terrorisme, ant $411-1-422-5$ CP). Bevelen tot niet-vervolging, zijn niet mogelijk.

49 Calamandrei, in Assemblea Costituente 1991, p. 1893 e.v.; Pizzorusso 1979, p. 39 e.v. deze aluteur was. tevens voorstander van een gelijktijdige invoering van de te bespreken controlecommissies; Galeoti 
Dit voorstel zou rechtsstatelike principes verzoenen met de eis van democratische legitimiteit. De zelfstandige functionele positie zou de onpartijdigheid kunnen waarborgen, terwijl de benoemingswijze legitimatie zou verschaffen. Verder zou het met name in Italie een betere coördinatie van de vervolging mogelijk maken.

Deze tweeslachtige figuur is kritisch ontvangen. De benoeming van deze procureurgeneraal, diens onafhankelijkheid en verantwoordelijkheid roepen vragen op. Het ambt zou zich in éen van de volgende twee richtingen kunnen ontwikkelen.

Ais de procureur-generaal enkel zijn benoeming zou ontlenen aan politieke organen, zou hij de benodigde legitimatie missen om een strafrechtelijke politiek te voeren. De legitimatie op grond wan de wet zou daarvoor onvoldoende zijn. De leden van het $O M$ zouden afhankelijk worden van een ambt dat nauwelijks verantwoording zou afleggen: Het handelen van de leiding van het OM zou niet noodzakelijkerwijs corresponderen met de parlementair demoeratisch gelegitimeerde wensen. Een dergelijk instituut zou een moeilijk controleerbaar machtscentrum kunnen worden. Een gebrek aan samenwerking met de regering zou disfuneties in het handelen kunnen opleveren. ${ }^{50}$

Anderzijds zou de procureur-generaal een politieke figuur kunnen worden. Hierdoor zou weer weinig overblijven van de autonome positie van het OM. Het hoofd van het $\mathrm{OM}$ zou in politiek gevoelige kwesties de mening van de politieke organen volgen. ${ }^{51}$ In Frankrijk zou het huidige wantrouwen tegenover de minister van Justitie zou zich kuinnen verplaatsen naar de procureur-generaal. Meer algemeen zou het wantrouwen zich kunnen richten op de rechterlijke macht, als hij daaruit benoemd zou worden. ${ }^{52}$ De dubbelzimnigheid van dit instituut lijkt in feite de bestaande problemen tussen de minister en het $\mathrm{OM}$ te importeren. Het vormt een poging om legitimatie en onpartijdigheid in én persoon te laten samensmelten. Een dergelijke combinatie overtuigt niet.

\subsection{Hervormingen in extremis}

Ten slotte zijn nog enkele voorstellen aangedragen die de positie van het $\mathrm{OM}$ in het rechtsstelsel ingrijpend wijzigen. Met name in Nederland krijgen deze enige aandacht.

1983, p. 659 661. Beschrijwend: Zanon 1996, p. 173. Een dergelijk voorstel lijkt niet in strijd te zijn met de grondwet. Zouls het Constitutioneel hof heeft bevestigd zou benoeming wan magistraten door de witwoerende macht op zichzelf niet de onaflankelijkheid aantasten, als de waarborg getd dat het OM functioneel onathankelijk zou blijven. Const. hof 1964, n. 103 ; Chimenti 1991, p. 285; Marafnoti 1991, p. 238 ; Zanon 1996, p. 168.

50 In Frunkrijk: Volff 1998, p. 92 ; Boudon 1997, p. 15; Foyer, Commission de rélexion sur la Justice, Amexes 1997, p. 27; Béteille, idem, p. 60; Drago, idem, p. 162. In Italiê: Carabba 1974, p. 99 en 103; Devoto 1996a, p. 2044. Tevens kritisch: Dominioni 1979, p. 63. In Nederland: Langemeijer 1968, p. 99; Remmelink 1968 , p. 171.

51 In Frankuijk: Boudon 1997, p. 15; Foyer, Commission de réflexion sur la Justice, Annexes 1997, p. 27; Drago, idem, p. 162. In deze zin zou het insuituut slechte herimeringen oproepen aan de Chancelier de Justice uil het Franse ancien régime of de Prokuratura van de Sovjet-Unie. In Nederland: Langemejer 1968, p. 99; Remmelink 1968, p. 171.

52 Turcey 1997, p. 18\%; Boudon 1997, p. 15; Nallet, Commission de reflexion sur la Justice, Annexes 1997. p. 42; Cotte, idem, p. 69; Terrier, idem, p. 102; Commission de reflexion sur la Justice 1997, p. 34. 
Het betreffen de ideeën on de vervolging direct op te dragen aan de minister, om burgers de leden van het OM rechtstreeks te laten kiezen en om het OM te privatiseren.

\subsubsection{Vervolgingstaak aan minister van Justitie}

Ter verbetering van de democratische controle ziet een enkele Nederlandse auteur iets in het toekennen van de taken van het OM aan de minister van Justitie zelf. Een dergelijk systeem zou duidelijkheid scheppen in de positie van het $O M$ en de verhouding tot de minister. De bestaande spanning in hun relatie zou wegvallen, aangezien het $O M$ in feite deel van het ministerie van Justitie zou worden. De minister zou geheel verantwoordelijk zijn voor het vervolgingsbeleid. Het parlement zou een sterkere greep krijgen op dat beleid. In het huidige systeem zou slechts een minder intensieve politieke controle mogelijk zijm. ${ }^{53}$

De betrokken auteur schreef zijn voorstel echter in een periode waarin parlementaire aandacht voor het $\mathrm{OM}$ gering was. Na de verwikkelingen in de tweede helft van de jaren zeventig is een roep om meer democratische controle niet meer valide. In de Lockheed-, Bloemenhove en Menten-affaires vonden voor het eerst diepgaande verantwoordingsprocessen plaats tegenover het parlement. ${ }^{54}$ Deze tendens heeft zich voortgezet. Daarbij komt dat door de bevoegdheidsuitoefening aan de minister toe te kennen, de controle van de minister over het OM niet vergroot wordt. Verreweg de meeste handelingen zullen toch feitelijk door het $\mathrm{OM}$ zelf uitgevoerd moeten worden. ${ }^{55} \mathrm{Wel}$ zou het de macht van de minister vergroten. Anders dan in het huidige Nederlandse én Franse) stelsel zou hij desnoods zelf vervolgingsbeslissingen kunnen nemen. Geen enkele functionele waarborg zou meer in de weg staan aan de minister.

\subsubsection{Gekozen OM}

De optie om het hoofd van het OM of de respectievelijke hoofden van de parketten te kiezen wordt in de drie landen door maar weinigen voorgestaan. De gedachte achter deze hervorming is dat de legitimiteit van de leiding over de vervolging verbeterd zou worden van een indirecte naar een directe. Het zou een rechtstreekse invloed van de politieke gemeenschap op de vervolging verzekeren. ${ }^{56}$

Dit voorstel wordt nauwelijks serieus genomen, en heeft zo zijn nadelen. Een enkele Italiaanse auteur werpt op dat een dergelijke oplossing vreemd zou zijn aan de (Europese en Italiaanse) traditie, en bovendien in strijd met de grondwet is. ${ }^{57}$ Het voorstel wordt daarom ook ondenkbaar geacht in Frankrijk. De context waarin de verkiezingen

53 Suyver 1976, p. 170-173. Van Duyne houdt iets, soortgelijks voor nogelijk, matr in combinatie met een mate van privatisering van taken van het OM, 1999, p. 17. Zie 3.7.3. Priwalisering OM.

54 Van Marseveen 1977, p. 213

55 Stroink 1978, p. 169

56 Voor Nederland: Vrakking in: NRC Handelsblad 14-15 september en 29 november 1999, p. 6. Voor Frankrijk: Giscard d'Estaing tijdens een televisie-uitzending, Turecy 1997, p. 189 en 194. Voor Italie: Vigoriti 1979 , p. 272-273; Nobili 1979, p. 126 e.v.

57 Zanon 1996, p. 165: Over het argument wan de traditie anders: Guarnieri, 1984, p. 36. Overigens vindt verkiezing van leden van het OM wel plats in Zwitserland (Gerichtsverfassungsgesetz). Over liet grondwentijke argument anders: Pizzonusso 1975 , p. 340. 
worden gehouden in de Amerikaanse variant zou vreemd zijn aan de Fransen. Het voorstel zou volgens hen in strijd zijn met hun juridische traditie. De legitimiteit van de Franse rechterlijke macht is daarin niet verbonden aan de verkiezing door het electoraat: ${ }^{58}$ Een dergelijke traditie kan verandering in praktische zin wel bemoeilijken, maar is geen principieel argument tegen verkiezing.

Verder zour de coördinatie van het vervolgingsbeleid tussen de parketten onderling bemoeilijkt kunnen worden, ${ }^{59}$ Een ander probleem zouden de mogelijke politieke interferentie zijn, van bijwoorbeeld beloftes gedaan tijdens verkiezingscampagnes. ${ }^{60}$ De vervolging zou zich sterk richten op zaken die de publieke opinie emotioneel raken, met een soort spektakeljustitie als gevolg. De kandidaten zouden welhaast onvermijdelijk de steun van de politieke partijen moeten zoeken, door wie ze als het ware gegijzeld zouden worden. $^{61}$ Een gekozen $O M$ zou het legitimiteitsvraagstuk oplossen, maar waarschijnlijk ten koste gaan van de onpartijdigheidseis. Met het oog op de verkiezingen zou het OM moeite hebben de objectiviteit te bewaren, juist in individuele zaken.

\subsubsection{Privatisering OM}

Eind 1999 ontstond in Nederland een korte discussie over het uitbesteden van taken van het OM aan de advocatuur. Het ging dan niet om het oprichten van privaatrechtelijke rechtspersonen die voortaan de vervolgingsbranche voor hun rekening zouden nemen. Men achtte het slechts denkbaar dat advocatenkantoren bepaalde functies zouden uitvoeren, zoals het voorbereidend (financieel) onderzoek of de behandeling ter zitting. $^{62}$

De kritiek op de privatiseringsgedachte brengt praktische en principiële bezwaren naar voren. Een vraag luidt of uitbesteding efficiënt zou zijn, en of niet evengoed geïnvesteerd zou kunnen worden in kwaliteitsverbetering van het $O M$. Daarnaast lijkt het OM nu al een volwaardig alternatief te hebben in de mogelijkheid van bijstand door deskundigen, zonder dat deze de taken of bevoegdheden zelf overnemen. Deze praktische aspecten laat ik verder buiten beschouwing. ${ }^{6.3}$

58 Pradel \& luaborde 1997, p. 142; Vauzelle, Commission de retlexion sur la Justice, Annexes 1997, p. 50.

59 Guarnem 1984, p. $170 * 17 !$.

60 Commini 1984, p. 185; Silkestri 1997, p. 102.

61 Castelli 1990, p. 102;" "Turcey 1997, p. 194

62 Van Wubergen in NRC Handelsblad 23 september 1999; Van Wijnbergen 1999, p. 19. Vrakking destijds hoofdofficien van Amsterdam, viel hem wijl dagen later bij in een lelevisieprogramma. Wiltems 1999, p. 14-15; Van Duyne 1999, p. 17. Burumacht het verder denkbar dat bedrijwen het OM gaan "sponsoren". Verzekeringsnatschappijen bijvoorbeeld zouden de Stat kunnen finaneiden voor capaciteitsulbteing bij hei OM tem behoeve van de vervolging wan werzekeritgsfraude. De prioriteitsstelling binnen het $O M$ zou volgens hem niet verstoord hoeven worder. Het OM zou slechts meer verzekeringstinude verwolgen, terwijl voor het overige de prioniteitsstelling en de rechisstatelijke overwegingen onangetast zouden blijwen, Buruma 1999, p. 1889. De auteur ziet over het hoofd dat de bedoelde haude hierdoor en relatiof bellangrijkene prioriteit zou worden. Vermogende (reehts)personen zouden zo divecte medezeggenschap krijgen over hel vervolgingsbeleid. Wan een democratische legitimatie van het geneel vatu dat beleid zou dan geem sprake meer zijn.

63 Sorgdrager 1999a, p. 5-6; Ficq \& Myjer 1999, p. 11, noot 15; Muller 1999, p. 13; Van der Landen 1999, p. 18 . 
Meer principieel luidt het dat de taken van het OMU tot de 'kerntaken' van de overheid behoren of "essentieel" zijn voor het bestaan en functioneren van een stat. Uitbesteding van de vervolging zou daarom geen optie zijn. Daarnaast zou het vervolgingsbeleid en de uitoefening van de bevoegdheden van het OM onder controle van het parlement moeten staan. Over niet-ambtelijke advocaten zou de minister geen bevoegdheden kunnen hebben, waardoor hij voor hen geen verantwoording schuldig zou zijin aan het parlement. ${ }^{64}$

De kwalificatie "kerntaken" is op zich onvoldoende redengevend. ${ }^{65}$ In een stelsel war private organisaties klassieke overheidstaken van beveiliging of de elektriciteitsvoorziening hebben gekregen, zijn meer inhoudelijke argumenten nodig om vervolgingstaken voor de overheid te behouden.

Het argument van de verantwoording is eerder an bod gekomen. In het bijzonder valt hier niet in te zien waarom de minister geen verantwoording zou kunnen afleggen over het handelen van een advocatenkantoor. De minister zou immers de mogelijkheid hebben om de uitbesteding aan een ander kantoor te gunnen, wanneer van ontevredenheid blijkt over de taakvervulling. Verder zou de minister toe moeten zien op de naleving van het contract dat hij gesloten heeft met het advocatenkantoor. Over het algemene vervolgingsbeleid zou hij volledige zeggenschap kunnen houden, door het vastleggen daarvan in het contract. Deze contracten zouden, net als het OM-beleid nu, jaarlijks bujgesteld kunnen worden.

Wel is het de vraag in hoeverre de optredende advocaat onpartijdig zou zijn. De rechtscultuur en de garanties verbonden aan de status van rechterlijk ambtenaar zouden wegvallen. Privatisering van taken van het OM zou een grotere nadruk op bedriffseconomische overwegingen meebrengen. Om deze reden lijkt het mij onwenselijk (taken vam) het $O M$ te privatiseren. ${ }^{66}$

\section{Europees Openbaar Ministerie}

$\mathrm{Na}$ de gepasseerde waterval aan nationale voorstellen kan de dorst gewekt zijn naar Europese ontwikkelingen in dit verband. In hooldstuk I betoogde ik dat op bovennationaal niveau het recht omtrent de relatie tusen OM en politiek nog niet zodanig vorm heeft gekregen dat het als zelfstandig referentiekader kan dienen. Op het niveau van de Europese Unie zijn echter gedetailleerde voorstellen beschikbaar voor een Europees Openbaar Ministerie (EOM). Tevens gaat de toekomstige impact van deze voorstellen op nationaal niveau verder dan die van de internationale aanbevelingen. Sporen de voorstellen en de hiervoor gebruikte argumentatie met elkaar? $\mathrm{Na}$ een korte uiteenzetting van de ontwikkeling wan de Europese idee ën hieromtrent, bespreek ik de institutionele aspecten van deze plannen binnen het kader van de voorgaande overwegingen aangaande de nationale stelsels.

64 Over 'essentieen' bij: Sorgdrager 1999a, p. 5-6. Over" "Kerntaken": Bovend'Eert 1999, p. 7*8; Mulle" 1999. p. 12-13. Vgl. Ficq \& Myjer 1999, p. 9-11.

65 Willens 1999, p. 15.

$66 \mathrm{Vgl}$.Ficq \& Myjer 1999, p. 9.10. 
Op initiatief van de Europese Commissie en het Europees Parlement ontwikkelde een groep van expers in 1997 een zogenaamd Corpus Juris. ${ }^{67}$ Dit academische voorstel gaf uniforme strafbepalingen om de financièle belangen van de Europese Gemeenschappen beter te beschermen. Daarnast behelsde het de instelling van een Europese aanklager die met betrekking tot deze delicten een specifieke competentie zou hebben. Twee jaar later kwam het Comité van onafhankelijke deskundigen met een vergelijkbaar idee. ${ }^{68}$ Dit comité meende dat een Europese aanklager een nuttig onderdeel zou zijn van de voorstellen voor het aanpakken van wanbeheer, onregelmatigheden en fraude binnen de Europese Gemeenschappen. Vervolgens stelde de Europese Commissie zelf een plan op voor een Europese aanklager. ${ }^{69}$ Dit werd besproken door de Europese Raad, maar deze ging niet verder dan het besluit om Eurojust in het Verdrag van Nice op te nemen (art. 29 en 31 EU-Verdrag) ${ }^{70}$ Deze instelling vormt slechts een coördinatie- en informatiepunt voor nationale aanklagers. Eurojust blijft hier verder buiten beschouwing. Hierna ging de Commissie verder met de ontwikkeling van het idee voor een $\mathrm{EOM}_{\text {, }}$ hetgeen resulteerde in een groenboek. ${ }^{71}$ De commissievoorstellen zijn grotendeels een herhaling en uitwerking van de ideeën van het Corpus Juris en het Comité van onafhankelijke deskundigen. Gezien het relatief zwaarwegende belang van het groenboek neem ik het hieronder als uitgangspunt voor de inhoudelijke bespreking.

In het commissievoorstel krijgt de Europese 'officier van justitie' een functioneel onafhankelijke positie. ${ }^{72}$ Hij zou geen aanwijzingen kunnen krijgen of kunnen vragen van

67 Art. 18 e.v. Corpus Juris. Delmas-Marty 1998; Delmas-Marty \& Vervaele 2000; Delmas-Marty \& Vervaele 2001.

68 Tweede verslag over de hervorming van de Commissie. Analyse van huidige praktijken en voorstellen voor het aanpakken van wanbeheer, onregelmatigheden en fraude, deel II, 10 september 199\%, p. 177 e.v.

69 Voorgesteld nieuw art. 280bis EU-Verdrag. Mededeling van de Commissie. Aanvallende bijdrage van de Commissie ten behoeve van de Intergouvernementele Conferentie over de institutionele vraagstukken. De strafrechtelijke bescherming van de financięle belangen van de Gemeenschap: een $\mathbb{E}$ turopese offucier wan justitie, COM(2000) 608 defiritief.

70 Beslwit van de Rad van 28 februari 2002 betreffende de oprichting van Eurojust teneinde de strijd tegen ernstige vormen wan criminaliteit te versterken, 2002/187/JBZ. Zie reeds paragraf 46 wan de Conclusies van het voorzitterschap van de Europese Rata van Tampere, 15-16 oktober 1999, SN $200 / 99$.

71 Groenboek inzake de strafrechtelijke bescherming van de financiale belangen van de Gemeenselnap en de instelling van een Europese officier van justitie, COM(2001) 715 definitief.

72 Nieuw artikel 280 bis EU.Verdag - I. 'Ten einde bij te dragen tot de verwezenlijking van de doelsiellingen van artikel 280 . lid $\mathrm{l}$, benoemt de Raad op voorstel van de Commossie met gekwalificeerde meerderheid van stemmen en met instemaning van het Europees Parlement voor een niet-hernietwbare termijin wan zes jaar een Europees officier van justitie. De Europese officier van justitie wordt belast met de opsporing, de vervolging en de inbeschuldigingstelling van de daders of medeplichtigen van inbreu$\mathrm{ken}$ watrdoor de financiele belangen wan de Gemeenschap worden geschand, en met de strafvordering wegtens deze inbreuken voor de bevoegde rechterlijke instanties van de lidstaten, onder de voorwaarden die zijn wastgesteld bij de in lid 3 bedoelde voorschriften.

2. De Europese officier van justitie word gekozen onder personen die alle warborgen voor onathankelijkheid bieden en die aan alle gestelde eisen voldoen om in han onderscheidene landen de hoogste rechterlijke ambten te bekleden. Bij de vervulling van zijn taken vaagt noch aanvaardt hij enigerlei instructies. Indien hij miet meer aan de eisen voor de uitoefening wan zijn anbt voldoet of op ernstige wijze is tekortgeschoten kan hij op verzoek van het Europees Partement door het Hof van Justitie van zijn ambt ontheven worden verklaard. De Raad stell volgens de procedure van artikel 251 het statuut vart de Europese officier van justicie vast. 
Europese of nationale instanties. Wel zouden deze instellingen aangifte kunnen doen: Verder zoul een verdachte na een Europees sepot nog door een lidstaat vervolgd kunnen worden, indien hij tevens national strafbare feiten gepleegd zou hebben. Ten slotte laat het groenboek uitdrukkelijk de mogelijkheid open dat de Europese gemeenschappen op enige wijze beroep kunnen instellen tegen de sepotbestissing. ${ }^{73}$ Het plan geeft echter geen enkele ruimte voor algemene beleidsaanwijzingen van externe ambten. De Commissie geeft de voorkeur aan het hanteren van een legaliteitsbeginsel met daarop enkele vast te stellen uitzonderingen. Daaronder zou kunnen vallen het gebruik van een criterium dat rekening zou houden met 'de geringe ernst wat betreft de financièle belangen van de Gemeenschap'. Dit zou gepreciseerd kunnen worden door het vaststellen van een financiële drempel. ${ }^{74}$

Deze functionele relatie tussen EOM en communautaire en regeringsambten correspondeert redelijk goed met de besproken redeneringen uit het vorige hoofdstuk. Daar verdedigde $i k$ het vermijden van instructies ten aanzien van specifieke zaken. Aanwijzingen tot niet-vervolging en ten aanzien van het requisitoir zijn dan ook uitgesloten in het commissievoorstel. Voor zover politieke organen een initiërende rol hebben, is gewaarborgd dat hun juridische interpretatie in een individuele zaak niet in hiërarchische zin de doorslag geeft. Daarentegen zijn algemene aanwijzingen evenmin mogelijk. Dit hoeft echter niet problematisch te zijn. Enerzijds is de competentie van de Europese aanklager immers inhoudelijk zeer beperkt. Anderzijds suggereert het groenboek de optie om de discretie van het EOM te beperken, door financiële criteria in regelgeving. Denkbaar is dat de Raad de taak zou krijgen om door het geven van nadere voorschriften de beleidsvoering te bepalen.

Wat betreft de rechtspositie het volgende. De Europese aanklager zou worden benoemd door de Raad op voorstel van de Commissie met gekwalificeerde meerderheid wan stemmen, en met instemming van het Europees Parlement. Net ais de leden van het Hof van Justitie zou hij 'alle waarborgen voor onafhankelijkheid' moeten bieden. Wanneer de Europese officier niet meer zou voldoen aan de eisen voor de uitoefening van zijn ambt of op ernstige wijze tekort zou schieten, zou hij op verzoek van het Europees Parlement door het Hof van Justitie van zijn ambt ontheven kunnen worden verklaard. ${ }^{75}$ De wijze van benoeming is overgelaten aan politieke instanties. De Europese Gemeenschappen ontberen dan ook een ambt waarin rechterlijke ambtenaren een belangrijke

3. De Raad stelt volgens de procedure van artikel 251 van het Verdrag de voorwaarden vast woor de uitoefening van de hunctie wan de Europese officier van justitie, en geeft met name

(a) woorschriften warbij de elementen worden vastgesteld van de stratrechtelijke inbreuken betreffende fraude en iedere andere onkettige activiteit die nadelig is voor de financiële belangen van de Geneenschap, evenals de straffen die op elk daarvan worden gesteld;

(b) procedurevoorschriften van toepassing op de activiteiten van de Europese officier van justitic, alsmede voorschniften betreffende de toelaatbaarheid van bewijzen;

(c) voorschriften inzake de rechterlijke toetsing wan de procedurele handelingen die de Europese officier van justitie in de uitoefening van zijn functie verricht.

74 COM(2001) 715 definitier, p. 54-55.

75 Het Corpus Juris verschilt op dit punt wan mening. Het stelt voor dat de Europese atanklager benotemd wordt door het Europees Parlenent, op voorstel van de Commissie. Het Corpus laat ook een enkele vernieuwing van de functieternijn van de anklager toe. Zie de implementing provision bij art. 18. 
vertegenwoordiging hebben. Een supranationale CSM met rechtspositionele bevoegdheden lijkt vooralsnog moeilijk in te passen in de Europese structuren. Desalniettemin is de benoemingsprocedure zwaar van ard en gelden inhoudelijke benoemingswereisten. Hierdoor lijkt politisering van de Europese aanklagersfunctie via een benoemingsbeleid zeer onwaarschinlijk. De voorgestelde ontslagwijze vermijdt in ieder geval elke politieke druk op een Europese officier van justitie in functie.

Vanuit het hier gehanteerde institutionele oogpunt valt de instelling van een EOM in de voorgestelde vorm wel aan te bevelen. De vormgeving voldoet aan de eerder behandelde eisen omtrent legitimiteit en onpartijdigheid. Voor het overige laat ik de opportuniteit van het voorstel hier echter buiten beschouwing. ${ }^{76}$

\section{Vergelijking van voorstellen}

Alleen de plannen voor een nationale procureur-generaal komen in alledrie de landen voor. In Frankrijk heeft dit voorstel wel de meeste steun. Niettemin ondervindt het overal ook scherpe kritiek. Daarnaast heeft het idee van de autonome rechtspositie met beperkte aanwijzingen brede steun, behalve in Nederland. In Frankrijk is vooral de variant met een genatigde ministerie̋le aanwijzingsbevoegdheid favoriet. Italië ziet meer in de optie van parlementaire aanwijzingen. Voorstellen die uitsluttend toetsing van aanwijzingen behelzen zijjn alleen in Nederland bekend. Frankrijk komt als enige met projecten voor enkel een autonome rechtspositie, of voor een combinatie met toetsing van aanwijzingent.

In Nederland vindt men geen pleidooi voor een autonome rechtspositie, ook niet gecombineerd met een toetsing of beperking van aanwijzingen. De afzonderlijke invoering van rechterlijke toetsing is in Frankrijk geen onderwerp van debat. Italiaanse auteurs zijn evenmin te vinden voor een aanwijzingsbevoegdheid net toetsing, samen met een ondergeschikte rechtspositie. Ook de volledige ondergeschiktheid van een OM met een autonome rechtspositie, eventueel met toetsing van aanwijzingen, krijgt geen Italiaanse steun. Het is verder opvallend hoezeer pleitbezongers voor invoering van een Nederlandse of Franse variant van de relatie tussen $O M$ en politiek schitteren door afwezigheid in ltalie. Zelfs de Italiaanse voorstanders wan functionele invloed van de minister wijzen in ieder geval bevelen tot vervolging of niet-vervolging af, en staan een autonome rechtspositie voor. Andersom pleit geen enkele Nederlandse of Franse auteur voor een geheel onafhankelijk OM, zoals in Italie.

In Nederland staat men blijkbar positief tegenover de huidige rechtspositionele regeling. Het vertrouwen geldt dat politici geen partijpolitieke interventies zullen ondernemen in de rechtspositie, of dat vermeende interventies geen invloed zullen hebben op het handelen van het OM. De meeste Fransen en met name Italianen daarentegen zien een autonome rechtspositie als een minimumeis.

Sommige van de behandelde voorstellen zijn al wel onderwerp geweest van officiële stukken van overheidswege. In Nederland is een bepalde beperking van de aanwijzingsbevoegdheid aan de orde gekomen (Commissie Roelvink). Frankrijk heeft een

Zie verder De Doelder 2002. Zeer kritiseh: lajoaut \& Groenhuijsen 2002. 
autonome rechtspositie met toetsing van aanwizingen (Commissie Delmas-Marty) of met beperking van de anwijzingsbevoegdheid aan de orde gesteld (Commissie Du Truche, CSM, regering Jospin). Daarnaast kent men het plan voor een nationale procureur-generaal (Franse senaatsvoorstel). In Italiè stelde men wel de parlementaire aanwijzingen voor (Commissie Gallo).

\section{Conclusie en eigen voorstellen}

De serie voorstellen die de revue passeerden doet wellicht de indruk ontstäan alsof de huidige systemen volkomen ontoereikend zijn. Dit is zoals gezegd niet het geval. De argumentatie in het vorige hoofdstuk laat zien dat de bestaande stelsels op sommige onderdelen voldoen aan rechtsstatelijke en democratische eisen en sommige nationale gevoeligheden. Kritiek werd evenwel ook zichtbaar. Een verbetering is mogelijk en gewenst.

Daartoe lijkt het mij geschikt voor de drie landen verschillende hervormingen in te voeren. Voor Italië zou invoering van parlementaire aanwijzingen de meest aangewezen optie zijn. Om formele of constitutionele geschillen te voorkomen zouden dergelijke aanwijzingen een grondslag moeten krijgen in de grondwet. Anders zou het parlement zich moeten beperken tot het stellen van prioriteiten, zonder specifieke posterioriteiten te noemen. In Frankrijk zou het streven naar een autonome rechtspositie met beperkte aanwijzingsbevoegdheid voortgezet moeten worden. Met betrekking tot in ieder geval de rechtspositionele aspecten zou grondwetswijziging aangewezen zijn. Ten slotte bepleit ik voor Nederland een beperking van de aanwijzingsbevoegdheid, met enkele rechtspositionele retoucheringen.

In de afgelopen paragrafen gaf ik reeds kort aan wat de voor- en nadelen zijn van deze voorstellen. Tevens noemde ik daarbij aspecten en redenen die voor de respectievelijke stelsels van bijzonder belang zijn. Voor Nederland wil ik het voorstel hieronder nader uitwerken.

\subsection{Hervorming van de functionele relatie tussen OM en minister}

De belangrijkste functionele verandering die ik voor het Nederlandse stelsel zou willen voorstellen is afschaffing van de mogelijkheid om aanwijzingen te geven tot nietvervolging en ten aanzien van het requisitoir. De minister zou alleen algemene aanwijzingen moeten kunnen geven. Daarvoor zou een officiële publicatieplicht moeten gelden. ${ }^{77}$ Voor de ministeriële initiatieven tot vervolging moet uitgesloten worden dat deze partijdig van aard zijn. In plaats van de huidige aanwijzingen tot vervolging zou ik daarom willen aansluiten bij voorstellen voor een soort ministerieel beklag op de rechter. $^{78}$ Voor de yormgeving daarvan wil ik ansluiting zoeken bij de bestaande beklagprocedure voor belanghebbenden. De minister zou aldus tegen het uitblijven van (ver-

77 In ieder geval zou het feit dat op en bepald terrein en algemeno armwijzing is gegeven gepublicewd moeten worden.

78 Voor ünvering van ministerieel gebruik warn de beklagprocedure, zie ook 3,2. Beperkte aamwijzingsbevoegdheid en ministerieel beklag. 
dere) vervolging beklag kunnen imstellen bij het gerechtshof. De Wet RO zou overeenkomstig deze ideeển gewijzigd dienen te worden. Daarnaast zou de minister natuurlijk gewoon aangifte kunnen (blijven) doen?

Tezamen met het afschaffen van de aanwijzingen tot niet-vervolging kunnen eventueel specifieke procedures ingevoerd worden voor 'gevoelig" geachte categorieën personen of delicten. Zo is het denkbaar om een toestemmingsvereiste te creëren voor de vervolging van de andere leden wan het koninklijk huis dan de Koning. ${ }^{80}$ Ten aanzien van hen ligt het voor de hand om aansluiting te zoeken bij de bestaande procedure bij vervolging van kamerleden en bewindslieden voor ambtsmisdrijven. De regering zou aldus bij koninklijk besluit een last tot vervolging kunnen geven aan de procureur-generaal bij de Floge Raad. De noodzaak van ondertekening door de Koning zou diens mogelijke, feitelijke betrokkenheid expliciteren.

Het ministerieel beklag en de lastgevings- of toestemmingsprocedures hebben een duidelijk voordeel boven de aanwijzingsprocedure. Bij een dreiging van verschil van inzicht tussen minister en OM ligt in mijn voorstel de bal bij de minister. Wil het $O M$ in een zaak vervolgen, dan zal het een officieel verzoek moeten indienen om een last of toestemming. Het $\mathrm{OM}$ is dan niet langer genoodzaakt tot voorafgaande consultatie van de minister. Voor het ontransparante overleg bestaat dan helemaal geen aanleiding. Wil de minister, anders dan het OM, geen vervolging, dan moet hij een officieel een besluit nemen waarin hij de last of de toestemming weigert. Hetzelfde geldt voor het geval de minister wèl vervolging wenst. Het overreden van het $O M$ in een overleg is in die situatie evenzeer overbodig. De bewindspersoon hoeft zich maar met een beklag tot de rechter te richten. Zonder de stok van de aanwijzing achter de deur verliest een overleg aan effectiviteit en belang. Doordat de minister gedwongen is zijn eigen opvatting in besluityorming kenbaar te maken, vermengt zijn rol zich niet met die van het OM.

Het ontbreken van een aanwijzingsbevoegdheid tot niet-vervolging zou ook de grondslag wegnemen voor het toekennen van rechtsgevolgen aan een toezegging. Een ministeriële toezegging dat een persoon niet vervolgd zal worden zou immers van betekenis verliezen als de bewindspersoon vervolging rechtens niet zou kunnen voorkomen.

De minister moet zich aldus voornamelijk gaan richten op het formuleren van het vervolgingsbeleid en strafvorderingsrichtlijnen. Het $\mathrm{OM}$ en de minister zouden niet alleen prioriteiten, maar ook expliciete posterioriteiten dienen te formuleren. Deze zouden opgenomen kunnen worden in het jaarlijkse beleidsplan. Dit zou duidelijkheid scheppen over categorieën van delicten of subjecten die niet of slechts onder bepaalde voorwaarden vervolgd zouden moeten worden. ${ }^{81}$

Art. 127 Wet RO niew - Onze Minister van Justitie kan algemene anwijzingen geven betreffende de uitoefening wan de taken en bevoegdheden ann het openbaar ministerie.

Art. 128 Wei RO nieuw - 1. Wordt een strafbaar feit niet vervolgd of de vervolging niet voortgezet, dan kan Onze Minister van Justitie daarover beklag doen bij het gerechtshof, binnen het rechtsgebied waarvan de bestissing tor niet-vervolging of niet verdere verwolging is genomen. Indien de beslissing tot nist-vervolging is genonnen door de officier van justitie bij het landelijk parket, is bevoegd het gerechtshof' te 's-Giravenhage. - 2. De artikelen 12a tot en met 13a van het Wetboek van Strafvordering zijn wan overeenkomstige toejpassing.

80 Vergelijk in dit verband de Lockheed-zaak, zie hoofdstuk 2, 6.2.2.5. Aanwijzing tot niet-vervolging.

812 ie de argumentatie bij hoofdstuk 6,5.4. Vervolgingsbeslissing als een individuele keuze, van algemeen 
De minister kan de bevoegdheid behouden om informatie te vragen owar zowel beleidsaangelegenheden als individuele strafzaken. Het OM blijft gehouden inlichtingen té verstrekken die voor de minister (vooral beleidsmatig) van belang kunnen zing . Daaronder vallen ook inlichtingen over specifieke handelingen of besiuiten van het $O \mathrm{M}$. Deze informatieverstrekking kan echter plaatsvinden zonder dat daarbij ovenleg gepleegd hoeft te worden over individuele beslissingen.

\subsection{Hervorming van de rechtspositie van het $\mathrm{OM}$}

Wat betreft de rechtspositie van het OM het volgende. Zoals gesteld in hoofdstuk 6 is het in beginsel vanuit legitimiteitsoverwegingen onnodig dat de minister of de regering hierin beslissingsbevoegdheden hebben. Dit argument is met name terug te vinden in de vele Franse voorstellen voor rechtspositionele autonomie en de Italiaanse stellingen voor het behoud daarvan. Het is zaak ook in Nederland negatieve consequenties van deze rechtspositionele invloed uit te sluiten.

Theoretisch gezien lijkt de beste oplossing om de besluitvorming hieromtrent toe te vertrouwen aan een derde ambt, een raad voor de rechterlijke macht, zoals in Frankrijk en Italië bestaat. Een dergelijk ambt is in Nederland echter niet aanwezig. Zoals eerder overwogen zou invoering van een volwaardige Nederlandse CSM grootscheepse wijzigingen meebrengen, die ook de rechtsprekende leden van de rechterlijke macht zouden betreffen. ${ }^{82}$ Zou zou de huidige Raad voor de rechtspraak jegens hen ook rechtspositionele bevoegdheden krijgen, dan zou ik wel parallelle bevoegdheden ten aanzien van de leden van het $O M$ willen bepleiten.

Momenteel vormt de collegiale aard van de leiding van het $\mathrm{OM}$ wel een zekere belemmering voor al te sterke rechtspositionele beönvloeding. ${ }^{83}$ Niettemin heeft de minister invloedrijke rechtspositionele bevoegdheden die ook in de praktijk geeffectueerd worden. In het huidige stelsel wordt teveel geleund op een beweerdelijk bestaande rechtscultuur, waarin de minister zich afzijdig zou houden van politieke rechtspositionele beinvloeding.

Niets lijkt in de weg te staan aan enkele wijzigingen ten aanzien van de benoeming, overplaatsing, disciplinaire regime en ontslagbevoegdheid. Deze zouden ten aanzien van de leden van het OM meer overeenkomstig die van de rechtsprekende leden van de rechterlijke macht kunnen plaatsvinden.

Wat betreft de benoeming zou alleen de procedure met betrekking tot de procureursgeneraal inhoudelijk enigszins veranderen. Naar het huidige beleid volgen de meeste benoemingen al op aanbeveling van het $O M$. Niet valt in te zien waarom deze aanbeveling niet zou kunnen gelden voor de procureurs-generaal. Deze zou in plaats kunnen komen van de plicht van de minister om het College te horen voordat hij de voordracht doet. De aanbevelingsrechten van het $O M$ zouden wel wettelijk vastgelegd moeten worden. ${ }^{84}$

belang. Zo kan bijwoorbeeld in beleid wastgelegd worden dat voor bepalde categoriebn delicien de leden van bet koninklijk huis niet vervolgd worden.

83 Zie hoofdstuk 5, 5.2. Organisatiestructuur.

84 De atabevelingsrechten zouden een plaats kumen krijgen in art. If Wrat. 
De oplegging van disciplinaire maatregelen voor leden van de rechterlijke colleges zou van owereenkomstige toepassing verklaard kunnen worden. $\mathrm{Bij}$ de disciplinaire procedure zou de minister echter wel een initiatiefrecht kunnen krijgen. ${ }^{85}$ Hij zou net als de functionele autoriteiten van de rechterljke ambtenaren daartoe een verzoek kumnen indienen bij de procureur-generall bij de Hoge Raad. Dit zou uitdrukking blijwen geven. aan zijn controlerende takk over de uitwoering van het vervolgingsbeleid: ${ }^{86}$ De te volgen procedures kunnen woor het overige hetzelfde zijn als die ten aanzien van rechters. Het bestaande sanctiearsenaal voor rechterlijke ambtenaren zou wel uitgebreid kunnen worden. Met name de sanctie van overplaatsing, of opdragen van een andere taak (anders dan wegens ziekte) zou een nuttige functie kunnen hebben.

De zogenaamde overplaatsing in het belang van de dienst zou kunnen worden afgeschaft. In plaats daarvan zou de instemming van de betrokkene nodig zijn bij een aanbod voor een andere functie. ${ }^{87}$

\subsection{Verantwoording voor het $O M$}

Voor de organisatie en bevoegdlaeden van het $O M$, de positie van de minister en het ministerie hoeven de onderhavige voorstellen geen gevolgen te hebben. De wijze van verantwoording zal feitelijk evenmin aanpassing behoeven.

Kamertleden zutlen echter met minder succes kunnen aanzetten tot het voorkomen van vervolgingen in concrete gevallen. De minister zal immers geen aanwijzing tot nietvervolging kunnen geven. Evenmin zal een parlementair gewenst specifiek requisitoir afgedwongen kunnen worden. Zoals gezegd doet het parlement dit feitelijk toch al nauwelijks. Wanneer de minister daar echter toch om gevraagd zal worden, zal hij uit moeten leggen dat hij daartoe geen bevoegdheid heeft. Daarentegen zal de kamer de minister wel kunnen bewegen tot overleg of beleidswijziging. Ten slotte zou hij een disciplinaire procedure kunnen laten starten.

De aandacht van het parlement zou de accentverschuiving in de relatie OM-minister moeten volgen - van een focus op individuele zaken naar beleid. ${ }^{88}$ Zo zou het parlement jaarlijks een debat kunnen wijden aan het beleidsplan en het jaarverslag van het OM. Het zou kumnen verifiëren of overeenstemming bestaat tussen enerzijds de vervolgingsprioriteiten en posterioriteiten en anderzijds de praktische resultaten. Dit zouden goede aanknopingspunten vormen voor parlementaire controle op het algemene beleid van het $O M$ en van de minister.

85 Overigens woht ik het principieal evenzerer anvaardbatr om dit recht ook te doen gelden jegens leden wan de rechisprekende colloges.

86 Vergelijk hooldstuk $6,5,1$. Beleidscontrole.

87 Vgl. het hudige art. 9 Wet RO voor de rechtsprekende leden van de rechterlike macht. In alternatief zou de buidige owerplatsingsbewogdheid exclusief kunnen worden toegekend an het College.

88 Over the expliciet vragen val partementaire goedkeuring wan strafvorderingsrichtijnen: Duker 2001 , p. $143-144 ; 2001 \mathrm{a}, \mathrm{p} .313$. 


\section{Summary}

\section{Legitimacy and impartiality in prosecution.}

A comparison of the relation between the public prosecution service and the minister of Justice in France, Italy and the Netherlands

The relation between the prosecution service and political bodies is marked by a tension between demandss of both democratic legitimacy and impartial objectivity. Each legal system has to meet these demands in sone way. This book attempts to show how the systems of the Netherlands, France and Italy approach this matter, which arguments lie behind and which reforms could be undertaken in this regard.

For each country, firstly, an analysis is set out of the position of the prosecution service within the constitutional framework. Then an outline follows of the organisational structure of the aforesaid service and of its powers under criminal law. After that, a description is given of the role and the various powers of the minister of Justice. Finally, the research into each system ends with a study of the accountability of the minister to parliament.

The conclusions to these country analyses can be summarized as follows. The Dutch prosecution service and minister of Justice relate to each other by consulting together on an equal basis. The minister is empowered to be informed about even the details of criminal cases. Prosecutors are totally subordinate in legal status, although this does not appear to politicise the prosecution. The minister is entitled to order any kind of prosecutorial action to be taken or to be stopped. In practice his influence nearly only takes the form of consultation. On a number of occasions this is done on the instance of parliament, which scrutinizes the minister closely.

The French relation between the prosecution service and politics is in a phase of change. The current legislation gives the minister a dominant role, checked by an advisory function of the High Council of the Magistracy. This statutory situation is contrasted by the official policy of some of the governments from the end of last century on. This policy was to follow all advice concerning appointments and disciplinary actions. Also, the minister no longer gave any orders in specific eriminal cases, but only issues general directives on matters of prosecution. Still, appointments of the highest prosecutor functions are of a marked politicised nature. Parliament plays a rather insignificant part in this field. The minister can afford to take a passive attitude, while he does not have to fear parliamentary sanctions.

Contradiction rules the Italian positions of the political bodies and the prosecutors. The prosecution service is highly independent from the government, who has no say in their legal status or their functional activity. The prosecutors still do exercise powers of similar importance as those in the aforementioned countries. On the other hand, the service is subject to a principle of legality of the prosecution, which states that every crime notice has to lead to prosecution. De facto the prosecutor does exercise discretion in deciding which cases should be prioritised and which not. The latter cases still end up being dismissed in the long run. Furthermore, although the government can exercise little influence on criminal cases, for these it does answer to parliament. Members of parliament can receive detailed criminal information from the minister, or through quasi-permanent commissions of inquiry. 
The Italian prosecution service appears to be comparatively the most autonomous in legal terms. In comparison with the Netherlands, France subjects its prosecutors to a more restricted range of ministerial orders. In the practice of all three countries the prosecution service enjoys some autonomy in legal status, in particular concerning appointments to lower functions. Practice allso shows independent decision making in individual cases. Also no political body in any of these countries imposes any directives that indicate which type of case should be treated without priority.

The descriptive analysis above can be paired with an investigation into the validity of the reasons behind the existing juridical relation between prosecution service and politics At this point democratie legitimacy sets certain demands. Since the prosecutors have a discretion in their decisions and the power whether to initiate a procedure, political bodies should have a say in the general policy of the prosecution. A second conclusion also regards the prosecution service's discretion not to prosecute an offender for an act punishable under criminal law. If the prosecutor may decide not to prosecute for other than legal reasons, then the government needs to be able to bring about a contrary decision. The demand for impartiality under the rule of law on the other hand imposes restraint from political interference in criminal cases. This should be furthered by minimizing governmental influence in the legal status of individual prosecutors.

These conclusions promate ideas for change in the system that governs the relation between politicians and prosecutors. Firstly, an appeal could be instituted against ministerial orders regarding specific cases. Secondly, sympathy exists for creating a national public prosecutor leading the prosecution service, while enjoying a certain functional autonomy. A further suggestion for reform is to give parliament the task of setting directives on the general prosecution policy. This option could be of particular interest to the Italian situation. Lastly, an independent legal status for prosecutors could be combined with a limitation of ministerial influence to general directives. Variations of these could function well in both France and the Netherlands. 


\section{Lijst van geraadpleegde literatuur}

Accomando \& Guéry 1996: G. Accomando \& C. Guery, 'Rapport introductif', in: Le Parquet dans la République 1996, p. 29 e.v.

Accomando 1997: $G$. Accomando, 'L'indépendance du parquet: un débat dépassé: opportunité / légallité et dépendance / indépendance vis-ă-vis de l'exécutif" Gaz. Pa. 1997 , n. 225 , p. $2-3$.

Accomando 1997a: G. Accomando, "Vers un nouveau ministère public?', Justices 1997. n. 7, p. 87 e.v.

Aguila 1994: Y. Aguila, 'La politique penale est-elle une politique publique comme une autre?', Revue administrative 1994, n. 277 , p. 7 e.v.

Albers \& Voermans 1999: P. Albers \& W. Voermans, Rechtspraak in de 2 le eeuw. Verantwoordelijkheid voor de rechtspleging, Den Haag: Ministerie van Justitie 1999.

Alt 1998: E. Alt, "De nouvelles politiques d'action publique?", Jtustice 1998, n. 155 , p. 5 e.v.

Amato 1995: G. Amato, 'In tema di indipendenza del Pubblico Ministero', Cass. pen. 1995, n. 12.

Amodio 1994: $\mathrm{E}$. Amodio, "I rapporti tra pubblico ministero e giudice delle indagini preliminari nel nuovo processo penale", in: Pubblico ministero oggi 1994, p. 210 e.w.

Andreani 1999: A. Andreani, Crist e metamovfosi del potere esecutivo, Padova: Cedam 1999.

André-Coret 1996: H. André-Coret, Intervention, in: Le Parquet dans la République 1996, p. 129 e.v.

Angeren, Van 1996: J.A.M. van Angeren, "Mag de ministeriële verantwoordelijkheid voor het bestuur worden beperkt?", RMThemis 1996, P. 367-375.

Angibaud 1999: B. Angibaud, Le parquet, Paris: PUF 1999.

Appello al Parlamento 1995: "Appello al Parlamento di 200 pubblici ministeri", Qhest. ginst. 1995, p. $421-424$.

Ascher 1999: B.J. Ascher, 'Consistente straftoemeting: prima, maar hoe?', $N / B 1999$, p. 1423-24.

Assemblea costituente 1991: La Costihuzione della Repubblica nei lawori prepararoni dell Assemblea costituente, Roma 1991, vol. VIII.

Atracks on Justice 2000: Attacks on Justice: The Harassment and Persecution of Judges and Lonyers, Genève: CIJ 2000.

Avril \& Gicquel 1996: P. Avril \& J. Gicquel, Droit parlemenaire, Montchrestien 1996.

Avril 1977: P. Avril, 'Pouvoir et responsabilité', Mélonges offerts"à Georges Burdean. Le powoir, Paris: LGDJ 1977, p. 9 e.v.

Avril 1999: P. Avril, "Responsabilité et accountability", in: Beaud \& Blanquer 1999, p. 85 e.v.

Barile 1992: P. Barile, 'L'obbligatorietà dell'azione penale", in: Shadi in onore di Bozzi, Padova: Cedam 1992, p. 29 e.v.

Bartole 1964: S. Bartole, Autonomia e indipendenza dell ordine giudiziario, Padova: Cedami 1964.

Bartole 1984: S. Bartole, "Ispezione parlamentare e Ministro di grazia e giustizia", in: Scrifti in onore di E. Tosato Milano 1984. p. 313 e.w. 
Bartole 1989: S. Bartole, "ll potere giudiziario", in: G. Amato \& A. Barbera (cur.), Mamuale di diritro pubblico II. L organizzazione costinzionale, Bologna: II Mulino 1997, p. 427 e.v.

Bartole 1991: S. Bartole, 'Governo Italiano', in Dig disc pub., VI, Torino: Utet 1991, p. 634 e.w.

Bartolomei 1996: L. Bartolomei, Intervention, in: Le Parquet dans la République 1996, p. 119 e.\%.

Basse 1996: J. Basse, Intervention, in: Le Parquet dans la République 1996, p. 163 e.v.

Basso 1990: E. Basso, "Richiesta di procedimento, principio di uguaglianza e obbligatorietà dell'azione penale", Giur. cost. 1990.

Beaud \& Blanquer 1999: O. Beaud \& J.-M. Blanquer (dir.), La responsabilité des gouvemants, Paris: Descartes 1999.

Beaud \& Blanquer 1999a: O. Beaud \& J.-M. Blanquer, "Introduction', in: Beaud \& Blanquer 1999, p. 7 e.v.

Beaud 1998: O. Beaud, "La contribution de l'irresponsabilité présidentielle au développement de l'irresponsabilité politique sous la Ve Rếpublicue, RDP $1998, \mathrm{p} .1547 \mathrm{e} . \mathrm{v}$.

Beaud 1999: $O$. Beaud, Le sang contaminé: essai crifique sur la criminalisation de la responsabilité des gowvemants, Paris: Presses Universitaires de France 1999.

Beaud 1999a: O. Beaud, 'Le double écueil de la criminalisation de la responsabilité et de lla justice politique', RDP 1999 , p. 419 e.v.

Beaud 1999b: O. Beaud, "Le transfert de la responsabilité politique du ministre vers ses proches subordonnés', in: Beaud \& Blanquer 1999, p. 203 e.v.

Beaud 2000: O. Beaud, "La responsabilité politique face à la concurrence d"autres formes de responsabilité des gouvernants", Pouvoirs 2000 , p. 17 e.v.

Beaufort, De 1979: L.A.R.J. de Beaufort, "Het eigen gezicht van het Openbaar ministerie", Trena 1979 , p. 167-168.

Beaufort, De 1981: L.A.R.J. de Beaufort, 'Buigen of barsten', Trema 1981, p. 131-133.

Beaufort, De 1983: L.A.R.J. de Beaufort, 'Over het O.M. en de politiek', in: Van de Bunt e.a. 1983 , p. $155-162$.

Belinfante 1980: A.D. Belinfante, Beginselen van Nederlands Stadsrecht, Samson: Alphen aan de Rijn 1980.

Bellone 1986: P.M. Bellone, voce 'Pubblico ministero (Diritto processuale penale)', in: Nov. dig. it. (appendice), VI, Torino 1986, p. 198 e.v.

Bemmelen, Van 1968: J.M. van Bemmelen, "De functies van het Openbar Ministerie", N.M 1968, p. 604-615.

Bertoni 1982: R. Bertoni, 'Per la giustizia, attuare e non riformare la Costituzione', Quad. giust. 1982, I, p. 35 e.w.

Bertoni 1984: R. Bertoni, "Il Ministero di grazia e giustizia", in: E. Spagna Musso (cur.), Cosrituzione estmuthra del Governo. La riforma dei ministeri. (parte prima), Padova 1984.

Besier 1968: B.J. Besier, interventie op de NJV-vergadering van 25 juni 1968, Handelingen Nederlandse Juristen-Vereniging 1968-II, Zwolle: W.E.J. Tjeenk Willink 1968, p. 65-68.

Bettiol 1998: R. Bettiol, 'Riflessioni sul Pubblico Ministero, Critica del diritro 1998, n. 4.

Bidégaray \& Emeri 1998: C. Bidégaray \& Cl. Emeri, La responsabilité politique, Paris: Dalloz, 1998.

Bientinesi 1995: F. Bienintesi, 'Poteri del Ministero di Grazia e Giustizia e rapporti con il Govemo", Giur. cost. 1995 , p. 2203 e.v. 
Bigaut \& Chantebout 2000: Ch. Bigaut, B. Chantebout; De l'irresponsabilité prétendue des ministres sous la Ve République', Powoirs 2000 , p. 77 e.v.

Biggelaar, Van den 1994: G.J.M. van den Biggelaar, De buhtengevechtelizke afdoening wan strafbare feiten door het apenbaam ministerie (diss. Maastricht), Arnhem: Gouda Quint 1994.

Bigot 1992: J. Bigot, "Le statut du ministère public en France", RIDP 1992, p. 585 e.v.

Binsbergen, Van 1968: W.C. van Binsbergen, interventie op de NJV-vergadering van 25 juni 1968, Handelingen Nederlandse Juristen-Vereniging 1968-II, Zwolle: W.EJ Tjeenk Willink 1968, p. $86-92$.

Bioy 2001: X. Bioy; "A propos de la réforme de la justice: sur l'institution des Commissions de recours contre les classements sans suite', RSC 2001, p. 341-352.

Blok 1908: A.J. Blok, Positie en taak van het openbaar ministerie, Leiden: Brill 1908.

Bockwinkel 1968: A. Bockwinkel, interventie op de NJV-vergadering van 25 juni 1968 , Handelingen Nederlandse Juristen-Vereniging 1968-II, Zwolle: W.E.J. Tjeenk Willink 1968, p. 83-86.

Boek 1997: J.L.M. Boek, "De bevoegdheidswerhouding tussen minister en Openbarar Ministerie: een commentaar', Beleid en Maatschappij 1997, p. 134-141.

Boer, Den 1999: M.M. den Boer, Ministeriele verantwoordelijkheid voor zelfstandige bestuursorganen", Regelmaar 1999, 1, p. 3-21.

Bognetti 1994: G. Bognetti, 'Considerazioni sul potere giudiziario', Ind pen. 1994, p. 441 e.v.

Bonnotte 2000: $\mathrm{C}$. Bonnotte, "Histoire doctrinale de la responsabilité politique", in: Ségur 2000 , p. 23 e.v.

Boorsma 1996: J. Boorsma, Het Ministerie zit fout', NIB 1996, p. 9.

Borman 1981: J.A. Borman, 'Openbaar ministerie en beginselen var behoorlijk bestuur", Trema 1981, p. 103-112.

Borraccetti 1998: V. Borraccetti, 'Il pubblico ministero: un investigatore sempre più disomogeneo rispetto al giudice', Critica del diritio 1998, p. 269 e.v.

Borrelli 1994: F. S. Borrelli, "Il ruolo del pubblico ministero nel nuovo processo penale', in: Pubblico ministero oggi 1994, p. 29 e.v.

Bosch 1992: A.G. Bosch, "De ontwikkeling van het Openbaar Ministerie in de $19 \mathrm{e}$ en $20 \mathrm{e}$ eeuw', in: T.M. Schalken e.a. (red.), Magistraat met beleid. de officier van justitie en zijn omgeving, Arnhem: Gouda Quint 1992, p. 15-31.

Boudon 1997: R. Boudon, "Remarques provisoires sur les canses du "soupçon" de non indépendance de la justice, sur l'articulation entre le parquet et l'exécutif, et sur la présomption d'innocence', in: Commission de réflexion sur la lustice, Annexess 1997. p. 2 e.v.

Bouvier 1998: J.C. Bouvier, Indépendance du parquet, "l'"nacceptable réforme" , Petites Affiches 1998, n. 57, p. 3 e.v.

Bouvier, Jacquin \& Vogelweith 1997: J. C. Bouvier, P. Jacquin \& A. Vogelweith, Les affaires ou comments"en débarrasser, Paris: Découvertes 1997.

Bovend'Eert 1999: P.P.T. Bovend'Eert, 'De privatisering van het OM: cen onzinnig idee', TP 1999,10, p. 7-8.

Bozzo 1994: N. Bozzo, "Organizzazione degli uffici requirenti e principio di indipendenza", Quest giust. 1994, p. 288 e.v.

Brancaccio 1994: A. Brancaccio, Intervento, in: Pubblico ministero oggi 1994, p. 239 e.v.

Brants \& Brants 1991 : C.H. Brants \& K.L.K. Brants, De sociale constructie van frande, Arnhem: Gouda Quint 1991. 
Brants \& Field 1995: C. Brants \& S. Field, 'Discretion and Accountability in Prosecution: A Comparative Perspective on Keeping Crime out of Court', in: Ph. Femell e.a. (ed.), Criminal Justice in Europe. A Comparative Study, Oxford: Clarendon Press 1995 , p. $127-148$.

Brenninkmeijer 1995: A.F.M. Brenninkmeijer, 'De magistraat in het strafrecht', $N J B$ $1995, p .211$.

Bricola 1997: F. Bricola, Politica criminale e scienza del diritio penale, 1997

Broeksteeg, Skkema \& Warmelink 2000: Broeksteeg, Sikkema \& Warmelink, 'Strafrechtelijke aansprakelijkheid van ministers: ruime verantwoordelijkheid, beperkte vervolgbaarheid", NNB 2000, p. 965-971.

Brouwer 1999: H.N. Brouwer, 'Een triootje zonder het Openbaar Ministerie', in: Ménage à trois. De rol van de Rechterlijke macht binnen de Trias, Nijmegen: Wolf Legal Publishers 1999, p. 50-55.

Bruijn, De 1989* R. de Bruijn, 'De Officier van Justitie als rechterlijke autoriteit?', $A A$ 1989, p. $973-979$.

Brutti Liberati 1999: E. Brutti Liberati, "Statul du parquet et de la magistrature" in: Indipendenza della givistizia, oggi, Milano: Giuffé 1999, p. 67 e.v.

Bunt, Van de 1982: H.G. wan de Bunt, "Naoorlogse ontwikkelingen in het Nederlandse OM", Tijdschift voor Criminologie 1982, p. 57-75.

Bunt, Van de 1985: H.G, wan de Bunt, Officieren van Justitie, Verslag van een participerend obsematieonderzoek, Zwolle: W.E.J. Tjeenk Willink 1985.

Bunt, Van de, 1983: H.G van de Bunt, 'De macht van het OM', in: Van de Bunt e.a. 1983, p. 3-45.

Bunt, Van de, e.a. 1983: H.G. van de Bunt e.a. (red.), De macht wan het OM, Nijmegen: Ars Aequi Libri 1983.

Buruma 1993: Y. Buruma, De strafrechrelijke handhaving wan bestuurswetten, Amhem: Gouda Quint 1993.

Buruma 1999: Y. Buruma, 'Privatisering van het openbaar mimisterie', $N J B 1999$, p. $1886-1889$.

Caliendo 1994: G. Caliendo, Intervento, in: Pubblico ministero oggi 1994, p. il39 e.v.

Calloni 1995: G. Calloni, Dizionario degli ati illecin e codice penale, Bergamo: Larus 1995.

Caprioli 1994: F. Caprioli, L archiviazione, Napoli: Jovene 1994.

Carabba 1974: . Carabba, "Il pubblico ministero nell'ordine costituzionale', in: Riforma del publico mimistero 1974, p. 83 e.v.

Caravita 1991: B. Caravita "Obbligatorietà dell'azione penale e collocazione del pubblico ministero: profili costituzionale', in: Gaito 1991, p. 297 e.v.

Carbasse 2000: J.-M. Carbasse (dir.), Histoire du parquet, Paris: PUF 2000.

Carbone 1982: V. Carbone, "P.M. e potere esecutivo", Quad giust. 1982, I, p. 77 e.v.

Carcano 1993: D. Carcano, "Governo e amministrazione della giurisdizione. Direzione degli Uflici", Cass. pen. 1993, p. 2147 e.v.

Careano 1998: D. Carcano, 'Stabilire i criteri di priorità nella trattazione dei procedimenti è un dovere dei capi degli uffici", Cass pen. 1998, p. 1490 e.v.

Careti \& De Siervo 1999: P. Caretti \& U. De Siervo, Istituzioni di divitto pubblico, Torino: Giappichelli 1999.

Cascini 1993: G. Cascini, "Il ruolo del pubblico mimistero: garanzie di indipendenza e prospettive di specializzazione funzionale", Quest. giust. 1993 , p. 419 e.v. 
Casetta 1959: E. Casetta, 'Legittimità costituzionale dell'istituto dell' autorizzazione a procedere;, Giur. cost 1959, p. 516 e.v.

Casorla 1976: F. Casorla, "Lu' indépendance du ministête public", NPJ avril $1976, \mathrm{p} .26$ e.v.

Casorla 1999: F. Casorla, 'Les magistrats du parquet et le Conseil Constitutionnel', Travaux de l'institut de sciences criminelles de Poitiers, in: Droit constitutionnel et droit pénal, Paris: Cujas 2000, p. 31 e.v.

Castelli 1990: C. Castelli, 'Esigenze di deflazione e risposte possibili tra obbligatorieta e discrezionalità dell"azione penale", Quest. giust. 1990, p. 97 e.v.

Catelani 1994: G. Catelani, Intervento, in: Pubblico ministero oggi 1994, p. 63 e.w.

Cavallari 1974: V. Cavallari, "Il pubblico ministero nelle prospettive di riforma del processo penale", in: Riforma del pubblico mimistero $1974, \mathrm{p} .147 \mathrm{e} \mathrm{v}_{\text {, }}$, idem in Riv. dir. proc. 1973 , p. 154 e.v.

Charbonnier 1991: L. Charbonnier, "Ministère public et Cour suprême" JCP 1991, 13532, p. 316 e.v.

Chiavario 1971: M. Chilavario, "Il pubblico ministero organo di giustizia?", Riv. it. dir. proc. pen. 1971.

Chiavario 1977: M. Chiavario, "Riflessioni sul principio di obbligatorieta dell azione penale', in: Studi in onore di C. Mortati, vol. IV, Milano 1977, p. 91 e.v.

Chiavario 1994: M. Chavario, 'Obbligatorietả dell'azione penale il principio e la realtà", in: Pubblico ministero oggi 1994, p. 75 e.v. Onder dezelfde titel in Cass. pen. 1993, p. 2658 e.v.

Chimenti 1991: C. Chimenti, "Organizzazione del pubblico ministero: un significativo intervento dello Capo dello Stato', in: Gaito 1991, 279 e.v.

Chiusano 1994: V. Chiusano, 'Pubblico ministero e polizia giudiziaria', in: Pubblico ministero oggi 1994 , p. $155 \mathrm{e.v}$.

Chrestia 2000: P. Chrestia; "Responsabilité politique et responsabilité pénale: entre fléau de la balance et fléau de société", RDP 2000 , p. 739 e.v.

Cleiren \& De Roos 2002: T. Cleiren \& Th. de Roos, "Democratisering van de strafrechtspleging', in: Boonen e.a. (red.), De weging van 't Hart. Idealen, waarden en taken van her strafrech, Deventer: Kluwer 2002, p. 171-188.

Cliteur 1996: P.B. Cliteur, "De aanwijzingsbevoegdheid van de minister ex artikel 5 RO", N.J 1996, p. 597-601.

Cliteur 1996a: P.B. Cliteur, "Hercules in Nederland", Nederlands Tijdschrift woor Rechtsfilosofie en Rechtstheorie 1996, p. 83-86.

Cliteur 1997: P.B. Cliteur, 'Het OM ter discussie', Trema 1997, p. 9\|-96.

Cliteur 1997a: P.B. Cliteur, "De bevoegdheidsverhouding tussen minister en Openbaar' Ministerie*, Beleid en Maatschappij 1997, p. 117-133.

College van procureurs-generaal 1997: Brief van het College van procureurs-generad aan de minister van Justitie van 11 maart 1997 (ongepubliceerd).

Colli 1975: G. Colli, "Relazione per l'inaugurazione dell'anno giudiziario 1975", Riv. pen. 1975, p. 11 e.v.

Comité consultatif pour la révision de la Constitution 1993: Comité consultatif pour la révision de la Constitution, Propositions pour une révision de la Constitution. Rapport au Président de la République, Paris: La documentation française 1993.

Commissie antimafia 1995: Commissione parlamentare antimafia, Relazione defla XI legislatura. Tomo I, Roma: Camera dei Deputati 1995.

Commissie Delmas-Marty 1990: Commission 'Justice pénale et droits de l'homme', La mise en état des affaires pénales, Paris: La documentation française 1990. 
Commissie Gallo 1994: Commissione minusteriale per la riforma dell'ordinamento giudiziario, 'Lavori della Commissione all 30 aprile 1994', Doc. Giust. 1994, p. 1087 ev.

Commissie Openbaar Ministerie 1994: Commissie Openbaar Ministerie, Fet functioneren wan het Openbaar Ministerie bimnen de rechushandhoving, Den Haag. Ministerie van Justitie 1994.

Commissie Roelvink 2002: H.L.J. Roelvink e.a., Strafrechtelike aansprakelijkheid wan de stocit, Den Haag, 2002.

Commissie Seheltema 1993. Rapport van de commissie staatkundige, bestuturlijke en staatsrechtelijke vernieuwing, Kamerstukken II $1992 / 93,21427$, nrs. 40 en 41 .

Commission de prévention de la corruption 1993: Commission de prêvention de la comption, Rapport, Paris: La documentation trançaise 1993.

Commission de réflexion sur la Justice 1997: Commission de réflexion sur la Justice, Rapport, París: La documentation française 1997.

Commission de réflexion sur la Justice, Annexes 1997: Rapport de la Commission de reflexion sur la Justice, Amexes, Par"s: La documentation française 1997.

Conso 1979: $\mathrm{G}$. Conso (cur.), Pubblico ministero e accusa penale, Bologna: Zanichelli 1979.

Conso 1979a: G. Conso, "Introduzione alla riforma", in: Conso 1979, p. XI e.v".

Consolii 1994: G: Consoli, Intervento, in: Pubblico ministero oggi 1994, p. 236.

Corbi 1980: $\mathrm{F}$. Corbi, 'Obbligatorietà dell'azione penale ed esigenze di razionalizzazione del processo', Riv. it. dir. proc. pen. 1980 , p. 1048 e.v.

Cordero 2000: F. Cordero, Procedura penale, Milano: Giuffré 2000 .

Corso 1993: P. Corso, "ltaly", in: C. van den Wyngaert e.a. (cur.), Criminal Pracedure Systems in the European Community, London: Butterworths 1993, p. 223 e.v.

Corstens \& Tak 1982: G.J.M.. Corstens \& P.J.P. Tak, Het Openbaar Ministerie, Zwolle: W.E.J. Tjeenk Willink 1982 .

Corstens 1974: G.J.M. Corstens, Waarborgen rondom het vervolgingsbeleid, ljmuiden: Vermande 1974.

Corstens 1988: G.J.M. Corstens, 'Open brief aan de Minister van Justitie', NJB 1988, p. 226.

Corstens 1988: GJ.M. Corstens, "Over twee staatsrechtelijke leerstukken', $N J B 1988$, p. 301.302 .

Corstens 1997: G.J.M. Corstens, "Democratie, minister van Justitie en Openbaar ministerie', Trema 1997, p. 223-224.

Corstens 1999: G.J.M. Corstens, 'De nieuwa organisatie van het OM en de gevolgen voor de onafhankelijkheid van de rechter', in: J.P. Loof (red.), Onafhankelikkheid en onparrifdigheid. De randwormaarden voor het bestumr en beheer wan de rechterlijke macht, Leiden: Stichting NJCM-Boekerij 1999, p. 93-101. Vrijwel identiek, met dezelfde titel, in: Menage à mois. De nol van de Rechterlike macht binnen de Trias, Nijnegen: Wolf Legal Publishers 1999, p. 56-67.

Corstens 2002: G.I.M. Corstens, Het Nederlands strafprocesrecht, Amhem: Gouda Quint 2002.

Corstens 2002a: G.I.M. Corstens, 'Vervolgbaarheid van de overheid', NJB 2002, p. 1049.

Cremers 1983: P.H.A.J. Cremers, 'De verhouding tussen de minister van justitie en het openbaar ministerie", Trema 1983, p. 49-52.

CSM 1995: Conseil Superieur de la Magistrature, Rapport ammel 1995, Paris: Journal officiel 1995 . 
CSM 1998: Conseil Supérieur de la Magistrature, Rappont ammel 1997-1998, Paris: Journal officiel 1998.

CSM 2000: Conseil Supérieur de la Magistrature, Rappont a activité 1999, Parts: Journal officiel 2000.

CSM 2001: Conseil Supérieur de la Magistrature, Rapport d"activité 2000, Parris: Journal officiel 2001.

CSM 2002: Conseill Supérieur de la Magistrature, Rapport d"achivié 2001, Paris: Journal officiel 2002.

Curatola 1994: P. Curatola, Intervento, in: Pubblico ministero oggi 1994, p. 259 e.v.

D'Ambrosio 1994: V. D’Ambrosio, Intervento, in: Pubblico ministero oggi 1994, p. 133 e.v.

D'Elia 1998: G. D'Elia, 'I principi costituzionali di stretta legalità, obbligatorietà dell'azione penale ed eguaglianza a proposito dei "criteria di priorita" nell."esercizio dell'azione penale', Giur, cost. 1998 , p. 1878 e.v.

D'Haese 1992: C.E. D'Haese, "Het Rapport Delmas-Marty. La nouvelle cuisine procédurale...", DD 1992, p. 111 e.v.

Daalder 1991: E.J. Daalder, "Het Openbaar Ministerie: magistraat of bestuursambtenaar?", Trema 1991, p. 88-91.

Daga 1991: L. Daga, "Pubblico ministero. II) Diritto costituzionale", Enc. gitur. XXV, Roma: Treccani 1991; p. 1 e.v.

Dalia 1991: A.A. Dalia, 'Il problema del coordinamento, dei collegamenti e dei controlli nell'esercizio della funzione di accusa', in: Gaito 1991, p. 75 e.v.

Dalle 1999: H. Dalle, "Juges et Procuretrs" une évolution divergente", in: Justices. Ce qui a changé dans la justice deputs 20 ans, Paris: Dalloz 1999.

Daniele 1994: M. Daniele, Intervento, in: Pubblico ministero oggi 1994, p. 234 e.v.

De Jonge 1983: $G$. de Jonge, 'Parlement geen partij voor openbaar ministerie", in: Van de Bunt e.a: 1983 , p. 145-154.

De Luca 1991: G. De Luca, 'Controlli extra-processuali ed endo-processuali nell'attività inquirente del pubblico ministero', in: Gaito 1991, p. 217 e.v.

Degoffe 1996: M. Degoffe, 'Responsabilité pénale et responsabilité politique du ministre', RFDC 1996, p. 385 e.v.

Degoffe 1998: M. Degoffe, 'La responsabilité pẻnale du ministre du fait de son administration', RDP $1998, \mathrm{p} .465$.

Del Vechio 1982: L. Del Vechio, "Il problema della responsabilità', Quad giust. 1982, 1, p. 73 e.v.

Delmas-Marty \& Vervaele 2000: M. Delmas-Marty \& J.A.E. Vervaele (ed.), The implementation of the Corpus Juris in the Member States. Penal prowisions for the protection of European Finances, Antwerpen: Intersentia 2000.

Delmas-Marty \& Vervaele 2001: M. Delmas-Marty, Corpus juris 2000: strafbepalingen ter bescherming wan de financiële belangen wan de Europese Unie, Utrecht: Centrum voor Rechtshandhaving en Europese Integratic 2001.

Delmas-Marty 1992: M. Delmas-Marty, "Vers un modéle européen de procès pénal, in: M. Delmas-Marty (dir.), Procès pénal ef droits de l'homme, vers une conscience européenne, Paris: PUF 1992, p. 291 e.v.

Delmas-Marty 1994: M. Delmas-Marty, "La politique pénale est-elle une politique comme les autres?" RSC 1994, p. 150 e.v.

Delmas-Marty 1995: M. Delmas-Marty, Procédures pénales d'Europe, Paris: PUF 1995. 
Delmas-Marty 1996: M. Delmas-Marty, "Evolution du ministère public et principes directeurs du procès pénal dans leśs démocraties européennes", Justices 1996, n. 3, p. $75 \mathrm{erv}$.

Delmas-Marty 1998: M. Delmas-Marty (red.), Corpus juris: houdende strafbepalingen ter besicherming van de financiele belangen van de Europese Unte, Antwerpen: Intersenta 1998.

Delmas-Marty/Chiavario 1998: M. Chiavario (cur), Delmas-Marty (cur.) Procedure penali in Europa, Padova: Cedam 1998.

Devos-Nieq 1999: Ch. Devos-Nicq, Lua responsabilité comptable; le ministre, comptable de fait, in: Beaud \& Blanquer 1999, p. 165 e.v.

Devoto 1996: M. Dewoto, "Il pubblico ministero potere autonomo dello Stato', Dir. pen. e proc pen. 1996, p. $374 \mathrm{ev}$.

Devoto 1996a: Devoto, "Obbligatorieta-discrezionalita dell'azione penale, ruolo del p.m. ', Cass. pen. 1996, p. 2024 e.v.

Di Ciolo 1983. V. Di Ciolo, 'Interrogazione parlamentare', in: Now dig. it. (Appendice), IV, Torino: Utet 1983, p. 334 e.v.

Di Federico 1989: G. Di Federico, 'La crisi del sistema giudiziario e la questione della responsabilità civile dei magistrati', in: P. Crobetta \& R Leonardi (cur.), Politica in Italia. I fati dell 'amno e le interpretazioni, Bologna 1989.

Di Federico 1991: G. Di Federico, 'Obbligatorietà dell'azione penale, coordinamento delle attivita del pubblico ministero e loro rispondenza alle aspettative della comunitâ", in:" Gaito 1991, p. 169-208. Onder dezelfde titel in Giust. pen. 1991, p. 159 e.v.

Di Federico 1995: G. Di Federico, "Il pubblico ministero: indipendenza, responsabilità, carriera separata", Ind' pen. 1995, n. 2. Bewerking van: "Dilemmi del ruolo del pubblico ministero: indipendenza e responsabilità', in: Pubblico ministero oggi 1994, p. 247 e.v.

Di Federico 1998: G. Di Federico, 'L'indipendenza del PM e il principio democratico della responsabilità in Italia: l'analisi di un caso deviante in prospettiva comparata', Riv. it. dir. proc pen. 1998, n. 1, p. 230. Ook gepubliceerd als: "Prosecutorial independence and the democratic requirement of accountability", British Joumal of Criminology 1998, p. 371 e.v., bewerking van zijn tekst in: J. De Figueiredo Dias e.a., The Role of the Public Prosecuro" in Criminal Justice according to the Differem Constitutional Systems, Bologna: Scarabeo 1986.

Dinace 1991: F.R. Dinacci, "Il controllo giurisdizionale sulla decisione del pubblico ministero di non esercitare l'azione penale', Cass. pen. 1991, p. 579 e.v.

Doelder, De \& "t Hart 1990: H. de Doelder \& A.C. "Hart, "De meerwaarde van het OM', Trema 1990, p. 250-252.

Doelder, De 1988: H. de Doelder, Het OM in positie, Arnhem: Gouda Quint 1988.

Doelder, De 1988a: $H$. de Doelder, 'De ministeriële verantwoordelijkheid voor het $O M$ ", Trena 1988 , p. 374-377.

Doelder, De 1991: H. de Doelder, 'Transactie een onrechtmatige overheidsdaad?', NIB 1991 , p. $481-482$.

Doelder, De 1992: H. de Doelder, "Van paasbrief tot herfstweer", DD 1992, p.9\1-921.

Doelder, De 1994: H. de Doelder, 'Het OM na Donner', Trema 1994, p. 445-451.

Doelder, De 1995: H. de Doelder, 'De politieke beïmvloeding van het OM', in: Mer recht op de wheh (Politofi-bundel), Arnhem: Gouda Quint 1995, p. 55-64.

Doelder, De 1996: H. de Doelder, "De vereiste afstand tussen het OM en de politiek", in: De inhowd van het gezag, Den Haag: Openbaar Ministerie 1996, p. 115-125. 
Doelder, De 1996a: H. de Doelder, Het $O \mathrm{M}$ als buitendienst wan het departement van Justitie", Trema 1996, p. $294-298$.

Doelder, De 2002: H. de Doelder, 'Europese opsporing en vervolging", 002002 , p. $712-725$.

Doelder, De 2002a: H. de Doelder, "Een politiek OM", Tijdschriff voor de Polive 2002, $7 / 8$, p. 4-7.

Dolcini \& Marinucei 1999: E. Dolcini \& G. Marinucci (cur.), Codice penole commentaio. Parte speciale, Milano: Ipsoa 1999.

Dolez 1999: B. Dolez, 'Quitter le gouvernement. Démission et révocation des ministres sous la Ve République’, in: Beaud \& Blanquer 1999, p. 279 e.v.

Dominioni 1979: O. Dominioni, "Per un collegamento tra mimistro della giustiza e pubblico ministero', in: Conso 1979 , p. 44 e.v.

Donati 1997: $\mathrm{F}$. Donati, La responsabilità politica dei ministri nella forma di govemo italiana, Torino: Giappichelli 1997.

Donker \& Van Eck: H.J. Donker \& J.J. van Eck, "Waar staat de staande magistratuur?", Trema 1991, p. 93-98.

Dufour 1998: O. Dufour, "Laa "drôle" d'indépendance du parquet', Petites Affiches 1998, n. 49, p. 4 e.v.

Duisterwinkel 1965: G. Duisterwinkel, Enige focetten wan de taak van her Openbaar Ministerie naar Nederlands rechi, Deventer: Kluwer 1965.

Duisterwinkel 1968: G. Duisterwinkel, Preadvies "Vereisen de functies van het Openbaar Ministerie nieuwe wettelijke voorzieningen?" in: Handelingen der Nederlandse JuristonVereniging 1968-1, Zwolle: W.E.J. Tjeenk Willink 1968, p. 197-257.

Duisterwinkel 1968a: G. Duisterwinkel, interventie op de NJV-vergadering van 25 juni 1968, Handelingen Nederlandse Juristen-Vereniging 1968-II, Zwolle: W.E.I. Tjeenk Willink 1968, p. 106-128.

Duisterwinkel 1975: G. Duisterwinkel, 'Corstens/Waarborgen rondom het vervolgingsbeleid' (boekbespreking), RMThemis 1975, p. 192-199.

Duisterwinkel 1977: G. Duisterwinkel, 'Taak en functioneren van het Openbaar ministerie', RMThemis 1977, p. 121-137.

Duker 2001: M.J.A. Duker, 'Controle over rechterlijke straftoemeting bij zware misdrijven", $D D 2001$, p. 135-156.

Duker 2001a: M.J.A. Duker, "De verhouding tussen wetgever" Openbaar Ministeric en rechter bij de straftoenteting", Trema 2001, p. $307-317$.

Dullemen, Van 1958: A.A.L.F. van Dutlemen, Preadvies over positie en taak van het Openbaar Ministerie in Nederland, Zwolle: Tjeenk Willink 1958.

Dupuis 1987: G. Dupuis, "Le gouvernement dispose de l'administration', in: F. Luchaire \& G. Conac (dir.), La constitution de la république framçaise, Paris. Economica 1987 , p. 581 e.v.

Dusi 1995: P. Dusi, "L'ispezione "usa e getta" sulla procura della Repubblica di Milano", Quest. guust. 1995, p. 361 e.v.

Duverger 1987: M. Duverger, Le gouvernement détermine et conduit la politique de la nation", in: F. Luchaire \& G. Conac (dir.), La constitution de la république française, Paris: Economica 1987, p. 575 e.y.

Duyne, Van 1999: P.C. wan Duyne, "Een geprivatiseerd OM. Statsmacht in de uitverkoop of vertrouwensversterking?" $T P, 10$, p. 16-17.

Egbers \& Hengeveld 1998: I.B.M. Egbers \& P.J. Hengeveld, Handboek rechispositie rechterlijke macht 1998/1999, "s-Gravenhage: SDU 1998. 
Eijkern, Van 1968: W.J. van Eijkem, interventie op de NJV-vergadering wan 25 juni 1968 , Handelingen Nederlandse Juristen-Vereniging 1968-1I, Zwolle: W.E.J. Tjeenk Willink 1968, p. 92-98.

Elainga \&oopman 1994: D.J Elzinga \& J. Koopman, Ministeriele verantwoordeligkheid en Openbaar Ministerie, in: Elzinga 1994b, p. 211-235.

Elzinga 1989: DJ. Elzinga, 'Politieke verantwoordelijkheid. Over werval en vooruitgang in de parlementaire democratie, in: M.A.P. Bovens, CJ.M. Schuyt \& W.J. Witteveen, Verantwoordelijkheid: Retoriek en realiteit, veranwoording in publiekrecht, politiek en macuschapply, Zwolle 1989, p.63-79

Elainga 1990: D.J. Elzinga, De staat wan het recht, Zwolle: W.E.d. Tjeenk Willink 1990.

Elzinga 1994: D.J. Elzinga, Een wolle ministeriele verantwoordelijkheid voor het Openbaar Ministerie, maar geen ongebreidelde sturing van het OM", NJB 1994, p. $529-537$.

Elxinga 1994a: D.J. Elzinga, "Naschrift', $N J B$ 1994, p. 751.

Elainga 1994b: D.J. Elzinga (red.) Ministeriele verantwoordelijkheid in Nederland, Zwolle: W.E.J. Tjeenk Willink 1994.

Elzinga 1994c. D. Elzinga, 'De politieke mimisterièle verantwoordelijkheid', in: Elzinga $1994 \mathrm{~b}$, p. $31-49$.

Elzinga 1996: D.J. Elzinga, "Verantwoordelijkheid en aanspreekbaarheid in de werhouding tussen bestuur, Openbaar Ministerie en politie", RMThemis 1996, p. 203-214.

Elzinga 1996a: D.I. Elzinga, "Openbaar Ministerie raakt in Gordiaanse knoop", $N J B 1996$, p. $1659-1662$.

Enguéléguélé 1998: S. Enguéléguélé, Les politiques pénales (1958-1995), Paris: L'Harmattan 1998.

Enquêtecommissie Opsporingsmethoden 1996: Enquêtecommissie Opsporingsmethoden, Inzake opsporing, Den Haag: Sdu 1996.

Enschedé 1968: Ch. J. Enschedé, interventie op de NJV-vergadering van 25 juni 1968 , Hondelingen Nederlandse Juristen-Vereniging 1968-II, Zwolle: W.E.J. Tjeenk Willink, p. 76-83.

Enschedé 1980: Ch.J. Enschedé, 'De constitutionele positie van de rechterlijke macht, in het bijzonder van het openbaar ministerie', Trema 1980, p. 83-90.

Euzet 2000: Ch. Euzet, 'L'inexistence pratique de la responsabilité politique', in: Ségur $2000, \mathrm{p}, 133 \mathrm{e}$.v.

Fabbrini \& Vassallo 1999: S. Fabbrini \& S. Vassallo, Il governo. Gli esecutivi nelle democrazie contemporanee*, Bari: Laterza 1999.

Falcone 1990: G. Falcone, "Evoluzione del principio dell'obbligatorietà dell"azione penale, II givsio processo 1990 , p. 164 e.w.

Falletti 1993: F. Falletti, 'La politique pénale est-elle une politique publique comme une autre. Intervention', in: Jourrée de réflexion sur le minisière public, Paris: École nationalle de la magistrature 1993.

Falletti 1996: F. Fallett, Intervention, in: Le Parquel dans la République 1996, p. 187 e.v.

Falletti 2001: $F$. Falletti, 'La recommandation 2000-19 du Comite des ministres du Conseil de l'Europe du 6 octobre 2000. Premiers pas vers l'identification génétique du ministère public à l'échelle Européenne', RPDP 2001 , p. 490-506.

Fasseur 1996: C. Fasseur; "Het nieuwe Openbar Ministerie en de nieuwe Politiewet; een repliek', NJB 1996, p. 60.

Favoreu 1994: L. Favoreu, 'Brèves observations sur la situation du parquet au regard de la Constitution", RSC 1994, p. 675 e.v. 
Favoreu 1996: L. Favoreu, "Le Parquet au regard de la Constitution", in: Le Purquer dons" la République 1996, p. 75 e.v.

Favoreu e.a. 2000: L. Favoreu e.a., Drot constitutionnet, Paris: Dalloz 2000.

Feltz \& Moons 1971: W.A. Feltz, M.M.A.V. Moons, De ambtelighe verhouding in het Nederlandse Openbaar Ministerie, Zwolle: Tjeenk Willink 1971.

Fêvrier 2000: J.-M. Février, "L'axiologie de la responsabilité politicue", in: Ségur 2000 , p. 213 e.v.

Fiandaca \& Musco 1997: G. Fiandaca \& E. Musco, Diritro penale. Parte spectale l, Bologna: Zanichelli 1997.

Ficq \& Myjer 1999: C.R.L.R.M. Ficq \& B.E.P. Myjer, 'Openbaar Ministerie privaat? Aantekeningen naar aanleiding van een non-gezegde', TP 1999, 10, p. 941 .

Ficq 1991: C.R.L.R.M. Ficq, 'De officier van justitie, magistrat (of besturursambtenaar?)', Trema I991, p. 158-166.

Fijnaut \& Groenhuijsen 2002: C.J.C.F Fijnaut \& M.S. Groenhuijsen, "Een Europees openbaar ministerie: kanttekeningen bij het Groenboek", $N / B$ 2002, p. 1234-1.241.

Fijnaut, Van Daele \& Parmentier 2000: C. Fijnaut, D. Van Daele \& S. Parmentier, Een openbaar ministerie voor de $21^{\text {sta }}$ eeuw, Leuven: Universitaire Pers Leuven 2000

Fionda 1995: J. Fionda, Public Prosecutors and Discretion, A Comparative Study, Oxford: Clarendon 1995.

Flier, Van der 1999: P.J. van der Flier, 'De wetgeving inzake de reorganisatie van het openbaar ministerie", $A A \mathbb{1 9 9 9}$, p. $740-745$.

Fortuna 1991: E. Fortuna, 'Pubblico ministero. III) Diritto processuale penale', Enc. giur. XXV, Roma: Treccani 1991, p. 1 e.v.

Franken 1998: H. Franken, 'Een Raad voor de Rechtspraak', RMThemis 1998, p. 129-130.

Frison-Roche 1998: M.-A. Frison-Roche, "Réforme de la justice " il faut libérer le juge du politique", Petites Affiches 1998, n. 42, p. 4 e.v.

Frissem 1998: P.H.A. Frissen, 'De Justitiecrisis in bestuurskundig perspectief, NJB 1988 , p. 727-731.

Fumu 1991: G. Fumu, "L'attività pre-procedimentale del pubblico ministero", in: Gaito 1991 , p. 135 e.v.

Gaay Fortman, De 1981: B. de Gaay Fortman, 'Parlement en vervolgingsbeleid', in: H. Bianchi e.a., Twssen misdado en straf, Nikerk: Intro 1981, p. 116\%134.

Gaito 1991: A. Gaito (cur.), Accusa penale e ruolo del pubblico ministeno, Napoli: Jovene 1991.

Gaito 1991a: A. Gaito, 'Natura caratteristiche e funzioni del pubblico ministero. Premesse per una discussione", in: Gaito 1991, p. 11 e.w.

Gaito 1994: A. Gaito, "Indipendenza del p.m. e "superprocura", in: B. Caravita (cur.), Magistratura, CSM e principi costituzionati, Bari: Laterza 1994, p. 149 e.v.

Galeotti 1983: S. Galeotti, "Il potere giudiziario I. L'organizzazione", in: 'Gruppo di Milano: Verso una nova Costituzione. Tomo I, Milano 1983, p. 641 e.x.

Gargani \& Panella 1998: G. Gargani \& C Panella, In nome det pubblici minisseri. Dalla Costifuente a Tangentopoli: storia di leggi sbagliate, Milano: Mondadori 1998.

Gerber 1990: F. Gerber, Justice indèpendante, justice su" commande, Paris: PUF 1990.

Ghiara 1971: A. Ghiara, "Riforma del ruolo e dei poteri del pubblico ministero', Riv, it. dir". proc. pen. 1971. p. 779 e.v.

Gicquel 1999: J. Gicquel, Droir constimtionnel et institutions politiques, Paris: Montchrestien 1999.

Giostra 1994: G. Giostra, Intervento, in: Pubblico ministero oggi 1994, p. 179 e.v. 
198: M. Gola, Riflession in tema di responsabilita politica e Amministrazione lica, Milano: Giuffre 1998.

2 2000* E, Grande, "Italian Criminal Justice: Borrowing and Resistance', American zal of Comparative Law 2000 , p $227 \mathrm{ew}$.

1991: Erasso, "Pubblico ministero. II) Diritto processuale civile', Enc giur. Roma: Treccani 1991, p. I ev.

1999: V. Grevi, 'Pubblico ministero e processo penale', in: Le garanzie della sdizione e del processo nel progetto della commissione bicamerale, Milano: Gutfre , p. 73 e.v.

feri \& Pederzoll 1996: C Guarnieri \& P. Pederzoli, La puissance de juger, pow wo iaire et dènocratie, Paris: Michalon 1996.

ien 1984: C. Guarnieri, Pubblico ministero e sistema politico, Padova: Cedam 1984. urd 1990: P. Guichard, 'Le tre gionate di sciopero dei magistrati in Francia', Quest. $1990, \mathrm{p} .915$.

hard \& Buisson 2000: Guinchard \& Büsson, Procédure pếnale, Paris: Litec 2000. aren, Van 1998: H.R. van Gunsteren, "Misvattingen over het primaat van de iek", DD 1998, p. 870-882.

pane 1999: A. Gustapane, L'autonomia e l'indipendenza della magistratwo aria nel sistema costimzionale italiano. Dagli albori dello statuto abertino al uscolo della bicamerale, Milano: Giuffré 1999.

2000: R. Haby, 'Le débat sur la justice", Regards sur l'achalité. La vie publique en tee, Paris: La documentation française 2000, p. 111 e.v.

rin 1996: J.-L. Halpérin, "Un quart de siècle décisif pour les relations entre la justice pouvoir en France", Justices; n. 3, 1996, p. 13 e.v.

't 1976: A.O. 't Hart, Om het O.M. een verkenning van enkele aspekten van taak en tioneren van het Openbaar Ministerie in Nederland (lectorale rede Tilburg), Zwolle: nk Willink 1976.

't 1989: A.C. "t Hart, 'Politiek en strafrechtspleging', DD 1998, p. 835-843.

't 1994: A.C. "t Hart, "Distantie in betrokkenheid: de plaats van het OM", Trema 4. p. $190-20$.

't 1994a: A.C. "t Hart, Openbaw' Ministerie en rechshandhoing: een werkeming, hem: Gouda Quint, 1994.

"t 1997: A.C. 'T Harl, "Politsering van strafrechtspleging", DD 1997, p. 207-212.

"1 1999: A.C. "1 Hart, "De nicuwe wet op de rechterlijke organisatie en de positie van $\mathrm{OM}^{*}$, in: J.P. Loof (red.), Onafhankelijkheid en onpartijdigheid. De randwoorwaarden $r$ her bestuw" en beheer van de rechterlijke macht, Leiden: Stichting NJCM-Boekerij 9, p. 103-119.

't 2001: A. C. 't Hart, Hier gelden wetten! Over strafiecht, Openbaar Ministerie en 'viculturalisme, Arohem: Gouda Quint 2001.

mann \& Van Russen Groen 1998: A.R. Hartmann \& P.M. Van Russen Groen, nounew van het bestursstrafrech (diss. Rotterdam), Arnhem: Gouda Quint 1998. uiker 1968: J.F. Hartsuiker, interventie op de N.IV-vergadering van 25 juni 1968 , adelingen Nederlandse Juristen-Vereniging 1968-M, Zwolle: W. E.J. Tjeenk Willink is, p. $70-75$. 
Hartsuiker 1978: I.F. Hartsuiker; "De ontwikkeling van het openbaar ministerie tot beleidvoerend orgaan", Trema 1978, p. 119-124

Hazewinkel-Suringa 1953: D. Hazewinkel-Suringa, 'Enige besehouwingen over de macht van het openbaar minsterie en haar grenzen', Tidschrif voor Straffecht 1953, dl. LXIL, p. 143-163.

Heijder 1981: A. Heijder, "Het openbaar ministerie en de planning van de politiek van de rechtshandhaving', in: Ad personam (Enschede-bundel), Zwolle: Tjeenk Willink 1981. p. $79-94$.

Heijnsbergen, Van 1929: P. van Heijnsbergen, Verspreide opstellen, Amsterdam: De Gulden Ster 1929.

Herstel 1978: A. Herstel, "Twee geloven op éen kussen? Het O.M. zit ertussen', in: G.A.A. Conyn, Rechter en politiek, Alphen aan den Rijn: H.D. Tjeenk Willink 1978, p. 63-78.

Hes 1999: J. Hes, Voetangels voor kopsnuken. Over de invloed van media en politrek op ambtsdragers bij Justitie, Amsterdam: De Balie 1999.

Hirsch Ballin 1990: E.M.H. Hirsch Ballin, 'Rechter en ofticier in 2000', Trema 1990, p. $246-249$.

Hirsch Ballin 1991 : E.M.H. Hirsch Ballin, 'De officier van justitie, magistrat of bestuursambtenaar?', Trema 1991, p. 195-200.

Hoefer 1976: F.G.R. Hoefer, 'Bloemenhove -- hoe ver reiken de bevoegdheden van de minister van Justitie bij opsporing en vervolging in individuele gevallen?", NIB 1976 , p. $1021-1022$.

Honert, Van den 1998: M.J.I. van den Honert, "De toekomst van de justitiele samenwerking in Europa', Trema 1998, p. 28-32.

Horvatz 1998: E. Horvatz, "Les relations entre le droit constitutionnel et l"organisation judiciaire" Revue internationale de droit comparé 1998, n. 1, p. 35-44.

Ichino 1994: đchino, 'La terzietà del giudice per le indagini preliminari: un problema aperto", in: Pubblico ministero oggi 1994, p. 227 e.v.

Illuminati 1994: G. Illuminati, "La separazione delle carriere come presupposto per un riequilibrio dei poteri delle parti’, in: Pubblico ministero oggi 1994, p. $215 \mathrm{e.}$.

Jaarplan OM 1999: Jaarplan 1999, Den Haag: Openbaar Ministerie 1998.

Jaarverslag OM 1986: Jaaverslag Openbaar Ministerie 1986, Den Haag: Procurenursgeneraal bij de gerechtshoven 1987.

Jacquin \& Vogelweith (Bot) 1997: P. Jacquin \&. A. Vogelweith, "Le politique pent contribuer à l"indépendance du magistrat" (interview Y. Bot), Justice 1997, n. 152, p. 8 e.v.

Jacquin \& Vogelweith (Mény) 1997: P. Jacquin \& A.Vogelweith, "... L'Exécutifn" n ni vocation ni légitimité pour tout contrôler" (interview Y. Mény), Justice 1998, n. 156, p. 5 e.v.

Jacquin (Colleu) 1997: P. Jacquin, "Le gouvemement doit conserver le pouvoir de nomination des procureurs" (interview $Y$. Colleu), fustices $1997, n .153$, p. 10 e.v. Jaubert 2000: A. Jaubert, "Les réformes de la responsabilité politique", in: Ségur 2000 , p. 261 e.v.

Jean 1999: J.-P. Jean, 'Les réformes de la justice", Regards sur l'acthalité 1999, n. 248 , p. 17 e.w.

Jeandidier 1987: W. Jeandidier, "L. "irresponsabilité d'un ministre" JCP 1987, p. 187. Jean-Pierre 1999: D. Jean-Pierre, La déontologie de l'administration, Paris: PUF 1999. Jehle 2000: J.-M. Jehle, "Prosecution in Europe: Varying Structures, Convergent Trends", European joumat on criminal policy and research 2000, p. 27-42. 
Jéol 1994: M. Jéol, "Le parquetier nouveau est arrivé", Gaz. Pal 1994, Doctr. p. 1363 e.v. Jêol 1996: M. Jéol, "Le Parquet entre le glaive et la balance", Justices 1996, n. 3, p. 69 e.v. Jiang 2000: J. Jiang, 'La défallance logique de la responsabilite politique', in. Ségur 2000 , p. $101 \mathrm{e.v}$.

Josserand 1998: . Josserand, L impartialité du magistrat en procédure pénale, Paris: LGDJ 1998.

Jung 1993: H Jung, "Le ministere public: portrait d"une institution", $A P C$ 1993, p. 15 e.v.

Jurgens 1994: E. Jurgens, "De Staten-Generaal en het OM', in: H. de Doelder, R.M.G.E. Foque \& R.A.F. Gerding (red), Taak en functioneren van het OM, Arrhem: Zwolle 1994, p. $267-274$.

Koopmans 1998: T. Koopmans, Het primaat van de politiek', RMThemis 1998, p. 97.

Korthals Altes 1988: F. Korthals Altes, "De verhouding tussen de minister van justitie en het openbaar ministerie", Trema 1988, p. 367-373.

Kortmann 1994: C.A.J.M. Kortmann, "Consistentie?', NJB" 1994, p. 750.

Kortmann 1995: C.A.I M. Kortmann, 'Ministeriekle verantwoordelijkheid en responsabillité du gouvernement", in: De Grondwet als voorwerp wan aanhoudende zorg, Zwolle: W.E.J. Tjeenk Willink 1995, p. 217-232.

Kortmann 1996: C.A.I.M. Kortmann, "Ministeriële verantwoordelijkheid", RMThemis" 1996, p. $243-244$.

Kortmann 2001: C.A.J.M. Kortmann, Constitutioneel recht, Deventer: Kluwer 2001.

Kosto 1986: A. Kosto, 'De betrokkenheid van de politiek op het OM', Trema 1986, p. $201-204$.

Landen, Van der 1999: D. van der Landen, "Advocaat als officier van justitie?', TP 1999, 10, p. 18-19.

Langemeijer 1968: G.E. Langemeijer, interventie op de NJV-vergadering van 25 juni 1968, Hondelingen Nederlandse Juristen-Vereniging 1968-II, Zwolle: W.E.J. Tjeenk Willink 1968, p. 99-106.

Le Parquet dans la République 1996: Le Parquet dans la République. Vers un nonveau Ministère public?, Bordeaux: ENM 1996.

Lee, Van der 1999: P.P. van der Lee, 'Nieuwe wet geen garantie voor evenwichtige relatie OM en ministerie', Stcht. 1999 , nr. 86, p. 5.

Leijendekker 1996: M. Leijendekker, De lialiaanse revolutie, Amsterdam: Meulenhof 1996.

Lemesle \& Pansier 1998: L. Lemesle \& F.-J. Pansier, Le procureur de la République, Paris: PUF 1998.

Liempt, Van \& Van Westing 2000: A. van Liempt \& G. van Westing, Klem in de dracidew. Arthur Docters van Leewnen en het Ministerie van Justitie 1995-1998; Apeldoorn: Balans 2000.

Lindo 1995: C.M.Th. Lindo, "Het Openbaar Ministerie onder Docters van Leeuwen" (interview), $N J B 1995$, p. $1597-1602$

Lindo 1998: C.M.Th. Lindo "Rust in het rechtsbestel, Interview met minister A.H. Korthals", NJB 1998, p. 1716-1721.

Linthorst 1996: H.M. Linthorst, 'Vrijheid van requisitoir?', NJB 1996, p. 287.

Lo Coco 1974: G. Lo Coco, "Appunti sul tema del pubblico ministero", in: Riforma del pubblico ministero 1974 , p. 225 e.v.

Lubberdink 1982: H.G. Lubberdink, De betekenis van de ministeriële veranmoordelijkheid voor de organisatie van het openbaar bestumr, Deventer: Kluwer 1982. 
Lyon-Caen 1997: P. Lyon-Caen, 'Le parquet entre indépendance et politigue penale'; Justice 1997, n. 154, p. 28 e.w.

Maarseveen, Van 1977: H.Th.J.F. van Maarseveen, 'Ministeriale verantwoordelijkheid en Openbaar Mimisterie na 1976, NJB 1977, p. $209-215$.

Maarseveen, Van 1977: H.Th.J.F. van Maarseveen, 'Naschrift', NJB 1976, p. 376-378.

Maarseveen, Van 1983: H.Th.J.F. van Marseveen, Openbaar ministerie, parlement en departement; enkele politiek-rechtelijke overdenkingen", in: Van de Bunt e.a. 1983. p. $175-189$.

Maarseveen, Van 1988: H. van Maarseveen, 'Over een minister', NJB 1988, p. 301.

Maddalena 1991: M. Maddalena, 'Azione penale, fumzioni e struttura del pubblico ministero: prospettive di riforma ordinamentale', in Gaito 1991, p. 143 e.v.

Maddalena 1994: M. Maddalena, "Il ruolo del pubblico ministero nel processo penale", in: Pubblico pninistero oggi 1994, p. 47 e.v.

Malibert 1994: P. Malibert, 'Art. 31 à 44. Le ministère public', in: Juris-classeurs Procédure pénale, Paris: LITEC 1994.

Manzella 1972: A. Manzella, 'Interrogazione e interpellanza parlamentare', in: Enc. dir., XII, Milaan: Giuffré 1972, p. 406 e.w.

Manzione 1995: D. Manzione, 'Publico ministero e polizia giudiziaria: organizzazione e posizione istituzionale e processuale', in: M. Chiavario (cur.), Protagonisti e comprimari del processo penale, Torino: Utet 1995, p. 91 e.v.

Marafioti 1991: D. Marafioti, 'Un vertice responsabile dell'andamento della funzione d'accusa', in: Gaito 1991, p. 235 e.v.

Maranini 1962: G. Maranini (cur), Magistrati a funzionari, Milano: Edizioni di Comunità 1962.

Martin 1997: A. Martin, "Le Conseil supérieur de la magistrature et I'indépenclance des juges' ${ }^{\prime}$ RDP 1997, p. 741 e.v.

Marzaduri 1994: E. Marzaduri, Intervento, in: Pubblico ministero oggi 1994, p. 144 e.v.

Matagrin 1996: D. Matagrin, Intervention, in: Le Parquet dans la République 1996, p. 113 e.v.

Mathias 1999: E. Mathias, Les procureurs du droit. De l"mpartialité du ministère public en France en en Allemagne, Paris: CNRS 1999.

Mathias 1999a: E. Mathias, 'Poursuivre autrement", Petires affiches 1999, n. 159, p. 4 e.v.

Mathieu 1993: B. Mathieu, "La responsabilité penale des ministres devant la Cour do justice de la République”, RFDC 1993, p. 601 .

Maynier \& Casorla 1993: H. Maynier \& F. Casorla, 'Du procureur général près la Cour de cassation au procureur génèral de la République, Gaz. Pal. 1993, Doctr. p. 539 e.v.

Mazeaud 1996: P. Mazeaud, Intervention, in: Le Parquel dans la République 1996, p. 241 e.v.

MeCarthy 1997: P. McCarthy, The Crisis of the Italian State. From the Origins of the Cold War ro the Foll of Berlusconi and Beyond, New York: St. Martin 1997.

Meijers 1984: L.C.M. Meijers, 'Grenzen van het openbaar ministerie', Trema 1984, p. $283-291$.

Meijers 1987: L.C.M. Meijers, 'Een bedreigd evenwicht', Trema 1987, p. 24-33,

Meijers 1987a: L.C.M. Meijers, "Het openbaar ministerie binnen de trias politica", in: De rechter als dictator?, Lochem: Wan den Brink 1987, p. 123-132.

Meijers 1988: L.C.M. Meijers, "Het Openbaar Ministerie, onpartijdig procesdeelnemer", in: Handhaving wan de rechtsorde, Zwolle 1988, p. 139-147. 
Meijers 1991: L.C.M. Meijers, "Het einde van de onpartijdigheid, Van openbar ministerie tot departementale vervolgingsdienst" RMThemis 1991, p. 170-174.

Melail c.s:: A.L. Melai, Het werboek van swafvordering.

Micali 1993: G. Micali 'Lu' indipendenza del pubblico ministero e l"esegesi dell" art 107 comma IV della Costituzione Cass pen. 1993, p. 1280 ev.

Miljard 2000: E. Miljard, 'La signification juridique de la responsabilité politique, in: Segur 2000, p. 8 in e.

Ministêre de la Justice 2002: Ministère de la Justice, Anrmaine statistique de la Justice. Edition 2002, La documentation française 2002.

Minkenhof/Reijntjes 2002. J.M. Reijntjes, A. Minkenhof. De Nederlandse Strafvordèring, Deventer: Kluwer 2002.

Montesquieu 1748: Ch.-L. de Secondat Montesquiteu, De l'esprit des lois, 1748.

Montgolfier, De 1996 : E. de Montgolfier, Intervention, in: Le Parquet dans la République 1996, p. 169 e.v.

Moons 1969: J.M.A.V. Moons, "Het opportuniteitsbeginsel. Enige notities over zijin inhoud en omvang", $N / B 1969$, p. 485-495 en $521-529$.

Morisi 1999: M. Morisi, Anatomia della magistratura Rtaliana, Bologna: Mulino 1999.

Morselli 1995: C. Morselli, "I pubblico ministero", in: Dig. disc pen. X, Torino: Utet $1995, p_{i} 476$ e.v.

Mostert 1968: P. Mostert, 'Vereisen de functies van het Openbaar Ministerie nieuwe wettelijke voorzieningen?' in: Handelingen der Nederlandse Juristen-Vereniging 1968-I, Zwolle: W.E.J. Tjeenk Willink 1968, p. 257-348.

Mostert 1968a: P. Mostert, interventie op de NJV-vergadering van 25 juni 1968 , Handelingen Nederlandse Jwristen-Vereniging 1968-II, Zwolle: W.E.J. Tjeenk Willink 1968, p. 129-134.

Muller 1994: E.R. Muller, Terrorisme en politieke verantwoordelijkheid, Arnhem: Gouda Quint, 1994.

Muller 1999: E.R. Muller, 'Privatisering van het Openbaar Ministerie belicht', TP' 1999, 10, p. $12-13$.

Munneke 1994: H. Munneke, "Wetmatigheid van besturur belangrijker dan toetsing politiek", N.IB 1994, p. 750-751.

Myjer 1999: B.E.P. Myjer; "Stat het OM voor mensenrechten?", Trema 1999, p. 198-202.

Myjer 1999a: B.E.P. Myjer, 'De IAP-standards; een unieke en eerste stap', Trema 1999, p. $266-272$.

Myjer 2001: B.E.P. Myjer," 'Gediragscode OM: irisse wind bij open deuren", Thema 2001, p. $245-252$.

Myjer 2002: B.E.P. Myjer, "De aanbeveling van de Raad van Europa over "the role of the Public Prosecution in the Criminal Justice System" en de Nederlandse OM-gedragscode OM", Thema 2002, p. 295-298.

Nannucci 1991: U. Nannucci, "Anallisi dei flussi delle notizie di reato in relazione all'obbligatorietà e facoltatività dell'azione penale', Cass. pen. 1991 , p. 1668 e.v.

Natura e funzione del p.m. 1967: Aa. Vv., Natura e funzioni del p.m. Limeamenti per una riforma - Atti del II Convegno nazionale dei Comitati di azione per la giustizia, Roma 1967.

Neppi Modona 1982: G. Neppi Modona, "Magistratura e potere politico', Quad. giust. 1982,1, p. 25 e.v.

Neppi Modona 1983: G. Neppi Modona, 'Fisiologia e patologia della supplenza giudiziaria", Politica del dirito 1983, p. 380 e.v. 
Neppi Modona 1987: G. Neppi Modona, 'Commento all'art. 12 (e 107 comma 4)' in: G. Branca (cur.), Commentario della Costituzione. La Magistratwra. II, Bologna: Zanichelli 1987, p. 39 e.v.

Neppi Modona 1994: G. Neppi Modona, 'Principio di legalità e nuovo processo penale", in: Pubblico ministero oggi 1994, p. 119 e.w.

NJCM 1996: "Redactioneel. Naar een openbaar ministerie van Justitie?", NJCM 1996, p. $983-986$.

Nobili 1979: M. Nobili, "Accusa e burocrazia. Profilo storico-costituzionale", in: Conso 1979, p. 126-129

Nobili 1983: M. Nobili, 'La recente polemica sul pubblico ministero: un pericoloso "aut-aut", Politica del diritio 1983, p. 377 e.v.

Nodio 1999: C. Nodio, Emergenza giusnizia, Milano: Guerini 1999.

Nunziata 1992: M. Nunziata, La "direzione nazionale anti-mafia" detha "Super-procura", Napoli: Loffredo 1992.

Nuvolone 1983: P. Nuvolone, "Indipendenza del pubblico ministero e diritti dei cittadini", Politica del diritto 1983 , p. 375 e.w.

NVvR 1996: Brief van de NV४R aan de minister van Justitie van 17 september 1996 , Trema 1996, p. 319-322.

NVvR 1997: Brief van de NVvR aan de minister van Justitie van 20 maart 1997 (ongepubliceerd).

OM 2002: Openbaar Ministerie, Jaarverslag 2001, Den Haag 2002.

OM 2002a: Openbaar Ministerie, Perspectief op 2006, Den Hag 2002.

Oranje 1976: L. Oranje, De politieke verommoondelijkheid voor het vervolgingsbeleid, Calivinistische juristenvereniging 1976.

Orlandi 1994: R. Orlandi, Aspetti processuali dell autorizzazione a procedere, Torino: Giappichelli 1994.

Osinga 1992: P. Osinga, Transactie in strafaken: een onderzoek naar de positie van de transactie in het strafrechrelijk systeem, Arnhem: Gouda Quint 1992.

Oven, Van 1983: G.J.W. van Oven, 'Corstens/De verhouding rechter-openbaar ministerie, een lat-relatie in het strafrecht' (boekbespreking), Trema 1983, p. 242-245.

Oven, Van 1984: G.J.W. van Oven, "Grenzen van het openbaar ministerie", Trema 1984, p. $276-282$.

Overleg tussen minister en PG's 1993: 'De relatie tussen de minister van justitic en het OM: overleg tussen minister en PG's', Trema 1993, p. 125 e.v.

Palombarini 1995: G. Palombarini, 'Ispezioni sulla procura milanese e contesto politico', Quest. giusr. 1995 , p. 354 e.v.

Patrono 1992: M. Patrono, "II P.M. nella riforma istituzionale", Doc. Giwst. 1992, p. 1374 e.w.

Pepino 1985: L. Pepino, "Il pubblico ministero tra dipendenza e controllo", Ouest. gizst. 1985 , p. 605, noot 44.

Pepino 1993: L. Pepino, "Legalità e diritti di cittadinanza nella democrazia maggioritaria", Quest. giast. 1993, 237 e.v.

Perrodet 2001: A. Perrodet, Etude pour un ministeve public européen, Paris: LODJ 2001.

Perrot 1998: R. Perrot, Institutions judiciaimes, Paris: Montchrestien 1998.

Peters 1983: A.A.G. Peters, 'Rechtmatigheid van strafvervolging', in: E. André de la Porte e.a., Bij deze stand wan zaken (Melai-bundel), Arrwhem: Gouda Quint 1983, p. 363-404.

Pieterman 1990: R. Pieterman, De plaats vam de rechter in Nederland 1813-1920, Arnhem: Gouda Quint 1990. 
Pieterman 1997: R. Pieterman, 'Domeinstrijd', Beleid en Maatschappij 1997, p. 142-150.

Pinot de Villechenon 1997: O. Pinot de Villechenon, 'La légitimité des juges et l'indépendance du parquet', Gaz. Pal. 1997, n. 155, p. 2.

Pintus 1994: $\mathrm{F}$. Pintus, "Gudici e pubblico ministero nell'ordinamento e nella dialettica del processo penale', in: Pubblico ministero oggi 1994, p. $195 \mathrm{e.v}$.

Pisapaia 1994: O. Pisapaia, "Relazione introduttiva", in: Pubblico münistero oggl 1994, p. 15 e. .

Pitruzzella 1997: A. Pitruzzella, 'Responsabilita politica', in Dig. disc. pub., XHI, Torino: Utet 1997, p. 289 e.v.

Pivetti 1995: M. Piveti, 'Imchieste ministeriali e indipendenza della magistratura', Qvest. gitust. 1995 , p. 23 e.v.

Pizzorusso 1973: A. Pizzorusso, 'Scricchiolii sempre più forti dall'istituto dell' autorizzazione a procedere', Giur. cost. 1973, p. 97 e.v.

Pizzorusso 1974: A. Pizzonusso (cur.), L'ordinamento gïudiziario, Bologna: Mulino 1974.

Pizzorusso 1975: A. Pizzorusso, "Democrazia partecipativa e attività gurisdizionale", Quale giustizia 1975, p. 340 e.v.

Pizzorusso 1979: A. Pizzorusso, "Per un collegamento fra organi costituzionali politici e pubblico ministero', in: Conso 1979, p. 30 e.v.

Pizzorusso 1982: A. Pizzorusso, "Rifflessioni sul ruolo del pubblico ministero", Quest. gitust. 1982 , p. 513 e.w.

Pizzonusso 1990: A. Pizzorusso, L'organizzazione della giustizia in Italia, Torino 1990.

Pizzorusso 1994: A. Pizzorusso, 'Commento all'art. 102', in: G. Berti e.a., Commentario della Costituzione. La Magistratura. I, Bologna-Roma 1994, p. 195 e.v.

Pot, Van der/Donner 1968: A.M. Domer, Van der Pot. Handboek van het Nederlandse Siactsrecht, Zwolle: W.E.J. Tjeenk Willink 1968.

Pradel \& Laborde 1997: J. Pradel J,P. Laborde, 'Du ministère public en matière pénale. A l"heure d"une éventuelle automomie?, D 1997 , p. 141 e.v.

Pradel 1990: J. Pradel, 'La mise en êtat des affaires pénales. Propos sceptiques sur le rapport de la commission Justice pénale et droits de l"homme (juin 1990), D 1990, p. 301 e.v.

Pradel 1991: J. Pradel 'Opportunité ou légalité de la poursuite? Aperçus sur quelques législations d'Euope, RPDP $1991, \mathrm{p}, 9 \mathrm{e} v$.

Pradel 1995: J. Pradel, Droit pénal comparé, Paris: Dalloz 1995.

Pradel 2000: J. Pradel, Mantel de Procédure pénale, Paris: Cujas 2000.

Pradel 2000a: II. Pradel, 'Le ministère public - Breves remarques sur son évolution depuis 1959", RPDP 2000, p. 25 e.v.

Pradel 2001: J. Pradel, 'Le ministère public, autorité omnipotente ou colosse aux pieds d'argile. Observations sur quelques législations pénales Européennes", RPDP 2001 , p. 464-481.

Pubblico ministero oggi 1994: /l Pubblico ministero oggi, Milano: Giuffrè 1994.

Pujas 2000: V. Pujas, "Carences et nouvelles dimensions de la responsabilitế politique: éléments de politiques comparées', Powwoirs 2000, n.92, p. 165 e.v.

Randwijck, Van 1993: R.J.C. van Randwijck, "Is het OM de vijand van zichzelf? Een reactie", $D D 1993, \mathrm{p} .676-679$.

Rapport relatie OM-zittende magistratunr 1981: 'Rapport relatie OM-zittende magistratuur', Trema 1981, p. 113-130.

Rassat 1967: M.L. Rassat, Le ministere public entre son passé et son avenir, Paris: LGDJ 1967. 
Rassat 1993: M.L. Rassat, Institutions judiciales, Parts, PUF 1993.

Rassat 1996: M.L. Rassat, 'Le Parquet au regard de la législation interne", in: Le Parquet dans la République 1996, p. 99 e...

Remmelink 1968: J. Remmelink, "Het openbaar ministerie ter diseussie, Verkeersrecht 1968 , p. 171-174 en 193-197.

Remmelink 1991: J. Remmelink, "De officier van justitie, magistraat of bestuursambtenaar?", Trema 1991, p. 167-179.

Remmelink 1995: J. Remmelink, Mr. D. Hazewinkel-Suringa's Inleiding tor de studie wan het Nederlandse strafiech, Arnhem: Gouda Quint 1995.

Renoux 1998: Th.-S. Renoux, Les Conseils Supérienrs de la Magistrature en Europe: étude comparée 1998.

Rescigno 1967: G.U. Rescigno, La responsabilità politica, Milano: Güffé 1967.

Rescigno 1988: G.U. Rescigno, 'Responsabilità (diritto costituzionale)" Enc. dir., XXXIX., Milano: Giuffré 1988.

Ricci 1982: R. Ricci, 'Autonomia e indipendenza del P.M.', Quad giust. 1982, I, p. 117 e.v.

Riforma del pubblico ministero 1974: La riforma del pubblico ministero, Milano: Giuffré 1974.

Rivello 1997: P.P. Rivello, 'Richiesta di procedimento', Dig. disc, pen, XII, Torino: Utet 1997, p. 191 e.v.

Röben 2001 : J.B.H. Röben; 'Het bestursorgaan OM', Trema 2001, p. 92-95.

Robert, D. 1996: D. Robert, La justice ou le chaos, Paris: Stock 1996.

Robert, J. 1988: J Robert, 'De l'indépendance des juges', RDP 1988, p. 3 e.v.

Robert, M. 1996: M. Robert, Intervention, in: Le Parquet dans la République 1996. p. 199 e.v.

Robert, Ph. 1996: Ph. Robert, Intervention, in: Le Parquet dans la République 1996, p. 143 e.v.

Roording 1994: J. Roording, Sanctierecht in de belastingen en de sociale zekerheid, Nijmegen: Ars Aequi Libri 1994.

Rovelli 1994: L. Rovelli, Intervento, in: Pubblico ministera oggt 1994, p. 267 e.v.

Salvi 1992: G. Salvi, "Funzioni e poteri del procuratore nazionalle antimafia", Cass. pen. 1992. p. 1079 e.r.

Scaparone 1994: M. Scaparone, 'Conclusioni', in: Pubblico ministero oggi 1994, p. 273 e.v.

Schalken 1990: T.M. Schalken, 'Het postmoderne OM: management in toga', NJB 1990, p. $1435-1436$.

Schalken 1991: T.M. Schalken, 'Het taboe van art. 5 RO', Trema 1991, p. 179-194.

Schalken 1992: Schalken 1992, "Een nieuwe cultuur binnen het openbaar ministerie?", NJB 1992, p. 813-818.

Schalken 1993: T.M. Schalken, "Is het OM de vijand van zichzelf? Over de filosofie vain een veranderingsproces", $D D 1993$, p. 393-398.

Schalken 1994: T.M. Schalken, "Het Om tussen departementale sturing en concrete wetstoepassing' in: H. de Doelder, R.M.G.E. Foqué \& R.A.F. Gerding (red), Taak en functionemen van het $O M$, Amhem: Zwolle 1994, p. 239-248.

Schalken 1995: T.M. Schalken, "Een nieuwe lente voor het OM", NJB 1995, p. $16-17$.

Schalken 1995a: T.M. Schalken, "Het vergeten Openbaat Ministerie", NJB 1995, p. 862-863. 
rijheid van requisitoir na een ministeriële

uropees OM?"DD 1998; p. 625-629.

warheid van het straffecht", $D D 1999$,

e besiuursorganen, Groningen: H.D. Tjeenk

vop de NJV-vergadering van 25 juni 1968 , iging 1968-II, Zwolle: W.E.J. Tjeenk Willink

adenza del P.M.', Quad gitust. 1982, l, p. 51 e.v. 'De officier van justitie: magistraat (of 5-116.

litique, Paris: Presses Universitaires de France

ponsabilité politique?', RDP 1999,

quelle responsabilité?, Paris: L'Harmattan 2000. idonotizie di reato: quale controllo?", Cass. pen.

ti di riforma dell' istituto del P.M.', Riv, pen

zia e giustizia', in: Dig. disc. pub., IX, Torino:

listero", in: Dig. disc. pub, IX, Torino: Utet

dici nel sistema costituzionale, Torino:

Myjer, 'De eigenstandige positie van het $O M$ bij zsbulletin 2001, p. 76-79.

mlijke organisatie in Nederland, Zwolle: W.E.J.

Tien jaarverslagen van het OM', RMThemis

'Het OM op glad ijs', Trema 1982, p. 85-88. del pubblico ministero nel nuovo processo 4 , p. 39 e.v.

uding minister-OM', Thema 1994, p. 289.

atie OM-minister', Trema 1989, p. 68-76.

sntiteitscrisis van bet Openbaar Ministerie",

ntie op het Raio-congres 'De eerbied waardig'

rantwoordelijke minister, Breda: De Geus 1999.

en met de privatiseringsgedachte ${ }^{7}, T P 1999,10$, 
Spagna Musso 1987. E. Spagna Musso, Rapporti tra potare politico potere gividiziario riforma del pubblico ministero e del consigli giudizian', in: Studi in onore di P: Biscarti di Ruffia. Tomo2, Milano: Gulffe 1987, p. 1211 e.

Spangher 1991: G. Spangher, "Le iniziative del pubblico ministero tra carenze ordinamentali e rischio di condizionamenti politici', in Gaito 1991, p. 123 e.v. Stéfani, Levasseur \& Bouloe 2000: G. Stéfani, G. Levasseur \& B. Bouloc, Procedune
pénale, Paris: Dalloz 2000 .

Stellinga 1953: JR. Stellinga, Grondrekken wan het Nederlands staatsrecth, Zwolle: W.E.J. Tjeenk Willink 1953 .

Stipo 1990: M. Stipo, "Ministero. D) Profili generali", Enc. dir, XX, Roma: Treccani 1990,
p. I e.v.

Stipo 1990a: M. Stipo, "Ministero. II) I singoli ministeri", Enc. dir., XX, Roma: Treccani 1990, p. I e.v.

Stolwijk 1992: S.A.M. Stolwijk, 'De minister van Jusiticie, het Openbaar Ministerie en artikel 5 RO', in: T.M. Schalken e.a. (red.), Magistraat met beleid de officier van justhe en zinn amgeving, Amhem: Gouda Quint 1992, p. 33-40.

Stolwijk 1998: S.A.M. Stolwijk, 'Strafrecht en politiek', $D D 1998-9$, p. 844-852.

Strafrecht met beleid: Strafrecht met beleid: beleidsplan Openbaar Ministerie, 1990-1995. Den Haag: SDU 1990.

Stroink 1978: F.A.M. Stroink, Het leerstuk der deconcentratie (diss. Utrecht), Den Haag: Vuga 1978.

Suyver 1976: J.J.H. Suyver, De zeggenschap ower het politieorgadnat Nederlands rech, Arnhem: Gouda Quint 1976.

Tak 1981 : P.I.P. 'Tak, "Naar een beheerst OM-beleid', in: A.J. Bins e.a. (red.), Beginselen. opstellen over strafiecht angeboden aan G.E. Mulder, Arnhem: Gouda Quint 1981. p. $369-381$.

Tak 1992: P.J.P. Tak, 'Enkele hoofdlijnen van de nieuwe ltaliaanse strafvordering", $D D$ 1992, p. 308 e.v.

Terquem 1998: F. Terquem, Le coup d'état judiciaire, Paris: Ramsay 1998.

Thorbecke 1848: J.R. Thorbecke, Bijdrage rot de herziening der Grondwef, Leiden: Van den Heuvell 1848; "s Graverhage: Nijhoff 1948 (facs. uitg.).

Tomesen 1992: W.B.M. Tomesen; 'De Paasbrief: De minister neemt positie in', Trema 1992, p. 407-409.

Tranchina 1987: G. Tranchina, 'Autorizsazione a procedere', Dig. disc. pen, 1, Torino: Utet 1987 , p. 377 e.v.

Truche, Du 1992: P. du Truche, "Justification et limites de laction du mintere public", in: M. Delmas-Marty (dir.) Procès pénal el droits de l'homme, vers une conscience européenne, Paris: PUF 1992, p. 255 e.v.

Truche, Du 1995: P. du Truche, "Justifications for and Limitations on the Actions of the Public Prosecutor", in: M. Delmas-Marty (ed.), The Criminal Process and Human Rights. Towards a Europecin Consciousness, Dordrecht: Martinus Nijhoff 1995, p. I $65 \mathrm{e}, \mathrm{v}$.

Turcey 1996: V. Turcey, Intervention, in: Le Parquet dans la République 1996, p. 125 e.v. Turcey 1997: V. Turcey, Le Prince et ses juges, Plon 1997.

Turcey 1998: $V$. Turcey, "La nouvelle indépendance du parquet: mythe ou realize ?", Les Petites Affiches 1998, n. 50, p.4-7.

Turpin 1999: D. Turpin, Droit constitutionnel, Paris: PUF 1999.

Tuurenhout 1992: M.E. Tuurenhout, Parlementaire controle en amblelijke verantwoordelijkheid, Arnhem: Gouda Quint 1992. 
Valentin Rewter 1994: C. Valentini Reuter, Le forme di controllo sull'esercizio dell' azione penale, Padova: Cedam 1994.

Van der Pot/Donner/Prakke e.a. 2001: L. Prakke, J.L. de Reede \& G.JM. wan Wissen, Van der Pot-Donner Handboek van het Nederlandse staatsrech, Zwolle: W. E.J. Tjeenk Willink 2001.

Vast 2000: A.B. Vast, "75 jaar Openbaar Ministerie. Uit de ivoren toren, in een glazen huis", N/B 2000, p. 96-106.

Veen, Van 1974: Th W, van Veen, "Het rekwisitoor", DD 1974, p. 517-528.

Veen, Van 1975: Th.W. van Veen, 'De vrijheid en zelfstandigheid van het Openbaar Ministerie, de jaarverslagen van het O.M. over 1970-1971 en 1972', in: Vriheid en recht, opstellen aangeboden aan prof mr. E.H. s'Jacob, Zwolle: W.E.J. Tjeenk Willink 1975, p. $319-335$.

Veen, Van 1977: Th.W. van Veen, 'Politieke verantwoordelijkheid voor het vervolgingsbeleid, $D D 1977$, p. 261-274.

Veen, Van 1979: Th.W. van Veen, "De minister mag niet zelf seponeren', RMThemis 1979, p. $113-117$.

Vellani 1970: Velllani, /l pubblico ministero nel processo. II Il dirito italiano vigente; Bologna: Zanichellil 1970.

Verburg 1994: M.E. Verburg, Geschiedenis van het Ministerie van Justitie. Deel I: 1798-1898, Den Haag: Sdu Uitgeverij 1994.

Verburg 2001: J.J.I. Verburg, 'NVvR verenigt leden ZM en OM', Trema 2001, p. 96-98.

Verde 1990: G. Verde, L amministrazione della giustizia fra ministero e Consiglio Superiove, Padova: Cedam 1990.

Verhey 2001 : L.F.M. Verhey, 'De organisatie van het openbaar ministerie: enkele beschouwingen mede in het licht van het EVRM', NJCM 2001, p. 169-189.

Viering \& Kummeling 1996: M.L.W.M. Viering \& H.R.B.M. Kummeling, "La plume est serve, la parole est un petit peu libre', NIB 1996, p. 592-596

Vigoriti 1979: V. Vigoriti, 'Pubblico ministero e discrezionalità dell'azione penale negli Stati Uniti d'America', in Conso 1979, p. 272 e.v.

Vigoriti 1991: V. Vigoriti, 'Responsabilità del giudice. D) Responsabilità del giudice dei suoi ausiliari, del P.M. ", Enc. giwr., XXVI, Roma: Treccani 1991, p. 1 e.v.

Vigorit 1991a: V. Vigoriti, "Responsabilità del giudice. II) Diritto comparato e straniero", Enc. gint., XXVI, Roma: Treccani 1991, p. 1 e.v.

Vincent e.a. 1999: J. Vincent e.a., Institurions judiciaires: organisation, juridictions, genst de justice, Paris: Dalloz 1999.

Vitalone 1991: C. Vitalone, "La funzione d'accusa tra obbligatorietà e discrezionalità', in: Gaito 1991, p. 291 e.v.

Vogelweith 1997: A. Vogelweith, '...Sortit de la pensée binaire', Justice 1997, n. 153, p. $12 \mathrm{e.v}$.

Volff 1998: J. Volt, Le ministère public, Paris: PUF 1998.

Vos \& Van Spanje 2002: O.P.G. Vos \& J.H.P. van Spanje, 'Staat en straf', NIB 2002, p. 1062-1063.

Vries, De 1960: W. de Vries, De positie van het Nederlandse O.M., NJB 1960, p. 698-705.

Warmelink 1994: H.G. Warmelink, 'Ministeriële verantwoordelijkheid voor ambtelijk handelen", in: Elzinga 1994b, p. 103-115.

Warmelink 1998: .G. Warmelink, 'Het gezag van de minister staat voorop; dat spreekt vanzelf?', $N J B 1998$, p. 1339-1344. 
Welschen 1996: T. Welschen, Het Ialiaanse complex. Partijen en bewegingen vam 1970 rot 1990, Bussum: THOTH 1996.

Werd, De 1998: M.F.J.M. de Werd, "Een Raad voor de Rechtspraak", Trena 1998, p. 3-7.

Wiewel 1991: P.G. Wiewel, 'De beslissing tot vervolging is bestuur', DD 1991, p. 7-15.

Wijkerslooth, de \& Simomis 2002: I.L. de Wijkerslooth \& J. Simonis, 'Een Europees OM heeft een Europese Rechter nodig, in: Magistraten zonder grenzen. De invloed van het Europese recht op de Nederlandse rechtspleging, Nijmegen: Wolf 2002, p. 79-85.

Wijnbergen, Van 1999: S.J.G. van Wijnbergen, "Nabeschouwing. Privatiseren van (delen van) het OM: zin of onzin?", TP $1999,10, \mathrm{p} .19$.

Wildt, De 1968: M.H. de Wildt, interventie op de NIV-vergadering van 25 juni 1968, Handelingen Nederlandse Juristen-Vereniging 1968-II, Zwolle: W.E.J. Tjeenk Willink 1968 , p. $64-65$.

Willems 1999: J.H.M. Willems, "Privatisering van het Openbaar Ministerie: een - te - losse flodder?", TP 1999, 10, p. 13-16.

Winter, De 1997: R.E. de Winter, 'Verantwoordelijkheid zonder zeggenschap', $M J B 1997$, p. $1269-1273$.

Winter, De 2001: R.E. de Winter, "Vrijheid van requisitoir", Trema 2001, p. 80 e.v.

Witteveen 1998: W.J. Witteveen, "De minister en de officier: botsende rechtsstatelijke idealen", DD 1998, p. 448-470.

Wittop Koning 1972: J.P. Wittop Koning, "Enkele opmerkingen bij art. 12 W.v.Sv.", DD 1972 , p. 280 e.v.

Zagrebelsky 1974: V. Zagrebelsky, "L"obbligatorietà dell'azione penale. Riflessi sulle garanzie, sull"'organizzazione degli uffici, sui poteri del pubblico ministero', in: Riforma del pubblico ministero 1974, p. 191 e.v.

Zagrebelsky 1979: V. Zagrebelsky, 'Indipendenza del pubblico ministero e obbligatorietà dell 'azione penale', in: Conso 1979, p. 3-29.

Zagrebelsky 1991: V. Zagrebelsky, 'Le soluzioni peggiori del male (a proposito del pubblico ministerol', Cass. pen. 1991 , II p. 308

Zagrebelsky 1992: V. Zagrebelsky, 'Le modificazioni dell'ordinamento givdiziario in funzione del nuovo codice di procedura penale", in: G. Conso, V. Grevi \& G. Neppi Modona, Il movo codice di procedura penale. Dalle leggi delega ai decreti delegati. Volume VhI Gli adeguameni dell ordinamento givdiziario. Tomo I, Padova: Cedam 1992. Bewerking van: Modifiche all ordinamento giudiziario e nuovi ruoli del pubblico ministero e del giudice', Cass pen. 1989 , p. 2122 ev.

Zagrebelsky 1994: V. Zagrebelsky, "Stabilire le priorita nell'esercizio obbligatorio della azione penale', in: Pubblico ministero oggi 1994. p. 115. Bewerking van:

"L"obbligatorietà dell'azione penale. Un punto fermo, una discussione mancata, un problema attuale", Cass.s. pen. 1992, p. 3183 e.k.

Zanon 1996: N. Zanon, Pubblico ministero e Costituzione, Padova: Cedam 1996.

Zimbelt 1996: J.-J. Zirnhelt, Intervention, in: Le Parquer dan's la République 1996, p. 207 e.v.

Zoller 1999: E. Zoller, Droit constitationnel, Paris: PUF 1999. 



\section{Zakenregister}

Aansprakelijkheid leden OM

$27,96,146$

64,66

Aanspreekbararheid minister

$172,238,270$

Aanwijzingsprocedure

$42-47,48-49$

- Nederland

$107,108-110$

- Frankrijk

$76-77$

25

Advies College bij benoemingen

$43-44$

Advies College bij aanwijzingen

31

$61-62$

Ambtenaren, vervolging van58,270

Ambtsmisdrijwen

Anticipatie van wetgeving

Autonomie van het $\mathrm{OM}$.

$76-77$

Autorité judiciaime

$50,56,237$

258

Begroting

- Nederland

$45,59,68$

- Frankrijk

$71,113,121$

- Italiè

$124,156,164$

Beklag

- door OM

- door minister

$20,22,38,46-47,173,184,218-219,251$

$252-253,269-270$

Beleid OM

- Nederland

$21,36-37$

- Frankrijk

$87,102-103$

- Italiè

$137-139$

214-216

Beleidscontrole minister

$211-212$

209-214

Beleid en strafzaken, onderscheid-

$175-176$

Beleidswrijheid OM

$25-26$

$92-94$

- Nederland

144

- Frankrijk

- Italiê

$200-201,236-237$

Bestuursorgaan, OM als-

Bezoldiging leden OM

- Nederland

- Frankrijk

- Italie

$23,31,37,52,72-73,226$

Bloemenhove-affaire

Bouterse, zaak

Bouwfraude-affaire

Budget OM, zie begroting

16,201

Buitendienst 
Buitenlandse betrekkingen

Burgerinfiltratie

Cabiner

91,100

Centrale Raad van Beroep

$29,48,50,225$

Circulatres

Cohabitatic

Collegeaanwijzingen $90,94,122-123,125,181$ $16,21,31$

Composinton penale

Consell Supérieur de la Magistrature

$77,92-94,96-97$

Consiglio superiore della magistratura $127-129,143-1.48$

Coordinatie vervolging 206-207

Corps judiciane

Deconcentratie

Democtatie

Departementsraad.

$5-6,196-199,209-214,220-222$

'Derde weg'

Disciplinaire procedure

- Nederland

- Frankrijk

$175-177,215,272$

$28-29,48,192$

- Italiè

$96-97,108-109,234$

147-148

209-214

Discretie OM

29,192

Docters van Leeuwen, zaak-

Doorlaten

Drenth, zaak-

$28,39,192,225$

Driehoeksoverleg

19,239

Droit de résistance

108,173

Duitsland

"Eigen gelaat"

$10,169,176,178,183,186,234$

OM 51

Engeland

$9,169,178,183$

Enquête

- Nederland

70,71

- Frankrijk

$119-120$

- Ilalie

$163,166,188$

Euthanasie

32,224

EVRM, artikel 6-

44,46

"Fluwelen thandschoen' minister

Gerechtelijk onderzoek

- Nederland

- Frankrijk

$85-86$

- Iralis

Gewoonterecht

Gratie

Grondrechten leden OM

- Nederland

- Italliè 
Hërarchisch beroep

- Frankrijk

- Italie

Hilten, zaak-

Historie, rechts-

Hors hiérarchie

Imnuniteiten

Informele invloed minister

- Nederland

$60 \cdot 62$

- Frankrijk

114-1.15

- Italiè

156-157

210-211

Initiatief $O M$

Internationale aanbevelingen

$8,193,212-213,220-222,231$

Jaarplan OM

21,31

CSM

Jaarverslag

- Frankrijk

- Italie

150,159

Jaarverslag OM

- Nederland

31,71

- Frankrijk

$187-188$

Kamervragen

$68-70$

- Nederland

$118-119$

- Frankrijk

160-163

- Italië

Kok, zaak-

202,270

Koning

Legaliteitsbeginse] (algemeen)

Legaliteitsbeginsel (vs opportuniteits-)

$128,133-134,137-138,183-186,206-210$

Legitimatie, legitimiteit

$196-197,198-222$

$23,39,263,270$

Lockheed-affaire

Machtenscheiding

$5,105,120,228-229$

57.58

Mededeling omtrent strafoaarheid

Médiation

Menten, zaak-

Minderhedenbescherming

Ministerie van Justitie

- Nederland

- Frankrijk

- Italiè

$52,57,69.70,263$

238,261

$181-182,263$

$15-16,23-24$

78,91

$129,142-143$

Ministeriele verantwoordelijkheid

- Nederland

- Frankrijk

$158-159$

- Italië

$181-182$

Minister-president

$23,27,42$

- Nederland

- Frankrijk

- Italiê 
Ministerrad

- Nederland

$23,25,28$

- Frankrijk

90,94

- Italié

142,155

229

Montesquieu

188

Motie

$71-72$

- Nederland

$20-122$

- Frankrijk

$116,120-122$

- Italié

$159,162,164$

Onafhankelijkheid rechterlijke macht

Onafhankelijkheid van de rechter

$199-200,241-242,247$

196-197

en verantwoordelijkheid

$63-64$

Onderzoeksrechter, zie gerechtelijk onderzoek

236-238

Onpartijdigheid ambtenaren

$196-197,230-241$
$183-186,206-209$

Onpartijdigheid OM

Opportuniteitsbeginsel

Opsporing

- Nederland

$174,183,211,238$

- Frankrijk

- Italië

Organieke wet

Organisatie OM

$19,3 \rrbracket-32,37,58-59,69$

$82-83,99,105-106,112-113$

$134-136,155-156,160,166$

92

$179-181$

- Nederland

$15-18$

- Frankrijk

$78-81$

- Italie

$129-132$

Overeenkomsten met criminelen

Overheid, vervolging van

$31,252-253$

Overleg minister-OM

$172-173,216,270-271$

- Nederland

- Frankrijk

$30-32,43-44,47,60-61,241$

$102,114,177$

Overplaatsing leden OM

$175,235,272$

- Nederland

26

- Jankrijk

94,97

- Italic

144- 145

232-236

Partijdigheid politiek

Plainte

Plume est serve, la parole esi libre, la-

$88-89,107-108,173,184,218-219$

$41-42,109,132,171$

Politieke keuze

Politieke partijen

$123,205-206,208,217-222$

$142,264,156-157,165$

Posterioriteiten

$171,184,221,269-270$

- Nederland

21,37

- Frankrijk

- Italie 
President

- Frankrijk

- Italië

$76-77,90-94,111,117,122-124,181,192-193,247$

$128,141-142,150-153,155,158$

$183,186,212$

$21,31,37$

- Nederland

$87,102,255$

- Frankrijk

- Italie

$128-129,132,137-138,155,161,167,184,259$

69.163

Privacy

$264-265$

Privatisering OM

$3,28,49-50,58,227,260$
$260-262$
$225-226$
29,72
$196-242$
$191-195$
$12,26-27,53,237$

Procureur-generaal bij de Hoge Raad

Procureur-generaal "de la Nation"

$3,28,49-50,58,227,260$
$260-262$
$225-226$
29,72
$196-242$
$191-195$
$12,26-27,53,237$

Proefproces

$3,28,49-50,58,227,260$
$260-262$
$225-226$
29,72
$196-242$
$191-195$
$12,26-27,53,237$

Randwijck, zaak Van-

$3,28,49-50,58,227,260$
$260-262$
$225-226$
29,72
$196-242$
$191-195$

Ratio functionele positie OM

$3,28,49-50,58,227,260$
$260-262$
$225-226$
29,72
$196-242$
$191-195$

Ratio rechtspositie OM

$3,28,49-50,58,227,260$
$260-262$
$225-226$
29,72
$196-242$
$191-195$
$12,26-27,53,237$

Rechterlijke ambtenaren

Rechterlijke taak OM

Rechterlijke toetsing aamwijzingen

Rechtsbescherming door minister

$12,26-27,53,237$
$229-230$

$48,50,250-252$

$222-225$

Rechtsbescherming leden OM

- Nederland

29

- Frankrijk

97

- Italië

Rechtshulp

$226-227$

Rechtsontwikkeling door minister

Rechtspersoonlijkheid OM

Rechtspositie leden OM

- Nederland

$91-98$

- Frankrijk

$143-148$

- Italiè

Rechtsstaat

Rechtszekerheid

$5,196-197,227-228$

$47,226,230$

$203-205$

Regeringsaangelegenheid, vervolging als-

$201-203$

Regeringswertegenwoordiger, $\mathrm{OM}$ als-

Rekenschap afleggen door minister

$66-67,70,73$

Nederland

- Frankrijk

- Italië

$158,161,165$

40 -42

Requisitoirvrijheid, zie ook plume est serve

$121,258-259$

Resolutie

20,40

Richtlijnent

Sang contaminé, affaire du

Schorsing leden OM

- Nederland

- Frankrijk

- Italië 
Schriftelijkheid aanwijzing

- Nederland

- Frankrijk

Sepot

$184-185,212,222-223,229$

- Nederland

$19-20,46$

- Frankijik

$83-84$

- Italie

$131,134,136-138$

Staatsbelang

Staatsgeheim

$44-46,48-49,69,205-206,218-222$

$119-120,219$

$203,218-219$

Statsveiligheid

$26,28,192$

Terughoudendheid minister

$71-172,228$

Toestenming voor vervolging

$110-112$

- Frankrijk

153-155

- Italie

48,173

Toetsing aanwijzingen door $\mathrm{OM}$

$56-58,174$

Toezegging minister

174,229

Transactie

- hoge

- Nederland

$19-20,31,38,59,185$

- Frankrijk

Uitvoerende macht.

$12,53,63$

Vaste kamercommissies

- Nederland

- Frankrijk

- Italie

$159,160,163$

Verantwoording $187-188,272$

$62-73$

- Nederland

$115-124$

- Frankrijk

$157-167$

- Italia.

Verbod van substitutie

Verkiering OM

Verzetsrecht, zie droit de résistance

$151-153$

Verzoek, ministerice l-

$234-235,239-240$
$33-34,63-64$

Wantrouwen jegens politiek

Wet RO 1827, artikel 5 -

3,171

Wetgeving 


\section{Dankwoord}

Danken is éen van de meest essentièle houdingen van de mens, die zelf van begin af aan wordt gegeven. Allen bedankt voor hetgeen zij gaven, opdat ik dit proefschrift kon (uit)geven.

Als eerste dank aan Reiner de Winter voor het aanzwengelen van het onderzoek, voor zijn gastvrije en onderhoudende aandacht en zijn pogingen om ook onder de dossierlast van het gerechtshof nog enig commentaar te leveren. Aalt Willem bedank ik voor het overnemen van de Reiners begeleiding en voor de verleende vrijheid en de procesbewaking.

Verder dank ik Fred Teeven en zijn team voor hun bereidheid mij een kijkje te geven binnen het Amsterdamse arrondissementsparket. Met genoegen denk ik daarnaast aan de openheid en soms culinaire gastvrijheid van de Franse en Italiaanse professoren en leden van de rechterlijke macht. Met name wil ik hier vermelden Jean Volff, Paolo Vadalà, Francesco Genovese, Alessandro Pizzorusso en Vladimiro Zagrebelsky. NWO, de Onderzoeksschool lus Commune en de Wetenschapscommissie ben ik erkentelijk voor de financiële ondersteuning van enkele verblijven in het buitenland.

Waardevol waren verder de opmerkingen van de leden van de leescommissie. Egbert Myjer en Frits Stroink namen ruim de tijd om hun kanttekeningen uiteen te zetten. Met Henk Kummeling, Gerard Mols en Luc Verhey had ik eveneens nuttige en plezierige contacten.

Nettie Litjens wil ik hartelijk bedanken voor het cameraready maken en de administratieve begeleiding van dit proefschrift.

En vrienden, familie, Laura, Gever van alle goeds, bedankt. 



\section{Curriculum vitae}

Paul van der Lee werd in 1974 geboren te Eindhoven. In 1992 behaalde hij het VWO-diploma aan het Christelijk Lyceum Veenendaal in de gelijknamige stad en begon zijn studie Nederlands recht aan de Universiteit Utrecht. Binnen het kader van het Europese Erasmus-project studeerde hij in 1996 een half jaar aan de Universiteit van Perugia, te Italië. Na zijn afstuderen in 1997 voerde bij in deze stad voor een jaar een rechtsvergelijkend onderzoek uit met een beurs uit een Cultureel Verdrag. In 1998 begon hij als assistent in opleiding bij de capaciteitsgroep Publiekrecht van de Universiteit Maastricht, vanaf 2000 als onderzoeker. Binnen het kader van het promotieonderzoek verbleef hij verscheidene perioden in Perugia en in Parijs. Sinds 2002 is hij als jurist verbonden aan de Koninklijke Nederlandsche Maatschappij ter bevordering van de Geneeskunst te Utrecht. 